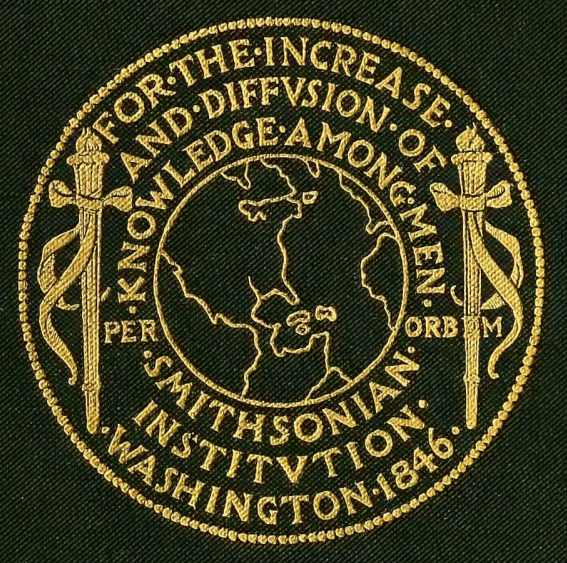




\section{ช. 5. MAational SiDuseum}

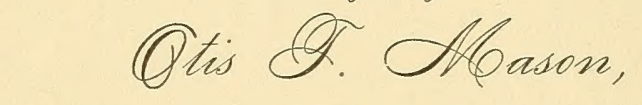

Qurator of the Division of Ethnology

Accession iflo. 






USEFUL PLANTS OF GUAM. 


\section{ADVERTISEMENT.}

The United States National Herbarium, which was founded by the Smithsonian Institution, was transferred in the year 1868 to the Department of Agriculture, and continued to be maintained by that Department until July 1, 1896, when it was returned to the official custody of the Smithsonian Institution. The Department of Agriculture, however, continued to publish the series of botanical reports entitled "Contributions from the U. S. National Herbarium," begun in the year 1890, until, on July 1, 1902, the National Museum, in pursuance of an act of Congress, assumed responsibility for the publication. The first seven volumes of the series were issued by the Department of Agriculture.

$$
\text { S. P. LANGLEY, }
$$

Secretary of the Smithsonian Institution. 



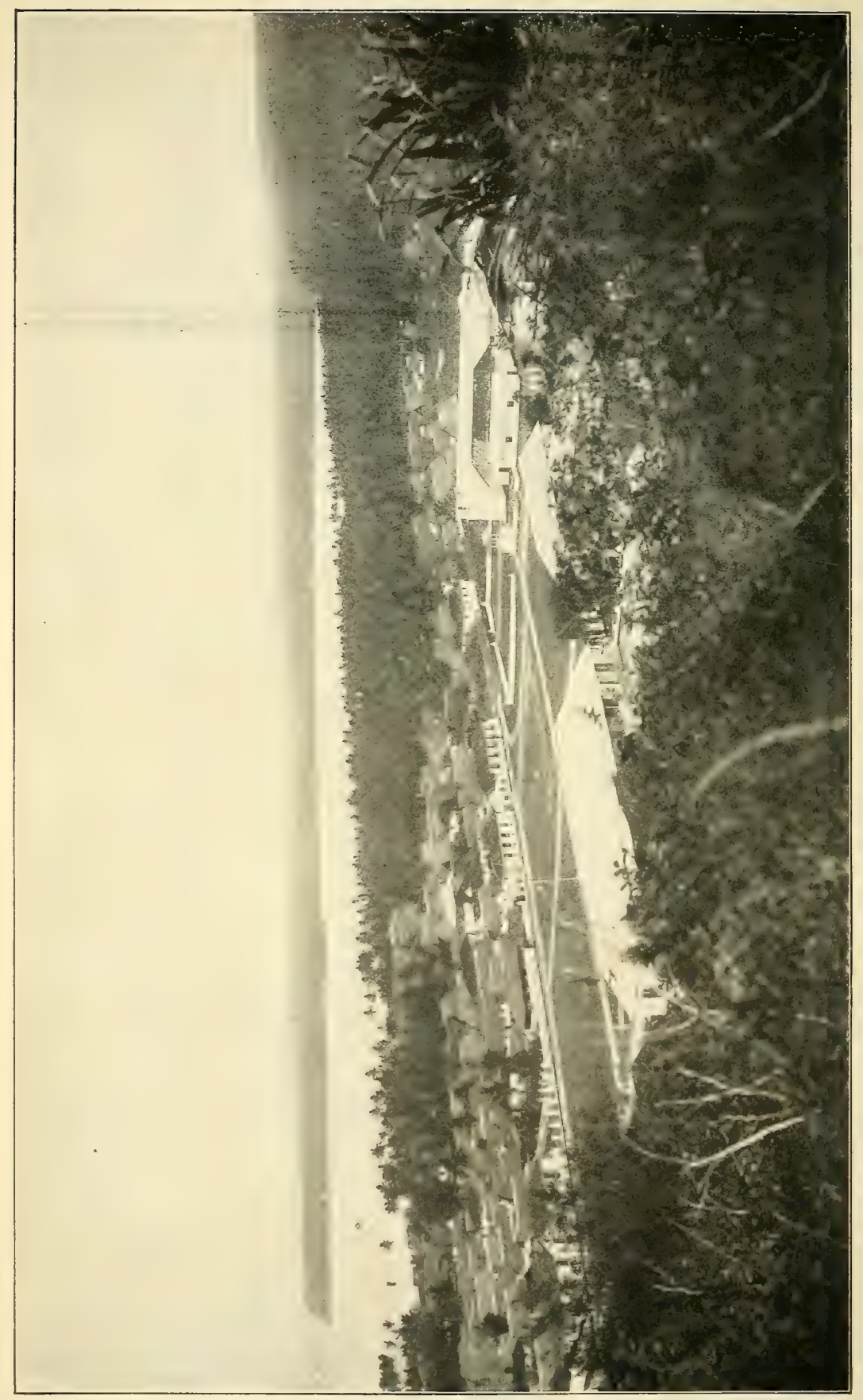

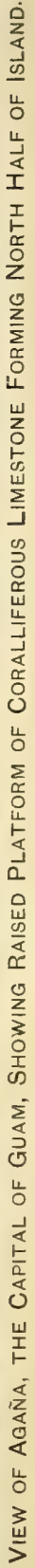




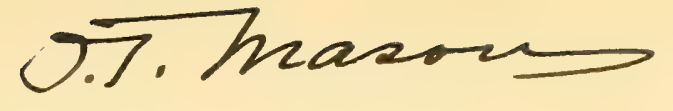

SMITHSONIAN INSTITUTION

UNITED STATES NATIONAL MUSEUM

\section{CONTRIBUTIONS}

FROM THE

\section{United States National Herbaritu}

\section{Volume IX}

\section{THE USEFUL PLANTS OF THE ISLAND OF GUAM}

WITH AN INTRODUCTORY ACCOUNT OF. THE

PHYSICAL FEATURES AND NATURAL HISTORY OF THE ISLAND, OF THE CHARACTER AND HISTORY OF ITS PEOPLE, AND OF THEIR AGRICULTURE

\section{By WILLIAIM EDWIN SAFFORD}

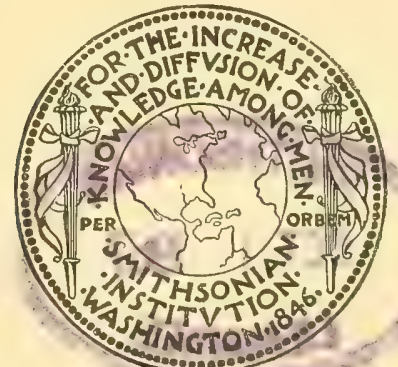

\section{WASHINGTON}

GOVERNMENT PRINTING OFFICE 
BULLETIN OF THE UNITED STATES NATIONAL MUSEUM:

Issued April 8, 1905. 


\section{PREFACE.}

Mr. W. E. Safford, assistant botanist in the Department of Agriculture, for several years availed himself of the opportunity afforded him as a lieutenant in the United States Navy to study and observe the useful plants of the Tropics. In addition to cruises in other parts of the world he visited, in 1886, 1887, 1894, and 1899, Upolu and Tutuila of the Samoan group, and Oahu of the Hawaiian group; and from August, 1899, to August, 1900, he acted as assistant governor of the island of Guam. This paper has been prepared by Mr. Safford through the recent elaboration of notes and observations made in those years. While presented under the title "The Useful Plants of Guam," it includes some reference, however brief, to every plant known to occur on that island, particular note being made of those which have been described from Guam by various writers as species new to seience. It discusses the principal plants used for food, fiber, oil, starch, sugar, and forage in the Pacific tropical islands recently acquired by the United States, and gives their common names not only in Guam but in the Philippine Islands, Samoa, Hawaii, and Porto Rico. The method of cultivating and propagating the more important species is treated in considerable detail, as is the preparation of their derivative products, such as arrowroot, copra, and cacao. The publication will be useful to the rapidly increasing number of American travelers and officers who wish to have in language of as little technicality as possible information about the economic plants of the world; and while the author does not lay claim to more-than a report on the island of Guam, much of the information hives is applicable throughout the Tropics.

Besides consulting the original narratives of travelers, Mr. Safford took advantage of his exceptional opportunities to study the archires of Guam, and his accoint of the discovery, early history, and explorations of the island, together with its climate, ethnology, and economic conditions, will afford the most comprehensive and authentic picture of Guam thus far published.

The technical names of the plants have been critically scrutinized by Mr. W. F. Wight, also assistant botanist in the Department of 
Agriculture. The task has been a laborious one, far more laborious than the printed results suggest, but in the progress of the work its necessity has been amply demonstrated. The result is a substantial basis for the uniform designation of economic tropical plants in accordance with the system now followed by American botanists.

Mr. Safford is indebted to Dr. Barton W. Evermann, of the Bureau of Fisheries, for photographs Nos. 1, 20, 22, and 44, taken by Dr. Alfred G. Mayer, of the Agassiz Expedition to the Tropical Pacific, while attached to the U.S. Fish Commission steamer Albatross; to Mr. William Bengough for photographs Nos. 2, 7, 8, 23, and 60, taken by him on the island of Guam in 1900; to Lieut. Commander J. E. Craven, U. S. Navy, for photograph No. 19; to Lieut. L. M. Nulton, U. S. Nary, for photographs on plate 21 ; to Dr. Harvey Whittaker, late of the U. S. Nary, for photograph No. 24; to Mr. B. J. Howard, of the Bureau of Chemistry, U. S. Department of Agriculture, for photographs on plates 9,10 (fig. 1), 11, 12, and 13; to Mr. F. L. Lewton, of the Bureau of Plant Industry, U. S. Department of Agriculture, for photograph No. 35, taken in Johore for the Government exhibit at Chicago; to Mr. Carl S. Scofield, of the U. S. Department of Agriculture, for photographs Nos. 5,50 , and 57, taken from herbarium specimens from the island of Guam; to Mr. C. B. Doyle for photographs Nos. $3,4,10$ (fig. 2), 31, 32, 38, 40, 41, 42, 46, 47, 49, 51, 52, $53,54,56,59,61,62,6 \pm, 65,68$, from herbarium specimens, for No. 15 from the seed collection, and No. 14 from cultivated specimens, taken under the supervision of the author, and No. 17 from specimens collected in Guam by Lieut. Franck Taylor Erans, U. S. Navy; to Messrs. O. F. Cook and Guy N. Collins for Nos. 6, 25, 26, 29, 33, 34, $43,44,48,55,58$, and 66, taken in Porto Rico, Nos. 27, 30, 36, 39, taken in Guatemala, and Nos. 28 and 67, taken in Mexico; and to Mr. Guy N. Collins for Nos. 16, 37, and 63, taken in the Hope Gardens, Kingston, Jamaica. He is also indebted to Mr. Charles M. Mansfield for photograph No. 69, taken from herbarium specimens sent to the author from Guam by Rev. José Palomo.

Through the courtesy of Professor Willis L. Moore, Chief of the Weather Bureau, an account of the climatology of Guam is also presented, the detailed study of which is the work of Dr. Cleveland Abbe, jr.

Frederick V. Coville, Curator of the U. S. National Herbarium. 


\section{CONTENTS.}

Page.

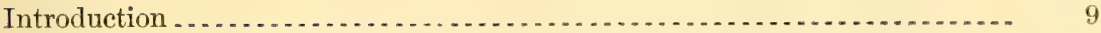

Origin and purpose of the present work, and acknowledgments......... 9

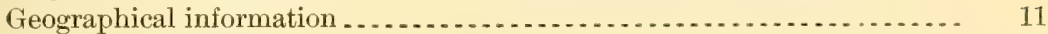

Historical notices. . . . . . . . . . . . . . . . . . . . . . . . . . . . . . . . . . . 12

Discovery of Guam and its early history .................... 12

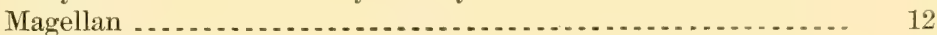

Dutch navigators ............................................ 13

Sailing routes in the Pacific . . . . . . . . . . . . . . . . . . . . . . . . . 13

Jesuit missionaries........................................... 13

Conquest of the natives ... . . . .

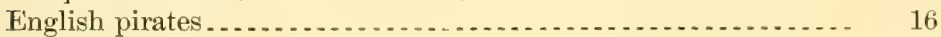

Dampier's visit. . . . . . . . .

Woodes Rogers. . . . . . . . . . . . . . . . . . . . . . . . . . . . . . . 19

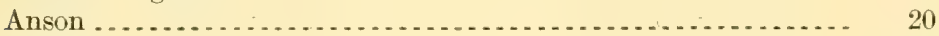

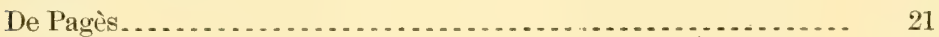

Expulsion of the Jesuits ................................ 21

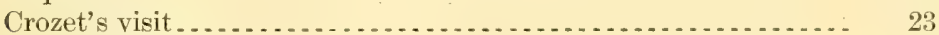

Scientific explorations of the island ... . . .

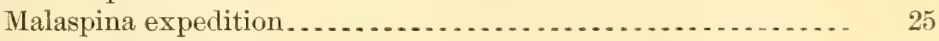

Romanzoff expedition ...................................... 28

Freycinet expedition ... . . . . . . . . . . . . . . . .

Dumont d'Urville's two visits ........................... 30

Extracts from the archives of Guam relating to its economic history - $\quad 32$

Francisco Ramon de Villalobos.......................... 33

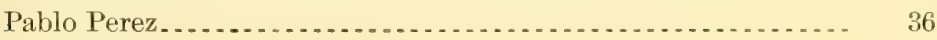

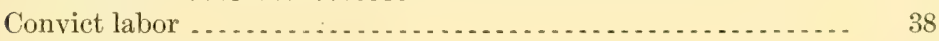

Felipe de la Corte $\ldots \ldots \ldots \ldots \ldots$

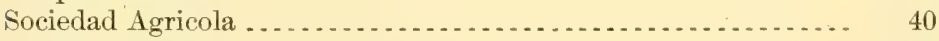

Summary ........................................... 40

Physical conditions of Guam .................................. 41

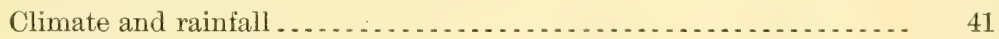

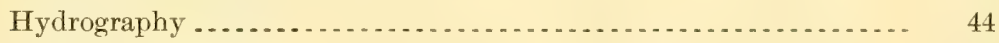

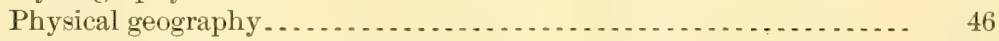

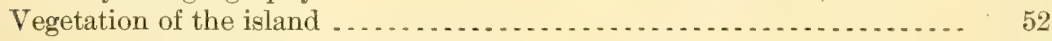

Plant covering according to habitat.............................. 52

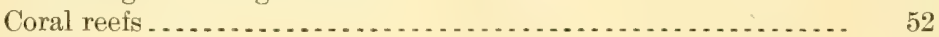

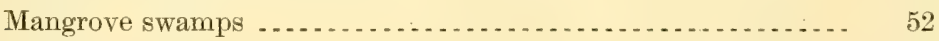

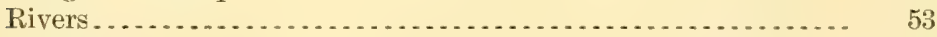

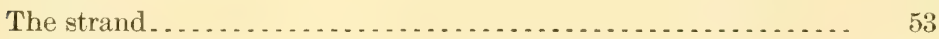

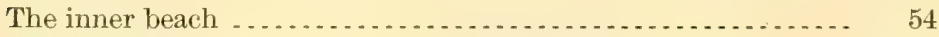

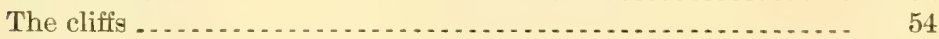

Forests . .

Marshes .............................................. 57

Savannas . . .

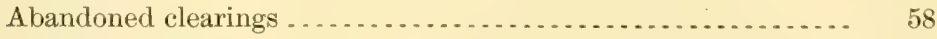

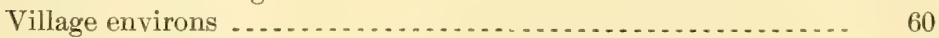

Plants of special interest ... . . . . . . . . . . . 61

Unidentified trees and shrubs ........................... 61

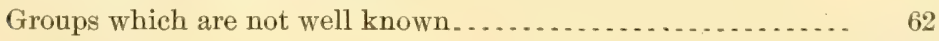

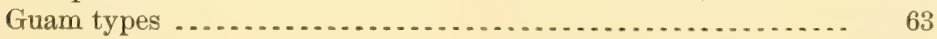


Introduction-Continued.

Pāge.

Vegetation of the Island-Continued.

Plants of special interest-Continued.

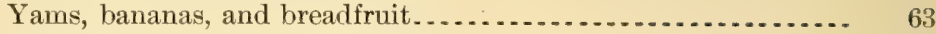

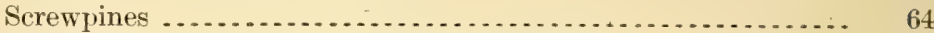

Banyans, mangroves, and epiphytes of the forest ........... 65

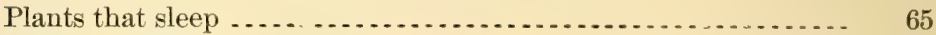

Plants which seldom bloom ...................................... 66

Plants with extrafloral nectaries. . . . . . . . . . . . . . . . . . . . 66

Plants with protective devices.......................... 68

Cycas circinalis and its fecundation ................................. 71

Dispersal of plants by oceanic currents .................... 72

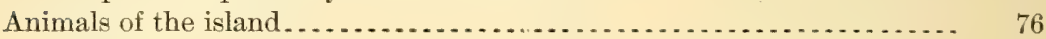

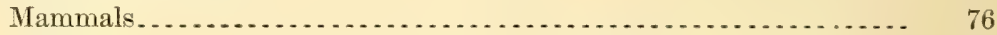

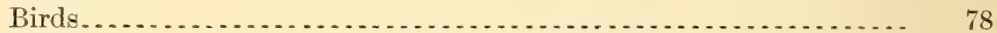

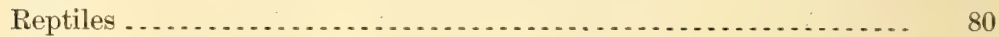

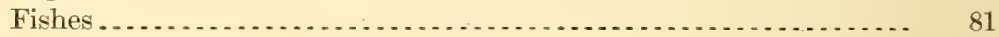

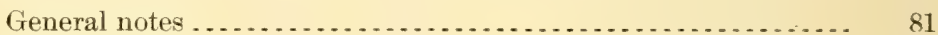

Alphabetical list of prineipal fishes ...................... 83

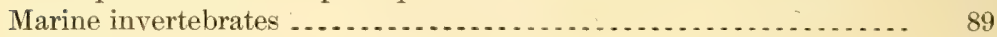

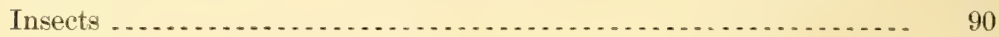

Scorpions, spiders, and centipedes ........................ 94

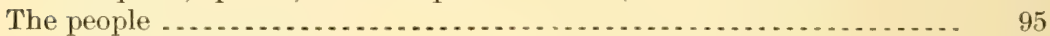

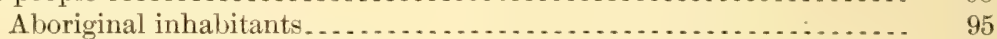

Physical characteristics................................ 95

Personal and domestic economy .......................... 96

Useful arts............................................. 100

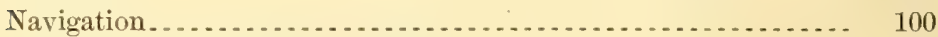

Mental and moral characteristics ........................ 102

Social institutions and customs ........................... 104

Religion and superstitions ............................ 109

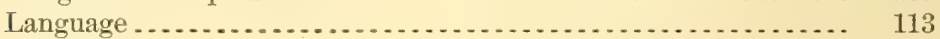

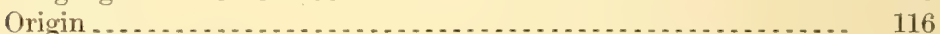

The modern inhabitants ..................................... 117

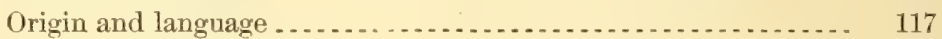

Physical characteristics . . . . . . . . . . . . . . . . . . . . . . . . 119

Personal and domestic economy ........................ 123

Useful arts.............................................. 124

Mental and moral characteristics ......................... 127

Social institutions and customs ......................... 128

Industrial system .................................... 131

Statistics of population, commerce, ete ................... 137

Standards of measure ................................... 138

Agriculture of the island ... . . . . . . . . . . . . . . . . . . . . . . . . . 139

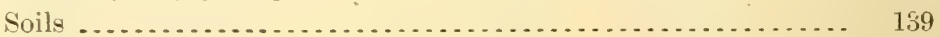

Indigenous and spontaneous economic plants................. 142

Cultivated food and stimulant plants....................... 143

Textile and thatch plants ............................... 148

Forage plants . . . .

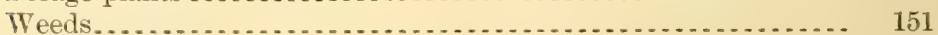

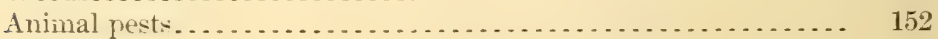

Plant names ................................................... 152

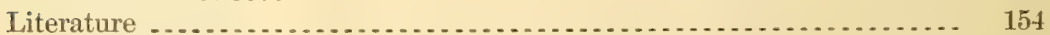

Topical sketch ............................................... 154

Alphabetical list of works consulted or cited . . . . . . . . . . . . . . 160

Descriptive catalogue of plants ............................... 170

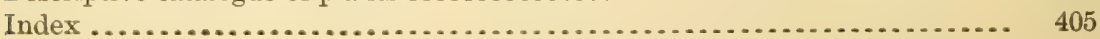




\section{ILLUSTRATIONS.}

Plate I. View of Agaña, the capital of Guam, showing raised platform of coralliferous limestone forming north half of island..... Frontispiece.

II. The forest, showing epiphytal vegetation ................ 55

III. Davallia solida, an epiphytal fern . . ..................... 56

IV. The great marsh fern, Acrostichum aureum................ 57

V. Lycopodium cerruum, a characteristic plant of the savannas ....... 57

VI. Agati grandiflora, a leguminous tree with edible flowers and pods.. 60

VII. The Agaña River, showing textile screwpine, breadfruit, and coco-

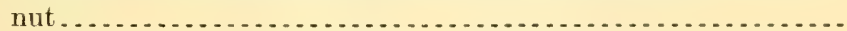

VIII. View of the forest, showing Cycas circinalis, screwpine, and roots of giant banyan . . . . . . . . . . . . . . . . . . . . . . . . . . . . . .

IX. Ricinus communis. Fig. 1. Marginal nectar glands. Fig 2. Cross section through petiole at base of leaf blade, showing extrafloral nectaries .

X. FrG. 1.-Nectar gland on midrib of cotton leaf (Gossypium sp.). Fig. 2.-Leaf of Pariti titiaceum, showing nectar gland.......... .

XI. Raphides, or needle crystals of oxalate of lime, in taro leaf........

XII. Needle cells of taro, their ends projecting into vacuoles...........

XIII. Cells of taro discharging their needles. . . . . . . . . . . . . . . . . .

XIV. Cycas circinalis, leaf and carpophyll bearing half-developed fruit ..

XV. Sea beans, showing air spaces which give them buoyancy ........

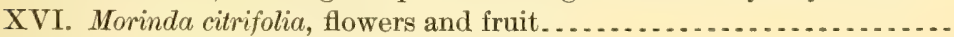

XVII. Stone adz and sling stones of aborigines . . . . . . . . . . . . . . . .

XVIII. The government house at Agaña .............................

XIX. House with thick walls of masonry and tiled roof ................

XX. Typical native dwelling, with sides of bamboo and woven reeds

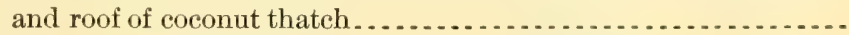

XXI. Fig. 1.-A modern oven. FIG. 2.-Evaporating salt. ............

XXII. Road from Agaña to Piti: Carabaos drawing an American wagon..

XXIII. Clearing the forest for planting . . . . . . . . . . . . . . . . . . . . . .

XXIV. A Pacific island taro patch, Caladium colocasia .................

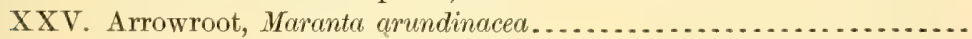

XXVI. Root of the cassava plant, Manihot manihot ...................

XXVII. Breadfruit tree, Artocarpus communis, foliage and fruit............

XXVIII. Mango tree, Mangifera indica, in full fruit.....................

XXIX. Cashew, Anacardium occidentale, half-grown fruit................

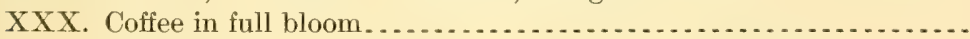

XXXI. The coral bead vine, Abrus abrus.............................

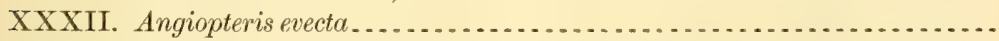

XXXIII. The sour sop, Annona muricata, flowers and fruit..............

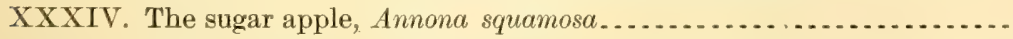

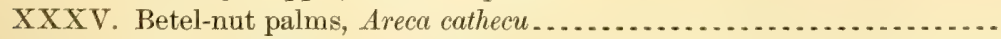

XXXV1. Fertile breadfruit, Artocarpus communis, male and female inflorescence, and young fruit ................................. 
Facing page.

Plate XXXVII. Averrhoa carambola, inflorescence and foliage........... 193

XXXVIII. Fruit of Barringtonia speciosa, a fish intoxicant........... 196

XXXIX. The arnotto tree, Bixa orellana, foliage and fruit..... . .... 199

XL. Bruguiera gymnorhiza, the many-petaled mangrove ........ 202

XLI. Casuarina equisetifolia. Male inflorescence, female inflorescence, and fruit............................. 220

XLII. Ceiba pentandra, the kapok tree. Leaf and pod.......... 221

XLIII. Cocos nucifera, the coconut tree, in bloom .............. 232

XLIV. Cocos nucifera, male flowers and female flower........... 233

XLV. Coelococcus amicarum, the Caroline ivory-nut palm ........ 244

XLVI. The ivory nut, Coelococcus amicarum .................... 244

XLVII. Cyclophorus adnascens, an epiphytal fern ............... 253

XLVIII. The wing-stemmed yam, Dioscorea alata............... 259

XLIX. The spiny yam, Dioscorea spinosa.................... 262

L. Gleichenia dichotoma, a fern growing on the savannas ..... 283

LI. Guilandina crista, the nicker nut, pods and seeds......... 288

LII. Heritiera littoralis, a strand tree, foliage and fruit......... 292

LIII. Humata heterophylla, the Umata fern ................ 295

LIV. Intsia bijuga, the ipil tree....................... 296

LV. The physic nut, Jatropha curcas.................... 301

LVI. Lens phaseoloides, the snuffbox sea bean, pod and inflorescence ............................................ 308

LVII. Lycopodium phlegmaria, an epiphytal clubmoss.......... 313

LVIII. Moringa moringa, the horse-radish tree............... 327

LIX. Ochrocarpos obovalis, an important hard-wood tree ........ 335

LX. Pandanus fragrans, a screwpine growing in jungle......... 344

LXI. Pariti titiaceum, the only source of cordage on the island ... 346

LXII. Phymatodes phymatodes, the oak-leaf fern................ 352

LXIII. Piper betle, the betel pepper ......................... 354

LXIV. Rhizophora mucronata, the four-petaled mangrove ....... 364

LXV. Stemmodontia canescens, a strand plant ............... 377

LXVI. Tamarindus indica, the tamarind. Foliage and fruit....... 383

LXVII. Theobroma cacao, the chocolate plant. Inflorescence...... 387

LXVIII. Tournefortia argentea, a characteristic strand shrub........ 390

LXIX. Xiphagrostis floridula, sword-grass. Spikelets and portion of leaf blade, magnified so as to show cutting teeth.....

LXX. Map of the island of Guam........................ 


\title{
THE USEFUL PLANTS OF THE ISLAND OF GUAM.
}

\author{
By Wilimam Edwin Safford.
}

\section{INTRODUCTION.}

\section{ORIGIN AND PURPOSE OF THE PRESENT WORK, AND ACKNOWLEDGMENTS.}

During a series of cruises in the Pacific Ocean the routine of my official duties was pleasantly broken by frequent excursions on shore for the purpose of collecting material for the United States National Museum, as well as for recreation. While sitting in native huts and while wading upon coral reefs, traversing forests and climbing mountains, I interested myself in taking notes on the languages and customs of the natives, their arts, medicines, food materials and the manner of preparing them, and the origin of their dyes, paints, fibers for fishing nets and lines, materials for mat making and thatching, woods used in constructing their houses and canoes, and gums and resins used in calking.

In attempting to identify many of the plants entering into their economy, I felt the need of some popular work containing the common names of the more important species in various island groups, together with their deseriptions and the uses to which they are applied in various parts of the world, the methods of their cultivation, and the processes of preparing the commercial staples which they yield. Some information of this nature may be derived from accounts of missionaries, travelers, and explorers, but our ship's library was woefully lacking in such works, and much of the information contained in the books which were available was incomplete and untrustworthy. Works of a scientific nature, such as the Botany of the Challenger Expedition, though discussing the geographical distribution of strand plants and the means of their dissemination, I found to contain only lists of names which were useful in comparing island floras, but did not serve in any way to identify the plants in which I was interested. Others, like Seemann's Flora of Fiji, were too rare and expensive to be placed in the library of an ordinary man-of-war, and could be consulted only during visits to San Francisco or Honolulu. Moreorer, 
though frequent mention is made of the uses of plants in this work, the descriptions are in Latin, and the book is not available to the arerage lay student. It occurred to me, therefore, that a popular work on the useful plants of Polynesia would be welcome, and I set out accordingly to gather together such information as I could for this purpose. Many of the plants with which I became familiar I encountered on widely separated shores. Some of them I found bearing the same name on islands whose inhabitants have had no intercommunication within historic times. These and kindred facts opened up an alluring field of ethnological inquiry as to the origin and dispersal of the inhabitants of the myriads of islands which dot the Pacific, a subject upon which I shall enter in an initial way during the course of this work."

It gives me great pleasure to acknowledge the valuable assistance I have receired in the preparation of this work from Mr. Frederick V. Coville, Botanist of the United States Department of Agriculture; Mr. O. F. Cook, Mr. Guy N. Collins, and Mr. F. L. Lewton, of the office of tropical agriculture, and the lite Mr. Henry E. Baum. I am indebted to Mr. Carl s. Scofield and Mr. Thomas H. Kearney for aid and suggestions during its progress, and to Messrs. Lyster H. Dewey, Rodney H. True, and V. K. Chesnut for references relating to the fiber plants, mediciual plants, and poisonous plants included in my lists. Acknowledgments are also due to Dr. H. W. Wiley and Mr. B. J. Howard, of the Burean of Chemistry, Department of Agriculture, for investigations as to the cause of the acridity of the taro plant and for fine micro-photographs showing the raphides, or needles of oxalate of lime, found in its leaves; also for beautifui representations of extrafloral nectaries of Ricinus and Gossypium.

For notes on the agriculture of the island I am indebted to Don Justo Dungea and Don Antonio Nartinez, citizens of Guam, and for botanical material forwarded to me since my departure from the island to Rev. José Palomo and Mr. Atanasio T. Perez.

In the determination of flowering plants I have been assisted by Mr. E. S. Steele and Mr. Philip Dorrell, and of cryptogams by Mr. William L. Maxon, of the National Herbarium.

In conclusion, I wish to express my thanks to Mr. E. S. Steele and Mr. F. L. Lewton for their great assistance in preparing this work for publication and in helping me to correct the proof sheets. In submitting it I renture to express the hope that it may fill a want not only of travelers and students of botany, but also of settlers on tropical islands and in other warm regions of the globe; and I trust that it may be of some use to merchants and manufacturers seeking new sources of tropical staples and raw materials. 


\section{GEOGRAPHICAL INFORMATION.}

Guam, the largest and most important of the group known as the Ladrones or Marianne Islands, is situated in the Pacific Ocean about 1,200 miles east of the Philippines. The group forms a chain 420 miles long, extending from latitude $20^{\circ} 30^{\prime}$ north, longitude $143^{\prime}+6^{\prime}$ east, to latitude $13^{\circ} 14^{\prime}$ north, longitude $142^{\circ} 31^{\prime}$ east. Beginning at the north, the names of the islands are Farallon de Pajaros, Las Urracas (Maug), Asuncion (Asomsom), Agrigan, Pagan, Alamagan, Guguan, Sariguan, Anatahan, Farallon de Medinilla, Saipan, Tinian, Aguigan, Rota (Luta), and Guam or Guáhan. ${ }^{a}$ Guam is the only island belonging to the United States. The rest were sold by Spain to Germany at the close of the late war. The seat of the German Government is on the island of Saipan, where there is a colony of Caroline Islander', besides a small population of Marianne natives.

The islands are of volcanic origin and are fringed with coral reefs. In the southern members of the group there are no active volcanoes, but on several of the northern islands there are still a number of smoking craters. Guam and Samoa lie in corresponding latitudes on opposite sides of the equator, and their climates are much alike. Their flora and fauna have many features in common, and many of the plants used in the economy of the natives are the same. The inhabitants of the two groups, however, though both of the Oceanic race (allied to the Malayan), belong to different grand divisions of it and have distinct languages and few traditions in common. Guam is considerably larger than Tutuila, the most important of the Samoan Islands owned by the United States, though its chief port, San Luis de Aprâ, can not be compared with Pango-Pango, our naval station in the South Pacific, and perhaps the finest harbor in the world. The advantage of Guam as a station for repair's and supplies is erident, forming, as it does, a stopping place for vessels between Hawaii and the Philippines. Its strategic importance has been greatly enhanced since it has been made the landing place of the trans-Pacific cable, and the completion of the Panama Canal will make it still more valuable to our Government.

The extreme length of the island from north-northeast to southsouthwest is 29 statute miles. Its width is from 7 to 9 miles, narrowing at the middle to a neck only 4 miles across. On the northwest coast of this neck is situated Agaña (Hagadña), the capital, a city of over 6,000 inbabitants. (Pl. LXX.) The entire population of the island, according to the census of 1901 , was $9,676 .^{b}$

$a$ For the pronunciation of vernacular names, see p. 170.

bThis indicates the number of actual residents on the island and does not include visitors nor the Government forces of the United States stationed there. 


\section{HISTORICAL NOTICES.}

\section{DISCOVERY OF GUAM AND ITS EARLY HISTORY.}

\section{MAGELLAN.}

The island of Guam was discovered on March 6, 1521, by Magellan, after a passage of three months and twenty days from the strait which bears his name. An account of the privations and suffering of his crew, many of whom died on the way across the hitberto unexplored ocean, is graphically given by Antonio Pigafetta, Magellan's historian. He describes how the expedition arrived at Guam with the crews suffering from scurvy and in a starving condition, having been compelled on the passage to eat rats and even the leather from off the standing rigging to keep soul and body together. In comparison with Magellan's feat of crossing the vast Pacific the first voyage of Columbus, from the Canary Islands to the West Indies, seems insignificant. The natives of Guam came out to meet the Spaniards in strange "flying praos" (canoes provided with outriggers and triangular sails of mats). The Spaniards had dropped anchor, furled their sails, and were about to land, when it was discovered that a small boat which rode astern of the flagship was missing. Suspecting the natives of having stolen it, Magellan himself went ashore at the head of a landing party of 40 armed men, burned 40 or 50 houses and many boats, and killed 7 or 8 natives, male and female. He then returned to his ship with the missing boat and immediately set sail, continuing his course to the westward.

Before we went ashore [says Pigafetta] some of our people who were sick said to us that if we should kill any of the natives, whether man or woman, that we should bring on board their entrails, being persuaded that with the latter they would be cured.

When we wounded some of those islanders with arrows, which entered their bodies, they tried to draw forth the arrow now in one way and now in another, in the meantime regarding it with great astonishment, and thus did they who were wounded in the breast, and they died of it, which did not fail to cause us compassion.

Seeing us take our cleparture then, they followed us with more than a hundred boats for more than a league. They approached our ships, showing us fish and feigning to wish to give them to us, but when we were near they cast stones at us and fled. We passed under full sail among their boats, which, with greatest dexterity, aroided us. We saw among them some women who were weeping and tearing their hair, surely for their husbands killed by us.

The natives did not fare much better at the hands of later visitors. Some of the early navigatorsenticed them on board and made slaves of them, so that they might man the pumps and keep the ships free from water." They were spoken of as "infidels," to slay whom was no great sin; but if encounters took place between them and Europeans and a white man was killed, he was declared to have been murdered, 
and his death was avenged by the burning of villages, boats, and boathouses, and by killing men, women, and children." They were branded by their discoverers with the name of ladrones (thieves) for stealing a boat and some bits of iron. The early navigators themselves did not hesitate to steal husbands from their wives and fathers from their children.

DUTCH NAVIGATORS.

Among the Dutch who visited the island was Oliver van Noort, who touched at Guam in 1600 on his way from the South American coast to Manila. About 200 canoes came off to meet him, bringing fish, fruit, rice, fowls, and fresh water to exchange for iron. He was followed in 1616 by the Duteh admiral, Joris Spilbergen, in command of a fleet fitted out by the Dutch Company, which was on its way to the Moluceas by the westward route; and in 1625 by the Nassau fleet, organized in Holland against Peru, and commanded by Jacob l'Heremite. One hundred and fifty canoes came off to meet them, to traffic with coconuts and yams. The fleet watered at the island, and in exchange for iron procured rice, fowls, coconuts, yams, and bananas. Coconuts were observed in inexhaustible quantities; rice was cultivated in many places, and the natives sold it by weight in bales of seventy to eighty pounds each. The Hollanders considered it unsafe for their men to ramble about the island singly or unarmed.

SAILING ROUTES IN THE PACIFIC.

Guam was reckoned seventy days from New Spain, as Mexico was then called. After the founding of Manila regular traffic was established between the coast of Mexico and the Philippines. The first port selected as a place of departure on the Mexican coast was Navidad, but Acapulco was substituted later. The vessels would leave Mexico each year in February or March, shaping their course a little to the southward until they reached the latitude of Guam, when they would continue due west until they reached that island. This season was chosen in order to avoid the westerly monsoon in the Philippines, which usually sets in about the middle of June. The vessels returned by a northerly route in order to avoid the trade winds and the adverse equatorial current. Both the Mariannes and the Philippines were made dependencies of New Spain and were ruled by the viceroy residing at the City of Mexico.

JESUIT MISSIONARIES.

On his way from New Spain to the Philippines in one of the regular vessels, Padre Diego Luis Sanvitores, a Jesuit priest, touched at Guam and was moved to pity at the sight of the natives living in spiritual

a See narrative of the expedition under Miguel Lopez Legazpi, which visited Guam $\mathrm{i}_{\mathrm{n}}$ 1565, in Burney, Chron. Hist., vol. 1. 
darkness in the midst of an earthly paradise. An account of his life and martyrdom is given in an old vellum-covered book, ${ }^{a}$ in which much interesting information may be found concerning the natives of Guam. In it, in contrast with the barbarous cruelty with which the natives had been treated by visiting Europeans, one may read of their kindness to shipwrecked sailors cast upon their shores, and of the cordial reception of Padre Sanvitores. They provided homes for him and his companions and built for them a church. All wished to be baptized forthwith, though the missionaries would at first baptize only the infants and dying persons; adults in good health had to be instructed in the Christian doctrine before they could enjoy the privilege.

In this book many wonderful occurrences are related-stories of supernatural apparitions, of miraculous cures of men possessed of the devil, of lances, cast by the natives, suddenly arrested in mid-air, and of stones hurled from their slings crumbling harmlessly to dust; but it must not be forgotten that this was an age of marvels. The devil's influence in the affairs of everyday life was recognized throughout Christendom, and it is not surprising that it found its way to Guam. It was to the power of the evil one over the elements that the early missionaries attributed the adverse winds, which blew almost constantly to the westward and prevented ships from sailing directly to Guam from the Philippines.

Sanvitores, "the Apostle of the Mariannes," was born in the city of Burgos, in northern Spain, Norember 12, 1627. The history of his life tells of his early boyhood, his call to the Society of Jesus and ordination, his work among the poor, his journey to Mexico; his departure from Acapulco, April 5, 1662, for Manila; the impression made upon him by the natives of Guam, whom he saw on his passage across the Pacific; his efforts to be sent to them as a missionary, the refusal of his superiors at Manila to grant his request, the King's decree ordering the gorernor of the Philippines to furnish him with the means of reaching the Mariannes, the building of the ship San Diego at Carite and his sailing therein to Acapulco, bis appeal for aid to the viceroy of Mexico, his arriral at Guam, March 3, 1668, his emotion on seeing the islanders coming out to meet him, the kindness with which they welcomed him to their island, the zeal with which he pursued his work, the hardships which he had to endure, and his final martyrdom.

The first serious stumbling block in the way of the missionaries was a C'hinaman named Choco, living in the village of Paa, at the southern end of the island. This man had been shipw recked about twenty years before their arrival, and had been kindly received by the natives. He pointed out to the islanders that many children and old people had died immediately after having been baptized. He spoke slightingly of the padres, saying that they were people despised and looked down 
upon by the Spaniards themselves, who for that reason had sent them into exile on this island; and he said that surely the water used in baptism was poisonous, though some of the more robust upon whom it was poured might resist its effects. As it was indeed true that many of those baptized had died shortly after the performance of the rite, and as the missionaries thought them happy in dying thus secure of salvation, it seemed to the natives that there might he truth in the Chinaman's charges. Henceforward, instead of receiving the missionaries joyfully in their villages and retaining them as guests almost against their will, the natives greeted them with scowling faces, and, calling them murderers, threatened them with their spears. They no longer offered them breadfruit, as had been their custom, and mothers on their approach would catch up their infants and fly with them to the woods for safety; or if the little ones were sick or dying, they would conceal them in their houses as best they could." In their zeal the missionaries would often baptize children in spite of the threats of the fathers and the tears and prayers of the mothers. Moreover, they awakened the enmity of the makahnas, or wise men, whom they declared to be imposters; they assailed the liberty of the uritaos, or bachelors, by their efforts to abolish the "great houses" of the villages, in which they lived with unmarried women; they tried to change the marriage customs, according to which the parents received presents from the bridegrooms for their daughters; they tried to put an end to the invocation of the aniti, or spirits, and taught that it was wrong to venerate the relics of ancestors.

Less than two years after the arrival of the missionaries in the islands, on January 29, 1670, a priest was killed on the island of Saipan for having baptized a child in spite of the protests of its parents; ${ }^{b}$ and on April 2, 1672, in Guam, Padre Sanvitores met his death in the same way.

CONQUEST OF THE NATIVES.

A war of extermination now began, which lasted twenty-three years, suspended from time to time when the Spaniards found themselves too weak to continue it, but resumed at the arrival of each ship bringing reinforcements, no matter whether in the meantime peace with the natives had been declared or not. Often whole villages were punished for the act of a single man, and innocent natives who had committed no crime whatever were shot down wantonly. ${ }^{c}$

Much did the evangelical ministers regret these excesses of the fervors of the new soldiers [says Padre Garcia], which, with the lack of experience and too great desire to make themselves feared, placed in jeopardy all Christianity; for the Indians retired from their villages to others more distant from Agadna, and it was feared with reason that the whole island would form a confederation against the Spaniaxds 
anci padres as against homicides, who, the ones with haptism, as many natives already said, and the others with arms, came to take the lives of themselves and their children. Padre Solano, calling together the soldiers of the post, declared to them that though arms used in their proper time and season were the defense of that Christianity, yet wielded intempestively they would be its destruction, since they would not only irritate with reason the Indians, but would become unworthy of the favor of the Lord, without which what could twenty or thirty men do against thirty thousand? For thus far only the barbarians' dread of firearms had protected the mission, and if this were lost the multitude could not be withstood. That they would lose this dread with their constant use, even at the price of injuries to themselves, and if they once rushed upon the arms they might seize them, and with these in their possession our defense would be converted into our injury. He charged the soldiers very particularly that in the southern part of the island, where the only villages were in which the missions were unhampered, they should abstain from all hostility, so as not to hinder the only harvest which at that season could be gleaned, and not to make enemies of those whom they now held as friends. The soldiers approved the discourse and promised to confine themselves within the limits of justice and prudence. $a$

It is not the province of these notes to give a detailed account of the uprisings of the natives and the methods taken by the various governors and military commander's to quell them. The yearly reports of the missionaries tell of the flight of the natives from island to island, pursued by their conquerors, whose arquebuses and arrows they resisted with their simple slings and spears as best they could, and of their reconcentration on the island of Guam, where they were stricken by an epidemic which almost exterminated them.

Moreover [says one of these writers], $b$ this diminution was caused greatly by the repugnance with which they hore a foreign yoke-lovers ever of all the latitude which their primitive freedom permitted them-and this burden weighed so heavily upon their haughtiness, laziness, and barbarity that some even sacrificed their lives in despair; and some women either purposely sterilized themselves or cast into the waters their new-horn infants, believing them happy to die thus early, saved from the toils of a life gloomy, painful, and miserable. In all the dominions of Spain there is no nation more free from burdens, since they pay no tribute to the King - a common custom in all nations - nor do they give to the church the fees which are given throughout Christendom; but, as they see not what the rest suffer, they judge that subjection is the worst misery of the world.

ENGLISH PIRATES.

Two vears after the publication of Padre Garcia's account of the island, on March 15, 1685, the English pirates, Eaton and Cowley, anchored at Guam. Ther found the governor, Don Damian Esplana, in a state of uneasiness owing to the hostile attitude of the natives, who, under a chief named Yura, had risen against the Spaniards less than a rear before. had wounded the governor and killed several missionaries and a number of soldier's. Cowler describes in his narrative

a Garcia, Vida y Martyrio de Sanvitores, p. 47.

b Murillo Velarde, Historia, Libro IV, 1749; Fray Juan de la Concepeion, Hist. Gen., Tomo VII, p. 348, 1788-92. 
how the ship was received by the natives, who brought them "potatoes, mananoes, coconuts, and plantains, selling them to us for old nails and old iron. But they being treacherous, we trusted them not; for we had always our small arms ready, and great guns loaden with round ball and cartridges. Sometimes we would have our deck full with these infidels; but we were always in arms, having our swords and pistols by our sides, with some Centinels standing abaft before them." Some of the Englishmen having gone fishing with the natives, the latter surrounded the boat by a seine, as though to draw it ashore together with its crew. The bucaneers in the boats being provided with firearms-

let go in amongst the thickest of them and killed a great many of their number, while the others, seeing their mates fall, ran away. Our other men which were on shoar meeting them, saluted them also by making Holes in their Hides. We took our Boat immediately thereupon, and went on board, most of our well men being on shoar, and seeing many of these Infidels' boats lie along our ship's side, did not know what design they might have on board [against] our sick men; but as it fell out, they were Boats which came from the governor, with more presents for our refreshment. ****

We took four of these infidels Prisoners, and brought them on board, binding their hands behind them; but they had not been long there, when three of them leaped over board into the sea, swimming away from the ship with their hands tied behind them. However, we sent the boat after them, and found a strong man at the first Blow could not penetrate their skins with a cutlace: One of them had received, in my judgment, 40 shots in his body before he died; and the last of the three that was killer, had swam a good English mile first, not only with his Hands behind him, as before, but also with his Arms pinion'd.

The governor gave carte blanche to the pirates to kill as many natives as they pleased and even rewarded them with presents of hogs, pumpkins, green stuff, "potatoes," and rice; after which they saluted him with three guns and sailed away. ${ }^{a}$

DAMPIER'S VISIT.

The following year, on May 20, 1686, Captain Swan arrived at Guam, accompanied by Dampier, ${ }^{b}$ who gives in the first volume of his voyages an excellent account of the island, its products, the inhabitants, and their wonderful canoes, which he "did believe to sail the best of any Boats in the World."

Under the above date he writes as follows:

At 4 a Clock, to our great Joy, we saw the Island Guam, at about 8 leagues distance. It was well for Captain Swan that we got sight of it before our Provision was spent, of which we had but enough for 3 days more; for, as I was afterwards informed, the Men had contriverl, first to kill Captain Swan and eat him when the Vituals was gone, and after him all of us who were accessary in promoting the undertaking this Voyage. This made Captain Swan say to me after our arrival at Guam, Ah! Dampier, you, would have made them but a poor Meal; for I was as lean as the Captain was lusty and fleshy.

a Cowley's voyage, in Dampier's Voyages, vol. 4, 1729.

hA new Voyage Round the World, by Capt. William Dampier, vol. 1, p. 283, 1717. $9773-05-2$ 
Dampier's accurate descriptions of the breadfruit and the coconut are given further on, in the Alphabetical list of useful plants, under the headings Artocarpus communis and Cocos nucifera. Of the breadfruit he says: ${ }^{a}$

I did never see of this Fruit any where but here. The Natives told us, that there is plenty of this Fruit growing on the rest of the Ladrone Islands; but I did never hear of it anywhere else.

\section{And of the coconuts he says: ${ }^{b}$}

These at Guam grow in dry ground, are of a middle size, and I think the sweetest that I did ever taste.

Dampier relates that when the natives were repulsed by the Spaniards in the recent uprising they destroyed the plantations and stock, and those implicated in the conspiracy then went to other islands. As for the remaining ones, if they were not actually concerned in that broil, yet their hearts were also bent against the Spaniards, for they offered to carry the Englishmen to the fort and assist them in the conquest of the island; but Captain Swan was not for molesting the Spaniards here, as it was to his interest to use the island as a base for supplies. At this time there were at Guam only the governor, twenty or thirty Spanish soldiers, and two or three priests.

Captain Swan detained a priest who came off to visit his ship, and requested him to write a letter to the gorernor stating that the English had come to the island not in any hostile manner, but as friends to purchase with their money what they wanted. He sent a present to the governor of 4 yards of scarlet cloth and a piece of silver and gold lace. The gorernor replied to the letter at once, complimenting Captain Swan for his present and promising as much provision as he could possibly spare.

As a token of his gratitude he sent a present of 6 Hogs of a small sort, most excellent Meat, the best I think that erer I eat [says Dampier]. They are fed with Coconuts, and their flesh is hard as Brisket Beef. They were doubtless of that breed in Americe which came originally from Spain. He sent also 12 Muskmelons, larger than ours in England, and as many Water-melons, both sorts here being a very excellent Fruit; and sent an order to the Indians that lived in a Village not far from our Ship, to bake every day as much of the Bread-fruit as we did desire, and to assist us in getting as many dry Coco-nuts as we would have; which they accordingly did, and hrought off the Bread-fruit every day hot, as much as we could eat. After this the Governour sent erery day a Canod or two with Hogs and Fruit, and desired for the same Powder, Shot, and Arms; which was sent according to his request. * * *

The 30th day of May, the Governour sent his last Present, which was some Hogs, a Jar of pickler Mangoes, a Jar of excellent pickled Fish, and a Jar of fine Rusk, or Bread of tine Wheat Flower, baked like Bisket, hut not so hard. He sent besides, 6 or 7 packs of Rice, desiring to be excused from sending any more Provision to us, saying he had no more on the Islaml that he could spare. He sent word also, that the West Ionsoon was at hand, that therefore it behoover us to be jogging from 
hence, unless we were resolverl to turn back to America again. Captain S'swan returnerl him thanks for his kindness and advice, and took his leave; and the same day sent the Frier ashoar that was seized on our first arrival, and gave him a large Brass Clock, an Astrolabe, and a large Telescope; for which Present the Frier sent us aboard six Hogs, and a roasting Pig, 3 or 4 Bushels of Potatoes, and 50 pounds of Innilu Tobaceo. Then we prepared to be gone, being pretty well furnished with Provision to carry us to Mindanao, where we designed next to touch. We took aboard as many Coco-nuts as we could well stow, and we had a good stock of Rice, and about 50 Hogs in salt. $a$

WOODES ROGERS.

On March 11, 1710, the celebrated English privateer Woodes Rogers arrived at Guam, accompanied by Alexander Selkirk, whom he had recently rescued from the island of Juan Fernandez, in the South Pacific. The English were in pretty bad condition. Their provisions were nearly exhausted, and many of them were sick and suffering from wounds received in battle with the Spaniards on the American coast. Rogers had with him a prize, Nuestre Señore de la Incarnacion, the name of which he had changed to the Batchelor Frigate. He carried with him considerable booty in the form of money, jewels, and fabrics taken from the natives of Guayaquil and other Spanish-American towns recently sacked by him, and among his prisoners were several officers of the recently captured prize. To the governor of Guam (Don Antonio Pimentel) Rogers and his associates wrote the following letter:

Srr: IVe being Servants of her Majesty of Great Britain, and stopping at these Islands on our Way to the East Indies, will not molest the settlement; provided you deal fairly with us. We will pay for whatever Provisions and Refreshments you have to spare, in such manner as best agrees with your Conveniency, either in Money or any Necessaries you want. But if after this civil Request you deny us, and do not act like a Man of Honour, you may immediately expect such Military Treatment, as we are with ease able to give you. This we thought fit to confirm under our Hands, recommending to you our Friendship and kind Treatment, which we hope you'll esteem, and assure yourself we then shall be with the strictest Honour

Your friends and humble Servants,

W. ROGERS.

S. Courtney.

Е. Сооке.

To the Honourable Governor of THE Island of Guam.

MARCH 23, 1709 (1710).

As the governor had no adequate means of resisting the English, he supplied them with provisions. Courtesies were interchanged, the spaniards entertaining the English on shore and accepting their inritation to entertainments on board the ships. Rogers presented to the governor two negro boys "dressed in liveries," 20 yards scarlet clothserge, and 6 pieces of cambric, "which he seemed wonderfully well pleased with." The ships were supplied with 60 hogs, 99 fowls, 24 
baskets of Indian corn, 14 bags of rice, 44 baskets of yams, and 800 coconuts. Fourteen bullocks, described as "small and lean," were distributed among the ships, and each ship was given 2 cows and calves. The English took receipts from the Spanish for their presents, and gave to them certificates "to show to any English that they had parted friendly." They sent ashore an old Spaniard whom they held as prisoner and got a receipt for him.

In Woodes Rogers's Narrative he gives the population of the islands and various other data. Among the fruits were oranges, lemons, citrons, muskmelons, and watermelons, which were brought hither by the Spaniards. The orange trees were thriving well. Cattle were plenty, but were small and poor. Much indigo was seen growing wild and not utilized. Money was scarce. The 200 soldiers were paid once a year in money brought from Manila, the ship bringing their pay carrying also clothing, sugar, rice, and liquors. These articles being sold on the island, the ship usually returned to Manila with most of the money she had brought. On this account the natives were planting rice and making other improrements in their agriculture. The hogs were described as "the best pork in the world, because they are fed altogether on coconuts and breadfruit, which are plentiful here."

The Spaniards were marrying with the natives. The Indians are described as tall, strong, and dark-colored, the men wearing no clothing but a breech clout and the women wearing little petticoats. The natives were skillful in slinging stones, which they made of clay, of an oval form, burning them till as hard as marble. They were such good marksmen that the Spaniards said they seldom missed hitting any mark, throwing a projectile with such force as to kill a man at a considerable distance. They also had lances, made of coconut wood. One of the flying praos of the natives was presented by the governor to Woodes Rogers, who gives a detailed description of it in his Narrative. ${ }^{a}$

The governor of Guam, Don Antonio Pimentel, was afterwards tried by the Spanish authorities for giving aid and comfort to the English. A copy of the proceedings now in the archires at Agaña, dated 1720, is marked "Causa formada en virtud de Real provision á Don Juan Antonio Pimentel, Gobernador de estas islas Marianas, sobre la acogida y refresco que dió á los Piratas, que apresaron la Nao Almiranta Irestra Señora de la Encapacion de la carrera de Acapulco."

A.sox.

Among the other travelers to visit the Marianne Islands was Anson, the famous cireumnarigator, who stopped at Tinian for repairs in 1742 , the same year that he captured the treasure-laden galleon from 
Acapulco, on which was found the chart containing, as far as is known, the first indication of the existence of the Hawaiian Islands. "Anson had been sent from England in 1740 to annoy the Spaniards in the South Seas. After having lost most of his men from scurvy, he crossed the Pacific in the only remaining ship out of his squadron of eight vessels, the Centurion. He found the island of Tinian nearly deserted and overrun with wild cattle and wild hogs. He gives a glowing account of the beauty of the island, but this was declared by Byron, who afterwards visited the island, to be overdrawn.

DE PAGÈS.

In 1768 Guam was visited by the French traveler, De Pagès, who was a passenger on the galleon that brought Don Enrique de Olavide $y$ Michelena. Don Enrique was about to begin a second term as governor of the Mariannes, relieving Don José de Soroa. In De Pagès's narrative $^{b}$ he gives a vivid account of his trip from Acapulco to Guam, describing the conditions on board the galleon, the character of the passengers and cargo, the courses steered, and the weather encountered. At Guam he saw the breadfruit for the first time, and he speaks of the habit of betel chewing, to which the natives were addicted, describing the areca nut and the betel pepper. As an illustration of the isolated state of Guam, he states that it had been eight years since a vessel from Manila had touched at the island.

EXPULSION OF THE JESUITS.

A year after the arrival of Olavide the Jesuit missionaries were expelled from the Mariannes by the edict of the King of Spain, Carlos III, dated February 27, 1767. It was this King who joined France in sending assistance to the American colonies during their struggle for independence. The Jesuits had been in the islands for a century, and whatever may have been the harsh means by which they were established there, they had won the love and confidence of the natives, and were kind and just in their dealings with them, protecting them when necessary against acts of cruelty, injustice, and oppression on the part of the military authorities, ${ }^{c}$ and never exacting services from them without due compensation. A school for the education of native children had been established shortly-after the death of Padre Sanvitores under the name of "Colegio de San Juan de Letran," and had been endowed with a fund yielding 3,000 pesos a year by Maria Anna

a See Lord Anson's Voyage Round the World, 1748.

$b$ De Pagès, Travels Round the World (English translation), 1791.

${ }^{c}$ Among the official papers in the archives at Agaña are the proceedings of sereral "residencias," or courts of inquiry, held at Agaña for the trial of governors and officers composing their staff. In these trials the padres represented the interests of natives who might have cause for complaint against the authorities. 
of Austria, in whose honor the islands were named. The Jesnits taught not only the Christian doctrine and the elements of learning, but many useful arts as well. They also instructed the native youths in music, as is shown by the inventory of their effects and the testimony of travelers visiting the island shortly after their expulsion. They had several farms in flourishing condition, the finest of which was that of Tachogña, in the interior of Guam, between Agaña and Pago. On this farm, called "San Ignacio de Tachogña," they had a fine herd of cattle, and elsewhere they had a stallion and a number of brood mares. They were in constant communication with missions of their order in other countries, receiving fabrics from New Spain as well as from China and Manila, spices from Ceylon, and tobaceo from Mexico. Under their superrision the natires learned to cultivate maize, tobacco, cacao, sweet potatoes, and other plants brought from America, and in the inventories, besides a supply of garden implements called "fosiños" (thrust hoes), new machetes for clearing the forest, and other implements, were found steel, iron, and blacksmith's tools, tan bark and rats for tanning, carpenters' tools, saws, crowbars, pickaxes, paints, stones for grinding pigments, "metates" and "manos," like those of the Mexicans for converting maize into tortillas, and material and instruments for making ornaments for their altars. The young lieutenant of the armada who brought the order for their expulsion had been instructed to take away in his schooner the Jesuits, together with all their belongings. Realizing that this would be impossible, he made an official statement in writing to the governor, saying that his little schooner, with a single deck, could not accomplish the task; that it would require sereral two-decked ressels much larger than his own to take away all the belongings of the Fathers. Nevertheless, on Norember 2, 1769, the schooner Nuestre Señora de Greadulupe, which had brought the decree of banishment, sailed awar from Guam, currying the Fathers, together with as many of their personal effects as possible. Many of their papers were burned. In the inventory of their effects in the archives at Agana is a list of letters, copies of memorials, manuscript sermons, and books. Eren the lay brother in the kitchen, who acted as procurador, had a library of his own. On the arrival of the decree the senior of the missionaries, Padre Xarier Stengel, was absent, having gone to the neighboring island of Rota to hear confessions and administer the annual communion to the natives. A canoe was sent to bring him. As one of the Father's had died sometime before the arrival of the decree, it was neceswary to carry back a certified statement of his death and burial to account for his not sailing with the others.

After the Jesuits' departure the farms were neglected, the cattle, now the property of the C'rown, ran wild, and many animals were killed by the natives. as may be seen in the records of trials in the 
archires. The spiritual administration of the islands was handed over to friars of the order of St. Augustine, who had come as passengers on the schooner bringing the decree. This religious order continued on the island until its seizure by the United States.

CROZET'S VISIT.

The next governor of the Mariannes, Don Mariano Tobias, has been immortalized by the Abbé Raynal in his Histoire et politique des établissements et du commerce des Européens dans les deux Indes. Raynal hated the tyranny and injustice with which primitive nations were so often treated, and believed that the rights of individuals should be considered even though their skins might be brown and their clothing scant. He called attention to glaring acts of cruelty and oppression perpetrated by European nations upon the natives of newly colonized countries. In consequence of his bold accusations his book was condemned to be burned (May 29, 1781), and he was obliged to fly from France.

An interesting account of the island during Tobias's administration is given by Crozet, who visited Guam September 27, 1772. ${ }^{a}$ Crozet was an officer of the expedition of the French navigator MarionDufresne, which left Mauritius on a voyage of discovery in the South Seas. On June 8, 1772, Marion was killed and eaten by natives of New Zealand by whom he and his men had been invited ashore to a feast. The Chevalier du Clesmeur, who commanded one of the vessels, left seeds of a number of useful plants at Guam. Among them were those of Cajan cajan, which has ever since been called "lenteja francesa" by the natives. Crozet describes the breadfruit tree, the manner of its propagation by cuttings, and the preparation of its fruit for food. He noticed that cattle are very fond of its leaves. He speaks of the edible chestnut-like seeds of the "dugdug," or fertile breadfruit, and mentions the principal fruits growing on the island. Guavas already formed thickets in open places. The indigenous capers growing near the sea attracted him by the beauty and fragrance of their flowers. They had already been transplanted to the Philippines. Provisions were so plentiful that it was not necessary to fish, though the French sailors caught some fresh-water fishes, including eels, in the streams of the island. These were held in less esteem by the natives than salt-water fish. Crozet says that Tobias had stimulated the natives to cultivate their fields, which they had neglected owing to the importation of breadstuff for the missionaries and garrison by the galleons from Mexico. He attributes the introduction of the cultivation of maize, rice, sugar cane, and other useful plants to Tobias, who also planted avenues of coconut palms and breadfruit trees four deep 
along the beach and around the town, making Agaña an enchanting place. Crozet is undoubtedly wrong in his statement as to the introduction of many of these plants. It is certain that maize was cultivated in Guam as early as 1676, nearly a hundred years before Tobias's time; for Padre Garcia states that the natives in that year destroyed the maize plantation, which was the principal sustenance of the missionaries and the soldiers. ${ }^{a}$ Rice and sugar cane were cultivated by the aborigines before the advent of the Spaniards. Many of the improvements attributed by Crozet to Tobias were due to the Jesuits, though it is undoubtedly true that he encouraged agriculture and other useful arts, and in all probability introduced domestic animals, as well as the deer which now overrun the island. What the Jesuits did for the island is shown by the documentary evidence left behind them. Crozet speaks of the use of cattle for draft animals, and says that then, as now, they were ridden like horses and that each family of natives had several riding beasts.

La Perouse, who visited Manila in 1787, has given the following account of Tobias's subsequent misfortunes:

I saw at Manila that virtuous and upright governor of the Ladrones, M. Tobias, who, unhappily for his repose, has been too much celebrated by Abbé Raynal. I saw him persecuted by the monks, who, representing him as a wretch destitute of piety, have alienated the affections of his wife, who has even demanded to be separated from him, that she might not live with a reputed reprobate, and all the fanatics have applauded her resolution. M. Tobias is the lieutenant-colonel of the regiment which forms the garrison of Manila, and is known to be the best officer in the country, yet the governor has ordered that his appointments, which are considerable, should be paid to this pious wife, leaving him only $\$ 26$ a month for his own subsistence and that of his son. This brave soldier, reduced to desperation, was waiting for a proper opportunity to quit the colony in order to obtain justice. $b$

It is interesting to read Crozet's description of Agaña as it was in 1872 , six year's before the rediscorery of the Hawaiian Islands by Captain Cook. He gives the population as about 1,500 natives.

There is a beautiful church, decorated according to the Spanish custom. The commandant's house is spacious and well built. The former residence of the Jesuits, now occupied hy the St. Augustinian Brotherhood, is spacious and convenient, but the fine Jesuits' college, built for the education of the Indians, is not inhabited, their successors, the Augustinians, having removed the college to a building near the convent. There is a barracks (apable of lodging a garrison of $500 \mathrm{men}$, and there is the King's fine, large magazine. All these buildings are of brick and tile. The island of Guam is the only island in the vast extent of the South Sea, sprinkled as it is with innumerable islands, which has a European-built town, a church, fortifications, and a civilized population.

On learing Guam Crozet carried two plants of the breadfruit with him to the island of Mauritius.

a Garcia, Vida y martyrio de Sanvitores, p. 554, 1683.

$\checkmark$ La Perouse, Voyage Around the World, vol. 2, p. 285, 1807. 
SCIENTIFIC EXPLORATIONS OF THE ISLAND.

MALASPINA EXPEDITION.

In February, 1792, Guam was visited by Alessandro Malaspina, in command of the corvettes Atrevida and Descubierta, which had been sent by Carlos IV, King of Spain, on a voyage of scientific investigation. Attached to his expedition as naturalists were Thaddaeus Haenke and Luis Née, who were the first to make systematic botanical collections on the island. They were also the first botanists to visit California, having the preceding year collected in the vicinity of San Diego and Monterey. ${ }^{a}$

The story of Haenke's adventures while attempting to join Malaspina is told both in the official narrative of the expedition and in the preface to Presl's Reliquiæ Haenkeanæ. Haenke was a Bohemian by birth. He received his botanical education from Jacquin, who for a time was professor of chemistry and botany in Vienna, and upon his recommendation was appointed botanist of the expedition by the King of Spain. Although he set out for Cadiz immediately on receiving his appointment, he reached that port only to find that the two corvettes had just set sail (July 30, 1789). Following them in the first vessel bound for Montevideo, he suffered shipwreck on one of the numerous shoals at the mouth of the Rio de la Plata, losing nearly all his books, papers, and effects. He succeeded in reaching shore, howerer, with his Linnæus and a collecting outfit, but he found that the expedition had already sailed. Knowing that it was to stop on the coast of Chile, he set out at once on foot, crossing the Pampas of Argentina and the Chilean cordillera of the Andes, collecting and drying plants on the way. ${ }^{b}$ On reaching Santiago, Chile, to his great joy he found there Malaspina and a number of his officers, who had left their ships at anchor in the harbor of Valparaiso to pay an official visit to the capital. He immediately reported for duty and was assigned to the Descubierta.

The expedition skirted the coasts of South America, Mexico, and North America as far as Port Mulgrave, which is situated in Yakutat Bay, southern Alaska. Their exploration of the latter region is commemorated by the name of the celebrated Malaspina Glacier. Returning to Mexico, Haenke went alone on a collecting tour from Acapulco to Mexico City and back. Leaving Acapulco on December 21, 1791, the expedition sailed for Guam, coming to anchor on February 12,

$a$ See Brewer, in Geological Survey of California, Botany, vol. 2, p. 553, 1880.

b"Con un verdadero amor ál las ciencias y particularmente á la botanica, consideraba resarcidos en mucha parte los sufrimientos pasados, pues le habian deparado la casualidad de atravesar las Pampres ó llanuras de Buenos Aires y las cordilleras del

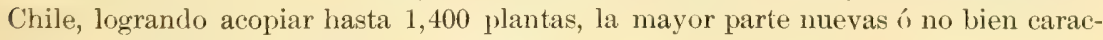
terizadas." Official narrative, p. 86, 1885. 
1792, in the roadstead of Umata. Many of the crew were suffering from an epidemic caught at Acapulco. Haenke proceeded to Agaña and the northern part of the island, Née to the bills near Umata, each making collections of plants. Don Antonio Pineda, who shortly afterwards lost his life in the Philippines, occupied himself with the geology and zoology of the island. The governor, Lieut. Col. Don José Arlegui, offered them every facility for carrying on their work. Don Juan Ravenet made sketches of a couple of the natives and of a native of the Caroline Islands, between which group and Guam a regular traffic had existed since 1788. The expedition set sail at daylight on the morning of February 24. A few plants were collected on Tinian, one of the northern islands, but the bulk of the collection from the Mariannes was made on the island of Guam. From Guam the expedition sailed for Cape Espiritu Santo, island of Samar, in the Philippine group. From the Philippines it proceeded to Botany Bay, and thence to the Society Islands. Returning to the Peruvian coast, the expedition received news of the French Revolution and of the declaration of war with France. The botanists separated. Née left the Atreviclu on the coast of Chile and proceeded overland, stopping at Talcahuano, Concepcion, and Santiago, and thence by way of the cordillera del Valle to Mendoza and over the pampas to Buenos Ayres. He rejoined the expedition May 10.

Haenke crossed the Peruvian Andes to Tarma and visited the region about Huanuco, at the headwaters of the Rio Huallaga, a tributary of the Marañon. With the approval of the riceroy of Peru, it was decided that he should proceed across the continent to Buenos Ayres by way of Huancavelica, Ayacucho, Cuzco, and Potosí (situated in what is now Bolivian territory), oceupring himself on the way with botany, zoology, and mineralogy; and a soldier named Geronimo Arcangel was detailed to accompany him. Letters were received from him from Cuzco and Arequipa reporting the progress of his explorations and stating that he expected to reach Monterideo the early part of the following year. The expedition, howerer, was suddenly ordered home on account of the war, and Haenke remained in south America, collecting extensively in the interior of what is now Chile, Peru, and Bolivia. In 1796 he established himself at Cochabamba, a city beautifully situated on the fertile plateau watered by the tributaries of the Rio Grande, now the chief agricultural and industrial center of Bolivia. Here he established a botanical garden, gave medieal assistance to his neighbors, and occupied himself with the study of natural science, making repeated excursions throughout the territory of what is now Chile, Peru. and Boliria. Alcide d'Orbigny, in his paper on the genus Victoria, tells of meeting in his travels in siouth America with a Spanish missionary. Padre Lacuera, who had accompanied Haenke on one of his expeditions. The padre related an incident which illustrates in a 
most tourhing manner the enthusiasm which was characteristic of the collector and observer. While they were navigating the Rio Mamore in a canoe they discovered in a marsh bordering the river a plant so marvelously beautiful that Haenke fell upon his knees in worship, offering to the Author of so magnificent a creation a prayer of grateful homage. He insisted on stopping and camping at this place and left it with the greatest reluctance." This was about the year 1801. The plant was in all probability the magnificent water lily afterwards described as Victoria amazonica.

Haenke looked forward to returning some day to Europe, but he was accidentally poisoned and died at Cochabama in 1817. Only a small proportion of his herbarium reached Europe, the greatest part having been sent by the authorities to Lima, where it was lost. About 9,000 plants collected on the Malaspina expedition were sent, according to his wish, to the National Museum of Bohemia, at Prague. Others found their way to the Royal Garden at Madrid, with those of Née. Duplicates of these were sent to the University of Prague and the Muscée Palatin at Vienna, and about 700 species to the Royal Herbarium at Munich. It was upon the collections at Prague and the notes accompanying them that the Reliquir Haenkeanæ of Presl was based. ${ }^{b}$

Née, who reached Cadiz in 1794, took back with him 10,000 plants, nearly half of which were apparently new. His herbarium, together with descriptive notes and drawings, belong to the Royal Garden at Madrid. Many of his Guam plants were described in 1802 by Cavanilles; ${ }^{c}$ among them are a number of ferns as well as of flowering plants that have not since been recognized, and no careful comparison has been made between the types in Madrid and material from the Pacific in England.

Notes of both Née and Haenke are included in Malaspina's official narrative, lying in manuscript in the archives of the Madrid hydrographic office. Malaspina shortly after his return to Spain was thrown into prison, suspected of revolutionary designs. The Spanish Gorernment refused to publish his narrative, and when a map appeared embodying the results of his explorations his name was not allowed to appear upon it. Humboldt speaks of this great injustice with indignation. Malaspina was an Italian by birth. A sketch of his life is included in Amat di San Filipo's Biografia dei viaggiatori italiani, Rome, 1881. For a long time his manuscript history disappeared from view and investigations concerning it were made by the Societi Geografica Italiana, the president of which, in his address of 1868 (Bolletino, 1865, pp. 7:3-74), announces its discovery in the archives of the hydrographic office at Madrid, and states that it is written in a great

a A. d'Orbigny, Annales des Sciences Naturelles, vol. 13, p. 55, 1840.

$b$ See List of works.

${ }^{c}$ Cavanilles, Josef, Descripcion, etc. See List of works. 
part by Malaspina's own hard. It is quite voluminous. A part of the narrative is said to have been published in the Anales Hidrograficos in 1871, but no such publication can be found in the official list. The narrative, much abridged, finally appeared in 1885, seventy-six years after the death of the brave and unfortunate navigator. ${ }^{a}$ For the most part it consists of bare statements of facts, resembling a log book, and has few descriptions and little detailed information concerning the countries visited. A satisfactory history of this important expedition still remains to be written.

ROMANZOFF EXPEDITION.

On the erening of November 24,1817 , the brig Rurik, fitted out at the expense of the chancellor of the Russian Empire, Count Romanzoff, for the purpose of seientific exploration, and commanded by Otto von Kotzebue, a lieutenant in the Russian navy, came to anchor in the harbor of San Luis de Aprâ. Attached to her were the botanist Adelbert von Chamisso; the naturalist Johann Friedrich Eschscholtz, and the artist Ludwig Choris.

Owing to the shortness of the Ruriti's stay at Guam it was not possible to make extensire collections. Chamisso, however, got much interesting and valuable information while on the island from the Sargento Mayor Don Luis de Torres. To botanists, Eschscholtz's name is chiefly associated with the beautiful "Californian poppy" (Eschscholtzia), named in his honor by Chamisso.

The narrative of the expedition was published by Kotzebue, under the title of "A Voyage of Discovery into the South Sea and Behring's Straits," etc." This narrative, which embodies Chamisso's observations, is filled with errors and misstatements. It was miserably "done into English" by a translator who "joined to a style at once bald and incorrect a deplorable ignorance of his subject; hence the work abounds in errors of the grossest kind." Chamisso, wishing to correct them, made ont a list of errata, but no attention whatever was paid to him. He accordingly puhlished his notes and journal independently, under the titles of "Bemerkungen und Ansichten," and "Tagebuch," in the former of which he gives comparative vocabularies of the languages of Guam, Yap, Ulea, and Radak. ${ }^{d}$

In these two works a most charming personality is revealed. Chamisso $\rightarrow$ lore of nature was equaled by his love for his fellow-man. He recognized the humanity in the simple brown-skinned natives of the remote islands of the Pacific, and did not consider them legitimate

a Novo y Colson, La vuelto al mundo, ete. See List of works.

$b$ See list of works.

c Quarterly Review, vol. 26, p. 364, 1822.

d Chamisso's gesammelte Werke. See List of works. 
victims of the selfish schemes of white adventurers. He was much moved by the sad havoc wrought by the Spaniards in the Marianne Islands, and repeated the story of persecution and cruelty accompanying the "reduction" of the natives as related by the spaniards themselves. ${ }^{a}$

From the statement published by Kotzebue that the natives of Guam had been exterminated by the Spaniards a wrong impression has gone abroad. The facts are presented under the head of "The modern inhabitants," below. ${ }^{b}$

The plants collected by the Romanzoff expedition were deposited in the Imperial Academy of Sciences, St. Petersburg. Duplicates were sent to the Hooker Herbarium, at Kew, England, and to the University of Kiel, Germany. A number of the plants were described by Chamisso and Schlechtendal in the journal Linnæa, the series beginning with the first paper of the first volume. ${ }^{c}$ In the introduction to this paper, Chamisso, in speaking of Eschscholtz, says, "Intimam instituimus amicitiam nunquam obnubilandam, communiaque semper habuimus studia, labores, fructus;" and in his Tagebuch he describes him as a young doctor from Dorpat, a naturalist and entomologist, shy and retiring by nature, but true and noble as gold. Such tributes reflect the character of their author.

FREYCINET EXPEDITION.

A little more than a year after Chamisso's visit, on March 17, 1819, the French corvette Uranie, Louis de Freycinet commanding, arrived at Guam. With him were the botanist, Charles Gaudichaud-Beaupré, the zoologists Quoy and Gaimard, and an artist named Arago. A stay of several months allowed the naturalists to make extensive collections and observations on the island of Guam, and the islands of Rota and Tinian were also visited by them. On the return voyage the Uranie, while at the Falkland Islands, struck a rock and foundered. Gaudichaud's collections were almost ruined. The hold, in which his herbarium was stowed, was flooded, and the plants saturated with sea water. Only a collector can appreciate the feelings of Gaudichaud when, several days afterwards, he fished them up and spread them out to dry as best he could. The collections were taken to France in the Physicienne, and deposited in the Muséum d'Histoire Naturelle, at Paris. An interesting account of the vegetation of Guam was given

a "Der fromme Missionär Don Diego Luis de San Vitores landete auf Guajan im Jahre 1667; er begehrte den Völkern das Heil zu bringen, aber es folgten ihm Soldaten und Geschütz. Noch vor dem Schlusse des Jahrhunderts war das WTerk vollbracht, und diese Nation war nicht mehr. Pacificar nennen's die Spanier." Char-isøo, Bemerkungen und Ansichten, p. 90.

$b$ See p. 117.

c De Plantis in Expeditione speculatoria Romanzoffiana observatis, etc. Linnera, erster Band, Jahrgang, 1826, Berlin. 
by Gaudichaud in the Botany of the Freycinet Expedition, "and the greater part of his observations are embodied in the narrative of the expedition published by Freycinet himself. ${ }^{b}$ The zoology was published by Quoy and Gaimard. A narrative of the expedition was published independently by the artist Jaques Arago, which abounds in exaggerations, scandalous stories, and unkind criticisms and ridicule of the people whose hospitality he had enjoyed. Its publication naturally offended the Spaniards, and the next expedition from France to visit the island met with a rery different reception at the hands of the gorernor. ${ }^{c}$ While waiting for supplies from Manila a survey of the island was made by M. Duperrey under the direction of Freycinet. Existing maps were corrected and several charts of small harbors were drawn.

DUMONT D'LRVILLE'S TWO VISITS.

Dumont d'Urville made two visits to the island of Guam. On his first risit, in Nay, 1828, he came in command of the Astrolabe, which had been sent out on an exploring royage with special instructions to look for traces of La Pérouse. Attached to the Astrolabe were Lesson, as pharmacist and botanist, who assisted d'Urville in collecting plants, and Quoy and Gaimard, as zoologists, who were the first to collect specimens of the Guam reed-Tarbler, Acrocephalus Tuscinia, the only true song bird of the island. A most interesting narrative of this expedition was written by Dumont d'Lrville himself, and the zoology was published by Quoy and Gaimard. ${ }^{d}$

The Astrolutre anchored at L'mata and was boarded by José Flores, alcalde of the rillage. He told the captain that he had seen the ships of Malaspina, who visited Guam in 1792. thirty-six year's hefore. In the roadstead d'Lrrille saw two ships which had been captured by the Spaniards from the independents of Mexico and were now being taken to Manila. Three years hefore this there had been a mutiny on board some spanish ressels lying at anchor in the roadstead of Umata. The squadron was commanded by Don Andrés Garcia Camba, Cahallero de Santiago, aftermards governor of the Philippines. General Camba had served in South America against the revolutionists and had been captured at the hattle of Avacucho, December 9, 182t, in which the

a Botanique du voyage autour du monde. See List of works.

$\checkmark$ Freycinet, Louis de: Voyage autour du monde. See List of works.

Sanchez y Zayas, Islas Marianas, p. 230. See List of works. The author calls attention to the fact that Medinilia, the governor of Guam at the time of the Cromie's visit, entertained the captain and all the French officers for eight months, giving them hed and hoaril; lut that his hospitality " was rery poorly repaid, according to old French custom, as may be scen in the hook written hy Arago, draftsman of the experlition, a book which unfortunately has been tranwlated into. Spanish, although the narrative of the commanding officer has not been translated."

$a$ Voyage de décourertes de $l^{\prime}$ Astrolabe, 1833. 
South American colonies won their final victory over Spain. On the 1st of January, 1825, he sailed in command of a squadron composed of the ship Asiel and the brigantines Aquiles and cimstente, bound for the Philippines. The water of the squadron becoming scarce, they anchored in the roadstear of Umata and filled their casks. On the night of March 10, while weighing anchor, the crews suddenly rose, set fire to one of the vessels, maltreated the commanding officer, and drove him ashore, together with his officers and 100 loyal men. Ganga-Herrero, the governor of Guam, went on board and tried to restore discipline, but they put him ashore, hoisted the flag of the insurgent republics of America, and set sail for Peru to join the independents. The general, accompanied by his officers and loyal men, proceeded in a whaling ressel to Manila, where they arrived April t, and were received with great hospitality by all classes of people."

D'Urville states that Governor Ganga-Herrero was much regretted by the natives, whom he permitted to trade on their own account with ressels anchoring at the island. His successor, Medinilla, on the other hand, was universally disliked. He forbade all traffic with risiting vessels, monopolizing it for himself. Among the officials visiting the ship was the captain of the port, a Scotchman named John Anderson, who had come to the island with Freycinet. He had served temporarily on the Uranie as chief quartermaster, and was allowed to remain in Guam at his own request. D'Urville describes him as a fine-looking man, well-behaved, and speaking French pretty well. Anderson knew Quoy and Gaimard, having been shipmates with them on the Tranie. He came to inrestigate the sickness on board, fearing that some contagious disease might be introduced into the island. He gave d'Urville information regarding the hydrography of the region. As an illustration of the conditions in Guam, he said that Medinilla, the governor, on his return from Manila had brought back more than 60,000 pesos worth of goods of all kinds to sell to the natives of Guam, and that he conducted a very profitable business, since he permitted no competitors in trade.

This monopoly [says d'Urville], which according to our ideas would not be very honorable on the part of a governor, does not cause surprise in the Mariannes. The governors have had this privilege from time immemorial.

D'Crville attributed the lack of enterprise and progress on the island to the absurd laws and this disheartening monopoly.

How should industry flourish? [he says]. The governor is the sole trader. He receives annually money for the salaries of the officers, which he sends back, giving them instead inferior goods at prices fixed by himself.

"This account is taken from the narrative of Dumont d'Lrville, supplemented by the report made to the Queen Regent, inserted in the work "Los diez y seis meses de raando superior de Filipinas," por el Mariscal de Campo Don Andrés Garcia Camba: Cadiz, 1839. 
On January 1, 1839, Dumont d'Urville, commanding the Astrolahe and Zelée, paid his second visit to Guam. Attached to the expedition were Hombron and Jacquinot, as doctors and botanists, and Arago as artist. Two collections of plants were made on this expedition, the first by the above-named botanists, the second, including several new species of algæ, by Dumont d'Urville himself. Besides the official reports of this expedition ${ }^{a}$ a narrative was written by Arago. ${ }^{b}$

Hombron gave his collection of plants to M. Benjamin Delessert, whose herbarium was afterwards presented by one of his nieces to the city of Geneva, Switzerland. It has been placed in a building in the Botanical Garden of that city.

EXTRACTS FROM THE ARCHIVES OF GUAM, RELATING TO ITS ECONOMIC HISTORY.

At Agaña, the capital of Guam, there are a number of letter books containing copies of the official communications of the governors of the Mariannes to their immediate superior, the captain-general of the Philippines. In these letters rarious questions are discussed at length regarding the policy which should be pursued to make the Marianne Islands self-supporting and profitable to Spain, and to make the natives prosperous and happy. Arguments are advanced in favor both of protection and of free trade with risiting vessels. Attempts were made to compel the natives to till the ground, and inducements were offered by tempting their self-interest. Causes for the failure of the population to increase were sought in the destruction of the crops by hurricanes and pests, in the use of unwholesome or injurious food, and in the disinclination of the natives to work more than was necessary for their daily needs. Some of the governors greedily monopolized all trade, forcing the natives and the soldiers of the barracks to buy goods from them at prices arbitrarily fixed by themselves, and forbidding the natives to sell their products to the whalers who flocked to the islands. Others gare the natives free license to trade and entered into their daily life by cultivating farms of their own after the native fishion. Efforts were made to henefit the islands by decrees of the captains-general of the Philippines, to whose ears came stories of dishonesty and oppression on the part of the governors, and confidential subordinates rere sent to the islands to see what could be done for their good. The following extracts, showing the efforts made in behalf of the islands and the natives, are taken from the archives at Agaña.

$a$ Voyage au pole sud, etc., 1841-1854. See List of works.

"Arago, Jacunes Etienne Victor. Voyage antour du monde, etc., 1843. See List of works. 
FRANCISCO RAMON DE VILLALOBOS.

On December 17, 1828, new regulations were issued by Don Mariano Ricafort, the captain-general of the Philippines, for the government of the Marianne Islands; and Don Francisco Ramon de Villalobos, captain in the royal corps of artillery, was sent thither to study the condition of affairs in that group, with a view of reporting upon them and making such suggestions as he might see fit for the improvement of the islands and the people. Instead of sending his correspondence through the governor, he communicated directly with the captaingeneral of the Philippines, as may be seen by his letter books in the archives at Agaña.

In the new regulations Article II provided for the absolute liberty of trade and for the abolishing of dues paid by vessels arriving at the islands. The object of this was to stimulate the application and the industry of the natives and inhabitants of the Marianne Islands, so that they might attain greater prosperity, even to such an extent, perhaps, as to become self-supporting. Villalobos belonged to that school of economists who believe "wealth" and "money" to be synonymous terms, estimating the wealth of a country by the amount of coin it contains, and holding that trade should be restrained in such a manner as to prevent money from being sent out of the country. He writes to the captain-general as follows:

The lack of circulation of coin is the cause of the very small interior and exterior trade of this territory, which consists almost entirely in bartering certain goods for others, with the countless difficulties arising therefrom which caused the establishment of money by our remote ancestors. This same cause has prevented the natives from dedicating themselves exclusively to one branch of industry or trade, each family finding itself obliged to engage in all occupations according to its needs, with the consequent imperfection and scarcity resulting therefrom, and, finally, as it is not possible for a single person or family to procure for itself as many articles and resources as are necessary for its nourishment, clothing, and conveniences, these natives have lacked the advantages enjoyed by other countries, in which the free circulation of money secures for them everything needful.

It is evident, then, in order that the Marianne Islands may issue from so sad a plight, it is indispensable that there should be in them an abundance of money, and as long as this is not the case, whether, as in the former system, little comes in and soon goes out, or whether great sums come in and go out immediately, as will happen in the present system, the evil will always be the same or nearly the same.

At present there are in the Marianne Islands no articles of export to attract the attention of the foreigner but some edibles or beverages made from the coconut palm. Freedom of trade once established, it would introduce many articles, and the few things produced by the country would not suffice to pay for them, so that the difference would have to be made good in money. From this it would follow that money paid for salaries would remain here only temporarily; the country would be merely a channel through which the money from the royal treasury would flow to foreign parts with no hope of its return. The Mariannes would be deprived of the spirit of agriculture and industry, which I think ought, in a certain degree, to come before commerce, and the islands would be no less poverty stricken than they have been $u \rho$ to the present time.

$9773-05-3$ 


\section{Don Francisco goes on to make the following suggestions:}

First, considering the impossibility of preventing the arrival of foreigners in these islands, they should be obliged to pay at least the established anchorage dues; second, industry and agriculture on the part of the natives should be fostered, obliging them, on their own account and for their own benefit, to engage in producing objects easy of exportation, such as dyewood, indigo, cotton, tortoise shell, mother-of-pearl, arrowroot, and bêches de mer, and in the breeding of animals, the more extensive cultivation of land, and the production of wines, brandies, sugar, and other articlesall in accordance with the regulations of good government-which will not be hard to formulate according to the system in force in the Visayan Islands; third, the said freedom of trade will allow the natives to sell their goods, as will be seen; fourth, the royal treasury will continue to send half of the appropriation for the pay of the forces on the island in goods at prices as moderate as practicable; and fifth and last, if national or foreign vessels arrive with articles of commerce, they shall take away with them the equivalent of what they leave in the country in products of the island, and, if they do not wish the latter, they shall be sent away.

He also suggests that the proceeds from the port dues be applied in part to the payment of premiums to persons who have most excelled in some branch of industry or agriculture or who have been of some benefit to the public.

By these methods [says Villalobns " ], sustained with constancy and intelligence and favored by the docility and good disposition which I observe in the inhabitants of these islands, I believe that the day will really come in which the Marianas will have much money, many goods; that they may without difficulty be self-supporting, like other provinces; that ships will concur, and that all amplitude desired will be given to trade.

Villalobos did much to benefit the people of Guam. In his official letters to his chief he reports, among other things, the segregation of lepers and provision for their care and comfort; the appointment of hunter's to supply the leper hospital with fresh meat by killing wild hogs and cattle; his efforts to encourage commerce. so that Guam may derive profit, like the Hawaiian Islands, from the visiting whalers; the raccination of the natives as a protection against smallpox; the reorganization of the urban militia; proposed reforms in the administration of the college for the education of native children; efforts to promote the cultivation of coffee, "which article may be the wealth of this country;" the condition of agriculture on the island; the preparation of the large marsh east of Agaña for the cultivation of rice; the injuries to maize caused by rats and weevils, and the consequent restriction of its cultivation to amounts barely sufficient for the needs of each family; the substitution of taro and yams for maize, when the latter has been destroyed by hurricanes, and the use of plantains and bananas as food staples instead of bread; the cultivation of sweet potatoes for supplying visiting ships; the excellence of the pineapples and the use made of pineapple fiber; the fine quality of Guam 
tobacco, and the means employed to keep the plants free from worms; the introduction of manila hemp and the failure to make it profitable; the cultivation of eggplants, red peppers, tomatoes, squashes, watermelons, muskmelons, and peanuts in the natives' gardens; the scarcity of sugar cane on the island; the importance of the coconut palm, and the manufacture from it of toddy, vinegar, yeast, brandy, oil, syrup, tiber, and thatch for houses; the importance of breadfruit, both sterile and fertile, as a food staple; the manufacture of fecula, like arrowroot, from nuts of "federico" (Cycas circinalis); the yield of betel nuts from Areca palms, growing spontaneously on the islands; the manufacture of mats, hats, and lashings from the leaves of Pandanus; the scarcity of mango trees and sappan wood (used for dyeing); the abundance of achiote or arnotto (Bixa orellana), and the cultivation of the orange, lemon, lime, citron, bergamot, custard apple, tamarind, papaya, carambola, island arrowroot, and turmeric. He also reports on the wild and domestic animals, and states that on the neighboring islands of Saipan and Tinian there are thousands of cattle and swine roaming in the woods. ${ }^{a}$

Villalobos erected a kiln for making pottery and tiles, paying the cost of it partly from his own pocket. He also made charts of the island at his own expense, and superintended in person the construction of bridges and the repairing of roads, stimulating the workmen by fees and small gratuities. In consequence of mutinies and acts of insubordination on the part of crews of ships in the harbor, England proposed to establish a consulate either at Guam or in the Bonin Islands. Villalobos objected to this, saying that if there were an English consul at Guam questions might arise leading to international complications, which might perhaps result in the loss of the island. On the other hand, if a consulate were established in the Bonin Islands, the whaling fleet would assemble there to the detriment of the natives of Guam, who derived much benefit from trading with the said vessels. He proposed that an arrangement be made whereby the British Government would authorize the governor of the Mariannes to act in settling cases of mutiny and the like. He also recommended the establishment of a store of marine supplies by either one of the two governments, and called attention to the immense advantages of the presence of many ships at Guam with liberty to trade with the islanders, the governor being prohibited from engaging in trade of any kind. Orders having been issued to collect import duties from the ships coming to Guam, Villalobos informed the captain-general that it would be practically impossible to carry out the provisions of the decree. He stated that if guards were placed on board the ships, the cost of maintaining them

a Villalobos, manuscript report to the captain-general of the Philippines, dated November $16,1831$. 
would exceed the amount received for duties. If no guards were stationed the duties would be only imaginary, on account of the bad faith of those who sold and their "lack of delicacy." Moreover, if it should come to light that a sale had been secretly made and the corresponding duties on the same be exacted from a foreign captain, his pride and insolence would be apt to compromise the dignity of the authorities beyond all bearable limits or bring about disagreeable consequences resembling perhaps an unhappy affair between the ex-Governor Ganga-Herrero and an English captain, Mr. Stavers, who, in 1824 , died from injuries received while resisting arrest. In view of these difficulties Villalobos on his own authority ventured to grant free trade between the visiting ships and the islanders.

PABLO PEREZ.

Don Pablo Perez began his service as governor of the Mariannes on September 8,1848. Among the first reports forwarded by him to the captain-general were statistical tables regarding the population of the islands, a list of ships anchoring at Guam, a report of recent hurricanes, the destruction of crops, and the resulting dearth of food, and a list of the useful woods of the island. He calls attention to the lack of lahorers in Guam, especially of men skilled in mechanical trades, and begs that convicts be sent to the island, including mechanics of various kinds and husbandmen or tillers of the soil. He speaks of the presence of a few such men on the island who remained there after the expiration of their terms of imprisonment, and states that these were the only individuals skilled in the use of the plow, carpenter's tools, ete. He comments upon the inadequacy of the method practiced by the natives of cultivating the soil by means of the "fosiño," or thrusthoe, "in consequence of which "their harrests are small which might be large." Don Pablo found the roads and bridges in a deplorable state, owing to the effects of recent floods and hurricanes, and he reported that there was a lack of suitable tools for carrying on public works and of iron for making such tools. Following the hurricanes and floods there was an epidemic, caused probably by a dearth of nutritious food, and shortly after this the island was visited by a severe earthquake. In response to the report of this, supplies of rice, maize, and other food were sent to Guam from Manila, together with a relief fund raised hy the roung ladies and gentlemen of that city by means of theatrical performances for the benefit of the sufferers. Don Pablo acknowledges the receipt of these contributions as follows: ${ }^{b}$

The governor of the Mariana Islands in the name of the inhabitants, who do not cease giving thanks to the Alnighty for not having succumbed to a desolating epidemic and the most horrible of earthquakes, which still continue, saw themselves

$a$ See p. 144 .

${ }^{b}$ Manuscript copy of letter in the archives of Guam, dated October 10, 1849. 
threatened anew by a devouring famine which threatened to put an end to their miserable existence. But Providence, which incessantly watches over those peoples who implore its aid, willed that the beneficent hand of our Superior (tovernment, ever benevolent and philanthropic, should put a happy end to so much misfortune and unhappiness so great.

What joy was ours on the $3 \mathrm{~d}$ day of September, when there arrived at this port the frigate Union, bearer of most bounteous supplies of rice, maize, and other grains, at prices more moderate than have ever before been known in these possessions! It is impossible to describe the joy and animation of the people of this community, whose misery and poverty were increasing by a plague of worms which consumed as much rice, maize, and other seed as were sown in the months of July, August, and September; so that if succor had not arrived so opportunely the ruined crops could not have been replaced for lack of seed. Such was the scarcity that on the 29th of August, four days before the arrival of the said ship, the only remaining five cabanes of rice were put up at auction and sold at 5 pesos a caban. From this alone may be formed an idea of the great if not the total lack which was suffered here. Like one who suddenly recovers from a mortal illness to perfect health, so was the air of contentment and rejoicing which seized upon all souls in their most sincere gratitude to the author of so many and such great benefits. Nor was our gratitude less to those gentlemen who contributed the subscription in money of $\$ 675-4-5$, which was distributed among the poor of these islands on this the birthday of our adored Queen, Doña Isabella II (whom God save), in accordance with the directions of the Superior Government.

Without elements, means, or resources whatever for manifesting our gratitude, I directed that on the 9 th of the same month of September a mass of thanksgiving be celebrated by three priests, something very rarely seen in this city, with a sermon preached eloquently and eruditely, as is his custom, by Padre Fray Manuel Encarnacion, the parish priest of the village of $A$ gat, who, in speaking of the calamities suffered by these islands, made his hearers understand and exhorted them to the gratitude due our Government, which so prodigally relieved our necessities, finishing the function with a solemn te deum, and displaying the most holy sacrament. All the people bowing down like those of Israel before His Divine Majesty, breathed forth their prayers and vows for the happiness of their benefactors.

In order to give another proof of the sentiments of gratitude which filled us and to carry out in a certain way the beneficent ideas of our Government, which especially distinguish it, as is seen by the sublime acts which illustrate the pages of the history of our colonies, I decided to act as godfather to the first girl baby which might be born, and I gave to it the name of Isabella, in memory of our august Queen; and the lieutenant-governor acted in the same capacity for the first boy baby, which he called Narcissus, in memory of his excellency our captain-general, Count of Manila, who so justly rules these remote regions, each one of us giving to his godchild 50 pesos and an outfit of decent clothing, which event took place at 9 o'clock on the morning of the 16th of September, with the assistance of the authorities and of nearly all the population, so that these children may be living testimony of the remembrance of the generosity of our Sovereign and of your excellency, who knows so well how to act as the instrument of so many and such great acts, which history will record for the honor and the glory of the great Spanish nation.

On August 10, 1851, the brigantine Clavelino arrived from the Philippines bringing 65 convicts. They were in a miserable plight. On the voyage two of their number had died, and nearly half of the remainder were afflicted with scurvy, virulent ulcers, or cutaneous diseases. No medicines were available for treating these poor people. They 
were handed over to a little Irish doctor named William E. George, who had acted as apothecary on a whaler and had been permitted to take up his residence in Guam; but his private supply of medicines was soon exhausted. Finally the board of directors of the hospital for lepers consented to furnish means out of their own fund for lint, bandages, and drugs to relieve the sufferers, asking the approval of their action by the captain-general.

On September 1, the governor caused 51 of these convicts, all of whom were farmers by calling, to be distributed over the island, putting them under the charge of the most thrifty cultivators of the soil The principal one of these was the priest of Agat, Fray Manuel Encarnacion, to whom 18 of them were assigned. The governor issued a circular prescribing the conditions under which they were to be employed. The sick were to be kept at Agaña under treatment. On the 1st of September there were 14 on the sick list and on October 17 all had been put to work but 6 .

CONVICT LABOR.

The governor apprehended no trouble in allowing the convicts to be scattered over the island so long as there were no ships in harbor, as there was no possible means for them to escape from the island. It was his intention to have them divided into gangs, placed under the surveillance of guards, and employed at as great a distance as possible from the port, as soon as the season for the whalers' visits should arrive. At these seasons there were often fifteen or twenty vessels in the harbor, and as most of them were short-handed, there would be great danger of their smuggling these people on board on the eve of sailing. Those conrict who should misbehave were to be punished by being placed in gangs under a guard and compelled to work in his sight. Those who might become sick or who were returned by their masters as unfit for work or as dangerous subjects, would have to be supported by the Government. The governor asked the captain-general to authorize their subsistence from Government funds under the direct supervision of the governor.

Scarcel! a month had passed when the gorernor was informed that the convicts had entered into a conspiracy to rise against the authorities and take possession of the island. They were surprised by the guard, who hired upon them and charged bayonets. Their leader, Fortunato de los Angeles, "a villain from the Province of Cavite," was taken prisoner, one was killed, and two wounded. The rest scattered through the town and sought refuge in the woods. Before a week had passed all had been captured. The governor in his report to the captaingeneral says:

I acknowledge that I was mistaken. Believing that men whom your excellency had pardoned from the punishment of death by your decree of the 11th of last January would live grateful of such a boon, I never dreamed that they would rise against the authorities and attempt to make us the victims of their ferocity. 
The prisoners were sent back to Manila in the brigantıne Clavelino, the same vessel which had brought them, in charge of Lieut. José Martinez, assisted by 12 privates and 2 corporals. Thus ended the attempt of Don Pablo to introduce convict labor into Guam.

FELIPE DE LA CORTE.

On May 16, 1855, Don Felipe de la Corte relieved Don Pablo Perez as governor of the Mariannes. During his administration Guam was visited by a terrible epidemic of smallpox, which lasted nine months and carried off two-fifths of the population. In a report upon economic conditions, dated June 19, 1856, Don Felipe says:

For a long time the attention of the superior Government has been called to the slow progress of the population of these Marianne Islands, and the governors and special commissioners sent here have been directed to investigate the causes of this stationary condition of the population and even the decrease sometimes noticed in the number of inhabitants. * * * Some have thought to find the origin of this evil in the changeableness of the climate and the inconstancy of its seasons; others in the use of articles of food not very nutritious or perhaps injurious (nuts of Cycas), and others in the great number of rats, which destroy the abundant harvests.

After a dissertation on the principles of political economy, "a science which teaches us by sure principles the means of bringing about the prosperity of a country and of ridding it of objects opposed to its progress," Don Felipe goes on to say:

It is not necessary to tire oneself in seeking other causes than that of poverty, which is the only thing that retards the progress of the population of the Marianne Islands. Other things to which it has been attributed are accidents. The use of hurtful food, poor clothing, and other things, far from being considered a cause, are in reality the effects of that poverty and the direct means through which it works for the speedy destruction of this unhappy portion of the human race. This poverty, the general and sole cause, has not, however, been perceived by many, because they could not believe that it could occur in the midst of a soil which produces abundant and varied fruits, in spite even of those plagues, and because they have confounded with wealth the occurrence here at all times of fruits growing spontaneously which the natives use for food during the periods when more wholesome kinds are lacking. * * * The prosperity of a country depends, instead of upon the abundance of its spontaneous products, rather upon the wealth accumulated in it, and here precisely is the great defectand the origin of the evil in the Marianne Islands. In them, most excellent Señor, nobody possesses anything, with very few exceptions. Here all live absolutely for the day, and domestic utensils, tools of laborers, lodgings, and everything-absolutely everything--is so mean, so little durable, and so incapable of constituting wealth that all, or nearly all, could with solemnity declare at all hours that they are poor. *** To correct the evils upon which I here have touched, and to ameliorate the condition of these islanders, my predecessors, with laudable zeal, have reproduced without ceasing exhortations, orders, and decrees that they should plant and harvest wholesome and abundant fruits. But whowould believe it? With fat harvests, of which the grain has sometimes even been burned for lack of consumers, poverty has continued and reached even to us; for not having sought the means of accumulating that wealth then superfluous, to fill out the dearth later in worse seasons, all has perished at the moment, and without object. And what is still worse, it has createrl in these natives the idea in good years as well as in bad, of large crops as well as of small, that they can not hope for a beneficial 
change. They have logically figured that it is futile to work for superfluous harvests which may have to be burned, consequently not relieving them in the periods of scarcity which are sure to come later; that it is better to work little than to work without result. On account of this they have been accused of possessing a lazy disposition, which they are far from manifesting on occasions in which they clearly see the good results of their work.

Preservation of Maize. - To dispel so harmful a prejudice $I$ have thought it of the greatest importance to inaugurate the first accumulation of wealth in the preservation of the article most important for the subsistence of these natives. This is maize, or Indian corn, which is harvested with the greatest ease and may be planted at three epochs of the year in such a way that three times as much as the amount necessary for consumption may be produced at each harvest if its cultivation be followed on a great scale and leaving out accidents.

There is in contrast with this the experience which they have that with their small resources the most careful can scarcely make their supply of this grain last from harvest to harvest, so that there are repeatedly seasons during which a great portion of the population, being without maize or even the other articles of food used here, finds itself forced to fall back on federico [Cyeas nuts] and other fruits and roots of the forest, which can not fail to do them injury either from their being essentially harmful or because the organic system of the native suffers from the repeated changes from one kind of diet to another.

Anxious to root out an evil which I consider the greatest in these islands, and persuaded that when this is once accomplished a new era will begin for their inhabitants, I have availed myself of the teachings pertaining to my profession, and I have thought that without prejudice to anyone and by means of light work of all there could be put into practice the ancient system practiced by Spain and other countries of preserving cereals in subterranean granaries, and, combining this idea with the beneficent institution of the public granaries of Spain and some places in the Indies, I published an order which I hope will meet with the approval of your excellency, assuring you that in taking this step I have been prompted by a fervid wish to benefit these natives.

Don Felipe de la Corte wrote a most interesting account of these islands, which was published by the Spanish Gorernment." He was relieved at his own request by Don Francisco Moscoso y Lara on January 28, 1866, after having served eleven years.

SOCIEDAD AGRICOLA.

During the administration of Grovernor Moscoso a society was formed under the title "Sociedad Agricola de la Concepcion." It was composed of the governor and sereral of the officials and leading citizens of the island. Laborers were introduced from Japan and efforts were made to develop the resources of the island. The project failed, however. Some of the Japanese died and the rest returned to Japan.

STMMARY.

From the abore extracts some idea may be gathered of the economic conditions on the island of Guam. The causes which have prevented the general prosperity of the natives have been (1) the frequent hur-

a Memoria descriptiva. See List of works. 
ricanes, which destroyed the results of their labor; (2) the unwise course of certain governor's in discouraging individual enterprise; (3) the absence of any effort to accumulate capital either in the form of money or of supplies.

\section{PHYSICAL CONDITIONS OF GUAM.}

CLIMATE AND RAINFALL.

Seasons. - Though Guam lies within the Tropics, its climate is tempered throughout the greater part of the year by a brisk trade wind, blowing from the northeast and east. Its mountains are not high enough to cause marked differences in the distribution of rain on the island, and the island is not of sufficient extent to cause the daily alternating currents of air known as land and sea breezes. Generally speaking, the seasons conform in a measure with those of Manila, the least rain falling in the colder months or the period called winter (invierno) by the natives, and the greatest rainfall occurring in the warm months, which are called summer (verano) by the natives. The year may be divided into a rainy and a dry season, but this division does not correspond exactly to that based on temperature, for the period of maximum temperature precedes that of the greatest rainfall.

During the winter months the wind blows briskly and steadily from the northeast and east. In June it becomes unsteady, veering to the east and southeast, and by September what is generally known as the "southwest monsoon" sets in. The climate is healthful in comparison with other tropical countries, the only period when sickness may be expected being that of July and August, when the absence of the trade wind and the presence of moisture in the atmosphere causes the heat to appear greater than it is.

The mean annual temperature is about $80^{\circ} \mathrm{F}$, and the mean monthly temperature ranges from $78^{\circ} \mathrm{F}$. in December, the coldest month, to $82^{\circ} \mathrm{F}$. in May and June, the hottest months. The highest absolute temperature recorded in $1902,90^{\circ} \mathrm{F}$, occurred in June and $\mathrm{July}$, the lowest, $66^{\circ} \mathrm{F}$., in December.

Though the mean monthly temperature varies only $2^{\circ}$ on either side of the mean annual temperature, yet the "winters" of Guam are so definitely marked that certain wasps which during the summer make their nests in the open fields among the bushes invade the houses of the people at that season and hibernate there.

Meteorological Tables. - The following tables, compiled from observations made at the naval station at Agaña, the capital of Guam, show the temperature, rainfall, and prevailing winds for each month of the year 1902. They are taken from a report drawn up by Dr. Cleveland Abbe, jr., who, through the courtesy of Prof. Willis L. 
Moore, Chief of the Weather Bureau, was detailed to examine and interpret the records forwarded to the United States Hydrographic Office:

Temperature, 1902.

[Degrees Fahrenheit and centigrade.]

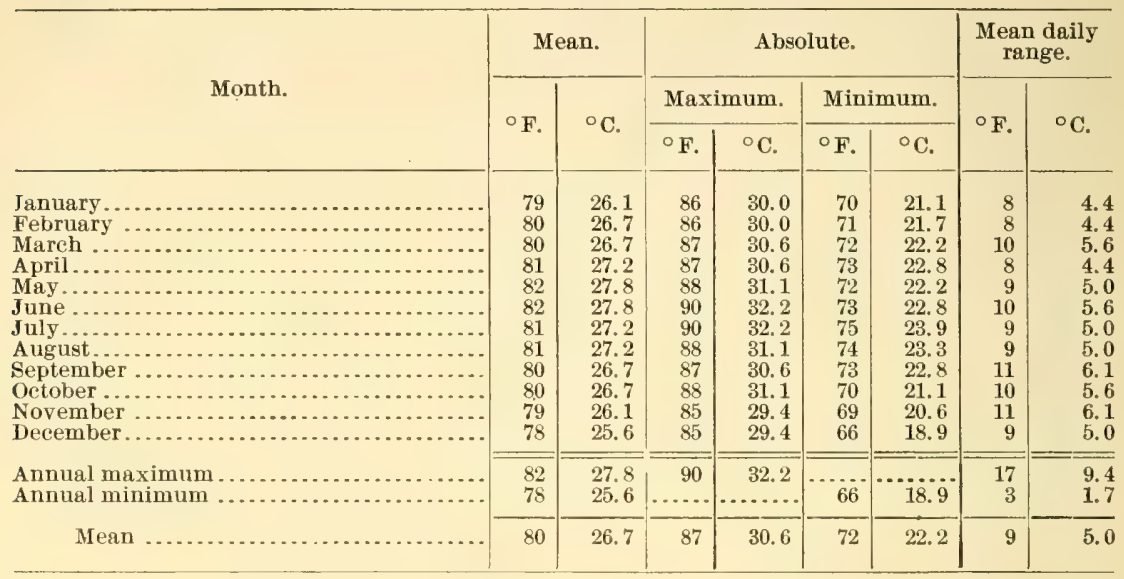

Rainfall, 1902.

[In inches and millimeters.]

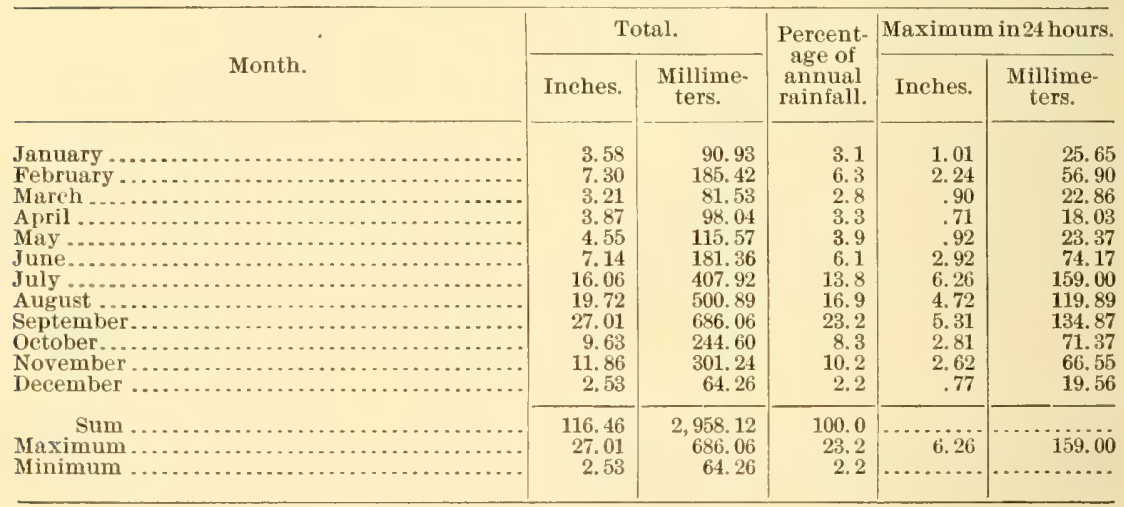

Number of days with rain, and amounts, 1902.

\begin{tabular}{|c|c|c|c|c|c|c|c|c|c|}
\hline Month. & $\begin{array}{l}\text { More } \\
\text { than a } \\
\text { trace. }\end{array}$ & $\begin{array}{l}\text { More } \\
\text { than } \\
0.10 \\
\text { inch. }\end{array}$ & $\begin{array}{l}\text { More } \\
\text { than } \\
0.50 \\
\text { inch. }\end{array}$ & $\begin{array}{c}\text { More } \\
\text { than } \\
1 \text { inch. }\end{array}$ & Month. & $\begin{array}{l}\text { More } \\
\text { than a } \\
\text { trace. }\end{array}$ & $\begin{array}{c}\text { More } \\
\text { than } \\
0.10 \\
\text { inch. }\end{array}$ & $\begin{array}{c}\text { More } \\
\text { than } \\
0.50 \\
\text { inch. }\end{array}$ & $\begin{array}{l}\text { More } \\
\text { than } \\
1 \text { inch. }\end{array}$ \\
\hline $\begin{array}{l}\text { January ........ } \\
\text { February .... } \\
\text { Mareh ......... } \\
\text { April .......... } \\
\text { May }\end{array}$ & $\begin{array}{l}18 \\
21 \\
16 \\
19 \\
2.2\end{array}$ & $\begin{array}{r}11 \\
9 \\
9 \\
11 \\
9\end{array}$ & $\begin{array}{l}2 \\
4 \\
2 \\
3 \\
3\end{array}$ & $\begin{array}{l}1 \\
3 \\
0 \\
0 \\
0\end{array}$ & $\begin{array}{l}\text { September ..... } \\
\text { October ........ } \\
\text { November ...... } \\
\text { December...... }\end{array}$ & $\begin{array}{l}27 \\
21 \\
25 \\
15\end{array}$ & $\begin{array}{r}26 \\
12 \\
17 \\
9\end{array}$ & $\begin{array}{r}15 \\
7 \\
6 \\
1\end{array}$ & $\begin{array}{l}8 \\
3 \\
4 \\
0\end{array}$ \\
\hline $\begin{array}{l}\text { June } \ldots \ldots \ldots \ldots \\
\text { July } \ldots \ldots \ldots \ldots \\
\text { August ........... }\end{array}$ & $\begin{array}{l}25 \\
28 \\
28\end{array}$ & $\begin{array}{l}12 \\
17 \\
23\end{array}$ & $\begin{array}{r}4 \\
7 \\
12\end{array}$ & $\begin{array}{l}1 \\
5 \\
\mathbf{4}\end{array}$ & $\begin{array}{l}\text { Sum ..... } \\
\text { Maximum ..... } \\
\text { Minimum..... }\end{array}$ & $\begin{array}{r}265 \\
28 \\
15\end{array}$ & $\begin{array}{r}165 \\
26 \\
9\end{array}$ & $\begin{array}{r}66 \\
15 \\
1\end{array}$ & $\begin{array}{r}29 \\
8 \\
0\end{array}$ \\
\hline
\end{tabular}


Directions of the wind, 1902.

\begin{tabular}{|c|c|c|c|c|c|c|c|c|c|}
\hline Month. & $\begin{array}{l}\text { North } \\
\text { days. }\end{array}$ & $\begin{array}{l}\text { North- } \\
\text { east } \\
\text { days. }\end{array}$ & $\begin{array}{l}\text { East } \\
\text { days. }\end{array}$ & $\begin{array}{c}\text { South- } \\
\text { east } \\
\text { days. }\end{array}$ & $\begin{array}{l}\text { South } \\
\text { days. }\end{array}$ & $\begin{array}{l}\text { South- } \\
\text { west } \\
\text { days. }\end{array}$ & $\begin{array}{l}\text { West } \\
\text { days. }\end{array}$ & $\begin{array}{l}\text { North- } \\
\text { west } \\
\text { days. }\end{array}$ & $\begin{array}{c}\text { Variable } \\
\text { days. }\end{array}$ \\
\hline January & & 16.5 & 11. 0 & 2.5 & 1.0 & & & & \\
\hline $\begin{array}{l}\text { Februa } \\
\text { March }\end{array}$ & 0 & & & 6.5 & 5 & 0.5 & & & \\
\hline $\begin{array}{l}\text { Mareh .. } \\
\text { April ... }\end{array}$ & 0.5 & & & $\begin{array}{r}.5 \\
1.5\end{array}$ & .5 & 0.5 & & & \\
\hline May & ....... & 13. & & 1. & & & & & 2.0 \\
\hline Jun & .... & & & 4. & 1.0 & & & & 1.0 \\
\hline July & & 13. & & 6. & & 1.0 & & & 1. \\
\hline August. & 1.5 & 1.5 & 2.5 & 5.0 & 6. & 3.0 & 3.5 & 1.0 & 6.5 \\
\hline Septem & …..... & & & & 6. & 16.5 & 5. 0 & 2.5 & \\
\hline October & ……… & & & 3.0 & 6. & 1.0 & 1.0 & ... & 6.0 \\
\hline $\begin{array}{l}\text { Novembe } \\
\text { Decembe }\end{array}$ & $\begin{array}{l}4.0 \\
2.0\end{array}$ & $\begin{array}{l}6.0 \\
8.0\end{array}$ & & .5 & 3.0 & & .0 & & 2.0 \\
\hline Sum (days). & 8.0 & 117.0 & 125.0 & 32.0 & 28.0 & 22.0 & 10.0 & 3.5 & 18.5 \\
\hline
\end{tabular}

STorms.-Hurricanes may visit the island at almost any season. According to available records they appear to have been most frequent during the months of April and November. The first one recorded occurred on the 8th of September, 1671, in the midst of a war between the Spaniards and the natives. It is described as "a typhoon, called 'baguio' by the natives, the most furious which had been seen on the island, veering in a short time all round the compass, and causing injuries which it would take years to remedy, ruining nearly all the houses of Agaña and the other towns of the island, especially those of the chief conspirators, as they have since confessed; tearing up breadfruit trees, together with palms and other plants with which they nourish themselves, leaving them in a condition without farms, without houses, and without food." Not even the church of the missionaries was spared, and one of the wizards of the natives declared that he was more powerful than the god of the Spaniards, since the hurricane had swept away their church and had not been able to injure his house.

A violent hurricane laid waste the island on the night of August 10, 1848. A description of the damages wrought by it may be found in a report of the Spanish governor, Don Pablo Perez, to the captaingeneral of the Philippines. Since the American occupation there have been several hard storms. The first occurred on May 26-27, 1900, the wind being accompanied by very heavy rainfall. Breadfruit, coconuts, coffee, and cacao were stripped from the trees and bushes; plantains and banana plants were torn to shreds, and many trees were snapped off or uprooted. In the southern part of the island fowls died from exposure. At the village of Sumai, on Orote Peninsula, the infirmary and wharf shed were demolished and several private houses were blown down. At Agat several dwellings were destroyed, together with the schoolhouse. At Merizo the rice fields were destroyed, and at Umata the corn was killed, the chapel unroofed, and several dwellings demolished. At Inalahan three bridges were carried away by swollen streams and the tribunal, rectory, and school- 
house unroofed. In the harbor of San Luis de Aprâ the U. S. S. Brutus was torn from her anchorage and blown upon the reef, without, however, suffering serious injury.

On the 13th of November following occurred the hurricane which caused the loss of the U. S. S. Yosemite, which was lying at anchor in the harbor. This vessel was swept from her moorings and carried out to sea, where she foundered. Five of her crew were lost. The sea overflowed the lowlands and flooded the streets of Agaña. Crops of all kinds were destroyed and most of the vegetation was stripped bare of foliage. Government buildings were injured and many native houses destroyed. Of the 255 deaths which occurred on the island during the year 1900,34 were caused by the hurricane. This destruction was followed, as is always the case, by a dearth of food. It caused our Government to expend nearly $\$ 10,000$ for the relief of the natives, who received the proffered aid with expressions of deep gratitude. ${ }^{\prime}$ Among the most serious results of hurricanes of this nature is the stripping of coconut trees of their leaves. The inflorescence is formed in the axils of the older leaves and if these are injured the flower buds shrivel up and the tree fails to produce. During the year which followed the hurricane not one ounce of copra, which is practically the only export of the island, was produced in Guam. Coffee and other shrubs and trees soon recover from the effects of a storm, and maize, tobacco, and rice may be replanted. Cacao, however, is often killed ontright, and sereral years are necessary for new plants to begin to bear.

The records for 1902 show that hurricanes passed near the island of Guam in May, July, September, and October. In examining the Philippine weather records Doctor Abbe was able to identify the stormy periods of Guam as days when typhoons must have passed close to the island. Many of the typhoons which sweep the Philippines apparently hare their origin in the vicinity of the Marianne Islands. Doctor Abbe has suggested in his report that a station be estahlished on the island of Guam for meteorological observations, to be connected by telegraph with Manila. This could not fail to be of great benefit to resisels about to put to sea, giving warning of approaching blows and indicating what kind of weather is to be expected.

\section{HYDROGRAPHY.}

CONTOCR OF THE OCEAN's BOTTOM.-In taking soundings with a view to selecting a cable route across the Pacitic the U. S. S. Nero found the ocean bed hetween Midway Island and Guam to be a great plain from 3,100 to 3.200 fathoms deep. somewhat broken in places by submarine reefs and mountain ranges. The first thousand miles from Midway,

"Annual Report of the Assistant Secretary of the Nayy, 1901, pp. 75-76. 
with the exception of a submarine mountain peak near Ocean Island, is entirely level. The remainder of the distance, though fairly level in general, is interspersed by a number of reefs and mountain ranges. On approaching the great submarine volcanic range running nearly north and south which forms the islands of the Marianne group, at a point a short distance east of Guam, this plain descends into an ahyss, which is the deepest yet discovered in the world, lacking only 66 feet of a depth of 6 statute miles. The temperature at this depth was found to be $36^{\circ} \mathrm{F}$. It was necessary to select for the cable a route around the northern limit of this depression, which has been christened the Nero Deep. Its southern limits are not yet known.

Between Guam and the Philippines the bed of the ocean is less regular than to the eastward. For the first 600 geographical miles the depth varies from 1,400 to 2,700 fathoms. The character of the bottom is described as undulating, but without definite ranges of hills or valleys. After this a low mountain range occurs which slopes to the westward down to a plain 3,000 to 3,500 fathoms deep, which reaches to the Philippines and has a bottom of soft mud and ooze.

A route was also surveyed between Guam and Yokohama, Japan, to the westward of the Mariannes and to the eastward of the Bonin Islands. For the first 500 geographical miles a level plain 2,100 fathoms deep was found. Then the Nero encountered a submarine mountain range which apparently connects that of the Marianne Islands with the range extending from the Bonin Islands to Japan. While crossing this range a submarine conical peak was discovered resembling Fujiyama in form. ${ }^{a}$

Ocena currents. - The currents in the vicinity of the Marianne Islands are much affected by the prevailing winds. During the greater part of the year there is a drift to the westward or southwestward of 1 to 2 knots per hour. On the sandy beaches of the east coast of the island of Guam driftwood of American origin is often found, including huge logs of Oregon fir. From July to September, when the easterly winds are interrupted by the influence of the southwest monsoon, the drift is frequently to the northeast.

Tides. - The rise of tides in the archipelago is generally less than 3 feet. In the harbor of San Luis de Aprâ the rise and fall is 3 to $t$ feet. High water occurs there at the full and change of the moon at about seven hours after its meridian passage. The tides play an important rôle in the economy of vessels lying in the harbor, as the water on the reef is too shallow to permit boats of considerable size to land eargo at any time but that of high water, and it is not unusual

"See "Trans-Pacific submarine telegraph cable survey," in the Report of the Secretary of the Navy for 1900 , pp. 299-302, from which the above information is derived. 
for a boat to stick upon the reef halfway between the ship and the shore. There is a crooked channel through which boats of small size may pass, and extensive dredging operations have been recommended in order to enlarge the harbor and clear a channel from the harbor to the shore, but the recommendations of the board have not yet been carried out. $^{a}$

PHYSICAL GEOGRAPHY.

Surface AND contour.-From a distance the island appears flat and even, but on approaching it the northern portion is seen to be a raised platform or plateau $(\mathrm{Pl}$. I), with several low peaks rising from it in the north, and to the southward a low, rounded hill, which has received the vernacular name of "Tiyan" (belly). The southern half of the island is mountainous. The island is irregular in shape. It may be compared roughly to the shape of a human footprint (the right foot), with the heel north-northeast and the toe south-southwest (see map, Pl. LXX). The general plane of the northern half is not horizontal but shelving, with eastern and higher side bounded by steep cliffs. The east coast of the southern half is penetrated by a few small bays, none of which is capable of receiving a vessel. On the west coast of the northern part of the island there are a number of sandy bays fringed with coconut groves and separated from one another by as many rocky points.

The east shore is constantly beaten by a heary sea caused by the stiff trade winds which prevail during the greater part of the year. The adjacent sea is very deep, so that it is impossible for vessels to find anchorage there. The swell is even so great that it is dangerous at most times for boats to attempt to enter the small ports in the southern part, except at Hahahyan, at the extreme south, which is sheltered from easterly and northeasterly winds. On the west side of the island the sea is shallow enough in several places to permit ressels to anchor within a safe distance of the shore, except during a certain part of the summer, when winds from the southwest may be expected. The favorite anchorage of the early navigators was the roadstead of Umata (Humátag), where a good supply of fresh water was always to be secured without difficulty. Afterwards the bay of San Luis de Aprâ became used as a harbor, and is now the only port of the island in which large ships can find anchorage. The little harbor of Agaña (Hagadña) can be entered only by vessels of the size of launches, and the anchorage in Agaña Bay is not considered safe.

In Alexander Agassiz's description of the island ${ }^{b}$ he gives a detailed account of its shore line and the physical features of the island. The

"See Report of the Guam Survey Board to the Secretary of the Navy, July 25, 1901.

$b$ The Coral Reefs of the Tropical Pacific, p. 366 et seq., 1903. 
Albatross encountered the east coast of Guam near Point Hanom. He found distinct coralliferous limestone terraces in the faces of the cliffis from Pago Bay north, marking the position of the former sea level, and indicating the periods of rest during the elevation of the island; and when these are not distinct, lines of caverns along the vertical faces of the cliffs indicate the former lines of sea level. The cliffs of the northern part of the island vary from 300 to 500 feet in height. The lower part of their faces is riddled with crevasses, and at a higher level, probably on the face of the fourth or fifth terrace, there are numerous caverns. North of Point Anao some of the coralliferous limestones are stratified, dipping toward the sea; others, nearer the northern extremity of the island, show evidence of great disturbance, probably caused by the volcanic outbursts of Mount Santa Rosa. Mr. Agassiz found them to resemble those of similar limestone islands, such as Makatea, Niue, Eua, Vavau, and others of the Fiji group. Outside of Viti Levu and Vanua Levu, Guam proved to be the largest island visited by the Albatross, composed in part of volcanic rocks and of elevated coralliferous limestone. At the northern end of the island, though there are five distinct terraces, these are concealed by the vegetation growing on the slopes. Talage ("Lookout") Bay, ${ }^{\text {" at }}$ the northern extremity of Guam, is an immense sandy flat, flanked by a comparatively broad reef platform full of "horseheads" and of "negroheads" of coral, which extends from Taga Point around the north extremity of the island and down the east coast, past Achae and Nigo points, to Ipapao. From the latter point the coast consists of a vertical cliff, with here and there a small stretch of sandy beach along the sea between projecting points until it reaches Tumhun Bay. Here the coral forms a great reef flat, which continues along the coast southward, past Hagadña Bay, as far as Âpapâ, or Cabras, island. To the south of Orote Peninsula, which projects 4 miles in a northwesterly direction and forms the southern side of the bay of San Luis de Aprâ, a narrow reef flat juts out from the west coast at various promontories in the extension of spurs of volcanic slopes. At Malesô, or Merizo, Bay a broad reef flat projects, which forms the southwestern extremity of the island of Guam and extends eastward to Point Hahahyan, but not as far as Inalahan Bay, on the east coast. North of that bay the coast is edged by a narrow reef flat, which continues as far as Pago Bay. Along the east coast of the northern half of the island there is a narrow reef flat, bordering the precipitous shore from Hanom Point to Point Anao.

The southern half of the island of Guam consists of what Mr. Agas-

"The name of this bay is improperly written on most charts "Taragay," a word with no significance. "Talage," (pronounced talágay) the vernacular name, signifies "to look toward." It was the point from which the ancient Chamorros looked out for vessels coming from the northern islands. 
siz describes as " a volcanic massif which has burst through the coralliferous limestone," and which at Mount Tengho reaches to a height of more than a thousand feet. The rolcanic range to which it belongs has burst through the limestone near Agaña and extends southward, parallel to the west coast, at a distance of about 1 or 2 miles from the shore. Its highest peak, called Hunuyong-mañlo ("Source-of-thewind"), back of Umata, reaches a height of 390 meters. Considerable denudation has already taken place on the voleanic slopes, forming in the interior of the island a number of peaks, ridges, and pinnacles. On the western and southern sides of the volcanic mountains the limestone masses which once covered their sides have in great measure disappeared through disintegration, and the soft material covering the slopes is constantly being washed down their sides. Many of the valleys form small canyons with very steep walls.

The peninsula of Orote and Âpapâ Island are composed of elevated coralliferous limestone containing well-preserved fossils. These show no signs of metamorphism, as do those collected in the immediate vicinity of Mount Makahnag, where the limestone comes into contact with volcanic rock. The fossils are, however, highly calcified, and their hardness and the crystallization of the rocks would seem to indicate considerable age.

The rarbor.-The bay of San Luis de Aprâ is the only harbor for vessels. It is protected on the southwest by the promontory of Orote, on the east by the island of Guam itself, on the north by Âpapâ island and the adjoining reef of Luminan, which is awash at high water. From this reef a bank (Kalálang) extends to the sonthwestward toward Orote Point, terminating in two rocks which rise to within a few feet of the surface, leaving a narrow but deep channel, which serves as an entrance to the harbor. Âpapi island consists entirely of elevated coralliferous limestone deeply pitted and honeycombed. The limestone mass is full of crevices, potholes, and funnels, covered with stalactites. The island does not rise more than $s$ or 10 feet above high-water mark. The shore is undercut and the island furrowed by numerous gullies; it is full of caverns, crevices, and pits. ${ }^{a}$

As the harbor is much obstructed by coral reefs and is at a considerable distance from the seat of government of the island, a board of officers was sent to make a survey of it, with a view to its improvement, either by dredging or the construction of a breakwater along the reef, or both. It is intended to make it the site of a naval base and coaling depot of large capacity, as well as to serve as a commercial port. The board was directed to make recommendations as to the remoral of reefs and other obstructions to navigation; to draw up plans for wharres, docks, storehouses, barracks, hospital, water sup- 
ply, and sewerage system; port defenses, fortifications, and magazines; and to lay out a town site, having in view the prospective increase in commercial importance of the port. The following extract is taken from the report of the board:

The bay of San Luis de Aprâ has a deep anchoring ground, extending about 1 mile north and south and about 2 miles east and west. It is broken, however, by several outlying reefs. It is protected except to the westward. Luminan Reef gives sufficient protection, but Kalálang Bank, with a depth of some 30 feet, does not, the swell making round the end of Luminan Reef even with the prevailing northeasterly wind. It would therefore be necessary, in order to thoroughly close the harbor against the ocean swell and storms, to build a breakwater along these banks, extending from Luminan Reef to Spanish Rocks, leaving a deep entrance between Spanish Rocks and Orote Island 2,000 feet wide.

The board did not recommend that such a breakwater should be built, on account, among other considerations, of its great cost and the uncertainty of the force of storms against a breakwater on this narrow bank with deep water so close to seaward. Even if such a breakwater were built, the proposal which had been made of utilizing some of the coral reefs in the harbor as sites for coal depots could not be followed out, as test borings made in these reefs showed that nearly all of them are formed, not of solid coral, but of coral sand interspersed with occasional coral heads, with growing coral of various kinds on the surface, so that they would make poor foundations for retaining walls.

After duly considering various plans the board recommended that an opening 30 feet deep be dredged through the reef separating the deep water of the main harbor from an inner basin south of the old fort, Santa Cruz, and not far from the village of Sumai on Orote Peninsula; that this basin be enlarged by dredging, and the top of a small reef in the outer anchorage, near Cabras Island, be removed to a depth of 6 fathoms; that the naval base and coaling station be established on Orote Peninsula, near Sumai, and be supplied with water brought from Paulana, a branch of the Atangtano River; that batteries be located on Orote Peninsula and Cabras Island with good military roads leading to them from the posts and boat landings; that the town site be established on the high land of Orote Peninsula, back of the naval station, and that commercial docks be constructed in places indicated by the board; and that a light-house be constructed on Orote Point with a light of the fourth order. The report of the board was published ${ }^{a}$ and handed to the Naval and Commerce Committees of Congress. An appropriation of $\$ 150,000$ for the improvement of the harbor of San Luis de Aprâ passed the Senate, but the House failed to concur and the measure was lost. The sum of $\$ 40,000$ asked for the acquisition of land was granted by Congress. The retention of Guam as an American possession after its capture, as provided for in the peace protocol at the close of the Span-

a Report of the Guam Survey Board to the Secretary of the Navy, July 25, 1901.

$9773-05-4$ 
ish war, was for the express purpose of establishing a naval coal depot. With completion of the Panama canal this will undoubtedly become an important mercantile port of call. ${ }^{a}$ (See map, Pl. LXX.)

EARTHQUaKes.-Earthquakes are frequent, but not often violent. Among the most severe were those of April 14, 1825, January 25, 1849, and September 22, 1902. Not long after that of 1849, which destroyed the church and the government house of Umata, a number of Caroline Islanders arrived at Guam in two canoes, stating that their islands had been swept by enormous waves, and begging the governor to allow them to take up their residence in the Marianne Islands. In the letter book of Don Pablo Perez, in the archives at Agaña, a detailed account of this earthquake is given. The first shock was felt at 2:49 p. m. It was followed by repeated shocks and trembling accompanied by a subterranean rumbling "which made the natives fear that a volcano was about to burst forth and blow them all to atoms." The earth was cracked open in many places, some houses were thrown down and others were injured; but the only life lost was that of a woman who happened to be in her rancho near the beach. She was carried away by one of the great waves which swept in from the ocean. Great masses of rocks fell from the cliffs. The shocks continued for several days in succession, and it was many days before the damages could be repaired. Sixteen whaling vessels lying at anchor in the harbor were uninjured. The captain of a whaling frigate which arrived shortly afterwards stated that he had felt the earthquake 1,000 miles to the eastward of the Mariannes. Since the American occupation of the island there have been a number of earthquakes, but the only one of serious importance was that of September 22, 1902. Governor Schroeder's account of this is almost a repetition of Don Pablo's report to the captain-general of the Philippines.

The earthquake which occurred at 11.24 a. m. [says Governor Scbroeder] is the severest of which there is any record. From the government house terrace, during its continuance, there could be seen clouds of dust rising suddenly from the different quarters of Agaña as the masonry houses would fall. The earth opened here and there in small places, from which water would spout and subside, leaving a few round, apparently hollow pits, and innumerable fine cracks were observable everywhere. A dull grinding roar preceded and accompanied the shaking of the earth; sure-footed bulls were tripped up and fell to their knees, while buildings rocked and swayed, water tanks were tossed over, and bells rung by the vibration. In other parts of the island fissures 1 to 2 feet wide were made, those of Piti emitting strong sulphurous fumes.

Masses were dislodged in the mountains and hills, plowing down the slopes and completely blocking the road from Agaña to Piti at three points. In the harbor of San Luis de Aprâ the collier Justin, anchored in 22 fathoms of water, was severely shaken. The disturbance of the white coral-mud bottom of the harbor was so great as to

$a$ Report of the Secretary of the Navy for the year 1902, pp. 361-362. 
give a milky appearance to the sea for some distance around. A number of the masonry houses of Agaña were destroyed, and those left standing were so badly injured as to be unfit for habitation. The old bell tower of masonry near the church, built in 1669, was seamed with large cracks. In the other towns of the island nearly all masonry houses, churches, and rectories were ruined. The collier .Justin was sent the day after the disaster with an officer to the German island of Saipan, 120 miles to the northward, to ascertain the damage done and offer aid. They found no casualties, though the earthquake had also violently shaken the island. Fortunately the disaster occurred in the daytime, as did the hurricane of 1890 , and the casualties included but one child killed and a few of the townspeople of Agaña hurt. The total cost of repairs to government buildings was estimated at $\$ 22,100$ gold.

A summary of the earthquake phenomena of 1902 is included in Doctor Abbe's report, published in Terrestrial Magnetism and Atmospheric Electricity, 1904, page 81.

Extinct volcanoes.-All of the mountain peaks of Guam are undoubtedly of volcanic origin. In some of them the outlines of the craters may still be traced and the lava presents the same appearance as in recent volcanoes. ${ }^{a}$ Surrounding the bases of the mountains are ancient coral reefs, the margins of which, in contact with the volcanic products, have in many places been converted into crystalline limestone, showing evidence of volcanic activity after the whole island had been raised from the sea. The heights of the principal mountains are approximately as follows: Santa Rosa 265 meters, Tiyan (Barrigada) 205 meters, Makáhnag 215 meters, Chachao 320 meters, Tengho 310 meters, Ilicho (Humuyong-mañglo) 390 meters, Sasalaguan (Hell mountain), at the southern end of the island, 340 meters.

Ancient Coral Rlefs. - The entire northern portion of the island is a raised coral platform penetrated in several places by the low volcanic peaks already referred to. On the west side of the island between the mesa and the sea several distinct flat terraces occur, showing successive upheavals. During the recent earthquakes the general level of the whole island was raised. It would require only a very slight elevation to convert into dry land the very extensive reef flats along the west coast which are covered at high tide by only a few feet of water. The bottom between the shore and the barrier reef is perfectly level and covered with very fine sand resembling flour in consistency.

Minerals. - With the exception of thin layers of iron-ore, no metalyielding deposits occur on the island. An inferior lignite is found in one or two places. There is also a volcanic rock called homón, which is used for fire places, and a soft pale-green mineral called lauka which

a This is especially true of Santa Rosa, in the northern part of the island. 
is easily worked. In certain localities nodules of flint are found similar to those from European chalk formations.

RIVERs. - In the northern portion of the island the ground is so porous that the water disappears as it falls. There are, however, a number of sink holes called lupog, and in the rainy season several small streams near the bases of the hills of Santa Rosa and Matáguag. Near the middle of the island about a mile and a half from Agaña there is a fine large spring or lake (Matan-hanom) from which a copious supply of water issues all the year round. This, after slowly oozing through the great swamp called the "Ciénaga," forms the Agaña River, the channel of which has been artificially lengthened and turned for about a mile parallel to the coast before it reaches the sea. This is for the purpose of affording a laundry to the women of Agaña. In the southern portion of the island there are a number of small streams on both sides, some of which lose themselves beneath the surface for a time and reappear, issuing from caverns. ${ }^{a}$

\section{VEGETATION OF THE ISLAND.}

PLANT COVERING ACCORDING TO HABITAT.

CORAL REEFS.

Among the alge growing on the reef the most conspicuous are the hrown Padinas with fan-like fronds expanded like the tail of a strutting peacock jointed Halimedas, like miniature Opuntias, and the feathery Canlerpa plumaris. Another Caulerpa ( $C$. claviferce uvi$f_{e}(t)$, green and succulent, looks as though it bore bunches of miniature grapes. Among the red algæ are the more delicate Acanthophora mientalis, Corallopsis salicomia, with terete cartilaginous fronds, and Mfastophore lemomouxii, with dense foliaceous fronds, somewhat like Chondrus in form. and conspicuous fruit. From some of the gelati nous specips the natives make blancmange. Among the more delicate sreen forms are the woolly Rhizoctonium tortuosum and the beautiful little Bryopsis plumosa. Near the mouths of rivers grow Enteromorphe clutheute and E. compress, with narrow, linear, grasslike fronds. (See Algit, catalogue.) Among the marine flowering plants are Itrtudule uninereis, a plant resembling a fine eelgrass (Zutera), and Ituluplita mate, belonging to the Vallisneriaceae, with a creeping rootstock and oral or linear-oblong petioled leaves.

M.A Tratiote STMAMPS.

At the mouths of many streams, where the water is brackish and the shores are muddr, are growths of mangroves and their allies;

"The principal cavern of this nature is that in the valley of the Talofofô River, about a mile from its mouth. 
which form dense thickets and extend far out into the water at high tide. Among those which send down aerial roots into the mud are Rhizophora mucronata (Pl. LXIV) and Bruguiera gymnorhiza (PI. $\mathrm{XL}$ ), both of which have large, opposite, entire, smooth leaves, and fruit which germinates before dropping from the tree. They are easily distinguished, the former having a four-parted perianth and the latter having 10 to 14 calyx segments and petals. Associated with these are found red-flowered Lumnitzeras, small trees belonging to the Combretaceae; Xylocarpus granatum (Carapa moluccensis), known in the East Indies as the "cannon-ball tree," on account of its hard, spherical fruits; and on adjacent firmer ground, Excoecaria agallocha, sometimes called the "milky mangrove" or the "blinding tree," the acrid juice of which is called "tigers milk" in the East Indies.

RIVERS.

Near the mouths of most of the rivers, where the water is brackish, are thickets of $N_{y j}$ frutirons, a stemless palm with great pinnate leaves, which furnish the natives with excellent material for thatching: their houses. Associated with it are large simply pinnate ferns, Acrostichum aureum (PI. IV), of wide distribution throughout the warmer regions of the globe, and growing submerged are species of Potamogeton and Ruppia muritima. There are also green, filamentous algre, including species of Conferva and Enteromorpha, and Charce fibrosa. Near the sources of some of the streams a small red alga (Thorea gaudichaidii) is found growing to rocks. On the banks of the rivers near the sea beds of Pancratium littorale occur, together with a creeping aroid, Cocos nucifera, screw pines, and Pariti tiliaceum. Higher up the stream there are beds of reeds (Trichoon) and, on the open hillsides, the sword grass, Xiphengrostis floridula. Where streams flow through shady forests several cordate-leaved aroids occur, together with a tree fern (Alsophila haenkei) and the widely spread Angiopteris evecta (PI. XXXIII).

THE STRANIY.

The principal beach plant is Ipomoea pes-caprae, often called "goatsfoot convolvulus," from the shape of its leaves. Its long, prostrate stems form a carpet over the sand without twining or taking root, and bear large, rose-purple, funnel-shaped flowers. Associated with it is the leguminous Canavali obtusifolium, with a similar habit of growth, and frequently Melastoma marianum, Vigna Zuten, and Ileliotropium curassavicum. Among the beach shrubs are Lobelia lioenigii, with thick, glabrous leaves, and white, zygomorphous flowers; Toumefortia argentea (Pl. LXVIII), a boraginaceous plant with fleshy leares, covered with silky white hairs, and white, heliotrope-like flowers with dark anthers growing in scorpioid racemes; and Pemphis acidula, a 
shrub with a dense habit of growth, small sessile leaves, and axillary flowers with 6-parted perianths. On the windward side of the island, and near the southern end on the leeward side, growing in the sandy beach at the very margin of the sea are groves of Casuarina equisetifolia (Pl. XLI), trees with tufts of linear, leafless, jointed branches resembling horsetails (Equisetum) and cone-like fruit. Among other beach plants are the composites Stemmodontia biflora, S. canescens, Eclipta alba, the recently introduced Synedrella nodiflora, and the bidens-like Glossogyne tenuifolia; and in places there are mounds formed by Sesuvium portulacastrum, the "sea purslane," often associated with creeping grasses. Coconuts are abundant on the west coast of the island (PI. I), but almost absent from the east coast.

THE INNER BEACH.

The principal trees forming the inner beach growth are Barringtonia speciosa, Barringtonia racemosa, Terminalia catappa, Heritiera littoralis, Parititiliaceum, Thespesia populnea, Ochrosia mariannensis. Hernandia peitata, Artocarpus communis, Calophyllum inophyllum. and Morinda citrifolia. Beneath their shade grow the white-flowered amaryllis (Crinum asiaticum), the grasses, Stenotaphrum subulatum and Centotheca Tappacea, and the shrubby Boerhaavia diffusa, Vitex trifolia, and Meibrmia umbellata. Climbing on the trunks of trees are a number of ferns, including Plymatodes phymatodes (Pl. LXII), with leathery lobed fronds, Cyclophoms adnascens, with small, linear-lanceolate, simple fronds, Davallia solida, with beautiful, glossy, divided fronds, and Humata heteropliylla, with fertile fronds differing from the sterile in shape (Pl. LIII). In addition to the abore-mentioned species there are a number of shrubs growing in the vicinity of the beach-the

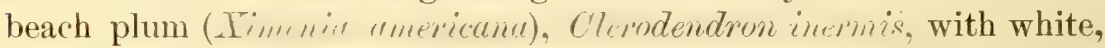
honeysuckle-like Howers and exserted pink stamens; Acacia farnesiana, with globular, yellow heads of fragrant flowers; Lencuena glaner, with similar heads of white, inodorous flowers; and the custard apple, Amona reticulata, the only species of this genus which grows spontaneously on the island. Twining among these shrubs are several species of Convolvulaceae, including Ipomoea choisiana and I. mariannensis, with purple flowers; the lavender-flowered "alálag" (Argyreia tilicefuliu), the flowers of which, called "abubo," are strung into garlands by the children; and Operculina peltata, which has white flowers.

THE CLIFFS.

On the promontory of Orote on the west coast, that of Kiroga on the east near Talofoffô Bay, on the rocky island of Cabras, or Âpapâ, and on the edges of cliffs are usually found the following plants: Cormigmus mariannensis, a shrub or small tree belonging to the Rubiaceae, with large, white, four-parted, trumpet-shaped flowers; Cycas 



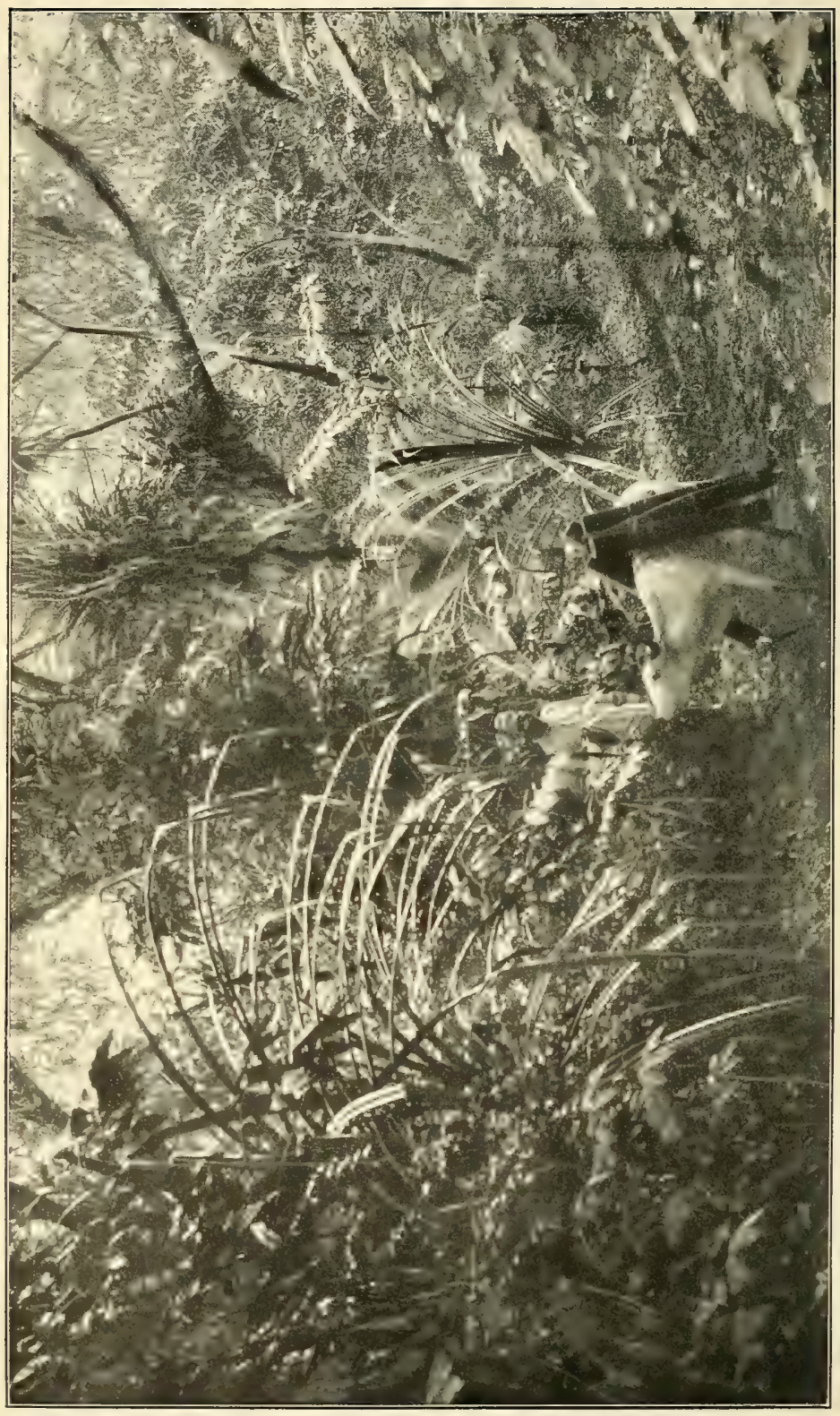


circinatis, with glossy pinnate leaves resembling fronds of ferns; and Boehmeria tenacissima, which yields the celebrated "rhea" fiber, here growing in the form of a shrub or small tree. Besides these plants Intsia bijuga, a handsome leguminous tree, which yields the excellent ifil wood (Pl. LIV); Premna gaudichaudii, a verbenaceous tree called ahgau, with elder-like flowers and durable hard wood used in construction; and the interesting "nunu" (Ficus sp.), a banyan which sends down aerial roots like life-lines over the edge of the cliffs. Among the smaller plants growing on rocky slopes is Gynopogon torresianus, with glossy, myrtle-like leaves and the aromatic fragrance of the "maile" (Gynopogon olivaeformis) so dear to the Hawaiians.

TORFSTS.

The forest vegetation of Guam (PI. II) consists almost entirely nf strand trees, epiphytal ferns, lianas, and a few undershrubs. The majority of the species are included in what Schimper has called the Barringtonia Formation. ${ }^{a}$ The principal trees are the wild, fertile breadfruit, Artocarpus communis; the Indian almond, Terminulia cateppa; jack-in-the-box, Hernandia peltuia; the giant banyan (PI. XII), called nunu by the natives (Ficus sp.); two other" species of Ficucalled "hodda" and "takete" or "taguete," the first with prop-like, aerial roots growing from the trunk near its base and with fruit resembling small, red crab apples and the second resembling the nunu. but with aerial roots from the trunk only and not from the limbs; Pandanus fragrans ("kafô") (PI. LX) and Pandanus dubius ("pahong"), two screw pines which differ from many of their congeners in not being found growing on the outer beach; Calophyllum inophyllum, a handsome tree known in the East Indies as Alexandrian laurel, which yields the tough crossgrained wood of which the natives make their cart wheels; Burringtonia racemosa, which, unlike its congener, B. speciosa, leaves the coast and follows along the banks of the streams into the interior; Heritiera littoralis (PI. LII), called in India the looking-glass tree, which furnishes the natives of Guam with tough wood for their plows and wheel spokes; and, among recently introduced trees, Canangium odoratum, the fragrant flowers of which are the source of the perfume known as ilangilang, Annona reticulata, the custard apple or bullock's heart, and Pithecolobium dulce, a leguminous tree known in the East Indies as the Manila tamarind, but which was brought from Mexico for the sake of its tannin-yielding bark and its edible pods. No truly indigenous palms occur, but Areca cathecu, the betel-nut palm, grows spontaneously in damp places; a small, slenderstemmed species allied to Areca, called "palma brava" by the natives, is gradually spreading over the island; and the Caroline Island "sagopalm, 'Cheloccocus amicarum, has been introduced sparingly. Those 
familiar with the forest vegetation of Eastern Polynesia will be struck by the absence from the forests of Guam of such genera as Freycinetia, Papyrius (Broussonetia), Urticastrum (Laportea), Myristica, Parinari, Bocoa (Inocarpus), Dysoxylum, Nyalelia (Aglaia), Macaranga, Bischofia, Aleurites, Omalanthus, Spondias, Rhus, Alphitonia, Melochia, Kleinhovia, Metrosideros, Maesa, and Diospyros.

Among the climbing plants and epiphytes of the forest are Lens phaseoloides, the scimitar-pod sea bean (PI. LVI), whose enormous, scabbard-like legumes contain lenticular seeds (Pl. XV) sometimes used for making snuffboxes; Stizolobium giganteum, often called "ox-eye" bean; a species of Calamus, with beautiful branching inflorescence of white flowers; Luisia teretifolia, an inconspicuous orchid, and the minute leafless Taeniophyllum fasciola; Dischidia puberula, an interesting asclepiad growing upon trees, with minute urceolate flowers and fleshy leaves; bird's-nest ferns (Neottopteris nidus), perched on the branches associated with broad ribbons of Oplioderna pendula, tufts of Nephrolepis acuta and N. hirsutula, grass-like Vittaria elongata, and pendent tassels of Lycopodium phlegmaria (Pl. LVII); climbing leathery-fronded Phymatodes phymatodes, lobed like oak leaves; Cyclophorus adnascens, with linear-lanceolate fronds; graceful Davallia solida (PI. III), with glossy divided fronds, and the interesting Humata heterophylla (Pl. LIII), which takes its generic name from the village of Humátag, or Umata, on the west coast of this island, where it was first collected.

Beneath the shade of the forest trees several undershrubs are usually found, including species of Icacorea, Piper, Peperomia, and the creeping rubiaceous Carinta leerbacea, with small white flowers and scarlet berries. On the edges of the woods and by roadsides are thickets of the spiny Guitandina crista, bearing the well-known gray, stony "nicker-nuts," the sharp recurved thorns of its branches catching or scratching every animal which brushes against them (PI. LI). Lemoncito thickets (Triphasia trifoliata) are also common, the bushes sprouting from the roots and bearing fragrant, white, jasmine-like flowers and scarlet berries resembling miniature oranges. Among the succulent plants are wild ginger (Zinziber zemubet), turmeric ( $C u r$ cumalonga), Canna indica, the Polynesian arrowroot (Tacca pinnatifida), and the introduced Tactsia teminalis, a liliaceous plant with graceful tufts of red leaven. Besides the climbing and epiphytal ferns already mentioned there are many others growing on the ground, including Belvisia spicata, Dryopteris dissecta, Dryopteris parasitica, Asplenium laserpitiifolium, A. nitidum, Microsorium irioides, and several species of Pteris. No filmy ferns (Hymenophyllaceae) have been found on the island. The only tree fern of Guam thus far known is Alsophilu haenkei, growing in damp places and often associated with Angiopteris evecta. 


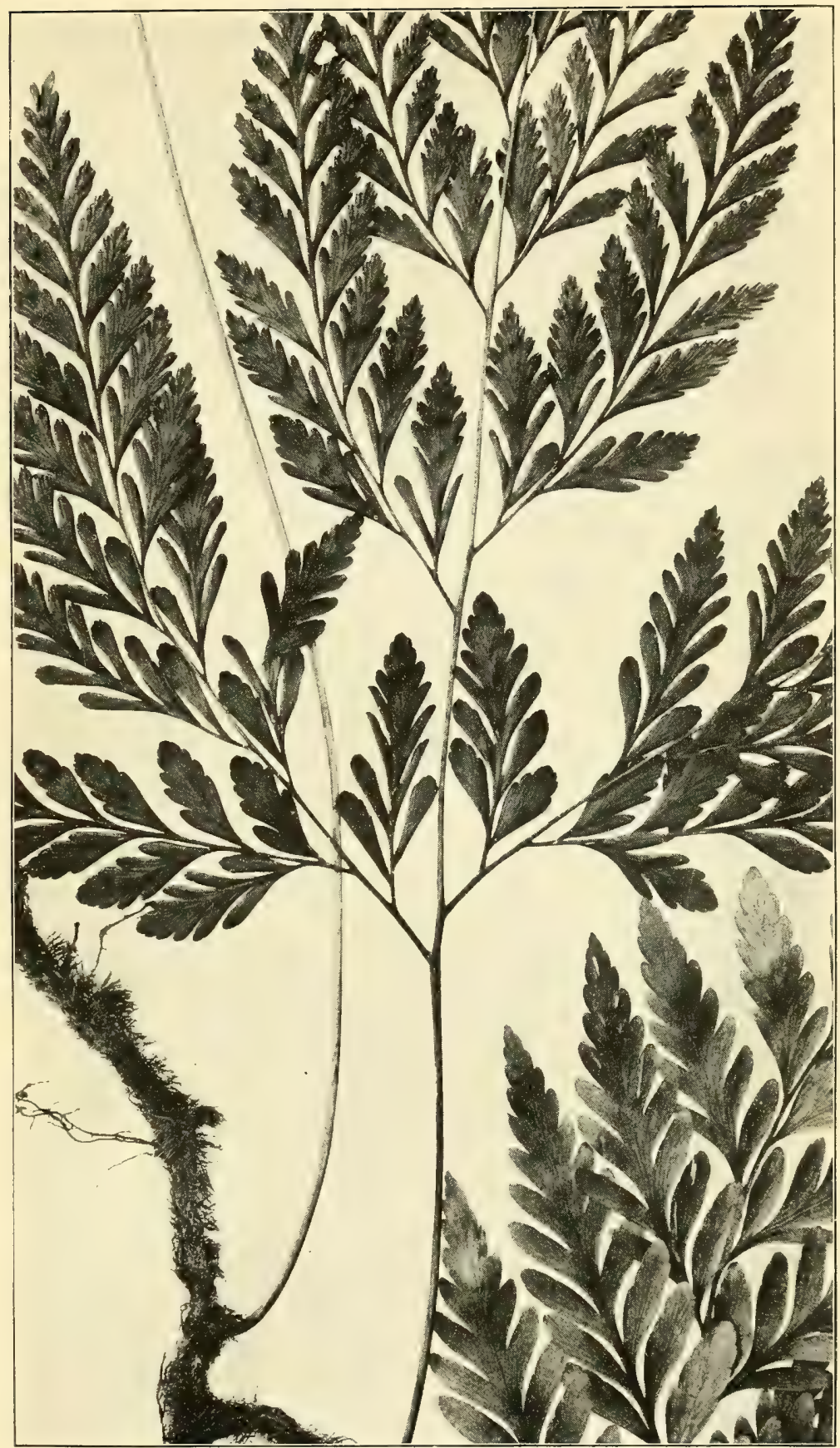

Davallia solida, an Epiphytal fERn COMmON in the Forests of Guam. NATURAL SIZE. 




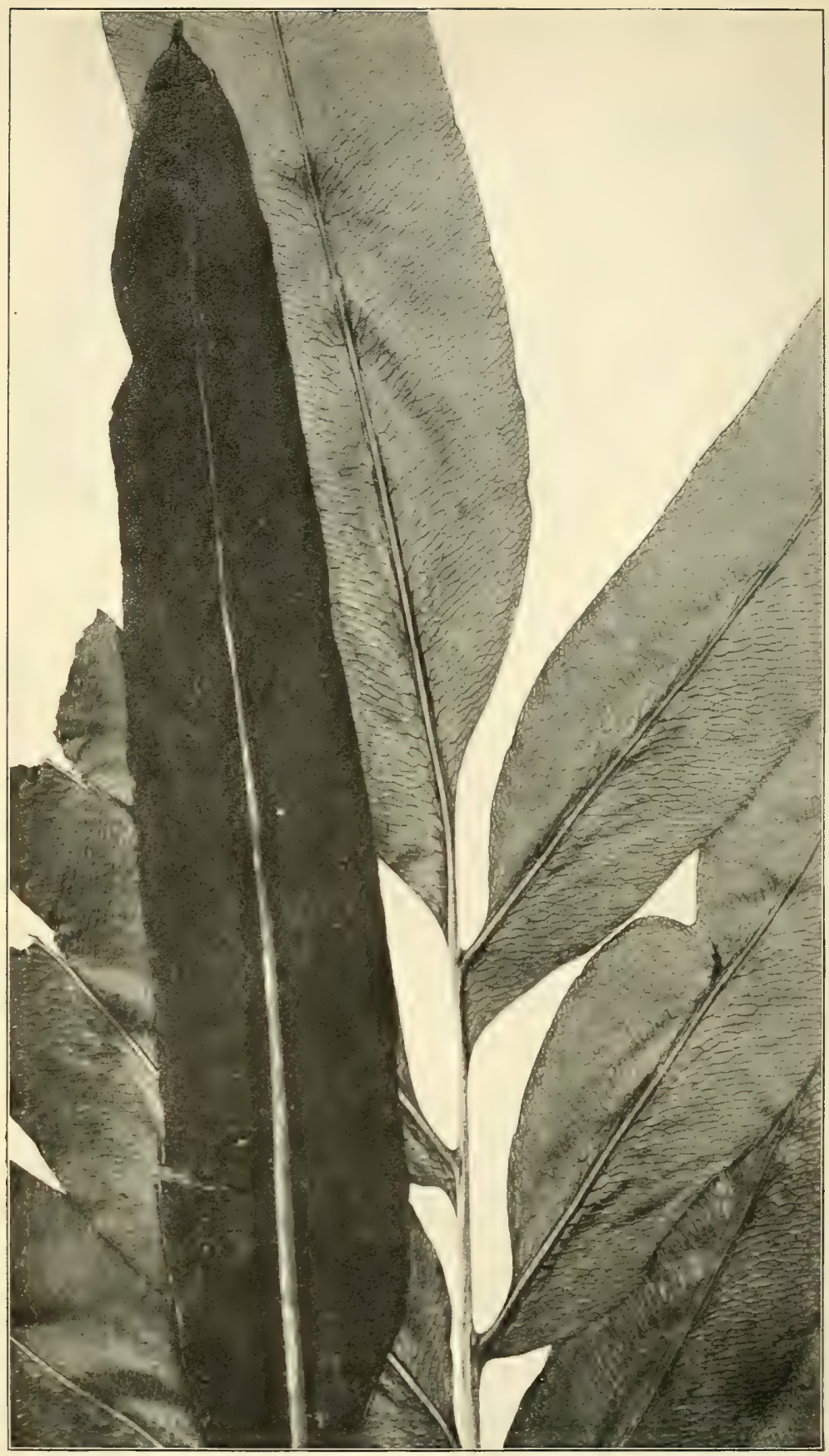

A Marsh Fern, Acrostichum aureum. Sterile Frond and a terminal PinNa of FERTILE Frond. NATURAL Size. 



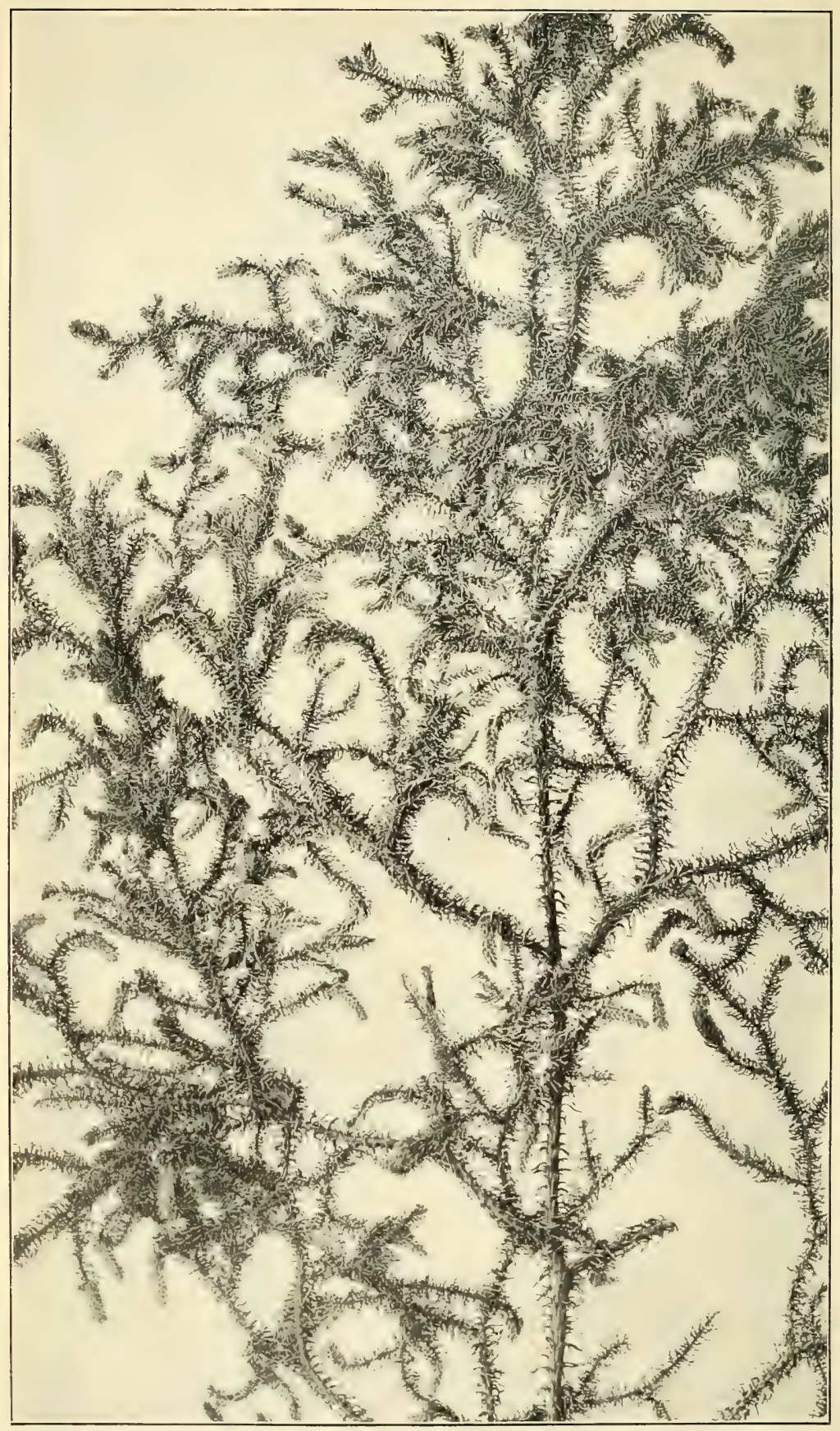

Lycopodium cernuum. a Characteristic Plant of the Savannas. NATURAL SizE. 
MARSHES.

The fresh-water marshes are usually overgrown with reeds (Trichoon roxburghii), associated with the great marsh fern (Acrostichum aureum) (PI. IV), the climbing Lygodium scandens, and several coarse grasses and sedges. The only trees are Pariti tiliaceum and a euphorbiaceous tree called "alom," probably a species of Echinus. Growing about the margins of swamps are the small Bacopa monniera, a creeping serophulariaceous plant with blue flowers and the habit of growth of purslane; Ambulia indica and $A$. fragrans, with an aromatic, camphorlike odor; Centella asiatica, the Asiatic pennywort; Aeschynomene indica; a species of Polygonum; and the water fern (Ceratopteris gaudichaudii), which has edible fronds. Several large aroids occur both cultivated and growing spontaneously, among them the common taro (Caladium colocasia), the caulescent Alocasia indica, and Alocasia macrortiza.' The introducer abakí, or "Manila hemp" (Musatextilis), grows in several places, but it is not now cultivated by the natives. At least two species of bamboo grow on the island, the most useful and durable of which (Bambos blumeana) is armed with recurved spines and forms impenetrable thickets in several places.

SAVANNAS.

These are grassy upland regions almost devoid of trees and shrubs. They are characterized by a red clay-like soil and lack of drainage, and by the reappearance of beach plants and marsh plants which are absent from the forests. Xipheagrostis floridula, which covers large areas, is called "sword grass" by foreigners on account of the cutting scabrous edges of its leaves (PI. LXIX). It grows higher than a man's head and offers refuge for deer. Roofs thatched with this grass are more durable than those of coconut or of nipa palm leaves, but more work is necessary in their preparation and they are not common except in regions where coconuts and nipa palms are scarce. Other savanna plants are the bracken-like fern Gleichenia dichotoma (Pl. L), Odontosoria retusa, Schizoloma ensifolium, Blechnum orientale, Pteris biaurita, Lycopodium cernum (Pl. V), (the wawae iole, or "ratsfoot" of the Hawaiians), and the little golden star grass Itypoxis aurea. The only tree is the ironwood (Casuarina equisetifolia), which also grows on the margin of the sea. Among other beach plants which reappear here are the shrubs Lobetia koenigii, Pemphis aciduld, and Melastoma marianum; the composites Stemmodontia biflona, S. canescens, and the Bidens-like Glossogyne tenuifolia; also the grasses Dimeria chloridiformis, Stenotaphrum subulatum, and Centotheca lappacea. The pretty little climbing marsh fern Lygodium scandens is common, and the lavender-flowered morning glory Ipomoea choisiana also occurs. 
ABANDONED CLEARINGS.

Abandoned clearings are usually overgrown either with common tropical weeds, thickets formed by hedge plants, plants once cultivated which have continued to grow, or indigenous species which usually grow on the edge of the forest or in open places. Among the tropical weeds of wide distribution are Achyranthes aspera, Waltheria indica, Asclepias curassavica, Abutiton indicum, Sida rhombifolia, Sida acuta, Datura fastuosa, Physalis angulata, Physalis minima, and Heliotropium indicum; the composites Elephantopus scaber, Elephantopus spicatus, Adenostemma viscosum, Ageratum conyzoides, Glossogyne tenuifolia, and Synedrella nodiflora; Euphorbia atoto, Euphorbia hirta, Phyllanthus niruri, Oxalis corniculata, and the creeping, clover-like Meibomia triftora. Among the scrubby Leguminosae are Indigofera anil, Indigofera tinctoria, Crotalaria quinquefolia, Cassia tora, Cassia occidentalis, Cassia sophera, and the fineleaved Cassia mimosoides. The principal hedge plants now forming thickets are the orange berry (Triphasia trifoliata); the physic nut (Jatropha curcas); sibucao, or sappan wood (Biancaea sappan); Leucaena glauca, called "tangantángan" in Guam, and "lead tree" in the British West Indies; and the well-known opoponax, Acacia farnesiana, which bears yellow globular heads of fragrant flowers.

Twining among these bushes are Abrus abrus (Pl. XXXII), which bears the tiny red-and-black seeds called crab's eyes; the spiny yam (Diosconen spinosit) (Pl. XLIX), which often renders the thickets impenetrable; Cassytha filiformis, a leafless, wiry parasite, sometimes called laurel-dodder; and several Leguminosae, including the yam bean, or híkamas (Cacara eros ). Among the Convolvulaceae are several species of Ipomoea; Argyreia tiliaefolin, the flowers of which, called $a b u b o$, are strung into garlands by the children; and the whiteflowered Operculina peltata.

On the sites of abandoned gardens are found trees, shrubs, and herbaceous plants, both indigenous to the island and introduced, which the natives usually plant near their houses. Among them are Calophyllum inophyllum, breadfruit both seedless and sterile, coconuts, Teminatia cateppa, Erythrina indice, Ceiba pentandra, Tamarindus indica, Anacardium nccidentale, Cussia fistula, Crescentia alata, Pandemus tectorius, Pandams dubius, Pandanus fragrans, Cycas circinalis, Annona reticulata, Canangiun odoratum, Agave vivipara, Adenanther paronina, Pithecolobium dulce, Hibiscus rosa-sinensis, Puriti tiliacelm, Herpetica alata, and bunches of Job's tears (Coix lachrymae-jobi) and of lemon grass (Andropogon nurdus). Many of these are self-propagating. The introduced Canangium odoratum (ilancilang tree). which the natives plant for the sake of its fragrant Hower's, is gradually spreading over the island through the medium of fruit pigeons. These hirds are also fond of the fruit of the ink berry 
(Cestrum pallidum), the hinoncito or orange berry (Triphasia trifoliata), and the piod or beach plum (Ximenia americana), which they spread in the same way. Pineapples continue to grow for years where they are planted, and in old garden spots are found plants of the introduced arrowroot (Maranta amudinacea) (Pl. XXV), the native arrowroot (gabgab), Tacca pinnatifida, turmeric, wild and cultivated ginger, and the cassava plant, or mandioca (Manihot manihot). Among the trees and shrubs which do not spread of their own accord in thim are the tamarind, the cashew nut (Anacardium occidentale), the tree which in Honolulu is called the "golden shower" (Cassia fistula), the pomegranate, the scarlet hibiscus, and the ornamental Phyllaureas, Aralias, and Acanthaceae of the gardens. It is interesting to note that of the three Annonas introduced into the island the custard apple or bullock'sheart ( $A$. reticulata) is the only species found wild, the soursop (A. muricata) (PI. XXXIV), and the sweet-sop or sugar apple ( $A$. syamosa) (Pl. XXXV), growing only where planted.

Among the plants which on account of their sterility must be planted by man are the textile screw pine or aggag (Pandanus tectorius), only une sex of which grows on the island; the seedless breadfruit or lemae (Artocarpus communis); taro (Caladium colocasia) and yams (Dioscorea spp.), which are seldom known to produce seed; sweet potatoes, which are propagated by cuttings, and bananas and plantains, which are seedless and must be grown from root suckers. Young plants of Agave vivipara, which the natives call "lirio de palo" or the "tree lily," are often found growing in circles, with the dead mother plant at the center.

Whole fields are overgrown with guava bushes, just as in the Hawaiian Islands and many other tropical countries but the common lantana (Lantana camara) and the sensitive plant (Mimosa pudica), which are pests in so many parts of the world, have, fortunately, not yet found their way to Guam.

Among the plants which have escaped from gardens are the pretty blue pea (Clitoria ternatea); the crimson-flowered cypress vine (Quamoclit quamoclit), which the natives call "angel's hair" (cabello del angel); Lochnera rosea, sometimes known as the Madagascar periwinkle; the marvel of Peru, or four-o'clock (Mirabilis jalapa), and the touch-me-not or garden balsam (Impatiens balsamina). Tomatoes bearing small fruit, either oval or globular, are also found growing near abandoned gardens, and occasionally gourd vines (Lagenaria lagenaria) are seen bearing bottle-shaped fruit.

On the edges of clearings, growing in partial shade, are two burbearing plants called "dadangse" (stickers) by the natives: Urenc sinuata, a malvaceous shrub with five-lobed leaves and rose-purple flowers, and Triumfetta rhomboidea, belonging to the Tiliaceae, with simple leaves and inconspicuous yellow flowers. The fruit of both is 
armed with hooked prickles and catches upon the clothing of men and the fur of animals, so that these plants are common along roadsides. Other wayside plants are the species of Sida, already mentioned, which the natives call "escobilla" (broom) and gather fresh each day for sweeping out their houses.

The commonest grasses are Andropogon aciculatus, Capriola dactylon, Centothece lrippacea, Chaetochloa glauca aurea, Dactyloctenium aegyptiacum, Elensine indica, Dimeria chloridiformis, Echinochloa colona, Eragrostis pilosa, Eragrostis tenella, Isachne minutula, Ischaemum digitatum polystachyum, Ischaemum chordatum, Panicum distachyum, Puspahum scrobiculatum, and Stenotaphrum subulatum. Associated with grasses are often found the creeping Commelina benglatensis and Commelina mudifora, and Zygomenes cristata, with scorpioid eymes of blue flowers inclosed in large falcate, inbricating bracts.

Among the sedges are Carex densiflona, Carex fuirenoides, Cladium gandichaudii, Cyperus rotundus, Cyperus difformis, several species of Fimbristylis, Fuirena umbellata, Eleocharis capitata, E. plantagimoidert, Lyllinga monocepleala, Mariscus albescens, and Rynchospora corymbosa.

TILLAGE EXTIRONS.

Besides the trees mentioned abore as groming on the sites of abandoned gardens mans others are planted about the villages. Oranges, lemons, limes, citrons, shatdocks, and bergamots are common. In many gardens grow the pomegranate, atis, or sugar apple (Annona squamose); laguana or soursop (Annona muricata); papaya (Carica papayn): Bimordlone, with bur-s resembling beechnuts and seed surrounder he at red coloring matter"; wllee which rields ahundant crops; batum:a and plantains of several varietic:: vincs of betel pepper (Piper betle) (covering trees and walls: bushes of the fragrant henna, or " cina-

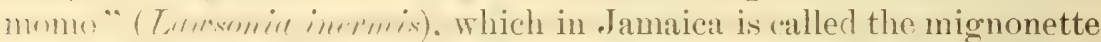
frar: the oleunder, crape myrtle, and scarlet hibiscus, planted for the sake of their flowers and nrmimental specien of Phyllaurea, and of Acanthareae and Araliaceac, plinted for the sake of their foliage. A long the roadsides are fine mango trees; Metia aredarch, the "pride of India, "bearing clusters of larender flowers with dark riolet stamens; the horse-radish tree (Ho,imfu morinfu) (Pl. LVIII), here called "marunggai;" the silk-cotton tree (Ciba pentandra), called "alyodon de Manila:" the leguminous Agati grondiftom. called "katurai" (Pl. Y1), with edible flowers and seed pods: I'minciuna pulcherrina, called "Hower fence" in the British Wrest Indies, bearing racemes of beautiful red and yellow flowers; the Indian almond (Terminatia catappa), here called " talisai," "t handsome tree with a straight trunk, whorls of

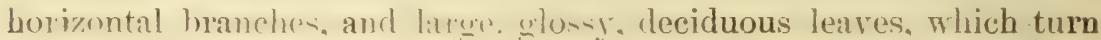
red befure falling off. 


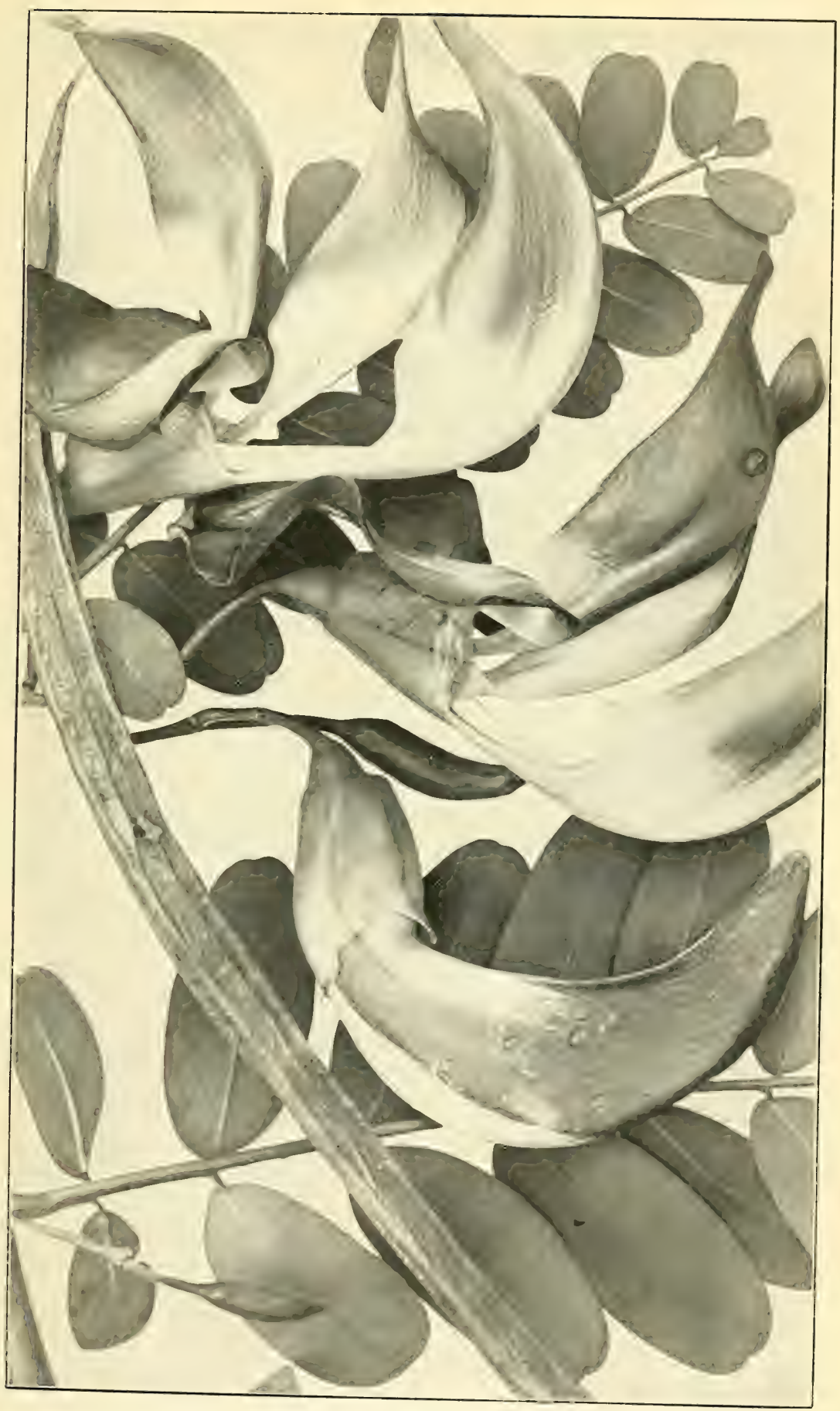

Agati grandiflora, a Leguminous TREe WITH Edible FloWers and PODS Natural Size. 

Among the rarer trees are Irfmis min, the magnificent flam-

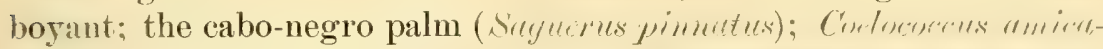
ilm, the ivory nut palm of the Caroline Islands (Pl. XLV): the candle nut (Aleurites moluccana), called "liukui" in Hawaii, hut here known by its Philippine name, "lumbang;" I'mnimm edule, called " jañyi in the Philippines and "rauel" or "rauwell" on the island of Yap. the jujube tree (Zi:yphus jujuba), here called "manzanas" (apples); and Sandoricum indicum, here called by the Malayan and Philippine name, "santol," the fruit of which has an acid pulp of fine flavor. Of the last species I know of but one tree, which grows on the ranch of Don .José de Leon Guerrero in the district called Lalo. There are also one or two date palms, but they have not been known to fruit. The occurrence on the island of Canarium commune has been recorded, but the writer has not seen this species. This is the tree called in Manila "brea blanca" (white pitch), which yields the valuable resin known in commerce as Manila "elemi" and the nuts called "pili," or Java almonds. Polynesian chestnuts (Bocoa edulis), avocados (Persea persea), Japanese loquats (Eriobotrya japonica), and navel oranges were introduced by the writer. All of them grew well at first, but the avocados were killed by a heavy rain, and it is not known whether the others are still living. Two trees of mandarin oranges grow in the garden of Don José Herrero in the district of San Ramon, Agaña, and opposite his house is a vigorous sapodilla tree (Sapota a apotilla). The mandarin trees bear very good fruit, but the sapodilla (here called "chica") has never borne. The durian (Durio zibethinus), the lanzon (Lansium domesticum), so common in the Philippines, and the mangosteen (Garcinia mangostana) do not occur on the island. Grapes and the edible fig (Ficus carica) have been introduced but do not thrive well.

PLANTS OF SPECIAI, INTEREST.

UNIDENTIFIED TREES AND SHRUBS.

Among the trees and shrubs of the island there are a number mentioned by early collectors and by the Spanish governor's in their official reports which have not yet been identified. It is a well-known fact that many tropical forest trees yielding important commercial woods, resins, gums, balsams, and medicines are not yet known to science. This is in most cases owing to the difficulty of preparing good botanical specimens of such plants for the herbarium. In this connection Mr. O. F. Cook, of the United States Department of Agriculture. writes as follows:

The size itself makes it difficult to observe a tree as a whole or to bring numerous individuals under the eye at once, as may be done with smaller plants. Moreover, trees can not be preserved as complete specimens, and only small fragments can be accommodated for ready reference in the herbarium. Nevertheless, the task may 
be said to be comparatively simple with the trees of temperate climates, where forests are comparatively open and frequently composed of only a few kinds of trees or, perhaps, of a single species. In the Tropics a natural forest of one species is practically unknown; hundreds of kinds grow indiscriminately mixed together. Crowded together in tropical forests trees have nothing like the shapes or habits they would assume if standing alone. All are putting forth, as it were, their best efforts to grow tall and thus secure as much sunlight as possible. Their leaves and branches are inextricably confused, interlaced with climbing plants, and encumbered with parasites and epiphytes. To cut down a particular tree may be impossible unless one is willing to clear a large neighboring area to permit it to fall. Unless the botanist finds a clearing his opportunities for securing even the desired fragments of branches with leaves, flowers, and fruit may be extremely few. Hence, our knowledge of tropical trees is still in the early pioneer stages. $a$

Among the trees mentioned by Gaudichaud under their vernacular names are the ifil, fago, aában, chopag, chuti (tchiuti), seyafi (sidjiafi), kadela, langiti, hodda (odda), tagete (tagaïti), nunu, hayun-lago; and in the list of woods forwarded by Governor Olive to the captain-general of the Philippines are agatelang, agaliyan-halomtano, aguanac, ahgao, alom, amahayan, a ̃ugilao, aplokhating, brea, chosgô, faka, fago, fañog, gáusale, guaguaot, gulos, hayunmananas, hayun-palaoan, lalaha, lalanyog, lañgiti, laña, lenaya, luluhut, makupa, mahlokhayu, mapuñao, nimo, ñolon, pacpac, palma brava, panago (or banalo), pengua, kelitae (or palaga-hilitae), sayafo (or seyafe), sumai, sumaclacla, umumo, yoga. Only a few of these trees have been identified. Good specimens of all are desirable for herbaria.

Among the unidentified shrubs are several species which Gaudichaud referred to the genus Pavetta, called by the natives "utud," "otud" or "utug," "sesbu" or "sosbu," and "guaguabug." A nother shrub not yet determined, having a disgusting fetid odor and flowers growing in axillary and terminal umbels, is called by the natives "pau-dedo."

GROUPS WHICH ARE NOT WELL KNOWN.

Certain families of plants have not been well worked up, such as the A pocynaceae, Rubiaceae, Verbenaceae, Urticaceae, and Euphorbiaceae. Among the first there are certain seaside shrubs allied to Cerbera referred to by Gaudichaud under the name of Rauwolfia and Plumiera. One of these is probably Ochmsin mariannensis, but the others are not yet known. Among the Rubiaceae are several small shrubs allied to the genus Ixora. Among the Verbenaceae the Guam plants belonging to the genera Premna and Vitex should be compared with series from other localities, and it is probable that there is a second species of Clerodendron, with bitter leaves, which has not yet been recorded. There are sereral species of Phyllanthus, Euphorbia, and Glochidion which have not yet been collected as well as a few Myrtaceae.

"Cook, Culture Central American Rubber Trees, U. S. Dept. Agr., Bur. Plant Industry, Bull. 49, p. 18, 1903. 
Very little is known of the algae, and still less of the fungi, lichens, mosses, and hepatics of the island.

As in every part of the tropical world, there is much uncertainty about the various forms of cultivated yams, aroids, bananas, plantains, and breadfruit, and complete botanical specimens of these should be obtained, together with photographs of the growing plants, their flowers, fruits, and roots, and notes of the odor of the flowers and flavor of the fruit or roots. Similar work should be done on the screw pines of the island in order that careful comparisons may be made with the species and well-defined varieties from other parts of the world. Notes of particular methods of propagation, cultivation, and preparation for use are also valuable. The bamboos are not definitely known, and the entire genus Ficus, which includes the banyans, remains to be worked up. Special efforts should be made to get photographs of flowering bamboos and aroids.

GUAM TYPES.

To the botanical collector the most desirable species are those which were first described from type specimens collected on this island. Some of these original types are in very poor condition or are incomplete, lacking fruit or flowers or leaves from various parts of the plant or a representation of one of the sexes, and the identity of others is not well established, owing to the lack of a sufficient number to form a series for comparison with closely allied species from other localities. The handsome caper growing on the rocky shores of the island (Capparis mariana Jacq.) is supposed to be a variety of Capparis spinosa; ${ }^{a}$ Clawylon marianum Müll. Arg. is very closely allied to Claoxylon taitense of Tahiti; Ipomoea mariannensis, a plant which has never been figured, should be compared with the American Ipomoea triloba; the epiphytal fleshy-leaved Dischidia puberula should be compared with Dischidia benghalensis, for which it was first mistaken by Gaudichaud; the fragrant Gynopogon torresianus of Guam should be compared with the allied species from other Pacific islands; a series of specimens of Melastoma marianum should be secured for comparison with the closely allied Melastoma denticulatum and M. malabathricum of Polynesia and the East Indies. The Guam Pipers and Peperomias need further study, and the Guam types of species of Ochrosia, Cormigonus, Phyllanthus, Glochidion, Euphorbia, and the hispid-leaved, yellow-flowered Stemmodontia canescens should also be secured.

YAMS, BANANAS, AND BREADFRUIT.

Many distinct kinds of yams (Dioscorea), bananas (Musa), and breadfruit (Artocarpus) are recognized wherever these plants are cul-

a See Schumann, Flora deutschen ost-asiatischen Schutzgebietes, p. 201, 1888. 
tivated, but very little has been done to fix the species and varieties and to compare those growing in different parts of the world. Yams are diøecious, and the flowers of many recognized varieties are imperfectly known. In some cases the flower's of but a single sex have been described; in others the fruit has never been observed, and in others only the tubers are known. Sir Joseph Hooker, ${ }^{a}$ who has done much to straighten out the Indian species, writes as follows:

The species of Dioscorea are in a state of indescribable confusion, and I can not hope to have escaped errors in the determination and delimitation of the Indian ones, to which I have devoted much labor. The Roxburghian food-yielding species are for the most part indeterminable, and, except through a knowledge of them as cultivated in India, they can not be understood. No doubt some of the species described by me have other earlier names in the Malayan flora than I have given; but the Malayan species are even more loosely described than the Indian. The Wallichian collection is very complete, but the species are often mixed.

What has been said of the Indian yams applies also to those of the Pacific islands, and is also true of the many varieties of Musa and Artocarpus. Nearly every collector gives a list of named varieties of Dioscorea, Musa, and Artocarpus in the vernacular of the various localities visited, but scarcely any attempt has been made to fix these varieties and to bring together the various kinds from different localities for comparison. These must be studied in the countries where they are found and should be represented in collections not only by series of botanical specimens of the flowers, fruit, leaves, and roots (in alcohol, when necessary), but by photographs of the fresh plants, including representations of the flowers, fruits, tubers, etc., of natural size or according to some definite scale of reduction or enlargement. In this way only will it be possible to bring together and compare species and varieties from India, Australia, the Malayan and Pacific islands, Africa, and America.

$$
\text { SCREW PINES. }
$$

The Pandanaceae are known no better than the yams. Some of them are propagated asexually for the sake of their textile leares, and much confusion exists among the species. Very few have been described. Warburg has done much to delimit the species and varieties and clear up questions of synonymy, but there remains much more to be done. In his monograph of the Pandanaceae ${ }^{b}$ Warburg mentions only one - species, Pandanus dubius Spreng. (Himbronia edulis Gaudich.), as occurring in the Marianne Islands, and does not refer to the textile \& species with glaucous leares (the aggak of the natives), which has been cultivated in Guam from prehistoric times (Pl. VII), nor the fragrantfruited species with bright green leares (kafô), which is one of the most common plants of the island (Pl. LX). As only one sex of the 


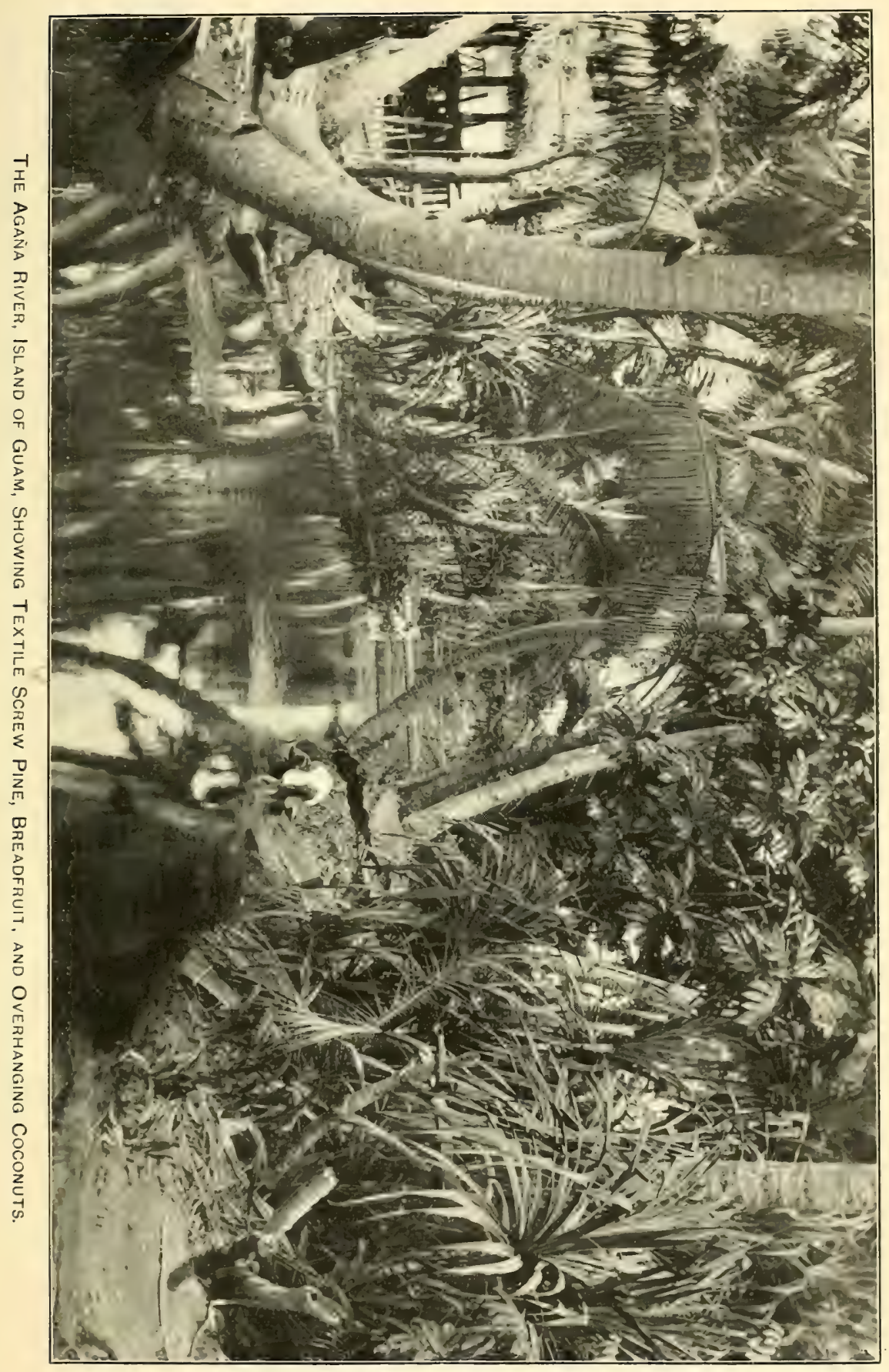






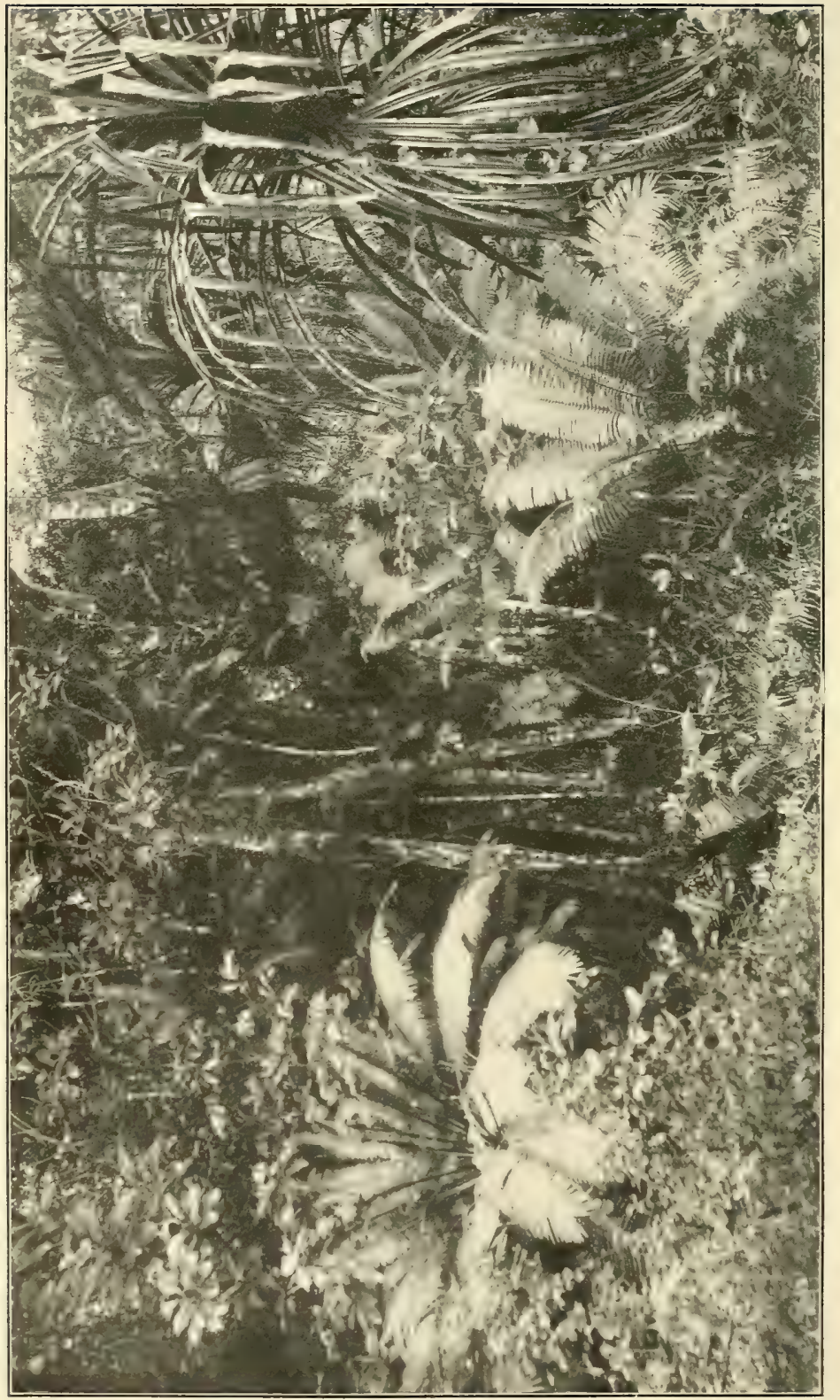

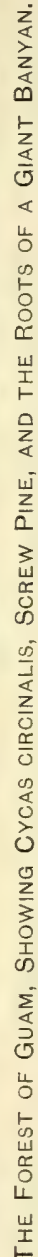


textile species occurs on the island no fruit of course is produced by it. The importance of collecting the flowers and preserving them carefully in alcohol or formalin is evident, as well as the necessity of making photographs of the growing tree to show its habit, the character of its bark, its method of branching, its fascicles of leaves, and the emergences on its stem and aerial roots.

BANYANS, MANGROVES, AND EPIPHYTES OF THE FOREST.

Of special interest on account of their method of germination and growth are the giant banyuns (Ficus spp.) of the forest. the unangroves of the brackish estuaries. and certain epiphytal cryptogams and other plants.

The banyans usually begin their existence upon other trees, sending down, aerial roots which interlace and grow together, clasping the trink of their host and eventually strangling it. They then lead an independent existence, their great spreading limbs sending down more roots, which are like pendent threads at first, but soon thicken after gaining a foothold in the earth, and serve as columns to support the great dome of foliage overhead, as well as to supply it with nourishment and moisture (Pl.VIII).

The chief interest in the mangroves (Rhizophora and Bruguiora) lies in the fact that their fruit germinates while still attached to the tree, the spindle-shaped radicle perforating the apex of the fruit, elongating and hanging vertically downward. When the fruit falls the radicle sticks into the soft mud below, retaining an upright position, like a stake thrust into the ground, and resisting the current of the tide as it ebbs and flows.

The forest epiphytes are not well known, owing to the difficulty in collecting them. Care should be taken to visit clearings where forest land is heing prepared for planting. 'In such places good material can undoubtedly be collected. The most interesting epiphyte thus far colJected in Guam is Dischidia puberula, which belongs to a genus having some of their fleshy leaves modified into urn-like receptacles. These usually contain water, and the adventitious roots of the stem often creep into them, as if for nourishment or moisture.

PLANTS THAT SLEEP.

Among the Gram plants there are a number which exhibit in a inarked degree the phenomenon known as "sleep movements," folding: their leaves each night and opening them again at sumrise. Some of them (Arir firmesianu and Abrus abrus, Pl. XXXII), are so sensitive to change:s in the intensity of light that they go to sleep if the sky suddenly becomes overcast, and wake up when the sun reappears. Most of these plants are leguminous, but there is one remarkable $9773-05-5$ 
example belonging to the Oxalidaceae. This is Arerrhoa carambola, the "bilimbines" of the natives, a tree which yields a pellucid ovalshaped, fire-angled fruit. (Pl. XXXVII.) Its foliage is not only sensitive to light and darkness, sunshine and shade, but also to sudden mechanical shocks, the leaves bending and their leaflets folding very much as in the case of the sensitive plant (Himosa pudica). Besides the above-mentioned plants are several species of Cassia, Caesalpinia, Erythrina indica and other Leguminosae; and, among the Euphorbiaceae, two or three species of Phyllanthus and Euphorbia.

PLANTS WHICH SELDOM BLOOM.

Many plants grow spontaneously on the island which in many other parts of the world are seen only in a state of cultivation. The plant which produces the celebrated "rhea" fiber, Boehmeria tenacissima, which in cultivation is herbaceous and seldom flowers, grows spontaneously in Guam in the form of a shrub or small tree, called in the island vernacular "amahajan." Species of Colocasia and Alocasia, which seldom bloom in cultivation, and which are classified according to their inflorescence, here appear to grow in a state of nature. Their soft, fleshy spathes should be collected and preserved in alcohol or formalin for comparison with species and varieties from other localities. Bamhoos also are among the plants which seldom flower. The species growing in Guam have not yet been identified with certainty owing to the lack of good specimens of inflorescence. In cultivation all the plants here mentioned are propagated asexually, and are divided into a number of varieties.

PLANTS WITH EXTRAFLORAL XECTARIES.

There are perhaps few localities which offer better facilities for the observation of extrafloral nectaries. Here within a small area, growing not in conservatories, but in a state of nature, may be observed a remarkahly large number of plants haring glands on the midribs, reins, petioles, or rachis of their leares, or on the peduncles, pedicels, or sepals of their flowers. Among them are species of Cassia, Erythrina, and Acacia, with stalked disk or cup-like glands, and, belonging to the Euphorbiaceae, the candle-nut (Aleurites) and the well-known calstor bean with well-marked nectaries at the junction of the blade and the petiole of the leaf.

Ricims communis is especially well provided with these nectar glands. They occur on the nodes of the stem, along the petioles of the leares, and the serrations of the leaf blades (PI. IX, fig. 2), as well as at the base of the blade where it is joined by the petiole. At this point there are usually two nectaries, though there may be but one, or there may be three or four when the leaf has a greater number of lobes than usual. Many of the Euphorbiaceae are provided with extra- 


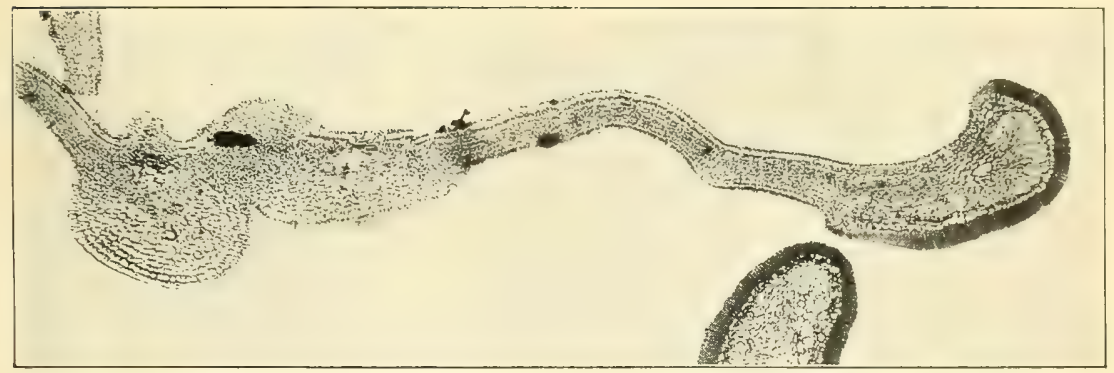

Fig. 1.-MAReinal Nectar Glands of Ricinus Leaf. EnLARged 43 Diameters.

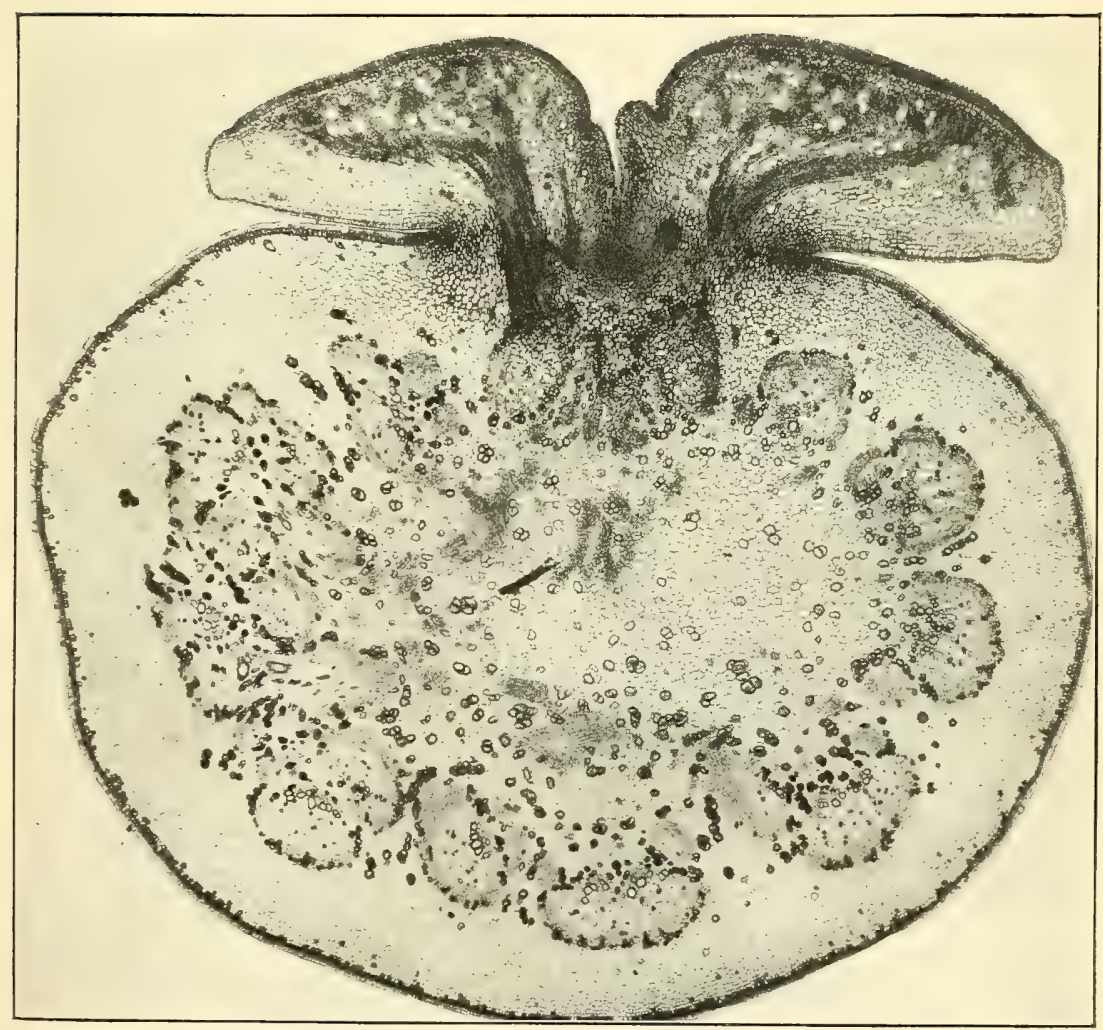

Fig. 2.-Cross Section Through Large Nectar Glands at Base of Ricinus LeafBLADE. ENLARGED 30 DIAMETERS. 




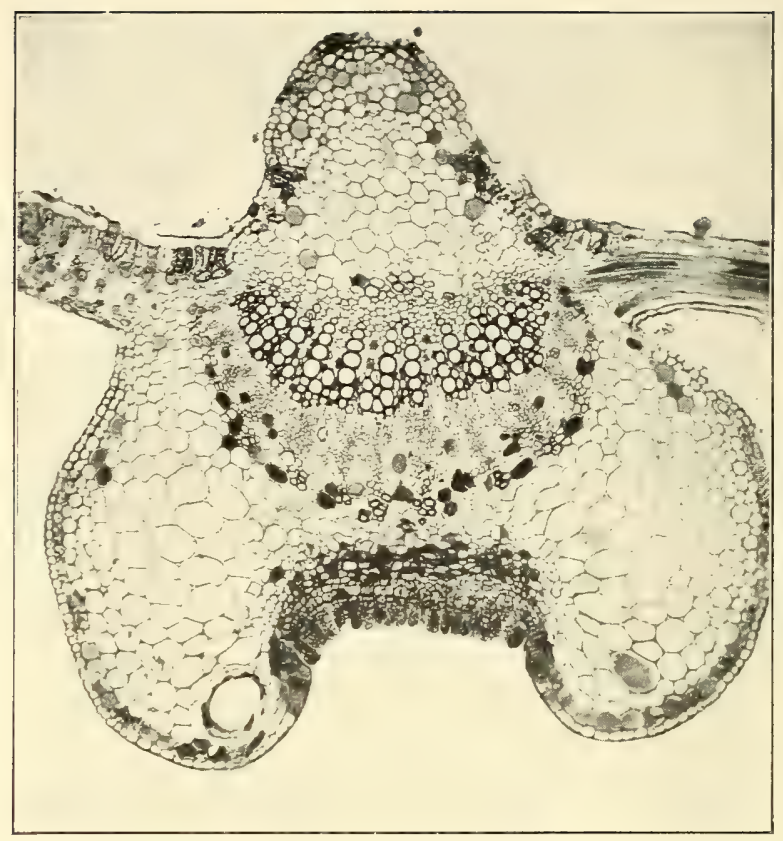

Fig. 1.-Nectar GLand in Lower Surface of Midrib of COTTON LEAF. ENLARGED 50 DIAMETERS.

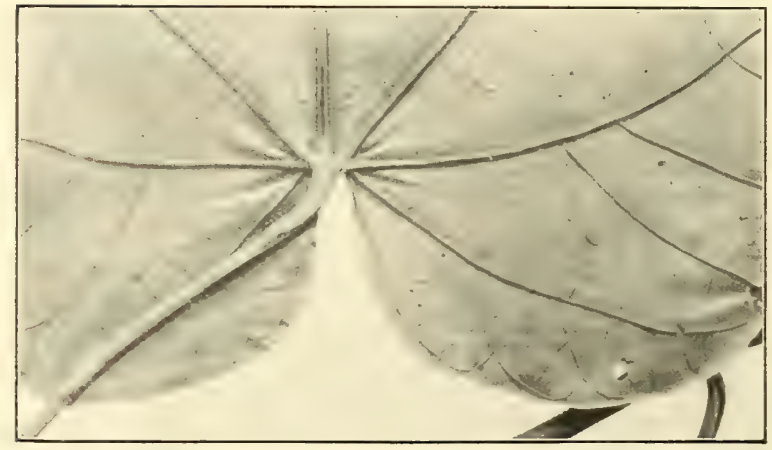

Fig. 2.-VAginate Nectar GLand IN Midrib of PARITI TILIACEUM. NATURAL SizE. 
floral nectar glands, which have been noticed by systematic as well as hy physiological botanists (Baillon, Müller Arg., Bentham and Hooker). They are found on the stipules of Jatroplere multifide, and on the petiole at the base of the leaf blade of Alenrites moluccaner. In a paper by Percy Groom on the extrafloral nectaries of the allied Alenites cordata these petiolar nectaries are described as follows:

Each nectary is a green-stalked shallow basin, the concavity of which is tinted rer. The secreting cells which line the basin form a single layer of palisade-like cells. The general cuticle is preserved over these, and the secretion emerges through splits in it. The main body of the basin is composed of an anastomosing system of conducting parenchyma and ground parenchyma. * * * The secreting cells contain proteids, sugar, a red coloring matter (a compound of tannin?), tannin, but no starch. In the ground parenchyma starch, tannin, and crystals of calcic oxalate occur. The conducting parenchyma contains sugar, but no starch or crystals. * * * Darkening the nectaries of leaves on the plant or of excised leaves, or darkening the whole leaves, caused a gradual clisappearance of the starch, but the nectaries continued to excrete for a time.

The above description applies very nearly to the stipulary nectaries of Ricinus, a photograph of a cross section of which, made by Mr. B. J. Howard, of the United States Department of Agriculture, is shown in Plate IX, fig. 1.

Among the Malvaceae growing in Guam several are provided with nectar glands on the underside of the midrib. These are most conspicuous in Urena simuata, occurring not only on the midrib, but sometimes on the main lateral ribs of the palmate leaves. They also occur on all leaves of cotton (Gossypium sp.) and on the midrib of Pariti tiliaceum (Pl. X, fig. 2), in the form of vaginate glands. A photograph of a cross section of the nectar gland of a cotton leaf, also made by Mr. Howard, is shown in Plate X, fig. 1.

The sweet fluid secreted by these glands is eagerly sought by sugarloving insects, and a number of authors maintain that the power of secreting it has been specially gained by plants for the sake of attracting ants and wasps, which will serve as defenders against caterpillars, leaf-cutting insects, or other enemies; but Darwin, ${ }^{b}$ after a series of observations, could not see any reason to believe this to be so with the species observed by him, although the fact that these glands are visited by insects for the sake of their nectar can be verified at any time of the day when the sun is shining, and these insects must serve as a protection for them. It is interesting to note that these glands may occur in one species and be absent from another closely allied to it of the same genus. Indeed, there are species in which the glands are present on some leaves and absent from others, and of their rariability we have already spoken in connection with Ricinus and UTena. 
On this account Delpino" argues that these glands ought not to he regarded as excretory, since if they were so, they would be more constant and would occur in every species. Their variability is especially noticeable in the genus Cassia, where the tiny cup-shaped nectaries may be found on the petioles of some species and the rachis of others, but are absent from both in others. If they performed some necssary function it is hard to believe that they would not occur in all the species. One thing is certain, they are more highly developed and more active in the young and tender leaves and about opening leaf buds than on the older and tougher leaves, which are less tempting to berbirorous animals, and more able to resist their attacks; and whatever may be the truth regarding the presence of these glands in general, Belt has shown conclusively ${ }^{b}$ that the bull's-horn acacia of Central America (Acacia splecterocepholat not only attracts stinging ants by its nectaries, but offers them as an additional attraction dainty food rich in oil and protoplasm in the form of small bodies at the end of the divisions of the compound leaflets, which the ant gather when ripe and carry to their homes in the stout hollow thorns of the plant itself. The fruit-like bodies do not ripen all at once, but successively, so that the ants are kept about the young leaf for some time after it unfolds, and Belt arrived at the conclusion that the ants are really kept by the acacia as a standing army, to protect its leaves from the attacks of herbirorous mammals and insects. In the same way there is a succession of active nectaries about the tender young leaf buds and flower cluster's of Ricinus, which are constantly risited by wasps and ants; and the important part played hy the nectar glands in the petioles of the cotton leaf $(\mathrm{Pl} . \mathrm{X})$ as an attraction to ant which serve to protect the plant from the boll weeril and other injurious insects has recently awakened great interest and has been turned to economic account. ${ }^{c}$

PLANTS TITH PROTECTIVE DEVICES

Interesting examples of self-protection are offered by sereral plants "rowing in Guan, the most striking of which is that of the spiny yam, l) in whend plant grows spontaneously on the island and in places forms impenetrable thickets. It takes its name not foum the small prickles on the stem but from a mass of spines surrounding the hase of the strm and serving as a protection to the starchy tubers helow from hogs and other enemies. This species has often been confused with Diosconed aculmatr, the cultivated prickly yam in Guam, called "nika." which it resembles in the form of its broad heart-shaped

" Rapporti tra insetti e tra nettarii estranuziali, p. 63, 1875.

$b$ Naturalist in Nicaragua, p. 218, 1874.

$\therefore$ Sae Couk, An knemy of the Cotton Boll Weevil, L. S. Dept. Ayr., Rept. No. 78; alsu his Report on the habits of the kelep, or cinatemalan cotton-boll weeril ant, U. S. Dept. Agr., Bur. Ent., Bull. No. 49, 1904. 



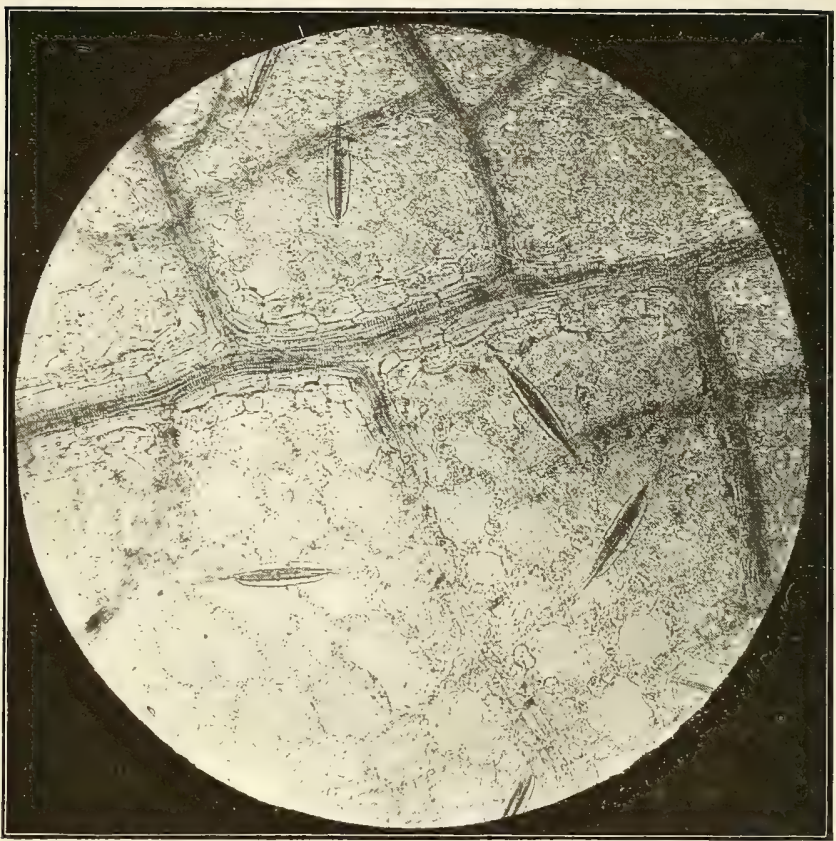

Fia. 1.-Raphides, or NeEdle-like Crystals of Oxalate of LIME IN LEAF-BLAde of TARO PLANT (CALAdium COLOCASIA). ENLARGED 100 DIAMETERS.

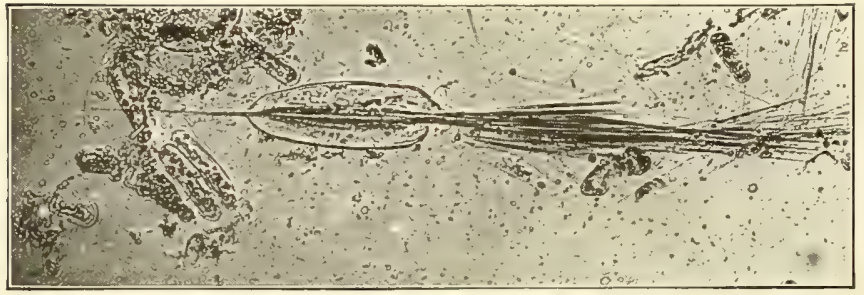

Fig. 2.-A Single Capsule Discharging its Needles. EnLarged 200 DIAMETERS. 



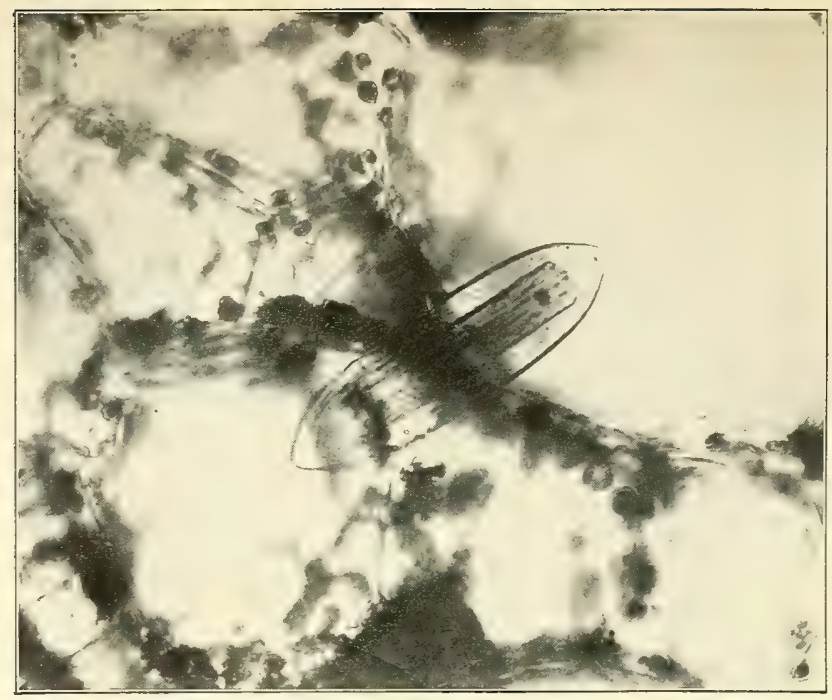

Fia. 1.-Needle Cell in Petiole of Taro leaf. enlarged 300 DIAMETERS.

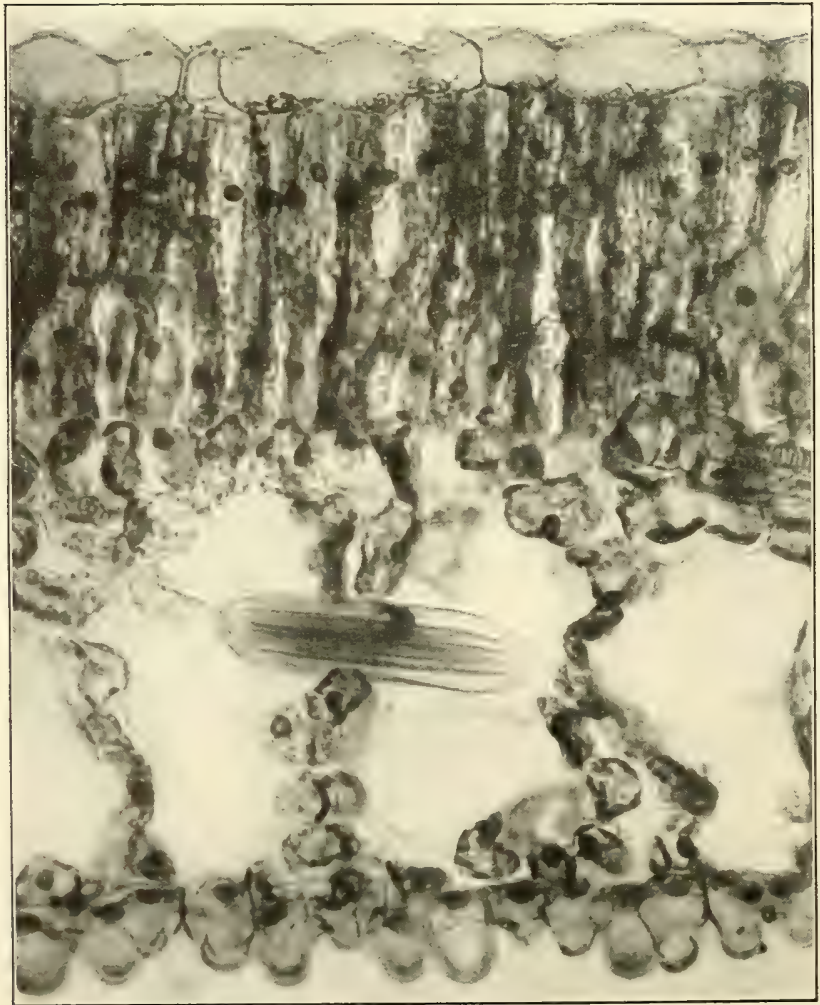

Fig. 2.-Needle Cell in Blade of taro leaf. Enlarged 300 DIAMETERS. 
leares, with deep hasal sinus, and in its prickly stem. (Pl. XIIX.) It is rery distinct, however, in having about its hase the mass of spines referred to. They are wiry and branching, and have very much the appearance of sharp compound fishhooks. In reality they are lateral roots which differ from typical monocotyledonous roots in their hard woody structure and the absence of root caps. Mr. T. G. Hill and Mrs. W. G. Freeman, who made a study of the root structure of an allied species growing in Africa, found that "the lateral roots form the actual spines. They only exhibit normal root-structures at the extreme apex; elsewhere the phloem strands travel regularly throughout the whole area of the stele, while the xylem is more or less restricted to the central region. The hardness both of the main roots and the spines is due to the thickening and lignification of the conjunctive tissue of the stele." a Whether or not these spines have been specially developed for the purpose of protecting the edible tuber may be questioned, but that they do protect it is certain.

Imong the principal food staples of Gitim is the taro, Caladium colocasia, a plant of the Arum family. Both the land and water varietic: (PI . IV) are found invariably to have their smooth, succulent, satiny leares free from the ravages of snails, insects, or herbivorous animals. Cattle and chickens delight in nipping off the young leaves of bananas and plantains; deer often inflict serious injury on a young coconut plantation in a single night; breadfruit trees suffer from the attacks of all herbivorous animals, and must be protected from themfruit, leaves, and bark; and even tobaceo will be devoured in the field by insect larvæ unless it is carefully watched and attended. On chewing a small portion of a taro leaf, the cause of its safety from attack is at once apparent. The tongue, roof of the mouth, and lining of the throat seem to be pierced by a thousand tiny needles. "This allicit

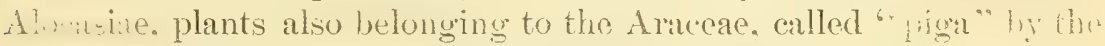
natives of Guam, are so very acrid that the skin is sometimes stung by merely rubbing against one of their leaves. Not only is the root of the taro edible, but the tender young leaves are eaten like spinach or asparagus. When not thoroughly cooked, however; they retain their acridity, and in Polynesia it is a common necurrence to experience an intense inflammation or burning of the hroat after a meal of savory taro tops cooked with cocounut custard.

Through the courtesy of Dr. H. W. Wiley, Chief of the Burean of Chemistry, United States Department of Agriculture, a careful chemical and histological examination of fresh taro plants was made for m. by Mr. Lyman F. Kebler and Mr. B. .J. Howard. The result of th. examination and experiments tends to corroborate the theory tha the burning sensation experienced on chewing the leaves is not camad by an acrid fluid, but by minute needle-like crystals of calcium uxalate 
(1": Xr) rontained in their tissue. Many plants in which these crystak are found are not acrid to the taste, but most of the Araceate. including our own Indian turnip, or jack-in-the-pulpit, are inten-ely so. In some plants the erestals are developed singly in a cell of the parenchyma; in other cases they are in the form of a radiating cluster, while in others, including several families of monocotylectons, they form compact bundles, called raphides. These raphides are sometimes found in a cell which can not be easily separated from the remaining tissue of the plant. In the genera Caladium and Alocasia they are inclosed in what appears to be an elongated transparent capsule filled with mucilage. These capsules, or cartridges, are situated in the partition wall between two racuoles, their ends projecting into the adjacent vacuoles. (PI. XII.) When the racuoles become filled with water by being crushed in chewing or when artificially macerated, the mucilage absorbs water through the capsule walls, increasing in volume so that it exerts such a pressure that the needles are ejected with considerable force from the capsule at one or both ends, where the cell wall is thinner than at the sides.

While Mr. Howard was examining a section containing some of these raphides, the capsules absorbed water and began to discharge themselves by what appeared to be a series of explosions." In $\mathrm{Pl}$. $\mathrm{XI}$, fig. 1, is shown a section of taro leaf multiplied by 100 diameters, with the raphides in place. The thirsty mucilage, as it has been called by one author, ${ }^{b}$ has absorbed a certain quantity of water and some of the needles have been forced out. In fig. 2 is shown a single capsule discharging the needles at both ends, the distance to which they have been projected to the right showing that the force of the discharge was considerable. At every discharge the capsule recoiled like a gun which has been fired. In Pl. XII, fig. 1, is shown a cross section of the hlade of a taro leaf magnified 300 diameters. This shows a capsule in place, with its ends projecting into adjacent empty racuoles. Fig. 2 shows a similar cell in the tissue of the petiole. These capsules retain their power to absorb water and discharge their needles after the leaf has been thoroughly dried. They must he subjected to great heat to lose their activity; and when this is lost. ats in cooking, the plant is no longer acrid. Sufficient heat is not always developed in boiling to effect the change. PI. XIII shows single capsules, or "bombs," as Doctor Wiley has called them, in fig. 1 just beginning to clischarge its needles and in fig. 2 in full action. Doctor Wiley in his description says:

I immediately took Mr. Howard's place at the microscope and saw for a perior of five or ten minutes a most remarkable display. Continual discharges were nutle from this bomb, the ends of the arrows spreading out as they emerged in grompen of 


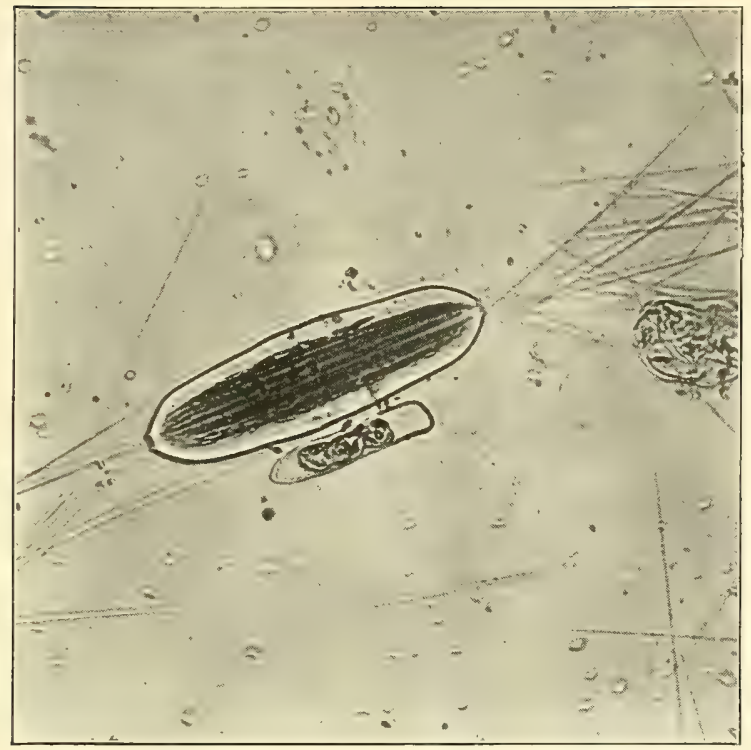

Fig. 1.-CAPsule of TARO Beginning to Discharge NEEDLES. ENLARGED 300 DIAMETERS.

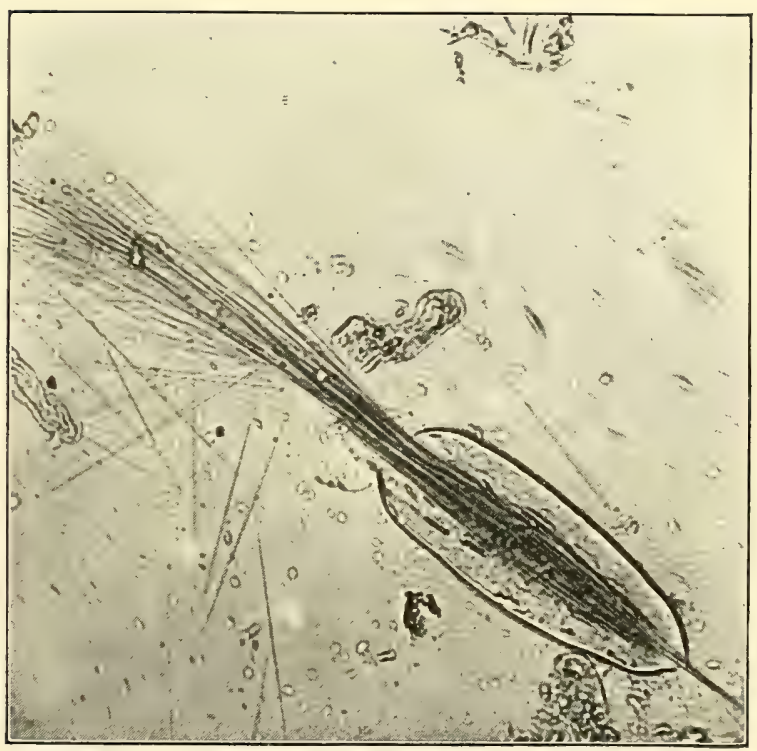

Fig. 2,-Capsule of TARo With the NeEdles Shooting FORTH. ENLARGED 300 DIAMETERS. 




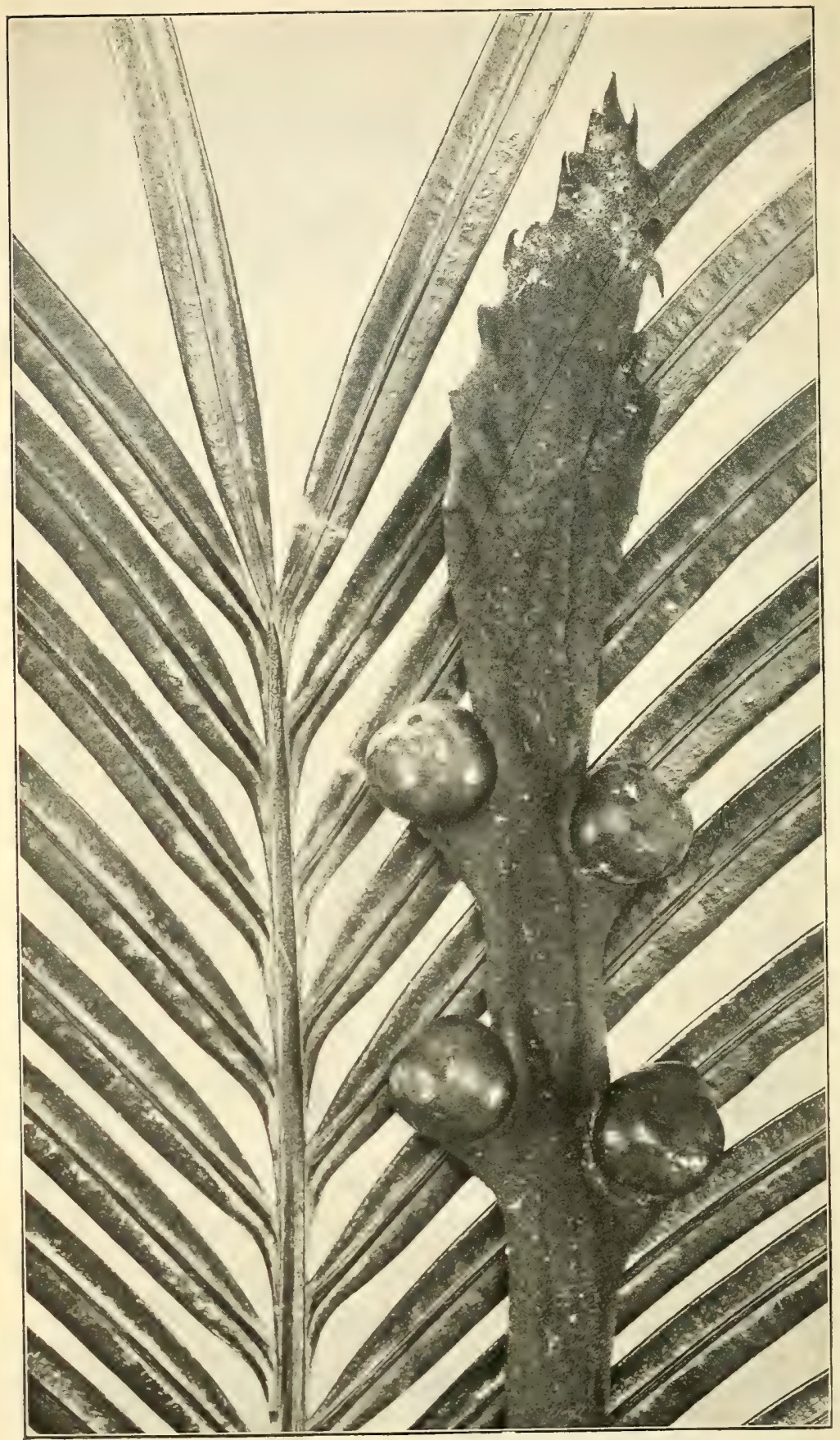

CyCAS CIRCINALIS. LEAF AND CARPOPHYLL BEARING HaLF-DEVELOPED FRUIT. NATURAL SIZE. 
from 4 to 10. As these groups were finally separated from the bombs they were discharged with considerable velocity into the ambient liquid, the bomb itself suffering a corresponding recoil. *** The field of vision in the vicinity of the boub became partially covered with these long crystals, but the supply within the bomb did not seem to diminish materially. There must have been hundreds of the arrows in one single spheroid. * * * If the plant is not thoroughly cooked its acrid qualities remain in some degree. If thoroughly cooked they are destroyed. It is interesting to note that in cases where the leaves are chewed, either fresh or dried, the stinging sensation is not perceived until a few moments afterward, and in many cases it is not until the taro has been eaten that the prickly sensation in the lining of the month and throat shows that it has not been thoroughly cooked. * * * Alocasia indica, a plant closely allied to the taro plant, is so acrid that the Pacific Islanders resort to it only in cases of great scarcity of food. The disagreeable effects caused by these plants seem to be confined to the temporary prickling sensation of the mouth and throat. They are undoubtedly nutritious and are held in high esteem by the natives.

The rôle played by raphides in protecting plants from herbivorous animals has been discussed by Otto Kuntze, in the Heft zur Botanischen Zeitung, 1877, and by Ernst Stahl in the Jenaische Zeitscrift für Naturwissenshaft und Medicine, 1888. The phenomenon of the explosion or shooting forth of the needles was first noticed by Turpin in 1836. He called the capsules containing them "biforines," erroneously supposing them to be provided with an opening at each end.

CYCAS CIRCINALIS AND ITS FECUNDATION.

One of the most interesting plants growing in Guam is the "fadan," or "federiko" (Cycas circinalis), the nuts of which were a food staple of the aborigines before the discovery of the island. Its cylindrical, scarred trunk, and stiff, pinnated, glossy leaves suggest ideal pictures of the forests of the Carboniferous age. (Pl. VIII.) Its nuts, poisonous when crude, but abounding in starch, are converted into a nutritious arrowroot, or sago, in several tropical countries. But its chief interest is in the structure of its inflorescence and the manner of its fructification. The group of plants to which it belongs occupies a place intermediate between the flowering plants and the cryptogams. Like the former, it has fruit with a large starchy endocarp, but, as in the latter, fecundation is accomplished by means of spermatozoids and archegonia, corresponding to the male and female elements in animals. The male inflorescence is in the form of an erect cone consisting of modified staminal leaves which bear on the under surface globose pollen sacs corresponding to microsporangia. The female inflorescence consists of a tuft of spreading carpellary leares having their margins coarsely notched. (Pl. XIV.) In the notches are situated the ovules, which are devoid of any protective covering. They correspond to macrosporangia. Pollination is effected by the wind. The pollen settles on the ovules and sends down a tube into the tissue of the nucellus. Archegonia are formed, egg cells derelop, 
and in the pollen tube are produced spermatozoids provided with minute morable cilia by which they are propelled. These are discharged over the archegonia and fecundate the egg.

The fecundation of the allied Cycas revolute of Japan has been studied by the Japanese botanist Ikeno; ${ }^{a}$ that of Zamia floridana and Z. prmila of the southern United States by Dr. H. J. Webber, of the United States Department of Agriculture. ${ }^{b}$ Doctor Webber found the mature spermatozoids of Zamia to be the largest known to occur in any plant or animal. They are even visible to the naked eye. He kept them alive in sugar solutions and found their motion to be due mainly to the action of cilia.

In fecundation the entire spermatozoid enters the egg cell, swimming in between the ruptured neck cells. Sometimes two or three spermatozoids enter the same egg, but only one is used in fecundation, the others perishing. On entering the upper part of the egg cytoplasm the nucleus escapes from the spermatozoid, being left slightly in rear of the active ciliferous band. The plasma membrane of the spermatozoid entirely disappears, seening to unite with the eytoplasm of the egg, and this allow the spermatozoid cytoplasm also to unite with the egg cytoplasm and leaves the nucleus free. The nucleus passes on to the egg nucleus, with which it unites. Fecundation thus consists of a fusion of two entire cells-cytoplasm with cytoplasm and nucleus with nucleus.

With ahundance of liring material at hand, the study of Cycas circinalis along the lines followed by Ikeno and Webber could not fail to yield interesting and important results.

\section{DISPERSAL OF PLANTS BY OCEAN CURRENTS.}

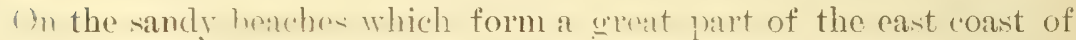
Gilan there is alway a line of drift. just above high-water mark, which is rich in seeds, fruits of various kinds, and driftwood brought by the great ocean current which sweeps across the Pacific from east to west. Sometimes the seeds and logs are riddled with teredo borings or are corered with harnacles, but often they appear fresh and little worn by the erosion of the waves and sand. Many of the seeds are dead: some of them are alive and capable of germination. Not all the species which reach the island bave gains! foothold there. The fruits of plants growing in muddy estuaries or mangrore swamps, for instance, can not estahlish themselres on a clean sandy beach. Germinating fruits of Rhizophora and Bruguiera are frequently cast ul) only to die, and nuts of the nipa palm, though found in perfect condition. can establish themselves only near the mouths of streams where the water is brackish. Though coconuts are of frequent

"s. Ikeno, T̃ntersichungen über die Entwickelung, etc. Jahrbücher für wissensch. Botanik, 32, Heft 4, p. 557, 1898. See list of works.

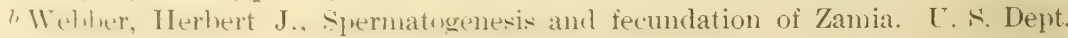
Agriculture, Bureau of Plant Industry, Bull. No. 2, 1901. See list of works.

$c$ Idem., p. 85. 



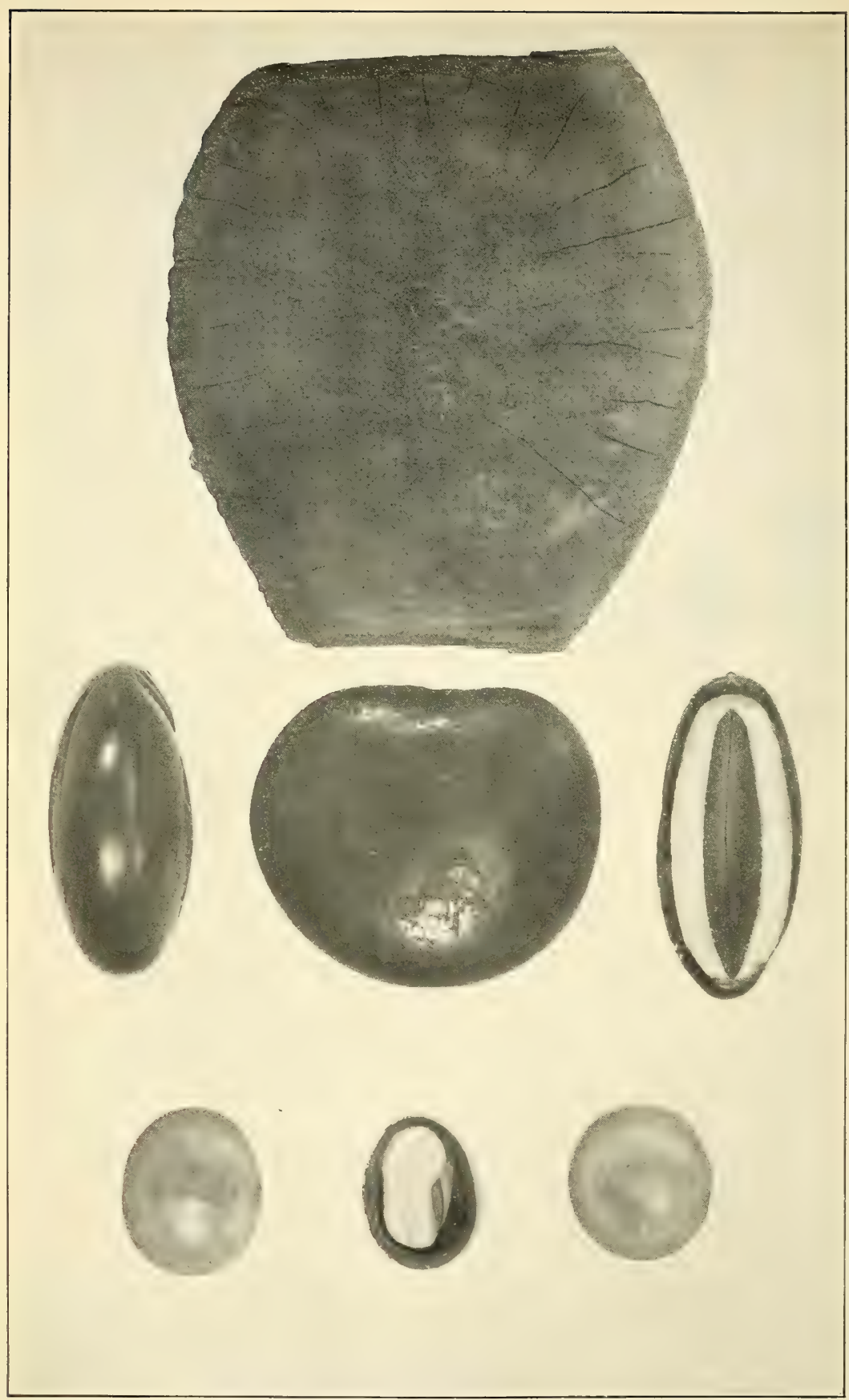

Sea Beans, Showing air Spaces which Give Them Buoyancy. Section of Pod and Seeds of Lens phaseoloides having Air Space Inclosed Between CotyLedons. Seeds of Guilandina crista with air Space Between the Kernel AND THE SHELL. 
occurrence in the drift, it is interesting to note that on the eastern. or weather, side of the islands where they are washed up, there is not a single coconut grove near the water's edge, while on the western, or lee, side, where groves have been planted, thry grow so near the sea that their roots are often bared by the waves. It seems probable that coconuts grow in Guam only where they have been planted, except in cases where nuts which have fallen from trees of established groves have taken root.

The seeds which oceur in the drift owe their buoyancy to various causes. Many of the "sea beans" inclose an air space between their cotyledons; others have kernels which do not fill the stony, water-tight shells, but leave a space for air to keep them afloat; others have a separate air chamber; others have fibrous envelopes or husks composed of light tissue, and still other's have woody or cork-like shells of low specific gravity.

SEa Beans adapted For Floating.-Among the hard stony seeds of leguminous plants cast up on the shores of Guam are gray "nickernuts" (Guilandina cristr), called "pakao" by the Guam, natives; hrown "horse-eye sea beans" (Stizolobium giganteum), with a conspicuous black raphe encircling nearly three-quarters of the periphery of the seed, and the large flat "snuffbox beans" (Lems "liaseoloides), called "bayog" or "badyog" in Guam and "cacoons" in the West Indies. These "sea beans," or their closely allied representatives growing in the West Indies, were figured as early as 1693 in an account of the objects cast up by the sea on the Orkney Islands by James Wallace, who knew nothing of their origin." They were recognized at once by Hans Sloane as the seeds of plants he had seen growing in Jamaica and which he had included in his catalogue of Jamaica plants. Their occurrence on the shores where they were collected, so far removed from the place of their origin, suggested to Sloane the existence of the current which was afterwards known as the Gulf Stream. Sloane published a paper on the subject in the Philosophical Transactions of London in 1696, in which he for the first time offered to the world the true explanation of the means by which they were transported. ${ }^{b}$

a"Cast up on the Shoar there are very oft those pretty Nutts, of which they use to make Snuff-boxes. There are four sorts of them, the figures of which are set down." Description Orkney Islands, p. 14, 1693.

$b$ "How these several Beans should come to the Scotch Isles, and one of them to Ireland, seems very hard to determine. It is easy to conceive, that growing in Jamaica in the Woods, they may either fall from the Trees into the Rivers or be any other way conveyed by them into the Sea: it is likewise easie to believe, that being got to Sea, and floating in it in the neighbourhood of that island, they may be carried from thence by the Wind and Current, which meeting with a stop on the main continent of Am. is forced through the Gulph of Florida, or Canal of Bahama, going there constantly E. and into the N. American Sea; for the . . . Sargasso grows on 
Grilanctime rristre has gray polished round seeds of stony hardness, about the size of small marbles. When shaken, these seeds, or "nicker-nuts," give forth a rattling sound, owing to the fact that the kernel, consisting of two closely oppressed cotyledons, fits loosely in the shell. leaving a large air space, which gives buoyancy to the seeds. (Pl. XV, figs. 5, 6, 7.)

The reeds of Lens phaseoloides (Pl. XV, figs. 2, 3, 4) do not rattle when shaken. Their kernels fill the shell completely, but inclosed between the two large cotyledons composing the kernel there is a large air space when the seeds are quite mature and dry. They are very light and float like bubbles on the surface of the sea. The seeds of Stizolohium are easily distinguished from those of Lens by their prominent raphe. Those of Lens have no raphe and are inclosed in an enormous woody, saber-shaped pod (Pl. LVI), consisting of many distinct joints, with a strong woody suture surrounding the whole legume. This suture is persistent and forms a sort of frame from which the inclosed joints may be removed separately. Each joint (Pl. $\mathrm{XV}$, fig. 1) is in the form of a closed cell in which the bean fits loosely and rattles ahout when shaken. This plant owes its very wide distribution to the buovancy of its seed and its habit of growing near the sea. Great numbers of the seeds are thrown up each year by the Gulf Stream on the Azores, but the plant has not succeeded in establishing itself on those islands. Seeds collected there by Darwin were sent by him to Sir Joseph Hooker. They were planted at Kew and many of them germinated and grew to be fine plants, "showing that their immersion during a vorage of nearly 3.000 miles had not affected their vitality." $b$

Morixda citrifolia. -This plant (Pl. XVI), called "ladda," or "lada," hy the natives of Guam, has seeds of unusual interest. Their buoyancy is insured hy a distinct air cell. They are frequently found in the drift of tropical shores, and experiments have been made which demonstrate the great length of time they will float in salt water.

the rocks about Jamaica, and is carried by the Winds and Current (which for the most frart go impetumsly the same way.) towards the coast of Florila, and thence into the Northern Am. Ocean, whereas I mention p. 4. of my Catal. it lyes very thick on the Surface of the Sea: But how they should come the rest of their Voyage I cannot tell, mules it be thought reasonable, that as ships when they go South expect a trate Easterly Wiml, so when they cone North, they expect and generally find a Westerly Wind for at least two parts of three of the Year, so that the Beans being bronght Furth ly the Current from the crulph of Florida, are put into these Westerly Winds way, and may be supposed by this means at last to arrive in Scotland. Sluane, An Account of Fuur sorts of strange Beans, etc." Philosophical Transactions, vol. 19, pp. 299, 300, 1696.

b J. D. Hooker, Insular Floras, Gardeners' Chronicle, 1867, pp. 27, 51.

cSee Shohimper, Die inch-malayische strandflora, p. 165, pl. vir, fig. 26, b and e, 1891; also Crinjy; The Dispersal of Plants, ete., Trans. Victoria Institute, vol. 27, p. 267,1890 . 


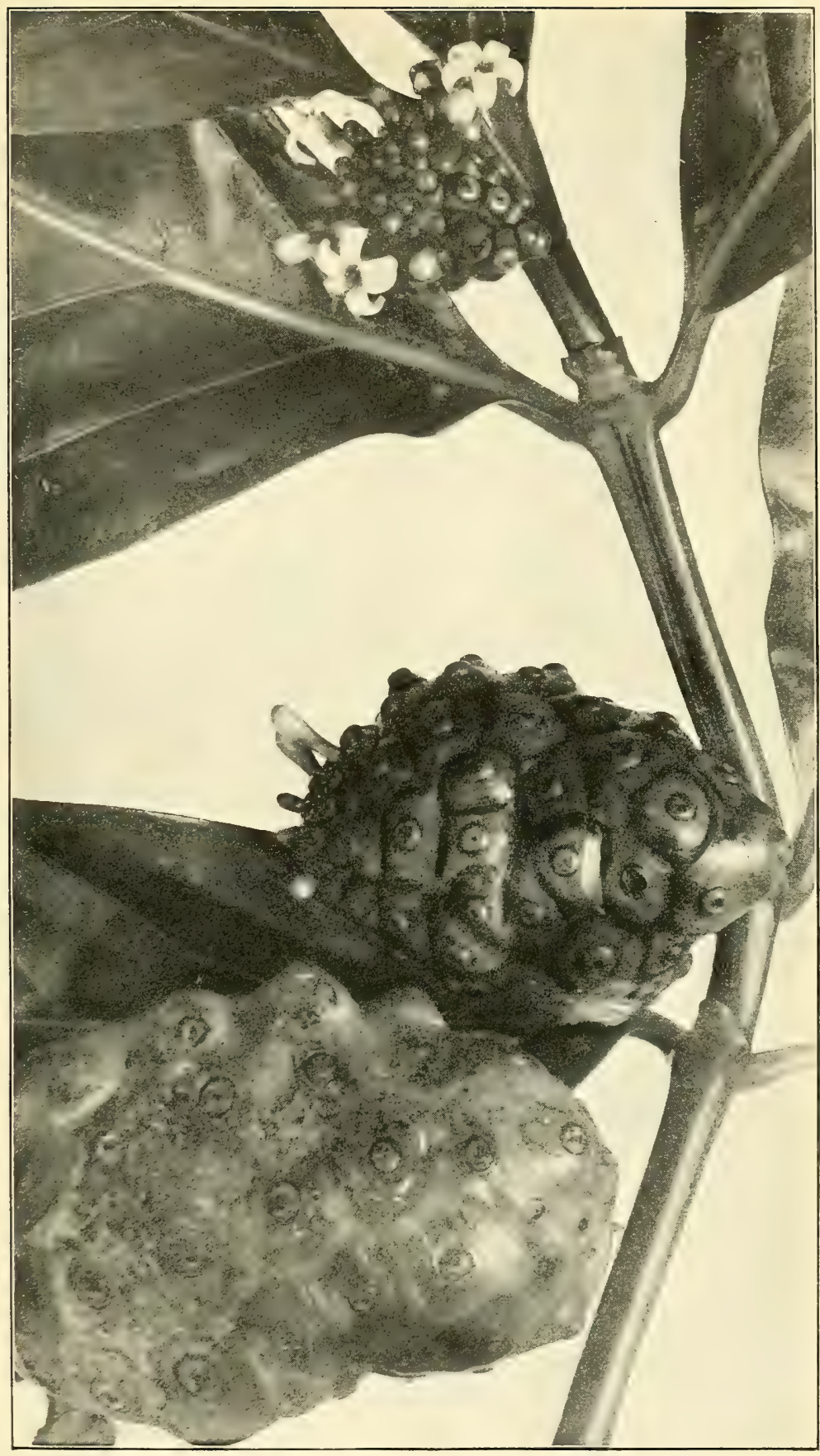

Morinda CITRIFolia. Flowers and Fruit. Natural Size. 

Fruits with izcoyant musks. - In addition to the coconut, which is provided with a fibrous envelope, and is known to float for long periods of time in the sea without losing its vitality, there are found in the drift of Guam the fruits of Barringtonia speciose, called "puting" by the natives, and Ochosia mariannensis, called "fago." Both of these fruits have fibrous husks, but that of the Barringtonia has a hard glossy surface, somewhat as in the case of the coconut, while the surface of the Ochrosia is soft and easily eroded. The fruits of this Barringtonia (PI. XXXVIII) are four-cornered and miter-shaped; he natives crush them and use them as a fish intoxicant. Those of the Ochrosia are oral in shape, and, like the closely allied Cerbera fruits of Samoa and other tropical countries, are soon deprived of their pulpy parenchyma, and display the cushion of fiber inclosing the mesocarp. This owes its buoyancy to intercellular air spaces. It is elastic and serves to protect the seed from erosion and from the attacks of animals.

MANGROVE FRUTTS. - Great numbers of these spindle-shaped young plants are continually carried by the tide from the estuaries into which they drop after having begun to germinate on the tree. The fruits of Rhizophora mucronate (PI. LXIV) are easily distinguished from those of Bruguiera gymnorkiza (PI. XL) by the four-parted persistent caly $x$, the calyx of Bruguiera consisting of many segments. Associated with them are found the seeds of the "red-flowered mangrove" (Lumnitzerc littorea), called "ñana" in Guam; those of Ercoecrive agallocha, the "milky mangrove," or "blinding-tree," which grow in catkin-like spikes; and the keeled nuts of the "ufa" (Itritiere littoralis), the hard shell of which includes a very large air space (Pl. LII).

LitToral TREes AND SHRUBs.-Other seeds found in the drift are those of Pariti tiliaceum. and Thespresin populnen, the "pago" and "kilulu" of the natives, both of which belong to the Malvaceae, and have cavities filled with air; the round nuts of Calophyllum inophyl. lu, called "daog;" the hoat-shaped "almonds" of Terminalic catrplpu, called "talisai," often much eroded; the angular woody seeds of the "lalanyug" (Xylocarpus gronatum), and the ribbed fruit of the nipa palm (Nypu fruticans). Among the plants which grow on the edge of the sea, whose fruit drops into the water continually, are the shrubby Lobelia knenigio and Tonmefortia argenten (PI. LXVIII), associated with the creeping "goats-foot convolvulus" (Ipomoea pes-ciprecte), the seeds of which contain air carities, and the "Polynesian ironwood" (Casumina equisetifolia), the cones of which (PI. XLI) are corky and luoyant and inclose seeds provided with wings which adapt them for transportation by the wind. The transparent wings of these seeds are stiffened by the persistent style. When a handful of them is thrown into the air they resemble a swarm of Hying insects. Hundreds of these seeds, together with the querr-shaped Barringtonia fruits, are 
always to be found germinating on the stretches of sandy heach along the southern portion of the east coast of the island. With Schimper as a guide, and the benefit of the experiments of Guppy and of Treub. a student on the island of Guam would find abundance of material and a most farorable opportunity for studying the seeds of the drift in the places where they have been deposited by the great transPacitic current, and where they could be observed in the process of germinating under absolutely natural conditions.

\section{ANIMALS OF THE ISLAND.}

\section{MAMMALS.}

BATS. - There are no indigenous quadrupeds in Guam. The only mammals in prehistoric times were two species of bats. the larefe fruit-

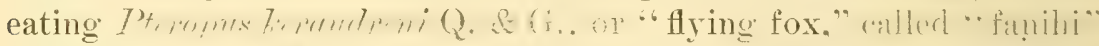

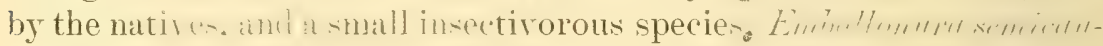

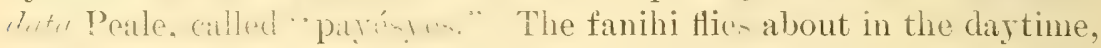
flapping its wings slowly like a crow. It has a disagreeable musky odor, but this leaves it when the skin is removed, and the natives sometimes eat it. The flesh is tough, but not unsarory. The principal fruits eaten by it are guaras. fertile breadfruit, the drupes of the

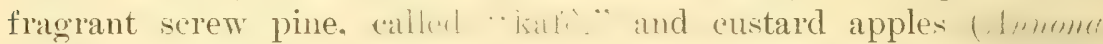
reticulutur), which it has undountedly helped to spread ofer the isliund. This species occurs in Fiji. the Eriendly Lslands. New Ilemrides, and l'elew Islands. It very clusely resembles the flying foxes of Samoa, which the natives of those islands call "pe'a," or "manu-langi" (bird

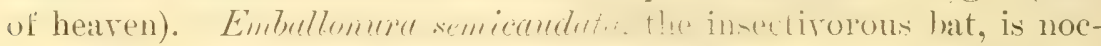
turnal in its habits, and flutters about rers much like our own common specie- It remains in cares during the day and rentures forth at twilight. It is rery similar to, if not identical with, the "apatau-vai" of the Sunoans, and has hen collected in Fiji and the New Hehrides.

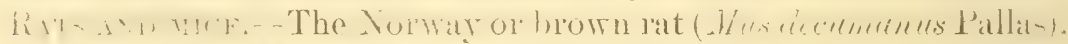

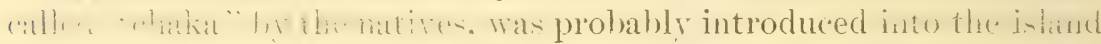
through the agency of shiph. It is rery alumdant and is a great pest,

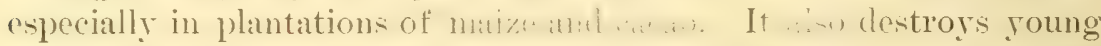
coconuts, ascending the trees and often making its nests there. The ('ommon movise ( I/ ently cause- little hatrm.

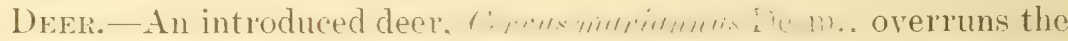

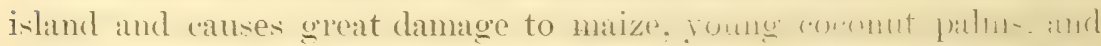
nher crops of the natives. It was hrought to the islan: he ilon Mariano Tolias. who was gorernor of the Mariannes from 1671 to 176t. Its flesh hats a tine renison flaror. and it is a farorite food staple of the natives. who hunt the animal with doge and guns, of ten burning 
great stretches of sword grass ( Tiphereforstis forrituln) in which it hides. These animals often make raids upon the garden patches of the natives, sometimes coming down into the palace yilden at night and eating the melons and other succulent vegetables cultivated there. During the rutting season the honking cries of the fighting bucks are heard at night, especially when the moon is full.

Donestic aninals. - Butialo, cattle. hormes. mules, pigs, goats, cats,

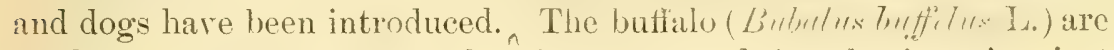
used for carrying bur ns, drawing carts, and for plowing rice, just as in the Philippines. Their flesh is seldom eaten in Guam and their milk, which is of exwellent quality and in some countries is an important food staple, is never used. They are very strong animals, but awkward and more difficult to manage than oxen. It is a common sight in Guam to see a small boy riding a buffalo bull. As the huge, ungainly, great-horned animal goes galloping along the road it suggests some monster of prehistoric times. Buffalo can not endure lrig periods of drought. They love to wallow in swamps and, if hot and dry, will sometimes lie down with their riders when crossing a marsh.

Many of the Guam cattle bear a general resemblance to Jerseys in size and color, though their udders are much smaller. Both bulls and cows are used as steeds and for drawing carts. A foreigner is especially struck with the speed developed by some of these animals. It is a common sight to see a dainty smooth-skinned cow saddled and haltered trotting along as swiftly as a horse, with her calf galloping at her side. With the exception of a few herds of cattle and buffalo in the interior of the island, all animals in domestic use are kept tethered, to keep them away from the unfenced garden patches and cornfields of the natives. They are subject to the attacks of wood ticks (Acarina), so that they must be frequently examined. The natives rub their skins and curry them like horses. Sometimes a neglecterl animal dies in consequence of the attacks of these pests.

Horse do not multiply on the island. Colts are born but do not thrive. Goats are not plentiful. Wild hogs roam the forests in the nortis an part of the isliul. They live on fallen wild breadfruit and various roots. It is interesting to note that they eat the exceedingly acrid rootstocks of the went Alumsin which grows wild in the forests (ien p. T). Hogs kept on ranches and fed on coconuts, breadfruit, and other regetable substances are prized for food. The excellent flavor of the (X:1am pork was much praised by early navigators (see pp. 18 and 20). Dogs are pests in the villages. They are not well cared for, as a rule, and get their living by foraging. Cats have gone wild, and wimetimes destroy thr egess of sitting hens and catch young Wirlinti and turkeys. Doge and cats are fed upon coconuts when other food is not available. 
BIRI:4"

LAYD BIRDS. The most heautiful bird on the island is the rowe-

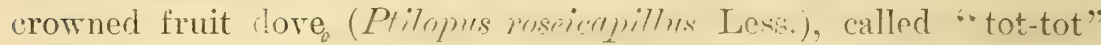
by the natives. and closely resembling the "manu-tangi" of Samoa (I'. firme l'eal $\%$. The general color of its plumage is green. Its head is capped with rose-purple and the lower surface is yellow and orange, with some purple on the breast. The sexes are similar. Then it utters its mournful sobbing note it presses its bill against its breast and swells the hack of its neck. Birds which were kept by the author in captirity rould frequently ary out in the middle of the night. Their farorite food was the fruit of the ilangilang (Cancenginm odorctum), Cestrum berries (called "tintan China"), and orange berries (Triphasia trifoliata). They also eat the plum-like fruit of Ximenin americana, called "pi'od" by the natives.

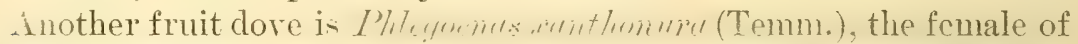
whicin is smaller than the male and is of a uniform reddish-brown color, while the male has a white throat and olive-green reflections on its breast. Another dove, which was probably introduced from the Philippince, is Tuptur dussumicri (Temm.). It is quite common in the open stretches of the mesa and is called "paluman-halomtano," or "wild pigeon," by the natives. It is a graceful, dore-colored bird resembling the common turtle dore, to which it is closely allied. Another introduced hird is the beantiful little pigmy quail,$\ldots \ldots$

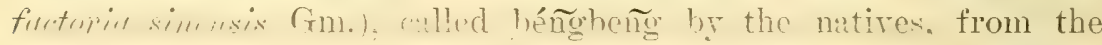
peculiar whirring noise it makes in flying. This little hird, which is only 5 inches long. is remarkable for the large size of its eggs. They are of a brownish color. sprinkled with deeper brownish dots, broadly ovate in form, and 1 inch through in their greatest diameter.

The most remarkable bird of the Marianmes is a megapode. M[ "yn"y.

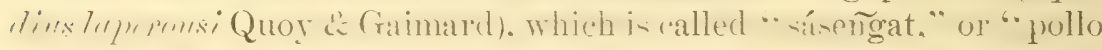
del monte." It i- duncly allied to if not identical with a megapode found in the Pelew Islands, and is of the same genus as the junglefowl or mound-builder of Australia ( $/$. n Marianne Islands the natires attract it br knocking stones together. These hirds are remarkable for the thickness of their legs and the size of their feet. Ther hare a habit of lieaping up mounds of earth, decared leares, and rubbish in which they lay their eggs. They are of a hrownish color with grayish head. On the head there is an area of naked skin of a reddish color. The bill and legs are rellow. The birds are about 9 inches long. They fly hearily. They are in tinown

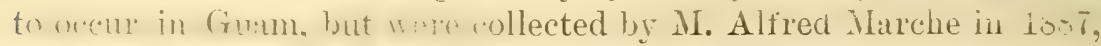
1.hs. and 1 on the islands of Rota, Saipan. Pagan, and Agrigan, lencenging to this group.

I Im indebted to Dr. Charles W. Richmond fur rerising the scientitic names of the birds in the following list. 


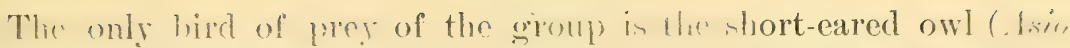

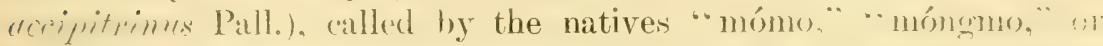
"móngo." Iiartert douhts its occurerence as a recirtent of the Miriamne Islands" but it is a hiri well known to the nutives. They describe it as having hig eyes and a cat-like face, and say that it catches lizards. It has not heen collected in Guam, hut is said to be common on the island of Tinian. It was collected by the Frey cinct experlitini..

Terrestrial KIngFishers. - One of the commonest birds in Guam is Hulcyon cinnamomimus Swains., called "sihig" by the natives. It is of a beautioul blue and tawny color, the female differing from the male in having white on the belly. This bilol in allied to the $601 \mathrm{in}$.

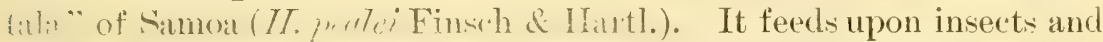
lizards and is said to eat young birds and to pick out the eyes of young chickens. It utters a strident rattling note which is often heard in the middle of the night. An allied species, Halcyom albicilla (Dumont) occurs in the northern islands of the group.

Other birds are the edible-nest swift, Collocalia freipharga (Thunb.) called "yayáguag" by the natives and "golondrina" by the Spaniards, which in Guam makes nests of leaves stuck together with a secretion from the mouth very different from the typical nests used for food by the Chinese; the fan tailed fly-catcher, Rhipidura uranias Oustalet, called "chichiríka," or "chichiríta," by the natives, a pretty little bird which follows one along the road and spreads its tail as though wishing to attract attention. Another little fly-catcher frequenting shady woods, Myiagra freycineti Oustalet, called "chiguánguan;" the starling-like sáli, Aplonis kittlitzi Finsch \& Hartl., closely allied to the Samoan miti-uli (A. brevirostris); a crow, Corvers kubaryi Reichenow, called "aga," which is fond of Terminalia nuts and does much damage to the maize crops of the natives; two honey eaters, the little red-and-black Myzomela rubratro (Less.), called "égigi," which frequents the blossoms of bananas, coconuts, and scarlet hibiscus, and the olive-green and yellow Zosterops comspicillata (Kittlitz), called "nóssak" by the natives. The only real song bird on the island is the gâ-karriso, or gâ-piao, a reed warbler which is well named Acroceplualus luscinia (Quoy \& Gaim.). It nests among the reeds of the large swamp near Agaña, known as "la Ciénaga," and has a song of exquisite sweetness.

SHore BIRDs. - Among the shore birds are a peculiar bittern, $A r$ detta sinensis (Gmel.), called "kákkag" by the natives; the common reef-heron of the Pacific, Demigretta sucr (Gm.), called "chúchukô," which is not rare but wary and hard to approach; two rails called "kôkô," IIypotaenidia onstoni Rothschild, and Poliolimmas cinerens. (Vieill.), both of which are caught by the natives by means of snares laid in paths; the widely distributed water hen or gallinule, Gallinulu 
chlor"fues Lath., called "pulátal" by the natives, excellent for food, and easily distinguished by a red shieid on its forehead; three birds called "kalálang." the Pacitic godwit, Limoxe lapponica baneri (Naum.), the Australian curlew, Tumenius cyanopus V ieill., often seen on newly tilled fields, and the oriental whimbrel Tumenius phaeopus variegatus (Scop.), somewhat smaller, usually seen at periods of migration; and the widely spread snipe, Gallinago megula Swinh. Among the whore birds called by the general name "dulíli" are the gray and white Asiatic wandering tattler, Ileterectitis brevipes Vieill.; the bullhead or black-bellied plover, Squatarola squatarola (L.); the well-known Asiatic golden plover, Charadrins dominicus fullus (Gm.), very common on cultivated fields and along the shores of the island; the Mongolian sand dotterel, Aegialitis mongola (Pall.); and the common turnstone, Arenceria interpres (L.), which may be easily distinguished from the rest hy its bright yellow feet. A duck, Aluas oustuleti Salv., called rgatinga by the natives, is peculiar to the Marianne islands. It is closely allied to species occurring in Hawaii and Samoa.

SEA bIRds. - No gulls are found in the vicinity of the island. Noddies, Anons tencruprithus Gould and Anousstolidus(L.), called "fáhan," by the natives, are common. The beantiful snow-white tern, Gygis villu littlitz; Hartert, called "chúnge" by the natives breeds on the island in great numbers, not making a nest but laying its single white egg on the bare branch of a tree. The common booby sula sula (L.), is common in the vicinity of the island. Great numbers of them may alwars be seen off the coast of Orote Peninsula, and the red-footed booly (Suln piscrtri, L.) with white plumage, also occurs. They pursue flying fish, and dart into the water from great heights. The frigate bird, Firsutu uquitı (L.). called "payaáya" by the natives, is not rare, but is seldom seen near the shore of Guam. The tropic bird. Plecethern lepturus Daudin, nests on the northern islands of the group."

\section{REPTILES. ${ }^{b}$}

There are fen reptiles in Guam. The most conspicuous is a large lizard (Tirmus sp.) ahout + feet long, of a black color speckled with lemon-yellow dots. The combination of these color's gives to the animal a greenish appearance as it runs through the bushes. As in the Guam kingtisher or "síhig " we have a lizard-eating bird, so in this animal, called "hilitai" hy the natives, we have a bird-eating lizard.

\footnotetext{
"Students of urnithology are referred to the report of Quoy and Gaic:ard in the zoology of the Frexcinet Experlition; Oustalet's "les manmiferes et les oiseaux des ile: Iiarianne:" "IIartert "un the hirds of the Marianne Islands;" and Seale's "Report of a mission to Guam." See list of works.

"I am inclebterl to Dr. Leonaril stejneger, of the U. S. Siational Museum, for the names of the reptiles.
} 
It is a great pest, frequently visiting the ranches of the natives, eating the eggs of fowls and young chickens, and robbing birds' nests. It is a common thing on walking through the woods of the island to hear an outcry among the birds and to discover one of these creatures in the vicinity of a nest which he has just robbed. Several pigeons belonging to the author were caught and killed by hilitais, their wings having been clipped to prevent their flying away from a ranch to which they had been carried. These lizards are caten by Filipinos living in Guam, but the natives look upon them with disgust.

All houses of Guam are frequented by small lizards called "geckos." They are harmless creatures and are welcomed by the natives on account of their habit of catching insects. Their toes are so constructed as to enable them to run upside-down on the ceiling and rafters with great rapidity. At night they may be seen quite motionless lying in wait for moths and other insects which may be attracted into the houses by the light. Three or four often pursue the same insect, approaching it stealthily like cats after their prey. From time to time they utter a chattering noise, which has won for them the name of "island canary birds."

In the woods is a pretty blue-tailed skink (Emoia cyanura Lesson), a small lizard with a tail the color of turquoise and with longitudinal hronze lines along the back. The only snake on the island is Typhlops l,aminus (Daudin), a small species, with microscopic eyes and mouth and covered with minute scales. It is sometimes called "blind-worm," from its general resemblance to a large earthworm, and is found in damp places, under stones and logs. Turtles are common in the sea, but are seldom taken.

FISHES.

GERE!: W WTES.

The fishes of Guam have been collected by Quoy and Gaimard and Mr. Alvin Seale, of the Bernice Pauahi Bishop Museum of Hawaii. ${ }^{b}$ Although the natives do not devote themselves to fishing so extensively now as was formerly the case, yet many of them have cast nets with which they catch small fish swimming in schools near the beach, and a few have traps and seines. The ancient custom of trawling for bonitos and flying fish has nearly died out, but the natives still resort occasionally to the method pursued by their ancestors of stupefying fish with the crushed fruit of Barringtonic speciosa, a narcotic widely

"I am indehted to Dr. Barton W. Evermann, of the U. S. Fish Commission, for revising the scientific names of the fishes and for reading the proof of the following list.

b See director's report for 1900, Honolulu, Hawaii, Bishop Museum Press, 1901, p. 61 .

$9773-05-6$ 
used for this purpose in the islands of the Pacific. The fruit is pounded into a paste, inclosed in a bag, and kept over night. The time of an especially low tide is selected, and bags of the pounded fruit are taken out on the reef the next morning and sunk in certain deep holes in the reef. The tish soon appear at the surface, some of them lifeless, others attempting to swim, or faintly struggling with their rentral side uppermost. The natives scoop them up in nets, spear them, or jump overboard and watch them in their hands, sometimes even diving for them. Nothing more striking could be imagined than the picture presented by the conglomeration of strange shapes and bright color's-snake-like sea eels (Ophicthus, Muraena, and Echidna); roracious lizard-fishes (Synodus); gar-like hound-fishes (Tylosurus), with their jaws prolonged into a sharp beak; half-beaks (Hemiramphus), with the lower jaw projecting like an awl and the upper one having the appearance of being broken off; long-snouted

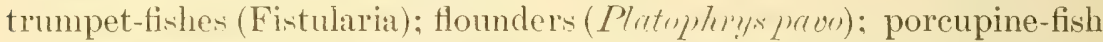
(Dinden hystri, ), hristling with spines: mullet of sereral kinds (Mugil), highly estcemed as fool-fishes; piike-like Sphyraenas; squirrel fishes (Holocentrus) of the brightest and most beautiful colors-scarlet, rose-

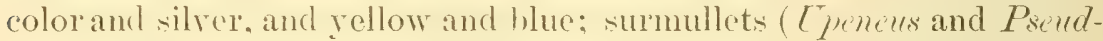
"1нmens) of rarious shades of yellow, marked with bluish lines from the eye to the snout; parrot-fishes (Nearus), with large scales, parrot-like beaks, and intense color's, some of them a deep greenish blue, oihers looking as though painted with blue and pink opaque colors; varicgatrod Chactodons. called "sea butterflies" by the natives; black-and-

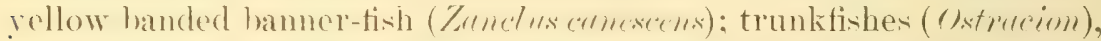
with holns and armor; gaily striped lancet tish (Tenthis linentus)

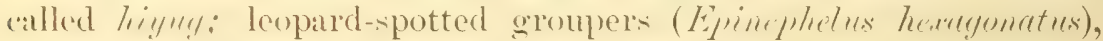

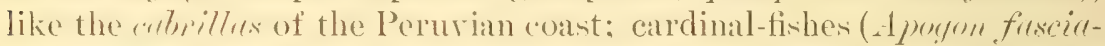
fis) striped from head to tail with bands of black and flesh color; hideous-looking, warty toadtishes, " "uf"," armed with poisonous spines. much dreaded by the natives: and a black fish (Honoceros margimutus). with a spur on its forehead.

As many young tish unfit for food are destroyed hy this process, the spanish Gorermment fortade this method of fishing: but since the American occupation of the island the practice has been revired.

In the mangrore swamps when the tide is low hundreds of little fishes with protruding eves may he seen hopping ahout in the mud and climing among the root of the Rhizophera and Bruguiera. These

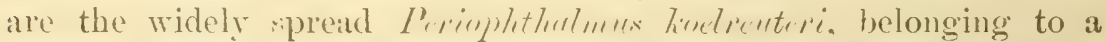
group of fishes interesting from the fact that their air-bladder has assumed in a measure the function of lungs, enabling the animal to breathe atmospheric air.

Following I give a list of some of the Grum fishes arranged according to their vernacular names: 
Abábang ("Butterfly").

A name applied to several short, flat fishes with conspicuous markings, such as species of Chactodon and Zanclus; also to the pretty little Tetradrachmum so abundant in tide pools on the coral reefs. Among these are ('hrutodom ornatisximus (Solander), ornamented with black and yellow stripes. In Samoa allied species are "alled "tifitifi" ("adorned").

Abảbang gupálau. Zanclus canescens L.

A beautiful harlequin, or banner-fish, with an elongated dorsal fin and black, yellow, and white transverse (rertical) bands. In Hawaii this species is called "kihikihi;" in Samoa "tifitifi."

Abábang pintado. Tetradrachmum amanum L.

A beautiful and striking little fish, common in the tide pools of the reef, silvery and yellow, with black spots and bands.

Agman, or Hagman. Wurcena tile Ham.

A sea cel, hrownish; common. In Samoa allied species are called "pusi;" in Hawaii "puhi."

Agman, or Hagman atúlong. Muraena nigra Day.

A dark-colored sea eel which lurks in holes in the coral-reef.

Bayag, or Badyag. Fistularia depressa L.

Trumpet-fish; trompetero (Spanish).

Boca dulce. Polydactylus sexfilis Cuv. \& Val.

A fish with shark-like mouth and large eyes; steel-blue on back, whitish on rest of hody. Edible. Called "barbudo" in Spanish. In Hatraii called "moi, or "moi lii;" in Samoa allied species called "afa."

Buha. Lutianus monostigma (Cuv. \& Val.).

Snapper; with a black spot on the lateral line under the anter'or soft dorsal ray.

Butele. Diodon hystrix L.

Porcupine-fish. In Porto Rico called "guanábano," after the spinyIruited sour sop (Ammon mmicatr). In Samoa it is called "tautu;" in Hawaii it is regarded as poisonous, but is eaten after having been prepared with certain precautions.

Chalag, or Chalak. Holocentrus spp. and Flammeo sammara (Forskål).

A general name for squirrel-fishes. Hotocentrus bimslutum Q. E G. is of a beautiful rose-color with silver longitudinal stripes. IInlecentmes fuscostricutus seale is pinkish with longitudinal rows of black spots and a black spot on spinous part of dorsal fin; red on top of head. Irolocenturn dlindrmol Lacép. is red with lighter longitudinal lines. "These heratiful colors soon fade in alcohol. In Hawaii allied species are called "alaihi;" in Samoa "malau." 
Dafa. Scarus cypho Seale. blue.

A parrot-fish; large scales and parrot-like beak; color deep green-

Danglon, or Dar̃glun. Ostracion punctatus Bloch.

A trunk-fish; body without ribs, inclosed by a hard carapax composed of hexagonal plates; 2 horns in front and 2 in rear; black speckled with white.

Fanihen-tasi ("sea-bat"). Stoasodon narinari (Euphr.).

An eagle-ray, with pectoral fins developed like two broad wings, and a long flexible tail armed with a serrated spine. Color of upper surface blue spotted with white.

Fómho, or Fóngho. Abudelduf spp. "Coral-fishes."

Small and flat, resembling a sun-fish, usually with a dark transverse band on after part of the body near the tail. Abudelduf dichii (Lienard) is livid pink with a black band on the posterior third of the body: caudal and pectoral fins yellowish white, dusky at the tip; remaining fins dusky. Abuddduf amboinensis (Bleeker) has the caudal fin deeply forked with the lobes much produced; color brownish, lighter helow; fins all washed with bluish except pectorals, which are white: deep brown spot at hase and in axils of pectorals.

Gadao. Epinephelus hexagonatus (Bloch).

A "grouper" with leopard-like spots. Cabrilla (Spanish).

Gadu. Cheilinus tritobatus Lacépède.

Greenish with red stripes and dots on the head, 3 oblique lines from eye down sides of snout; each scale with red rertical lines; vertical fins green with light margins; ventrals green; pectorals yellow. Allied to the "poou" of Hawaii ( $C$. hexagonatus Günth.).

Gadúdog. Amphiprion spp.

Ampleiprion bicinctus Rüppell, has a cinnamon and black body with 2 transverse bluish bands, 1 on cheek, and 1 on abdomen; the first band of equal width with the eye and extending orer the neck vertically down to the lower edge of the opercle; the other band extending down from the dorsal fin to the anal opening; caudal tin emarginate, upper lobe produced; color tawny. Amphiprion eptippium Bloch, is brownish black, lighter in front, with a blue band one and one-half times as wide as eye, extending from neck to eye, and down along the opercie and preopercle, ending in an acute angle on the subopercle; ventrai and anal tins black; pectorals, caudal peduncle, and fin yellow.

Gahga, or Gajga (Spanish orthog.). Parexocuetus and ('ypsetums. Flying-fishl.

Guaguas, or Aguas. Mugil planiceps Cuv. \& Val. Gray mullet.

Color silvery with wash of yellow on hody. Good food fish.

Hagman. See Agman. Muraena spp. 
Hagónfa Oxymonacanthus longirostris Bleeker.

A small file-fish; mouth like a turned-up beak; skin blue with orange spots. Collected June 14, 1900.

Halúo. Carcherias melanopterus Q. \& G.

A shark with dark-colored fins.

Hamóktan. Zebrasoma guttatus Forster.

A spotted lancet-fish. Body elevated, compressed, short; brownish speckled with round white dots; 2 bluish-white cross bands on the body and 1 on the shoulders, extending down on opercles; tail armed with spines; tail and ventral fins yellow; mouth like the snout of a sheep. This species occurs also in Hawaii.

Hánkut. Hemiramphus limbatus Cuv. \& Val. Half-beak.

Upper jaw short; lower jaw prolonged into a beak. In Samoa allied species are called "ise;" in Hawaii "ihe-ihe."

Hasule. Anguilla sp.

An eel living in fresh-water streams. Edible.

Hígum. Harpe axillaris (Bennett).

A small-mouthed fish, belonging to the Labridae, the family which also includes the tatalun, gadu, and tatanung. The anterior half of the body is dark-colored, the posterior half of a livid salmon-color; caudal fin yellow; spinous dorsal fin brown; posterior half of soft dorsal and anal fins light yellowish; a deep black spot on the first 3 dorsal spines; a black spot on base and in axil of pectoral fins.

Hiting. Siganas hexagonata Günther.

Like a large sesyan (a little more than a foot long); dark purplish with yellowish hexagonal spots. Other species of Siganas are Sigunas marmorata Q. \& G., Siganas rostrata Cuv. \& Val., which is bluish with indistinct markings of yellow spots and lines, and the "mañáhag," a fish which appear's at intervals in great numbers and is preserved by the natives by drying. This name is probably applied to the young of the hiting or the sesyan, or perhaps of both.

Hiyug or Hidyug. Teuthis lineatus Bloch.

A beautiful surgeon-fish; body elevated, compressed; movable white spine on caudal peduncle; longitudinal stripes of yellow-black-blueblack-yellow extendin back to root of caudal fin; blue line down middle of forehead, dividing and forming ring about mouth; other blue lines on each side of this. In Samoa this species is called "alongo."

Hugúpau. Monoceros garretti Seale.

A black surgeon-fish, with two bony plates or keels on caudal peduncle, having a yellow base; caudal fin black with subterminal band of yellow and a marginal band of white; dorsal fin black with a submarginal line of white, which begins very narrow and widens 
posteriorly to half the width of the fin. It has a narrow margin of back above this, but it has no colored line at hase of dorsal as in M. liturutus. The name "hugúpau" is applied also to M. liturutus" (Forst.), with the yellow coloring of the bases of the caudal plates intermingling, and with a colored line along the base of the dorsal fin. A nother allied species, M. marginatus Cur. \& Val., is called "tátaga."

Kákaka. Lutianus fulvus (Bloch).

A snapper; pinkish and yellowish, with dark tail and yellow pectorals and ventrals; dark spot at base of pectorals; upper part of dorsal black with narrow white margin, and narrow white margin on tail. In Samoa allied species called "mu-mea" and "tavai-uliuli" are sometimes poisonous.

Laiguan. Mugit maigiensis (). \& G.

Mullet; called "lisa" by the Spanish. Head flat; scales large; hody silvery with slight wash of yellow; darker abore; pectorals dusky with lower margins yellowish. A favorite food fish.

Lansí. Apogon fasciatus Q. \& G.

Small; livid flesh-c'olor, stripea longitudinally with black from head to tail. Abundant on reefs, associated with chietodons and other coral fishes.

Loro.

A name applied in Guam to species of Searus, or parrot-fishes, and to the genu- Gomphosus. Scamex cetefricus Bloch is a beautiful species of a deep cohalt hlue and pink color; scales large. Gomprhosus tricolor, Q. \& G.: intense dark green and dark blue; snout elongated; a yellow marking as wide as orbit from lower part of pectoral axis to a little ahove a lateral line on shoulders: pectoralis dusky with a deep hlue band across posterior third: tail yellow, outer margin blue-green. Allied species ("panuhunuhu") are sometimes eaten raw by the Hawaiians.

Maching. Periophthelmes koelientriti (Pallas).

Mangrove-hopper. A imall, brown, flahby fish with livid flesh-color markings. its air bladder modified into a breathing organ. It leares the rater and hops ahout stones and on the mangrove roots and muddy bottom of salt-water mud flats.

Mafúti. Lutianus bonhamensis Günther.

Pale greenish -napper with pinkish fins and tail, sometimes a black spot on sides: a favorite food fish: cau be caught with a hook. Among other species of Lutianus, are the kákaka ( $L$. fulvos), the buha (L. munustimun): L. bengulenis (with \pm blue-brown edged stripes along the side of the rellowi:h body); and $L$. rytherpterus (yeilowish white with wash of reddish brown: dorsal fin with a tine black margin). 
Magáhan. Scarus cerelırims (Bloch).

A deep green-biue parrot-fish, with large scales and parrot-like beak; resembling the dafa $(S$. cypho), but smaller.

Mañáhag. Siganas mañahak Q. \& G.

Fish which appear at intervals in great numbers; dried and preserved by natives. Probably the young of Siganms mammatre (Q. \& G., and Siganas hexagonata, Günth.

Nufu. Synanceia thersites Seale.

A hideous toadfish with poisonous dorsal spines; brownish with mottlings of dark brown; covered with warts; mouth directed upward. Nuch dreaded by the natives. In Samoa an allied species is called "nofu," or " ngofu."

Pípupu. Percis cephalopunctatus Seale.

A fish belonging to the Agonidae, or sea-poachers, marked with vertical, suake-like bands of brown. In spirits, upper surface greenish, with 9 indistinct darker lines over the back; below axis the color is yellowish white with 9 greenish bands; the upper parts of these bands are all united by a narrow greenish line on the axis, extending from axis of pectoral to lower part of caudal fin; just above this line and alternating with green bands of lower half are 9 greenish spots with yellowish white margins from pectoral fin to caudal.

Polónon. Amanses sandwichensis Gray. (Sásada, Spanish.)

A black file-fish with yellowish fins; body elevated and compressed; teeth like those of a sheep; 4 spines each side of tail and 1 on back; youngest individuals without the spines on the tail.

Pulan. Kullia mupestris (Lacépède.).

A dark silvery fish, bluish above. Lives in fresh-water streams. In Hawaii allied species are called "aholehole;" in Samoa "sesele."

Púlus. Tylosurus giganteus Schlegel.

A garfish; long beak. It is identical with the Hawaiian "au-au."

Sagámelong. Myripristis murdjan (Forskål.).

A squirrel-fish of a beautiful deep rose color; gill-openings and axilla of pectoral fins black; eyes large. In Hawaii this species is caled "u-u;" in Samoa allied species called "6 malau."

\section{Sagsag.}

A red fish with large eyes; probably a species of Holocentrus; edible.

Salmonete. Upeneus saffordi Seale.

A fish belonging to the Mullidae, or surmullets, having 2 long barbules growing from throat extending back as far as base of ventral fins; scales large; pinkish yellow, with bright yellow fins; ycllow stripe down side; saddle of bright yellow exterding over the upper part of caudal peduncle and down the lateral line, with 2 distinct bluish 
lines from eye two-thirds of distance down sides of snout; iris bright yellow. The name salmonete is also applied to other Mullidae, or goatfishes, one of which, Mulloides flarolineatus Lacép., has a yellowish stripe down the side and a dusky back. In Samoa allied species called "i'a-sina" (white fish); in Hawaii "weke."

Sapisapi. Pempheris otaitensis (Cuv. \& Val.).

A small fish of a beautiful glossy rose purple; eyes large; snout blunt; back straight; belly curved. Belongs to the Pempheridae.

Sesiog. Holocentrus unipunctatus Günther.

A squirrel-fish of a beautiful crimson color, with a number of lines of darker red. This color fades in spirits, the-fish becoming a grayish white, except a small blotch of black between the first and second dorsal spines near the base.

Sesyan, Siyan, or Sidyan. Siganas marmorata (Q. \& G.).

Blackish purple; mackerel-shaped; head and back covered with vermiculated lines, which are wavy and longitudinal on sides. Belongs to the Teuthidae or lancet-fishes. Edible. The young are called "mañáhag."

Síhig. Scolopsis lineatus Q. \& G.

Greenish and pink; head curved; eyes large; an indistinct line from snout to first dorsal spine; 2 distinct lines from above the orbit to sixth and seventh rays of soft dorsal; a third line wider anteriorly and more or less broken from upper third of eye to just abaft the after margin of the dorsal fin; a fourth line forms the boundary of the coloring along the median line from eye to caudal; 6 to 7.50 inches long. The vernacular name taken from that of the Guam kingtisher, Halcyon cimnamominus. Swainson, which is greenish blue and cinnamon-colored.

Támpat. Platophrys pavo Q. \& G.

A flounder; good food fish. In Samoa allied species called "ali." Tarakito. Carangus ascensionis (Forster.).

A pómpano; silvery, with wash of yellow; pectorals yellow; dorsal and anal bluish (in spirits); a farorite food tish; caught by hook; usually tiao used for bait. In Samoa and Hawaii allied species cal'ed "ulua."

Tátaga. Monoceros marginatus Cuv. \& Val.

A black fish with a spur on its forehead and two sharp hony plates on peduncle of tail; in younger specimens spur shorter; in youngest spur and tail plates absent; in spirits of a dirty olive, slightly lighter below.

Tátalun. Anampses coemuleopunctatus (Rüppell).

Brown, reddish on belly; bright blue spots and 8 to 10 blue lines marking the head; most of them radiating from the eye; pectorals rellow, their bases black; rentrals duskr, the first ray's blue; caudal dusky, with numerous blue spots; dorsal and anal with 2 or 3 rows of 
spots or lines. In Samoa allied species called "sungale;" in Hawaii "opule" or "hilu."

Tátanung. Coris aygule Lacépède.

Blackish; pectorals margined with yellow; opercular flap of a deep blue; prominent hump on nape of neck; teeth projecting curved forward; length, 13 inches.

Tiao.

Silvery, small; like small salmonete (Mullidae); a favorite food fish with flavor like smelt.

Torillo. Ostracion cornutus L.

A curious small fish with hard carapax covering the body; 2 frontal spines resemble the horns of an ox, therefore the common name; also 2 posterior spines.

Ugupa amarilla. Holacanthus cyanotis Günther.

A short flat fish with a blunt head; yellow, with blue ring around the eye and a blue line down the posterior edge of the opercle. Fins yellow, dorsal, caudal, and anal with a marginal line of bluish black.

\section{MARINE INVERTEBRATES. $"$}

Guam offers most favorable conditions for the study of marine invertebrates. On the western coast of the island there are broad fringing coral reefs and level platforms, covered even at high tide with only a few feet of water and at low water bare over considerable areas. Here a collector in a boat or wading, with his feet protected from the sharp spines of sea-urchins and the rough branches of the coral, can always get abundance of material. When the reef is corered with a foot of water and there is no breeze to ruffle the surface the bottom appears like a garden, the corals and marine annelids expanding like beautiful rayed composites. On the bottom lie fungia corals, like huge inverted mushrooms, with pale green tentacles expanding from their radiating laminæ; indigo-blue, five-fingered starfish; sea-urchins; and holothurians. Some of the latter creep about like huge brown slugs. If one attempts to pick them up they thrust one of their extremities between the branches of coral or into a crevice of the rock, and by forcing water to that part of the body distend it and wedge it so tightly that it can not be removed without being torn in two. A long translucent holothurian (Synapta) moves through the water so rapidly that it is caught with difficulty. When lifted from the water it hangs limp and helpless, like a skin full of water, its internal organs showing distinctly through the body wall. As soon as it is dropped back into its native element it makes off at a great speed and soon finds shelter in some hole in the reef.

"I am indebted to Miss Mary J. Rathbun, of the U.S. National Musemm, for reviing the names of the crustaceans mentioned below. 
Among the mollusks are a number of handsome olives, rones, and many small cowries which evidently feed upon the coral. There are also naked mollusks that protect themselves by spurting forth clouds of purple fluid. File-fishes, tetrodons, and other fishes are always seen nibbling at the coral. Sometimes a great sea porcupine makes for them, and off they all swim as though afraid for their lives.

The natives eat many kinds of marine animals, but they do not depend upon the reef to the extent that the Samoans and Caroline Islander's do, haring become essentially an agricultural people, and few of them find it to their advantage to neglect their fields for fishing. In former times sereral gorernors found it profitable to collect and dry certain kinds of holothurians, called "trepang," or "bêches de mer," and ship them to Manila or Canton;" but these animals are no longer sought in Guam, and are seldom eaten by the natives.

Crabs of sereral kinds abound, most of them of wide distribution in the Pacitic. Some of them ("alimasag") have shells brightly decorated with orange-red spots (Znimus aenems (L.)), others are corered with spines, and others, when they fold in their claws, look like smooth, waterworn bowlders. Scrambling orer rocks along the shore are Grupsus gripsus temicmustatus (Herhst.), of a deep red color, speckled and striped with yellow. Spiny lohsters or crayfish (Panulirus), with long antenne and carapax covered with spines, abound at certain points along the coast; and in the fresh-water streams on the islands are delicate semitramsparent prawns (Bithrnis), which move about the pook in as stealthy ghostlike manner, and are almost invisible to the casual observer. Both the spiny lobsters and the prawns are valued as food.

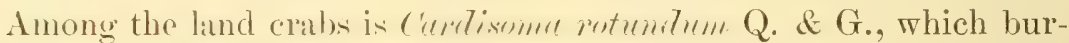
rows in the ground and does yreat dimage to gardens. This is caught in traps made of bamboo hy the natives. It visits the sea at regular intervals to deposit its eggs, going after nightfall in straight lines and climbing over all obstacles in its way. Among the hermit crabs are L fuirulus anicullus (IIerbst.). with a red carapax ornamented with deep red spot., and Durdumus punctulutus (Olivier), prettily marked with blue ocelli with white centers. The most interesting of all the land crustaceans is the well-known Birgus lutro(L.), or robber crab, called "aruyu," which is kept in captivity by the natives and fattened on coconuts for the table.

\section{INSECTS. ?}

The insects of Grum hare nerer been srstematically collected. Many of those now occurring on the island have undoubtedly been introduced

"('hamisso, Tagehudh, 1. 2.4:3.

bI am indebted to Dr. W. H. Ashmead, of the U. S. National Museum, for the nanes of the insects mentionet. 
since the discovery. The Intterflies are not especially striking to the astal observer. Among them is the widely spread tawny-cololed milkneed butterfly, Lmsiu jexijmus. Fabr., which has found its way to Guam, together with the introduced diclepirs curresavica, on which its larva feeds. Both the plant and the insect, although of American origin, now oecur on many islands of the Pacific Ocean. Among the night-flying lepidoptera there is a large sphinx moth (Protopurecelers Hbrt.), the larra of which feeds on the tobaceo plant and resembles very closely the tobacco worms of America. It is possible that this insect may hare lived on the island before the introduction of tobacco, feeding upon some solanaceous plant, but it is probable that it came to Guam with the tobacco. Possibly its eggs were brought on dried leaves of the plant. Among the other pests introduced by the foreigner are clothes moths (Tinea pellimalla L.). In the zoology of the Freycinet expedition sereral butterflies collected in Guam, including an Argynnis and two species of Danaïs, were described as new.

Among the hymenoptera there are several interesting species of wasps and ants. One wasp, probably a species of Polistes ( $P$. lectraens Fabr.?), is social in its habits. During the greater part of the year it frequents open tields, building its nests in bushes a foot or two from the ground, attaching them to a limb by a jeduncle with the mouth of the cells pointed downward, and not covered by a papery wall, as in our hornets' nests. In these cells the eggs are laid and the larve are fed. When about to undergo transformation the larra spin a covering which seals up the cell. The males differ from the female in appearance and are stingless. Besides the males and perfect females there are workers. Both the females and the workers sting, but their sting is not very severe. These insects are very abundant all orer the island, especially in abandoned clearings grown up to guavas and other low bushes. It is almost impossible to cross such a field without stirring up a nest or two, and one of the commonest occurrences on an excursion is to hear a loud outcry on the part of your guide, whose naked legs are covered with the stings of the "sasata," as they are called. In revenge he usually finds a dry leaf of a coconut, which he converts into a torch and burns the nest. These wasps are not very pugnacious, and will only sting when they think their nest is attacked. After it has been burned they fly round and round the place without attemptiug to take rengeance. In the winter time (the month of December) they flock into houses in great numbers and settle upon some prominent point on the ceiling or on a chandelier, clinging together in masses like swarming bees. There they remain for a month or two in a state of torpidity. They are disagreeable guests, as they have a habit of dropping to the floor from tine to time, and it is not unusual on getting out of bed in the moming to step on one of them, too stupid to fly but 
lively enough to sting. On one of the Government vessels, which had visited Guam in January, were found some of these wasps after her arrival in San Francisco. They had sought an asylum while she lay in the harbor of Aprâ, and remained hibernating during the return voyage of the vessel. Another species found on board was a solitary wasp, a species of Odynerus or an allied genus. The mother had made a series of mud-like cells in a pamphlet, which had remained rolled up, and in each cell she had deposited a small green caterpillar, the larva of one of the smaller motbs of the island, laying an egg and sealing up the cell and then making another cell on top of it and repeating the operation. In Guam these cell-making wasps are very common. Every hole in the wall of a house is plastered up by them; rolled-up magazines or newspapers lying on the table, bamboos, empty cartridge cases, even gun barrels--everything which is tubular in shape is filled by their cells. Their sting stupefies the caterpillar, but does not kill it, and their larve in eating their animal food are much more active than those of pollen-feeding species, turning their heads from side to side and living for some time after having been taken from their cells.

Among the ants ("otdot," or" "utdut") there is one (Solenopsis sp.?) of which the workers are very small and sting severely. The females are considerably larger. These little creatures, when out on foraging expeditions, travel in lines and sting every animal that crosses their path. Sometimes young chickens are killed by them. They are common in houses, and it is not unusual on turning in at night to find a line of them crossing the hed. In another species belonging to the same family (Mrrmicidae), probably of the genus Pheidole, there is a form with enormously dereloped cubical heads and strong jaws, called "soldiers." It is very interesting to watch these insects swarm. They come out of the ground in great numbers. Both the males and females are winged. The females are rery much larger than the males and the workers are smaller. The soldiers, which are rery conspicuous, are sometimes called "worker's major," and the common small-headed form "workers minor." Soon after swarming the sexes mate. They then lose their wings and establish new colonies. Another stinging ant, much larger and of a black color, is called "hating."

Leaf-cutting ants, the pests of many tropical countries, are happily absent from (ruam. Consequently, gardens do not need to be protected from them, and the green turf and luxuriant herbage of the island offers a most pleasing contrast to the bare earth and canalprotected gardens of Central America and Brazil.

The diptera are represented by several species of flies and at least two mosyuitoes. It has been asserted that the early natives blamed the spaniardis for haring introduced both flies and mosquitoes to 
Guam." This is probably false, since the vernacular names of these insects in Guam are etymologically identical with the names of the same insects through the greater part of Melanesia, Polynesia, and New Zealand, and have evidently the same origin as the modern Malayan.

\begin{tabular}{|c|c|c|c|c|c|c|}
\hline English. & Guam. & Melanesian. & Samoan. & Haw. & Malayan. & Maori. \\
\hline $\begin{array}{l}\text { Fly. } \\
\text { Mosquito. } \\
\text { Louse. } \\
\text { Maggot. }\end{array}$ & $\begin{array}{l}\text { Lalo. } \\
\text { Namo. } \\
\text { Huto. } \\
\text { Ulô. }\end{array}$ & $\begin{array}{l}\text { lañgo. } \\
\text { namu. } \\
\text { gutu. }\end{array}$ & $\begin{array}{l}\text { lañgo. } \\
\text { namu. } \\
\text { 'utu. } \\
\text { ilo. }\end{array}$ & $\begin{array}{l}\text { nalo. } \\
\text { uku. }\end{array}$ & $\begin{array}{l}\text { lañau. } \\
\text { ñamok. } \\
\text { kutu. }\end{array}$ & $\begin{array}{l}\text { ñgaro. } \\
\text { waeroa. } \\
\text { kutu. }\end{array}$ \\
\hline
\end{tabular}

The common Malay word for $\mathrm{fly}$ is "lala," yet "langau" is also used. In New Zealand either " "ngaro" or "rango" is used, and the first form is etymologically identical with the Hawaiian "nalo." Evidently the aborigines of Guam, in common with the inhabitants of most of the Pacific islands, were familiar with flies, mosquitoes, and lice before the arrival of the Spaniards. On the other hand, it is probable that fleas and bedbugs were introduced, as there are no Chamorro words for these insects. In Samoa the flea is called "Fijian louse." In Codrington's comparative vocabulary of the Melanesian languages it is not given. It is interesting to note in this connection that in Hawaii, where the approximate date of the introduction of the mosquito is known, there is no Hawaiian name for it, and in New Zealand its name is of independent origin and is quite distinct from the common Malayan and Polynesian forms.

Mosquitoes are very troublesome both day and night in Guam. The day-flying species avoids the sunlight, but makes life a burden in the shade. All Europeans sleep under mosquito nets, and the natives habitually make a smudge in their houses after dark to smoke out the night-flying species. This is effective if the lights in the house are first extinguished and not relighted.

Fleas are not common; the climate is probably too damp for them to flourish. The author passed a year on the island without seeing either a flea or a bedbug. Neither do lice appear to be abundant. This may be owing to the habit of the natives of frequently washing the hair with soap oranges and bergamots.

a Ces Européans "veulent nous persuader qu'ils nous rendent heureux, et plusieurs d'entre nous sont assez aveugles pour les en croire sur leur parole. Mais pourrionsnous avoir ces sentimens, si nous faisions réflexion que nous ne sommes accablez de misères et de maladies, que depuis que ces étrangers sont venus nous desoler et troubler nôtre repos. A vant leur arrivée dans ces isles, sçarions-nons ce que c'étoitque toutes ces insectes qui nous persécutent si cruellement? Connoissions-nous les rats, les souris, les mouches, les mosquites, et tous ces autres petits animaux, qui ne sont au monde que pour nous tourmenter? Toilì les beaux présens qu'ils nous ont faits, et que leurs machines flotantes nous ont apportez!" (Le Gobien, Charles. Histoire des isles Mariannes, nouvellement converties à la religion Chrétienne, ‥ 141, Paris, 1700.) 
Among the Hemiptera besides lice there are plant lice of severial kinds, large water bugs (Belostoma) in stagnant pools, and swarms of Ploteres, which skip over the surface of the water. Several varieties of roses have been introduced into Guam, but happily the rose aphis (Siphonophora) has not reached the island.

Among the Neuroptera are several handsome dragon flies, one of which is bright red. Termites, or "white ants," called "anai" by the natives, are pests. They do great injury to books and furniture and to the woodwork of houses, often building corered galleries of mud along the walls of a room. In construction wood must be chosen which will resist the attacks of these insects. It is not an uncommon occurrence for a chair or table to collapse, and to find that it has been honeycombed by termites. Sometimes they form continuous galleries through a whole shelf of books or a pile of manuscript. These insects do not confine their attacks to dead woor; they attack living trees and are among the insects injurious to the cacao. ${ }^{a}$

Among the Coleoptera may be mentioned the weerils, which destroy great quantities of corn, rice, and other farinaceous food. Grain must he thoronghly dried in the sum and then stowed in earthen jar's for protection against these pests.

The Orthoptera are represented by sereral species of grasshoppers, which furnish excellent food for chickens and turkeys, and which do not seem to ause much injury to the crops of the island. Mole crickets (Gryllotalpae) are very common.

SCORPIONS, SPIDERS, AND CENTIPEDES.

A small scorpion is common in Guan. Its sting is painful, but not dangerous. Among the spiders one of the most interesting is a large dark hrown species, probably belonging to the Epeiridae, which carries ahout with it a white disk-shaped membranous case filled with eggrs. There are no tarantulas nor other dangerous spider's. Wood ticks (Acarina) are great perts and sometimes infest cattle to such an extent as to cause them to sicken and die.

Centipeder, called "saligao" by the natives. are common. They inflict a very painful but not dangerous hite. They are usually found in damp places under stones or rotten wood, the mother often surrounded hy a brood of brightly colored young, similar to her in form. Like spiders and crustacean they cast their skins in growing. The jaws are modifications of a pair of legs. They are sharp. prehensile, and fang-like, and are perforated at the tip so as to inject the renom into the wound inflicted hy them. Their body is thattened, so that they can force their way into small cracks. under stones ant beneath the

"See Bank:- lieport of the Philippine Commission, 1903, Pt. 2, p. 605, figs 166 to 169 . 
loose bark of trees, in search of their insect prey. "They are carnivorous and seize their victims with their pincer-like jaws, injecting their renom. They are very quick in their movements and tenacious of life. When one is cut in two each part makes off in an independent direction at full speed, but the posterior part does not get very far.

\section{THE PEOPLE.}

\section{ABORIGINAL INHABITANTS. ${ }^{a}$}

\section{IIIYSICAL CHARACTERISTICS.}

The aborigines of Guam were described by the early navigators and miswionaries as fine-looking, tall, robust, well built, and of better proportions than the Spaniards, though sonetimes inclined to be corpulent, and as possessing. "great strength fitting to their statures." They were of a brown color (un pardo bazo), lighter than the natives of the Plilippine Islands and taller than they. Their hair was naturally jet hlack, hut at the time of Legazpi's visit was hleached to a yellow color. At the time of the discovery the men wore it loose or coiled in a knot on the top of the head. Later they were described as shaving the head with the exception of a erest about a finger long, which they left on the crown. Some of the men were bearded. The women, too, were tall. They were handsome and graceful and fairer and more delicate than the men, and at the time of the discovery wore their hair so long that it touched the ground. ${ }^{b}$ No mention is made of tatooing or of piercing the ear's or nowe. Both sexes anointed themselves with coconut oil. The natives were remarkably free from disease and physical defects, and many of them lived to an advanced age, "for among those alone who were baptized the first year of the mission there were more than 120 who were past the age of a bundred years; owing perhaps to their rugged constitutions, inured from their infancy to distempers which afterwards do not affect them, or to the uniformity and naturalness (naturalidad) of their food without the artifice which gluttony has introduced to waste the life which it sustains, or to their occupations necessitating plenty of exercise without too great fatigne, or to the ahsence of vices and worries - which are romes and thorns whose prick-

"The information regarding the aborigines of Guam is derived from the narratives of early navigators and from contemporary accounts of the Jesuit missionaries who first settled on the island. The most important of the former are Piwafetta's history of Magellan's royage, the several narratives of Legazpi's expedition in the archives at Marlrirl, and those of (iaspar and Grijalva, who accompranied Legazpi. The latter were Imblisher at Marlrirl in 1685 by Padre Francisco (rarcía, of the Society of Jesus, in his Vida y martyrio del venerable Padre Diego Luis de Sanvitores. (See List of works.)

${ }^{b}$ Le donne son belle, di figura svelta, più delicate e bianche degli uomini, con capegli neriscimi sciolti \&umghi fino a terra. (Pigafetta, Primo viaggio intorno al globo terracqueo, p. 51, Milano, 1800.) 
ing and piercing put an end to man-or perhaps all of these causes combined contribute to the prolix age of these islanders. As they know few infirmities so they know few medicines, and cure themselves with a few herbs which necessity and experience have taught them to be possessed of some virtue." a

Both sexes were expert swimmers and were as much at ease in the water as on land. As they threw themselves into the sea and came bounding from wave to wave they reminded Pigafetta of dolphins. The men were good divers. Legazpi states that they would catch fish in their hands. The children accompanied their parents while fishing, and were so expert in the water that Gareia declared they appeared rather fish than human beings.

PERSONAL AND DOMESTIC ECONOMY.

Clothing and ornaments. - The men went absolutely naked, not even wearing a breech clout. ${ }^{b}$ The women wore fringes of grass or leaves hanging from a waistband and sometimes aprons called "tifi," $c$ described by Pigafetta as narrow and of paper-like consisteney, and said by him to be made from the inner bark of a palm. ${ }^{d}$ Pigafetta was certainly mistaken as to the origin of this bark. The natives of

$\therefore$ Guan were not tapa makers like the Polynesians. No description of bark cloth is now made by them, but within the memory of some of the people still living aprons were made of the inner bark of the breadfruit whring a long interval between the risits of European vessels, when the suppls of foreign cloth became exhausted. In other islands the bark of banyans (Ficus spp.) is also used for this purpose. In the narrative of Legazpi's expedition it is also stated that "palm-leaf" mats were used by the women for aprons, the rest of the body being left uncovered. The men wore hats or eye shades of pandanus leaves while fishing.

On festive occasions the women adorned their heads with wreaths of flowers or beads and disks of tortoise shell pendant from a band of red spondylus shells, which " they prized as highly as Europeans prize pearls," also making helts with pendants of mall coconuts, nicely fitted orer skirts or fringes of roots of trees, thus completing their gala attire. "which resembled rather a cage than a dress." Their

a García vida y martyrio de Sanvitores, p. 197.

$b$ Relation of Legazpi.

'Padre García's History. It is interesting to find this name for bark-cloth aprons in the dialects of Isahel and Florida islands, of the Solomon group, where it has been transferred by the natives to introduced foreign cloth, which is now called "tivi." (See Coddrington, The Melanesians, p. 321, 1891.)

d" Tanno per esse iguude, se non che coprono le parti vergognose con una corteccia stretta e sottile quanto la carta, tratta dalla scorza interna che sta fra la corteccia il legno della palma." (Pigafetta, Frimo viaggio intorno al globo terracqueo, p. 51.) 
teeth were stained black for the sake of ormament and they bleached their hair "with divers washes."

Houses. - According to the testimony of early writer's their houses were high and neatly made and better constructed than those of any aboriginal race hitherto discovered in the Indies. They were rectangular in shape, with walls and roofs of palm leaves curiously woven. $v$ Ther were made of coconut wood and palo maria (Calophyllum in(p) phllum) and were raised from the ground on wooden posts or pillars of stone. In one of the narratives of the Legazpi expedition it is said that some of the houses supported on stone pillars served as sleeping apartments; other's built on the ground were used for cooking and other work. Besides these there were large buildings that served as storehouses for all in common, wherein the large boats and covered canoes were kept. " These were rery spacions, broad, and high, and morth seeing." As described by the missionaries some of the houses had four rooms or compartments with doors or curtains of mats, one serving as a sleeping room, another as a storeroom for fruits, a third for cooking, and a fourth as a workshop and boathouse. ${ }^{l}$ Gaspar and Grijalva described one boathouse near the watering place as being supported on strong stone pillars and sheltering four of the largest canoes of the natives. Many of these stone or masonry pillars are still standing arranged in double rows. They are called "latde" or " casas de los antiguos" by the natives, who regard them with superstitions dread. Much has been made of the pillars on the island of Tinian, shaped like the rest in the form of a truncated pyramid and capped by hemispherical stones, but in all probability they are notbing more than the remains of large houses which served the same purposes as the "arsenals," described in the narratives of the Legazpi expedition. These large houses may be compared with the kiala of Florida and Isabel islands in the Solomon group, one of which is described as 100 feet long by 50 feet wide and 50 feet high. In these great houses "the large canoes are kept, men congregate and young men sleep, strangers are entertained," and in some islands the skulls of the dead, called "mangiti" (in all probability corresponding to the word "aniti" of the Chamorros) were suspended." The dwelling houses of Guain also resembled those of Irahel and Florida islands, which differ from typical Melanesian honses in being raised on piles, and in their neater construction. They are excellent dwellings, square in shape, with the side walls and the floor formed of split bamboos flattened and interlaced and the roof thatched with coconut leaves.

The houses were grouped in villages located either on the beach in

a Blair and Robertson, The Philippine Islands, vol. 2, p. 113, 1903.

b Garcia, Vida y Martyrio de Sanvitores, p. 197, 1685.

c Codrington, The Melanesians, p. 299, 1891.

$9773-05-7$ 
proximity to a good harbor, on the banks of a river for the sake of a vconstant supply of fresh water, or on a high and inaccessible hill, as $\checkmark$ in the case of Chúchugo, for the sake of security from attack. Those on the beach were composed of 50 to 150 houses, those in the interior of from 20 down to a half dozen. The principal town was Agadña, on the west coast of the island, where a fine river, having its source in a great spring called "Matan-hanom," emptied into the sea. In all the larger villages there was a "great house " frequented by the "urritao," or bachelors, in which unmarried men and women lived together.

The houses contained little that could be called furniture. There were common floor mats, diagonally braided, and sleeping mats, some $\checkmark$ of very fine texture, made from the leaves of the textile Pandanus. The water ressels were not coconut shells, as in many Polynesian islands, but sections of large hollow bamboos, about 5 or 6 feet long, which were inclined against the wall. There were coarse bags of Pandanus matting holding dried breadfruit, and every native carried a finely woren bag of the same material containing betel nut. Coarse baskets were made of fresh coconut leares, as required, to be thrown away when dry and useless. Baskets of better construction were woren from strips of bamboo (piao). In the kitchen there was a hole in the ground and a pile of stones for an oven.

Food.-They subsisted principally on fruit., yams, taro, and fish. They ate coconuts prepared in rarious ways, sugar cane, bananas. plantains, and hreadfruit. The last was in season only about four months of the rear. but after it rams became mature. In the times of famine following hurricanes they resorted to the woods for "fadang," or nuts of cycus cincimalis, the poisonous properties of which they remored by soaking and repeatedly changing the water, after which the macerated starehy substance was ground in carities of convenient stones and baked. For relishes ther ate certain seaweeds, Terminalia nuts, and the kernels of Pandanns seeds. Pandanus drupes, which are an important food staple on many islands, did not enter into their domestic economy and the widely spread "Polynesian chestnut" (Brementulis) was absent from the island. Ther had neither sweet potatoes nor maize until after the discovery, nor did the yam hean (C'acara) occur on the island. Rice was cultivated by them and sold to risiting ships. They regarded it as a luxury and kept it for their feasts. They did not practice cannibalism. Indeed the early narigators said that they could not be induced to eat meat of any kind. Although they had pigs at a rery early date it is probable that these mere introduced after the discovery. They also had fowls and kept dores in captivity, but we hare no evidence that they ate them. They could not be induced to eat eels, and spoke disparagingly of some of the early missionaries for eating them. The creamy juice expressed from the grated meat of ripe cocoanuts entered into the composition 
of several of their dishes. As was nearly the universal custom throughout the tropical Pacific, they cooked in pits in the earth in which they built fires and heated stones, covering their food with hot stones and leaves somewhat after the manner of a New England clambake. Cooking in this manner they called "chahan." To cook on the embers they called "peha." Few articles of their food could be eaten raw. Fish called "mañáhag" "were caught in great quantities at certain periods, dried in the sun, and stored for future consumption. Breadfruit was cut into thin slices and dried. It could be kept for a long time and eaten during the season when the fresh fruit was lacking. The dried slices could be eaten without further preparation, or they could be prepared in various ways for food. At their feasts a sort of broth or stew was made of rice. Taro was not made into poi, as in the Hawaiian Islands.

They did not eat to excess nor did they use wine or other intoxicating liquor. It was not until the Spaniards brought Filipinos to Guam that the natives learned to ferment tuba from the sap of the coconut and to distill it into aguardiente. Water was their only beverage ${ }^{b}$ besides the milk of unripe coconuts.

Narcotics.-The custom of betel chewing was universal, and has survived to the present day. Around a fragment of the nut of the betel palm (Areca cathecu) is wrapped a fresh leaf of betel pepper (Piper betle) and a pinch of lime burned from coral rock is added. This stains the saliva red and discolors the teeth. An aromatic fragrance is imparted to the breath, which is not disagreeable. Kava, an infusion of the root of Piper methysticum, of wide use throughout the greater part of the Pacific islands was, unknown to them.

FIrE. - It was asserted by the early missionaries that the aborigines of Guam were ignorant of fire before the advent of the Spaniards. ${ }^{c}$

a See list of fishes, p. 83 .

$b$ "Their drink is water," says one of the early missionaries, "and consequently their most usual infirmity is hydropsy." Garcia, Vida y Martyrio de Sanvitores, p. 198,1685 .

cThis statement was first made by Garcia, who says: "It need not be asked whether they had any knowledge of letters, science, or art concerning those who were ignorant of one of the elements and knew not that there was fire in the world until they saw it kindled by the Spaniards in the shipwreck of the year 1638." (Garcia, note $b$, p. 198.) The assertion was probably made in consequence of the yarns of some of the shipw recked sailors, who also recounted a number of miraculous happenings. Using Padre Garcia's statement as a theme, Père Charles le Gobien, repeats it with elaborate variations, though he does not give his authority for his information. Having read Pigafetta's narrative of Magellan's experdition, Le Gobien dates back their introduction to fire to the time of his discovery of the island, when he causerl a number of houses and boats to be burned. "What is most astonishing:" says Le Gobien, "and what one will find hard to believe, is that they had never seen fire. This element so necessary was entirely unknown to them. They knew neither the use of it nor its qualities; and never were they more surprised than when 
The statement has been frequently repeated" and Pigafetta erroneously cited as authority for it. That it is not true is evident when one considers that their principal food staples could not be eaten uncooked. Moreover, they had words pertaining to fire in their vernacular, many of which were of etymological identity with similar terms in other islands of the Pacific. Among these were guafi (fire), apo (ashes), aso (smoke), tuno (roast), mañila (flame), pínigan (live coal), songge (burn, v. t.), hanon (burn, r. intr.), sotne (boil), and other words. They must have possessed these words in prehistoric times. Not one of them is derived from the Spanish; all are allied to corresponding words in Malayan and Pacific languages.

T'SEFCL ARTS.

The natives made excellent houses and were skillful canoe builder's. They furnished themselves with spears and slings for fighting, stone adzes or gouges for working in mood (Pl. XVII), and lines, hooks, and nets for fishing, and they planted and cultirated their gardens and rice fields. They were not wood carvers nor engravers, nor did they possess the art of wearing by looms, as did the Caroline Islanders, the natives of Santa Cruz, and some of the Philippine tribes. Their mats they braided diagonally after the manner of the Polynesians and Melanesians. The men made the houses and boats, the women braided the mats for beds and for boat sails. Pottery was unknown. Fish were caught by hooks from the shore (etupog) or by trawling from canoes under sail. They were also speared on the reef, attracted by torches (sulô) and caught with a net at night (gade), stupefied by sinking narcotics in holes in the reef, and trapped in pounds of bamboo wickerwork (guigao). Fishhooks (hagüet) were made of mother-ofpearl and tortoise shell.

NAVIGATION.

( Their wonderful "flying praos" were the admiration of all the early navigators. Descriptions of then were given by Pigafetta (1521),

they saw it for the first time when Magellan lamled in one of their islands, where he bumed about 50 houses in orler to punish these islanders for the trouble they hat causer him. Ther regarled the fire at first as a kind of animal, which attached itself to the woul, upon which it ferl. The first who approached it too closely having humed themselves, mate the others afrain of it, and only lared look upon it afterwards from a clistance for fear said they of being bitten by it, and lest this terrible animal might wound them hy its violent hreath, for this was the idea they first formed of the tlame and the leat. This frivolous fear did not last. They saw their mistake, and they heame accustomed in a short time to see the fire and to use it as we dw." ("harles le (rolhen, Iristuire des Isles Marianes, nouvellement converties ì la religion Chrétienne, etc., p. 44, Paris, 1700.)

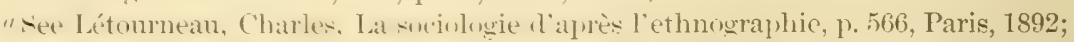
Gurnet, A.-I., De l'origine des lois. b'm édition, I. J. 89, 1758; Raynal's Indies, vol. 3,1 1. 381, 178s. See also Plutarch: “Aquíme an ignis sit utilior," in Plutarch's works (rol. 2., p. 955, Frankfort, 1620), which probably suggested to Père le Gobien his graphic description. 


\section{Dampier (1686), Woodes Rogers (1710), Anson (1742), and Crozet (1772). Dampier's description is as follows: ${ }^{\theta}$}

The natives are very ingenious leyond any people in making boats, or "proes," as they are called in the East-Indies, and therein they take great delight. These are built sharp at both ends. The bottom is of one piece, made like the bottom of a little canoa, very neatly dug and left of a good substance. This bottom part is instead of a keel. It is about 26 or 28 foot long. The under part of this keel is made round, but inclining to a wedge and smooth, and the upper part is almost flat, having a very gentle hollow, and is about a foot broad. From hence both sides of the boat are carried up to about 5 foot high with narrow plank, not above 4 or 5 inches broad, and each end of the boat turns up round very prettily. But what is very singular, one side of the boat is made perpendicular, like a wall, while the other side is rounding, made as other vessels are, with a pretty full belly. Just in the middle it is about 4 or 5 foot broad aloft, or more, according to the length of the boat. The mast stands exactly in the middle, with a long yard that peeps up and down like a mizzen-yard. One end of it reacheth down to the end or head of the boat, where it is placed in a notch that is made there purposely to receive it and keep it fast. The other end hangs over the stern. To this yard the sail is fastened. At the foot of the sail there is another small yard to keep the sail out square and to roll up the sail on when it blows hard, for it serves instead of a reef to take up the sail to what degree they please, according to the strength of the wind. Along the belly side of the boat, parallel with it, at about 6 or 7 foot distant, lies another small boat, or canoa, being a log of very light wood, almost as long as the great boat, but not so wide, being not above a foot and an half wide at the upper part and very sharp like a wedge at each end. And there are two bamboes of about 8 or 10 foot long and as big as ones leg placed over the great boat's side, one near each end of it, and reaching about 6 or 7 foot from the side of the boat, by the help of which the little boat is made firm and contiguous to the other. These are generally called by the Dutch and by the English from them "outlayers." $b$ The use of them is to keep the great boat upright from oversetting **** and the vessel having a head at each end, so as to sail with either of them foremost (indifferently) they need not tack, or go about, as all our vessels do, but each end of the boat serves either for head or stern as they please. When they ply to the windward and are minded to go about he that steers bears away a little from the wind, by which means the stern comes to the wind, which is now become the head only by shifting the end of the yard. This boat is steered with a broad paddle instead of a rudder.

I have been the more particular in describing these boats, because I do believe they sail the best of any boats in the world. I did here for my own satisfiaction try the swiftness of one of them. Sailing by our $\log$, we had 12 knots on our reel, and she run it all out before the half-minute glass was half out; which, if it had been no more, is after the rate of 12 mile an hour; but I do believe she would have run 24 inile an hour. It was very pleasant to see the little boat running along so swift by the other's side.

The native Indians are no less dextrous in managing than in building these boats. By report they will go hence to another of the Ladrone Islands about 30 leagues off and there do their business and return again in less than 12 hours. I was told that one of these boats was sent express to Manila, which is about 400 leagues, and performed the voyage in 4 days time. There are of these proes, or boats, used in many places of the East-Indies, but with a belly [curve] and a little boat [outrigger] on each side. Only at Mindanao I saw one like these, with the belly and little boat only on one side and the other flat, but not so neatly built. 
Anson, who in his narrative gives a figure of a flying prao of Guam, differ's from Dampier in correctly stating that the flat side is always kept to the leeward and the outrigger to the windward. He describes the outrigger as a $\log$ fashioned in the shape of a small boat and made hollow, the sail made of matting, and the mast, yard, and thwartship pieces connecting the outrigger, of hamboo. In his figure, however, the sail is shown incorrectly. It should be of lateen or triangular shape with the upper yardarm projecting well aft beyond the stern."

Besides the large praos they had small canoes, which were very swift, light, and pretty, "for they painted them with a coating made of red earth from the island of Guam, mixed with lime, with coconut oil as a medium, which beautified them greatly." ${ }^{b}$ Pigafetta, in speaking of their canoes, says that they were all painted; some black and others red. They had paddles of the form of bakers' shorels, which could be used either for steering or propelling the canoes.

MENTAL AND MORAL CHARAC'TERISTICS.

In counting they used a decimal system, the names of the numerals corresponding with those of Malayo-Polynesian languages. Different forms of numerals were used in-counting living and dead objects, and in expressing measurements. ${ }^{\circ}$

They were a happs, careless people. fond of festivities, dancing, singing, story telling, and contests of strength and skill, yet sufficiently industrious to cultivate their fields and garden patches, build excellent houses for their families, braid mats of tine texture, and construct canoes which were the admiration of all the early narigator's. They were much given to buffoonery, mockery, playing tricks, jesting, mimicry, and ridicule, offering in this respect a striking contrast to the undemonstrative Malayans. Legazpi. who risited the island in 1565 , speaks of the loud laughter of those who surrounded his ship:. In selling rice to passing ships they would often increase the weight and bulk of the packages by stones and leaves. "For each nail," say" Legazpi, "they gare measures of rice containing half a fanega," morc or less." When straw and stones at the bottcm of the packages were discovered by the spaniards, the natives seemed to regard the deception ats a huge joke: they "clapped their hands in glee anc' laughed long and loud, going from that ressel to another and playing the same trick. Then again they would take nails and fir without giving anything in return." On the other hand, the Spaniards gave them in exchange for rice and fruits-the most raluable possessions of the

$a$ See Anson, Voyage Round the World, p. 340, 1748.

$b$ Garcia, Vida y Martyrio de Sanvitores, p. 198, 1683.

c For numeral system and calendar of the aborigines, see Safford, W. E., Tho Chamorro language of Guam, Amer. Anthrop., n. s., vol. 6, pp. 95-104, 1904.

a $A$ fanega is about 1.6 bushels. 
islanders-such worthless things as the face cards from old packs of playing cards, bits of cloth which the Spaniards pretended to value, putting them first about their own necks and laughing to see the gullible natives imitate them in doing the same. Legazpi says that these natives were well named ladrones (thieves). They would not board his ships, though he invited them to do so, "showing them much love and affection and looking upon them as friends." This is easily accounted for by the treatment the natives had met with at the hands of the Loaisa expedition (1526), which, when ready to depart from Guam, allured 11 of the islanders on board by deceitful means and carried them away for the purpose of making them work the ship's pumps.

That they were naturally kind and generous is shown by their treatment of shipwrecked sailors cast upon their shores and their reception of the early missionaries who founded the first colony on the island. These missionaries complained that they could not make the natives take life seriously, saying that what they promised one minute they forgot the next. On the other hand, the missionaries spoke of the remarkable intelligence shown by the children in learning the Christian doctrine, the moderation of the natives in eating, and the absence of intoxicants. Their sense of hospitality was very marked. Women were treated with consideration, and had greater authority than in almost any other land hitherto known. It is certain that the natives distinguished between right and wrong. An upright man was called "tunas," or "straight," and the abstract quality of right or rectitude was called "tininas," or "straightness." A bad man was called "abale," which signifies evil or immoral, in distinction from the word "tailaye," which has more the sense of "worthless" and is also applied to things.

"As to their customs," says Padre Garcia, "I feel called upon to say that although they have been called 'ladrones,' on account of the pilfering of a few pieces of iron from our ships, they do not deserve the name, for though they leare open their houses it is rery seldom that anything is missed." They were very courteous on meeting or in passing before one another, saying "ati adingmo," which signitied "let me kiss your feet." A traveler in passing by their houses was always invited to stop and partake of food. One of the first manifestations of ill will on the part of the natives toward the early missionaries was their discontinuance of this courtesy." It was also customary to offer betel nut and leaves of betel pepper to risitor's. It was considered a mark of politeness to take the hand of another and gently pass it across the breast. They held poetry in high esteem and regarded their poets as men of supernatural endowments. ${ }^{b}$ They were

$$
\text { "Garcia, Vida y Martyrio de Sanvitores, p. 224, } 1683 . \quad \text { b Idem., p. } 198 .
$$


inordinately vain, considering themselves to be men of the greatest genius and wisctom in the world, in comparison with whom all other nations were contemptible. The y attached great importance to caste, and had sharply defined lines between families of high, low, and middle extraction. This led the early fathers to imagine that they must be descendants of some polite nation. "Thus it is seen," says Padre Garcia, "how Pride, hanished from Heaven, dwells in all parts of the earth, going in some nations clothed and in others naked." " Under no consideration could a Chamorri, or noble, marry a girl of common caste, thongh she might be rich and he poor. In ancient times it was even customary for kinsmen to kill a noble who for love or for gain should disgrace his family l, y such a marriage. People of low caste were not permitted to eat or drink in the houses of nobles or even to come near them. If they wished to communicate with them, they must do so from a distance. This custom was especially marked among the nobles liring at Agaña, where, on account of the excellence of the water and for other advantages of the site, lived the nohles of the highest rank. They were regarded hy all the rest of the island with fear and respect. In this town there were 53 houses in which the nobility lived. The rest, about a hundred and fifty, belonging to the common people, occupied a position apart and were not considered as a part of the town or of the court. The prejudice of caste was one of the first difficulties encountered by the early missionaries. The chiefs did not consider it seemly that people of low caste should share with them the benefits of baptism, saying that so noble an institution as the fathers taught them to regard it should be enjoged only by the nobility and not by plebeians; and, indeed, the fathers had great difficulty in overcoming the fear of the common people, so firmly rooted was their feeling of abasement in the presence of their betters. ${ }^{b}$

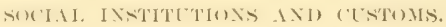

Marriage. - Though more than one wife was permitted, yet a man had, as a rule. only one. Marriage between relatires was strictly forbidden. The wife was essentially the head of the family. Adultery on the part of a man was punished in rarious mamers. Sometimes the injured wife would all together the other women of the village, and putting on their husbands" hats and aming themselves with spears. they would go to the homse of the actulterer, destroy his groming 'rops, and. making a demonstration as though ahout to spear him, they would drive him from his house. At other times the injured wife would punish her hushand by deserting him, whereupon her relations would assemble at his house and carry away all the property, leaving 
him without even a spear or a mat to sleep upon - nothing but the mere shell of the house. Sometimes they would eren demolish the house itself. If a woman was unfaithful the hushand might kill the adulterer. but the wife would receive no punishment. ${ }^{c}$

Divorce was frequent and might take place for any cause of discontent on the part of either the husband or the wife. The most frequent cause was jealousy. In all cases the children accompanied the mother, and should she remarry they looked upon her new hushand at a father.

Concubinage. - It was customary for the urritaos, or hachelors, to live in a "great house," often in companionship with young women whom they purchased from their parents or hired for a certain time. This did not injure the chances of either for marriage. As in other islands of the Pacific where a similar custom prevailed, it is probahle that the girls obtained from their families in this way came from other rillages, and not from that in which they were to live. Certainly degrees of relationship were respected in such cases as scrupulously as in marriage. Sexual relations hetween kindred were considered infamous. After marriage, fidelity was expected and as a rule was observed on the part of both husband and wife.

In cases of true marriage presents were also made by the groom to the father of the bride. A disregard for the marriage customs of the natives on the part of the early missionaries was one of the causes of complaint of the natives and finally led to bloodshed and war. ${ }^{b}$ In 1676 , the first regularly appointed governor, Don Francisco Irisari y Vivar, shortly after his arrival in Guam, wishing to punish the rillage of Talisai for the pride of its inhabitants, who had remained away from the fiesta of Corpus Cristi, celebrated by the missionaries with processions, dances, and contests of the children in reciting the catechism, marched upon it during the night, and at daybreak fired upon the unsuspecting inhabitants; several of them were killed and others escaped to the woods badly wounded. The house of the urritaos wats burned and three babies were carried to the mission and baptized. Shortly afterwards several marriages were solemnized by the padres between girls educated at the mission schools and spanish soldiers. In the school at the village of Orote there was a young girl who wished to marry a Spaniard. Padre Sebastian de Monroy, the missionary stationed at that village, performed the ceremony secretly, without the consent or knowledge of the girl's parents. While the party were still in the church the bride's father came in a great rage protesting against the marriage of his daughter with the Spaniard, and attacked both the bridegroom and the priest. The newly wedded couple were sent for safety to Agaña, and the padre, to console the 
enraged father, told him to calm himself, that he would not be a loser in consequence of the marriage as the padre would give him as much as he could have gotten for his daughter if he had sold her to an urritao. This only made matters worse and finally led to the burning of the entire mission and the assassination of the padre and all of his companions.

Property. - The nobles owned entailed estates of coconut groves, banana plantations, and other choice lands. These were not inherited by a man's son at his death, but by his brother or nephew (probably by the son of his sister, as in many other islands of the Pacific), who on coming into possession of the property changed his name and took that of the founder or most illustrious ancestor of the family. The children belonged essentially to the mother. They inherited the property of their mother's brothers. A man did not dare to dispose of any property of his family, except, perhaps, a canoe, knife, spear, or fishing tackle made br himself or land reclaimed by him from the bush. Tortoise shell was used for money.

Governiext. - They had no king nor defined code of laws, nor was there a ruler for the island in general nor for any village. The nobles of each village formed a kind of council or assembly, which, however, had no real authority orer the rest; but everybody did pretty much what he pleased, unless prevented from doing so by some one stronger than himself. The head of each family was the father or eldest relative, but his authority was so limited as to call for little respect on the part of the sons, who obered it only when forced to do so. Children were seldom chastised by their parents. Offenses were punished by war if the were against a community, or by private revenge if they were against an individual. Owing to this lack of organization no community felt itself responsible for the misconduct of one of its members. When hostages were taken by the spaniards to insure good treatment of their people ashore, or to exact certain promises from the natives, the immediate famils of the hostage alone seemed to feel responsibility or concern for him. The rest continued as before: nor could they understand the justice of the Spaniards' burning whole villages and many boats for the act of a single indiridual, who might or might not belong to the village or be allied to the owners of the boats.

WARFARE.-Their weapons were sling's and spears. Bows and arrows were unknown to them, nor had they swords, war clubs, or shields. They relied upon their quickness and agility to protect them from the hlows of their adversaries. Their spears were of wood with points either of wood hardened by fire, or made of the shin bones of men or of the bones of fishes. Ther had no throwing sticks. The bone spearheads were barbed and had three or four blades or points 



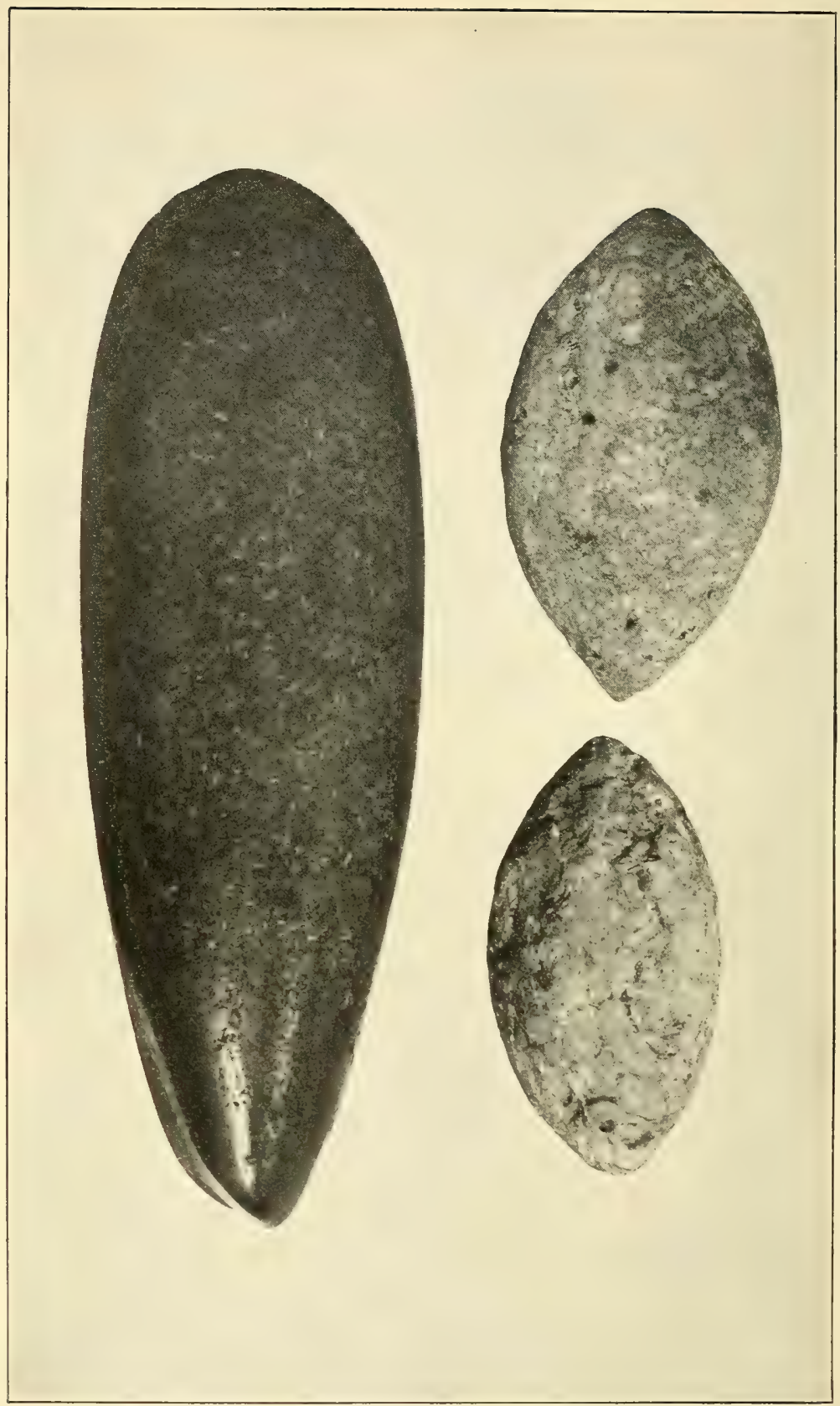

StONe ADZ AND SLING STONES OF ABORIGINES OF THE ISLAND OF GUAM. NATURAL Size. 
which readily broke off. They were supposed by the Spaniards to be deadly poisonous. The wounds inflicted by them often caused death; but, as in the case of the weapons of natives of other Pacific islands reputed to be poisonous, it is probable that their virtue was attributed by the natives to some supernatural influence of the dead man from whose body the bones were taken, and the frequent deaths were due to lockjaw or blood poisoning from natural causes. The sling stones were of oval shape, fashioned out of stone or made of some sort of clay and baked. (PI. XVII.) These were thrown with remarkable force and precision, as far, states one observer, as an arquebus can shoot, and with such swiftness as to embed themselves in the trunkof trees. The natives practiced with these weapons from their earliest childhood and consequently became very skillful in their use.

They carried on a primitive kind of warfare, "being easily ronsed and easily quieted, slow to attack and quick to flee." A village would prepare for war with another village with great bustle but without a leader or any sort of organization or discipline. After war had been declared the two parties would often be two or three days in the field without making an attack, each watching the movements of the other. After engaging they very soon made peace; for a party considered itself vanquished if one or two or three of its men were killed, and ambassadors were sent to the other with offerings of tortoise shell, which was the sign of surrender. The victors would then celebrate their victory with satirical songs, vaunting their valor and scofling at the vanquished. In their fights with the Spaniards they sometimes resorted to fire, burning the vegetation adjacent to the fort of the enemy and hurling flaming darts upon the thatched roofs of their buildings. They often selected inaccessible places for their villages for the sake of security, and in wars with the Spaniards constructed trenches in which they protected themselves, carrying with them the sacred skulls of their ancestors to counteract the power of the crucifixes of their opponents. They also strewed the roads and passes with sharp spines (puas) to serve as caltrops. The use of these and the manner of constructing intrenchments they may have learned from the Spaniards themselves.

SPorts.--One of their favorite sports was sailing in their wonderful canoes, wires accompanying their husbands and vying with them in swimming and diving. As already noted, they were fond of gayety and festivities and took great delight in jokes and buffoonery. The men united together to dance and had contests of spear throwing, running, jumping, wrestling, and exercising their strength in rarious ways. In the midst of their sports they would recount with great peals of laughter their myths and fables and refresh themselves and their guests with cakes made of rice, fish, fruits, and a kind of gruel 
made of rice and grated coconut. The women had their special feasts, dressing themselves in gala attire and decorating their persons with flower's and lright shells and beads. They arranged themselves in a ring of twelve or thirteen, remaining stationary, singing in verse their stories and traditions in perfect time and in three-part harmony"treble, contralto, and falsetto"-accompanied at times by one of the chief men, who assist at these festivities, carrying the tenor. The words were accompanied by morements of the hands, with which they sounded rattles or castanets made of shells, all in such perfect time and with movements of the body and gestures fitting so well with the words as to eall forth no little admiration for their aptitude for learning things to which they apply themselves. ${ }^{a}$

Burial cereuronies.- At funerals the demonstrations of grief were rery extraragant, accompanied by much weeping, fasting, and sounding on shell trumpets. The wailing continued a week or longer, according to the affection and esteen in which the deceased was held. The people assembled, dolefully chanting, around a mound which ther raised over the grave. or near it, decorated with flowers, palms, shells, and other things esteemed by them. ${ }^{b}$ The mother of the deceased usually cut off some hair as a sourenir of her grief, recording the nights that had passed since his death by knots in a cord worn around her neck. These demonstrations were grreater on the occasion of a high rhief's or Chamorri's death and at the death of a matron of distinction, for in addition to the ordinary manifestations of grief they would corer the streets with garlands of palms, erect arches and other devices expressire of mourning, destroy coconut trees, burn houses, break mp hoats, and raise hefore their houses the tattered sails as a sign of their grief and sorrow, and to their songs they added elegies no less eloquent than sorrowful, which grief would teach to the rudest and most barharous among them, exclaiming with many tears, that thenceforth life would not be worth living, he being gone who was the life of all. the sun of their nobility, the moon which lighted them in the night of their ignorance, the star of all their deeds of prowess, the ralor of their battles, the honor of their race, of their rillage, of their land: and thus ther would continue far into the night, praising the deceased. whose tomb they cromned with paddles as a symbol of one celehrated as a tisherman. or with spears as a derice for the brave, or with both paddles and spears if he were both a brave warrior and an expert fisberman.

a Garcia, Vida y Martyrio de Sanvitores, pp. 200-201, 1683.

b Chiefs were sumetimes huried under buildings called "great houses" (debajo de unas casas que llaman grandes.) (Garcia, p. 220.)

The recitation or chanting of elegies was called taitai, a word which is now used for the verbs "to read" and "to pray." The corresponding nouns "prayer" and "lecture" are called tinaitai. 
Animisu. - They believed in the immortality of the soul, which they called "ante." At the death of a person they put upon the head of the corpse a little basket, "as though inviting the spirit to make its home in that basket in place of the body it leaves, or in order that it may have a nesting place when it shall come from the other life to pay them a visit from the place of its sojourn." The souls of those who died a violent death were supposed to go to Sasalaguan, or the dwelling place of Chayfi, who heats them in a forge and beats them incessantly. Those dying a natural death were supposed to descend to a paradise in the underworld, where there are hananas, coconuts, sugar cane, and other fruits of the earth. In determining the future destiny of the soul good and evil conduct apparently har no part. The souls of the dead, especially of ancestors, were looked upon as demons (aniti) and venerated.

The spirits of the dead, like the lares of the Romans, were regarded as natural protectors. They were called aniti, and were thought to be powerful for evil if not duly respected and propitiated. In times of distress they were called upon and their aid was invoked to keep arvay evil and to bring good luck to those for whom prayers were offered. The natives held the aniti in dread, and they sometimes paid them homage for self-protection; "for," says Padre Garcia, "the deril, in order in some fashion to retain this respect and servile fear, is wont to appear to them in the form of their fathers and ancestors and to terrify them and maltreat them." They had no temples, sacrifices, idols, nor defined creed. ${ }^{b}$ They had, however, certain superstitions, especially in connection with their fisheries, during which they kept profound silence and practiced great abstinence for fear or for flattery of the aniti, lest they punish them by driving away the fish or risit them in dreams to frighten them, which the natives really believed they had the power to do. These aniti, it thus appears, were of an unkindly disposition rather than beneficent, and may be considered rather as demons than as divinities. To this day there is among the natives a superstitious dread of the aniti, who are supposed to dwell in the forest. Sometimes benighted travelers going through the bush are seized by the throat or scratched with sharp claws; sometimes stones are hurled by unseen hands, and sometimes in solitary places by the shore a headless figure may be seen sitting motionless fishing in the sea. The aniti are supposed to lurk among the many trunks of the nunu or banyan tree (Ficus sp.) and haunt the sites of ancient houses (casas de los antiguas). ${ }^{c}$ 
A similar belief is still found among certain native tribes of the Philippines, who have the same name for the spirits of their ancestor. Semper, in speaking of the religious faith of the Iraya and Catalangan tribes inhabiting the western part of Isabela, northern Luzon, near the seventeenth parallel of latitude, says:

The faith of both tribes, however, has, in spite of manifold variations, so much of similarity that we may feel safe in assuming in the few recognizable traces, which are also common to all the remaining wild tribes of the land, that we see the remains of a religious faith as it may have prevailed in the purely Malayan period before the arrival of the Mahometans. Besides a few pairs of gods, concerning whose relations and attributes I was not able to become quite clear, they venerate quite particularly the souls of their ancestors, which they place in the rank of their lesser gods under the name of "anito." They are house gods, true lares and penates. Here stands in a corner of the house interior a kind of jar, which would have in itself nothing striking about it, but it is easily to be seen that the members of the family treat this corner with great reverence. In the jar one of their anitos has its seat. The space under the house, which ordinarily serves also as a place of burial, is consecrated through various signs to other anitos; likewise the small spot before the ladder, which is in front of the entrance and beneath the overhanging roof of the house; the hut in which the forges are; and above all certain places before the house which are distinguished ly altars resembling little houses. Moreover, the harvest is consecrated to their anitos, to whom the first fruits are offered in great general feasts."

MYтнs. - In accounting for the creation of the world they say that Puntán, a very ingenions being, who lived in an imaginary place before the creation of hearen and earth, as he was about to die, called to his sister, horn like himself without father or mother, and gave directions for the disposal of his bodr. He transferred to her all his power's, so that at his death she should make of his breast and back the sky and the earth: of his eyes the sun and the moon; of his eyebrows the rainbow. and so on with the rest of his body; not without some analogy to the less and greater world, like that which peets make daily, and this they took not srmbolically. but literally, as scripture and gospel, singing it in certain rerses, which they knew by heart. Yet with all this. no sort of formal worship, invocation, or prayer was offered to Puntán or his sister to indicate that they were regarded as divinities. Other myths and ancient fables and stories of the feats of their ancestors were related and sung in their feasts by those who took pride in their learning, rying with one another as to who could recite the most couplets. ${ }^{b}$

In accounting for the origin of man, they said that everything in the world was derived from at certain earth on the island of Guam, which first became human, then a stone, which gave hirth to all men. From this island they were scattered all over the world, and as they separated 
from the people and place of their origin they forgot their language. On this account the people of other nations knew no language and talked like fools without understanding one another nor knowing what they said. Thus they attributed to the ignorance of the foreigners their own inability to understand a language strange to their ears. ${ }^{*}$

The particular spot from which the first men originated was a rock situated on the west coast of the southern portion of the island, at a place called Fuuña, a short distance north of Umátag. It rose 6 or 8 fathoms from the sea. From its summit vessels going and coming could be seen at a great distance. It was washed by the sea on three sides, on which it was inaccessible; on the east-southeast, at the point where it connected with the mainland, it could be easily fortified. On this rock the missionaries established themselves and built a church, which they dedicated to Nan José, and they soon succeeded in convincing the people of the falsity of the myth concerning Fuuna, the alleged mother of the human race. ${ }^{b}$

Sorcerers.-Their priests, called makahna, were supposed to have the power of communication with the spirits of the dead, to cause sickness and bring health, to produce rain and bring good luck in fishing. To accomplish a desired object they invoked the favor of the deceased, whose skulls, inclosed in baskets, were kept in the dwellings of their descendants. At the time of the arrival of the early missionaries some of the natives showed veneration for the bones and skulls of their ancestor's, and represented their images on the bark of trees and in carvings of wood. Garcia attributed this custom to the influence of a Chinaman who had been shipwrecked on the island and who had gained ascendency over the natives. He was probably wrong in this, since he compared the makahnas with Indian bonzes, who carried on the worship of the devil for their own interests. After describing the veneration or worship of the aniti, he says:

This is the most that the devil has been able to obtain from these poor Marianos; not temples, nor sacrifices, nor idols, nor profession of any sect whatever-a condition of affairs which greatly facilitates the introduction of the faith; for it is easier to introduce a religion where none exist than to abolish one and introduce another.

The makahnas naturally opposed with all their might the introduction of Christianity and put every possible obstacle in the way of the missionaries, who tried to bring them into disrepute, and each party declared that the other were charlatans and impostor's." In their excess of zeal to overthrow the religious practices of the islanders some of the missionaries adopted radical measures. Padre Luis de Medina, "in order to root out once for all the superstition of these Marianos,"

a Garcia, Vida y Martyrio de Sanvitores, p. 203, 1683.

b Idem., p. 468-469.

c Idem., p. 204. 
when he baptized them took away from them their "idols" or figures of their ancestors, to which they paid certain reneration, and burned them. " in order that hy the light from these fires they might see more clearly the truth of our holy faith." On his first risit to Guam he caused a goodly pile of these little idols (idolillos) to be burned hefore the holy cross on the day of its triumph, July 16, 166s, and for this rictory which the cross gained orer the deril he named the village, which before was called Pigpug (Pegpog), " The Triumph of the (ross." He made them bury the skuls of their ancestors in ordel that they might he considered people of God." Br his zeal there were established on the island of Gum the customs and Christian ceremonies of solemn masses. sermons, processions, offices of holy week, and the other principal feastr of the year. according to the capacity of the villages. Thus he arailed himself of all the means and attractions posible to win the love of the Marianos for the Christian faith. In order that ther might go the more willingly to mass and to school for instruction in the doctrine, he gave them some slight presents, so that not only the people of the rillage of Agana hut many others of outlying villages flocked to him. At Christmas he made an altar of the nativity, and people from nearly all the rillages of the island came, attracted by curiosity, and he allowed them to see it on the condition that they should say the creed, the commandments. the act of contrition. and other pravers: and the same father testifies that he reaped much fruit from the Christmas ceremony. On the death of Kipulat the chief who receired them on the island. the father determined to give him a solem funeral: he conquered many difticulties in order to hury the dead chief in the church. going for him to his house with a trumpet and the banner of san Ignacio and san Francisco Xarier. and he said his vigil (wake) and chanterl mass and aused to be performed for him the ceremonies which were tont to be performed for one of the Society of Jesus. which pleased the people of Igania. who at first were opposed to the new mamner of hurial, so that ther now asked whether when they should die they would be buried in the same way. ${ }^{b}$

riperstitioxs. - The natiren took care to spit when no one was looking. and ther would not spit near the house of another nor in the morning. which seemed to he connected with some superstitious fear." This superstition was prohahly of the same nature as that of other islands of the Pacific and of the East Indier, where it is feared that some eril chatrm can he worked upon a person by one getting possession

"See also (farcia, Virla y Martyrio de Sanvitures, 1. 221. 1683. Some of the natives resenterl the lesecration of the bums and inages of their ancestors, threatening to kill the fathers and their atsistants with their suears: lut this lid not rleter them from burning the images amil the jeers of other natives, who dir not share in their reneration.

$b$ Item., 1. $4(1) \lesssim, 409$.

c Idem., p. 198. 
of his spittle, a bit of his hair, nails, refuse of his food, or other thing intimately connected with him. ${ }^{a}$

L.INGIUACIE.

The language spoken by the natives of Guam is called the Chamorro. It belongs to the great Malayan family, which includes the languages spoken by the aborigines of Malaysia, portions of Cambodia, the Pacific Islands from Formosa and Hawaii to New Zealand and Easter Island, and the great island of Madagascar, situated in the Indian Ocean, on the coast of Africa. Some idea of the rast area over which this group of languages extends may be formed when it is borne in mind that Formosa and Hawaii are on the border of the North Temperate Zone, and New Zealand and Easter Island are wholly within the South Temperate Zone, and that the language extends in longitude from Madagascar across the great Indian and Pacific oceans to Easter Island, its eastern limit, the longitude of which is east of the meridian of Salt Lake City in the State of Utah.

On examining the rocabularies of the various languages included in this widely spread family a wonderful correspondence will be found in the names of many common objects, such as fire and water, earth and sky, fish and fowl, many parts of the body, the personal pronouns, and the numerals.

In addition to these are the names of a number of useful plants and trees.

All of these languages have certain characteristic features in common, such as the absence of a copulative rerb, two forms of the plural of the first personal pronoun, one including, the other excluding the person addressed. Thus the adjective "sick" may be regarded as a rerb "to be sick," and the noun "father" may be considered as a rert) "to he a father," each of them requiring only a simple subject to declare a fact.

The languages of the family naturally group themselves into two great divisions. The first, which is characterized by simple rerbal forms and separate possessive pronouns, together with attributive adjectives preceding or following their nouns without an intermediate ligation, or ligature, to connect then, includes the languages of Polynesia proper, viz, the Hawaiian, Samoan, Tongan, Rarotongan, Tahitian, Easter Island, and the Mari of New Zealand. The second is characterized by the addition of prefixes, suftixes, and intixes to the rerb, together with reduplication, to express the various tenses and numbers, and to distinguish transitive verhs with a definite object from intransitive rerbs, so that the original root or primitive word is often difficult to detect at first sight. Possession is indicated by appending possessire

${ }^{a}$ In the Hawaiian Islands the high chiefs made use of spittoons, which were carefully carried out to sea and emptied.

$9773-05-8$ 
particles to the noun, which become united enclitically to it, as " tata-ho," my father; "tata-mo," thy father; "tata-ña," his father; "tata-ta," our father (including the person addressed); "tatan-mame" (excluding the person addressed), etc. To this division belongs the Chamorro language of Guam.

One feature of the Chamorro language, which has led to much confusion in the various vocabularies of that language appearing in the reports of scientific expeditions, is the modification of tonic vowels of nouns and adjectives when immediately following the definite article. Thus "a" (like "a" in father) becomes "ä" (very much like "a" in hat), "o" becomes "e," and "u" becomes "i." We have "lahe," man, but "i lähe," the man; guma, house, but "i gima," the house; "lokâ na guma," high house, but "i lekâ na guma," or "i gima na lokâ," the high house. It also possesses the characteristic, common to the group to which it belongs, of uniting' an attributive adjective to its noun by means of a ligature ("na") as shown in the preceding example." The plural of a few nouns is formed by reduplication of the tonic syllable, the plural of all adjectives and a certain class of nouns is formed by prefixing the particle "man" to the word; as "mauleg i läbe," good is the man; "manmauleg i lialïhe," good are the men; "aniti," ghost, "mananiti," ghosts." The plural of most nouns, howerer, is indicated by placing after them the word "siha," which is the plural of the third personal pronoun, as "guma siha" houses.

For a more complete ac'ount of the Chamorro language of Guam the reader is referred to a series of paper's by the author in the American Anthropologist. new series, rolumes 5, 6, and $7,1903-5$.

In the two following tahles a number of Guam words are compared with corresponding words in the Polynesian, Philippine, and Malaysian languages. In the column of Philippine names "T." indicates the Tagáloy language: "V.." the Visayan; "I.," the Ilocano, and "P.," the Pampayo. In the column of Polynesian names "s." stands for Samoa, "H." for Hawaii, and "N. Z." for New Zealand. The words giren in these tables are selected from among a great number which do not show such alose correspondence. It would be misleading to give the impression that the Chamorro language bears a rery close resemblance to the Polynesian dialects or that it may be considered a Philippine dialect. Certain words, it is true, are closely allied to hoth the Polrnesian and Philippine names for the same thing, but on the other hand there are words much more nearly like the primitive Malayan than either the Philippine or Polynesian forms, and in no one language of the Philippine Archipelago is there a close correspondence either in the rocabulary or in the rerbal forms with those of the Chsmorro.

"This feature will he seen in many Philippine plant names. The ligation is in some (ases shortened $(1)$ an 11 or ing added to the noun; as rhotilan layo (foreign banana), and kamoting kahoi (tree sweet-potato), cassava plant. 
Words with Polynesian and Malayan affinities. a

\begin{tabular}{|c|c|c|c|c|}
\hline Ėuglish. & Guam. & Malaysia. & Philippines. & Polynesia. \\
\hline $\begin{array}{l}\text { Breasts. } \\
\text { Cocoanut. } \\
\text { Dead. } \\
\text { Drink. } \\
\text { Ear. } \\
\text { Eye. } \\
\text { Face. } \\
\text { Feather. } \\
\text { Few. } \\
\text { Fire. } \\
\text { Fish. } \\
\text { Fly. } \\
\text { Fowl. } \\
\text { He. } \\
\text { Head. } \\
\text { Hear. } \\
\text { I. } \\
\text { Louse. } \\
\text { Mosquito. } \\
\text { Moss. } \\
\text { My. } \\
\text { Our (inclusive). } \\
\text { Our (exclusive). } \\
\text { Rain. } \\
\text { Road. } \\
\text { Sea. } \\
\text { Sky. } \\
\text { Smoke. } \\
\text { Star. } \\
\text { Stone. } \\
\text { Sugareane. } \\
\text { Tooth. } \\
\text { We (inclusive). } \\
\text { We (exclusive). } \\
\text { Weep. } \\
\text { What. } \\
\text { Wind. } \\
\text { Wing. } \\
\text { Wood. } \\
\text { Wour. }\end{array}$ & $\begin{array}{l}\text { susô. } \\
\text { niyog. } \\
\text { matui. } \\
\text { ginem. } \\
\text { talañga. } \\
\text { mata. } \\
\text { mata. } \\
\text { pulu. } \\
\text { dididi. } \\
\text { guafi. } \\
\text { guihan. } \\
\text { lalo. } \\
\text { manog. } \\
\text { guiya. } \\
\text { ulo. } \\
\text { huñgog. } \\
\text { guaho. } \\
\text { hutu. } \\
\text { ñamo. } \\
\text { lumut. } \\
\text { ko, -ho. } \\
\text {-ta. } \\
\text {-mani. } \\
\text { uchan. } \\
\text { chalan. } \\
\text { tasi. } \\
\text { lañit. } \\
\text { asu. } \\
\text { pution. } \\
\text { achu. } \\
\text { tupo. } \\
\text { nifen. } \\
\text { hita. } \\
\text { hame. } \\
\text { tañgis. } \\
\text { hafa. } \\
\text { mañglo. } \\
\text { papâ. } \\
\text { hayu. }\end{array}$ & $\begin{array}{l}\text { susu. } \\
\text { nior. } \\
\text { mati. } \\
\text { minum. } \\
\text { telinga. } \\
\text { mata. } \\
\text { muka. } \\
\text { bulu. } \\
\text { sadikit. } \\
\text { api. } \\
\text { ikan. } \\
\text { lalat. } \\
\text { nanok. } \\
\text { iya. } \\
\text { ulu. } \\
\text { dengar. } \\
\text { aku. } \\
\text { kutu. } \\
\text { niamok. } \\
\text { lumut. } \\
\text {-ku. } \\
\text { kita. } \\
\text { kami. } \\
\text { hujan. } \\
\text { jalan. } \\
\text { tasi. } \\
\text { langit. } \\
\text { asap. } \\
\text { bituy. } \\
\text { batu. } \\
\text { tebu. } \\
\text { nifin. } \\
\text { kita. } \\
\text { kami. } \\
\text { tangis. } \\
\text { apa. } \\
\text { ahgin. } \\
\text { kepak. } \\
\text { kayu. }\end{array}$ & $\begin{array}{l}\text { susu (T.). } \\
\text { niog }\left(\mathrm{T}_{.}\right) \\
\text {patai (T.). } \\
\text { inum (T.). } \\
\text { taiñga (T.). } \\
\text { mata. } \\
\text { ropa. } \\
\text { bulbul (P.). } \\
\text { didiot (V.). } \\
\text { apoi (T.). } \\
\text { hisdá (T.). } \\
\text { lango (P.). } \\
\text { manok. } \\
\text { siyá (T.). } \\
\text { ulo (T.). } \\
\text { duñgog (V.). } \\
\text { ako. } \\
\text { kutu. } \\
\text { yamuk (P.). } \\
\text { limut (T.). } \\
\text {-ko. } \\
\text {-ta (V.). } \\
\text {-amo (V.). } \\
\text { ulan (T.). } \\
\text { dalan (V.). } \\
\text { dagat. } \\
\text { langit. } \\
\text { asuk (P.). } \\
\text { bituin. } \\
\text { batu. } \\
\text { tubu. } \\
\text { ñgipin (T.). } \\
\text { kitá. } \\
\text { kami. } \\
\text { tangis. } \\
\text { ano. } \\
\text { hangin. } \\
\text { pakpak (P.). } \\
\text { kahoi. }\end{array}$ & $\begin{array}{l}\text { susu (S.). } \\
\text { niu (S.). } \\
\text { mate (N. Z.). } \\
\text { inu. } \\
\text { talinga. } \\
\text { mata. } \\
\text { mata. } \\
\text { fulu (S.). } \\
\text { itiiti (S.). } \\
\text { afi (S.). } \\
\text { i'a (S.). } \\
\text { lango (S.). } \\
\text { manu (S.). } \\
\text { ia. } \\
\text { ulu (S.). } \\
\text { longo (S.). } \\
\text { a'u (S.). } \\
\text { 'utu (S.). } \\
\text { namu (S.). } \\
\text { limu. } \\
\text { to-ku (N.Z.). } \\
\text { lo ta-tou. } \\
\text { lo ma-tou. } \\
\text { ua. } \\
\text { ala. } \\
\text { tai. } \\
\text { langi. } \\
\text { asu (S.). } \\
\text { fetũ (S.). } \\
\text { fatu (S.). } \\
\text { tolo (S.). } \\
\text { nifo (S.). } \\
\text { ta-tou (S.). } \\
\text { ma-tou (S.). } \\
\text { tangi (S.). } \\
\text { aha iN.Z.). } \\
\text { matangi (S.). } \\
\text { pakau (N.Z.). } \\
\text { rakau (N.Z.). }\end{array}$ \\
\hline
\end{tabular}

Guam words unlike the Polynesian.

\begin{tabular}{|c|c|c|c|c|}
\hline English. & Guam. & Malaysia. & Philippines. & Polynesia. \\
\hline $\begin{array}{l}\text { Ashes. } \\
\text { Bad. } \\
\text { Belly. } \\
\text { Big. } \\
\text { Black. } \\
\text { Bone. } \\
\text { Bridge. } \\
\text { Day. } \\
\text { Earth. } \\
\text { Fear. } \\
\text { Foot. } \\
\text { Fruit. } \\
\text { Hair. } \\
\text { Hand. } \\
\text { Hot. } \\
\text { House. } \\
\text { Kill. } \\
\text { Lightning. } \\
\text { Male. } \\
\text { Man (person). } \\
\text { Moon. } \\
\text { Mouth. } \\
\text { Night. } \\
\text { Not. } \\
\text { Nose. } \\
\text { Farent. } \\
\text { Pig. } \\
\text { Rat. } \\
\text { Rice (unhulled). } \\
\text { River. } \\
\text { Roof. } \\
\text { Sail. }\end{array}$ & $\begin{array}{l}\text { apu. } \\
\text { chat. } \\
\text { tiyan. } \\
\text { dañkulo. } \\
\text { atulong. } \\
\text { tolang. } \\
\text { tolai. } \\
\text { haane. } \\
\text { tanô. } \\
\text { maaña. } \\
\text { adeng. } \\
\text { tinegcha. } \\
\text { gapun-ulo } \\
\text { kanai. } \\
\text { maipe. } \\
\text { guma. } \\
\text { punô. } \\
\text { lamla. } \\
\text { lahi. } \\
\text { taotao. } \\
\text { pulan. } \\
\text { pachod } \\
\text { pueñge. } \\
\text { ti. } \\
\text { guiing. } \\
\text { saina. } \\
\text { babue. } \\
\text { châka. } \\
\text { fãi. } \\
\text { sadog. } \\
\text { atuf. } \\
\text { layag. }\end{array}$ & $\begin{array}{l}\text { habu. } \\
\text { jahat. } \\
\text { tiyan. } \\
\text { besar. } \\
\text { itam. } \\
\text { tulang. } \\
\text { titi. } \\
\text { hari. } \\
\text { tanah. } \\
\text { takut. } \\
\text { kaki. } \\
\text { bua. } \\
\text { rambut. } \\
\text { tangan. } \\
\text { panas. } \\
\text { rumah. } \\
\text { bunoh. } \\
\text { kilat. } \\
\text { laki-laki. } \\
\text { orang. } \\
\text { bulan. } \\
\text { mulut. } \\
\text { malam. } \\
\text { bukan. } \\
\text { hidong. } \\
\text { ibu-papa. } \\
\text { babi. } \\
\text { tikus. } \\
\text { padi. } \\
\text { sungei. } \\
\text { bumbong. } \\
\text { layar. }\end{array}$ & 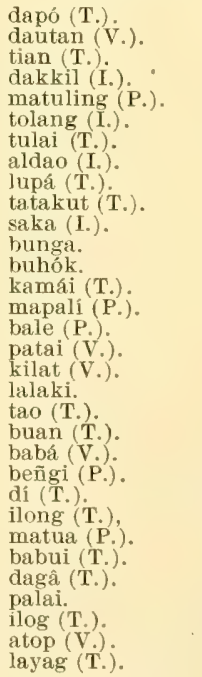 & 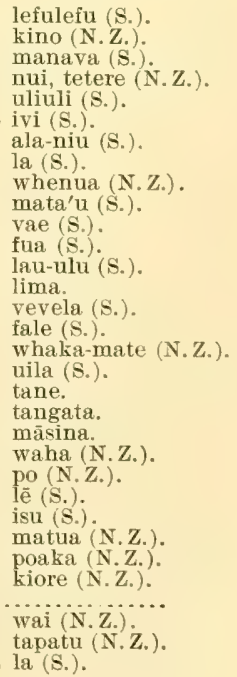 \\
\hline
\end{tabular}


Guam words unlike the Polynesian-Continued.

\begin{tabular}{|c|c|c|c|c|}
\hline English. & Guam. & Malaysia. & Philippines. & Polynesir. \\
\hline $\begin{array}{l}\text { Skin. } \\
\text { Sleep. } \\
\text { Spear. } \\
\text { Spittle. } \\
\text { Sun. } \\
\text { Sweet. } \\
\text { Swim. } \\
\text { Taro. } \\
\text { Great taro. } \\
\text { Tomorrow. } \\
\text { Tongue. } \\
\text { Water. } \\
\text { White. } \\
\text { Woman. } \\
\text { Yam. } \\
\text { Yesterday. } \\
\text { You (pl.). } \\
\text { Your. }\end{array}$ & $\begin{array}{l}\text { lasas. } \\
\text { maigo. } \\
\text { togeha. } \\
\text { tola. } \\
\text { atdao. } \\
\text { mamis. } \\
\text { nañgo. } \\
\text { sune. } \\
\text { piga. } \\
\text { agupa. } \\
\text { hulâ. } \\
\text { banom. } \\
\text { apaka. } \\
\text { palaoan. } \\
\text { àgo. } \\
\text { nigap. } \\
\text { liamyo. } \\
\text {-miyo. }\end{array}$ & $\begin{array}{l}\text { kulit. } \\
\text { tidor. } \\
\text { tombak. } \\
\text { tohula. } \\
\text { mata-hari. } \\
\text { manis. } \\
\text { berenang. } \\
\text { keladi. } \\
\text { bia. } \\
\text { esok. } \\
\text { liday. } \\
\text { ayer. } \\
\text { putih. } \\
\text { perampus:. } \\
\text { ubi. } \\
\text { kalmarin. } \\
\text { kamu. } \\
\text {-mu. }\end{array}$ & $\begin{array}{l}\text { balat (T.). } \\
\text { tolog (V.). } \\
\text { tandus. } \\
\text { lurâ. } \\
\text { aldao (T.). } \\
\text { matamis (T.). } \\
\text { lañgoi (T.). } \\
\text { gabi, gabe. } \\
\text { biga (T.). } \\
\text { búkas (T.). } \\
\text { dila (T.). } \\
\text { danum (P.). } \\
\text { maputi. } \\
\text { babsi (T.). } \\
\text { ubi. } \\
\text { kahapun. } \\
\text { kayó (T.). } \\
\text { ninyó (T.). }\end{array}$ & 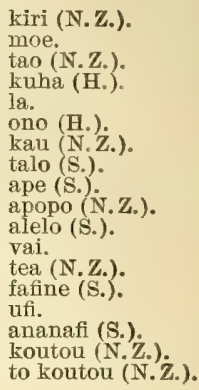 \\
\hline
\end{tabular}

ORIGIN.

Of the common origin of the aborigines of Guam with those of Polynesia, the Philippines, and many of the islands of the Malay Archipelago there can be no doubt. This is shown especially by their language, their arts, social organization, and superstitions, as well as by the physical appearance of the natives themselves. It is not probable that the population was purely Malayan; there is evidence of certain affinities with the Melanesians or Papuans. These may have been the result of conquest or of the amalgamation of Melanesians settling upon the island. Certain customs of the ancient Chahorros were very similar to those still existing on some of the islands of Melanesia, such as the liring together of the bachelor's in great houses and the prevalence of the custom of concubinage before marriage. An aftinity with the natives of many of the islands known as Micronesia is also undoubted, but this is much more remote. Unlike the Melanesians and Papuans, the ancient Chamorros were ignorant of the manufacture of pottery and of the use of the bow and arrow in warfare, nor did they possess the art of carving in wood. Their canoes were without other ornamentation than painted designs of red and black. Unlike the Micronesians, they were ignorant of the art of wearing with looms. Their mats were plaited or braided diagonally like those of the true Polynesians. In their art of fire making and cooking they resembled the latter, and their canoes, provided with outriggers and pointed at both ends, were of the general shape of those found in the Eastern Pacific. In their use of slings for fighting they resembled the aborigines of many Pacific islands, and their adzes or gouges of stone were scarcely to be distinguished from those of many Melanesian and Polynesian tribes.

The elaborate system of forming derivative words from verbal roots by the use of prefixes, suffixes, and infixes joined enclitically to the 



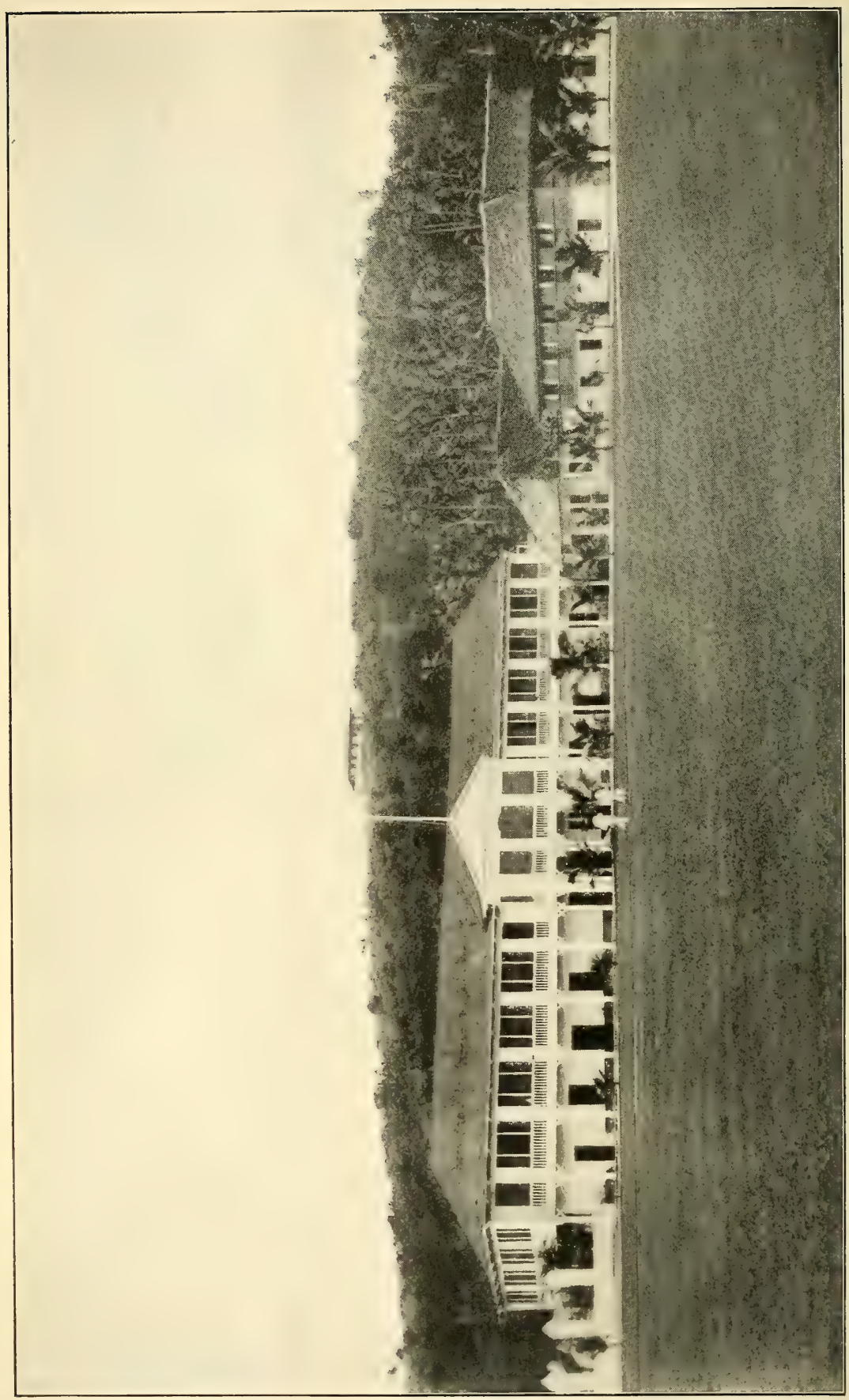

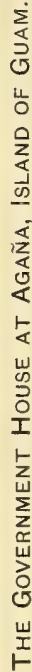


primitive word, as well as the use of possessive particles appended to the name of the object possessed, and the sharp distinction between transitive rerbs having a definite object from intransitive verbs and rerbs of which the object is not definitely specified are features of their language which at once separate them from the Polynesians of the Eastern Pacific and ally them with the inhabitants of the Malay Archipelago, the Philippines, and Madagascar. Their use of the betel pepper and areca nut as narcotics instead of kava pepper is another feature connecting them with the Philippine Islanders and the Malayans, and their possession of rice in prehistoric times bearing the same name as in the Malay Archipelago and Madagascar is another bond between them and the inhabitants of these islands. On the other hand, they did not possess the paper mulberry, which is so important in the economy of the natives of the Eastern Pacific islands as the source of bark cloth or tapa. Other trees of importance in the economy of the true Polynesians which were absent from Guam are the candle nut (Aleurites moluccana) and the Polynesian "chestnut" (Bocoa edulis).

From a consideration of these features in the language, customs, and arts of the aboriginal inhabitants of Guam it is evident that they did not accompany the settlers of Polynesia in their exodus from the region of their common origin, but that they remained united or in communication with the ancestors of the inhabitants of the Philippines, Madagascar, Malaysia, and certain districts of Cambodia until after the evolution of the grammatical features which are common to their languages and the introduction of rice as a food staple. And it is probable that they did not leave the cradle of the race until after the adoption of the habit of betel chewing, which was introduced from India long after the departure eastward of the settlers of eastern Polynesia, who took with them yams, taro, sugar cane, and coconuts from their former home.

\section{THE MODERN INHABITANTS.}

ORIGIN AND LANGUAGE.

Assertions have been repeatedly made that the Chamorros, as the Marianne Islanders are called, no longer exist as a separate people;" that "at the present day not one of the original race survives, and that the islands are peopled chiefly by Tagals and Bisayans from the Philippines, with a few Caroline Islanders, and numerous half-breeds, but also by the mixed descendants of natives of South American tribes." It is also asserted that the present inhabitunts are able to speak Spanish, which is gradually supplanting the native language, "a Micronesian dialect nearly allied to that used by the Tagals of the

"Coutts Trotter in Encyclopædia Britannica, 9th ed., vol. 16, p. 256, 1883.

$\checkmark$ This remarkable statement is made by Guillemard, in Stanford's Compendium of Geography and Travel (new issue), Australasia, vol. 2, p. 554, 1894. 
Philippines." $a$ In the classification of the Indo-Pacific races of man, by S. J. Whitmee, the natives of the Marianne Islands are not even mentioned. ${ }^{b}$ In 'Tregear's Maori-Polynesian Comparative Dictionary ${ }^{c}$ (1891) two distinct sets of references are given to words of the Chamorro language, evidently compiled from separate vocabularies, neither of which have the words properly spelled. Thus, under the word for stone the Chamorro word "achu" is cited as "Guaham, ashou; Chamori, atju," as though these were two languages; and no mention is made of the resemblance of the Chamorro "guafi" to the Polynesian "afi" (fire), "guihan" to "ika" (fish), "uchan" to "ua" (rain), "chalan" to "ala" (path), though the corresponding Malayan words "api," "ikan," "hujan," and "jalan" are cited.

As a matter of fact the Chamorro language is not a Micronesian dialect, nor is it closely similar to that used by the Tagals of the Philippines. One need only compare the words given in the preceding lists with Micronesian vocabularies to be convinced of this fact, and to note the difference between the Chamorro "guma" (house) and the Tagalo "bahai," the Chamorro "hanom" (water) and the Tagalo "tubig," the Chamorrro "palaoan" (woman) and the Tagalo "babai," and the dissimilarity between the corresponding verbs, prepositions, adverbs, and adjectives of the two languages.

Pure-blooded Chamorros are no longer found on the island, it is true, but in every native family of Guam the Chamorro language is the medium of communication, "and though the men of the original stock were nearly all killed off by the Spaniards in their efforts to "reduce" them, ret many of the women were married to Spanish, Mexican, and Philippine soldiers brought by the Spaniards to the island to assist in the conquest, as well as to mariners of Great Britain and France who settled in the island. Few foreign women have found their way to Guam, and it was from their Chamorro mothers that the children learned to talk. Thus the Chamorro language has survived, though it has become modified by the introduction of many Spanish words and idioms. just as the Hawaiian and Maori languages have been influenced by the English. and the Tahitian and Malagassy by the French. The entire srstem of numeration has been replaced by the Spanish. The Spanish indetinite article "un" has been adopted, as well as the prepositions "para" (for), "con" (with), and a number of other words. It shonld be noted, however, that where Spanish nouns, adjectives, and rerhs have entered the language they are made to conform with the grammatical features of the Chamorro; thus the plural

\footnotetext{
a Encyclopædia Britannica, vol. 14, p. 200, 1882.

$b$ Idem., vol. 19, pp. $422-428,1885$.

c Under Whatu, p. bili.

a See Safford, Natives of the Island of Guam, American Anthropologist, n. s., vol. 4 , p. 194, 1902 .
} 
of "santos," saint, becomes "mañantos;" the dual of "parientes" becomes "pumarientes," two relatives of each other; and from the Spanish verb "sentir" are derived the reduplicated form "siésienta" and "unsiésientehá," "thou dost indeed feel," or "thou art truly feeling."

The various races have amalgamated thoroughly. Among the principal families on the island are found the names of Anderson, ${ }^{a}$ Robert, Wilson, and Millechamp, as well as those of Torres, Palomo, Martinez, Cruz, Perez, Herrero, and others of Spanish and Mexican origin, names all prominent in the archives of the island. In these archives are copies of official orders of the captain-general of the Philippines directing that all foreigners be sent away from Guam and, in reply, petitions from a number of worthy men stating that they had adopted this little island for their home and begging the captain-general that they might be allowed to remain with their wives and little ones. Some of them even went to Manila and were granted permission to return, becoming useful members of the community and rendering great assistance to the governor as interpreters, captains of the port, and pilots. Many of their descendents inherit their sterling qualities, but are true Chamorros in language, in manners, and in heart.

As for the Caroline islanders, their entire colony has been sent to the German islands of the group. They never intermarried with the Chamorros, but retained their own language and customs, living like savages in small huts with only a few leaves spread upon the ground to serve as a floor and bed, subsisting on fish, wild yams, and fruits, and resisting all attempts to christianize them. There are no records of people of South American origin having settled in Guam, but in the northern islands of the group the census of 1902, taken by the German authorities, shows that there are 15 persons of American origin, recorded as "Chilians, Peruvians, and Mexicans."

PHYSICAL CHARACTERISTICS.

The natives of Guam are, as a rule, of good physique and pleasing appearance. Owing to their mixed blood their complexion varies from the white of a Caucasian to the brown of a Malay. Most of them have glossy black hair, which is either straight or slightly curly. It is worn short by the men and long by the women, either braided, coiled, or dressed after the styles prevailing in Manila.

DISEASEs. - The remarkable freedom from disease of the aborigines at the time of the arrival of the Spaniards has already been noted. ${ }^{b}$ Shortly afterward, however, a kind of leprosy made its appearance on the island, introduced very probably by Filipino convicts who were brought in 1680 from Manila to assist, together with soldiers from

${ }^{a}$ Descendents of a Scotchman who came to Guam with Freycinet; see p. 31.

${ }^{b}$ Garcia, Vida y Martyrio de Sanvitores p. 197, 1683. 
Mexico, in the "reduction" of the natives. Dampier, describing the natives of Guam in 1686, says:

The Tatives of this Island are strong-bodied, large-limb' $d$, and well-shap'd. They are Copper-coloured, like other Indians: their hair is black and long, their eyes meanly proportioned; they hare pretty high Noses; their Lips are pretty full, and their teeth indifferent white. They are long visaged, and stern of countenance; yet we found them to be affable and courteous. They are many of them troubled with a kind of Leprosie. This distemper is very common at Mindanao: therefore I shall speak more of it in my next Cnapter. They of Guam are otherwise very healthy, especially in the dry season: but in the wet season, which comes in June, and holds till October, the air is more thick and unwholsome; which occasions Fevers: but the Rains are not violent nor lasting. For the Island lies so far Westerly from the Philippine Islands, or any other Land, that the Westerly Winds do seldom blow so far; and when they do, they do not last long: but the Easterly Winds do constantly blow here, which are dry and healthy; and this island is found to be very healthful, as we were informed while we lay by it.

In his description of the "sort of Leprosie" observed on the island of Guam and in Mindanao, Dampier says:

This Distemper rums with a Iry Seurf all orer their Bodies, and causeth great itching in those that have it, making them frequently scratch and scrub themselves, which raiseth the outer skin in small whitish flakes, like the scales of little Fish, when they are raised on end with a Knife. This makes their skin extraordinary rough, and in some you shall see broad white spots in several parts of their Body. I judge such have had it, but are cured; for their skins were smooth, and I did not perceive them to scrul, themselyes: yet I have learnt from their own mouths that these spots were from this Distemper. Whether they use any means to cure themselves, or whether it goes away of it self, I know not: but I did not perceive that they made any great matter of it, for they did never refrain [from] any company for it; none of our People caught it of them, for we were afraid of it, and kept off. $b$

The disease described by Dampier, though possibly one of the forms knowns as "lepra," was certainly not Lepme andesthexiace, a later introduction, which in characterized by absence of sensibility of the surface, comparatire smoothness of the skin, and ulceration and loss of the finger's and toes. The latter disease is not nearly so prevalent on the island as it was at the time of the risit of Freycinet, and it is constantly decreasing. One reason for this mar be the change from a fish diet to one almost entirelr regetable, with occasional indulgence of heef, renison, pork, and forls: as it is a mell-known fact that a fish diet renders every symptom of the disease worse. During the interregnum which followed the seizure of the island by the United States, all lout one of the patients in the leper hospital at Asan escaped and were cared for by relatives in various parts of the island. A leper ('olony mals established hy Gorernor Seaton Schroeder on the shore of Tumbum Bar, and the fer natives suffering from leprosy have been segregated there. They are attended by nurses and are treated by the naval medical officers stationed on the island.

"Dampier, New Voyage, 6th ed., vol. 1, pp. 297-298, 1717.

b Idem., p. 334 . 
Several cases of ichthyosis have been noted by our doctor's, all of them congenital. In this discase the skin of the patient has the appearance of being composed of small scales like those of fishes. Though the disease is apparently incurable, the patients do not appear to suffer and their general health is good. Among other skin diseases is that known in the Eastern Tropics as "dhobie itch" (Tinece circinutru), a kind of ringworm which, if unchecked, spreads over the skin in large areas. This was very common among our own men. A good remedy for skin diseases is the "xingworm shrub" (ILerpetica rlatr), introduced into Guam and the Philippines from Mexico, and called by the natives "acapulco." Another excellent remedy is an ointment made of $t$ per cent of chrysarobin with vaseline. Chrysarobin, known also as "goa powder," is obtained from the longitudinal canals and interspaces of the wood of Andire arurobe, a Brazilian tree belonging to the Leguminosae.

The most prevalent disease among the natives is hereditary syphilis. During the first years of the American occupation of the island no primary or secondary cases were observed. The most frequent symptoms of this disease are ulcers and hard lumps on various parts of the body and destructive joint and bone lesions. It is not uncommon for a young man or woman, or even a little child, of apparently fine physique to be afflicted with an ulcer in the palate or nose, which often spreads over the face and sometimes destroys the eyes. Syphilis, like leprosy, was probably introduced into Guam by diseased convicts and laborers, some of whom were Chinese, sent to the island from the Philippines at the request of some of the early governors. One governor's report, to which reference has already been made, describes the condition of some of the convict laborers sent to Guam, who were afflicted with scurry and skin diseases and foul ulcers. After undergoing medical treatment for a short time they were distributed over the island." It is probable that many others previously sent, of whose importation we have no record, were also diseased in like manner, and that little or no effort was made on the part of the authorities to prevent the contagion from spreading.

On the arrival of the Americans at Guam, the natives flocked by scores to our medical officer's for treatment. In the report of the Surgeon-General of the Navy for 1900, attention is called to the extraordinary success attending the treatment of hereditary syphilis, nearly every casc of which responded immediately to potassium iodide or to mercury, administered either in large or in small doses.

A nother source of disease was the frequent visits of whaling ressels and the establishment on the island of a hospital for the treatment of

a"Llegaron 21 enfermos, unos escorbutados y otros con llagas y enfermedades cutaneas." (Don Pablo Perez, letter to the captain-general of the Philippines, ined., October 17, 1851.) 
diseased seamen. It was sometimes impossible for those in charge of the hospital to keep the patients under control, and their disorderly behavior caused much worry to the Spanish officials.

Among the many wise and benerolent acts which characterized he administration of Gorernor Schroeder was the establishment of a ciril hospital. The corner stone was laid by Mrs. Schroeder on the 10th of June, 1900, and the building was dedicated by the Rererend Father José Palomo." One of the principal causes of the stationary condition of the population, as shown by the census of the island, was the death of new-born infants and of women in childbirth. A school for the instruction of midwires was accordingly established, and all women on the island employed in this capacity were obliged to undergo a course of instruction before receiving license to continue their profession.

The doctors reported typhoid ferer to be endemic. Diseases of the eje were not very conmon, though several cases of conjunctivitis and iritis were treated. Malaria is apparently absent, though mosquitoes abound. Among the parasitic diseases are taperorm and lumbricoid worms. In one year 17 deaths from the latter were reported, and in the preceding year 5 cases of the former were successfully treated. Tuberculosis exists on the island, but is not widely spread.

It is not strange that the early inhabitants complained that the spaniards brought curses to their islands without bringing remedies for their cure. The last serious epidemic was that of smallpox brought from Manila in March, 1550 , by the schooner E. L. Frost, and lasting until the following Norember. More than two-tifths of the population perished, and in some cases whole villages were wiped out of existence.

In the summer of 1sys the Spanish transport Elcano brought to the island a disease thought at first to be cerehro-spinal meningitis, but afterwards believed to be anterior poliomyelitis. In some respects it resembled beriberi, hut it was not attended with dropsical symptoms. The rictims, all adults, were suddenly stricken when in apparently perfect health. Frequently death ensued in three or four days. If the rictim survived. paraly is either in the arms or legs was sure to follow. and the muscles of the afflicted parts became atrophied. ${ }^{b}$ The disease was chiefly confined to the rillage of Sumai, on the shore of the harbor of Apra. It would be interesting to know whether this epidemic could be traced to the importation of moldy or damaged rice, which in Japan and the Philippines is supposed to be the cause of beriberi.

" Report of the Secretary of the Navy for the year 1901, p. 82.

"Alfred (r. (irunwell, assistant surgeon, $\mathrm{C}$. S. Nary, in Report of the SurgeonGeneral of the Nary for 1900, pp. 224-227. 



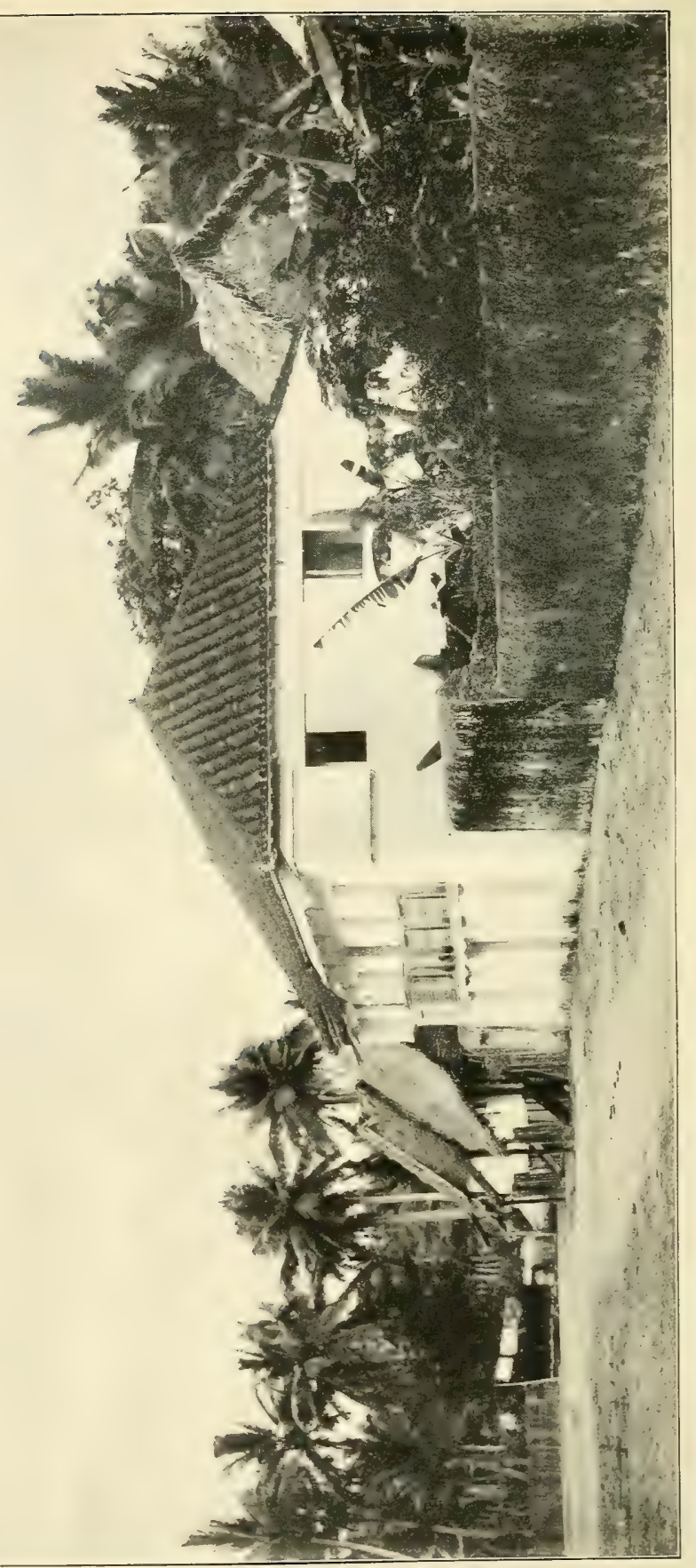

$\frac{1}{3}$ 3 
PERSONAL AND DOMESTIC ECONOMY.

Dress. - The natives dress very much after the manner of the people of Manila. The men wear cotton trousers, and shirts outside of the trousers, either white or of some striped material. Some of them wear white jackets which tit closely about the neck, fastened with buttons or silver studs. They wear either imported hats of straw or felt, or hats of pandanus woren on the island. When fishing on the reef or when at work on their ranchos many of them content themselves with a breechcloth and a straw hat. They wear shoes. slippers, or sandals, or, if engaged in work which does not require the feet to he protected, go barefooted. As is the case in Japan and at Manila it is the custom while sitting in the house to slip off the shoes. At church the women usually take them off and kneel upon them.

The ordinary dress of the women is an ample skirt of print or bright-colored gingham with a short chemisette of thin white material. cut low in the neck and provided with wide flowing sleeres. Stockings are worn by few except on feast days and Sundays. Women of the better class follow the Manila fashions and wear garments of more costly materials. Some of them have begun to wear corsets. A few wear European hats; the remainder go bareheaded or content themselves with handkerchiefs tied over the head. Nearly all of them wear kerchiefs across the bosom and a rosary about the neck. some of the native costumes are very prettily ornamented with lace or embroidery, and the handkerchiefs are often of fine texture, with a colored border. It is considered unseemly for the older women to wear bright colors or fancy laces. Flowers are scarcely at all worn by the natives, but that they have a love for beauty is shown by the decorated altars in their houses and the bright-colored foliage plants and flowers in their gardens.

Dwellings. - With the exception of a few families living in rancherías, the natives live in villages and go to their fincas, or country places, for the purpose of feeding and watering their stock or for cultivating their fields. The town houses are well constructed. They are raised from the ground on substantial, durable posts (Pl. XX), or built of masonry with a basement or "bodega" which is used as a storeroom or cellar (Pl. XIX). Some of them are surrounded by balconies, inclosed by shutters or by windows with translucent Placuna shelts for panes. The roofs are either of thatch or tile, the best thatch being that made of the leaflets of the nipa palm. Many of the houses are provided with vegetable gardens in which dome-shaped orens mar be seen. Under the eaves, so as to catch the drippings from the roof, are rows of bright-colored Phyllaurea and variegated Acanthaceae. Ornamental Araliaceae are also planted, some with finely divided leaves (Nothopanax fruticosum), others with leaves shaped like saucers ( $N$. 
cuctitentmim), and others prettils rariegated with white (Aralia guitfoylei). Besides fruit trees, wnch as lemons, limes, pomegranates, soursops, and sugar apples, there are shruhs, rines, and trees prized for the fragrance of their flowers such ar Lawsonia. Telosma (Pergularia), and ilangilang.

Ranchos rary in size from simple huts, intended for the temporary shelter of one or two persons attending to adjoining patches of cultiration, to well-built permanent drellings large enough for a whole family. A plat of ground after having been cultivated for four or five years is often ahandoned and allowed to lie fallow a few rears. Lnder these conditions it would not pay to erect permanent habitations on the mesa. The usual form of a small rancho is that of a shed with walls of woren reeds, coconut leares, or split hamboos and a coconutthatched roof with eares projecting sufficientl to keep the rain from coming in through the cracks. Half the hut is taken up by a platform of split bamboo, raised abont 2 feet from the ground. This is the family bed. Beneath it are penned up each night the roungest broods of chickens with their mothers, to protect them from rats, eats, and lizards. The larger forls fly to the spreading limbs of a neighboring tree (the site for a rancho in alwars selected near a suitable roosting tree), or upon the ridge of the root, or perhaps on some conrenient perch in the hut itself. where there are always four or five setting hens in baskets hung on the posts. Sometimes the whole fanily remains at the rancho during the reek, returning to tomn on Saturday so that their owners ma be ready for early mas the next morning. On Saturday erening a procession of ox carts a mile long mas be seen en route to the capital.

They have little furniture. In homes of the better sort are usually found tables and benches of ifil rood, cane-bottomed beds, a few chairs, and almost inrariat)ly an altar with the image of a saint enshrined abore it, hefore which a light of cocoanut oil is kept burning. A few homes have handwome heds. tahles. and chairs from the Philippines left hehind hy Spanish ofticials. Homes of the poorer kinds are destitute of bedsteads or tables. the natires sleeping and sometimes eating from mats on the floor.

TSEFUL ARTS.

Thongh it may he said that all the natives of Guam are essentially furmer's yet many of them show decided aptitude for various kinds of handiwork. In Agana there are excellent blacksmiths, silversmiths, carpenters. cubinetmakers, tanners, and shoeusakers, and fairly good masons. In other parts of the island there are men skilled in lime and chatroal burning. A number of the romen are adepts at weaving: mats and bats of excellent quality from pandanus leares; men twist string and make nets of pineapple fiber and ropes from hibiscus bark, 


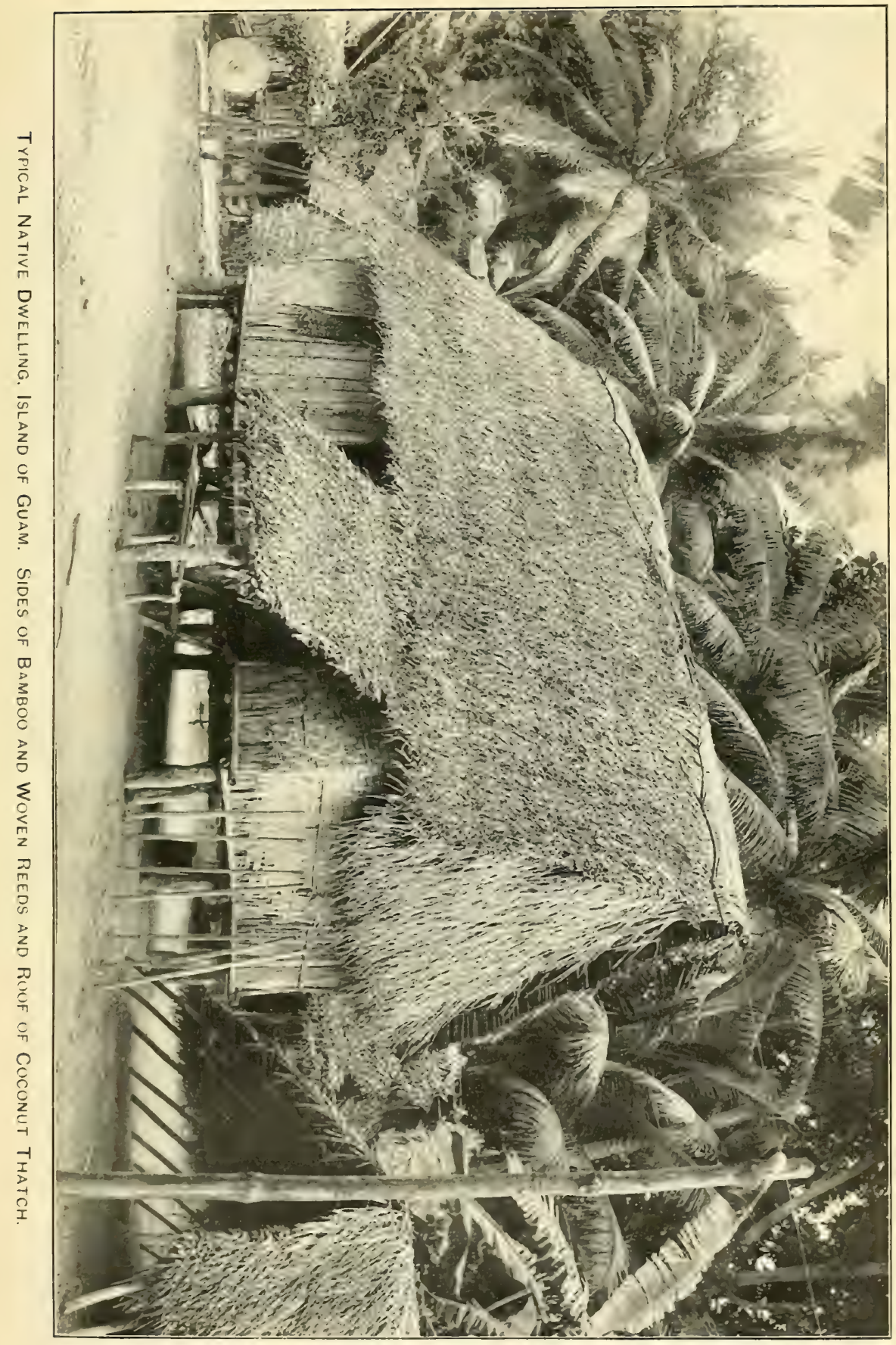



and everybody knows how to prepare coconut leaves for thatching and pandanus leaves for lashing together the parts of a house or rancho. Some of the natives are remarkably versatile, being called upon to practice various callings, as oceasion may require. One of the Spanish governors, who elsewhere speaks somewhat disparagingly of the Chamorros, writes as follows:

The late master armorer of the post, Don Vicente Pangelinan, workerl with greater or less perfection as armorer, locksmith, blacksmith, wood carver, cabinetmaker, carpenter, silversmith, lathe turner. He was well fitted to perform clerical work, having been employed as clerk in the treasury, assisting with the local accounts as well as with the college fund in cases of urgency; speaks and writes Spanish fairly well and speaks English, and remaining after all these accomplishments a person of simple life and modest bearing.

The successor and son-in-law of Don Vicente, the present armorer, also works as gunsmith, locksmith, blacksmith, silversmith, turner, carver, inlayer, clock repairer, and tortoise-shell worker. He is also a thrifty rice grower, and attends personally to his plantations. One of the most interesting sights is to see him take a condemned musket and convert a portion of its barrel into a knife blade, welding in the steel spring for the edge and fitting to it a handle of buffalo horn inlaid with mosaic designs of silver, mother-of-pearl, or tortoise shell. All of this he does with most primitive appliances. With equal skill and apparent pleasure in his work he converts an old piece of iron into a fosiño or scuffle hoe or into a plowpoint. The husband of one of Don Vicente's granddaughters is the principal silversmith of the island. He makes spoons, forks, ladles, cups, or bowls well shaped and finely finished, and he imitates models furnished him remarkably well, melting up worn coin and silver pesos for his material.

The principal cabinetmaker, a Filipino by birth, is also a rice planter. He makes beautiful wardrobes of ifilwood, carving them in designs of his own invention and finishing them beautifully. Not many chairs are made in Guam, as the natives prefer benches or settees. The ordinary tables, benches, and other furniture bear a close resemblance to the forms now popular in the United States known as "mission furniture." Canopies for beds and tops of wardrobes are often carred, and show Philippine influence, the forms resembling those used by the Malayan people. The beds are usually provided with woven bottoms of rattan, like our cane-bottom chairs. There are men in Guam who make these bottoms, but they get their "behuko," as they call the rattan, from the Philippines.

Boards for the sides of houses and for floors are sawed by hand with large two-handled ripsaws, the logs being inclined against a raised platform, so that one man may stand on a stage above and the other on the ground. Serviceable carts are made with tough elastic 
shafts and with solid wooden wheels of Calophyllum wood, which are inclosed in iron tires usually made from old gun barrels.

Leather of excellent quality is made from the hides of cattle and buffalo and from deerskins. The principal tan bark used is that of Pithecolobium clulce, a leguminous tree of Mexican origin. Shoes are commonly made without heels, after the Philippine fashion, the uppers of yellow deerskin, ornamented with red leather, and the soles of cow skin or buffialo hide. Very good shoes are also made after European styles. Ordinarily while working on their farms the people wear sandals, for making which a piece of sole leather is kept on band in each family. Each individual cuts sandals to the shape of his foot, as he may require them, securing them by thongs passing backward on each side of the foot from between the first and second toes.

As a rule, the masonry work on the island, chiefly stone walls and the basements of houses, is substantial but crude. In squaring the stones and in laying them horizontal the mason frequently depends upon his eye, though he may have both square and level at home. The result is, as may well be imagined, that frequently the corners of buildings supposed to be square are by no means right angles, and stone steps and terraces intended to be horizontal are far from it. On having his attention called to such defects the workman may excuse himself by saying, "Ay, señor, I am not a master mason. I didn't know you were so particular about having it square. I'll go home and get my level and square; or will you send your boy to borrow Don Juan's?"

The source of both the stone and the mortar used for building is chiefly coral rock. Coral fresh from the reef is not used, as it contains salt and remains moist for a long time, and the mortar it yields is also salty, with a tendency to remain soft and sticky. Coral hummocks for building are taken from the reef and allowed to weather for a long time, and the best of lime is burnt from coral rock and limestone of the ancient reefs composing the greater portion of the island.

Preparation of FOod.-The principal food staples of the natives are maize, rice, breadfruit, yams, taro, sweet potatoes, leguminous pods and seeds, and sereral species of Cucurbitaceae. They often eat fish of rarious kinds, renison, pork, and chicken, and less frequently beef. Wild ducks (Anas oustaleti) are highly esteemed. The sport of trawling under sail for bonito and other game fish has died out, and tish are caught only in tide pools and with cast nets along the beach. Most of the cooking is done in kitchens adjacent to the dwellings, raised like the latter from the ground and connected by means of a bridge or a solid terrace of masonry filled in with earth. In the kitchen there is a rawed shelf at the end opposite the direction of the prevailing wind covered with earth which is retained by raised slabs along the edge. Stones are arranged in pairs at certain dis- 



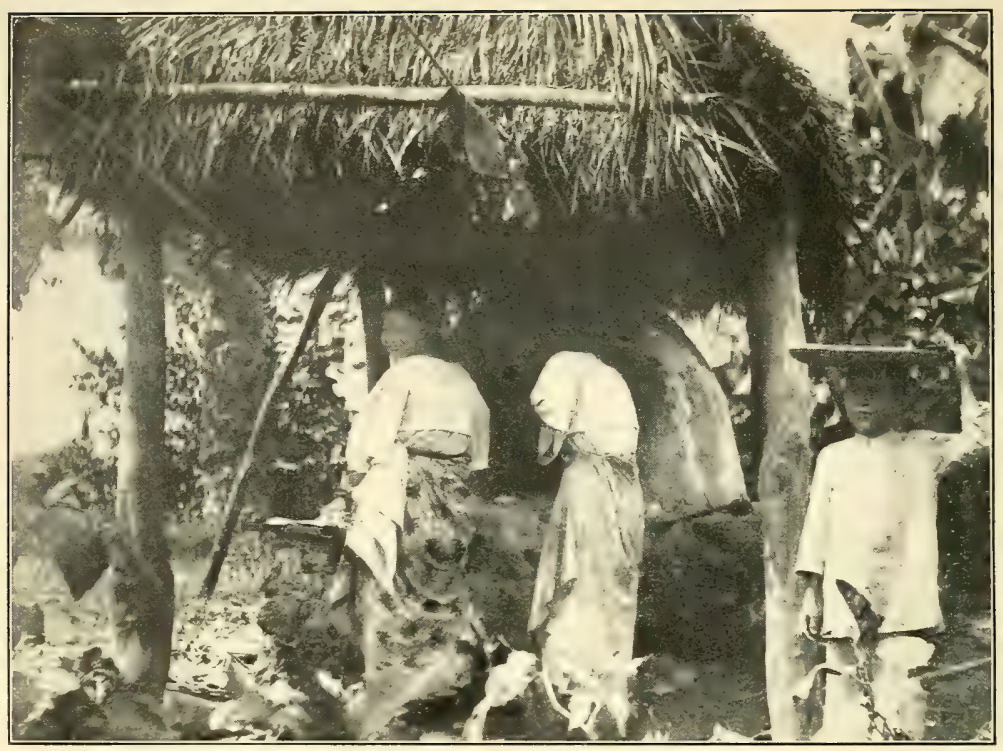

Fig. 1.-A Modern Oven, Island of Guam.

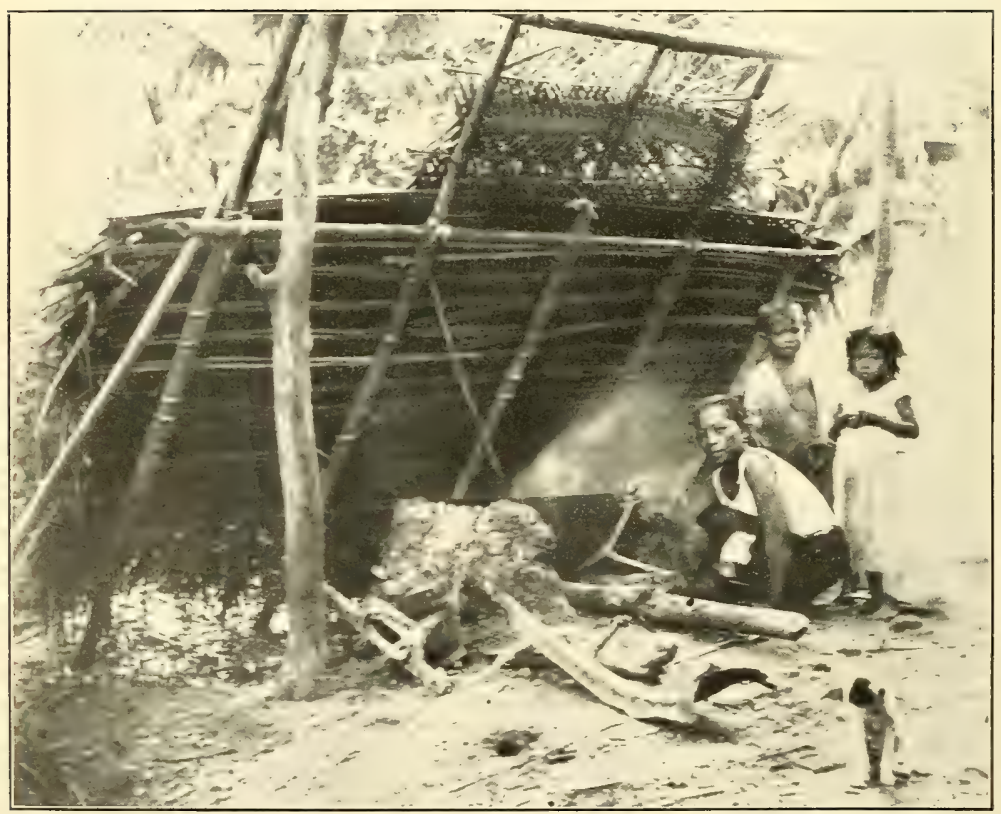

Fig. 2.-Evaporating Salt from Sea Water. 
tances apart to rest the cooking utensils upon, high enough to admit of fagots under the pots, gridirons, and frying pans. The cooking of the present day is very much after the manner of that in Mexico. The excavated ovens of the aborigines are little used except on ranches, and baking is done in dome-shape ovens of masonry which were probably introduced from Mexico. (Pl. XXI, fig. 1.) Bread and breadfruit are baked. Yams and taro are baked or boiled or first boiled and then baked in ashes. Venison and beef are fried or broiled, and fish is cooked in various ways. Coconut oil, when fresh, is used in cooking and is a good substitute for lard and butter. Coconut custard, expressed from the grated meat of ripe coconuts, is used in various combinations, giving a pleasant rich flavor to the dishes into which it enters. Arrowroot of Tace pinnatifida is used for certain sweetmeats, and preserves or dulces are made of soursops, eitrons, and fruits of various kinds. Maize is made into a paste and baked in the form of tortillas, after the Mexican fashion. Tender leaves of taro and other greens are used in place of spinach and asparagus. Coffee and chocolate are ground upon the stone used for making tortillas.

Bread of excellent quality is made from imported wheat flour, fermenting coconut sap being used to leaven it. This sap, when boiled fresh, is converted into sweet syrup and brown sugar. When the fermentation is allowed to continue it yields vinegar of excellent quality. Salt is eraporated from sea water in iron kettles. (Pl. XXI, fig. 2.) Nearly every native is addicted to the use of tobacco and to the habit of betel chewing. Fermenting tuba (coconut sap) is a refreshing drink like cider, and is the common beverage of laborers. Formerly a kind of rum called aguardierte, or "aguayente," was distilled from it on the island. The distillation of this liquor is no longer permitted. The use of opium is unknown.

MENTAL AND MORAI, CHARACTERISTICS.

Though the natives of Guam are naturally intelligent and quick to learn, little has been done for their education, and many of them are illiterate. The college of San Juan de Letran was founded by Queen Maria Anna of Austria, widow of Philip IV, who settled upon it an annual endowment of 3,000 pesos. Through misappropriation and dishonesty the annual income of the college gradually dwindled to about 1,000 pesos. The greater part of this was absorbed by the rector, who was nsually the priest stationed at Agaña, and by the running expenses of the school, which were the subsistence and wages paid to janitor, porter, steward, doetor, and the lighting of the building. A head herdsman was employed with two assistants to look out for the cattle belonging to the school. All of these men were paid salaries, so that there remained for actual expenses of instruction only 192 pesos a year, 98 pesos of which were paid to the head master, 48 pesos 
to his assistant, and 48 pesos for the minor expenses attending the education of "poor children."

The education dispensed was of the most elementary nature. At times it consisted of a course in "music and primary letters" and in giring to a few boys sufficient instruction to serve as acolytes for the priests. Many of the governor's disapproved of the higher education of the natives. Don Francisco Villalobos suggested to the captaingeneral that the college be aholished and that the funds be applied to "general education, to repairs and ornaments of the churches, and to the improrement of gorernment building's and priests' residences on the island." He also recommended that the schoolhouse be converted into an im or guest house for the entertainment of strangers, and that the fixed income therefrom he applied to government purposes.

The supils, it was asserted, were injured rather than benefited by their eat :cation and rendered unfit for future usefulness. On entering $\%$ collect they soon forgot the misery and porerty of their homes, and during their stay of fire or six years became aceustomed to good food, clothing, and lodging, without learning any trade by which they might afterwards earn a living and without forming habits of industry. The discipline was declared to be bad, and ererything tended to make the students incompetent to earn their liring, discontented with their lot, and, the more quick-ritted among them, thorns in the side of the governor, who was often obliged to impose "correctional punishments" upon them."

Another governor, Don Felipe de la Corte, recommended that the education of the natives be limited to the merest rudiments, to aroid their acyuiring a superficial knowledge of the more adranced branches of learning, which would lead to pretensions on their part to be men of education. Such persons, he declared, gare more trouble to the authorities than any other class and were a disturbing element among the natives. In spite of Don Felipe's recommendation the captaingeneral at Manila did not see fit to divert the fund from its original object.

From these and other extracts from the archives it is easily seen that the Fpanish gorernors of the island of Guam discouraged the higher education of the natives not hecause they thought them incapahle of receiring it, hut because they believed they would be more tractable if they remained ignorant.

SOCIAL INSTITUTIONS AND CUSTOMS.

Marriage. - The natives marry at a comparatively early age, and the young couple, though they may continue to live with the family of the hride or of the groom in the town residence, usually enter into

"Don Frameisco Villalobos, letters to the captain-general of the Philippines, inedited, November 16, 1831, and February 9, 1833. 
possession of property which the parents of both have been gradually accumulating for their benefit. A would-be purchaser of a plantation of young coconuts or perhaps of some lumber observed lying under a house will probably meet with a refusal, the owner saying that he has cleared and pianted the cocal for little Juan or Maria, or that he is accumulating a number of good posts so that Pedro may have a house of his own when he marries. Old bachelors and unmarried women are not common in Guan. Most families have several children, differing in this respect from the Samoans, where there are often only one or two, or where many of the women are barren. But before the American occupation the laws of the island did not permit divorce and remarriage, so that new alliances which might be formed by those who had separated could not be legalized. In consequence of this such unlegalized alliances have been held up as examples of the shocking immorality of the island, whereas, in reality, in most cases observed by the writer they were to all intents and purposes marriages in which the husband and wife were mutually faithful and the children in all cases well cared for. At the time of the American occupation prostitution was almost unknown on the island, though there were many cases of couples living together without having been married by the church or civil authorities. These alliances were looked down upon by the more respectable element, but as a rule illegitimacy was not considered a serious misfortune, and an unmarried mother was treated with pitying kindness by her neighbors.

Relations between parents and CHILdREn. - The carefulness of parents to provide for their children has already been referred to. There are perhaps few countries in the world where greater attention is paid to the establishing of a young couple in life, though of course in Guam their wants are comparatively few on account of the simplicity of their surroundings and their mode of living. One of the most striking features to a stranger is the conscientious way in which illegitimate children are provided for. While registrar of property on the island, the writer was struck in many cases by the earnest desire of fathers to secure legal titles for their illegitimate children to houses and plantations especially prepared for them, and the records show that some of the best estates on the island were the creation of unmarried parents for their children. On their part sons and daughters show the greatest respect and affection for their parents, recognizing their authority as long as they live. It is not unusual for a man or woman of 40 or 50 years to ask permission of his parents before engaging in a business transaction, and the spectacle of old women, abandoned and forgotten by their children, acting as water carriers, etc., so common in Samoa and among our Indian tribes, is unknown in Guam. Parents are tenderly eared for in their old age, treated with deference even when in their dotage, and depart this life arcompanied 
by the prayers of all their family, all of whom leave their occupations and come from the most distant parts of the island to be with them during their last moments. One of the most touching examples of filial piety witnessed by the writer was the case of a middle-aged married man who had been sued by his sister for the possession of some property. He made a clear, manly, straightforward statement to the court, but when his old mother testified against him he burst into tears, saying he could not contradict her because she was his mother, though it was found afterwards that the old lady had been influenced by her daughter to testify falsely.

RESPECT FOR THE LAWS.-In referring to the law-abiding spirit of the natives Governor Schroeder writes as follows:

I have had occasion at rarious times to note and to mention to the Department that many little actions on the part of the natives of the island indicate a friendly feeling for the American Government, its flag, and its representatives here. This feeling is quite unmistakable and will, I hope, become well founderl. * * * It is hoped that in time one prime difficulty will be removed, viz, the dread by this peaceable and law-abiding people of complaining and testifying against those who maltreat them. To preserve law and order among the people themselves is a matter of no difficulty; the little company of [native] insular artillery, which forms the constabulary, although inefticiently armerl, is an excellent body of respectful and reliable soldiers, with whose support alone there could be no hesitation in undertaking the government of the island. $a$

Feasts and Cerenonies. - On the erening before a wedding, fandangos, or dancing parties, are giren at the homes of both the bride and groom. Refreshments are served and betel nuts and cigars are passed to the guests. The guests attend both entertainments, going in parties from one house to the other. The music for dancing is furnished either by a violin and guitar, an accordion, or a piano, if there be one. Waltzes and square dances are performed, and occasionally a Spanish "fandango." The redding is solemnized in the church the next morning at early mass, and there is always a wedding breakfast, to which the family and special friends of the bride and groom are invited.

The usual church feasts are celebrated, especially those of Corpus Christi and of boly week. The ceremonies at funerals are rery impressive. It is customary for all the relatives and friends of a dying person to assemble at the house, which is often too small to hold them. The custom of offering refreshments, betel nuts, and cigar's recalls the death-bed scenes of the olden time described in the history of England and other European countries, when it was not unusual for thrifty persons in making their wills to ask that there should be no expenditure for spirits at their funeral. Though there is usually great

a Schrouler, Seaton, commaniler, [. S. Nary, Report of the (iovernor of Guam, July 8, 1901, in Report of the Secretary of the Nary for the year 1901, part 1, pp. 82-83. 
demonstration of grief for the dead, yet the family is soon comforted, firmly believing in the immortality of the soul and of the ultimate happiness of the departed. The body is accompanied to the church and to the cemetery by the men, who go on foot, the women remaining at home. As a rule the coffin is carried by four bearers, four others walking behind them to relieve them. At the cemetery the body is either placed in a boveda, or vault, the entrance to which is closed py a stone and sealed with mortar, or it is buried in consecrated ground. Usually the niche in the boveda is rented for a certain period of time, at the expiration of which the bones are removed and buried.

Sports AND PAstimes. - Sunday is observed by all as a holiday. Nearly everybody attends mass in the morning. Before the arrival of the Americans it was customary to have cockfights in the afternoon, and the government received a regular income for its share of the receipts of the cockpit. Sunday cockfights were abolished by a general order of the governor, and thus a check was given to the passion of gambling, which with some of the natives amounted to a vice. The natives have no other sports except hunting for deer with dogs and guns. The boys amuse themselves with various games of Philippine origin. Kiteflying is popular, especially in the trade-wind season. In this sport some of them are experts, causing their kites to fight one another in the air, like fighting cocks.

INDUSTRLAL SYSTEM.

Manner of Securing Livelihood.-The people of Guam are essentially agricultural. There are few masters and few servants on the island. As a rule the farms are not too extensive to be cultivated by the family, all of whom, even the little children, lend a hand. Often the owners of neighboring farms work together in communal fashion, one day on A's corn, the next on B's, and so on, laughing, singing, and skylarking at their work, and stopping whenever they feel so inclined to take a drink of tuba from a bamboo vessel hanging to a neighboring coconut tree. Each does his share without constraint, nor will he indulge so freely in tuba as to incapacitate himself for work; for experience has taught the necessity of temperance, and everyone must do his share if the services rre to be reciprocal. In the evening they separate, each going to his own rancho to feed his bullock, pigs, and chickens. After a good supper they lie down for the night on a pandanus mat spread over an elastic platform of split bamboo.

None of the natives depends for his livelihood on his handiwork or on trade alone. There are men who can make shoes, tan leather, and cut stone for building purposes; but such a thing as a Chamorro shoemaker, tanner, stone mason, or merchant, who supports his family hy his trade is unknown. In the midst of building a stone wall the man who has consented to help do the work will probably say: "Excuse" me, Señor, but I must go to my rancho for three or four days; the 
weeds are getting ahead of my corn." And when lime is needed, the native to whom one is directed may say: "After I have finished gathering my coconuts for copra I will get my boys to eut wood and gather limestone to make a kiln. Never fear, Señor, you shall have your lime within six weeks." On one occasion a blacksmith was delayed two weeks in making a plow, owing to the fact that the man from whom he got his charcoal had been so busy supplying visiting vessels with fruits and vegetables that he could not find time to burn it.

ABsENCE OF POVERTY. - The result of this condition of society is that when a father dies the wife and children are not left ciestitute, as would be the case if they depended on the results of his handiwork alone. The crops continue to ripen and are gathered in due time by the family; the weeds and worms are kept out of the tobacco; the coffee bushes bend each year under their weight of berries; the coconuts, as usual, yield their annual dividend. Indeed, in most cases the annual income in provisions is amply sufficient to keep the family supplied with its simple clothing, some flour and rice brought by the traders from Japan or America to exchange for copra, and perhaps a few delicacies, a ribbon or two, or a kerchief to go over the head, and a new saint to place in the little alcove of the side room, where the light is always kept burning.

Absence of wealth. - Very few of the natives have accumulated money or property of value. Some of them own fine coconut groves, rice fields, and coffee plantations, and a few own small herds of cattle and buffalo. At first sight it seems an impossibility that poverty should exist where food can be produced in such abundance; and indeed were it not for the frequent hurricanes which sweep the islands there would be little necessity for accumulating capital. In spite of the dearth of food which invariably follows hurricanes, the majority of natives are not inclined to cultivate larger crops than are absolutely necessary for the immediate subsistence of their families. They say that corn and rice will become moldy and spoil, or will be infested by weerils if kept a long time, and that all their extra labor in planting and reaping will be lost. This demonstrates the necessity for capital, and capital not in perishable rice and corn, but in the shape of good indestructible and dirisible money having intrinsic value. In this Way surplus food could be converted into money at the end of a good harvest and reconverted into food (imported rice or flour or tinned meats) in times of scarcity. As it is, when crops are ruined and the natives see starration staring them in the face, the traders will not furnish them with supplies in return for the superfluous rosaries and trinkets they have accepted in exchange for their copra and other marketable products, and they have to go to the woods for cycas nuts and wild yams in order to keep themselves alive until succor comes from abroad. 
Peonage.-Before the arrival of the Americans in Guam it was the practice of certain enterprising citizens of the island to encourage the natives to go into debt, advancing them goods or money for the use of their families or for the payment of funeral expenses and masses for the dead, in order to engage in advance as much copra as possible or to secure labor for their fields. As a rule very poor wages were paid; the employer by managing to make further advances from time to time increased rather than diminished the debt and kept the debtor in continuous servitude. A written contract was always drawn up before the first loan would be advanced, by means of which the debtor promised to work for his creditor until his indebtedness should be canceled." Shortly after the American occupation complaints were receired by our officials that certain servants had "escaped," and attention was called to the system by which improvident or unfortunate natives were virtually made slaves, having sold themselves into bondage. By order of the governor all contracts binding natives to labor in consideration for money advanced to them were declared void and the natives were permitted to work where they could get the best price for their labor, and to pay their creditors in money. Barter, or exchange of produce for imported goods, was also forbidden; so that the natives were not obliged to accept articles of which they really had no need, but were paid in money, and thus might begin to accumulate capital to serve them in time of necessity. Not only was this a benefit in itself, but it allowed them to spend their money where they could do so to the best advantage, whereas under the old order they were obliged to accept what the traders, to whom they had mortgaged their crops, chose to give them.

LABOR.-The natives of Guam hàve often been accused of laziness because they will not voluntarily raise large crops nor work as day laborers for others. Don Felipe de la Corte, one of the wisest and best of the Spanish governors, says, however, it does not follow because they did not cheerfully obey orders to plant excessively large crops for the benefit of others that they are naturally indolent. Notwithstanding the fact that they had at times produced more food than could possibly be consumed, there was no provision for storing it, and when hurricanes laid waste their fields they found themselves as before, without resources, and consequently they thought it was better for them "to work little than to work in vain. Owing to this they are accused of laziness, which they are far from manifesting when they clearly see the good acconplished by their labor."

Governor Schroeder, in his official report to the Navy Department, says: "

In the study of this question [exploitation of the unoccupied public land] account must be taken of a noticeable trait of the Chamorro character, viz, the pride and 
happiness in the possession of land, which results in the community being composer of a large number of small landowners. The effect of this is, of course, to minimize the amount of labor that can be hired, with the direct consequence that large holders are rare and that application of capital would be handicapped by the dearth of labor. While this seems to offer something of a barrier to material productiveness, it is a very wholesome trait, which it is to be hoped will hold its own against outside influences. $a$

Means of comudnication.-Transportation is effected by boats as well as by means of oxen, cows, and buffaloes. (Pl. XXII.) Owing to the difficulties met with in crossing the mountainous interior of the southern portion of the island, especially in the rainy season, when the roads are slippery and dangerous, transportation from the vicinity of Inalahan, on the east coast, to Agaña, on the west coast, is often carried on in boats, the small bay of Hahahyan, at the southern end $c^{+}$the island, being used as a landing place for that region. This bay car be entered only by boats of moderate size. The journey from Agaña to Merizo is also much easier by sea than by land, and boats are used whenever articles of considerable bulk are to be transported between the two points.

There are only three good roads on the island. The best is that leading from Punta Piti, the landing place of the port to Agana, the capital, which continues northward to Apurguan, the site of the late village of Maria Cristina, inhabited by Caroline Islanders. This follows the west coast of the island throughout its entire extent and is almost level. Another road leads from the landing place at Apra, on the south shore of the harbor of San Luis, to the village of Agat, and from this road there is a third branching off to the rillage of Sumai, on the peninsula of Orote.

There is a road across the island at its narrowest part, from Agaña to Pago, which can be traversed only on foot or on the backs of animals. During the administration of Don Pablo Perez, who made use of convict lahor to carry on the public works of the island, this road was for the first time made passable for carts, which fact is duly recorded on a tablet in a small shed erected on the crest of a hill about halfway across the island. Now it is impossible for a cart to cross the island by means of this road, and in the rainy season parts of it are no bogey that it is almost impassable with pack animals. The road from Punta Piti to Agat, which passes around the margin of the harbor of San Luis, is so bad in places that it is frequently impassable on horsehack. For crosing boggy places and passing muddy fords oxen and butfaloes are found to be much more efficient steeds than horses on account of their natural propensity for wading. From Agat to Merizo, the village at the southern extremity of the island, the road is interrupted in several places by abrupt headlands, which must either be rounded by entering the sea or crossed by very steep

"Governor Sihrueter's report, in Report of the Secretary of the Nayy for the year 1901, pp. 82-83. 


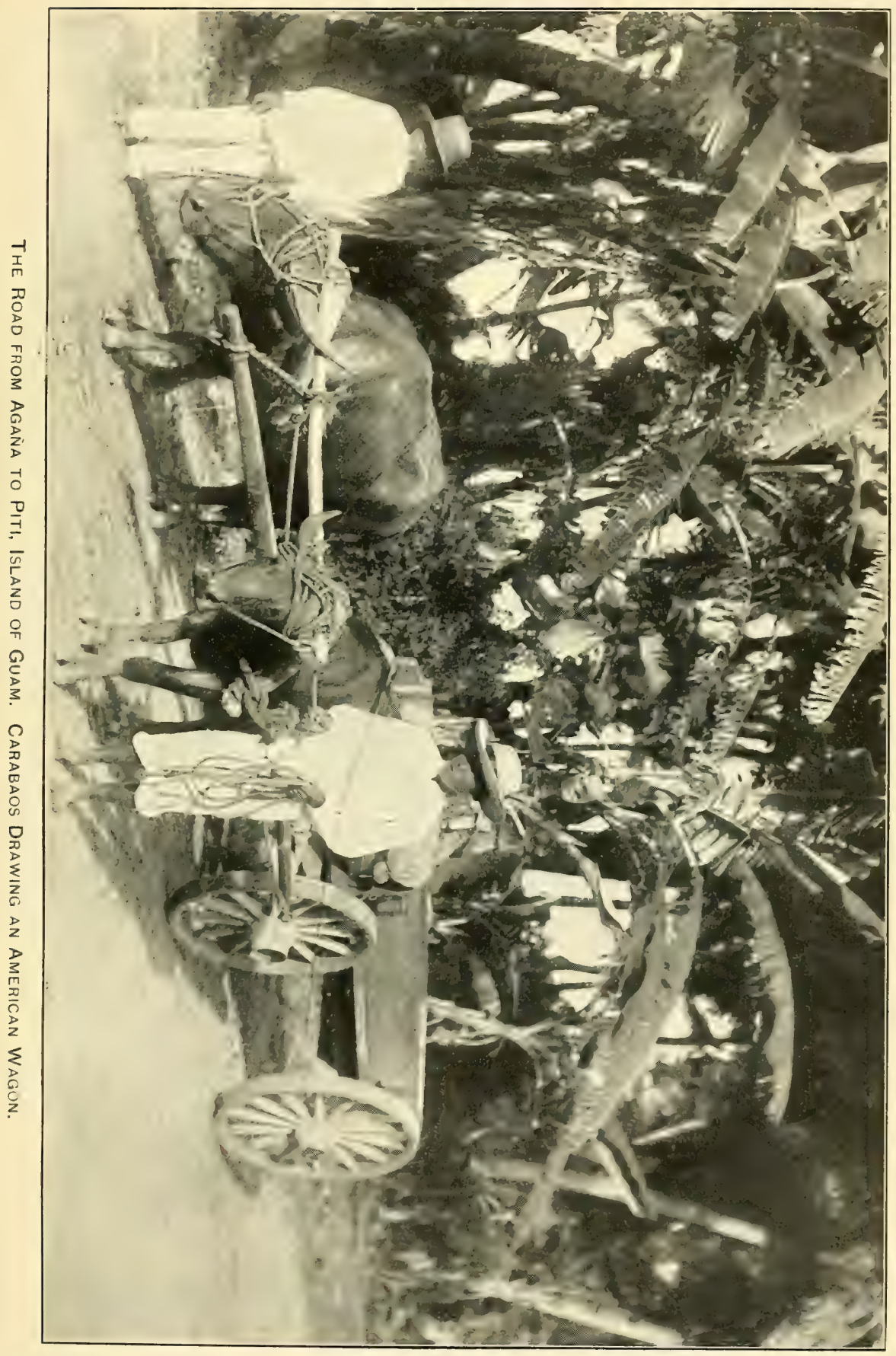



paths. From Merizo to Inalahan, around the southern end of the island, several marshy places intervene, so that cart traffic between these villages is impossible. Going northward along the east coast, from Inalahan to Pago, the road encounters the mouths of several rivers, two of which must be crossed on rafts or "balsas," composed of several layers of large bamboos. There is a trail crossing the island from Inalahan to Apra, which in many places is precipitous and is slippery and dangerous where the soil is of heavy red clay devoid of regetation. Where this trail descends to cross a river the path has become so deeply worn that its vertical sides are as high as a horse's head.

The road leading from Agaña to the fine agricultural districts of Yigo, Santa Rosa, Mataguag, Mogfog, and Finaguáyog may be traversed by carts, but it is far from good. As Governor Schroeder has said in his official report" on the economic conditions in Guam, "Lack of good means of transportation is one of the chief drawbacks to the development of the island." In speaking of the most important agricultural and grazing region, which lies to the eastward and northward of Agaña, Governor Schroeder expresses the opinion that good cart roads, capable of withstanding the heavy and frequent rains, would probably lead to the acquisition of more public land by private persons.

Individual efforts [he says] should be encouraged fully as much as collective cooperation, affecting, as it does, the entire community, and to this end it is proposed to lay out one arterial route, tapping in general plan, the middle of the region, and build a good road there as soon as may be. The country being flat, no difficulties should exist beyond having, in some parts, to carry the material for roadbed and surface some distance. With this thoroughfare created in place of the present miserable boggy trail, it is believed that the present and future owners of neighboring ranches will build small roads leading to it, and that agriculture will receive an impulse. This proposed road will be some 15 miles in length. The cost of an entirely new road there is estimated at about 45,000 pesos, but a few short stretches of rock here and there will diminish the cost. The expenditure of 30,000 pesos, spread over two years, should produce very useful results. Later on, in after years, perhaps, (art-road communication should be established between towns on the southeast and southwest coasts and the harbor of San Luis de Apra and Piti. This will best be done by a shore-line road around the south end and up the west coast. In many parts this will require causeways to be built in the water around high projecting points, which now have to be climbed; but as the water is very shallow this work should not be as expensive as would first appear, and as the shore is protected from the sea by a barrier reef it would not be liable to injury by the sea except during hurricanes of unusual violence. A limited amount of attention could be j,rofitably given to the present bull paths or trails across the mountainous interior of the island, but I am convinced that for the purpose of traffic on any useful seale direct routes over the mountains would best be eschewed in favor of the shore-line route.

Each able-bodied native is required to contribute ten days each year to work on the roads of the island, or in lieu of this to pay a personal tax of $\$ 8$. A tax of 1 per cent was levied on all real estate, but during 
the past year, in consequence of the poor financial condition of the natives, half of this has been remitted. The proceeds of this tax go for the benefit of the schools and roads of the island, and the natives do not complain of the taxation.

Present conditions.-From a letter recently received from one of the most intelligent and enterprising of the residents of the island the information in the following three paragraphs is taken:

Government employees receive salaries twenty times greater than under the administration of the Spaniards. Simple laborers receive more than a dollar a day (silver) and carpenters and masons $\$ 3$ a day. Servants will not work for less wages than 20 pesos (silver) a month. Notwithstanding these high rates money is by no means plentiful in the island. Employees of the island government are paid from the island funds. In cases where work is performed for the naval authorities they are paid from federal funds, but these cases are rare. The only money coming to the people from the outside, in addition to that paid in wages to servants and laundresses, is what they receive from visiting ships and officers stationed on the island for fruit, eggs, and fowls. No other money is brought to the island; for copra, the only article of export, is paid for in clothing, sugar, flour, rice, candles, and kerosene. On the other hand, the Japanese and American trading companies collect all the money of the island and send it home.

In March, 1904 , rice was $\$ 25$ per sack; flour, $\$ 13$ per barrel of 100 pounds; corn, $37 \frac{1}{4}$ cents a ganta; ${ }^{\prime \prime}$ chickens, $\$ 1.25$ apiece; eggs, $6 \frac{1}{2}$ cents each; meat, 25 cents a pound. The result is that the natives are compelled to depend more and more upon the island products for their subsistence.

In the ciril hospital the sick are cared for by medical officers of the Nary, and medicines are dispensed free of charge to all those needing them. A number of marriages have taken place between Americans employed by the government and native women. Most of these marriages have proved happy, but there are sereral cases in which American marines have abandoned their native wives and left the island at the expiration of the term of their enlistment. The natives are very anxious for the establishment of a ciril government on the island. citizenship for themselves, and public schools for their children. A supply of pure drinking water is sorely needed in Agaña, where all the wells are polluted, and a system of scwers is necessary for the health of natives and officials.

STATISTICS OF COMMERCE, POPULATION, ETC.

Foreigr commerce.-From the report published by the United States Treasury Department for the year ending June 30, 1903, the following information is taken: 
The principal imports are lumber, cotton fabrics, flour, rice, sugar. kerosene, candles, and distilled spirits. The lumber comes principally from the United States; the cotton fabrics from Japan, the United States, the Caroline Islands (probably of German manufacture), and the Philippines; the flour from the United States and Japan; the rice from Hongkong and Japan; the sugar from the United States, Japan, and Hawaii; the kerosene from the United States and Japan; the majority of candles from Japan; and the distilled liquors from Hawaii, the United States, Japan, and the Philippines.

The only export is copra, or dried coconut meat. Of this the greater part is shipped to Japan, the rest to the United States. During the year 1903 money in the form of specie was sent from Guam to Japan amounting to $\$ 18,550$. The amount sent to the United States is not recorded.

Population of Gram.--A census of the island of Guam was taken in August, 1901, in obedience to the orders of Governor Schroeder, with the following results:

TABLE I.-Population according to villages.

\begin{tabular}{|c|c|c|c|}
\hline Villages. & Males. & Females. & Total. \\
\hline $\begin{array}{l}\text { Agaña and its dependent villages } \ldots \ldots \ldots \ldots \\
\text { Agat (village proper) } \\
\text { Agat (district of Sumai) } \\
\text { Merizo (village proper) } \\
\text { Merizo (district of Umatag) } \\
\text { Indahan }\end{array}$ & $\begin{array}{r}3,216 \\
397 \\
331 \\
237 \\
123 \\
262\end{array}$ & $\begin{array}{r}3,616 \\
446 \\
365 \\
279 \\
126 \\
278\end{array}$ & $\begin{array}{r}6,832 \\
843 \\
696 \\
516 \\
249 \\
540\end{array}$ \\
\hline Total ... & 4,566 & 5,110 & 9,676 \\
\hline
\end{tabular}

NoTE.-In this table are included only the residents of the island, not those here temporarily, nor the United States forces and employees of the naval station.

TABLE II.-Population according to nationality.

\begin{tabular}{|c|c|c|c|}
\hline & Males. & Females. & Total. \\
\hline 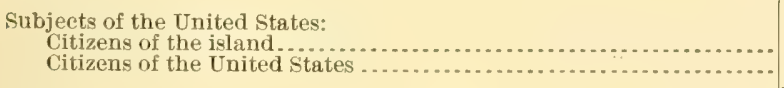 & $\begin{array}{r}4,539 \\
6\end{array}$ & $\begin{array}{r}5,091 \\
8\end{array}$ & $\begin{array}{r}9,630 \\
14\end{array}$ \\
\hline Total ........ & 4,545 & 5,099 & 9,644 \\
\hline 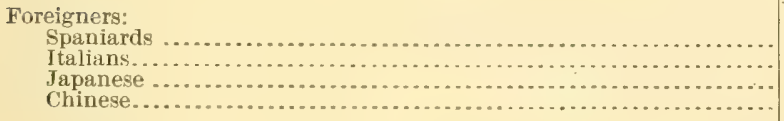 & $\begin{array}{r}6 \\
0 \\
12 \\
3\end{array}$ & $\begin{array}{l}8 \\
2 \\
1 \\
0\end{array}$ & $\begin{array}{r}14 \\
13 \\
13 \\
3\end{array}$ \\
\hline Total.... & 21 & 11 & 32 \\
\hline $\begin{array}{l}\text { Resume: } \\
\quad \text { Subjects of the United States } \ldots \ldots \ldots \ldots \ldots \ldots \\
\text { Foreigners ........ }\end{array}$ & $\begin{array}{r}4,545 \\
21\end{array}$ & $\begin{array}{r}5,099 \\
11\end{array}$ & $\begin{array}{r}9,644 \\
32\end{array}$ \\
\hline Total ........ & 4,566 & 5,110 & 9,676 \\
\hline
\end{tabular}


TABLE III.- Population with reference to place of trinth.

\begin{tabular}{|c|c|c|c|}
\hline Place of birth. & Males. & Females. & TotaI. \\
\hline 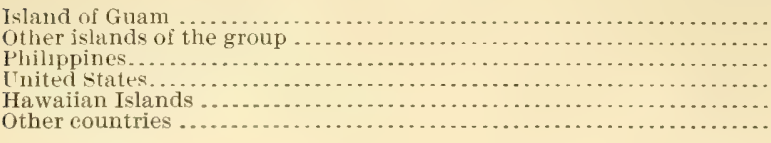 & $\begin{array}{r}4,460 \\
15 \\
56 \\
5 \\
0 \\
30\end{array}$ & $\begin{array}{r}5,079 \\
7 \\
9 \\
7 \\
2 \\
6\end{array}$ & $\begin{array}{r}9,539 \\
2.2 \\
65 \\
12 \\
2 \\
36\end{array}$ \\
\hline Total .. & 4,566 & 5,110 & 9,676 \\
\hline
\end{tabular}

TABle IV.-Educational statistics.

Knowing how to read and writ

Able to read and to sign name.

Able to read only.

Able to sign name only.

Absolutely illiterate (over 7 years old)

Total number above the age of 7 years

Number of children younger than 7 years.

Total population.

\begin{tabular}{|c|c|c|c|}
\hline Males. & Females. & Total. & $\begin{array}{l}\text { Approxi- } \\
\text { mate per } \\
\text { cent. }\end{array}$ \\
\hline $\begin{array}{r}2,203 \\
40 \\
665 \\
11 \\
541\end{array}$ & $\begin{array}{r}1,236 \\
30 \\
1,775 \\
5 \\
965\end{array}$ & $\begin{array}{r}3,439 \\
70 \\
2,440 \\
16 \\
1,506\end{array}$ & $\begin{array}{c}46 \\
1 \\
3: \frac{1}{2} \\
20^{\frac{1}{4}}\end{array}$ \\
\hline $\begin{array}{l}3,460 \\
1,106\end{array}$ & $\begin{array}{l}4,011 \\
1,099\end{array}$ & $\begin{array}{l}7,471 \\
2,205\end{array}$ & $\begin{array}{r}100 \\
\ldots .\end{array}$ \\
\hline 4,566 & 5,110 & 4,676 & \\
\hline
\end{tabular}

Note.-From the above table it will also be seen that only $15 \frac{2}{3}$ per cent of the males and 24 per cent of the females who have passed the age of 7 years are absolutely illiterate.

Populatiox of the remaining islands of the Groct.-Only seven of the northern islands now known as the "German Mariannes," are inhabited. The population is divided as follows, according to a census taken in April, 1902: ${ }^{a}$

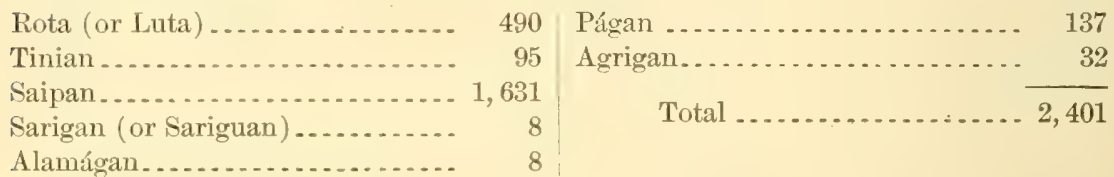

This population inhabits 626 square kilometers, so that the people are distributed according to the proportion of 3.8 to each square kilometer. According to nationality the population is divided as follows:

Native Chamorros and Caroline Islanders ...................... 2, 357

Malayans ................... 3

Chilians, Peruvians, and Mexicans. $\quad 15$

Japanese..................... 18

spmiards.................. 3

Giermans..................... 7

STANDARDS OF MEASLRE.

Land is measured in Guam according to the metric system, 1 hectare being equal to 2.471 acres.

"Fitzner, Ruclolph, "Die Berülkerung der leutschen Südseekolonien," in Globus, vol. 84, p. 21. (July 9, 1903.) 
The measurements of weight and capacity are those formerly used in the Philippines. They are gradually being replaced by the metric system. I am indebted to Mr. Louis A. Fischer, of the United States Bureau of Standards, for correcting the following tables.

Linear measure.

1 braza $=1.672$ meters $=2$ varas $=65.82$ inches.
1 vara $=836.00$ millimeters $=3$ pies $=32.9$ inches.
1 pie $=278.70$ millimeters $=12$ pulgadas $=10.97$ inches.
1 pulgada $=23.22$ millimeters $=12$ líneas $=.91$ inch.

Measures of capacity.

DRY MEASURE.

1 kaban or cavan $=25$ gantas $=99.90$ liters $=2.75$ U.S. bushels $=11$ pecks.

1 ganta $=8$ chupas $=3.99$ liters $=.44$ U.S. peck $=3.52$ quarts.

1 chupa $\quad=4$ apatanes $=.499$ liter $=.44 \mathrm{U} . \mathrm{S}$. quart $=.88$ pint.

Liquid measure.

1 tinaha $=16$ gantas $=63.84$ liters $=14.02$ gallons.

1 ganta $=8$ chupas $=3.99$ liters $=3.52$ quarts.

1 chupa $=3$ copas $=.499$ liter $=.88$ pint.

Measures of weight.

1 quintal $=4$ arrobas $=46.012$ kilograms $=101.44$ pounds.

1 arroba $=25$ libras $=11.503$ kilograms $=25.36$ pounds.

1 libra $=2$ mareos $=.460$ kilogram $=16.23$ ounces.

1 marco $=8$ onzas $=.230$ kilogram $=8.12$ ounces.

1 onza $=16$ adarmes $=28.758$ grams $=1.02$ ounces.

1 picul $=10$ chinantas $=62.550$ kilograms $=137.9$ pounds.

1 chinanta $=10$ cates $\quad=6.255$ kilograms $=13.79$ pounds.

1 catty $=16$ taels $=.626$ kilogram $=1.38$ pounds.

1 tael $=39.094$ grams $=1.38$ ounces.

A kaban of cacao weighs 38.6 kilograms.

A kaban of rice weighs 60.272 kilograms.

\section{AGRICULTURE OF THE ISLAND.}

SOILs. $a$

The STRAND. - The beaches are composed of fine coral sand and are especially well adapted to coconut plantations. Specimens of this soil examined by the Bureau of Soils, United States Department of Agriculture, were found to contain considerable organic matter, though not of such a nature as to be readily decomposed, and for this reason it might be well to apply manure to it. Considerable organic matter is constantly being added to the stretches of beach in the form of decaying vegetation and animal matter from fragments of fresh coral and shellfish cast up by the sea and dispersed by the wind. From prehistoric times extensive coconut groves have been continuously growing along the west coast of the island without apparent exhaus-

" I am indehted to Mr. Milton Whitney, chief of the Bureau of Boils, for much of the following information. 
tion of the soil. On the east coast, which is exposed almost constantly to stiff winds from the eastward, no coconut groves occur, and almost the only tree found growing near the waters edge is the Polynesian ironwood, Casuarina equisetifolia. At a short distance from the beach, however, in places more sheltered from the wind, fine coconuts are produced. Bananas, plantains, eggplants, peanuts, garden vegetables, and several kinds of fruit trees are grown by the natives along the beach, and great breadfruit trees and mangoes are also found growing in what appears to be nearly pure sand. Near Agaña great stretches of sandy beach are covered with beds of seaside daffodils (Pancratium 7ittorale), and the outer strand is carpeted with the goats-foot convolvulus (Ipomoea pes-capr(ce) and sereral leguminous plants. These must all contribute humus to the soil and serve to increase its fertility.

Marshes. - Marshes of sufficient elevation to admit of drainage are planted in rice. Where the water is stagnant and the soil is sour rice can not be grown. Several attempts have been made to cultivate the large swamp, or "ciénaga," near Agaña, but they hare not as yet proved successful. This swamp is but a foot or two above the level of high tide. It was once a lagoon and from its general level a few hillocks rise like islands, which are covered with coconuts and shrubbery. Patches of the ciénaga are cleared each year of the reeds which cover it (Trichoon) and are planted in taro, and in a number of places along the margin are groves of cocoanuts. Near Matan-hanom, at the upper end of the ciénaga are small plantations of cacao and thrifty abaká, or "manila hemp" plants. The latter grow without care and are not utilized. Swamp land is plowed with the aid of buffaloes. It is divided by low mud banks into fields of moderate size. It contains considerable organic matter from the rice stalks, which are turned under after the crop has been harvested.

In the southern portion of the island there are a number of low, damp tracts of land at the mouths of streams. The soil corering them is deep and black, and has evidently been deposited by slowly-flowing currents. Where this land has been allowed to lie idle it becomes solidified like adobe, and in the dry season is crossed in every direction by deep cracks. Such an area may be seen in a tract on the west side of the Maso River, near Tepungan, which was formerly the property of the Sociedad Agricola de la Concepeion. With proper irrigation there is no reason why it should not be made to yield good returns. Other low-lying tracts are planted in sugar cane, but this industry has nearly died out in Guam. Fine tillable tracts lie near the mouths of the Asan, Sasil, Laguas, Aguada, Guatali, and Atantano rivers, and on the east side of the island near Inalahan.

INTERIOR VALLEYS. - In low-lying interior valleys, sheltered from the winds which constantly sweep the island, are a number of fertile tracts. On the east side of the island the valley of the Talofôfô River 



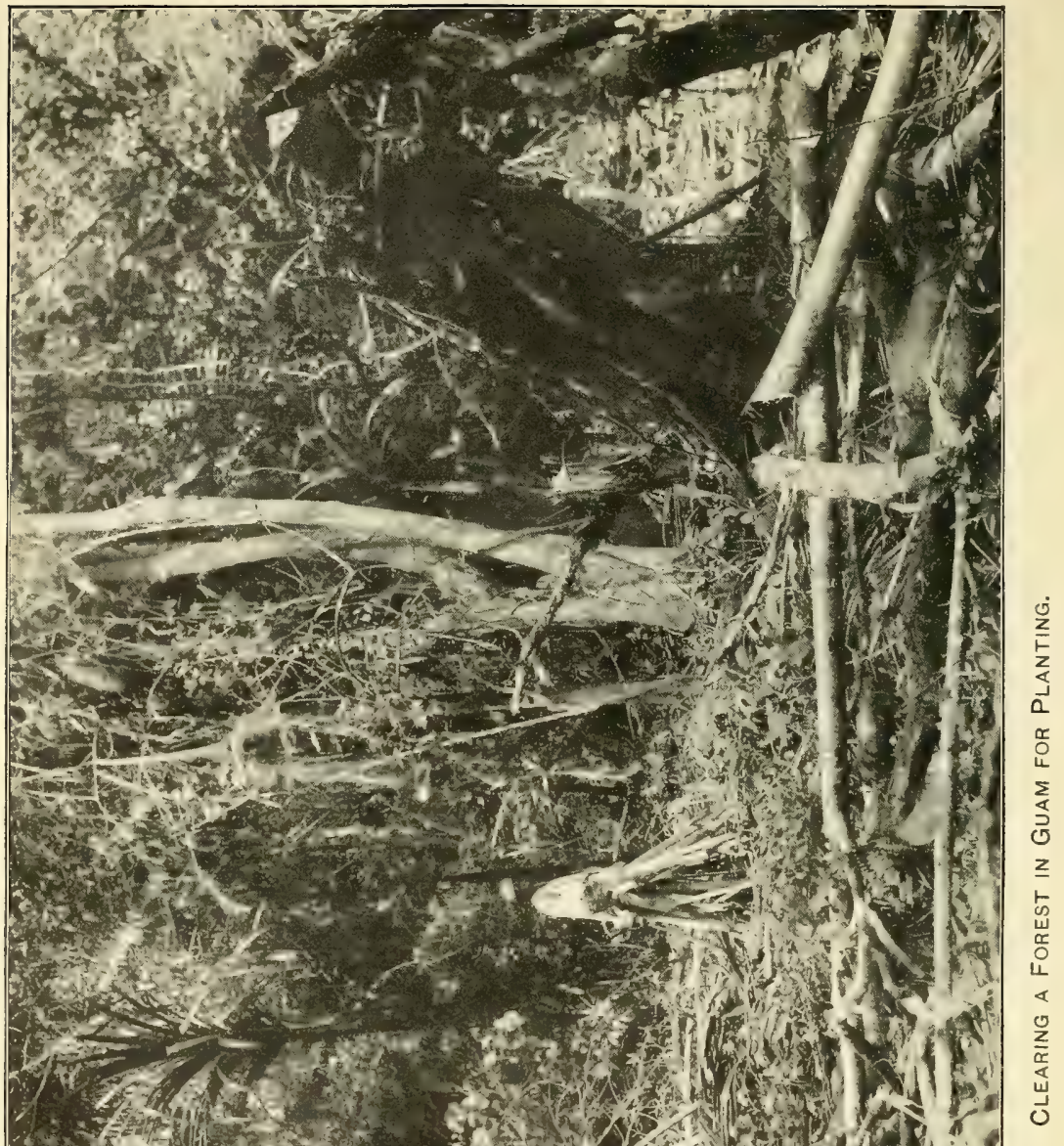

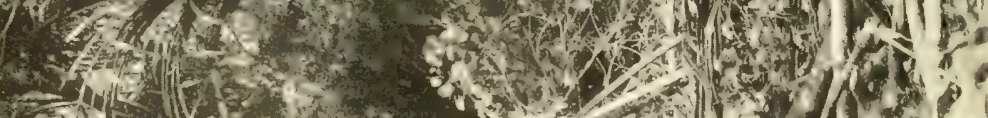
-

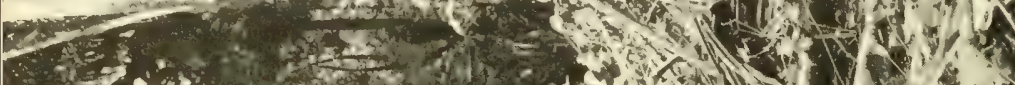

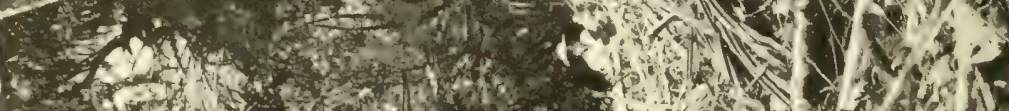

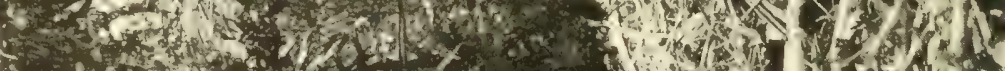

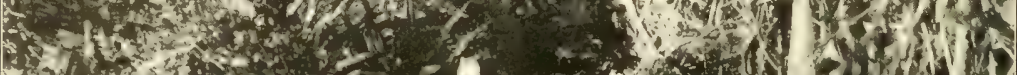

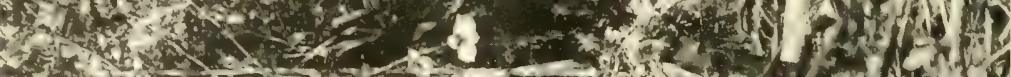

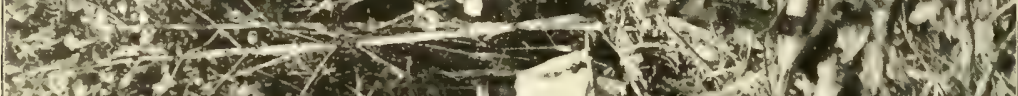
H.

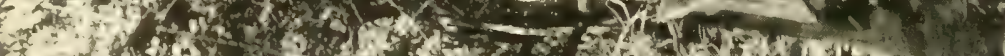

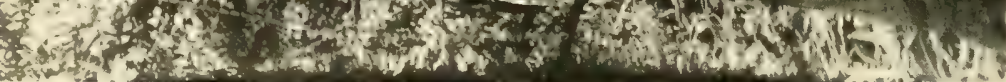


is especially rich. During the rainy season it is for the most part flooded, but in December it becomes sufficiently dry to admit of cultivation, and yields a harvest of corn at a time when corn can not he grown on higher and drier land. In the northern part of the island the regions known as Santa Rosa, Matáguag, and Yigo are famous for the excellence of their products. These regions have been less cultivated than those in the center and south of the island, owing to the fact that there are no sources of water supply for man or animals with the exception of one or two small streams in the immediate vicinity of Mataguag and Santa Rosa, where the platform of porous coralliferous limestone is pierced by volcanic outcrops. An analysis of the best soils of this part of the island shows that they consist largely of heavy reddish clay, and are comparatively rich in nitrates. Where the land is uncultivated it is covered with forest growth. When the forest is cleared (PI. XXIII) it is first planted in land taro, bananas, and plantains, and when the stumps are burned and the land sufficiently clean coconuts, cacao, and coffee are planted. Oranges of excellent quality are produced in the Yigo and Santa Rosa districts, and in sheltered places fine cacao is successfully grown. The coffee of these districts is also of excellent quality. The determination of the water soluble plant food constituents in these soils, which was made by the Bureau of Soils, United States Department of Agriculture, shows that they compare very farorably with tropical soils in general. All are relatively high in lime, due to their coral origin. The amounts of potassium in the samples examined are large as compared with the soils of the United States, and the large amount of nitrates in the Yigo and Matáguag soils is especially noteworthy, characterizing them as very productive.

THE MESA. - The northern half of the island consists almost entirely of a raised platform of coralliferous limestone called the "mesa" or "meseta." Its surface is covered with a layer of soil often only a few inches in depth, of a reddish color from the presence of oxide of iron in the decomposing coral of which it largely consists. Beneath the superficial layer the subsoil is of rotten coral, and beneath this is a solid mass of the hard coral composing the ancient reef, cemented together hy carbonate of lime formed by the action of water upon the oxidized surface limestone. Where the meseta has been cultivated for a long time its productive power is small, and the natives declare it to be "cansada," or tired. Much of the mesa produces excellent tobacco, sweet potatoes, and maize, though no effort is apparently made to fertilize it artificially. Abandoned tracts on the mesa soon become orergrown with scrubby bushes, including cassia, indigo, sappan wood, and other leguminous plants. The natives understand the economy of allowing them to lie fallow for a period of time sufficient for the undergrowth to form a thicket, and in selecting a tract for planting 
they are guided by the richness of the growth of bushes, which they are careful to burn upon the site. The leguminous shrubs undoubtedly act as nitrogen storers. Peanuts could be cultivated with advantage for this purpose, and would be useful as a crop to alternate with maize and tobaceo.

Savannas. - On the higher parts of the island there are stretches of land almost hare or covered with sword grass, called "neti" (Xiphrtgrostis. floridula), a few weedy labiates, and a sprinkling of ironwood trees (Casuarina equisetifolia). The boundary between the savannas and the wooded region is very sharply marked. All savannas are characterized by absence of drainage. The soil is a red clay, which becomes sticky and paint-like when wet, so that during the rainy season the roads across the savannas in the southern portion of the island become dangerously slippery and impassable. An analysis of savanna soil showed it to be almost deroid of organic matter, free from gravel and coarse sand, and consisting almost entirely of clay and silt. Although it is rather low in nitrates it is possible that this deficiency might be remedied by cultivation and the application of manure. Though the amount of water-soluble phosphate contained by it is lower than in the soils examined from other parts of the island, yet, according to the report of the Bureau of Soils, it is as large as that in many productive soils of the United States, and it is quite possible that some savanna grass good for forage may be found to replace the coarse, sharp-leaved neti, which is of little economic value except for thatching.

Cascajo, or GRavel. - The subsoil of the mesa and the cliffs forming the sides of the plateau consist in many places almost entirely of coral gravel. This is excellent road material and the streets of Agaña are formed of it. When first removed it is soft and crumbling, but it becomes hard and compact on exposure to the air. It consists largely of alcium carbonate. Similar material is used in the Philippines for road huilding, but it does not stand heary travel for a long time and must be renewed at intervals. According to the report of the Bureau of Soils, material of this kind gradually decomposes into a red clay exceedingly high in iron compounds, and when organic material is present frequently hecomes converted into black waxy fertile soils resembling, in many respects, the adobe soils of the southwestern United States.

INDIGENOUS AND SPONTANEOUS ECONOMIC PLANTS.

Among the plants growing without cultivation on the island are Cyers circinalis, the nuts or seeds of which furnish the natives with food in times of famine; the wild fertile breadfruit (Artocarpus (nmmunis), haring edible chestnut-like seeds; wild yams (Dioscrment sprimster which in places form impenetrable thickets; the betel-nut palm (Arece cutfecu), which is abundant in some of the rich ralleys in 
the southern part of the island; and Prriti tilincum, which furnishes the natives with cordage. Besides these a number of plant of ninor importance have escaped from cultivation and are spreading over the island, such as the guava, the bullock's heart, the orange berry, I'ithecolubium dulce, which yields fine tan bark, and Biancaea sappan, which is important as a dyewood.

CULTIVATED FOOD AND STHMUANT PLANTS.

Garden plants. - In addition to their small farms nearly all the natives of Guam have a town house. Adjacent to many of these are gardens in which grow perennial eggplants, red peppers, hananas, plantains, various kinds of beans, squashes, gourds, watermelons, melons, peanuts, tomatoes of a small and inferior kind, balsam pears, mustard, and perhaps yams and a few vines of betel pepper. Among the fruit trees in gardens the most common are lemons, limes, the sugar apple, and the soursop. Pomegranates are grown more for ornament than for use, although a very refreshing drink is made from the acidulous pulp surrounding their seed. In some of the gardens giant taro (Alocasia) is grown for the sake of its leares, which are used instead of paper for wrapping up meat and fish. Banana and plantain leaves deprived of their stiff midrib are used for the same purpose, and for cordage strings are stripped from their stem, or the leaves of the textile Pandanus are used, a plant of which is sometimes grown in the garden for convenience. Radishes, onions, garlic, and lettuce are sometimes planted, but they do not thrive. (See under Gardens in catalogue.

Cereals.- The only cereals cultivated in Guam are rice and maize. The natives cultivated rice in considerable quantities before the discovery. It was among the supplies furnished to Magellan and Legazpi. The Dutch navigators, who came after them in 1600 and 1621, complained that the bales were increased in weight by the addition of sand and stones. These bales weighed on an average from 70 to 80 pounds.

At present not sufficient rice is grown on the island for the use of the natives, though there are several localities well suited for its culture. The methods followed are very much like those of the Filipinos. Buffaloes are used for plowing. The plow is of wood with an iron point, usually fashioned by the blacksmith of Guam out of an old gun barrel. It has but one handle. Many of the best rice growers on the island within recent years have been Filipinos. At present rice is imported from Japan, Manila, and the United States. This would not be recessary if a little greater effort were made on the part of the planters. As a rule, they plant only enough for their own use and do not lay by a surplus. The result is that when the erop is ruined by a burricane or a drought, which not infrequently happens, there is a 
dearth of rice on the island. One reason for the small size of the erops is the difficulty of obtaining labor. Nearly everybody has a ranch of his own, and prefers to reap all the benefits of his own labor rather than to share them with an employer.

Maize was introduced from Mexico at a very early date, " and soon became the principal food staple of the early missionaries and the soldiers sent to assist them in the conquest of the islands. With maize came the Mexican metate and mano, a low inclined stone slab supported on three legs on which tortillas are prepared, and a stone rolling pin, cylindrical in shape with the ends slightly tapering.

Maize is now the most important crop. On the higher land it is planted at the beginning of the rainy season. In the lowland, as in the valley of the Talofôfô River, it is planted at the beginning of the dry season. As soon as it is harvested it is shelled and spread out on mats in the streets to dry in the sun. Then it is stored in earthen jars as a protection against dampness and against rats and weevils. In places where the soil is deep enough the land is prepared for maize by plowing. On the higher land the weeds and bushes are cleared, dried, spread over the field, and burned. This process serves to kill many weeds and at the same time to fertilize the land. The only instrument of cultivation used in such places is the fosiño, or scuffle hoe, which consists of a wide transverse blade, placed T-like on the end of a long slender handle, the stem of the $T$ being a hollow socket into which the end of the handle fits tightly. This is thrust ahead of the laborer, and serves to clear away bushes and to cut the weeds. After the corn is once planted, the surface is easily kept clear of weeds with the fosiño, the natives usually covering at one thrust a space of 6 feet in length and the width of the blade. The $u=$ a of this implement is universal. Even the women are adepts, and tiny fosiños are made for the little children.

Edrble Roots.-Among the edible roots of the island are taro (Culudium colocesia) and yams (Dioscorece spp.), both of which are cultirated by the natircs and are a resource for them during the periods of famine, which usually follow hurricanes. Taro is cultivated either in swamps (Pl. XXIV) or in newly cleared ground. Certain varieties, the best of which has purplish stems and is called Visayan taro, "sunin visa ya," are grown on hillsides and are of fine consistency and flaror. The closely allied Alocasia indice and A. macromtiza are not so commonly cultivated, but grow wild in many places. They are very acrid and are only eaten in cases of necessity.

The cultirated yams are probably rarieties of Dioscrea alrata, $D$. sutive, and $D$. uculectu. Closely allied to the last is the wild gado or nika cimarron (Dimsenper spinerser), which forms thickets in many 


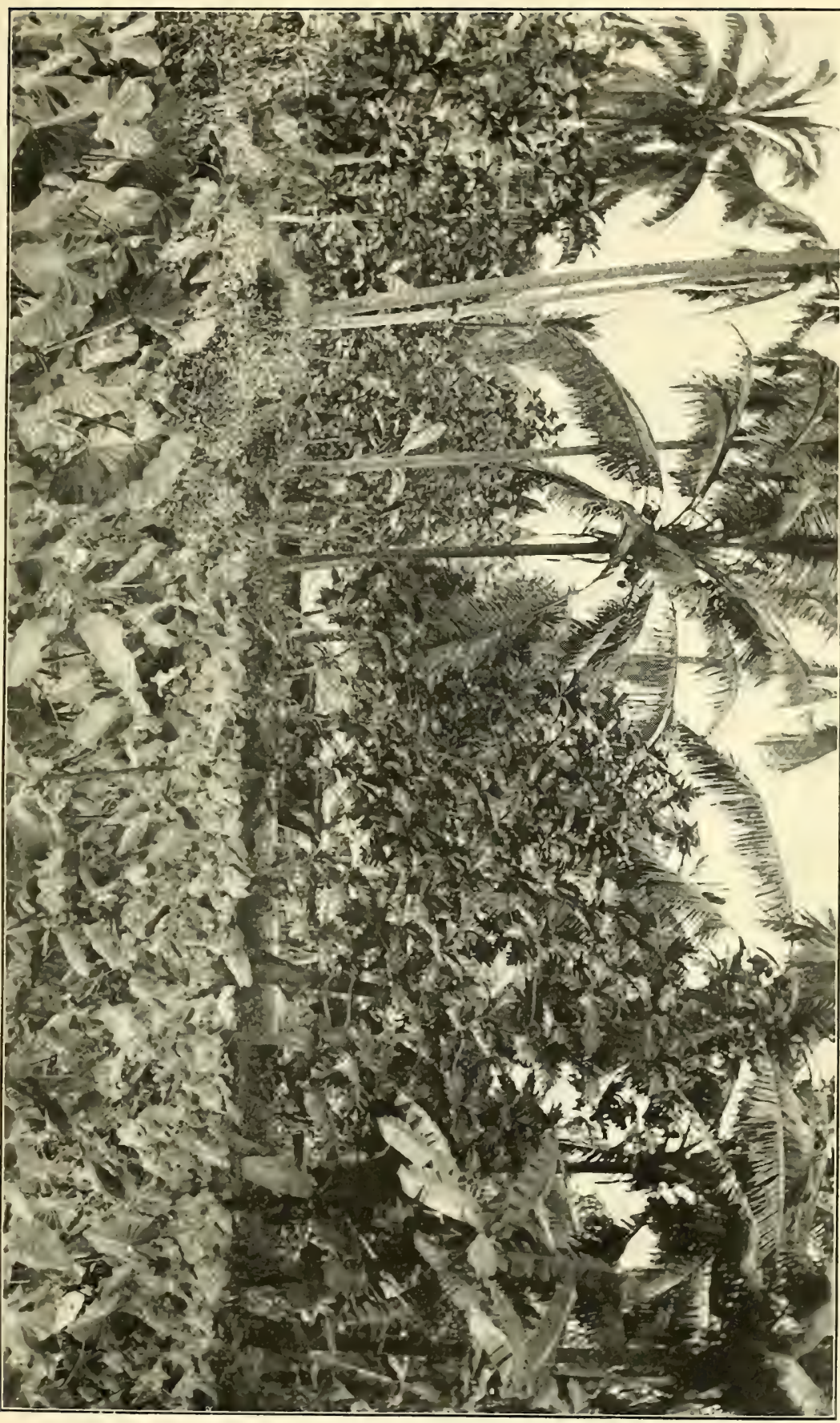






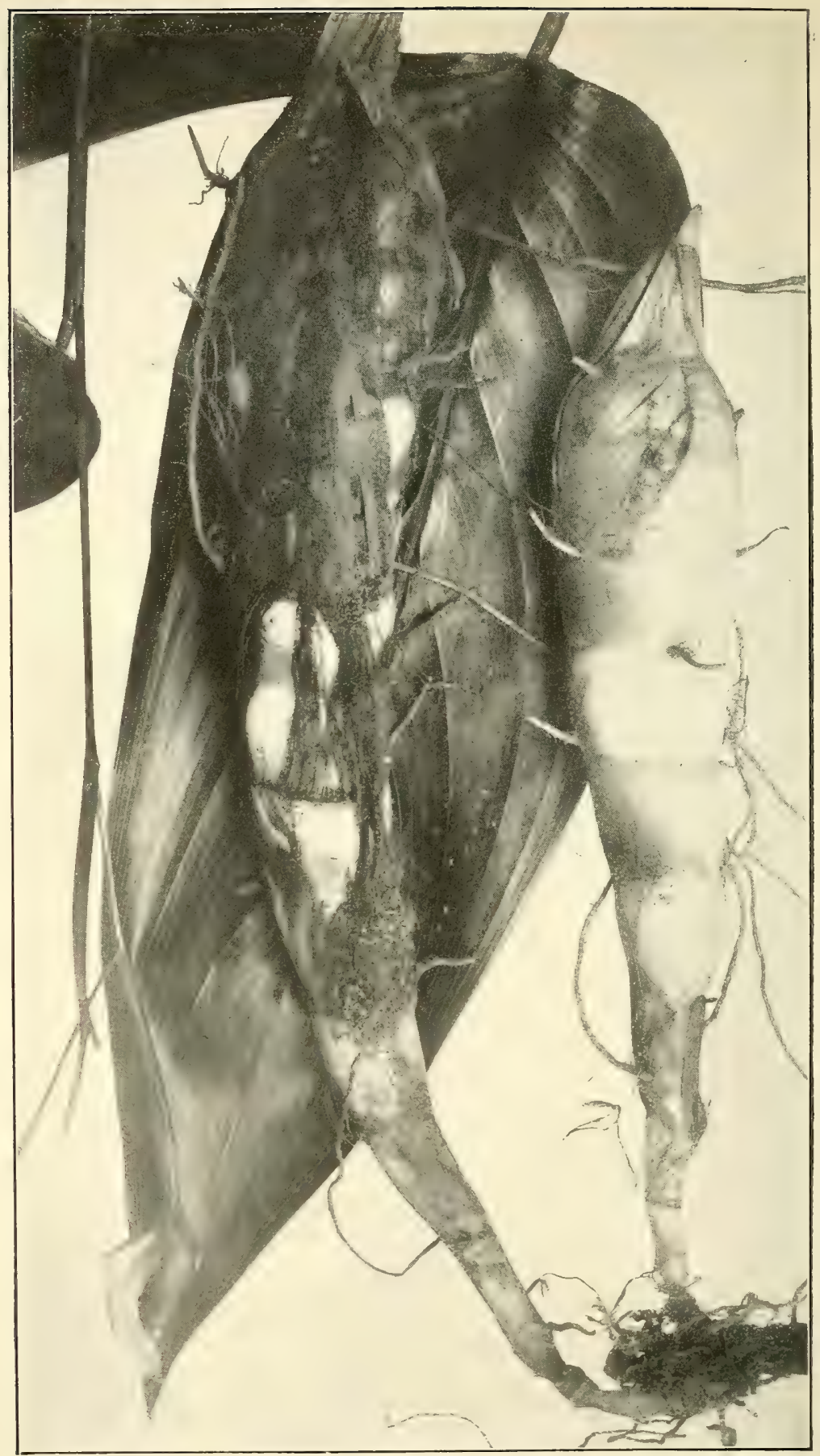

ARrowroot (Maranta ARUndinacea). Natural Size. 



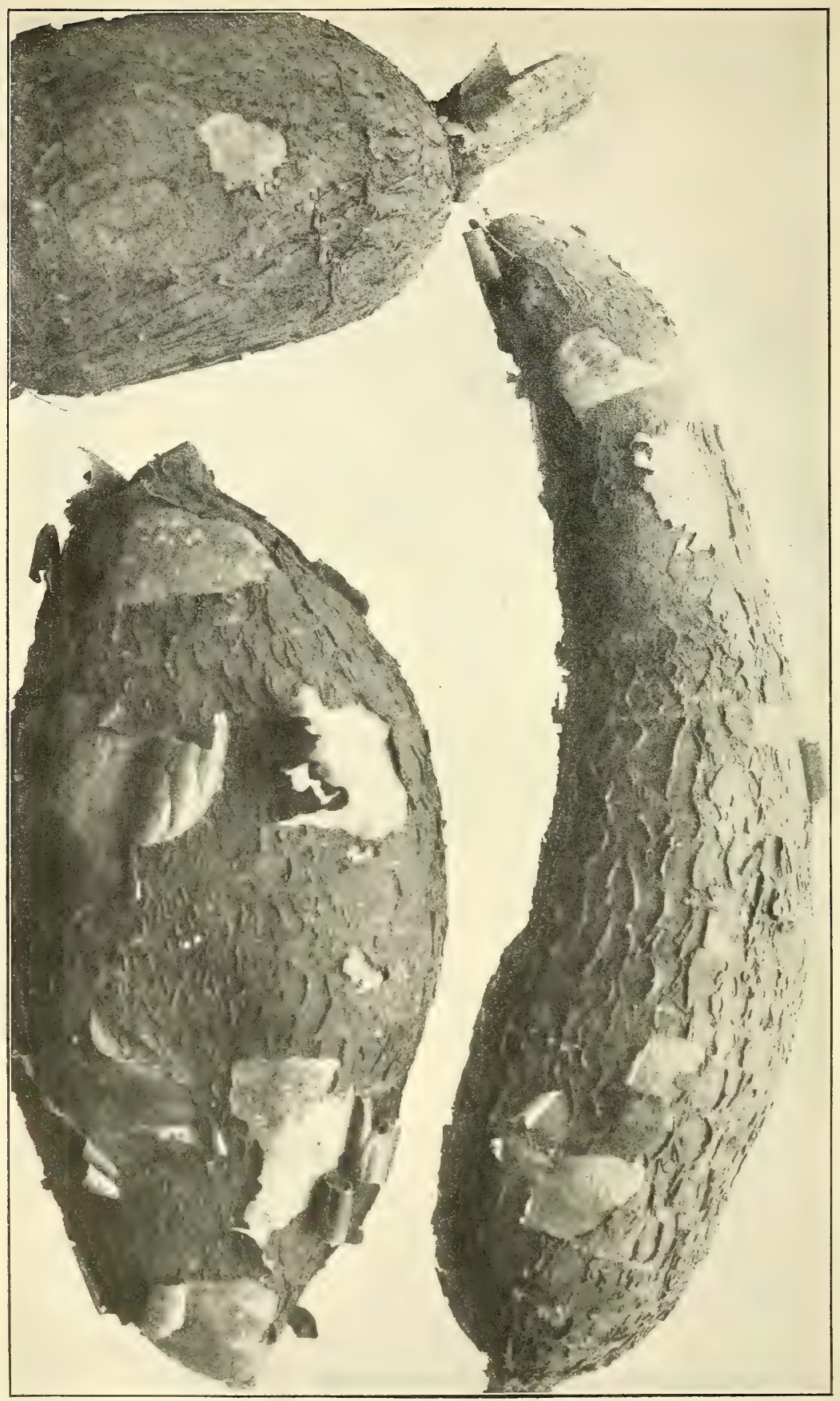

Roots of the Cassava Plant (Manihot manihot). natural Size. 



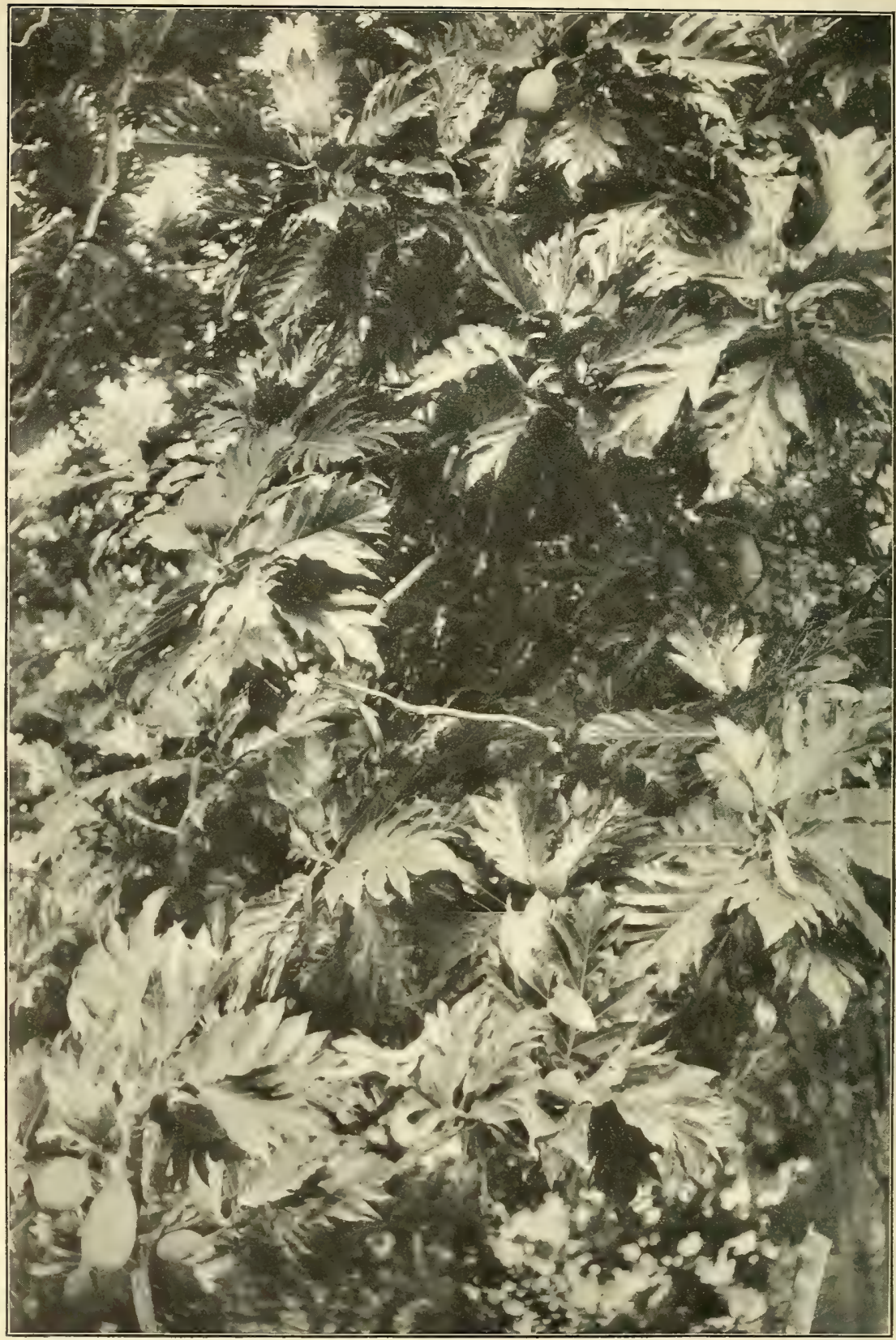

Breadfruit Tree (Artocarpus communis), Showing Foliage, Inflorescence, and IMMATURE FRUIT. 
places on the island. Yams are more difficult to cultivate than taro, and are therefore not planted so commonly by the natives.

Sweet potatoes are far superior to the best varieties of yams and of taro. The natives grow them principally to supply visiting ships. Several varieties occur in Guam. Unlike the yams and taro, which grew on the island before the discovery, sweet potatoes were introduced by the Spaniards. One variety was brought from the island of Agrigan, where it had been introduced by settlers from the Hawaiian Islands.

Among other plants with starch-bearing roots are the indigenous Treca pinnatifida, or Polynesian arrowroot; the true arrowroot (Maranta amendinacea, Pl. XXV); and the mandioc plant (Manihot manihot, Pl. XXVI), which yields cassava and tapioca.

STARChy FRUITs.-The principal starchy fruits are those of the sterile breadfruit (Artocarpus communis, Pl. XXVII), called "lemae" or "rima" by the natives, and the well-known plantain (Musa paradisiaca). Of the plantain there are several varieties. The fruit differs from that of the banana in being starchy instead of sweet, and it must be cooked before eating. When baked it has somewhat the taste and consistency of a potato, but is inferior to it in flavor.

As both the breadfruit and plantain are seedless they must be propagated by suckers. This is readily done with both plants. They both grow with little eare and produce abundantly in Guam. As the breadfruit is in season only during certain months of the year, some of the natives lay in a store of it for the rest of the year by slicing it and drying or toasting it in ovens, making a kind of biscuit of it which they call "biscocho de lemae." If kept dry this will last indefinitely and may be eaten either without further preparation or cooked in various ways. It is fine food for taking on a journey, as it is light and conveniently carried.

Squashes and pumpkins are grown, but they do not occupy a prominent place in the economy of the natives.

The nuts of the Cycas circinalis, called "fadan" by the Chamorros and "federiko" by the Filipinos, yield a nutritious starch. As these nuts are poisonous in their crude condition, there has been considerable prejudice against them on the part of some of the Spanish governors of the island. In other countries, however, a fine sago, or arrowroot, is made from them, which is declared to be superior to that made from the pith of sago palms.

It is remarkable that the "Polynesian chestnut" (Bocoa edulis), so widely spread over the Pacific, is not included in the Guam flora.

Tree Frurts.--The principal fruits are oranges, bananas, mangoes (Pl. XXVIII), and sugar apples (Annona squammosa), all of which are of tine quality. In the vicinity of Agat and the harbor of San Luis de 9773-05-10 
Aprâ there are inferior varieties of oranges, but in the districts of Santa Rosa and Yigo, in the northern part of the island, and in Yoña, on the eastern coast, the oranges are excellent.

Lemons and limes produce continuously in great quantities all the year round. Among the introduced Annonaceae the sour sop (A. muricrta) is used for making jellies and preserves, and the bullock's heart (A. reticulata) is eaten as a fruit, but it is inferior to the sugar apple above mentioned. Citrons, pomelos, shaddocks, and bergamots are abundant. Averrloo carambola, improperly called "bilimbines" by the natives of Guam and the Filipinos, bears a translucent oblong fruit with the cross section of a five-pointed star, which has a pleasant acidulous flavor. Guavas grow spontaneously and produce abundantly. Little use is made of the fruit, however, owing to the scarcity of sugar on the island. Among introduced trees are the cashew (Anacardium occidentale, Pl. XXIX) and the tamarind (Tamarindus indica, PI. LXVI), neither of which have spread upon the island, but which are found only near villages or on the sites of ranches either in cultivation or abandoned.

COFFEe and CACAO. - Coffee and cacao have been introduced and thrive well in Guam. Coffee receives little care. It will grow in various situations and in almost any soil, and yields abundant harvests. Often most of the houses of a village, as at Sinahaña, are seen surrounded by coffee bushes, and the fresh seeds sprout spontaneously beneath the parent plant or if thrown upon the surface of the soil in a shady place. There are no large plantations in the island, each family planting enough only for its own consumption. The berries are gathered, pulped, and hulled by hand.

The cultivation of cacao is more difficult. The plants are very tender. They have a long taproot which is easily broken, and the plants do not bear transplanting well. They are very sensative to violent winds, and must be planted in sheltered valleys. Both coffee and cacao must be protected from the sun when very young. The use of shade trees is not necessary in Guam, though, in starting a cacao or coffee plantation, the interrening space between the rows of plants is usually planted in bananas, which yield fruit and at the same time serve to protect the tender young plants from the sun.

Narcotics. - The principal narcotics cultivated on the island are the betel palm and the betel pepper, which grew on the island before the discovery, and tobacco, which was introduced by the Spaniards from America. The betel palm, although frequently planted by the natives, also grows spontaneously. Thousands of young plants may be seen in the rich valleys of the southern part of the island where seeds have fallen from the palms. The betel pepper is a vine with glossy green laves closely resembling the common black pepper (Piper nigrum). It occurs only in a state of cultivation, but requires little care, the 


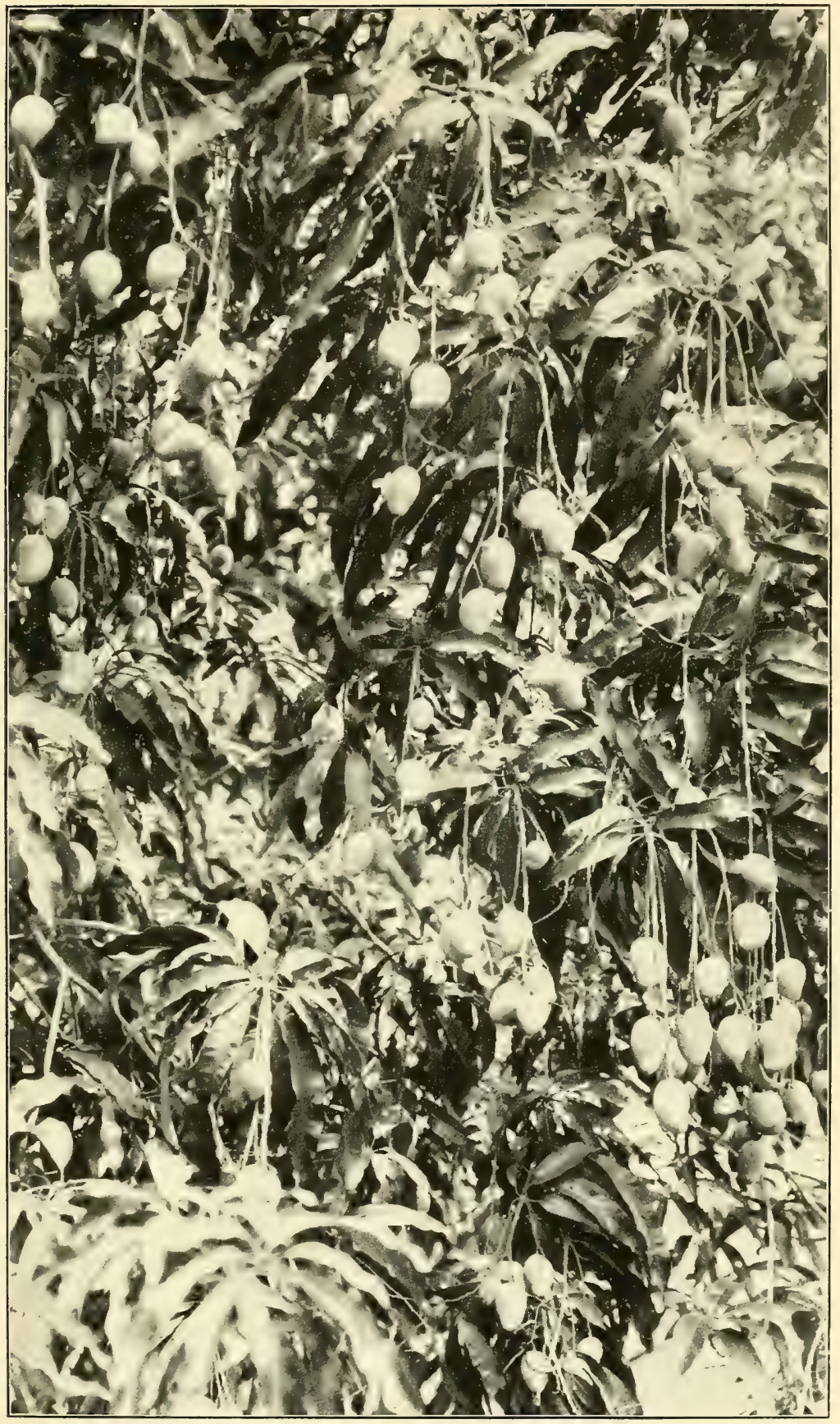

MANGo TREe (MANGIFERA INDICA) IN FULL FRUIT. 




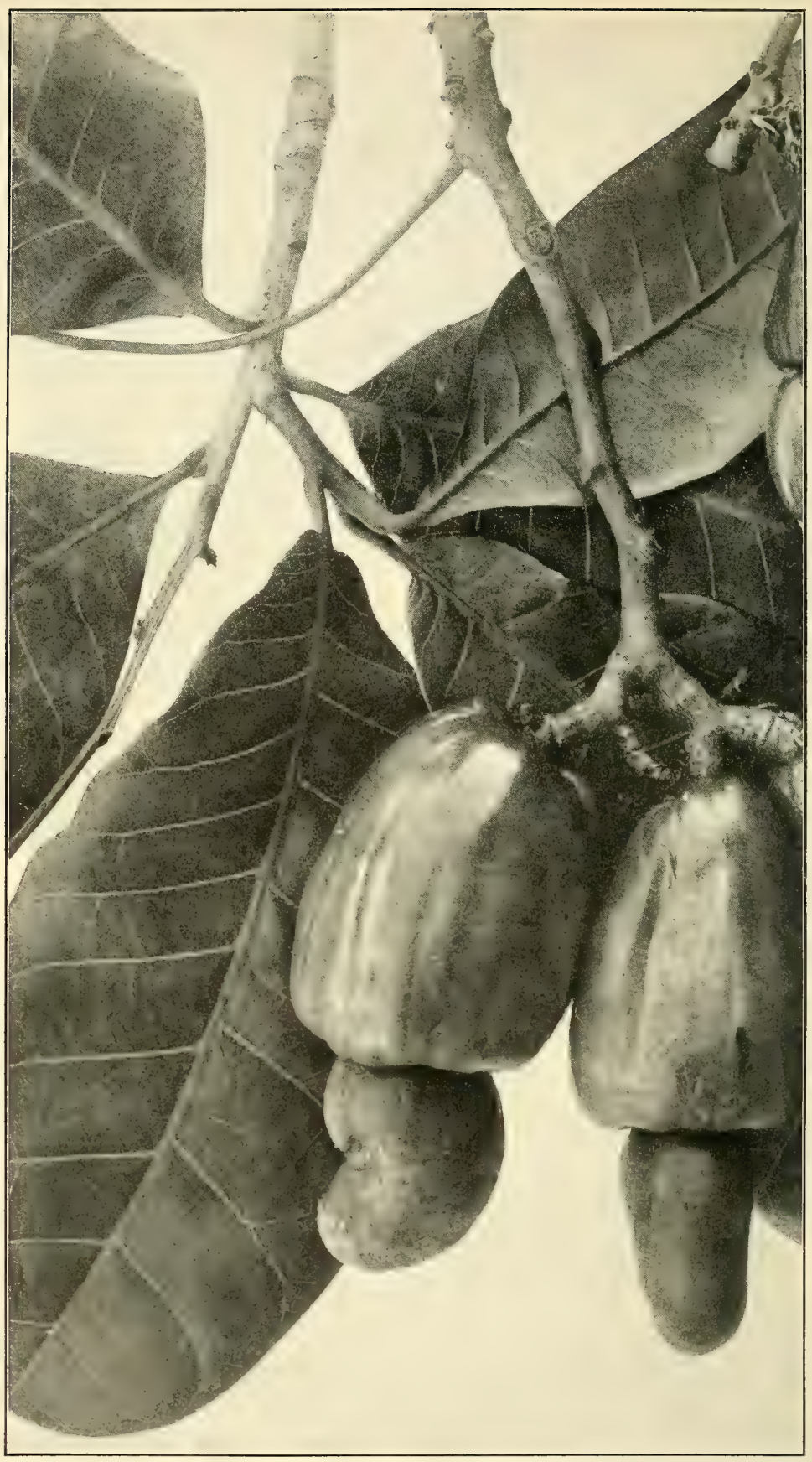

Cashew (anacardium occidentale). Foliage and half-grown fruit. NATURAL SIZE. 
natives propagating it very easily from cuttings and allowing it to creep upon stone walls and to climb over trees. (See Plates XXXV and LXIII.)

Toddy, or tuba, is a fermented drink made from the sap of the coconut. Before the arrival of the Filipinos brought by the early Spaniards to assist in the conquest of the islands the use of tuba was unknown. Until the arrival of the Americans an inferior brandy was distilled from fermented tuba, but its manufacture has been prohibited.

Nearly every family on the island has its tobacco patch, each raising barely enough for its own consumption. The seeds are germinated in nurseries and transplanted to spots near the plantations, where they are kept shaded by canopies of muslin, and then are set out in fields, each plant shaded by the segment of a coconut leaf. All hands assist in its cultivation-parents, children, and grandparents - and it requires constant attention and no little effort in fighting against weeds and tobacco worms to make the crop a success.

OIL-IIELding Plants. - The coconut is the principal source from which the natives derive oil. Coconut oil is used for cooking, lighting, and anointing. In taking the place of lard fresh coconut oil imparts an agreeable flavor to many articles of diet. Nearly every house on the island has its patron saint enshrined in a niche or side room, with a light of coconut oil burning before it. The oil is contained in a goblet half filled with water, which keeps the glass cool. The wick is supported on a float. Oil used for massaging the body (a custom which Guam shares with many Pacific islands) and for anointing the hair is often perfumed with flowers of various kinds (p. 210). Dried coconut meat, or "copra," is exported from the island. Most of it is used for oil which enters into the manufacture of candles and soaps, and is an ingredient of a number of medicines. Among other oil yielding plants are the castor bean (Ricinus communis), the physic nut (Jatropha curcas), and the the candle nut (Aleurites moluccana), which has been sparingly introduced. These plants are all members of the Euphorbia family. Their nuts and oil are drastic purgatives if taken in quantity, and are poisonous if taken in too great doses. The candle nut, called "kukui" in Hawaii and "lama" in Samoa, derives its name from the custom of the ancient Polynesians of stringing the roasted kernels on the rib of a coconut leaflet, the tip of which is set on fire and burns like a candle, the flame consuming the oily kernels as it descends. At all luaus, or native feasts, in the Hawaiian Islands, chopped kukui kernels mixed with seaweed form an indispensable dish, which takes the place of a relish. In many tropical countries illuminating and lubricating oils are made from the castor bean and the physie nut, and both of these oils are important medicines.

An oil like that derived from the almond may be obtained from the nuts of Terminatia catappa. The seeds of Moringa moringa are the 
source of the ben oil of commerce, which is much prized as a lubricant by watch makers and is sometimes used in the West Indies as a saiad oil. Dilo oil is derived from the fruit of Calophyllum inophyllum, and peanuts and sesame are well known oil-yielding plants. An acrid, oily liquid called "cardol" has been derived from the shells of cashew nuts (Anacardium occidentale). It is used to varnish furniture and books as a protection against white ants and other pests. These oils are not prepared by the natives of Guam.

TEXTILE AND THATCH PLANTS.

Fiber PLANTS.-Among the monocotyledons yielding fiber are the w coconut (Cocos muciferc), from the husks of which is derived the coir which is twisted and braided into cords and sennit; the pineapple $\therefore$ (Ananas ananas), the leaves of which yield a beautiful, fine, silky fiber, which the natives of Guam twist into thread for making the finer fish nets; the abaká, or manila hemp (Musc textilis), introduced from the Philippines, and growing without care on the part of the natives, but not utilized by them on account of the labor and skill necessary to extract it fiber"; and a species of Agave, called "lirio de palo," evidently introduced from Mexico, the leaves of which yield an excellent fiber, which in Guam is utilized only for wrapping cigars. In addition to these, a palm called "cabo negro" has been introduced from the Philippines. This species, which is known to commerce as athe "gomuto," is Saguems pinnatus. Its stem when young is entirely covered with sheaths of fallen leares and black, horsehair-like fibers, which issue in great abundance from their margins. As the tree increases in age these drop off, learing a columnar stem or trunk. In the Malay Archipelago the thickest fibers are used by the natives as w styles for writing on leares of other palms. The finest fibers are known in Eastern commerce as gomuto or ejoo fiber, and are much used for making strong cordage, particularly for cables and standing rigging of vessels, whence the name "caho negro," or "black rope" is given it in the Philippines. The ropes made of this fiber are not pliable enough for rumning rigging or for fine cordage. The fibers need no preparation but spinning or twisting. Cabo negro ropes are said to be more durable than any other kind when suljected to repeated wetting. At the base of the leaves there is a woolly material suitable for calking the seams of ressels. The species grows well in Guam, but on account of the abundance of other fibers it is not utilized by the natives.

Among the dicotyledons the principal fiber plants belong to the Malraceae, Tiliaceae. L'rticaceae, and Moraceae. The chief of all is Paniti tilucem, a tree widely spread orer the tropical regions of the world, from the inner bark of which ropes and twine are twisted. Its use for this purpose is so extensive in Guam that there is scarcely a 


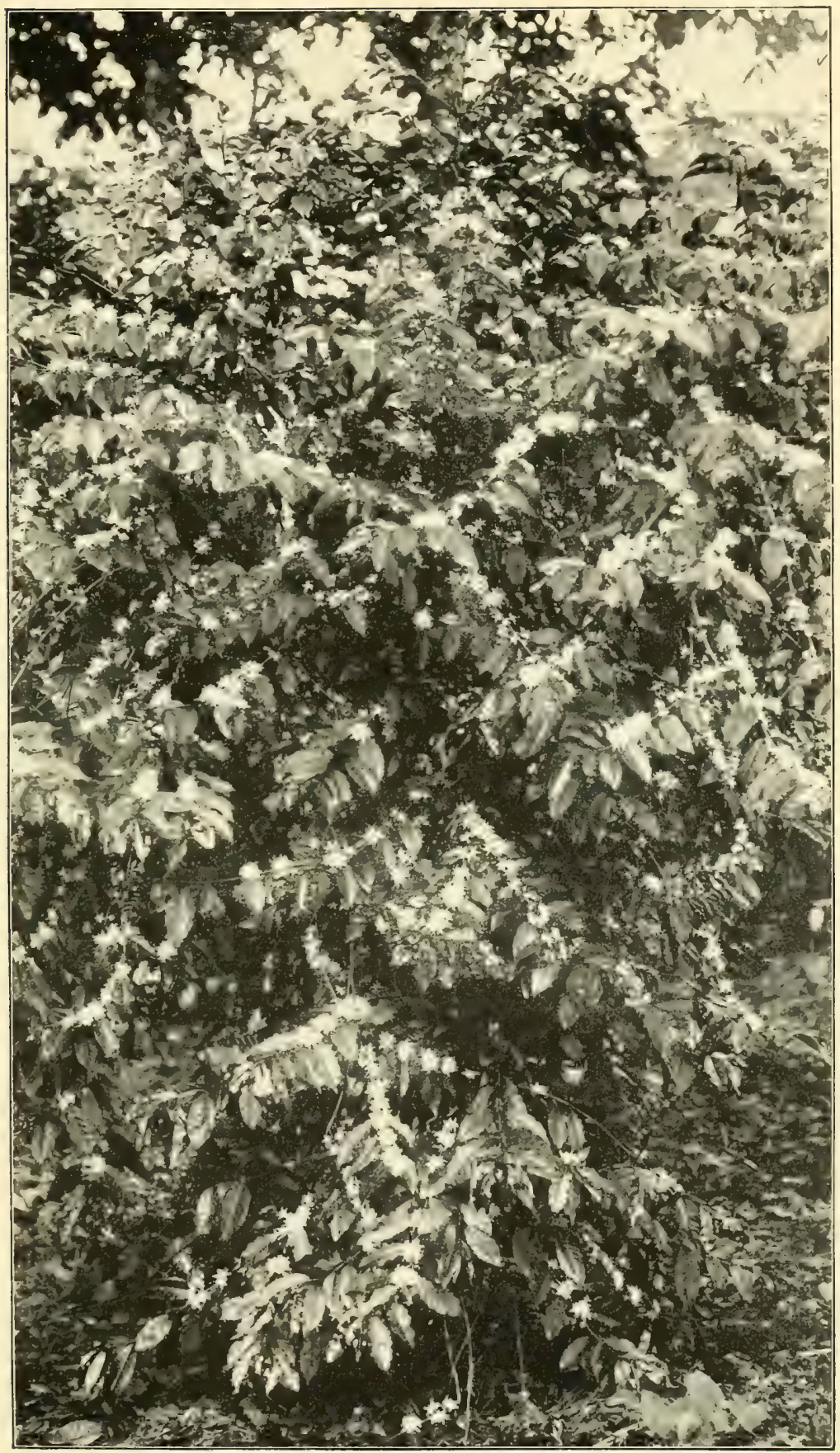

Coffee in FULL BLOOM 

family which does not possess a rope-making apparatus similar to the simpler forms of those used in rope walks elsewhere. On the east coast of Guam, in traveling from Pago to the southern extremity of the island, it is necessary to cross the mouths of several rivers. Balsas, composed of sereral layers of bamboo, are used for this purpose. The cables by means of which they are pulled across are made from the fiber of Pariti tiliaceum. Though this fiber is not easily worn out in its natural condition, its strength and durability are increased by the application of tar, such as that used on board ship. Among other members of the mallow family are several species of Sida, called "escobilla" by the natives. They grow without cultivation on the island, in waste places and along the roadsides. They yield a good, strong fiber, but on account of the abundance of other material the natives do not use it. Allied to these in general appearance and use are several species of Tiliaceae, including Triumfetta procumbens, which is called "masigsig" by the natives, allied to the species which produce the jute of commerce, so extensively used in the manufacture of gunny sacks, matting, and carpets. They are not, however, utilized in Guam.

The principal member of the Urticaceae, or Nettle family, is the celebrated rhea fiber plant (Boehmeria tenacissima). In Guam it grows to the height of a shrub or small tree, though in many other parts of the world it is herbaceous. Though allied to the nettles in appearance and inflorescence, it is not armed with. stinging hairs. The elosely related Boehmeria nivea, which yields the China "grass cloth" fiber, is a plant of temperate regions, the lower surface of the leaves being covered with white down, like felt. The leaves of the Guam plant, though pale beneath, are not coated with felt. This plant, though of great importance in other parts of the world and growing in Guam rankly and without care, is in this island not utilized at all, except for medicine.

The last species I shall mention is the principal member of the Moraceae, the breadfruit tree (Artocarpus comnnunis). In addition to its importance as yielding the principal staple of food, excellent wood, fodder for animals, and a gum suitable for paying the seams of canoes and for use as a medium in mixing paints, it yields a tough leathery bark, which in the olden times was made by the natives into aprons or breecheloths.

Tapa cloth, which is made from it in other islands of the Pacific, was apparently not made by the aboriginal inhabitants of Guam. The paper mulberry, Papyrius (Broussonetia) papyriferus, the tapa plant so widely spread throughout Polynesia, does not occur in Guam.

Mat and hat plants. - At least four species of pandanus occur in Guam, two of which, called "pahong" and "kafô" by the natives, are widely spread in the forests, and furnish food to the fruit-eating bats 
and wild rats. The third species furnishes leares which, when young and tender, are cooked with vegetables as a flavoring. The fourth species is called "aggag." Its leaves are remarkably strong and pliable. They are used for lashing together the parts of a house or hut and for string; and when divided into narrow ribbons tbey are braided into hats, sleeping mats, mats upon which corn and other seed are dried, and bag's for holding corn and rice. Only one sex of this plant occurs in Guam. It is propagated by cuttings, limbs when cut off taking root readily in almost any kind of soil. The leaves of the other species are inferior and are searcely at all used.

A coarse kind of mat is made by weaving or wattling the stems of a reed which grows in marshy places (Trichoon roxburghii), called "karriso" by the natives. These mats are often used to cover the walls of lightly constructed houses and are sometimes coated with a kind of clay.

Thatch PLANTS. - The majority of houses in Guam are thatched with coconut leares, but those of the better class with the leaves of Nypa fruticans, an interesting trunkless palm introduced from the Philippines, which has established itself at the mouth of every stream of importance in the island. When there is a dearth of coconuts and nipa, sword-grass, or "neti" (Xiphagrostis floridula), is used.

Coconut leaves to be used for thatching are gathered, dried and split down the midrib, the two halves being placed together in reverse direction and the leaflets interworen diagonally. Women are usually employed in this work. Leaves thus prepared are lashed to the framework of the roof with strips of pandanus leaves, beginning at the eaves and ending at the ridgepole, the leaves being placed so close together that they form a thick imbricating thatch. Coconut thatch is not very durable. As a rule it lasts only three or four years.

In preparing the leaves of the nipa palm the leatiets are detached from the midrib or rachis, cured by drying, and attached to reeds in the form of a fringe. These are laid on the timbers of the roof frame in the same way as the coconut leaves, but closer together. Neti is prepared in the same way. The thatch thus formed is more homogeneous, compact, waterproof, and durable than the former.

As garden patches are not inclosed, cattle, horses, buffalo, and pigs can not he allowed to run at large. They are kept tethered and consequently require to be cared for, fed, and watered. Often the arailable pasturage in the ricinity of a town or village is exhausted and it is necessary to take the animals a considerable distance before a good grazing place can be found. Usually forage is gathered and brought to the animals. Besides several species of grasses the best forage plant is the breadfruit (Artmorpus communis), great quantities of the leaves 
of which are gathered for this purpose. The branches of several leguminous shrubs and of Mloringu moringa are much relished by cattle, and the plants of the cultivated Pluseolus mungr and of peanuts form excellent forage. Attempts have been made to cultivate alfalfa (Hedicago sativa), but this plant evidently flourishes best in dry climates where irrigation is practiced. It does not thrive in Guam. The nearest approach to clover on the island is the tiny Meibomia triflom, which grows close to the ground and forms a thick sward in places where the grass does not crowd it out.

Cattle and hogs are very fond of the fruit of Artocarpus communis. After hurricanes, when the ground becomes covered with breadfruit, hogs eat great quantities of it and become very fat. The sweet pods of Pithecolobium dulce are also eaten by animals. Prosopis juliflora, which is an important forage tree in the Hawaiian Islands, has not yet become established in Guam. Cattle and horses feed upon its foliage as well as upon its pods, and there is no reason why it should not thrive on the island.

Among the grasses the most nutritious is Bermuda grass (Capriola dactylon), called "grama" by the natives. It grows luxuriantly in the sandy soil of the lowlands. Dactyloctenium aegyptiacum and Eleusine indicu are edible, but coarse and not much relished by horses. Stalks of green maize and the leaves of ripe maize are excellent for food. Many of the coarser grasses growing in damp places which horses and cattle will not eat are eaten by buffaloes. Reeds. (Trichoon roxburghii) are often collected for fodder, and are especially relished by buffaloes. They are rather coarse when old for cattle, but the young shoots are eaten by them.

Among the plants elsewhere reputed to be injurious to animals is Leucuena glanca, an introduced shrub, which is very common in the Bahama Islands. Mr. L. H. Dewey, of the United States Department of Agriculture, while on the island of New Providence was shown horses, without manes or tails, which had lost them, it was declared, as the effect of eating this plant.

WEEDS.

The number of tropical weeds which have found their way to Guam is remarkable. In waste places, along the roadsides, on the borders of rice fields, and among growing vegetables, nearly all the weeds are of species widely spread over the warmer regions of the world. Some of them, like the malvaceous Urena and tiliaceous Triumfetta have prickly, bur-like fruits with hooked spines; others like the milkweed (Asclepias curassavica) have silky pappus attached to the seed, which provides for their dispersal by the wind. There are also composites (Glossogyne) with retrorsely scabrid bristles attached to their archenes, and marsh plants with seeds which readily adhere to the feet 
or feathers of hirds. These peculiarities undoubtedly account for the wide dissemination of many of the weeds. Many of the marsh birds and shore birds visiting Guam are migratory, and it is very probable that they hare brought with them seeds or fruits from other regions.

It is pleasant to note the absence of the troublesome sensitive plant (Mimosa pudica) and the Lantana camara from the flora of Guam. Other shrubby plants of wide distribution occur in Guam, however, especially the guava, the two common species of indigo, Levcaena glance, and several American species of Cassia. Nearly all the composites on the island are introduced weeds, belonging to the genera Vernonia, Elephantopus, Adenostemma, Ageratum, Eclipta, Glossogyne, and Synedrella.

ANIMAL PESTS.

The most serious injury to growing crops is caused by the deer, which orerrun the island. They often destroy whole fields of corn, garden patches, and tender young coconut plants, approaching villages by night and eating watermelons, squashes, and other succulent fruits on the rines. Rats occur in great numbers and attack many vegetable products, especially corn and cacao, and flying foxes cause considerable damage to certain fruits. Weevils get into the gathered corn and rice, which must be kept in earthen jars well closed as a protection against them; termites destroy living trees as well as dead wood; and tobacco patches are infested with the larvæ of a sphinx moth. Few garden patches are inclosed by hedges or fences, so that serious injury is often caused by bogs and cattle running at large. Horses and cows are especially fond of the foliage of the breadfruit, and will injure young trees if unprotected. Among the staple food plants there are fewer diseases and insect pests than in most tropical countries.

\section{PLANT NAMES.}

Classes of rames.--The common names of (xuam plants may be classified under three heads: First, rernacular names applied to plants which grew in the island before the discorery, such as "fai" (rice), "pugua" (hetel nut); second, East Indian and American names of plants which have been introduced since the discovery, such as "mañgga" (mango), "kanıte" (sweet potato); and a third rlass including names applied by the natives to plants brought to the island either from other parts of the Pacitic or from more remote regions, as "baston de San Jose" (St. Joseph's statt), applied to Trutsin trminatis, the "ti," or "ki," of Polynesia. and "cadena de amor" (chain of lore), applied to the Mexican Antigonon leptopus on account of its racemes of rosecolored heart-like flowers.

ORIGIN OF PLANTS INDICATED BY THEIR VERNACULAR NAMES. - It is easy to trace the names of most of the plants introduced since the 
discovery. In most cases they are identical with the common name applied to them in the regions from which they have been directly obtained, or have been somewhat modified to correspond with the genius of the language spoken by the natives of their new environment. Of greater interest to the student of ethnology and of the origin of cultirated plants is a comparison of the common names of plants disseminated in prehistoric times throughout the entire range of their cultiration. From such a comparison it has been possible to determine the origin of a number of the more common food staples, such as sugar cane, the coconut, the winged yam (Dioscorea alata), the common names of which are etymologically identical from the eastern limits of Polynesia throughout the islands of the Pacific, the Philippine Islands, and the Malay Archipelago. Some names extend even to the continent of Asia and to the island of Madagascar, on the edge of Africa. That most of these plants hare been spread through human agency is evident from the fact that they do not grow spontaneously, but need the help of man for their propagation. Some of them even, such as the banana, plantain, breadfruit, sugar cane, yams, and taro, seldom produce seed and are propagated asexually by means of cuttings, offshoots, or tubers.

In addition to garden products a number of trees bear the same or similar names in many groups of islands, such as Barringtonia speciosu, Intsiabijuga, and Periti tiliaceum, all of economic value to the natives. This is especially striking when we consider that some of these plants have the same names on islands so remote that their inhabitants hare had no intereommunication within historic times. We have some light upon the method by which the more important plants were spread in the traditions of the Hawaiians, which tell of voyages to distant island groups for the purpose of obtaining breadfruit and other useful plants.

Some of the widely spread species bear one name throughout the islands of eastern Polynesia, but are known by a different name in the islands of the western Pacific and of the Malay Archipelago. Among these are the breadfruit, screw pine, kava pepper, taro, and ironwood (Cusuctina equisetifolic). In a few cases a name is applied, not to the same plant, but to a plant more or less similar. Thus the name "gabe" is applied in the Philippines to the taro plant (Caladium colocasia); in Samoa, Rarotonga, Tahiti, Hawaii, and Easter Island to a species of Alocasia (kape, or 'ape); and in the Caroline Islands to a yam (kap)all plants having starchy, edible roots. The Philippine name for Alo"asia (biga), which becomes "piga" in Guam, reappears in Fiji as "via." The etymological identity of these words is undoubted, for the changes wbich the consonants undergo follow the same law in many oiher words.

On the island of Guam several important plants were eultivated by the aborigines which were unknown in eastern Polynesia-such as rice, 
the betel pepper, and the areca palm. These are undoubtedly of Malayan origin and bear Malayan names. They probably found their way to the Malayan islands after the departure of the people who spread orer the eastern Pacific islands, but before the separation of the settlers of Guam from the parent stock. It is interesting to note that the Guam name for rice (fae, or fai) is more closely allied to the Jara name (bai) than to the Philippine (palai). Besides rice, the betel pepper, and the areca palm the natires of Guam took with them a textile screw pine (Pandanus tectorius), which has to be propagated by cuttings, as only one sex occurs on the island, and it consequently does not fruit. On the other hand, the eastern Polynesians took with them a number of plants unknown to the ancient Chamorros, such as the paper mulberry, the kara pepper, the candle nut, and the so-called chestnut of Polynesia (Bocou edulis), all of which are of East Indian origin.

ENDEMIC NAMEs. - One of the most striking facts connected with Guam plant names is the occurrence of some which are, as far as can be ascertained, quite different from those of any other region. Such are the names of the sereral forms of yam (nika and dago), bananas and plantains (chotda), Cycas (fadang), bamboo (piao), and the various species of screw pine (aggag, pahong, kafô). The name for breadfruit (lemae) bear's no resemblance to that used by the Polynesians (ulu), and the name for the taro plant (suni), which I have been unable to find elsewhere in the Pacific or the Philippines, I believe to be identified with "sunge," or "songe," its name in the islands of Madagascar and Réunion.

\section{LITERATURE. $\because$}

\section{BIBLIOGRAPHY.}

A list of hooks in the Library of Cougress relating to Samoa and Guam, with references to periodicals, was compiled under the direction of Mr. A. P. C. Griffin and published in 1901. A second list, with important additions on the Marianne Islands, was published two years later under the same auspices, forming a part of the Bibliography of the Philippine Islands (pp. 138-14t), Washington, 1903.

EARLI VOYAGES.

Magellax. - Pigafetta's narrative of Magellan's royage, containing an account of the diworery of Guam, was published in Italian at Milan in 1810. The best English translation is that published in vol. 52 of the Hakluyt society publications. A critical account of the editions of this work is given in W'insor's Narrative and Critical History of America, rol. 2. pp. 613-617. Herrera's Historia general de los hechos de los Castellanos en las islas i tierra firme del mar oceano

"I am inclehted to Dr. Ainsworth R. Spofford for reading the proof of the following nute's aml list of works eonsulted. 
gives an account of the royage evidently drawn from contemporary information. Various documents relating to the voyage are reproduced in English in Blair and Robertson, vol. 1.

Loaisa. - Andres de Urdaneta's account of the expedition of Loaisa, which visited Guam in September, 1526, is given in Navarrete's Coleccion de viages, vol. 5. An abridgment of it appears in Medina's Coleccion de documentos inéditos, vol. 3, and an English translation in Burney's Chronological History, vol. 1, p. 217.

LEgazPI. - Accounts of the expedition of Miguel Lopez de Legazpi, which visited Guam in January and February, 1565, are given in Gaspar de San Agustin's Conquista de las Philipinas, lib. 1, cap. 17, Madrid, 169s, and in Juan de Grijalva's Cronica de la Orden de n. p.s. Augustin en las provincias de Nueva España. Burney's Chronological History, vol. 1, contains a narrative in English, translated from Gaspar and Grijalva's accounts.

Carendish. - The narrative of the voyage of Thomas Cavendish, the English freebooter, who touched at Guam in January, 1588, is giren in Hakluyt's Voyages, vol. 3, 1837, and Burney's Chronological History, vol. 1, pp. 64-94.

Vax Noort.-An account of the visit of the Dutch navigator, Olicer van Noort, in September, 1600, is given in the Abbé Prévost's Histoire générale des voyages, vol. 10, taken from the narrative of the vorage published in French at Amsterdam in 1602. An account of the voyage in English is given in Purchas, His Pilgrimes, vol. 1, book 2, pp. 71-78.

SpIlberghen.-The narrative of the voyage of Joris van Spilberghen, who touched at Guam January 23, 1616, is given in Miroir Oost et West. Indical, published in French at Amsterdam in 1621.

Nassau Fleet. - The account of the visit of this fleet in 1625 is giren in the Journael van de Nassausche Vloot, Amsterdam, 1626.

Cowley. - The account of the pirates Cowley and Eaton's visit to Guam in March, 1685, is published in Dampier's Voyages, vol. 4.

DAMPIER. - The account of Dampier's visit to Guam in 1686 is given in A New Voyage Round the World, by Capt. William Dampier, vol. 1.

Woodes Rogers. - The account of the visit of this celebrated freebooter to Guam in 1710 is given in Woodes Rogers' Narrative.

Anson.- No book ever met with more favorable reception than Lord Anson's Voyage Round the World, which, though printed under the name of his chaplain, Richard Walter, was composed by Benjamin Robbins, under the inspection of Anson himself. During his visit to the group, in 1742, Anson gleaned much interesting information regarding the island of Guam, its inhabitants, and its products. His geographical, hydrographic, and botanical descriptions are remarkably accurate and exceedingly interesting, though his picture of the island of Tinian is perhaps a little too highly colored. 
DE PAGlès.-For an account of the visit of Captain De Pagès to Guam in 1768, see his Travels Round the World in the Year's 17671771, English translation; see also his second voyage, 1788-90, in Nouveau Voyage autour du Monde, vol. 2, p. 47.

Crozet.-For an account of the visit in 1772 of the fleet which had been fitted out at Mauritius by Captain Marion, see Crozet's Noureau royage à la Mer du Sud, commencé sous les ordres de Marion.

\section{SCIENTIFIC EXPEDITIONS.}

Mataspina.-For the narrative of Malaspina's expedition, which visited Guam in February, 1792, see the introduction to Presl's Reliquiae Haenkeanae, Prague, 1825-1830; also Novo y Colson's La ruelta al mundo por las corbetas Descubierta y Atrevida al mando del Capitan de Navio Don Alejandro Malaspina, desde 1789 á 1794.

Koтzeвue. - The best account of Kotzebue's expedition, which visited Guam in Norember, 1817, is that of Adelbert Chamisso, published in his Bemerkungen und Ansichten and his Tagebuch. See reprint in Chamisso's complete works, 4 vols. Kotzebue's own narrative is unreliable.

Fretciner. - The narrative of royage of the Uranie, which visited Guam in 1819, was written by Freycinet himself, the botany by Gaudichaud, and the zoology by Quoy and Gaimard. See Voyage autour du monde entrepris par ordre du Roi, exécuté sur les correttes de s. M. l'Uranie et la Physicienne.

Dunont D'URYILLe.-The accounts of Dumont d'Urville's two visits to the island, in 182s as commanding officer of the Astrolabe and in 1839 in command of the Astrolube and Zétée, are given in the narratives of the two expeditions, Vorage de décourertes de l'Astrolabe, Pari., 1830, and Voyage au Pole sud et dans l'Océanie sur les corvettes l'Astrolabe et la Zélée, Paris, 1841-1854.

\section{DESCRIPTION.}

Among the most important works describing the island of Guam may be mentioned Dampier's royages and Freycinet's Narrative, to which references have already been made, and the following works: Don Felipe de la Corte's Memoria descriptiva é historica de lan Islas Marianas, Madrid, 1875; Lslas Marianas: Viaje de la corbeta de guerra Narraez desde Manila á dichas islıs, por Don Eugenio Sanchez y Zayas, Teniente de Nario, in Anuario de la Direccion de Hidrografia, 1865; and Islas Marianas. por Francisco Olire y Garcia, Teniente Coronel, ex-Gobernador Politico Militar, Manila, 1887. A description of the island was also given in a paper by the author published in the Ameri(an Anthropologist, n. s., vol. 4, 1902, and afterwards republished in the Report of the Secretary of the Smithsonian Institution for 1902. See also the description of Alexander Agassiz in his coral reefs of the Tropical Pacific, 1903. 
HISTORY.

The most important historical work relating to the island is Garcia's Vida y martyrio de el venerable Padre Diego Luis de Sanvitores (see below). This work was dedicated by the author to the Excelentisima Señora Doña Maria de Guadalupe, Duchess of Aveyro y Maqueda, Duchess of Areos, since it was by her generosity that its publication was rendered possible. It is made up almost entirely from the annual reports of the Jesuit missionaries living on the island of Guam and was published very shortly after the events it records. It forms the basis of all subsequent histories.

In the year 1700 there appeared at Paris a little book entitled "Histoire des isles Marianes, nourellement converties à la religion Chrétienne; et de la mort glorieuse des premiers missionaires qui y ont prêché la Foy," par le Père Charles le Gobien, de la Compagnie de Jesus. The greater part of this work is almost a literal translation of the preceding, though in the introduction the name of Padre Garcia is not mentioned. Père le Gobien continued the narrative from 1681 to 1694. In conformity with the decrees of Pope Urban VIII, and of other sorereign pontiffs, Père le Gobien protests at the beginning of the work that he does not pretend to attribute the title of saint, apostle, or martyr to the apostolic men of whom he speaks in the history. In his work he has used on several occasions simple statements of Padre Garcia as themes for elaborate variations, giving speeches of natires in the form of direct discourse and sometimes exaggerating in a most misleading manner, as in his account of the sensations of the natives of Guam when first beholding fire. ${ }^{a}$

In Burney's Chronological History of the Discoveries in the South Sea or Pacific Ocean, to which reference has already been made, there is a résumé of the principal works referring to the Marianne Islands. Burney's work is most interesting and is characterized by a broad humanity and sympathy for the simple natives of the islands of which he writes and hatred for injustice and oppression.

Don Luis de Ihañez y Garcia, in his Historia de las Islas Marianas, 1886, repeats the historical information given by Père le Gobien. His account of the social institutions, religion, and superstitions of the aboriginal inhabitants (chap. 10, p. 73), has nothing to do with the natives of Guam, who were ignorant of the gods, the bloody sacrifices, and disgusting practices of which he speaks. He tells of crocodiles, hogs, and other animals, which were unknown in Guam, and relates myths which he had evidently gleaned from some of the Philippine tribes. 


\section{LANGUAGE.}

A grammar of the language of Guam, of which three parts have already appeared, is now in process of publication in the American Anthropologist. See "The Chamorro language of Guam," by William Edwin Satford, in vols. 5, 6, and $7(1903-5)$ of that journal.

See also the "Christian Doctrine" entitled "Devoción á San Francisco de Borja, patrón de Rota," etc., by Padre Aniceto Ibañez del Carmen, agustino recoleto y antiguo cura y vicario en Marianas. In this little work the ereed, prayers, and instructions are printed in Spanish and Chamorro in parallel columns. A small Spanish-Chamorro dictionary by the same author was published in Manila in 1865, also a text book for teaching Spanish grammar to the children of the Marianne Islands. This work is entitled "Gramática Chamorra" but it is simply a translation of a grammar written by Luis Mata y Araujo, and is dedicated to the schools of the Mariannes for the purpose of teaching Spanish to the native children. It does not in the least treat of the grammar of the Chamorro language. As far as is known to the author, no grammar of the Chamorro language has hitherto been published.

\section{NATURAL HISTORY.}

In addition to the publications of the scientific expeditions already referred to, attention is called to the following works:

Les mammifères et les oiseaux des îles Mariannes, par M. E. Oustalet, published in the Nouvelles Archives du Muséum d'Histoire Naturelle, troisième série, tomes 6 et 7, 1895-96.

On the Birds of the Marianne Islands, by Ernest Hartert, in Novitates Zoologicæ, vol. 5, 1898.

Report of a Mission to Guam, containing a list of Guam birds and fishes collected by Mr. Alvin Seale, together with descriptions of new species, published in the Report of the Director of the Bernice Pauahi Bishop Museum of Polynesian Ethnology and Natural History for 1900. Honolulu, 1901.

\section{BOTANY.}

PACIFIC ISLAND Floras. - The principal works relating to the regetation of islands in the Pacitic Ocean are Schumann und Lauterbach's Flora der deutschen Schutzgebiete in der Südsee; Karl Schumann's Flora der deutschen ost-asiatischen Schutzgebiete (Engler's Jahrb., rol. 9, 1887); Thomas Powell, On Various Samoan Plants and Their Vernacular Names (Seemann's Journ. of Botany, vol. 6, 1868); F. Reinecke's Flora der Samoa-Inseln (Engler's Jahrb., vols. 23 and 25, 1897 and 1998); Luerssen's Farne der Samoa-Inseln and Filices Graeffeana, in Mittheilungen aus der Botanik, I, 1874; Seemann's Flora Vitiensis; Hillebrand's Flora of the Hawaiian islands; Drake 
del C'astillo's Flore de la Polynésie française; Doctor Guppy's Solomon Islands and their Natives; Warhurg, Beiträge zur Kenntniss der papuanischen Flora (Engler's Jahr'b., vol. 13, 1890). In addition to these may be mentioned the publications of results of the scientific expeditions of Malaspina, Romanzoff, Freycinet, and Dumont d'Urville, already referred to, and the botany of the Challenger expedition.

Other tropical floras. - Since many of the plants of Guam are of wide distribution in the Tropics, it is interesting to compare its flora with those of other tropical countries. The principal workis used for comparison have been Padre Blanco's Flora de Filipinas; Hooker's Flora of British India; Trimen's Handbook of the Flora of Ceylon; Miquel's Flora van Nederlandsch Indië; Grisebach's Flora of the British West Indian Islands; Seemann's Flora of the Isthmus of Panama, in the Botanj of the Voyage of the Herald; Urban's Symbolae Antillanae; Pittier's Primitiae florae costaricensis; and the Flore phanérogamique des Antilles françaises (Guadeloupe et Martinique), par le R. P. Duss (in Annales de I'Institut Colonial de Marseille). Many of the botanical descriptions included in the Descriptive catalogue of plants hare been taken directly from Padre Blanco, Hooker, and Trimen, and a few from Hillebrand, Grisebach, and Seemann.

Geographical distribution and ECOLOGy.-The following are the more important works consulted: Grisebach's Geographische Verbreitung and Vegetation der Erde; Schimper's Pflanzen-Geographie and Indomalayische Strandflora; Treub's Notice sur la nouvelle flore de Krakatau; Haherlandt's Botanische Tropenreise; Darwin's Voyage of the Bergle; Wrarming's Ökologische Pflanzengeographie (German edition); De Candolle's Origin of Cultivated Plants; and Wallace's Island Life. The attention of those interested in the dispersal of plants by ocean currents is called to the works of Hemsley and Guppy, given in the list below, and the works of Treub and Schimper, already cited.

Systematic and physiological botany.--Engier and Prantl's Natürliche Pflanzenfamilien; Strasburger, Noll, Schenck, und Schimper's Lehrbuch der Botanik; Haherlandt's Pflanzenanatomie; Coulter's plant structure; Delpino's Rapporti tra insetti e tra nettarii estranuziali; and Darwin's Power of Movement in Plants and Effects of Cross and Self Fertilization, are among the principal works consulted.

TROPICAL AGRICULTURE AND ECONOMIC PRODUCTS.

Among the most important works on tropical agriculture consulted are Firminger's Manual of Gardening for Bengal and Upper India; Simmonds's Tropical Agriculture; Nicholls's Text-book of Tropical Agriculture; Dyłowski's Traité pratique de cultures tropicales; Sadebeck"s Kulturgewächse der deutschen Kolonien und ihre Erzeugnisise; Semler's Tropische Agrikultur; Poulet's Livre du Colon. Of these 
perhaps the most useful to an English-speaking colonist is the work of Nicholls. A translation has been made of it into Spanish by Prof. 11 . Pittier and published at San Juan de Costa Rica in 1901.

In addition to these are Cook and Collins's Useful Plants of Porto Rico; Reinecke's "Samoa;" Wohltmann's Pflanzung und Siedlung auf Samoa; Père Sébire's Plantes utiles du Sénégal; Mueller's Select Extratropical Plants; Maiden's Useful Native Plants of Australia; and Major Drury's Useful Plants of India.

More comprehensive works are Watt's Dictionary of the Economic Products of India; Spons' Encyclopædia of the Industrial Arts, Manafactures, and Raw Commercial Products; and Wiesner's Rohstoffe des Pflanzenreiches.

\section{ALPHABETICAL LIST OF WORKS CONSULTED.}

The following is a list of the more important works, journals, reports, and other publications which have been consulted in the preparation of the Useful Plants of the Island of Guam.

Abbe, Cleveland, Jr. Earthquake records from Agaña, Island of Guam, 1892-1903. Terrestrial Magnetism and Atmospheric Electricity, June, 1904, p. 81.

Agassiz, Alexander. Reports on the scientific results of the expedition to the tropical Pacific, in charge of Alexander Agassiz, by the U. S. Fish Commission steamer Albatross, from August, 1899, to March, 1900. IV. The coral reefs of the tropical Pacific. Memoirs of the Museum of Comparative Zoology at Harvard College. Vol. 28, Guam, p. 366; pls. 194-198, 232, 233, fig. 4. Cambridge, 1903.

Agricultural and Botanical Bulletins, Journals, and Reviews.

Agricultural Bulletin of the Straits and Federated Malay States. Singapore, 1891 to date.

Annales de l'Institut colonial de Marseille. Macon, France, 1893 to date.

Bulletin agricole de la Martinique. St. Pierre, Martinique.

Bulletin économique de l'Indo-Chine. Hanoi, French Indo-China.

Bulletin de la Société d'Études coloniales. Brussels, 1894 to date.

Bulletin of the Botanical Department, Jamaica. Kingston, Jamaica, 1887-1902.

From Jan., 1903, titie reads Bull. of the Dept. of Agr., Jamaica.

Journal d'agriculture tropicale. Paris, 1901-date.

Kew Bulletin of Miscellaneous Information. London, 1887 to date.

The Plant World. Washington, D. C., 1897 to date.

Revue des cultures coloniales. Paris, 1897 to date.

Der Tropenpflanzer. Berlin, 1897 to date.

Tropical Agriculturist. Colombo, Ceylon, 1881 to date.

West Indian Bulletin. Barbados, West Indies, 1899 to date.

Agricultural Society of JAPAN. Useful plants of Japan. Tokyo, 1895.

Aners, Georie P. Compilation of notes on the most important timber-tree species of the Philippine Islands. Forestry bureau, Manila, P. I., 1901.

Arreri, (ieorie P. Special repurt of Capt. George P. Ahern, Ninth U. S. Infantry, in charge of forestry hureau, Philippine Islands, from April, 1900, to July 30, 1901. Government Printing Office, Washin ton, 1901.

Amıt di Sax Frlipo, Pintro. Biografia dei viaggiatori italiani, p. 526. Alessandro Malaspina, 1754-1809. Roma, 1881. 
Axnés, Lotis E. Vegetable fats and oils. Translated by Charles Salter. London, 1897.

Anson, George. A voyage round the world in the years 1740-1744. Compiled * * * by Richard Walter (pseud.). London, 1748. (Guam, pp. 337-339.)

Arago, JacQues. Narrative of a voyage round the world. Translated from the French. 2 v. in 1. London, 1823.

BaIley, L. H. Cyclopedia of American horticulture. New York, 1900-1902.

BAKer, J. G. Flora of Mauritius and the Seychelles. London, 1877.

Baltet, Charles. L'art de greffer. Paris, 1892.

Banks, Charles S. A preliminary report on insects of the cacao. Report of the Philippine Commission, 1903. Part 2, p. 597. Washington, 1904.

BARox, R. Notes on the economic plants of Madagascar. Kew Bull. of Misc. Inf., 1890, pp. 203 et seq.

Buum, H. E. The breadfruit, by Henry E. Baum, together with a biographical sketch of the author by W. E. Safford. Reprinted from the Plant World, vols. 6 and 7, 1903-4. Washington, H. L. MeQueen. 1904.

Belt, Thomas. The naturalist in Nicaragua. London, 1874.

Bentha , G. Flora hongkongensis, with supplement. London, 1861-1872.

Bexthaм, G. Flora australiensis. London, 1863-1878.

Bетсне, E. V'egetationskizze der Marschalls Inseln. Wittmack's Gartenzeitung, v. 3, pp. 133-134. 1884.

Blair, Helex, and Robertson, James Alexander. The Philippine Islands, 14931903. Official documents, narratives of missionaries, and historical works. The original sources of our knowledge of the islands and their inhabitants. Cleveland, Ohio, 1903.

Blanco, Manuel. Flora de Filipinas. ed. 1, Manila, 1837. Gran edición . . bajo la dirección científica del P. Fr. A. Naves. text, 4 v., pls., 2 v. Manila, $1877-1880$.

Blasdale, WALter C. A description of some Chinese vegetable food materials and their nutritive and economic value. U. S. Dept. of Agr., Office of Experiment Stations, Bull. No. 68, 1899.

Bonatia, Emanuel. The cultivated oranges and lemons of India and Ceylon. $2 \mathrm{v}$, text and pls. London, 1890.

Bradford, R. B. Report of the Chief of the Bureau of Equipment, United States Navy, for 1902. In Report of the Secretary of the Navy for 1902.

Brewer, Willitan H. Geological survey of California. Botany, v. 2, 1880.

BrÜHL, J. W. Die Pflanzen-Alkaloide Braunschweig. 1900.

Burney, Janies. A chronological history of the discoveries in the South Sea or Pacific Ocean. London, 1803-1817. Vol. 1 contains narratives of the Loaisa expedition and of that under Legazpi.

Catanilles, Josef. Descripción de las plantas que Don Josef Cavanilles demostró en las Lecciones públicas del año 1801, precedida de los principios elementales de la botánica. Madrid en la Imprenta Real, año 1802.

Chamisso, Adelbert. Chamisso's gesammelte Werke, in 4 Bänden, mit biographischer Einleitung, herausgegeben von Max Koch. Dritter Band: Reise um die Welt. Erster Teil: Tagebuch. Vierter Band: Reise um die Welt. Zweiter Teil: Bemerkungen und Ansichten. Stuttgart. Verlag der I. G. Cotta'schen Buchhandlung.

Chamisso, Adelbertis, et Schlechtendal, Diedericus. De plantis in expeditione speculatoria Romanzoffiana observatis, ete. Linnæa Bde. 1 to 10. Berlin, 1826 to 1836 .

Chapman, A. W. Flora of the Southern States. 2. ed. New York, 1883.

Chorrs, Lotrs. Voyage pittrresque autour du monde, avec des portraits des sauvages d'Amérique, d'Asie, d'Afriquie ... F F $^{\circ}$. Paris, Didot, 1822. 
Codringtox, R. H. The Melanesians. Studies in their anthropology and folk-lore. Oxford, 1891.

Collins, G. N. The mango in Porto Rico. U. S. Dept. of Agr., Bureau of Plant Industry, Bull. No. 28. Washington, 1903.

Colmeiro, Mgevel. La botánica y los botánicos de la peninsula hispano-lusitana. Madrid, 1858.

Concepcion, Juan de LA. Historia General de Philipinas. (Vol. VII contains a map of Guam and one of Saipan.) 1788-1892.

Cook, O. F. Shade in coffee culture. J. S. Dept. of Agr., Division of Botany, Bull. No. 25. Washington, 1901.

Coок, O. F. A synopsis of the palms of Porto Rico. Bull. Torr. Botanical Club, v. 28, p. 528. (October, 1891.)

Соок, O. F. Agriculture in the tropical islands of the United States. Yearbook, U. S. Dept. of Agr., for 1901. Washington, 1901.

Cook, O. F. The American origin of agriculture. Popular Science Monthly, October, 1902, pp. 492 et seq.

Cook, O. F. Origin and distribution of the cocoa palm. Contr. U. S. Nat. Herb., vol. 7, no. 2. Washington, 1902 .

Соок, O. F. The culture of the Central American rubber tree. U. S. Dept. of Agr., Bureau of Plant Industry, Bull. No. 49. Washington, 1903.

Cook, O. F. Report on the habits of the Kelep, or Guatemalan cotton-boll weevil ant. U. S. Dept. of Agr., Bureau of Entomology, Bull. No. 49, 1904.

Cook, O. F., and Collins, G. N. Economic plants of Porto Rico. Contr. U. S. Nat. Herb., vol. 8, pt. 2. Washington, 1903.

Coulter, John M. Plant structures. New York, 1900.

Coulter, John M., and Chamberlaix, C.J. Morphology of spermatophytes. New York, 1901.

Coville, Frederick V. Some additions to our vegetable dietary. Yearbook, U. S. Dept. of Agr. for 1895, p. 205.

Cowley, CApt. - Voyage around the globe. Dampier's voyages, v. 4. London, 1729 .

Crozet, - - Nouveau voyage à la Mer du Sud, commencé sous les ordres de Marion. Paris, 1783.

Dampier, William, Captain, Royal Navy. A new voyage round the world. 6. ed. cor. London, 1717. $4 \mathrm{v}$.

DANA, JAmes D. Corals and coral islands. New York, 1872.

DARwin, C. A naturalist's voyage. 1845.

DARwin C. On the action of sea water on the germination of seeds. Jour. Linn. Soc. Lond., v. 1, pp. 130-140, 1857.

Darwin, C. Power of movement in plants. New York, 1895.

DARwix, C. The effects of cross and self fertilization in the vegetable kingdom. New York, 1877.

De Candolle, Alphonse. Origin of cultivated plants. New York, 1885.

De Caxdolle, Alphosise. Géographie hotanique raisonnée, ou Exposition des faits principaux et de lois concernant la distribution géographique des plantes de l'époque actuelle. 2 v. Paris, 1855.

Delpino, Federico. Rapporti tra insetti e tra nettarii estranuziali in alcune piante. Soc. ital. di Sci. nat., atti 18, p. 63, 1875.

Dewar, J. Cumming. Voyage of the Nyanza. R. N. Y. C., London, 1892.

Dodie, C. R. Catalogue of the useful fibre plants of the world. U. S. Dept. Agr., Fibre Invest. Rep. No. 9, 1897.

Drafe del Castillo, Emaylel. Flore de la Polynésie Française. Paris, 1892.

Drury, Heber. The useful plants of India. Madras, 1858.

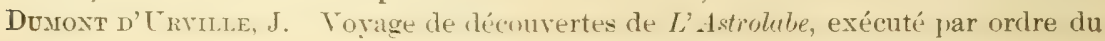
roi pendant les années, 1826, 1827, 1828, et 1829. 12 v. Paris, 1830. 
Dumont D'Tritle, J. Voyage au Pôle Sud et dans l’Océanie sur les corvettes L'Astrolabe et La Zélée: Paris, 1841-1854.

Dúss, R. P. Flore phanérogamique des Antilles Françaises. Annales rle l'Institut colonial de Marseille, 1897.

Duver, J. W. T. The vitality and germination of seeds. U. S. Dept. of Agr., Bur. Plant Industry, Bull. 58, 1904.

Drвowski, J. Traité pratique de cultures tropicales par J. Dybowski. Paris, 1902.

Elis, Wilithy. Polynesiau researches during a residence of nearly eight years in the Society and Sandwich islands. 4 v. London, 1859.

Exducher, Stephex. Bemerkungen über die Flora der Südseeinseln. Annalen des Wiener Museums der Naturgeschichte, v. 1., pp. 129-186, 1836.

Evgler \& Prantl. Die Natürlichen Pflanzenfamilien. Leipzig, 1887-1901.

Eschscholtz, Johann Friedrich. Histoire naturelle d'un voyage autour du monde, fait avec le Capitaine de Kotzebue, 1823-1826. Moscou, Soc. nat., Bull. 1, 1829, pp. 19-24.

Featherman, A. Social history of the races of mankind. London, 1885-1891.

Firminger, T. A. C. Manual of gardening for Bengal and upper India: Ed. 4. Calcutta, 1890.

Fitzxer, Rcdolph. Die Bevölkerung der deutschen südseekolonien. Globus, v. 84, p. $21,1903$.

Forbes, H. O. A naturalist's wanderings in the eastern archipelago. Ed. 2. London, 1885.

Forster, J. G. A. Florulæ insularum australium prodromus. Goettingæ, 1786.

Forster, J. G. 1. De plantis esculentis insularum oceani australis commentatio botanica. Berolini, 1786.

Fonster, J. R. and J. ( . A. Characteres generum plantarum, quas ad insulas maris australis collegerunt, descripserunt, delinearunt. * * * Londini, 1776.

Freiciset, L. DE. Toyage autour du monde entrepris par ordre du roi, executé sur les corvettes de S. M. L' Uranie et La Physicienne pendant les années, 1817, 1818, 1819 et 1820. Paris, 1825. Partie historique et nautique redigée par M. de Freycinet.

Garcí, Fraxcisco. Vida y martyrio del Venerable Padre Diego Luis de Sanvitores de la Compañía de Jesús, primer apostol de las islas Marianas, y sucesos de estas islas desde el año de 1668 asta el de 1681. Madrid, 1683.

Gaspar de San Agustín. Conquista de las Philipinas. Madrid, 1698.

Gaudichatd-Beatpré, Charles. Botanique du voyage autour du monde, fait par ordre du roi sur les corvettes L'Uranie et La Physicienne pendant les années 1817-20 par M. Louis Freycinet. Paris, 1826.

Gaudichaud-Beaupré, Charles. Biographical sketch. See Pascallet.

Gies, William J. On the nutritive value and some of the economic uses of the cocoanut. Jour. N. Y. Bot. Garden, v. 3, p. 169, 1892. See also Kirkwood and Gies.

Gill, William Wyatt. Life in the southern isles. London, 1876.

Giluore, Joнх W. Preliminary report on the commercial fibers of the Philippines. Bur. Agr. (Philippines), Farmers' Bull. No. 4, Manila, 1903.

Goguet, A.-Y. De l'origine des loix, des arts, et des sciences; et de leurs progrìs chez les anciens peuples. Paris, 1758.

Gray, Asa. Manual of the botany of the northern United States. 6th ed., 1889.

Grijalva, Jcax de. Crónica de la orden de n. p. s. Augustin en las provincias de la Nueva España, en quatro edares, desde el año de 1533 hasta el de 1592 . Mexico City, 1624.

Grisebach, A. H. R. Flora of the British West Indian Islands. London, 1864.

Ǵrisebach, A. H. R. Die geographische Verbreitung der Pflanzen-Westindiens. Göttingen, 1865. 
Grisebach, A. H. R. Die Tegetation der Erde nach ihrer klimatischen Anordnung. Leipzig, 1872.

Guam Surver Board. Report to the Secretary of the Navy, July 25, 1901. Washington, 1902. (This board was appointed to make detailed surveys and investigations and to report on the improvements of the harbor of San Luis de Aprâ. Among the maps published with the report is one of the harbor of San Luis de Aprâ and one of the shore line and road from Piti to Agaña.)

Guillemin, J. B. A. Zephrytis taitensis. Enumération des plantes découvertes par les voyageurs dans les isles de la Société, principalement dans celle de Taiti. Ann. d. Sci. nat. de Paris, II, Botan., tome 6, p. 297, 1836; tome 7, pp. 177, $241,349.1837$.

Guppr, H. B. The dispersal of plants as illustrated by the flora of the Keeling or Cocos Islands. Trans. Victoria Inst., v. 24. 1890-91.

Guppy, H. B. Fruits from the crops of pigeons. Jour. \& Proc. Roy. Soc., New South Wales, v. 17, p. 226.1883.

Guppy, H. B. The gizzard contents of some oceanic birds. Nature, v. 26, p. 12, 1882.

Guppy, H. B. The Solomon Islands and their natives. London, 1887.

Haberlandt, G. Physiologische Pflanzenanatomie. II. Auflage. 1896.

Haberlandt, G. Eine botanische Tropenreise. Leipzig, 1893.

Hackett, Frank W. Annual report of the Assistant Secretary of the Navy. In Report of the Secretary of the Navy for 1901, p. 75.

Haenke, Thaddeus. See Presl and Novo y Colson.

Hantert, Ernest. On the birds of the Marianne Islands. Novitates zoologicæ, v. $5,1898$.

Hemsley, W. B. I. Report on the present state of knowledge of various insular floras, etc. II. Report on the botany of the Bermudas and various islands of the Atlantic and Southern oceans. III, IV. Report on the botany of Juan Fernandez, the southeastern Moluceas, and the Admiralty Islands. Appendix: On the dispersal of plants by ocean currents and birds. In Report of the scientific results of the voyage of H. M. S. Challenger during the years 1873-1876. Botany, v. 1,1885 .

Hecze, Grstave. Les plantes alimentaires des pays chauds et des colonies. Paris, 1899.

Heuze, Gustave. Les Plantes industrielles. Ed. 3. Paris, 1895.

Hicks, G. H. Oil-producing seeds. Yearbook, L.S. Dept. of Agr., Washington, 1895, p. 185.

Hillebraxd, Wy. Flora of the Hawaiian Islands. London, New York, and Heidelberg, 1888.

Hombron, Jacques Bernard. See Lasègue, Antoine.

Hooker, J. D. Handbook of the New Zealand flora. London, 1864-1867.

HоокеR, J. D. Insular floras. Gardeners' Chronicle, 1867, pp. 27, 51.

Hooker, J. D. Flora of British India. 7 v. London, 1872-1897.

Hooker, W. J., and WAlker-ARxott, (i. A. The botany of Captain Beechey's voyage. London, 1841.

IbÁšez del CARMex, Axiceto. Diccionario español-chamorro que dedica á las escuelas marianas el ${ }^{-}$. Fr. Aniceto Ibáñez del Carmen, cura párroco de Agaña. Manila, 1865 .

Ibá̃̄ez del Carmex, Axiceto. Gramática chamorra que, traducido literalmente de la que escribió D. Luis IIata y Iraujo, dedica á las escuelas de Marianas con el fin de que los niños aprendan el castellano el P. Fr. Aniceto Ibúñez del Carmen, cura párroco de Agaña. Año 1864. Manila, 1865.

Ibáx̃ez del Caruen, Axiceto. Devociún a san Francisco de Borja, patrón de Rota: esplicación de los santos sacramentos y modo de recibirlos dignamente: devo- 
Ibáx̌̃ez del Carmen, Axiceto-Continued.

ción á San Dimas el buen ladrón, Patrón de Merizo, y doctrina esplicada. Escrito por el Padre Fr. Aniceto Ibánez del Carmen, Agustino Recoleto \&c. Manila, 1887.

Ibañez y García, Luis de. Historia de las islas Marianas. Granada, 1886.

Ikexo, S. Untersuchungen über die Entwickelung der Geschlechtsorgane und den Vorgang der Befruchtung bei Cycts revolutt. Jahrbücher für wissenschaftliche Botanik, v. 32, Heft 4, p. 557, 1898.

IRIsh, H. C. A revision of the genus Capsicum. Ninth Ann. Rep. Missouri Botanical Garden, p. 53, 1898.

$\mathrm{J}_{\mathrm{AGOR}}, \mathrm{F}$. Reisen in den Philippinen. Berlin, 1873.

Jumelle, Henri. Les cultures coloniales. Plantes alimentaires. Paris, 1901. Plantes industrielles et médicinales. Paris, 1901.

Jехснинг, F. Java, seine Gestalt, Pflanzendecke und innere Bauart. Leipzig, 1852.

Kente, George. An account of the Pelew Islands situated in the western Pacific Ocean. Ed. 2. London, 1788.

Kerver von Marilaun, Anton. Pflanzenleben. 2 v. Leipzig, 1890-91.

Kerser yox Marilatx, Axtox. Die Schutzmittel der Blüthen gegen unberufene Gäste. Wien, 1876.

Krliner, F. B. The story of the papaw. Amer. Jour. Pharmacy, v. 75, pp. 272, 336, 388, 1901.

KirkTood, J. E., and Gies, W. J. Chemical studies of the cocoanut, with some notes on the changes during germination. Bull. Torrey Bot. Club, v. 29, pp. $321 \mathrm{ff}$., 1902.

Kirtikar, K. R. Poisonous plants of Bombay. Jour. Bombay Nat. Hist. Soc., v. 15, p. $56,1903$.

Kiтtuitz, F. H. r. Vier und zwanzig Vegetationsansichten von Küustenländern und Inseln des stillen Oceans. Siegen und Wiesbaden, 1844.

КотzeвtЕ, Oтto vox. Toyage of discovery into the South Sea and Behring's Straits, for the purpose of exploring a northeast passage, in the years 1815-1818, in the ship Rurick. Translated by H. E. Lloyd. 3 v. London, 1821.

Kunkel, A. J. Handbuch der Toxikologie. Jena, 1899-1901.

Krхтze, Oтto. Die Schutzmittel der Pflanzen gegen Thiere und Wetterungunst und die Frage vom salzfreien Urmeer. Leipzig, Arthur Felix, 1877.

Klrz, Sulpiz. Forest flora of British Burmah. Calcutta, 1877.

La Billardiére, J. G. Sertum austro-caledonicum. Paris, 1824-25.

LA Corte, Felipe de. Memoria descriptiva é histórica de las Islas Marianas. Boletín del Ministerio de Ultramar, 1875. Madrid, Imprenta Nacional, 1875.

La Gratière, Jeax Pierre Edmond Juries de. Voyage en Chine et dans les mers et archipels de cet Empire. Pendant les années 1847, 1848, 1849, 1850. Paris, 1854.

La Pérocise, Jeax Fraxçors de Galaup. Voyage round the world during the years 1785, 1786, 1787, and 1788, by La Pérouse. London, 1807.

LAségé, Axtonxe. Musée hotanique de M. Benjamin Delessert. Paris, 1845.

Le Gobiex, Charles. Histoire des isles Marianes. Paris, 1700.

Lesson, A. See Dumont d'Urville.

Lindery, Johr, and Moore, Thomas. The treasury of botany. New impression. London, New York, and Bombay, 1899.

Listoe, S. Cocoa butter in the Netherlands. U. S. Consular Report, October 15, 1902.

Ltersisex, Chr. Die Farne der Samoa-Inseln, in Schenck und Luerssen's Mittheilungen aus der Botanik, v. 1, p. 345. Leipzig, 1874.

Luersex, Chr. Filices Ctreffean-Beitrag zur Kenntniss der Farnflora der Viti-, Samoa-, Tonga-, und Ellice's Inseln. Ibid., p. 57. 
Lron, Williams. The cocoanut with reference to its products and cultivation in the Philippines. Bur. of Agr. (Philippines), Bull. No. 8. Manila, 1903.

Manden, Joseph Henry. The useful native plants of Australia. London and Sydney, 1889.

Malaspina, Alessandro. See Novo y Colson.

Marche, Alfred. Rapport général sur une mission aux îles Mariannes. Archives des missions, 1891.

Marche, Alfred. Mon voyage aux îles Mariannes. Société de géographie de Marseille, v. 14, pp. 22-30, 1890.

Marche, Alfred. Note de voyage sur les îles Mariannes. Société de géographie commerciale de Havre, Bull., v. 15, pp. 49-61, 65-96, 1898-99.

Mercado, Ignacio de. Libro de medicinas de esta tierra y declaraciónes de las virtudes de los arboles y plantas que estan en estas islas Filipinas. Compuesto por el P. Predicador Fr. Ignacio de Mercado, Filipense del orden de San Agustin. Blanco's Flora de Filipinas, vol. 4, 1880.

Merrill, Elmer D. A dictionary of the plant names of the Philippine Islands. Manila, 1903.

Mirtens, F. K. Notices (botaniques) sur les îles Carolines. (Luetke, Voyage, v. 3.) Paris, 1836.

Miqued, F. A. W. Flora Indiæ Bataviæ. 3 v. in 4. Amsterdam, 1855-1859.

Mrquel, F. A. W. Systema Piperacearum. Rotterdam, 1843-44.

Montero y Vidal, José. El Archipiélago Filipino y las Marianas, Carolinas y Palaos. Madrid, 1886.

Morga, Antonio De. Svcesos de las islas Philipinas. Mexico, 1609.

Moseley, H. N. Notes of a naturalist on the Challenger. London, 1879.

Moseler, H. N. Notes on plants collected and observed on the Admiralty Islands. Jour. Linn. Soc. Lond., v. 15, p. 73; 1876.

Moseley, H. N. Notes on the various plants made use of as food and as implements, clothing, etc., by the natives of the Admiralty Islands. Jour. Linn. Soc. Lond., v. 15, 1876.

Muelder, Ferdinand von. Select extratropical plants. Melbourne, 1891.

Murillo Velarde, Penro. Historia de la provincia de Philipinas, de la Compania de Jesvs, desde el año 1616 hasta 1716. Libro 4. Manila, 1749.

Natidis, Charles. Melastomacearum quae in Museo Paris continentur monogr. descript. tentamen. Ann. sci. nat., III, v. 12-18.

Narmaxi, F. C. Teber den Tegetationscharakter der Inseln des Neu-Britannischen Archipels und der Insel Bougainville. Engler's Jahrb., v. 6, p. 422, 1885.

Née, Lris. Del abacá (Musu tertilis). Anal. de ciencias naturales, v. 4. Madrid, July, 1801.

Née, Luis. Del buyo (Piper betle). Ibid,, v. 6. October, 1803.

NÉE, Lús. See also Cavanilles and Novo y Colson.

NeIsI, JAyes. Leuscher's method of preparing hanana flour. Jour. Jamaica Agr. Soc., v. 7, p. 439, 1903.

Nichol.s, H. A. A. A text-book of tropical agriculture. London, 1897.

Noro y Colson, PeDro DE. La vuelto al mundo por las corbetas Descubierta y Atrecida al mando del Capitín de Tavío Don Alejandro Malaspina, deste 1789 í 1794. Publicado con una introducción en 1885 por el Teniente de Navío Don Pedro de Novo y Colson. Madrid, 1885.

Outve y Garcia, Francisco. Islas Marianas, Manila, 1887.

d'Orbigny, Alcide. Sur les espèces du genre Victoria. Ann. sci. nat., II, v. 13, p. $55,1840$.

Orderampex, J. Bydrage tot de Kennis van Melia azedarach L. Utrecht, 1902.

Otstılet, E. A. Les mammifères et les oiseanx des îles Mariannes. Nouvelles archives đlu Muséum d'histoire naturelle de Paris, III, v. 7, 8, 1895, 1896. 
Pagiss, Prerre Marte Françors de. Travels round the world in the years 1767, $1768,1769,1770,1771$. Translated from the French. 3 v., $8^{\circ}$. London, 1791-92. PAGÉs (P. MI. F. de). Nouveau voyage autourdu monde en 1788-90. 3 v. Paris, 1797. Pascallet, E. Notice biographique sur M. Gaudichaud-Beaupré. Paris, 1844.

PÉrez, Pablo. Official letters to the captain-general of the Philippines. In the Guam Archives (MSS.).

Pigafetta, Francesco Antonio. Primo viaggio intorno al globo terracqueo. Milano, 1800.

Pittrer, H. Primitiæ Florae Costaricensis, vol. 2 and 3. San José de Costa Rica, 1898 to 1901.

Pittier, H. Manual de agricultura tropical, por H. A. Alford Nicholls. (Translation.) San José de Costa Rica, 1901.

Poulet, Georges. Le livre du Colon. Paris, 1899.

Poweld, Thomas. On various Samoan plants and their vernacular names. Seeman's Jour. of Bot., v. 6, pp. 278, 342, 355, 1868.

Pratt, George. Grammar and dictionary of the Samoan language. Ed. 3. London, 1893.

Prest, Karel B. Reliquire Haenkeanæ, seu descriptiones et icones plantarum, quas in America meridionali et boreali, in insulas Philippinis et Marianis collegit Thaddæus Haenke. Prague, 1825-1830.

Qrot, Jean René Constant, and Gamard, Joseph Paul. Notice sur les mammifères et les oiseaux des îles Timor, Rawak, Boni, Vaigiou, Guam, Rota et Tinian. Ann. sci. nat., v. 6, pp. 138-150, 1825.

Qtoy, Jean Rexé Constaxt, and Gamard, Joseph Paul. See also Dumont d'Urville. Raminez, José. Sinonomia vulgar y cientifica de las plantas Mexicanas arreglada por el Dr. José Ramirez * * * con la colaboracion del Sr. Gabriel V. Alcocer. Mexico, 1902.

RAYNal, ABвÉ. Philosophical and political history of the Indies, p. 379, vol. 3. London, 1788.

Reinecke, F. Die Flora der Samoa Inseln. Engler's Bot. Jahrb., v. 23, 24, 1897, 1898.

Reinecke, F. Samoa. Verlag von Wilhelm Süsserott, Berlin, 1902.

Richardson and Watts. Chemical technology. Ed. 2, v. 1, pt. 3. London, 1863.

Rogers, Woodes. Woodes Rogers's narrative. London, 1712.

Rolf, R. A. On the flora of the Philippine Islands and its probable derivation. Jour. Linn. Soc. Bot., v. 21.

Roxburgh, William. Flora indica; or description of Indian plants. $3 \mathrm{v}$.

SADEBeck, Richard. Die Kulturgewächse der deutschen Kolonien und ihre Erzeugnisse. Jena, 1899.

SAFFord, W. E. Guam and its people. Am. Anthr., n. s., v. 4, p. 707. 1902.

SAFFord, W. E. Extracts from the note-book of a naturalist on the island of Guam. The Plant World, v. 4, 5, 6, Washington, 1902-1904.

SAFFORD, W. E. The birds of the Marianne Islands and their vernacular names. The Osprey, n. s., v. 1, 1902.

SAfForD, W. E. The Chamorro language of Guam. Am. Anthr., v. 5, 6, and 7, 1903-5.

Sixchez y Ziyas, Eugexto. Islas Marianas. Viaje de la corbeta de guerra Núruez desde Manila á dichas islas. Anuario de la Dirección de hidrografía, pt. 4, p. 230,1865 .

Sauvalle, Francisco Adolfo. Flora cubana. 1873.

SCHERzER, KarL vox. Narrative of the circumnavigation of the globe by the Austrian frigate Nowara. London, 1861--1863.

Schimper, A. F. W. Die indo-malayische Strandflora. Jena, 1891.

Schrmper, A. F. W. Pflanzen-Geographie auf physiologiseher Grundlage. 1898.

Schiofiner, Seitrix. Report of the gisernor of Guam for the fiscal year ending June 30, 1901. Report of the Secretary of the Navy for the year 1901, pp. 81 ff. 
Schulze, L. F. M. Führer auf Java. Leipzig, 1890.

Schumary, K. und Holdruxg, M. Die Flora ron Kaiser-Wilhelmsland. Berlin, 1889.

Sснгмaxx, K. Musaceae. Engler's Das Pflanzenreich, 1. Heft, r. 4, p. 45. Leipzig, 1900.

Schumaxx, K. Die Flora der deutschen ost-asiatischen Schutzgebiete. Engler's Jahrb., v. 9, pp. 186-225, 1887.

Schumasx, Karl, und Latterbach, Karl. Die Flora der dentschen Schutzgebiete in der Südsee. Leipzig, 1901.

Seale, Alvin. Report of a mission to Guam. Occasional papers of the Bernice Pauahi Bishop Museum of Polynesian Ethnology and Natural History, r. 1, No. 3. Director's Report for 1900. Honolulu, 1901.

Sebire, A. Les plantes utiles de Sénégal. Paris, 1899.

Secretari of the [U. S.] Natx. Trans-Pacific submarine telegraph cable survey. In Annual Report for 1900, pp. 299-302.

Secretart of the [C. S.] NAYY. Report of Guam survey board to the Secretary of the Navy, July 25, 1901. Washington, 1902.

Semuan, B. Flora vitiensis. London, 1865-1873.

Sezmixy, B. Flora of the Isthmus of Panama, in the Botany of the Voyage of H. M. S. Herald. London, 1852 to 1857.

Semler, Hetnrich. Die tropische Agrikultur. 2 v. Wismar, 1897-1900.

Semper, Cart. Die Philippinen und ihre Bewohner. Würzburg, 1869.

Semper, Cart. Die Palau Inseln im Stillen Ocean. Leipzig, 1873.

Shortт, John. A monograph on the cocoanut palm, or Cocos nucifera. Madras, 1888.

Simonds, P. L. Tropical agriculture. London and New York, 1877.

Skinxer, Robert P. Copra products of Marseilles. U. S. Consular report, October 18, 1902.

Siodxe, Haxs. An account of four sorts of strange beans, frequently cast on shoar on the Orkney Isles. Phil. Trans. Royal Soc. of London, v. 19, p. 298, 1696.

Suith, Frederick Porter. Contributions toward the materia medied and natural history of China. Shanghai and London, 1871.

Solms-Laubach. Monographia Pandanacearum. Linnæa, v. 2, 1878.

Spox, E. and F. X. Spons' encrelopedia of the industrial arts, manufactures, and raw commercial products; edited by Charles G. Warnfork Lock. London, 1882.

Stafl, Erxit. Pflanzen und Schnecken; eine biologiwche Studie über die Schutzmittel der Ptlanzen gegen Schneckenfrass. Jenaische Zeitschrift für Naturwissenschaft und Medicine, v. 22, pp. 640-656, 1888.

StaIr, J. B. Old Samoa. London, 1897.

Strasburcier, Noli, Schmper, und Schexck. Lehrbuch der Botanik. Jena, 1898.

Tonmatmeff, P. DE. Iles océaniques. La régétation du globe par A. Grisebach, traduit de l'Allemand, v. 2, pp. 747-883. Paris, 1878.

Tirusiox, sin W., and Mrrks J, J. Report on the scientific results of the royage of H. M. S. Challenger during the years 1873-1876, etc. v. 1. Botany by W. B. Hemsley. London, 1885.

Tracr, S. M. Cassara. U. S. Dept. of Agr., Farmers' Bull. No. 167, 1903.

Tracy, S. M. Mississippi Bull. No. 39, 1896.

Tracy, W. W., JR. A list of American varieties of peppers. U. S. Dept. of Agr., Bur. Pl. Ind. Bull. No. 6, 1902.

Trechar, Edward. The Maori-Polynesian comparative dictionary. Wellington, New Zealand, 1891.

Trerb, M. Noticesur la nonvelle Flure de Krakatau. Aunales du Jardin Botanique de Buitenzorg, v. 7, 1888. 
Trimex, Henry. A handbook of the flora of Ceylon. $5 \mathrm{v}$. London, 1893-1900.

Tirpix, P. J. F. Observations sur les biforines, organes nouveaux situés entre les vésicules du tissu cellulaire des feuilles . . . des Aroïdées. Ann. des Sci. Nat., II, v. 6, p. 5, pl. 1-5, 1836.

Urited States Dispensatory. By Dr. George B. Wood and Dr. Franklin Bache. Ed. 18, thoroughly revised and largely rewritten by H. C. Wood, M. D., LL. D.; Joseph P. Remington, Ph. M., F. C. S., and Samuel P. Sadtler, Ph. D., F. C. S. Philadelphia, 1899.

Lxited States Hydrographic Office. Meteorological records (hourly) taken at the U. S. naval station, island of Guam (MSS.).

Trobax, Ignatids. Symbolæ Antillanæe seu fundamenta floræ Indiæ Occidentalis. 1898 to date.

VARigny, H. DE. L'étude de M. Guppy. Revue scientifique, March 28, 1891.

Trlalobos, Francisco Rajóx de. Official letters to the captain-general of the Philippines. Guam Archives (MSS.).

Wallace, A. R. The Malay Archipelago. New York, 1869.

WALLACE, A. R. Island life, or the phenomena and causes of insular faunas and tloras. New York, 1881.

WALlACE, A. R. Tropical nature, and other essays. London, 1878.

Wallace, James. A description of the Orkney Islands. 1693.

WARBCRG, O. Beiträge zur Kenntniss der papuanischen Flora. Engler's Jahrb., v. 13, 1890-91.

WArburg, O. Pandanaceae. Engler's Pflanzenreich, v. 4, p. 9. Leipzig, 1900.

TIARBurg, O. Ueber Verbreitung, Systematik und Verwerthung der polynesischen Steinnuss-Palmen. Berichte der Deutschen-botanischen Gesellschaft, v. 14, p. $133,1896$.

WARbl RG, O. Das Pflanzenkleid und die Nutzpflanzen von Neu-Guinea. Bibliothek der Länderkunde 5/6, Krieger, U., New Guinea; pp. 36-72.

Warmixg, E. Ökologische Pflanzengeographie. German edition. Berlin, 1896.

Watt, George. A dictionary of the economic products of India. Calcutta, 18851893.

Webber, Herbert J. Spermatogenesis and fecundation of Zamia. U. S. Dept. of Agr., Bureau of Plant Industry, Bull. No. 2, 1901.

TTeber, R. A. Raphides the cause of the acridity of certain plants. Jour. Amer. Chem. Soc., September, 1891, p. 215.

ITIesner, Juluts. Die Rohstoffe des Pflanzenreiches. 2 v. Leipzig, 1900-1903.

Wт тнт, R. Icones plantarum Indiæe Orientalis, or figures of Indian plants. Madras, $1840-56$.

Wrldeman, E. DĖ. Melia Azedarach. Revue des cultures coloniales, v. 13, p. 75, 1903.

Wrideman, E. DE. Les plantes tropicales de grande culture. Brussels, 1902.

Wiley, H. W. The manufacture of starch from potatoes and cassava. U. S. Dept. of Agr., Division of Chemistry, Bull. No. 58, 1900.

Wilex, H. W. Crystals of oxalate of lime in plants. Science, July 24, 1903.

Williams, D. On the farina of Tacea pinnatifida. Pharm. Jour. and Trans., v. 6, p. $383,1846-47$.

WiNkLER, E. Real Lexikon. 2 v。 Leipzig, 1840, 1842.

Wintox, A. L. The anatomy of the fruit of Cocos nucifera. Amer. Jour. Sci., IV, v. 12, p. $265,1901$.

Wohltyaxx, F. Pflanzung und Siedlung auf Samoa. Erkundungsbericht von Prof. Dr. F. Wohltmann, Kaiserlicher Geheimer Regierungsrat an das KolonialWirtschaftliche Komitee zu Berlin. Beihefte zum Tropenpflanzer. Berlin, Jan., 1904. 


\section{DESCRIPTIVE CATALOGUE OF PLANTS.}

In the following catalogue the Guam names and those of the Hawaiian and Samoan Islands are taken chiefly from the manuscript notes of the author. His list of the vernacular names of the plants growing in Guam is supplemented by the lists of several Spanish governors of the island in official reports to the captain-general of the Philippines, copies of which were found in the archives of Agana, and also by the names cited by Chamisso and Gaudichaud in the reports of the botany of the expeditions to which they were attached. The list of Hawaiian names is supplemented by a number taken from Hillebrand's Flora of the Hawaiian Islauds, and that of the Sanoan names from Rev. Thomas Powell's list of Samoan plants and their vernacular names published in Seemann's Journal of Botany, 1868, and Rev. George Pratt's Grammar and Dictionary of the Samoan Language, 1893. The Philippine names have been taken from Padre Blanco's Flora de Filipinas and Padre Mercado's Libro de Medicinas, supplemented by Mr. Merrill's Dictionary of the Plant Names of the Philippine Islands, 1903; the Fijian names from Seemann's Flora Vitiensis; the Tahitian names from Drake del Castillo's Flore de la Polynesie Française; the Mexican names from Dr. Edward Palmer's manuscript notes and from Dr. José Ramirez's Sinonomia vulgar y cientifica de las Plantas Mexicanas, 1902; the Panama names from Seemann's Flora of the Isthmus of Panama, published in the Botany of the Voyage of the Herald, 1852 to 185\%; and the Porto Rico names from Cook and Collins's Economic plants of Porto Rico, supplemented by the first part of Urban's Flora Portoricensis, in Symbolae Antillanae, 1903.

The Guam names are pronounced in general according to the continental method. the rowels haring more or less resemblance to those of the German and Italian languages, and the consonants being like those of the English. It must be observed, however, that $g$ is always hard, as in the Fnglish word "go," except in the combination $\widetilde{n g} ; \mathrm{h}$ is always aspirated. eren at the end of a syllable, rery much like the German ch in "ach" ("ahgao," the name of a tree, is pronounced "ahh-gao"): $\tilde{n}$ is like the ppanish letter in the word "canon," or ni in the English word "onion;" $\tilde{n g}^{.}$is like ng in the English word "song" (not like ng in "finger"); y is always a consonant, pronounced like the English letter j ( "haso" or "hayu" (wood), corresponding to the Malayan "kayn," is pronounced "hajyu"). The C'hamorro romels e and i are frequently confused by the natives, as in the name for taro, "sune" or "suni:" and the same is true of u 



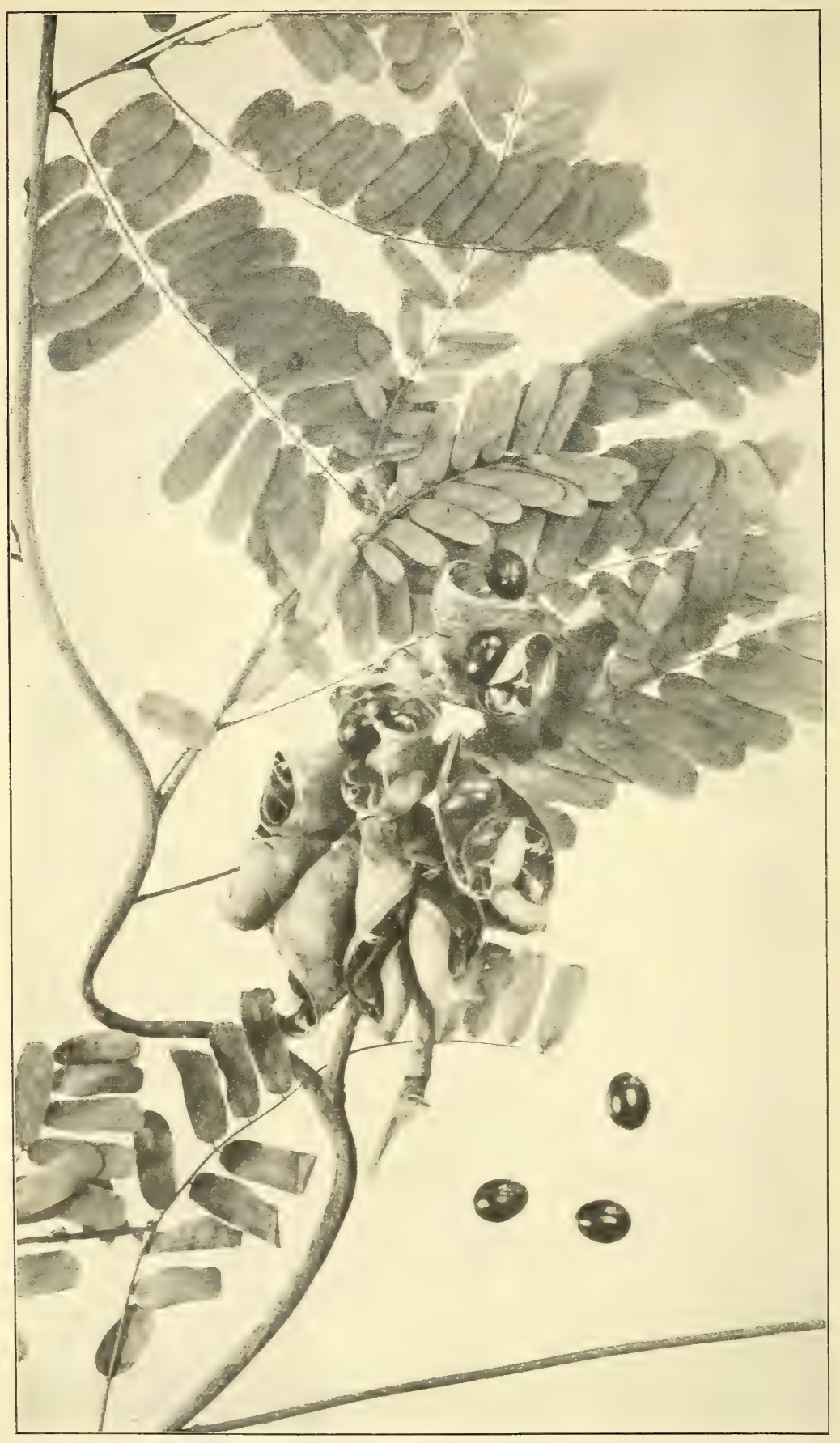

The coral-bead Vine (abrus abrus). foliage and Open Pods, Showing Seeds. Natural Size. 
and $o$, as may be seen in the name for sugar cane, written "tupu" by some authorities and "tupo" by others. The diphthong ai pronounced like the English $\mathrm{i}$ is also frequently confused with ae, the name for bread fruit being written either "lêmae" or "lêmai." The circumflex accent placed over a vowel indicates that it is pronounced gutturally. For a more complete account of the language of the island the reader is referred to The Chamorro Language of Guam, by William Edwin Safford. Reprinted from the American Anthropologist, new series, vols. $5 ; 6$, and 7 . 1903, 1904, and 1905 .

In Samoan names the apostrophe (') before a vowel or between rowels marks the position of an original Polynesian $\mathrm{k}$, and is indicated in speaking by a break in the continuity of the vowel sound. Thus the Tongan "kava" (Piper methysticum) and "muka," an adjective applied to tender young leaves, become in Samoan "'ava" and "mu'a;" and the Tongan "faki," signifying" to break off fruit from a bunch," becomes in Samoa "fa'i," the name for."banana."

Except where otherwise indicated in the text, the matter given under "references," including the critical notes, is the work of $\mathrm{Mr}$. II. F. Wight, and the authorship of the new names is therefore to be accredited to him.

\section{Aában or Aábang (Guam).}

A species of Eugenia, the hard, close-grained, durable wood of which is much used in construction on the island of Guam.

Abacá or Abaká (Philippines). See Musa textilis.

Ábas (Guam).

Local name, derived from the Spanish "guayaba," for the guava (Psidium guajava).

Abelmoschus esculentus.

OKra. OChra.

Family Malvaceae.

Local Names.-Gumbo (Louisiana); Guingambo (Porto Rico); Quingombo (Mexico); Quimbombo (Spanish); Ñaju (Panama).

An annual plant, indigenous to the West Irdies, but introduced in cultivation into all tropical and subtropical countries. Stems hairy; leaves alternate, cordate, toothed, 3 to 5-Iobed, scabrous on both sides, on long petioles; pedicels axillary, shorter than the petiole; calyx surrounded by an involucel of 9 to 12 linear deciduous leaves; petals yellow, with reddish claws; capsule oblong-lanceolate, hairy, 5-celled; cells many-seeded.

The young green mucilaginous capsules are used for thickening soup and are pickled like capers. Like many other Malvaceae, the plant yields a strong, silky fiber, and this is used in certain parts of India in the manufacture of cordage, sacking, and paper. See Okra, under Gardens.

References:

Abelmoschus esculentus (L.) Moench, Meth. 617. 1794.

Hitiscus esculentus L. SF. Pl. 2: 696. 1753.

Abrus abrus.

Coral-bead vine. Plate xxxi.

Family Fabaceae.

Locil rames.-Kolales halom-tano (Guam); Sagasaga (Philippines); Matamatamoso (Samoa); Pepitio (Tahiti); Peronia (Porto Rico); Wild licorice (India); Indian licorice (Australia); Crakneye seeds (West Indies); Jequirity (Brazil). 
A twining vine with alternate, abruptly pinnate leaves; leaflets small, linear-oval, obtuse at apex and base, in 8 to 20 pairs; flowers pale purple to white, in axillary racemes; legumes oblong, compressed, containing 4 to 6 hard, glossy, scarlet seeds marked with a black spot.

Very common in thickets throughout the island. Like many other leguminous plants it is very sensitive to changes in the intensity of light, the leaflets hanging down vertically at night, as though asleep, and rising with the dawn. These movements are also caused in a measure by the overclouding and clearing of the sky. When ripe the pods burst open, displaying the pretty, bright-colored seeds, which are very conspicuous in the tangled undergrowth of the forest. The plant is of wide distribution in the Tropics. It has evidently been introduced into Guam, where the native name "kolales" (also applied to Adenanthera pavonina) is the Chamorro pronumciation of the Spanish "corales," signifying strings of corals or beads. "Halom-tano" signifies "in-land" - that is to say, "growing in the forest" —an adjective specifying many plants to distinguish them from allied species growing in cuitivation or on the seashore.

In India the seeds are used by jewelers and druggists as weights, each seed weighing almost exactly one grain. The plant derived its former specific name "precatorius" from the fact that rosaries are made of the seeds. The Germans call them "Paternostererbse." In many tropical countries they are made into necklaces, bracelets, and other ormaments.

The seeds, known in pharmacy as jequirity beans, contain two proteid poisons, which are almost identical in their physiological and toxic properties with those found in snakes' venom, though less powerful in their effects. $a$ In India the seeds are ground to powder in a mortar, into which the natives dip the points of their daggers, and the wounds inflicted by daggers thus prepared cause death. When a small quantity of the powdered seeds is introduced beneath the skin fatal results follow; less than 2 grains of the powder administered in this way to cattle cause death within 48 hours. One of these poisons, called "abrin," is a tox-albumen. It is easily decomposed by heat, and in Egypt the seerls are sometimes cooked and eaten when food is scarce, though they are very hard and indigestible. The root has been used as a substitute for licorice.

REFERENCES:

Abrus abrus (L.)

Glycine abrus L. Sp. Pl. 2: 753. 1753.

Abrus precatorius L. Syst. ed. 12. 472. 1767.

Abrus precatorius. Same as Abrus abrus.

Abubo (Guam). See Argyreia titiaefolia.

Abutilon indicum.

INDIAN MALLOW.

Family Malvaceae.

Local NAmes.-Malbas, Matbas, Malva (Guam); Cuacuacohan, Tabing, Yampong (Philippines).

A low shrub with soft relvety leaves and orange-colored flowers, introduced into Guam and now common in waste places. Leares cordate, somewhat lobed, unequally toothéd or entire; calyx 5-cleft, withont a leafy involucel; pedicels longer than tha petioles, jointel near the flower; capsules truncate, carpels 11 to 20 , acute, truncate or shortly beaked.

The plant is of wide tropical distribution. It yields a tairly good fiber, which might be used for cordage. Its leaves contain mucilage, and are used in India in the same manner as those of the marsh mallow in Europe. The seeds are laxative, and in India the root is used as a remedy in leprosy.

ReFERENCES:

Abutiton indicum (L.) Sweet, Hort. Brit. 54. 1826.

Sida indica L. Cent. Pl. 2: 26. 1756; Amoen. Acad. 4: 324. 1759.

a See Kunkel, A. J., Handbuch (Her Toxikologie, p. 993, 1901. 
Acacia farnesiana.

SweEt ACACia.

Family Mimosaceae.

Local Names.-Aromo (Guam, Philippines, and Spanish America); Black Thorn (British West Indies); Opoponax (southern United States); Huisache (Texas); Cassie (France).

A shrub or small tree bearing yellow globular heads of fragrant flowers, and bipinnate leaves. Pinnae 4 to 8 pairs; leaflets small, narrow-linear, 10 to 25 pairs; peduncles 2 or 3 in the older axils; pods almost cylindrical, indehiscent, at length turgid and pulpy. The leaves are peculiarly sensitive to changes of weather. When a cloud obscures the sun the opposite leaflets close together and so remain until the sky brightens. They also close at night, the plant appearing to sleep until the sun rises. The petioles have stipulary thorns, with a gland above the base and another usually between the uppermost pinnae.

This species is widely distributed in the Tropics and in warm temperate regions. It has established itself in Egypt, India, Australia, Hawaii, the Philippines, and tropical Africa. It is common in the West Indies, and is spread from the Gulf region of the United States to the Pampas of Uruguay and Argentina.

It yields a gum similar to that of the closely allied Acacia scorpioides, ${ }^{\circ}$ which the natives of Guam sometimes use in the same way as the gum arabic. In southern France it is grown for perfumery, its flowers being known in commerce as cassie fluwers. In Hawaii and on the Central American coast its perfume is often borne by the land breeze to vessels more than a mile from the shore. In some parts of India the bark and the pods, called "babla," are used as dyestuffs and for tanning. Its hard, rose-colored wood is of considerable value.

REFERENCES:

Acacia farnesiana (L.) Willd. Sp. Pl. 42: 1083. 1805.

Mimosa farnesiana L. Sp. Pl. 1: 521.1753.

Acacia glauca. Same as Leucaena glauca.

Acacia, hedge. See Leucaena glauca.

Acacia leucocephala. Same as Leucaena ylauca.

Acalypha indica.

INDIAN MERCURY.

Family Euphorbiaceae.

Local names.-Bugos (Philippines); Mookto-joori (Bengal) .

A low, herbaceous, nettle-like weed growing in waste places and in crevices of stone walls, easily distinguished by the cup-shaped involucre which surrounds the small greenish flowers. Leaves ovate-cordate, 3-nerved, acuminate, serrated, on long petioles; spikes axillary, male flowers above, female below; stamens 8 to 16 , styles 3 , capsules of 3 carpels, each one-seeded.

In India the root of this plant bruised in hot water is used as a cathartic and a decoction of its leaves as a laxative. The leaves mixed with salt are applied externally in scabies.

REFERENCES:

Acalypha indica L. Sp. Pl. 2: 1003. 1753.

Acanthaceae.

Acanthus Family.

This family is represented in Guam by two ornamental shrubs, introduced from the Philippines-the well-known "caricature plant," Graptophyllum pictum, and an Eranthemum with dark-purple foliage. Both are common in gardens, and are often planted by the natives in a row under the eaves of their houses, so that they may ie watered by the drippings from the roof.

Acanthophora orientalis. See under Algæ.

"Acacia scorpioides (L.) W. F. Wight; Mimosu scorpioides L. Sp. Pl. 1:521. 1753; Mimosa arabica Lam. Encyc. 1: 19, 1783; Acacia arabica Wild. Sp. P1. 4²: 1085, 1805. 


\section{Acapulco (Guam).}

Vernacular name for Herpetice clata, a plant introduced into the Philippines and Guam from Mexico.

Achiote or Achote (Spanish). - See Bixa orellana.

Achiotl (Mexico). See Bixa orellana.

Achras sapota. See Sapota zapotilla.

Achuete (Philippines). See Bixa orellana.

Achugan (Guam).

Vernacular name for a coarse swamp grass. Only carabaos will eat it.

\section{Achyranthes aspera.}

PRICKLY CHAFF-FLOWER.

Family Amaranthaceae.

Local rames._Chichitun (Guam); Saromo (Philippines); Lau tefe-ule (Samoa).

A shrubby weed growing to the height of 3 feet, with slender elongated spikes of purplish-green flowers, which are at length reflexed and appressed to the axis; flowers cartilaginous; bracts at first soft, but soon becoming rigid and pricklelike; capsules 5-seeded, reddish; stems downy, inclined to be 4 -angled; leaves opposite, ovate or rounded, abruptiy attenuate at the base, pubescent.

A species widely spread throughout the warmer regions of the globe. In Guam it is a troublesome weed; the vernacular name, signifying "tick," is given on account of the property the fruit has of sticking to the clothing. In Samoa it is thought by the natives to have healing properties, and is called "circumcision plant." In India the leaves taken fresh and rubbed to a pulp are applied externally to the stings of scorpions. A decoction of them is used as a diuretic, and the seeds are used as a remedy for hydrophobia and snake bites.

REFERENCES:

Achyranthes aspera L. Sp. Pl. 1: 204. 1753.

\section{Acrostichum aureum.}

Marsh fern. Plate iv.

Family Polypodiaceae.

Local Xayes.-Langayao (Guam); Lau sa'ato (Samoa); Lagolo (Philippines).

A large, robust, pinnatisect fern growing in marshy places, with smooth, leathery fronds, the upper segments of which hear the sori on the under surface and the lower of which are sterile; veins forming a network; midrib almost excurrent.

This species is of wide distribution in the Tropics. In Guam it is common in the large marsh near Agaña called lic ciéungu. In Fiji its fronds, together with the leaves of Parium laurium, were formerly used for thatching the temples of the aborigines. It occurs in the West Indies and in southern Florida.

\section{REFERENCES:}

Acrostichum aureum L. Sp. PI. 1068. 1753.

Acrostichum spicatum. Same as Belvisia spicata. See Ferns.

Adelfa (Spanish). See Nerium oleander.

Adenanthera pavonina.

Corat-Bean tree.

Family Mimosaceae.

Local Nures.-Koláles, Kulális (Guam); Bahay, Casay (Philippines); La'au lopá (Samoa); Redwood, Red sandalwood (India).

A handsome deciduous tree with spreading branches and bipinnate leaves, bearing pods of glossy, scarlet, bicunvex seeds. Pinnae 2 to 6 pairs; leaflets 6 to 12 pairs, oval, obtuse, glabrous; flowers in racemes, numerous, small, white and yellow mixed, fragrant; calyx 4 or 5 -toothed; stamens 8 to 10 ; pods linear, somewhat curved, bivalved, 10 to 12 -seeded.

The tree is a native of the East Indies, where the jewelers use the seerts for weights, each weighing almost exactly 4 grains. The heartwond of the larger trees is of a deep ret color. It is hard and durable and in India is sometimes used as a substitute for red sandalwoorl. It vields a dye, which the Brahmins of India use for 
marking their foreheads. It has long been growing in Guam, and is pretty well distributed over the island. Its vernacular name is an imitation of the Spranish "corales" (coral beads), and is likewise applied to the smaller-seeded Abrus abrus.

REFERENCES:

Adenanthera pavonina L. Sp. P1. 1: 384. 1753.

\section{Adenostemma viscosum.}

Family Asteraceae.

Local naves.-Bulak manúk (Philippines); Vaianu (Tahiti).

A herbaceous pubescent composite resembling a white-flowered $\Lambda$ geratum, often viscous, with heads of flowers in panicles or corymbs. Leaves opposite, or the upper alternate, varying in shape from linear to broadly ovate, serrate; involucre campanulate, bracts many, narrow, herbaceous, receptacle flat; corollas all equal, tubular, regular; tube short, limb campanulate, 5-toothed; anthers truncate with a glandular tip, base obtuse; style branches elongate, dilated above; achenes obtuse, 5 -ribbed, glandular. A cosmopolitan herbaceous weod. It was collected on the island of Guam by Chamisso.

REFERENCES:

Adenostemma viscosum Forst. Char. Gen. 90. t. 45. 1776.

\section{Aeschynomene indica.}

INDIAN JOINT VETCH.

\section{Family Fabaceae.}

A plant growing in marshy places, with papilionaceous flowers and pinnately compound leaves. Stems herbaceous, erect; leares odd-pinnate; leaflets sensitive, small, linear, 15 to 20 pairs, smooth; stipules semisagittate; racemes axillary, the pedicels with 2 bracteoles below the calyx; peduncles few-flowered; pods smooth, linear, compressed, transversely jointed, one seed in each joint.

This plant is closely allied to Indian "shola" (Aeschynomene aspera), the stems of which yield the pith used in making helmets. From it are also made artificial flowers, models of temples, and various toys. In Guam there are a number of small images of saints very cleverly carved from pith, evidently obtained from this or an allied plant.

REFERENCES:

Aeschynomene indica L. Sp. Pl. 2: 713. 1753.

Afzelia bijuga. Same as Intsia bijuga.

Aga (Guam). The ripe fruit of plantains and bananas.

Agaliya (Guam). See Ricinus communis.

Agar-agar (Ceylon). See Algæ: Gracilaria confervoides.

Agatelang or Agatílon (Guam). See Eugenia spp.

Agati grandiflora.

Plate vi.

Family Fabaceae.

Local Names. - Katúrai (Guam); Caturai, Katudai, Gáuay-gáuay (Philippines).

A small introduced tree, bearing large edible, white, papilionaceous flowers and long sickle-shaped pods. Leaves long, narrow, and abruptly pinnate, with very numerous, linear-oblong, obtuse, mucronate leaflets; calyx shallowly 2-lipped; corolla 7.5 to $10 \mathrm{~cm}$. in length; pod $30 \mathrm{~cm}$. or more long, with thickened sutures.

Frequently planted near the houses of the natives and along the roadsides. The flowers and green pods are eaten as a salad or potherb. They are said to be laxative. The bark is astringent and is used in India as a remedy in smallpox. The leaves and young shoots are sometimes gathered as fodder for cattle.

\section{REFERENCES:}

Agati grandiflora (L.) Desv. Journ. Bot. 1:120. t.4.f.6. 1813.

Robinia grandiflora L. Sp. Pl. 2: 722. 1753.

Aeschynomene grandiflara L. Sp. Pl. ed. 2. 2:1060. 1763,

Sestan grandiftorus Poir. Encyc. 7:127, 1806. 
Agave vivipara.

Maguey.

Family Amaryllidaceae.

Local names.-Lirio de Palo (Guam); Maguay, Maguey (Philippines); Teometl (Mexico).

An Agave of Mexican origin, now spread in the Philippines and India, bearing bulbs which sprout before falling to the ground. It has been introduced into Guam, where it is called by the natives the "tree lily." The leaves resemble those of Agace americana, but have few spines on the margin. The flower scape grows to the height of 4.5 meters. From the leaves the natives get a fiber with which they wrap their cigars. In the Philippines it is sometimes used for making violin strings, $a$ and in India it is used for cordage and twine.

REFERENCES:

Agave vivipara L. Sp. Pl. 1: 323. 1753.

Agboy (Philippines). See Mussaenda frondosa.

\section{Ageratum conyzoides.}

GOATWEED.

Family Asteraceae.

A low, weedy, pubescent composite with terminal corymbs of blue or white flowers forming small discoid heads. Leaves ovate, on hispid petioles, obtuse, crenate, truncate or cordate at the base.

It is of American origin, but is now widely spread throughout the Pacific and has found its way to many tropical countries. It yields a vegetable proximate principle known as "coumarin," which is also found in the allied genus Eupatorium.

REFERENCES:

Ageratum conyzoides L. Sp. Pl. 2: 839. 1753.

Aggag, Aggak, or Akgak (Guam). See Pandanaceae and Pundanus tectorius.

Agho (Philippines). See Leucaena glauca.

Agoho (Philippines). See Casuarina equisetifolia.

Agsom or Apson (Guam).

Vernacular name, signifying "sour," applierd to Oxalis corniculate, and (improperly) to Meibomia triflor . This confusion of two plants under one name may be compared with that in case of the name shamrock among the Irish, which is sometimes applied to an Oxalis, sometimes to a Trifolium. The resemblance in both cases is chiefly in the trifoliolate leaves.

Aguanak (Guam).

The name of a tree not identified, mentioned by Governor Olive $y$ Garcia in a report to the Captain-General of the Philippines as yielding strong wood used in the construction of houses.

Aguardiente (Spanish). See Cocos nucifera.

Ahgao or Ajgao (Guam). See Premna gaudichaudii.

Ahgap (Guam). Same as Ahgao.

Ahonholi (Guam). See Sesamum orientale.

Ahos (Guam). See Allium sativum.

Aizoaceae.

CARPET-WeEd FAMily.

The only representative of this family in cruam is the seaside purslane, Sesurium portulacastrum.

$\mathbf{A j i}$ (Spanish). See Capsicum annuum and C. frutescens.

${ }^{\star}$ Kew Bulletin, 1893, p. 80. 
Ajo (Spanish). See Allium sativum.

Ajonjoli (Spanish). Se Sesamum orientale.

Akánkan dáñgkulo ( Liam). See Stizolobium giganteum.

Akánkan kalátun (Gram). See Stizolobium pruriens.

Akánkan-tasi (Guam See Canavali obtusifolium.

Alacran, flor del ( $\mathrm{Ta} a \mathrm{ama}$ ). See Heliotropium indicum.

Alaihai-tasi (Guara). See Ipomoea pes-caprae.

Alálag (Guam). S̀e Argyreia tiliaefolia.

Alálag-tasi (Guan:). See Ipomoea pes-caprae.

Alambrillo (Spanish).

Name in Guan or a climbing fern, Lygodium scandens.

Alangílang (F livpines). See Canangium odoratum; also called "ilangilang."

Alañgitr̃git ( : ilippines). See Ehretia microphylla.

Alapasotes ( ilippines). See Chenopodium ambrosioides.

Albahaca (\& nish). See Ocimum basiticum and O. canum.

Albahaca mic cada (Spanish). See Ocimum sanctum.

Alcaparro (ipanish). See Capparis mariana.

Aleurites moluccana.

Candenent tree.

Family Euphorbiaceae.

Local naves.-Lumbang, Raguar (Guam); Lumbang, Capili (Philippines); Kukui (Hawaii); Lama (Samoa); Raguar (Caroline Islands); Akhrot (Bengal).

A handsome tree with spreading branches, alternate, lobed, pubescent leaves of a pa.e color, rounded or cordate at the base, with two glands at the top of the petiole. Flowers small, white, in terminal lax cymes; fruit fleshy, coriaceous, globose, with 4 shallow furrows; seeds one or two, rugose, gibbous.

The candlenut tree is widely spread over Polynesia, a great part of Malaysia, and the Philippine Islands. It is remarkable that it has not established itself in Guam. Only a few specimens grow on the island, which are called either by the Philippine name "lumbang," or the Caroline Island name "raguar." The natives say the nuts wer brought here from the Caroline Islands. They have not come into use in Guam.

Throughout Polynesia the nuts, strung on cocoanut-leaflet ribs, served the natives for candles to light their houses. In Hawaii they are roasted, chopped up, mixed with seaweed, and served at native feasts as a relish. They yield an oil which is very $\mathrm{fl}$ id, of an amber color, without smell, insoluble in alcohol, readily saponifiable, and quickly drying. This oil is a mild cathartic, acting in the same manner as castor oil, but causing no nausea nor griping, and having the further advantage of a nutty flavor and of being more prompt in its effects. (Journ. de Pharm. 3e ser., vol. 24, p. 228. 1853.)

REFERENCES:

Aleurites moluccana (L.) Willd. Sp. PI. 4': 590. 1805.

Jatropha moluccana L. Sp. Pl. 2:1006. 1753.

Aleurites triloba. Same as $A$. moluccana.

Alfalfa. See Medicago sativa.

Algæ.

SEAW EEDS.

Local Names. -Lumut (Guam, Malay Archipelago); I umot (Philippines); Limu

(Samoa, Hawaii); Rimu (Tahiti, Mangaia).

Among the edible seaweeds growing on the shores of Guam are the gelatinous Gracilaria confervoides (L.) J. Ag. and the peppery Caulerpa clavifera (Turn.) Ag. The first, called in Guam by the Philippine name "gulamán," is gathered by the natives and bleached in the sun. It is used for making jellies and blancmange in the 
same way as the Irish moss or carrageen (Chondrus crispus). The natives cook it with milk or with water, adding to it the juice of fruits to give it an agreeable flavor, and then cool it in molds. In Ceylon it is an article of commerce and is one of the seaweeds called "agar-agar." It is also known commercially as Ceylon moss.

Caulerpa clavifera is used as a condiment in the same way as the pepper dulse of Scotland (Laurencia pinnatifida). It is sometimes eaten with vinegar as a salad. Both of these seaweeds are of wide distribution. In Samoa also Caulerpu claciferu, called "limu fuafua," is a common article of diet. It is also used by the natives of many other Pacific islands. It is said to be the favorite food of sea turtles. In India and Ceylon Graciluria conferroides is one of the seaweeds used medicinally, especially for pectoral affections. In Tasmania it is used for making jelly, and is ranked in nutritive value with Chondrus crispus. 6

In Hawaii many seaweeds are used as articles of food. The favorite of the Hawaiians is the limu-lipoa (Dictyopteris plagiogrumma Montagne). This is even celebrated in the songs of the natives, who describe the breath of their maidens as perfumed with the limu-lipoa, though to a novice the odor of this alga is anything but agreeable.

Gracilaria confervoides and Gracilaria lichenoides (L.) J. Ag. are of wide distribution in the Pacific and Indian oceans. They belong to the Rbodophyceae, or red algre, which include, among other species growing on the shores of Guam, Acanthophora orientalis J. Ag., and Corallopsis salicornia Grev. (Sphaerococcus salicornia C. Ag.). Among the Corallinaceae occurs Mastophom lamourouxii (Dene.) Harv. (described by Agardh as Zonaria rosea), the typical form of which was collected in Guam by Gaudichaud, and the variety macrocarpa. Montr. by Dumont d'Urville.

Algre are also found on the surface and in the rivers of the island. In the rainy season (August and September) the ground is covered in places with dark-green jelly-like masses of Nostoc commune Ag. and Brachytrichia quoyi Born. \& Flah. In the Agaña River traudichaud collected Chara fibrose Ag. and Conferva funimular Ag., and in the Pago River Thoreu guadichaudii Ag., a delicate plant belonging to the Rhodophyceae.

In the Agana River, near its mouth, where the water becomes brackish, occur the green, ulva-like Enteromorpha clathruta (Roth.) Ag. and E. compressa (L.) Grev. These also grow on the sea beach. Other green algæe growing in the sea are Rhizoclinum tortuosum fastigiatum Ag., allied to Cladophora, Caulerpa clarifera, already mentioned as a favorite condiment of the South Sea Islanders, Caulerpa Humaris (Forsk.) Ag. and cumlerpe fiencinetii Ag. The latter have creeping stems resembling those of flowering plants in general appearance, with colorless rhizoids and branched fronds abounding in chlorophyl. One of the most interesting and sraceful species is the wirlely spread Bryopsis plumosc Grev, the minute thallus of which, though branching like a feather, consists of a single cell. It branehes subdivicle into miniature leaf-like processes, and are finally separated from the original cell by transverse walls. The gametes, by means of which it is reproduced, both male and female, are provided with movable cilia. Of a very different habit is

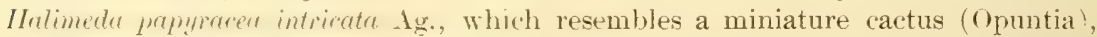
with broad flattened joints. (Frowing on the coral reef is the common "peacock's tail," Pectime parmire (L. ), a lorown alga with thin, papery, fan-shaped fronds marked by concentric zones; and with it Freycinet collected a second species, Padina commersonii Bory., which also occurs on the shores of Japan and of Florida.

Associated with the alge are several flowering plants, including Potamogeton natans and $P$. zizii, growing in the Agaña River; Hulophila ovalis, growing in brackish marshes; and the grass-like Halodule uninerris, like a miniature Zostera, growing in the sea. 
Algodon (Spanish) or Atgodon (Guam). See Gossypium barbadense.

Algodon de Manila (Guam). See Ceiba pentandra.

Algodoncillo (Porto Rico). See Asclepias curassavica.

Algodonero (Spanish). See Gossypium arboreum.

Alhucema (Cuba). See Mesosphaerum pectinatum.

Aligbangon (Philippines). See Commeline benghulensis and Commelinu nudiftorr.

Alimodias (Philippines). See Coix lacryma-jobi.

Alipata (Philippines). See Excoecaria agallocha.

Alligator pear. See Persea persea.

The cultivation of this plant, though many times attempted, has never been successful on the island of Guam.

\section{Allium cepa.}

ONION.

Family Liliaceae.

Local Names.-Seboyas (Guam); Cebolla (Spanish); Ceboya, Lasona (Philippines).

Onions are frequently planted in Guam, but they do not thrive well. Only very small bulbs are produced, but these are much relished by the natives.

REFERENCES:

Allium cepa L. Sp. Pl. 1:300. 1753.

Allium sativum.

GARLIC.

Locat Names.-Ahos (Guam); Ajo (Spanish); Bawang, Ganda (Philippines).

Garlic is cultivated perhaps more extensively than onions, though the conditions on the island are scarcely more favorable to it than to them. It is a favorite ingredient in many dishes of the Chamorros.

REFERENCES:

Allium sativum L. Sp. Pl. 1: 296. 1753.

Almendra (Spanish).

The fruit of Terminalia catappa.

Almendro (Spanish). See Terminalia catappa.

Almond, Indian. See Terminalia catappa.

Almond, Java. See Canarium indicum.

Almond, Malabar. See Terminalic catappa.

Aloalo-sina (Samoa). See Mussaenda frondosa.

Aloalo-tai (Samoa). See Clerodendron inerme.

Alocasia indica.

Giant taro. Acrid taro.

Family Araceae.

Local NAMEs.-Piga (Guam); Biga (Philippines); Via, Dranu (Fiji); Ape, $\mathrm{Ta}^{\prime} \mathrm{amū}$ (Samoa).

This great arum, which is closely allied to, if not identical with, the following species, is so acrid that its juice will blister the skin. It differs from the common taro (Calredium colocasia) in having a trunk as well as corm, which is edible. It is a huge plant, growing in marshy places, with very large ovate-cordate, bright-green leaves and an inflorescence consisting of a convolute spathe inclosing a spadix which bears female flowers (ovaries) at its base, male flowers (stamens) higher up, and neutral organs in the interval, and ends in a thickened barren portion called the appendage. The appenrlage is marked with reticulated furrows, which distinguish this genus from Caladium, in which the appendage is smooth. The flowers have a disagreeable odor.

In fruam there are several varieties of Alocasia recognized, which may be referred either to this or to the following species, three of which are called "piga." Two other allied varieties are called "papao," and a third is called "baba." 
The natives eat piga only in times of scarcity of food. The fleshy trunks must be thoroughly roasted to destroy their acridity. (See p. 69.)

ReFERENCES:

Alocasia indica (Lour.) Schott, Öestr. Bot. Wochenbl. 4: 410. 1854. Arum indicum Lour. Fl. Cochin. 2: 536. 1790.

\section{Alocasia macrorrhiza.}

Giant taro. Acrid taro.

Local Names.-Piga (Guam); Biga (Philippines); Ape, Ta'amū (Samoa); Kape (Rarotonga, Easter Island); Ape (Tahiti); Apii, Ape (Hawaii).

Similar to the preceding, but with sagittate ovate leaves, the broadly ovate obtuse basal lobes or auricles distinct to the petiole, the stout nerves prominent above and below, the midrib rery broad and conspicuous; flowers with pale greenish yellow spathes, emitting a strong, disagrecable odor; appendix at the end of spadix obtuse, reticulate; berries at base of spadix red when ripe. Very acrid, but, like the preceding species, a food staple in times of scarcity. The Polynesian name of this plant is in the Philippines applied to the common taro (Caladium colocasia). See p. 153.

References:

Alocasia macrorrhiza (L.) Schott in Schott \& Endl. Melet. 18. 1832.

Arum macrorrhizum L. Sp. Pl. 2:965. 1753.

Alom or alum (Guam). See Echinus sp.

Alsophila haenkei. See Tree ferns.

Alverja (Spanish). See Pisum sativum.

Amahadyan or amahayan (Guam). See Boehmeria tenacissima.

Amaranth, edible. See Amaranthus oleraceus.

Amaranthaceae.

Auaranth Family.

This family is represented in Guam by the cultivated Gomphrena globosu and the following species of Amaranthus:

\section{Amaranthus oleraceus.}

EDIBLE AMARANTH.

Family Amaranthaceae.

Local Names.-Halom (Philippines); Bledos blancos (Spanish).

A glabrous, succulent, weedy plant, growing in waste places, and cultirated as a pot herb in India, China, and other places in the Tropics. Leaves long-petioled, ovate, oblong, or rounded; flowers small, green, growing in axillary clusters and terminal spikes; sepals 3, linear-oblong, stamens 2 or 3; fruit an oroid utricle, or bladder-like pericarp containing 1 seed, not hursting open. First collected in Guam by Gaudichaud. The young and tender shoots are cooked like spinach.

REFERENCES:

Amaranthus oleraceus L. Sp. PI. ed. 2. 2:1403. 1763.

\section{Amaranthus spinosus.}

SPINy PIGWEED.

Local xines. - Kuletes, Kiletes (Guam, Philippines); Quelite (Mexico); Zépinard piquant, Épinard rouge (French Antilles).

A glalmous weed with rigid stipular spines at each norle of the stem. Stems stout, rigid, sometimes red; leaves long-petioled, ovate, whombic, or rhombic-lanceolate; flowers in axillary clusters and in long spikes, stamens 5, sepals 5, elfualing the awned bracts; utricle thin, wrinkled, splitting open transversely, the top opening like a lid.

This plant is of wide tropical distribution. When young it is often used as a pot herb, but it is not cultivated.

\section{REFERENCES:}

Amaranthus spinosus L. Sp. Pl. 2: 991. 1753:

Amaranthus viridis.

Green pigiteed.

Local Names.-Kuletes, Kiletes (Guam, Philippines); Eaea mata (Tahiti).

A glabrous weed resembling the preceding, hut without spines on the stem. Leaves with long jetioles, tip rounded or notched, base truncate or cuneate; flower clusters 
Tery small, green, in axillary and terminal panicled slender spikes; bracts usually shorter than the 3 sepals and utricle; stamens 2 or 3 ; utricle acute, indehiscent.

This is the species most commonly cultivated in India. The tender succulent tops of the young stems and branches are cooked as a substitute for asparagus. The various forms growing wild in Guam are not much esteemed, but, like asparagus, would doubtless be improved by cultivation.

Widely spread in the Tropics, growing as a weed in waste places, not cultivated in Guam, but like the preceding species used as a pot herb when young and tender.

REFERENCES:

Amaranthus viridis L. Sp. Pl. ed. 2. 2: 1405. 1763.

Amargosa (Spanish). See Momordica charantia.

Amaryllidaceae.

Amaryluis Family.

This family is represented in Guam by the indigenous Crinum asiaticum; by Hypoxis aureu, which grows upon the savannas; and by the introduced tuberose (Polianthes tuherosa), the pretty pink-flowered Atamosco rosea, and the white spider lily; or "seashore daffodil" (Pancratium littorale).

\section{Ambulia fragrans.}

Family Scrophulariaceae.

Local NaMeSs.-Gégé, Guegue, Gégé sensonyan (Guam).

A small, procumbent, very fragrant plant growing in marshy places and stagnant pools near the coast. Leaves sessile, oblong, lanceolate, serrate, with rounded subamplexicaul bases; calyx smooth, 5-parted, with lanceolate-subulate segments; structure of the flower similar to the preceding species; corolla scarcely longer than the calyx.

This plant is much esteemed by the natives for its aromatic fragrance. It is spread among the islands of the Pacific and in the Malay Archipelago, and occurs in north Australia. Gaudichaud was the first to collect it in Guam.

\section{RefERENCES:}

Ambulia fragrans (Forst. f.) Drake, Fl. Polyn. Franc. 140. 1892.

Ruellia fragrans Forst. f. Prod. 44. 1786.

Limnophila serrata Gaudich. Bot. Freyc. Voy. 448, t. 5\%,f. 2. 1826.

\section{Ambulia indica.}

Local Nanms.-Gégé, Guegue (Guam); Inata (Philippines).

A low, glabrous, aromatic plant growing in swamps and on the edges of rice fields. The leaves may be either all whorled and pinnatifid, 6 to $19 \mathrm{~mm}$. long, or in wetter places there may be a few emersed opposite entire ones at the top of the stem and numerous multifid ones at its base; flowers axillary, solitary, pedicelled, rarely subracemose, the pedicels longer than the calyx; calyx 5-parted, hemispheric in fruit, the lobes equal, ovate, acuminate, not striate; corolla-tube cylindric, upper lip the outer in the bud, suberect; lower lip spreading, 3-fid; stamens 4, didynamous, included; style deflexed at the tip, stigma shortly 2-lamellate; fruit a capsule, seeds numerous, small, angular, truncate, reticulate.

This plant is esteemed by the natives for its aromatic odor, which somewhat resembles turpentine. It was first collected in Guam by Gaudichand. It is found in India, the Malay Archipelago, China, Australia, and tropical Africa.

REFERENCES:

Ambutia indica (L.).

Hottonia indica L. Syst. ed. 10. 919. 1759.

Limnophila gratioloides R. Br. Prod. 442. 1810.

Amiga de noche (Guam). See Polianthes tuberosa.

Amigos (Philippines). See Lycopodium cernuum.

Amiray (Philippines). See Boehmeria tenacissima. 


\section{Ammannia coccinea.}

Family Lythraceae.

An annual erect glabrous herb growing in damp places, with 4 -angled stem and narrowly linear, opposite leaves, which are obtusely cordate-auriculate and dilated at the somewhat clasping base, entire, 2 to $8 \mathrm{~cm}$. long, 2 to $6 \mathrm{~mm}$. wide, flowers small, nearly axillary, 1 to 5 in each axil, sessile; calyx campanulate, with 8 ribs or nerves; petals 4 , purple, deciduous, style elongated, very slender; stamens 4 to 8 , inserted on the calyx-tube; ovary nearly globular, bursting irregularly.

Collected in Guam by Lesson, who accompanied Dumont d'Urville on the Astrolabe as naturalist. It occurs also in the United States, Mexico, and Brazil.

REFERENCES:

Ammannia coccinea Rottb. Pl. Hort. Univ. (Havn.) Programm. Desc. 7. 1773.

Ammannia octandra Cham. \& Schlecht. Same as A. coccinea.

Ampaléa (Philippines). See Momordica charantia.

Amor seco (Spanish). See Gomphrena globosa.

Amores secos (Philippines, Guam). See Andropogon rciculatus.

Amot-tomaga or Amot-tumaga (Guam). See Cassia sophera.

Anacardiaceae.

CASHEW FAMILY.

This family is represented in Guam hy the introduced Anacurlium orcidentale and Mangifera indica.

\section{Anacardium occidentale.}

Cashew. Plate xxix.

Family Anacardiaceae.

Local xames.-Kasué, Kasóy (Guam); Casoy, Kasíe, Balubar, Bol-logo (Philippines); Marañon (Mexico, Cuba, Panama); Pajuil (Porto Rico).

A spreading tree with simple, oval, entire leares, rounded or emarginate at the top, bearing a peculiar fruit, which consists of the enlarged, fleshy peduncle bearing a kidney-shaped nut. The peduncle is pear-shaped, of a yellow or reddish color, astringent when green, but when thoroughly ripe pleasantly arid and edible. The nut is oily and its shell very acrid. When roasted it is edible, the kernel acquiring a pleasant milky flavor. In roasting, the eves and face should not be exposed to the caustic fumes which rise from the shell. A yellowish oil of a sweet flavor may be expressed from the kernel. The trunk and branches on being abraded yield a transparent gum obnoxious to insects. An acrid oily liquid derived from the shell is used to protect books and furniture from the attacks of insects, and in the Antaman Islands to preserve fishing lines. This tree, which is of great economic imprtance in tropical America, is not much esteemed by the natives of Guam. They sometimes eat the fruit and roast the nuts, but neither can be called a food staple of the island. Although introduced more than a century ago, it has not spread upon the island and is found only near the houses of natives, where it has been planted, or on the sites of abandoned ranches.

REFERENCES:

Anacardiume occidentale L. Sp. Pl. 1: 383. 1753.

Anagalide azul (Spanish). See Commelina benghalensis and C. nudiflora.

Ananas (Spanish). See Ananas ananas.

Ananas ananas.

Pineapple.

Family Bromeliaceae.

Locıl xames,-Piña (Crum, Philippines): Piña, Ananas (Spanish); Matzatli (Mexico).

A plant with rigil sword-shaped leaves, having the erlges armed with spines, and bearing the well-known fruit. The flower have a 6 -cleft perianth, with 6 stamens band 1 style. The ripe head cousists of the thickened rachis, in which the flesh erries are imbedded, and the Heshy persistent hracts. The plant produces a singely 



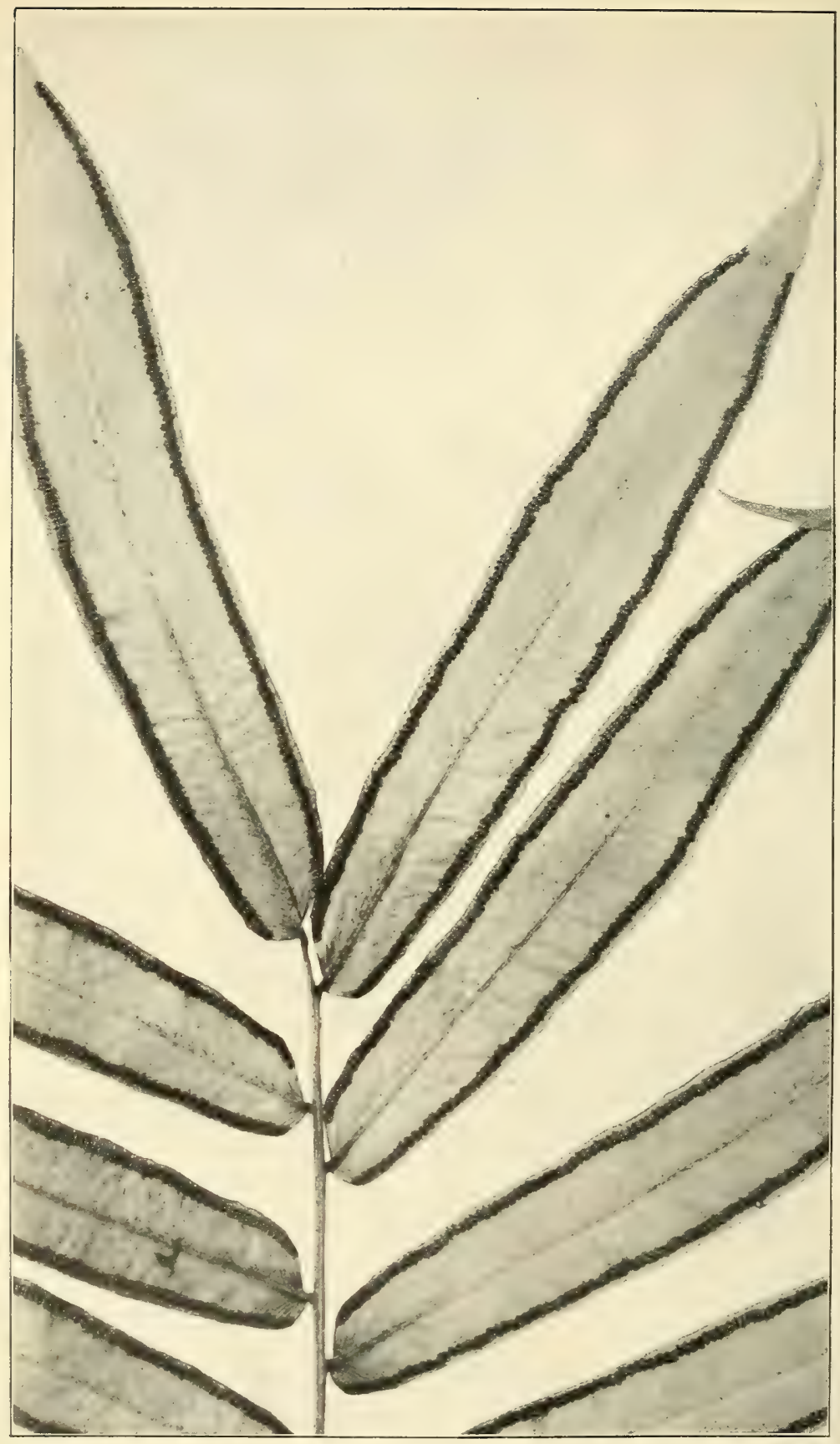

Angiopteris eVecta. Natural Size. 
shaft 60 to $120 \mathrm{~cm}$. high. On the top of the head, or pineapple, a rosette of stiff leaves is borne. The same stalk does not bear a second time, but a new shoot may arise and bear another. The species is propagater from the suckers or by removing the crown and planting it in sand. This should be done during the rainy season. The adventitious sprouts of the stump of the fruit will also yield a growth of young plants if the stump be planted and kept moist.

In Guam pineapples of excellent quality are produced. When once established the plants continue to reproduce for years, though frequent replanting and change of soil is recommended. Patches of pineapples are often found growing on the sites of abandoned ranches. The first ripens in May and June.

The leaf yields a fine silky fiber, which in the Philippine Islands is woven into beautiful gauzy fabries. In Guam it is twisted by hand and made into the finer kinds of cast nets for fishing. Sometimes single fibers are used by the natives in lien of thread for sewing or for wrapping cigars.

REFERENCES:

Ananas ananas (L.) Karst. Deutsch. Fl. 466. 1880-1883, as Ananassa ananas.

Bromelia ananas L. Sp. Pl. 1: 285. 1753.

Anunas sativus Schult. Syst. $7^{2}: 1283.1830$.

Ananassa sativa. Same as Ananas ananas.

Anaoso (Samoa). See Guilandina crista.

Andropogon acicularis. Same as Andropogon aciculatus.

Andropogon aciculatus.

AWNED BEARDGRASS.

Family Poaceae.

Local Names.-Amores secos (Philippines, Guam); Piipii (Hawaii).

A grass with spikelets occurring in pairs, at each node of a jointed hairy rachis, one sessile and perfect, the other with a pedicel; stem creeping and branching below, leaves short, sheaths terete, panicle very narrow, callus very long, acicular.

Collected in Guam by Gaudichaud. Common on the island and furnishing good pasture, but disagreeable on account of its adherent awns. It is widely spread in Polynesia, Australia, India, and China. In the Philippines the straw is used for making hats and mats.

\section{REFERENCES:}

Andropogon aciculatus Retz. Obs. 5: 22. 1789.

\section{Andropogon chloridiformis. Same as Dimeria chloridiformis.}

Andropogon nardus.

LEMON-GRASS.

Local Names.-Junquillo oloroso (Spanish); Tanglad (Philippines).

A fragrant, lemon-scented grass, said to have been introduced into Guam from the Caroline Islands. In Guam the natives plant it near their honses, where it grows in tufts to the height of 90 to $120 \mathrm{~cm}$.

It yields an essential oil, which is used in perfumery, and is known as "oil of rerbena" or "citronella." It is also applied externally as a stimulant in rheumatic affections. In India a sort of tea is made of the fresh young leaves, and the white center of the sncculent stems is used to impart a flavor to curries. The grass is too coarse to be eaten by cattle except when young.

REFERENCES:

Andropogon nardus L. Sp. Pl. 2: 1046. 1753.

Añgilao (Guam). See Grewia multiflora.

Angiopteris evecta.

Giant fern. Plate xxxit.

Family Marattiaceae.

Local Names. - Nase, Fa'angáse (Samoa).

A fern-like plant with enormous fronds and a fleshy stem 1 to 2 meters high, growing in damp situations. It is distinguisher by having the sporangia inclosed in capsules, 
which open by a slit down the side. Leaves 2 to 5 meters long, mostly bipinnate, with swollen rachises; leaflets 10 to $30 \mathrm{~cm}$. long, 1.5 to $4 \mathrm{~cm}$. wide, the margin entire or slightly toothed.

This species is common on many Polynesian islands. It grows in the Philippines, India, Japan, Madagascar, and Queensiand. It is easily propagated by the fleshy scales at the base of each frond, each scale containing at least two dormant buds. In Samoa the name by which the natives distinguish it is also applied to Muruttin fraxinea, an allied species with the same habit of growth.

REFERENCES:

Angiopteris evecta (Forst.) Hoffm. Com. Goett. 12: 29. t. 5. (ex Luerssen in Schenck \& Luerssen, Mittheilungen aus der Botanik 1:257. 1874.

Polypodium evectum Forst. Prod. 81. 1786.

Año (Samoa). See Curcuma longa.

Anilao (Guam). See Grewia multiflora.

Añilis (Guam). See Indigoferc anil and I. tinctoria.

Anis hinojo (Philippines, Guam). See Foeniculum foeniculum.

Annatto. See Bixa orellana.

\section{Annona muricata.}

Soursop. Plate xxxim.

Family Annonaceae.

Local Names.-Laguaná (Guam); Guanábano (Philippines, Mexico, Peru).

A small tree bearing large oblong or conical, dark green fruit having a rough spiny skin and filled with soft white juicy acid pulp. The leaves are elliptical, pointed, glossy above and rusty beneath, becoming glabrous; young growth scurfy-pubescent; flower with six petals, the three outer ones acute, greenish, the three inner ones more conspicuous, obtuse, yellow or red; pistils many, each with one erect ovule, uniting to form the fleshy fruit or syncarpium.

In Guam this species is not so commonly cultivated as the sugar apple (A.squamosa). It has a pleasant acid flavor. The natives make jelly of it and preserve the fruit. In the East Indies it is used for flaroring ice cream and puddings. It is of American origin and was introduced into Guam at least a century ago. The vernacular name, Tayuanú, is probably derived from La Guanábana, the Spanish-American name of the fruit.

REFERENCES:

Annona muricata L. Sp. PI. 1: 536. 1753.

\section{Annona reticulata.}

Bullock's heart. Custard-apple.

Local Najres.-Anonas (Guam, Philippines); Corazon (Porto Rico).

A tree of American origin, $t$ to 8 meters high, bearing a smooth, heart-shaped fruit with small depressions on the surface, yellowists before maturity and often becoming a deep red at length, which gives to it its appropriate English name. Leares lanceolate or oblong and pointed, glabrons above and rough, at length becoming smooth beneath; flowers with the three exterior petals oblong-linear and keeled on the inside, acute, greenish, with purple spots at the base; inner petals minute; pistils many, united into the fleshy syncarpium (multiple fruit).

In Guam this species has established itself more fully than the others of the genus. It is found growing wild in the woods and along roadsides. The fruit is long in ripening, the plant yielding but one crop a year, while ripe fruit of the sour-sop and sugar-apple can be found during most months of the year. The flavor of the fruit of Aumona reticuluta growing in Guam is not nearly so good as that of the other sprecies. It is sweet but insipid, and the pulp has a tallow-like consistency. The natives do not esteem it highly, but it is a farorite food of the "fanihi," or fruiteating bat of the island (Pteropus keraudreni).

REFEREXCES:

Annona reticulata L. Sp. Pl. 1: 537. 1753. 


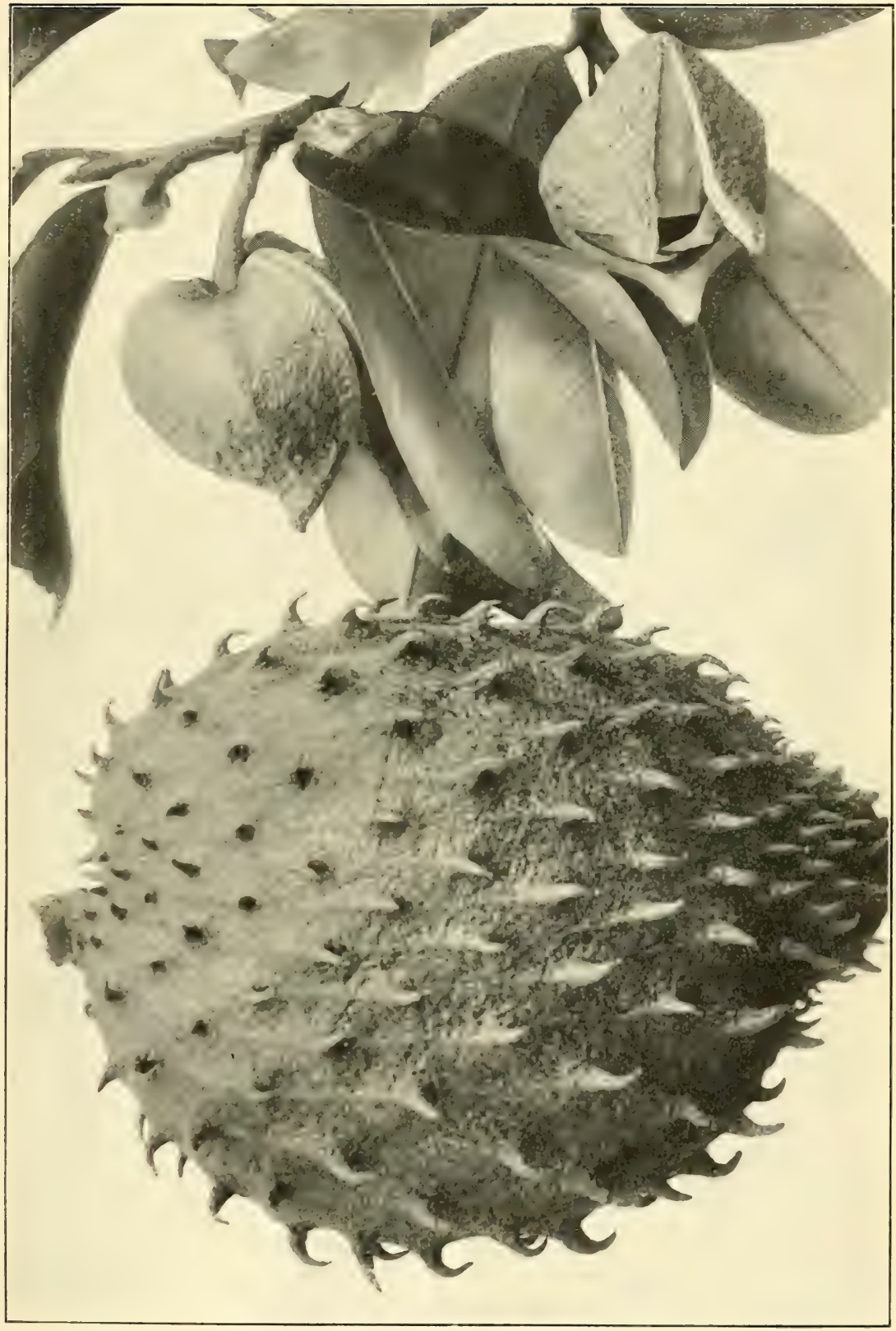

The Soursop (annona muricata). Flowers and fruit. Slightly Reduced. 




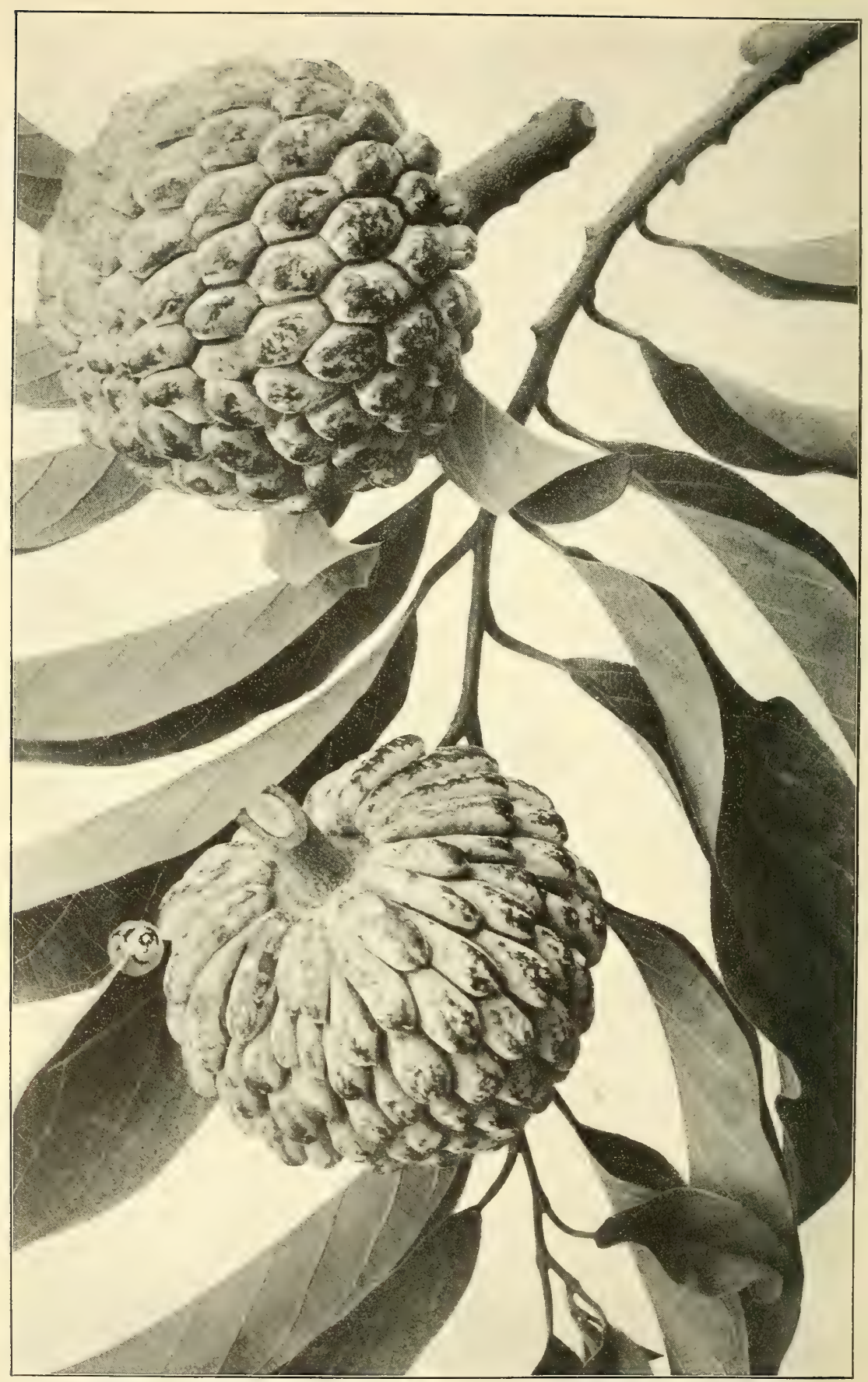

The sugar apple, or Sweetsop (annona squamosa). Foliage and Fruit. NATURAL SizE. 


\section{Annona squamosa.}

Sugar-apple. Sweetsop. Plate xxxis.

Local Names.-Atis (Guam, Philippines); Annona blanca (Mexico); Ata (Hindu); Sweetsop (British West Indies).

A shrub or small tree of American origin, the fruit of which is tuberculate, each carpel forming a protuberance, egg shaped or of the form of an artichoke or a short pine cone, 7.5 to $10 \mathrm{~cm}$. in diameter; yellowish green, frequently covered with a whitish or glaucous bluish bloom; pulp very sweet, creamy yellow and custard-like, inclosing smooth black or dark-brown seeds, and of an agreeable flavor; leaves thin, glaucous, oblong-ovate, very sparsely hairy on both sides, but often becoming smooth, flowers with the three outer petals oblong-linear and blunt, keeled on the inner side, greenish; pistils many, united to form the fleshy fruit.

This is the favorite custard apple of the natives of Guam. It is found planted by nearly every house. It does not grow wild like $A$. reticulata. It loses its leaves in the dry season, putting forth flowers and leaves when the first rains fall, and bearing a succession of crops of fruit during most months of the year. The fruit becomes very soft when ripe, often bursting open on the tree, when it is greedily eaten by ants. These insects do not attack it as long as the surface remains unbroken. It is eaten uncooked, the soursop (A. muricata) being the only species utilized by the natives for jelly and preserves. The best of the Annonas, Innona cherimolia, a fruit very highly esteemed in South America, does not grow in Guam. Attempts to introduce it into Java and many other tropical countries have met with failure.

Annonacsae.

CUstard-APPLE FAMily.

This family, which includes the "pawpaw" (Asimina triloba) of the United States, is represented in Guam by the ilangilang tree (Canangium odoratum) and the above species of Annona.

\section{REFERENCES:}

Annona squamosa L. Sp. Pl. 1: 537. 1753.

Anonas (Guam). See Annona reticulata.

Antidote lily. See Crinum asiaticum.

Antigonon leptopus.

Mexican CREePer.

Family Polygonaceae.

Local names.-Cadena de amor (Guam); Coralillo (Cuba); Coamecate, Hierba de Santa Rosa (Mexico).

A creeper with clusters of rose-colored flowers. Stem slender, glabrous, or nearly so; leaves alternate, entire, cordate and acuminate or hastate-ovate; flowers in racemes, which end in branching tendrils; sepals 5 , rose-colored and petal-like, the two interior ones narrower; stamens 8; styles 3; ovary 5-angled.

Cultivated in the gardens of Guam, but not common. It takes its pretty and appropriate local name ("the chain of love") from the form of its flowers, which look like miniature hearts of coral.

\section{REFERENCES:}

Antigonon leptopus Hook. \& Arn. Bot. Beech. Voy. 308. t. 69. 1841.

Antipolo (Philippines). See Artocarpus communis (seeded).

Antrophyum. See Ferns.

Aoa (Samoa). See Ficus sp.

Apasotes (Philippines).

The name used in Guam for "Mexican tea," Chenopodium amlrosioides, which is grown in many of the gardens of the natives. Also called "alapasotes."

Ape (Polynesia). See Alocasia indica and A. macrorrhiza.

Apiaceae.

The only represen'ative in Guam of this family is Centella asiatica.

Carrot family. 
Apii (Hawaii). See Alocasia macrorrhiza.

Apium petroselinum. Same as Petroselinum petroselinum.

Aphloghating or Aplokhating (Guam). See Psychotria mariana.

Aplog (Guam.)

The local name for a small coconut in which water has begun to form.

\section{Apocynaceae.}

DogBane FAMity.

Among the indigenous Apocynaceae growing in Guam are Ochrosia muriunnensi., a tree with glossy leaves, milky sap, and yellow wood, and the Guam "nanago" (Fynopogon torresimus), a plant allied to the "máile" of Hawaii, with fragrant ghusy leaves and small white flowers. Among the cultivated plants are the common oleander (Nerium oleander), here called "adelfa," and the common pink periwinkle, Lorhmera rosea. It is surprising to note the alsence of such common plants as Plumeriu alba and Cerbera thevetia, which oceur in tropical gardens all over the world.

Apson (Guam). See Agsom.

Araceae. See Alocasia and Caladium.

Arachis hypogaea.

Peanut. Earthnut. Groundnut.

Family Fabaceae

LOCAL YAMEs.-Kakahuate, Kakaguate (Guam); Cacahuate, Tlalcacúhuatl (Mexico); Maní (Panama, Peru, Chile, Philippines); Katjang-tana (Java).

A low plant which bears the well-known peanut. Leaves abruptly pinnate, with two pairs of leaflets and no tendril; flowers yellow, 5 to 7 together in the axils of the leaves. After the plant has finisherl flowering and the pods begin to lengthen the pedicels force them into the earth, where they ripen their seeds.

Commonly cultivated in Guam, where it thrives, but never planted on an extensive scale. Between Agaña, the capital, and Punta Piti, the landing place in the harbor of Apra, the roas is bordered with small patches of this plant at several points, where it has been planted by the inhabitants of neighboring houses. It grows readily and with little care in the sandy soil, and the nuts are of good quality. It could be cultivated more generally and would be a benefit to the soil if planted in rotation with maize and sweet potatoes.

REFERENCES:

Arak.

Arachis hypogaea L. Sp. Pl. 2: 741. 1753.

Spirits distilled from the fermented sap of the coconut; in Guam called "aguardiente." See Cocos nuciferu.

Aralia guilfoylei.

GUILFOYLE'S ARALIA.

Family Araliaceae.

A handsome ornamental shrub with variegated pinnate leaves. Leaflets 3 to 7 , wate or oblong, irregularly cut on the exlges or ohseurely lobed, margined with white, and sometimes splashed with gray; stem spotted, erect. A native of the New Hehrides, but nuw widely spreal throughout the Tropies. In Honolulu beautiful hedges are marle of it. In the IIope (iarlens in the island of Jamaica it is used as a wind-break for the nursery. a In Guam it is planted near many of the natives' houses, associated with species of Panax, Graptophyllum, Phyllaurea, and a dark purple Eranthemum.

References:

Aralia guilfoylei Cogn. \& March. Pl. Ornem. 2: $t .58 .1874$ (ex Ind. Kew.).

Aralia tripinnata Blanco. Same as Panax fruticosum.

Araliaceae.

Aralia family.

No indigenous Araliaceae occur in Guam. The family is represented on the island by several ornanental shrubs brought from the Philippines and commonly jlanted 



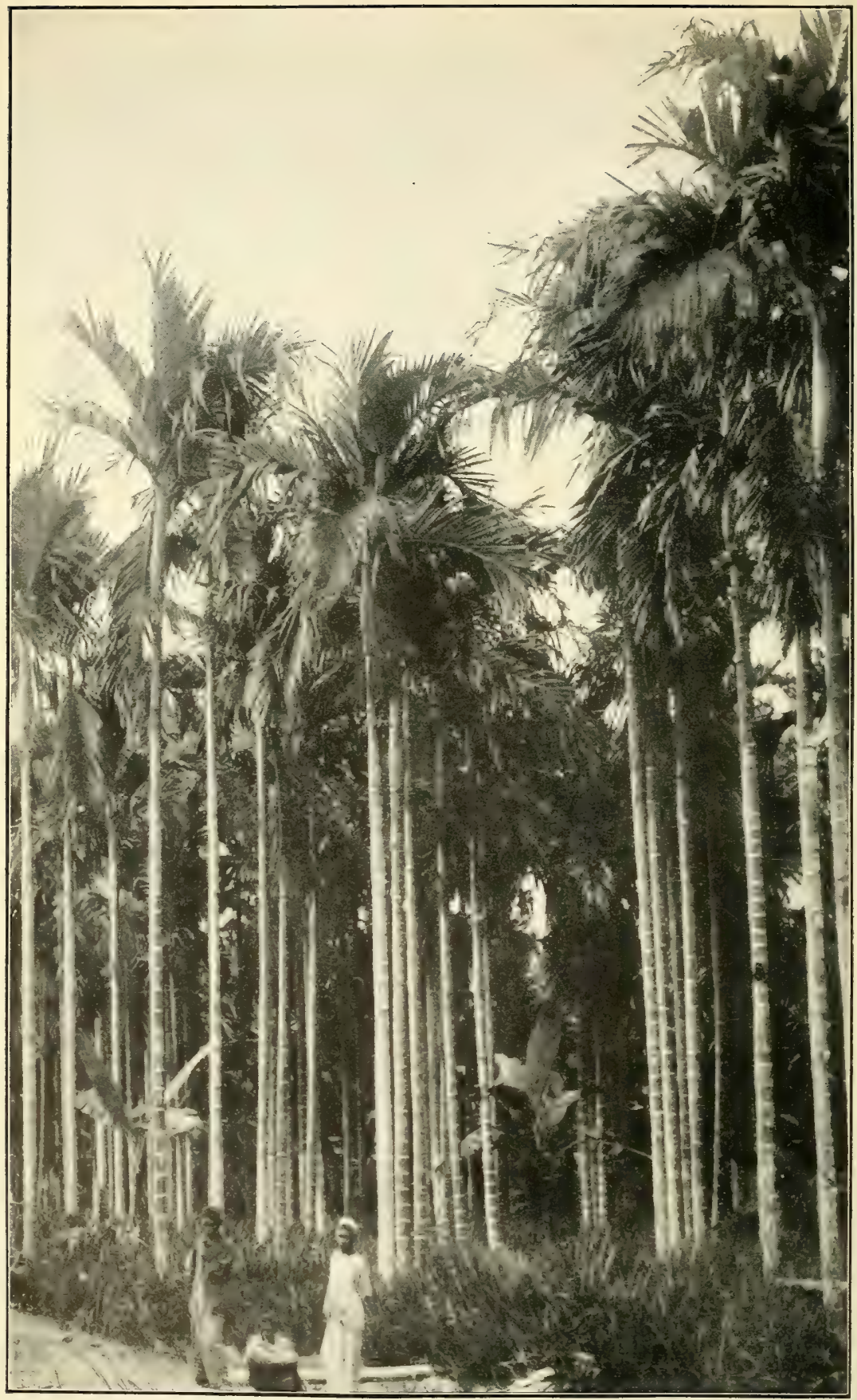

BETEL-NUT PALMS (ARECA CATHECU). 
near the houses of the natives. Among them are Aruliu gruilfoylei, Nothopanux frulicosum, and Nothopanax cochleatum.

Ararao, Araró, Ararú (Philippines). See Maranta arundinacea.

Arbol del fuego (Philippines, Guam). See Delonix regia.

Ardisia. Same as Icacorea.

Areca cathecu.

Betelnut, Platexixy.

Family Phoenicaceae.

Local naxes.-Pugua (Guam); Pua (Banda); Puah, Buah (Amboina); Puak, Poak (Ceylon); Boa (Duke of York Island, Solomon Group); Bue (New

Britain); Boa (Bali); Bua(Pelew Islands); Bonga, Bunga, Luyos(Philippines); Gua, Gooa (Bengal); Pinang (Modern Malay).

A palm introduced into Guam in prehistoric times, but not indigenous on the island, and planted by the natives for the sake of its aromatic seeds, which are generally called "betel nuts." The trunk is tall and slender and ringed; leaves glabrous, pinnate, the segments narrowly lanceolate, acuminate, plicate, with margins recurved it the base, the upper ones confluent and bifid or truncate and many-parted; rachis 3 -sided, the upper face acute, the back convex, the base and petiole concave; sheaths elongater; spadix with spreading branches at length pendent; spathes several, papery, the lowest complete, the upper ones bract-like; flowers white and very fragrant; fruit a one-seeded, orange-colored drupe or nut about the size of a small hen's egg, with outer fibrous husk, astringent, pungent, and aromatic, with a flavor and consistency somewhat like that of a nutmeg. It hangs in long bunches below the dark-green leaves.

In Guam this snecies is found in abundance growing in damp woods and along the margins of streams. The nut is held in great esteem by the natives, who chew it together with the leaf of the hetel pepper ( Piper betle), a plant having properties akin to those of Piper methysticum, the kava plant of Polynesia.

The nut is divided and a piece of it is wrapped in the pepper leaf, together with a pinch of quicklime. It imparts a red color to the saliva, so that the lips and teeth appear to be covered with blood and in time become blackened. It injures the teeth and sometimes almost destroys them. Children begin to chew it at an early age. ()ld men and women are frequently seen with their teeth reduced from its habitual use to mere blackened snags. The odor imparted. by it to the breath is aromatic and not disagreeable unless tobaceo be mixed with it, a custom practiced by some natives, but not a common one. The nut is called either "pugua," or by its Tagálog name "bonga;" the leaf is called "pupulu," or by the Visayan name "buyo," and the packet made up for chewing is called "mamao."

In Guam betel chewing is a matter of etiquette at all wedding assemblies, fandangos, and funerals. Nuts deprived of their fibrous envelopes, fresh pepper leaves, and quicklime, together with cigars, are passed around to the assembled guests.

According to Jahns, arecaine, the active principle of the areca nut, is a powerful agent for destroying tapeworms, resembling in its action pelletierine, an aromatic, oily alkaloir obtained fron the bark of the pomegranate. Like nicotine it is poisonous, half a grain sufficing to kill a rabbit in a few moments. It influences the respiration as well as the heart, causes tetanic convulsions, and has an extraordinary influence in increasing intestinal peristalsis. Locally applied or when given internally it contracts the pupils." In India the nut has long been used as a vermifuge, the dose being a teaspoonful of the freshly grated kernel. Throughout the Malay Archipelago the nut is of great commercial importance.

REFERENCES:

Areca cathecu L. Sp. Pl. 2:1189. 1753. (Often written Areca catechu.)

a See Alkaloide der Arekanuss, in Brühl's Pflanzen-Alkaloide, p. 33, 1900. 
Arecaceae.

Palm family.

Among the palms growing in Guam are Areca cathecu, Saguerus pinmutus, rocos muifera, Nippe fruticans, the recently introduced Coelococens amicarum and Phoenix dectyliferc, and a small, slender-stemmed paln with pinnate leaves called "palma brava."

Arenga saccharifera. Same as Saguerus pinnatus.

Argyreia tiliaefolia.

LINDEN-LEAVED MORNING-GLORY.

Family Convolvulaceae.

Local Names.-Alálag, Abubo (Guam); Bululacao (Philippines); Pilikai (Hawaii).

A stout, climbing morning-glory with pale purple flowers, woody stem, and cordate or reniform leaves. Corolla large, funnel-shaped; style single, bearing 2 globose stigmas; fruit a leathery capsule, not bursting open like that of an Ipomoea; sepals coriaceous, silky-pubescent; young shoots canescent; leaves glabrate with age, 6 to $7.5 \mathrm{~cm}$. long and as much or more in breadth.

A common plant in the thickets of Guam. Unlike other members of its family it does not bloom continuously, but flowers in the month of November. The flowers do not wither like many morning-glories, but remain open all day. The natives call them "abubo," a different name from that applied to the plant itself. The children string them on strings and sticks, and are very fond of them as ornaments. The species is found in India and the Philippines. It has been introduced into the Hawaiian Islands, where it has escaped from cultivation and established itself.

References:

Argyreia tiliaefolia (Desr.) Wight, Ic. 4²: 12. t. 1358. 1850.

Convolvulus tiliaefolius Desr. in Lam. Encyc. 3: 544. 1789.

Rivea tiliaefolia Choisy, Mem. Soc. Phys. Genev. 6: 407. 1833.

Arimay (Philippines). See Boehmeria tenacissima.

\section{Aristolochia elegans.}

Family Aristolochiaceae.

A pretty flowering species cultivated in a few gardens of Guam. Slender and glabrous, the flowers borne on the pendulous young wood; leaves long-stalked, reniform-cordate, with wide sinus and rounded basal lobes, the rib obtuse; flowers solitary, long-stalked, the tube yellow-green, the flaring limb cordate-circular, purple and white blotched, white on the exterior, the eye yellow.

Introduced into Guam by the ehief of staff of the last Spanish governor, Don Juan Marina.

REFERENCES:

Aristolochia elegans Mast. Gard. Chron. II. 24: 301. 1885.

Arnotto or Arnatto. See Bixa orellana,

Aromo. See Acacia farnesiana.

Arongay (Philippines). See Moringa moringa.

Arorú, Arurú (Guam). See Maranta arundinacea.

Arrowroot, East Indian. See Tacca pinnatifida.

Arrowroot, Polynesian. See Tacca pinnatifida.

Artemisia vulgaris.

MUGWORT. WORMWOOD.

Family Asteraceae.

Local names.-Hierba de Santa Maria, Yerba de Santa Maria (Guam, Philippines).

A composite with aromatic, pinnatifid leaves, the lower petioled, the upper sessile, dark green on upper surface, white beneath; flowers in small discoid greenish heads arranged in panicled spikes, involucre oblong, bell-shaped. Planted in gardens and pots by the natives, who use it medicinally.

References:

Artemisia vulgaris L. Sp. Pl. 2:848. 1753. 



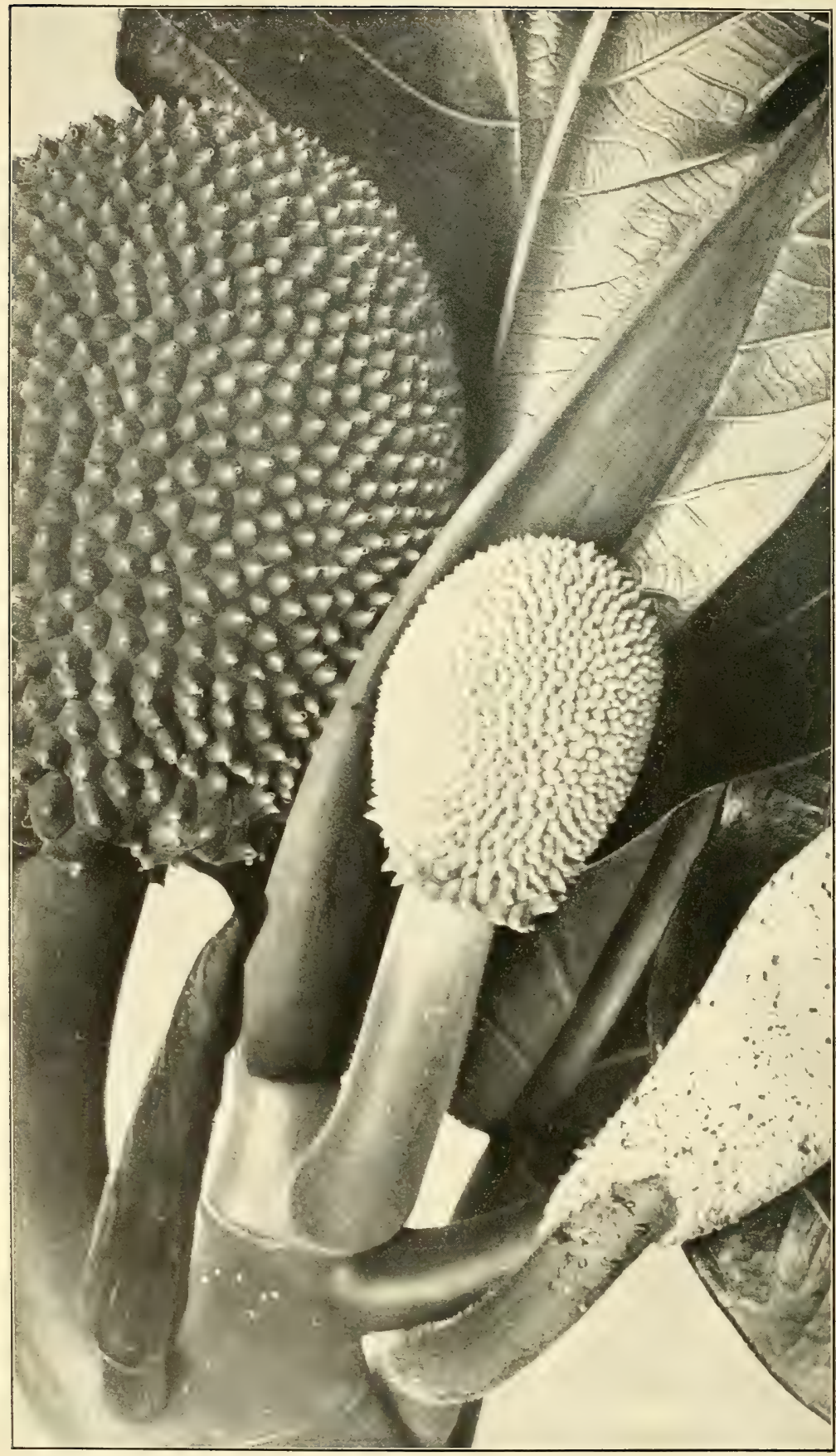

The Fertile Breadfruit (ARTOCARPUS COMmunis), Showing MALE and Female INFLORESCENCES, IMMATURE FRUIT, and LEAF BRACT. SLIGHTLY REDUCED. 
Local yanes. - Seedlass variety: Lêmae, Lêmai, Lêmay, Rima (Guam); Rima, Coló, Kolo (Philippines); 'Ulu (Samoa, Hawaii); Uto (Fiji). Arbol del pan (Spanish). Seeded variety: Dugdug, Dogdog (Guam); Breadnut (Burma); Tipolo, Antipolo (Philippines); 'Ulu-ma'a (Samoa); Uto-sore (Fiji); Bulia (Solomon Islands).

A handsome tree, with viscid, milky juice, broad-lobed or digitate leaves, and gently curving limbs, bearing the celebrated breadfruit. This fruit is oval or spheroir in shape, about the size of a child's head or of a melon. It is formed by the female flowers, which are very numerous, and are grouped in a prickly hear upon a spongy receptacle. In the fertile typical form the fruit is covered with short hard projections, but in the cultivated breadfruit, which is seedless, it is much smoother and reticulated. The male flowers grow in dense, yellow, club-shaped catkins. The leaves are very large, leathery, ovate, wedge-shaped and entire at the base, the upper part 3 to 9 -lobed or pinnatifid, dark green and glossy, and paler beneath. The fruit is at first green, becoming brownish when imperfectly ripe and yellow when fully so. It contains a somewhat fibrous pulp, pure white at first, but becoming yellow at maturity. It is attached to the small branches of the tree by a short, thick stalk, and hangs either singly or in clusters of two or three together.

It is eaten before it becomes ripe, while the pulp is still white and mealy, of a consistency intermediate between new bread and sweet potatoes. In Guam it was formerly cooked after the manner of most Pacific island aborigines, by means of heated stones in a hole in the earth, layers of the stones, breadfruit, and green leaves alternating. It is still sometimes cooked in this way on ranches; but the usual way of cooking it is to boil it or to bake it in ovens; or it is cut in slices and fried like potatoes. The last method is the one usually preferred by foreigners. The fruit baked or boiled is rather tasteless by itself, but with salt and butter or with gravy it is a palatable as well as a nutritious article of diet. Ovens were introduced into Guam by the Mexican soldiers who were brought by the Spaniards to assist in the "reduction" of the natives. They are of masonry and of the typical dome shape of the ovens so common in Mexico. A kind of biscuit is made by slicing the fruit into moderately thin sections after having cooked it, and drying the slices either in the sun or in ovens. Thus prepared it will last from one breadfruit season to another. The dried slices may be eaten either as they are or toasted, or ground up and cooked in various ways. The Caroline Islanders, a colony of whom lived until recently on the island of Guam, follow a custom widely spread in the Pacific of preserving breadfruit in pits, where it ferments and is converted into a mass resembling new cheese, in which state it gives forth a very disagreeable odor. The fermented paste is made into cakes and haked, and is then palatable and nutritious. This method of preserving breadfruit is also followed by the Samoans, who call the cakes "masi," a name now applied by them to ship biscuit and crackers. In Rarotonga the fermented paste is called "mai."

The tree yields other products of economic value, such as native cloth or tapa, from the fibrous inner bark of young trees and branches, and a kind of glue and calking material obtained from the viscid milky juice, which exudes copiously from incisions marle in the stem. Bark cloth is no longer made in Guam. It is recorded that during an interval of eleven years, wher no ship visited the island and there was a scarcity of woven fabrics, a number of women made petticoats from the breadfruit bark. In Pigafetta's account of the discovery of the group by Magellan he says: "The women also go naked, except that they cover their nature with a thin bark, pliable like paper, which grows between the tree and the bark of the palm." Now the paper mulberry (Pap!rius papyriferus), the most common tapa-cloth plant of the Pacific islands, does not grow in Guam. There is no palm to which Pigafetta's description could apply, and it is quite probable that the "thin bark, pliable like 
paper, growing between the tree and the bark" was that of the breadfruit, thongh it may possibly have been that of the nunu, or banyan.

Besides using the latex in calking boats, the natives of Guam find it, when fresh and viscid, an excellent medium for mixing paint, and it is a good sizing for whitewash. The usual pigments were a red ferruginous earth and lampblack made by burning cocoanut shells. The Caroline Islanders still use it with various pigments for painting their canoes, and it resists the action of water pretty well, though for this purpose it is inferior to oil.

The wood is of fine yellow color. It is not very hard, but it has the virtue of resisting the white ant, and if kept dry it is durable. In Guam it is used for cupboards, shelving, furniture, and for partitions between rooms. It is also used for (anoes, but as these are not well cared for by the natives and moisture injures the wood, they do not last very long. In Samoa the framework of the roofs of all the hest houses is made of the curved limbs of the breadfruit, beautifully rounded and scarped together and wrapped at the joints with coconut sennit.

Dhigdug, the "breadnut," or seeded variety of the breadfruit, grows everywhere in Guam-in the woods, on rocky cliffs, and in low, sandy soil. It is the chief source of timber and of gum, the seedless lêmae being too valuable as a fruit tree to be used generally for these articles. The fruit of the dugdug is inferior to that of the lêmae, than which it is softer and more sweetish. It is seldom eaten, but its seeds, called "nangka" (the name in the Philippines for Artocurpus integrifolia, the "jack-fruit"), are rich in oil and are relished by the natives They are eaten roasted or boiled and are much like chestnuts.

Lemue, being sterile, is propagated from the shoots which spring up around the base of the trunk. They readily take root. The dugdug is grown from the seed, though it occurs in such abundance on the island that it is not nuch planted. There are a number of varieties of breadfruit recognized by the natives. The species grows so readily that it might prove profitable to plant it for the manufacture of starch or "arrowroot" from the fruit.

Horses and cattle are very fond of the leaves and bark, so that young trees must he protected from them. When pasture is starce breadfruit leaves are gathered and fed to stock; and the fruit is so abundant that it is fed to cattle, horses, and pigs.

The brearlfuit season hegins in June and lasts for about five months. This accounts for the fact that Pigafetta and several other early navigators who visited Guam lluring the time of the year when it was ont of season fail to mention it among the fruits which they obtained from the islanders. Magellan visiterl the island in March, Legaspi in January, and the Nassan fleet also in Jannary. In the narrative of the latter expedition the cultivation of rice is mentioned (see quotation under oryza sativa), and a food stapleso inportant as breadfruit would surely have been mentioned had it come within the notice of the Dutch.

The first to record the breadfruit as a food staple of the Marianne Islands was Dampier, who has given the following accurate description of it in his New Voyage Round the World:

The Breal-fruit (as we call it) grows on a large Tree, as big and as high as our largest Apple-Trees. It hath a spreading head full of lranches, and rark leares. The fruit grows on the houghs like Apples: It is as big as a Penny-loaf, when Wheat is at fire shillings the Bushel. It is of a rouml shape, and hath a thick tough rind. When the fruit is ripe, it is rellow an suft; and the taste is sweet and pleasant. The Natires of this Island use it for Prearl: they gather it when full grown, while it is green and hard; then they hake it in an Oven, which scorcheth the rind and makes it black: but they scrape off the outsile black crust, and there remains a tender thin crust, and the inside is soft, tender and white, like the crumb of a Penny Loaf. There is neither seed nor stone in the inside, but all is of a pure substance like Bread: it must be eaten new, for if it is kept above 24 hours, it becomes dry, and eats harsh and choaky; but'tis very pleasant before it is too stale. This fruit lasts in season 8 months in the year; during which time the Natives eat no other 
sort of food of Bread kind. I did never see of this Fruit any where but here. The Natives told us, that there is plenty of this Fruit growing on the rest of the Ladrone Islands; and I did never hear of any of it any where else. $a$

\section{REFERENCES:}

Artocarpus communis Forst. Char. Gen. 102. 1776.

Artocarpus incisa L. f. Suppl. 411. 1781.

Artocarpus incisa. Same as Artocarpus communis.

Arum, Egyptian (Italy). See Caladium colocasia; in Guam called "suni."

Arundo bambos. See under Bambos.

Arundo tecta. Same as Trichoon roxburghii.

Arungay (Philippines). See Moringa moringa.

Arurú (Guam). See Maranta arundinacea.

Asaua (Samoa). See Gleichenia dichotoma.

Asclepiadaceae.

Milkweed Family.

This family is represented in Guan by Dischidia puberula, a climber peculiar to the island, the widely diffused Asclepias curassurica, and the fragrant "mil leguas" (Telosma odoratissima), a garden climber of Chinese origin.

Asclepias curassavica.

Curagao milkweed.

Family Asclepiadaceae.

Local Xases.-Asuncion (Guam); Rosa de Francia (Philippines); Algodoncillo (Porto Rico); Wild ipecac (Hawaii) Blood flower (Jamaica); Chocholloxin (Maya of Mexico).

A handsome milkweed, with orange-scarlet flowers, growing erect in solitary, lateral umbels. Leares opposite, oblong-lanceolate, tapering at both ends; stem somewhat downy, simple, sometimes a little branched, growing from 30 to $90 \mathrm{~cm}$. high.

The plant is of American origin, but has found its way to almost all tropical countries. It is very common in Guam, growing in open fields which were formerly cultivated. Its root possesses emetic properties, and the expressed juice of its leaves is used as a remedy for intestinal worms.

REFERENCES:

Asclepias curassavica L. Sp. Pl. 1: 215. 1753.

Ash Pumpkin (Ceylon). See Benincasa cerifera.

Asisio (Philippines). See Physalis angulata and $P$. minima.

Asngod (Guam). See Zinziber zingiber.

Asñgod halom-tano (Guam). See Zinziber zerumbet.

Aspidium. See Ferns.

Aspidium dissectum and A. parasiticum. Same as Dryopteris dissecta and $D$. parasitica. See Ferns.

Asplenium. See Ferns.

Asplenium cultratum Gaud. Same as Asplenium falcatum. See Ferns.

Asplenium nidus. Same as Neottopteris nidus. See Ferns.

Asteraceae.

Aster Famil.Y.

Among the representatives, of this family are Ternonia villosa and T. cinerea, Elephentopus secther and $E$. spicatus, Adenostemina viscosum, Ageratum conyzoides, Eclipita. allen, Stemmortomia canescens", Stemmodontic biflora, Artemisia vulgaris ("hierba de Santa Maria"), Synedrella nodiftora, Glossogyne tenuifolia, and Chrysunthemum indicum ("manzanilla").

"See also Banm, The Breadfruit, reprinted from The Plant World, vols. 6 and 7. Washington, 1904. 
Asthma herb. See Euphorbia pilulifera.

Asunción (Guam). See Asclepias curassavica.

Ata (Hindu). See Annona squamosa.

\section{Atamosco rosea.}

ZEPHYR LILY.

Family Amaryllidaceae.

Local NaMes. - Nardo (Guam); Fairy lily (United States).

A bulbous plant of tropical American origin, with solitary 6-parted rose-colored flowers. Bulb glohose, 7.6 to $10 \mathrm{~cm}$. thick; leaves linear, contemporaneous with the flower; perianth regular, about $2.5 \mathrm{~cm}$. long and $4 \mathrm{~cm}$. broad; spathe 2 -fid at the tip; anthers versatile; ovary stalked, ovules many, superimposed; seeds black, flat; stigma 3 -fid.

A beautiful flower, cultivated widely. I found it escaped, growing in the Plaza cle Magallanes, Agaña, and transplanted it to my garden, where it bloomed monthly.

REFERENCES:

Atamosco rosea (Lindl.) Greene, Pitt. 3:188. 1897.

Zephyranthes rosea Lindl. Bot. Reg. 10: t. 821. 1824.

Atbahakat (Guam). See Ocimum basilicum and O. canum.

Ateate (Samoa). See Stemmodontia biflora.

Atgodon (Guam). See Gossypium arboreum and G. barbadense.

Atgodon de Manila. See Ceiba pentandra.

Atis (Guam, Philippines). See Annona squamosa.

Atis-aniti (Guam). See Meibomia gangetica.

Atole (Guam, Mexico, Cuba).

A gruel made by boiling pounded maize. In Peru it is called "mazamorra."

Atoto (Tahiti). See Euphorbia atoto.

Auricularia auricula-judae. See under Fungi.

'Aute (Samoa). See Hibiscus rosa-sinensis.

'Ava-pui (Samoa). See Zinziber zerumbet.

Averrhoa carambola.

Caraybola. Plate xxxiri.

Family Oxalidaceae.

Local Names._Bilimbines (Guam); Carambola, Balimbing (Philippines); Coro-, mandel gooseberry (India); Kumurunga (Bengal).

A small tree bearing an oval, angular, translucent, edible fruit. Leaves alternate, odd-pinnate, with 4 or 5 pairs of leaflets; leaflets alternate, ovate-acuminate, cntire, stalked; flowers fragrant, small, ribes-like, rose-purple or magenta, growing in crowded clusters, which give to the tree a showy appearance when in full bloom; racemes growing from the bark of young and old branches (caulifloral), or from the axils of the leares; petals 5 ; stamens usually 10 , only 5 of them with anthers. The fruit has a thin, yellow, smooth skin. It is longitudinally ribbed or angled, so that a cross section has the shape of a three, four, or five-angled star. It contains a clear watery pulp, astringent when green and tasting like sorrel or green gooseberries, but pleasantly acid when ripe, or even sweet, with an agreeable fruity flavor, and a strong perfume like that of a quince. The leaves and younger branches are irritable, closing and drooping somewhat like those of the sensitive mimosas and oxalids when the tree is shaken or suddenly shocked. The leares are affected by light very much like those of many acacias, which close and apparently go to sleep when the sun disappears and awake when it shines again. The tree is readily propagated from the seed. It is long-lived and a constant bearer. In Guam it produces several crops a year. It grows near dwellings, on the sites of abandoned ranches, and by roarlsides, but it is not abundant. The natives make preserves of it, but these are somewhat 



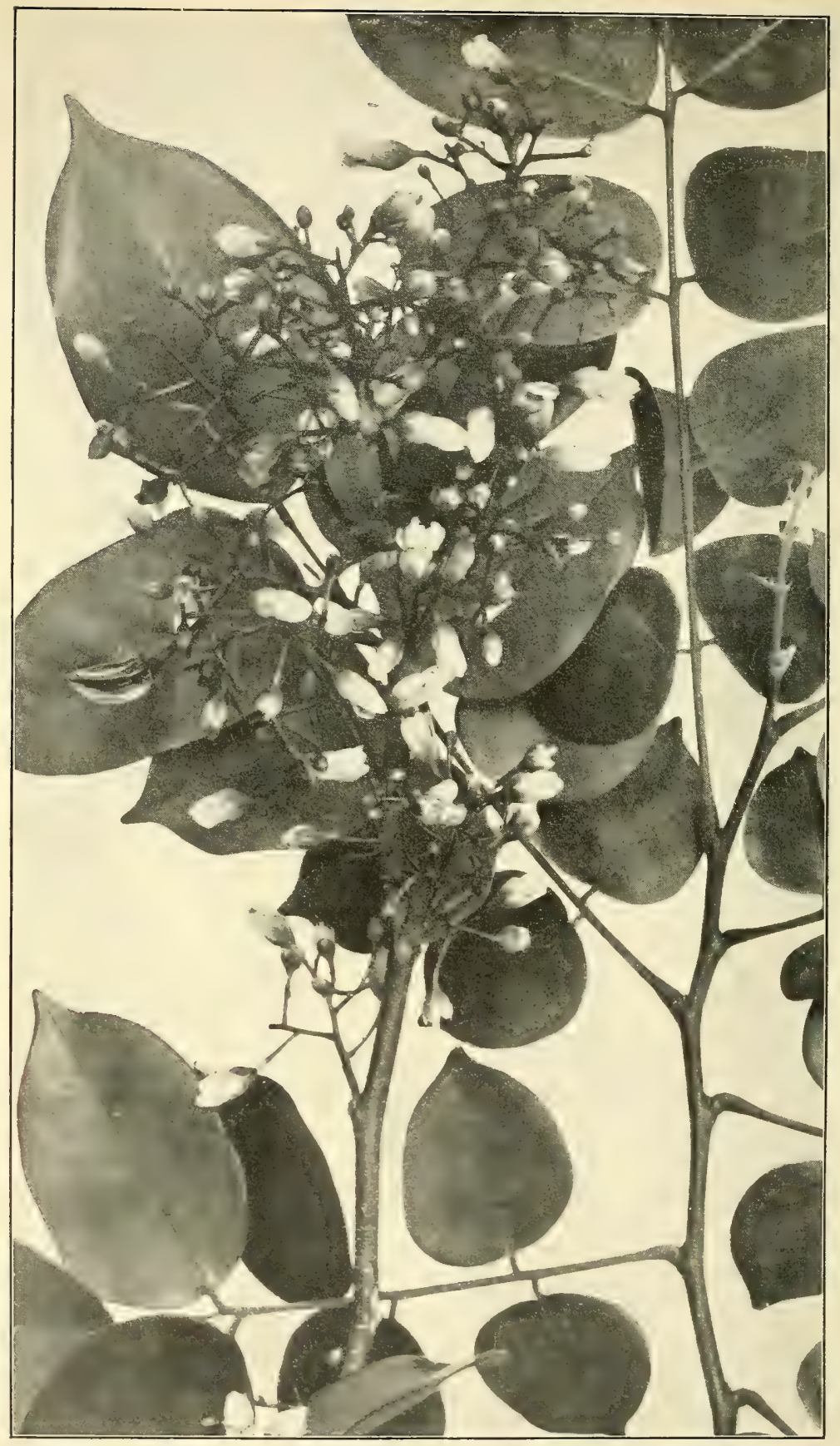

Averrhoa carambola. Inflorescence and foliage. Natural Size. 
tough. When strained the pulp yields a fine jelly. Foreigners are warned against eating the uncooked fruit, the natives declaring that it will cause hiccoughs. Tarts made of it have very much the flavor of rhubarb. The natives do not appear to value the fruit very highly, but this may be owing to the scarcity of sugar, a large proportion of which is necessary for making jelly and preserves, and to the abundance of other fruits equally good or better. In India the unripe fruit is used in dyeing, the acid acting probably as a mordant. The juice removes iron rust from linen. The dried fruit is antiscorbutic and, together with the leaves and root, is used as a remedy in fevers.

The tree was introduced into Guam many years ago. Gaudichaud mentions it, together with the allied Arerrhoa bilimbi $L$., a species in which the clustered, caulifloral, pendant fruit is smaller and not angled, and the leaves have smaller and more numerous leaflets. The latter species is no longer found on the island; it has probably died out since Gaudichaud's visit.

\section{REFERENCES:}

Averhoa carambola L. Sp. Pl. 1: 428. 1753.

Awned beard grass. See Andropogon aciculatus.

Azafran (Spanish). See Curcuma longa.

Azucena (Guam). See Polianthes tuberosa.

Baba (Guam).

A plant belonging to the Arum family, with heart-shaped leaves 2 to 2.5 meters long and reddish stems; probably a species of Alocasia.

Bacao, Bacauan, or Bakawan (Philippines). See Rhizophora mucronata and Bruguiera gymnorhiza.

\section{Bacopa monniera.}

WATER HYSSOP.

Family Scrophulariaceae.

LOCAL NAMES.-Graciola (Cuba).

A snall, creeping, glabrous plant with rather thick, entire leaves and a pale buue or nearly white flower growing in moist situations. Leaves obovate or oblong, entire or crenate, without prominent veins; flowers few, on pedicels usually rather longer than the leaves, with 2 small bracteoles under the calyx; calyx divided to the base into 5 distinct sepals, the outer one oval, the others ovate-lanceolate or lanceolate; corolla-tube scarcely so long as the calyx, the 5 lobes spreading, broad, as long as the tube, the 2 upper ones rather smaller and less deeply separated than the others; capsule ovid, shorter than the calyx, opening loculicidally in 2 valves, which at length separate from the dissepiment and sometimes split into two.

Common in Guam, especially in the ciénaga, near Agaña. In India it is used medicinally by the Hindoos, who consider it to be aperient and a stimulant for the secretion of urine.

\section{References:}

Bacopa monnieria (L.) Wettst. in Engler \& Prantl, Pflanzenfam. 4 ${ }^{3 \mathrm{~b}}$ : 77.1891.

Gratiola monnieria L. Cent. Pl. 2: n. 120. 1756; Amoen. Acad. 4: 306.1759.

Monniera brownei Pers. Syn. 2: 166. 1807.

Herpestis monnieria H. B. K. Nov. Gen. et Sp. 2: 366. 1817.

Badyog (Guam). The seeds of the snuff-box sea-bean. See Lens phaseoloides.

Bahama grass. See Capriola dactylon.

Bahay (Philippines). See Adenanthera pavonina.

Bakao, Bakawan, or Bakawan (Philippines). See Rhizophora mucronata and Bruguiera gymnorhiza.

Balañgigan (Philippines). See Guettarda speciosa

$9773-05-13$ 


\section{Balanophora sp.}

Family Balanophoraceae.

A low, fleshy, leafless parasitic plant of an orange-scarlet color devoid of chlorophyll growing on the roots of other plants, and shaped when young like an asparagus - sprout. The whole plant is waxy and translucent. The flowers are unisexual and are closely crowded together. The male flowers have a regular perianth, but the female flowers have none. The latter consist of a one-celled ovary having a single ovule and a long style. It resembles a species growing in the Fiji Islands, but the latter is pale yellow instead of reddish-orange.

Balasbas (Philippines). See Graptophyllum pictum.

Balatong (Philippines). See Phaseolus mungo.

Balatong aso (Philippines). See Cassia occidentalis.

Baliácag (Visayan): See Dioscorea aculeata and D. sativa.

Balibago (Philippines). See Pariti tiliaceum; in the Guam vernacular called "pago."

Balimbing (Philippines). See Averrhoa carambola.

Baliskug (Visayan). See Clerodendron inerme.

Baliti (Philippines). See Ficus sp.

Balloon vine. See Cardiospernum halicacabum.

Balokbalok (Philippines). See Lobelia koenigii.

Balogo (Visayan). See Lers phaseoloides.

Balones (Philippines). See Lens phaseoloides.

Balonggai (Visayan). See Moringa moringa.

Balsam, Garden. See Impatiens balsamina.

Balsam-pear. See-Momordica chararitia.

Balsamina (Spanish). See Momordica charantia.

Balubad (Philippines). See Anacardium occidentale.

Balunggai (Philippines). See Moringa moringa.

Bamboo. See Bambos blumeana and Bambos sp.

Bambos blumeana.

ThORNY BAMBOo.

Family Poaceae.

Local Names. - Pian tituka, Piao lahe (Guam); Cauayang tinic (Philippines); Caña espinas, Caña macho (Spanish).

A handsome bamboo armed with sharp recurved spines, forming impenetrable thickets in moist places, and often attaining the height of 50 feet. Stems growing in elumps; hard, smooth, glossy green when growing, walls thick, nodes not prominent; flowers produced at long intervals, the plants dying after the seeds have matured.

This plant was introducer fron the Philippines. It is much stronger and more durable than the common spineless piur, and is used by the natives in building houses (Plate XX), ranchos, and inclosures. Fresh canes stuck in the ground often take root. Large canes cut into lengths of 6 to 8 feet with the septa removed are used as water vessels (see Plate II; young carabao loaded with bamboo vessels filled with water), and single joints are used as flower pots and for collecting the sap of the coconut, as described under Cocos nucifera. The stem split into slats about an inch wide is used for making platforms in farmhouses, upon which the natives sleep, and also for inclosures under these platforms for the protection of young chickens from rats, cats, and lizards.

REFERENCES:

Bambos blumeana Schult. f. Syst. $7^{2}: 13+3$. 1830, as Bambusa blumeana. 
Local names.-Piao, Piao palaoan (Guam); Caña hembra (Spanish).

A large bamboo without spines; stems growing to 4 inches or more in diameter; branches numerous. Inferior to the preceding in hardness and durability, and subject to the attacks of insects. The canes are used for water vessels, fences, frame poles for ranches and houses, and when split into widths of an inch or more they are used for floors and sleeping platforms in the poorer kinds of houses and in ranches. Troughs for collecting water from roofs and drinking troughs for fowls are made by splitting the canes and removing the septa. The identity of this plant has not been established. It may possibly be a species of Schizostachyum. Gaudichaud, in the report of the botany of the Freycinet expedition mentions Bambos bambos Wight (Arundo bambos L., Bambusa arundinacea Willd.) as occurring on the island, but this is probably a mistake. The vernacular name signifies "female bamboo," to distinguish it from the species armed with spines. The durability of both species is increased by soaking the split canes in water for a week or two and then drying them thoroughly. They are springy and elastic. Platforms of them with mats spread over them make very comfortable beds.

Bambusa. See Bambos.

Banago (Guam). See Jasminum marianum.

Banalo (Philippines). See Cordia subcordata.

Banana. See Musa paradisiaca.

Bangcóang bóndôk (Philippines). See Pandanus dubius.

Bangil (Visayan). See Sophora tomentosa.

Bantigui (Philippines). See Pemphis acidula.

Banyan. See Ficus sp.

Baong (Philippines). See Dioscorea sativa.

Barbados pride. See Poinciana pulcherrima.

Barringtonia butonica. Same as Barringtonia speciosa.

\section{Barringtonia racemosa.}

Local NAMES.-Langaasag, Langãsat, Langat (Guam); Potat (Philippines); Putat (Malay); Du'ra (Andamans); Samutra-pullum (India).

A tree having pendant racemes of flowers; petals 4, white or rose-tinted; calyx 2 or 3-cleft; filaments of the stamens longer than the petals; style long; fruit ovate, bluntly 4-angled, smooth, brownish-red; leaves oblong, acuminate, wedge-shaped at the base, crenate or obscurely serrate.

This species is common in Guam near the sea and along the banks of streams. It is not utilized by the natives. In India, however, according to Major Drury, the seed is used as a fish intoxicant, and the powdered fruit is applied externally in combination with other remedies for sore throat and cutaneous eruptions.

From the seed of an allied species of the Malay Peninsula, called "putat gajah" by the natives, a starchy food is derived which is eaten by certain tribes. The kernels of the seeds are grated on a piece of thorny stem of a rattan (Calamus). Water is added and a milky juice is squeezed out of the pulp, resembling the milk expressed from grated coconut. This milky liquid is allowed to stand in boat-shaped dishes made of palm sheaths. A starchy substance is deposited and the water carefully drawn off. The deposit is made into cakes, which are roasted and eaten. If eaten without having been washed the gratings cause sickness.a The name " putat," applied

a See Ridley, H. N. Barringtonia seed as a Sakai food, Agricultural Bull. of the Straits and Federated Malay States, vol. 2, p. 165, 1903. 
to all species of Barringtonia, is undoubtedly of the same origin as the Guam, Philippine, and Polynesian names for species of the same genus.

REFERENCES:

Barringtonia racemosa (L.) Roxb. Hort. Beng. 52. 1814 (ex Ind. Kew.); Fl. Ind. 2: 634. 1832.

Eugenia racemosa L. Sp. Pl. 1: 471.1753.

\section{Barringtonia speciosa.}

Futu. Plate xxxviri.

Family Lecythidaceae.

Local NaMes.-Puting (Guam); Putat (Malay); Botong (Philippines); Futu (Samoa, Tonga); Hutu, Hudu, Fudu (Tahiti); Vutu (Fiji); Utu (Rarotonga); Hutum (Amboina); Dod-da (Andaman Islands).

A handsome glabrous tree, with dark, glossy, entire, wedge-shaped, oblong, obtuse, coriaceous leaves, and conspicuous flowers having 4 white petals and a dense tuft or brush of erimson-tipped stamens; style very long and slender; fruit in the form of a 4-sided pyramid, about 3 inches across the middle, consisting when dry of a hard, smooth case containing solid fibrous matter and 1 seed.

This species is widely spread in the Pacific, but does not occur in the Hawaiian Islands. It is found in the Malay Archipelago, the Andaman Islands, and Ceylon.

The fruits are buoyant, and, as the tree grows down to the very edge of the sea, they often fall into the water and are carried by currents and cast upon other shores. In Samoa I have seen seeds left in depressions on a newly formed reef sending forth vigorous sprouts and shoots. The futu and the goat's foot convolvulus were there the pioneer settlers on the new territory.

In Guam this tree is very abundant. In places on the east shore between Pago and Talofôfô one can scarcely walk without stepping on the fallen fruit or crushing the young plants. The natives use the fruit when dry as floats for their nets, and the fresh fruit for stupefying fish. $a$ The use of the seeds of this plant as a fish intoxicant is widely spread in Polynesia and the East Indies.

REFERENCES:

Barringtonia speciosa Forst. Char. Gen. 76. t. 38. 1776.

Bartramia. See Mosses.

Barubatones (Visayan). See Kyllinga monocephala.

Baseng (Philippines). See Zinziber zingiber.

Basengbaseng (Philippines). See Sida rhombifolia.

Basil. See Ocimum canum and $O$. sanctum.

Basil, sweet. See Ocimum basilicum.

Basora prieta (Porto Rico). See Waltheria americana.

Basote (Porto Rico). See Chenopodium ambrosioides.

Bastard currant. See Ehretia microphylla.

Baston-de-San-José (Guam). See Taetsia terminalis.

Batao (Philippines). See Dolichos lablab.

Batobatonis (Tagálog). See Euphorbia hirta.

Batunes (Guam). See Mesosphaerum capitatum.

Bauhinia sp.

Family Caesalpiniaceae.

LoCal Names. - Flor de mariposa (Guam).

A shrub or small tree with beautiful, large, variegated, red-and-yellow flowers, somewhat like those of Bauhinia variegata. Introduced into Guam and cultivated by a few natives in their gardens as an ornamental plant. 


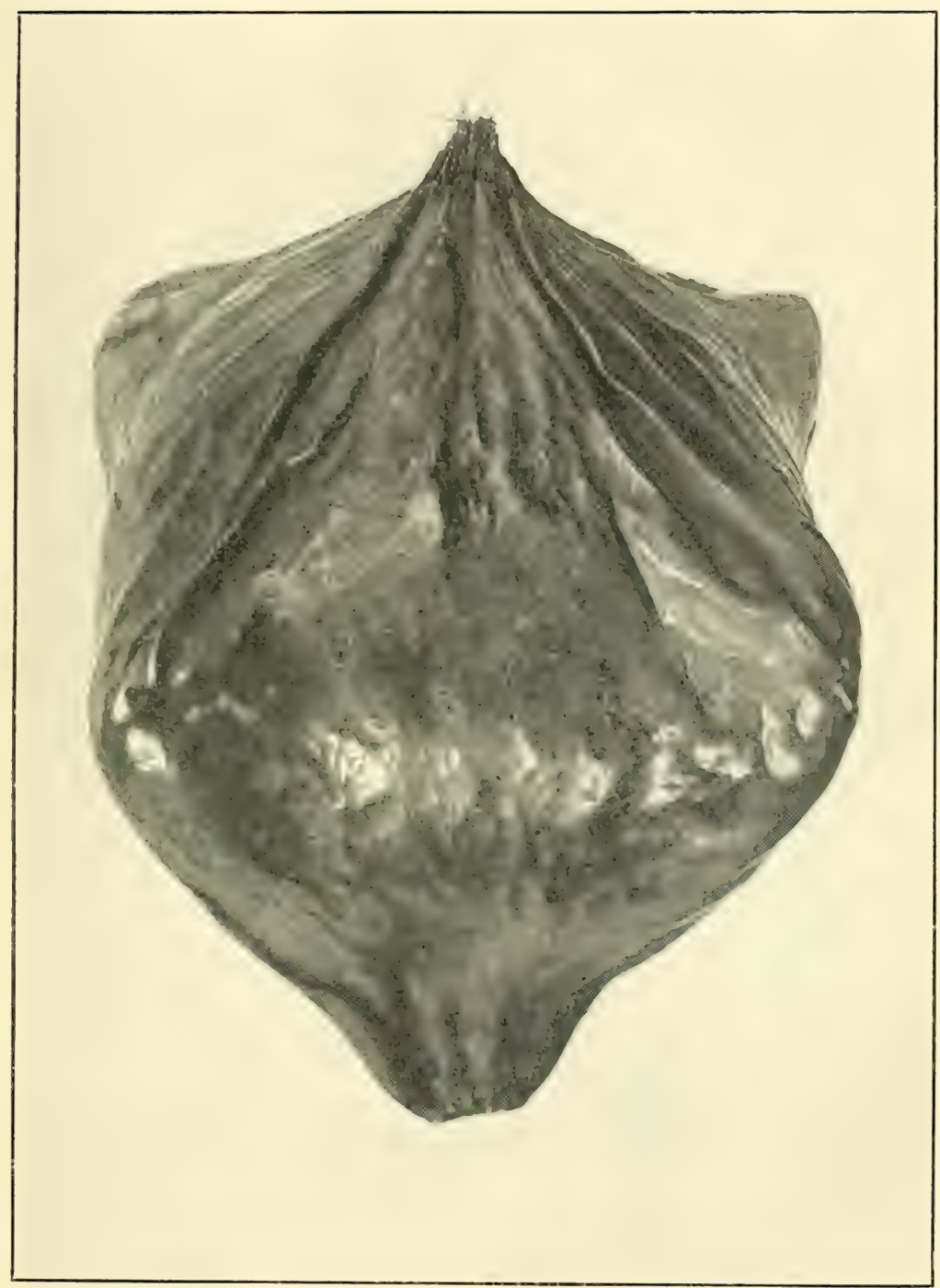

Fruit of Barringtonia speciosa, a Fish Intoxicant. Natural Size. 

A second species growing on the hillside above San Ramon on the left-hand side of the road leading to Sinahana is of very recent introduction. It has large illsmelling flowers of pale sulphur-yellow which resemble the figure of Bauhinia blancoi in Blanco's Flora de Filipinas.

Baumea mariscoides Gaudich. Same as Cladium gaudichaudii.

Bayabas (Philippines). See Psidium guajava.

Bayag cambing (Tagálog). See Guilandina crista.

Bayog or Bayogo (Guam; Philippines).

The seeds of Lens phaseoloides.

Bayog cabayo (Philippines). See Dioscorea sativa.

Bead tree, Syrian. See Melia azedarach.

Beak rush. See Rynchospora corymbosa.

Bean family. See Fabaceae.

Beans:

Chinese asparagus. See Vigna sinensis.

Coral. See Adenanthera pavonina.

Egyptian kidney. See Dolichos lablab.

Goa. See Botor tetragonoloba.

Horse. See Canavali ensiforme.

Horse-eye. See Stizolobium pruriens and S. giganteum.

Hyacinth. See Dolichos lablab.

Lima. See Gardens.

Match-box. See Lens phaseoloides.

Molucca. See Guilandina crista.

Ox-eye. See Stizolobium pruriens and S. giganteum.

Queensland. See Lens phaseoloides.

Sea. See Stizolobium pruriens, S. giganteum, Lens phaseoloides, and Guilandina crista.

Seaside. See Canavali obtusifolium and Vigna lutea.

Snuffbox. See Lens phaseoloides.

Sword. See Canavali ensiforme.

Turnip. See Cacara erosa.

Yam. See Cacara erosa.

Beardgrass, awned. See Andropogon aciculatus.

Beefwood (Australia). See Casuarina equisetifolia.

Beet. See Gardens.

Behuko halom-tano (Guam). See Calamus sp.

Bejuco (Spanish).

General name for climbing or twining plant. In the Philippines and in Guam it is specially applied to species of elimbing palms (Calamus).

Bejuco cimarron (Spanish). See Calamus sp.

Bejuco de vaca (Porto Rico). See Ipomoea pes-caprae.

Bell pepper. See Capsicum unnuum grossum.

Belvisia spicata. See under Ferns.

Ben oil. See Moringa moringa.

Benincasa cerifera.

WAX GOURD.

Family Cucurbitaceae.

Local Names.-Kondot, Condor (Guam); Kondol (Philippines); Calabaza blanca (Spanish); Ash pumpkin (Ceylon).

A gourd with oblong, white, waxy fruit, growing on a vine, like a muskmelon; 
hairy, with heart-shaped lobed leaves and yellow flowers, the male flowers with long stalks, the female almost stalkless. Cultivated in the gardens of Guam for the fruit, which is cooked as a vegetable and also as a "dulce."

REFERENCES:

Benincasa cerifera Savi, Bibl. Ital. 9: 158. 1818 (ex Ind. Kew.).

Benne. See Sesamum orientale.

Berbena (Guam). See Heliotropium indicum.

Berengena (Spanish). See Solanum melongena.

Bereñghenas (Guam). See Solanum melongena.

Bergamot. See Citrus aurantium bergamia.

Bermuda grass. See Capriola dactylon.

Beta vulgaris (the common beet). See Gardens.

Betel leaf. See Piper betle.

Betelnut. See Areca cathecu.

Betel pepper. See Piper betle.

Biancaea sappan.

SAPPAN.

Local Names,--Sibukao, Sibucao (Guam and Philippines); Palo del Brazil (Spanish).

A thorny shrub or small tree with racemes of showy yellow flowers. Leaves abruptly bipinnate; pinnæ 20 to 24 ; spines on rachis of leaves at base of pinnæ and stipulary spines at base of petioles; leaflets 20 to 30 , small oblong, very oblique; stamens woolly; pods short, broad $(7.5$ to $10 \mathrm{~cm}$. long by $4 \mathrm{~cm}$. broad), oblique, woody, with recurved beak at the upper angle, 3 or 4 seeded.

This species was introduced into Guam at least a century ago. It grows readily on the island, and boundary hedges composed of it have spread into thickets in many places. Its heartwood yields a fine red dye, which is extensively used in India, and it is exported from Ceylon. The bark and the root are also used for dyeing. The wood is an astringent and contains tannic and gallic acids. It is used medicinally in India. In Guam the natives make little use of it, as it requires considerable labor to separate the heart from the rest of the wool. It could be grown with success on the island, as it spreads there of its own accord and requires little or no attention. Owing to the ease with which it grows and its thick habit of growth, it is used for defining the boundaries of land. The wood takes a fine polish and does not warp nor crack.

In preparing the wood for dyeing it is cut into chips, which are pounded and boiled for several hours in water. It yields a red color, which is intensified by alkalies. For dyeing cotton tannin and alum are used as mordants, for wool a mixture of alum and cream of tartar. In India it is combined with indigo to produce a purple dye and with turmeric and sulphate of iron to produce a rich maroon. A dye is extracted from the bark of the trunk and roots by boiling, and the pods are used, like those of several other allied species, together with the protosulphate of iron, to make an ink or black dye.

\section{REFERENCES:}

Biancaea sappan (L.) Todaro, Hort. Bot. Pan. 1: 3. 1876.

Caesalpinia sappan L. Sp. Pl. 1: 381, 1753.

The type of the Linuean genus (aesalpinia, to which this species was referred by Linneus, and by nearly all authors since his time, is C. brasiliensis L. Sp. Pl. ed. 1. 1: 380.1753 , so far as it relates to the species of Plumier, from whom Linnæus adopted the genus with a slight modification in the spelling of the name. It is not, however, Cuesalpiniu brasiliensis L. Sp. Pl. ed. 2. 1:54t. 1762, which is an unarmed tree and does not belong to the same genus as Plumier's species, but under the specific name limaei has in part usually been referred to Peltophorum. Neither should the original Caesalpinia brasiliensis, though named ('. crista by Linnæus Sp. Pl. ed. 2. 1: 544. 1762, be confused with C. crista L. Sp. Pl. ed. 1. 1:380. 1753, which is Guilandina crista 



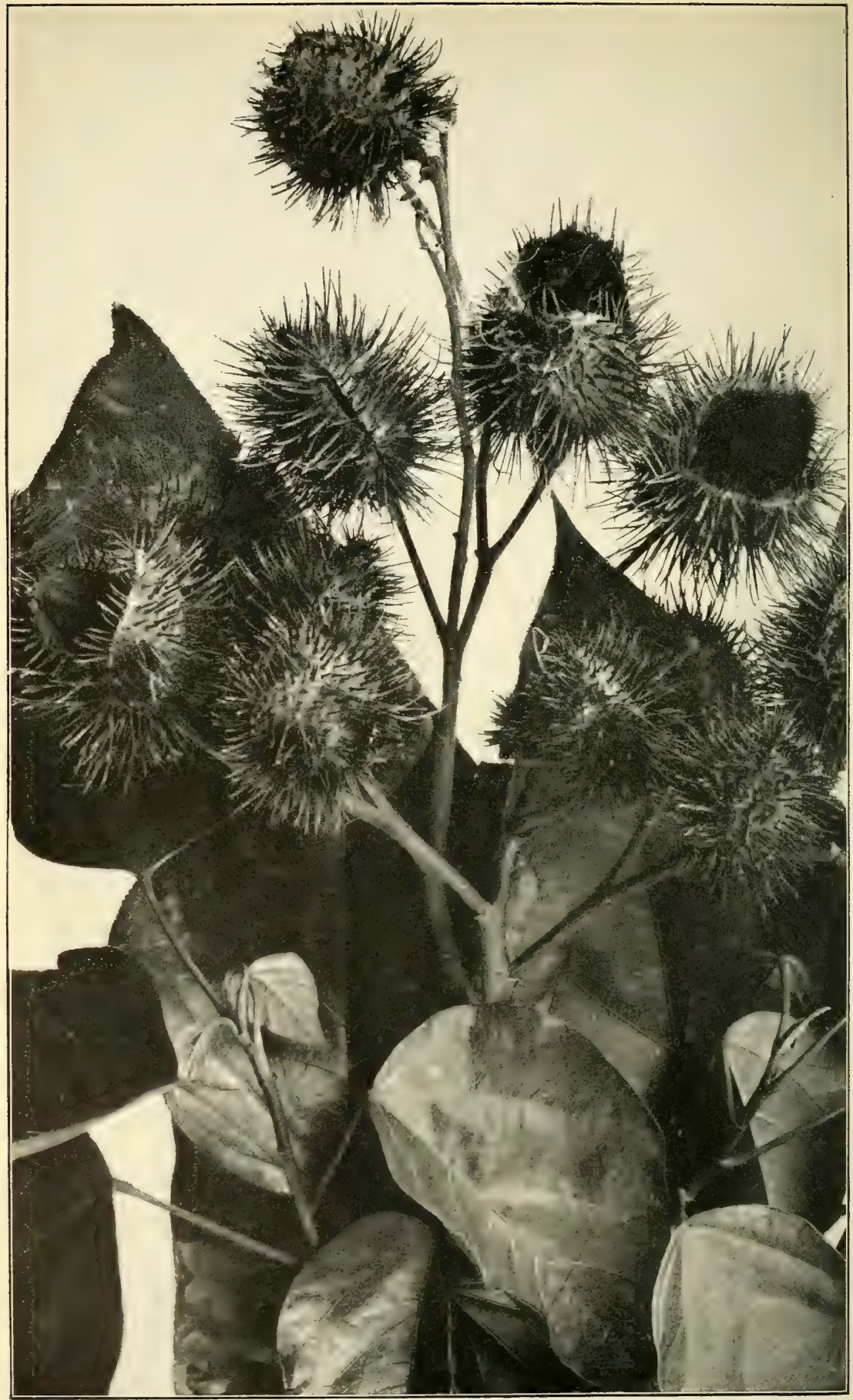

the arnotto tree (Bixa orellana). Foliage and fruit. Natural Size. 
(L.) Small. The synonomy of these much-confused species seems to have been first made clear by Urban Symb. 2: 269-285. 1900. Caesalpinia brasiliensis, however, does not appear to be congeneric with the species known as Caesalpinit sappan, and the name published by Todaro for the group to which the latter species does belong is accordingly adopted.-W. F. W.

Bidens tenuifolia. See Glossogyne tenuifolia.

Biga (Philippines). See Alocasia indica and A. macrorrhiza.

Bikkia mariannensis. See Cormigonus mariannensis.

Bilangbilang (Philippines). See Sesuvium portulacastrum.

Bilimbines (Guam). See Averrhoc carambola.

Bird pepper. See Capsicum frutescens; in Guam ealled "doni."

Bird's-nest fern. See Neottopteris nidus under Ferns; in Guam called "galak."

Bitanhol, Bitaog (Philippines). See Calophyllum inophyllum.

Bitogo (Philippines). See Cycas circinalis.

Bixa orellana.

Arnotto. Plate xxxix.

Family Bixaceae.

Local Names.-Achiote, Achuete (Guam, Philippines); Achote (Spanish); Achiotl (Mexico); Loa (Samoa).

A small tree bearing prickly capsules containing seeds surrounded by a red pulp, which yields the well-known arnotto of commerce. Leaves cordate-ovate, acuminate, entire or angular, smooth on both surfaces.

Arnotto is prepared by macerating the pods in boiling water, removing the seeds, and leaving the pulp to settle. The water is then poured off and the residuum, which is of a bright yellow or orange color, is used as a dyestuff. In Guam it is sometimes put in soup and rice. The Caroline Islanders use it to paint their bodies, together with turmeric. It is sometimes used in the same way by the Samoans.

The chief uses to which arnotto is applied are for dyeing silk and cotton orangeyellow, and for coloring cheese and butter. The color imparted to fabrics, however, is not lasting.

REFERENCES:

Bixa orellana L. Sp. Pl. 1 : 512. 1753.

Black fibre palm. See Saguerus pinnatus.

Black thorn (British West Indies). See Acacia farnesiana.

Bledos blancos (Spanish). See Amaranthus oleraceus.

Blind-your-eyes (Australia). See Excoecaria agallocha.

Blinding tree. See Excoecaria agallocha.

Blood flower (Jamaica). See Asclepias curassavica.

Blue pea. See Clitoria ternatea.

Bocoa edulis.

Polynesian Chestinut.

Family Fabaceae.

Local names.-If (N. Guinea); Ivi (Fiji); Ifi (Samoa); I'i (Samoa); Cayam,

Kayam (Cebu); Mapé (Tahiti); Marrap (Ponape); Marefa (Mortlocks).

A tree bearing an edible kidney-shaped fruit, recently introduced into Guam from the Caroline Islands, but not yet bearing. In Polynesia and in some of the Malayan Islands its fruit is an important food staple. The tree grows to a great size, often towering above the general level of the forest. When young the trunk is nearly cylindrical. It later becomes fluted, as though surrounded by adherent columns, which when older develop into radiating buttresses, like great planks. In Samoa it is one of the most striking features of the forest. Leaves oblong, leathery, feather-veined, short-petioled, with small stipules; flowers inconspicuous, in loose axillary spikes, white or yellowish, very fragrant; calyx tubular or somewhat bell-shaped, irregularly 
2 or 3-lobed, divisions rounded; petals 5 , united at the base together with the stamens into a tube; ovary nearly sessile; style very short; stigma oblique; pod shortstemmed, obovate, curved, hard, drupe-like, one-seeded.

In Polynesia the seed is eaten cooked when not quite ripe, and tastes much like a chestnut. In some islands it is preserved, like the breadfruit, in pits, where it is left to ferment. In Samoa it is a staple food for several months of the year. The bark of the tree is astringent. The wood is perishable and is of little economic value.

REFERENCES:

Bocoa edulis (Forst.) Baill. Adansonia 9: 237. 1868-70.

Inocarpus edulis Forst. Char. Gen. 66. t. 33. 1776.

Boehmeria candolleana Gaudich. Same as Pipturus argenteus.

Boehmeria paniculata. Same as Schychowskya ruderalis.

Boehmeria tenacissima.

RHEa.

Family Urticaceae.

Local Names.-Amahayan, Amahadyan (Guam); Labnis, Arimay, Amiray (Philippines); Oramai (Ponape); Lafai (Solomon Islands).

A shrub or small tree with alternate, broally ovate, acuminate, 3-nerved leaves, green above, white beneath, with dentate margins. Flowers minute, green, monoecious, in axillary panicles, with numerous sessile flower-heads along the entire length of the branches of the inflorescence; male flowers in the axils of the lower leaves; perianth 4-partite; stamens 4, opposite the perianth lobes; female flowers in the axils of the upper leaves; perianth gamophyllous, tubular, hairy, 4-dentate at the contracted mouth; style much exserted, hairy; ovary inclosed completely by the perianth; stigma papillose, on one side of the style; achene inclosed in the perianth, the pericarp crustaceous.

This plant is indigenous to the island. It differs from the allied Boehmeria nivea in its more robust habit of growth, in its larger leares, the lower surface of which is white, but not covered with the thick felt-like coating of that species, and in being shrubby instead of herbaceous. It was collected in Guam by Gaudichaud, who described it as having "feuilles tomenteuses et argentees au-dessous," and, growing near the seashore; a but he confused its vernacular name, "amahayan" with that of an allied plant called "sayiafi," having ovate, cordate, acuminate leaves, the petioles and lower surface of reins being covered with reddish pubescence, while the reins of the amahayan are smooth.

This species is figured by Wight. $b$ The form growing in Guam has leaves more finely serrate on the margin than in his figure.

Boehmeric nice is essentially a plant of temperate climates, and yields the "ramie" fiber from which "China grass cloth" is male. The name "rhea" should be confined to the fiber obtainerl from the tropical species. In Guam the plant is not utilized by the natives for textile purposes, but they use the bark as a remedy in certain diseases. An interesting account of the methods of cultivation and of extracting the fiber of Buehmeria niven is given by Charles Richards Dodge in his catalogue of the Useful Fibre Plants of the World. $c$

To be suitable for fiber purposes the stems should be unbranched. The trees or shrubs growing alone branch freely. In cultivation they should be planted close together, so as to throw up straight shoots, as in the case of hemp.

REFERENCES:

Boehmeria tenacissima Gaudich. Bot. Freyc. Voy. 500. 1826.

Urtica tenacissima Roxb. Hort. Beng. 67. 1814 (ex Ind. Kew.); Fl. Ind. 3: 590. 1832.

Boehmeria nivea tenacissima (Roxb.) Miq. Fl. Ind. Bot. 1²: 253. 1859.

a Narrative of Freycinet's Expedition, 1825.

$b$ Icones, vol. 2, pl. 688, 1842.

c Report No. 9, U. S. Department of Agriculture, 1897. 
Boerhaavia diffusa.

Glueweed.

Family Nyctaginaceae.

Local names.-Dafau, Dafao (Guam); Mata-pavo, Pega-pollo (Spanish).

A troublesone weed widely spread in the Tropics, diffusely branched, with white or reddish minute flowers growing in heads, which are arranged in terminal or axillary panicles. Leaves linear, ovate, oblong, or rounded, obtuse or acute, the base rounded or cordate; flowers jointed on the pedicel; bracteoles small; perianth tubular, limb funnel-shaped, 5-lobed; stamens 1 to 5, exserted; ovary oblique, stipitate; stigma peltate; fruit 5-ribbed, viscid, top rounded.

In some parts of India this plant is used as a pot herb. It is fed to hogs and cattle, and is thought to increase the supply of milk. The root is used medicinally, and is recommended as a remedy for dropsy and asthma. ${ }^{*}$ The very viscid perianth tube containing the fruit readily adheres to other objects and detaches itself from the plant. Smali insects are caught by the secretion, and young chickens and turkeys sometimes die in consequence of their eyes becoming sealed up by the sticky fruits. $b$

REFERENCES:

Boerhaavia diffusa L. Sp. Pl. 1: 3.1753.

Boerhaavia glutinosa, B. mutabilis, B. procumbens, B. repens. Same as Boerhaavia diffusa.

Bokábok (Philippines). See Lobelia koenigii.

Bollogo (Ilocos). See Anacardium occidentale.

Bolobotones (Philippines). See Kyllinga monocephala.

Bolót (Philippines). See Dioscorea fasciculata.

Bombacaceae.

Bombax FAMiLY.

The only representative of this family in Guam is the silk cotton tree, Ceiba pentandra.

Bombax orientale, B. pentandrum. Same as Ceiba pentandra.

Bonga (Philippines). See Areca cathecu.

Boragináceae.

Borage FaMiLY.

In Guam this family is represented by the kou tree or banalo (Cordia subcordata), Toumefortia argentea (called "hunig" by the natives), Ehretia microphylla, and two or three species of Heliotropium.

Borona (Philippines). See Zea mays.

Borót (Philippines). See Dioscorea fasciculata.

Bosbóron (Philippines). See Lobelia koenigii.

Botoncillo (Guam). See Kyllinga monocephala.

Botong (Philippines). See Barringtonia speciosa.

Botor tetragonoloba.

FOUR-WINGED BEAN.

Family Fabaceae.

Local Names.-Seguidillas (Guam); Camaluson, Seguidillas, Calamismis, Pallam, Pallang (Philippines); Goa Bean.

A twining herbaceous bean bearing edible pods having four longitudinal wings. Roots tuberous; leaves 3 -foliate, stipellate; stipules attached above the base, lanceolate each way from the insertion; leaflets large, broad, ovate, acute, glabrous, the base subdeltoid; racemes few-flowered, flowers rather large, lilac; peduncles 7.5 to $15 \mathrm{~cm}$. long; pedicels geminate, as long as the calyx; bracteoles ovate, small; calyx $12 \mathrm{~mm}$. long, glabrous, teeth shorter than the tube, the two upper connate, the side-teeth oblong, the lowest shorter, deltoid; corolla much exserted, the petals equal in length;

a Wratt, Dictionary of the Economic Products of India, vol. 1, p. 485, 1899.

$b$ Trimen, Handbook to the Flora of Ceylon, vol. 3, p. 390, 1895. 
keel much incurved, but not beaked; stamens monadelphous, the upper free below; style long, much recurved, flattened laterally, densely bearded round the terminal stigma; pod 15 to $22.5 \mathrm{~cm}$. long, square, with a distinct longitudinal wing at each angle, distinctly partitioned between the roundish seeds; wings thin, rufflelike, usually much crisped and toothed.

The green pods of this plant are eaten in Guam as a vegetable. They are tender, free from stringiness, and of excellent flavor. The tuberous root is edible, but is not utilized in Guam. Common in the gardens of the natives, twining along fences. In India the pods are used in pickles and the seeds are eaten.

REFERENCES:

Botor tetragonoloba (Stickman) Kuntze, Rev. Gen. 1: 162. 1891.

Dolichos tetragonolobus Stickman, Herb. Amb. 1754; Amoen. Acad. 4: 132.1759. Psophocarpus tetragonolobus DC. Prod. 2: 403. 1825.

Bottlegourd. See Lagenaria lagenaria.

Bowstring hemp. See Cordyline zeylanica.

Brachytrichia quoyi. See under Algr.

Brassica juncea.

INDIAN MUSTARD.

Local Names.-Mostaza (Spanish).

A yellow-flowered crucifer, cultivated in Guam and also growing wild; with palegreen leaves, smooth or slightly pubescent and somewhat glaucous. Lower leaves long-petioled, toothed or pinnatifid, upper ones sessile or nearly so, but not clasping the stem, lanceolate or linear, commonly entire, much smaller; seed pods with a conical awl-like tip, containing no seed.

This species is a native of Asia, but is now widely diffused. See Mustard under Gardens.

REFERENCES:

Brassica juncea (L.) Coss. Bull. Soc. Bot. Fr. 6: 609. 1859.

Sinapis juncea L. Sp. Pl. 2: 668. 1753.

Brassica napa. Turnips will not grow in Guam.

REFERENCES:

Brassica napa L. Sp. Pl. 2:666. 1753.

Brassica oleracea. The Cabbage. See Gardens.

REFERENCES:

Brassica oleracea L. Sp. Pl. 2: 667.1753.

Brassicaceae.

MUSTARD FAMILY.

In addition to the preceding species of Brassica, there is a kind of cress, probably a species of Cardamine, growing spontaneously in Guam.

Brea blanca (Guam, Philippines). See Canarium indicum.

Breadfruit. See Artocarpus communis.

Breadnut (Burma).

The fertile variety of the breadruit, in Cruam called "dugdug." See Artocarpus communis.

Bromeliaceae.

Pineapple family.

The only representative of this family in (iuam is the pineapple, Ananas ananas.

Broomweed ("Escobilla," Spanish).

A name applied to several species of Sida and Triumfetta.

Bruguiera gymnorhiza:

Many-Petaled mangrove. Plate XL.

Family Rhizophoraceae.

Locth X.Mes. - Mangle macho (Guam); Bacao, Bacauan bakawan (Philippines); Taka-tsuku, Kure-tsuku (Japan).

A glabrus tree growing to a height of 12 or 15 meters, with short, prop-like supporting roots growing from the trunk near the base. The leaves are opposite, glossy, 


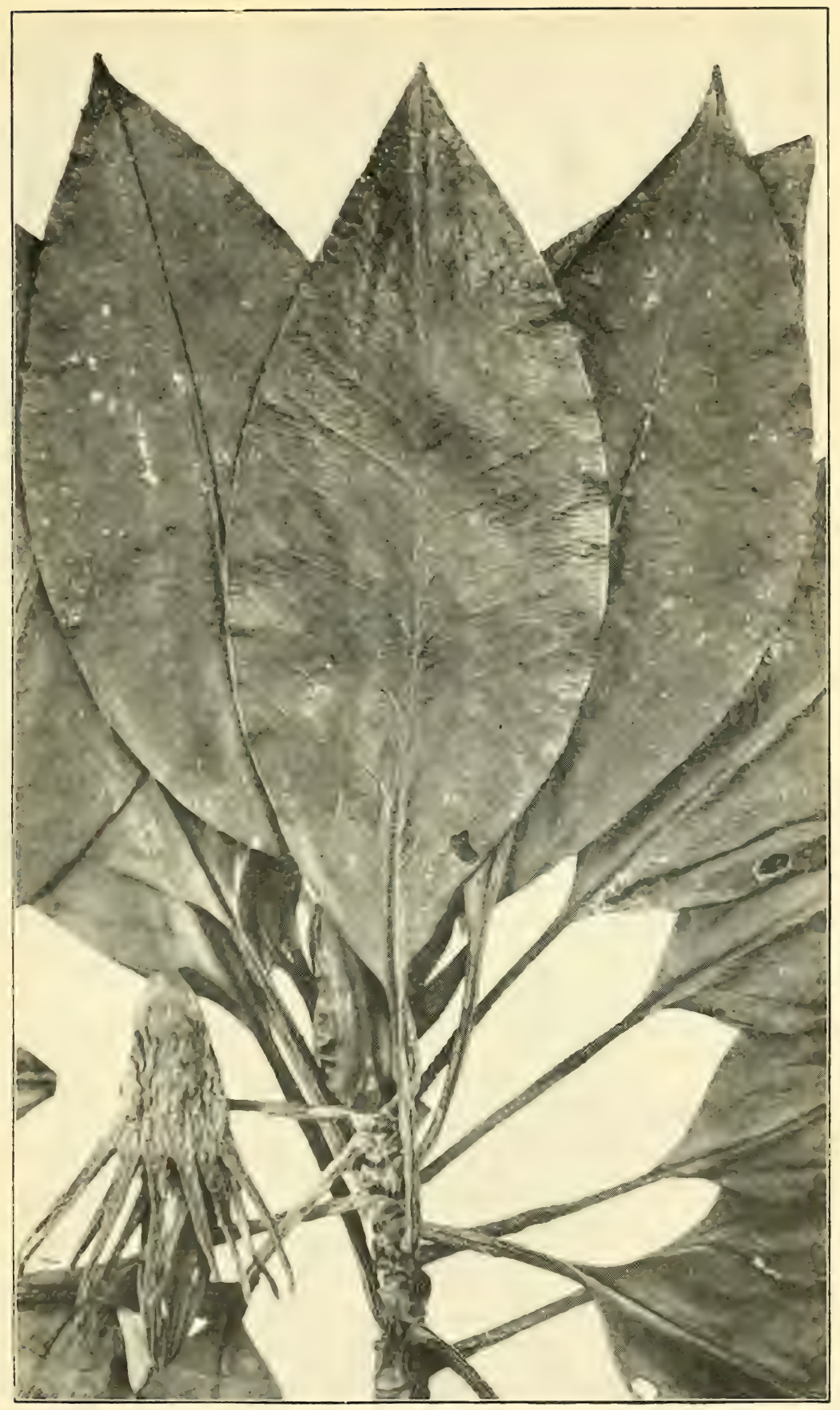

Bruguiera gymnorhiza, the many-petaled mangrove. Natural Size. 

leathery, oblong and slightly acuminate, with entire margins and stipules which soon drop off; flowers axillary, about 1 inch in diameter, peduncles 1-flowered, calyx 10 to 14-cleft, bell-shaped, without bracts, growing attached to the base of the ovary, lobes linear, acuminate, erect, about $18 \mathrm{~mm}$. in length, equaling the tube in fruit; petals 10 to 14 , oblong, 2 -lobed, with 2 to 4 bristles on each lobe and 1 in the notch; stamens many, embraced by the petals and springing elastically from them when mature; ovary 3 or 4 celled; style filiform; stigma 2 to 4 lobed, minute, fruit topshaped, leathery, erowned with the calyx limb; radicle spindle-shaped, with about 6 prominent angles, obtuse at the apex, perforating the apex of the fruit and germinating while the fruit still adheres to the tree, then descending from the tree into the mud.

This species is common in Guam, growing in the swamps at the mouths of nearly all streams; especially abundant near Atantano and along the southern shores of the island. Its heartwood is very heavy, hard, and of a dark-red color. In India it is used for posts, piles, planks, and furniture. The sapwood is lighter and softer and reddish white. The astringent bark is used in India for tanning and in dyeing black. In Japan a reddish brown dye is obtained from it.

This is the handsomest of all the mangroves and is widely spread on tropical shores of the Pacific and Indian oceans. In Japan it grows on the coasts of Satsuma.

REFERENCES:

Bruguiera gymnorhiza Lam. Encyc. Tableau 2: 517. t.897. 1793.

Bruja (Mexico). See Bryophyllum calycinum.

Bryophyllum pinnatum.

Witchleaf, Lifeplant.

Family Crassulaceae.

Local Names. - Siempre-viva (Spanish, Guam); Prodigiosa, Hoja de bruja (Cuba); Bruja (Mexico); Lifeplant (British W. Indies).

A singular plant with simple or pinnate fleshy leaves which have the peculiarity of producing buds on their margins which send forth roots and sprouts and thus produce new plants. Leaflets 3 to 5 , ovate, with crenate margins. When the leaf is cut off or drops to the ground the buds form in the indentations between the crenations, and in a short time new plants appear all around the margin. The flowers are pendulous, growing in terminal compound panicles; calyx bladder-like when growing, at length oblong bell-shaped, t-cleft; corolla tube somewhat 4-cornered, the lobes of its limb ovate or somewhat triangular; at the base of the carpels a number of glandlike, compressed scales; carpels on very short stalks. Flowers reddish or purplish green, spotted with white.

The plant is supposed to be a native of the Moluccas, Madagascar, and Mauritius. It is now widely spread in the Tropics. In Guam it is common by the roadsides, especially along the road leading up the hill from San Antonio east of Agaña.

The leaves, slightly scorched, are used as poultices for wounds and ulcers. They are considered to be disinfectant.

REFERENCES:

Bryophyllum pinnatum (Lam.) S. Kurtz, Journ. As. Soc. Beng. 40²:52. 1871 (ex Ind. Kew.).

Votyledon pinnata Lam. Encyc. 2: 141. 1786.

Bryophyllum calycinum Salisb. Parad. Lond. t.3. 1805.

Bryopsis plumosa. See under Algæ.

Bua (Pelew Islands). See Areca cathecu.

Bubui (Tagálog). See Ceiba pentandra.

Bubui gubat (Tagálog). See Thespesia populnea.

Buena vista (Guam, Philippines).

A name sometimes applied to the ornamental, bright-colc red Phyllaurea varieguta.

Buenas tardes (Panama). See Mirabilis jalapa. 
Búgos (Philippines). See Acalypha indica.

Bukike (Guam). See Clitorio ternatea; also called the "queen's cloak" (capa de la reina).

Bulak (Philippines). Vernacular for all cottons (Gossypium spp.).

Bulakan (Philippines). See Thespesia populnea.

Bullock̨'s heart. See Annona reticulata.

Bululacao (Philippines). See Argyreia tiliaefolia.

Bunga (Philippines). See Areca cathecu.

Buntot capon (Philippines). A fern, Asplenium falcatum.

Burgrass. See Centotheca lappacea.

Burweed. See the species of Triumfetta; also Urena sinuata.

Butabuta (Philippines). See Excoecaria agallocha.

Button sedge. See Kyllinga monocephala.

Buyo (Philippines). See Piper betle.

Caballero (Guam). See Poinciana pulcherrima.

Cabbage. See Gardens.

Cabello del angel (Spanish).

A name applied in Guam to the cypress vine, Quamoclit quamoclit.

\section{Cabinet woods.}

Among the trees furnishing wood suitable for cabinetwork may be mentioned the following: Adenunthera paronina, Artocarpus communis, Barringtonia speciosa, Bruguiera gymnorhiza, Calophyllum inophyllum, Eugenia sp. ("aábang"), Heritiera littoralis, Intsia bijuga, Melia azedarach, Ochrocarpus obovalis, Ochrosia mariannensis, Premna gaudichaudii, Terminalia catappa, Thespesia populnea.

Cabo negro (Spanish). See Saguerus pinnatus.

Cacahuate or Cacaguate (Guam).

Local name for the peanut, Arachis hypogaea.

Cacao (Spanish). See Theobroma cacao.

Cacara erosa.

YAM-BEAN. TURNIP-BEAN.

Family Fabaceae.

Local NAyes. - Híkamas (Guam); Jícama, Cazotl (Mexico); Kamas, Tícamas, Hícamas, Síncamas (Philippines); Jícama dulce (Cuba); Ahipa, Ashipa (South America); Fan ko (China).

A climbing herbaceous plant, with trifoliolate leaves and a turnip-like root. Leaflets large, stipellate, membranous, deltoid-ovate, angular, toothed, pubescent beneath or glabrescent; flowers bluish or purplish, in long lax racemes with fascicled pedicels, the lower nodes often prolonged into short branches; bracts and bracteoles bristle-like, caducous; calyx 2-lipped, the upper lip emarginate, the lower deeply 3-toothed; corolla much exserted, wings semilunate with a long projection at the base, the petals subequal; keel obtuse; stamens diadelphous ( 1 and 9 ), filaments alternately shorter; style with a crenulate nectarial ring around the base, spirally incurved at the apex, almost as in the Phaseoli; stigma large, round, oblique; legume linear, turgid, compressed, laterally contracted between the seeds, of a dark-brown color, sparsely hairy; seeds nearly circular, flat, smooth.

This plant, which both in Guam and the Philippines bears its Mexican name, was probably brought from Mexico. It is now common in the woods, climbing among the bushes and trees and twining about everything with which it comes in contact. The young root is much like a turnip in shape and consistency, and is easily peeled like a turnip. It is usually eaten raw, and may be prepared with oil and vinegar in the form of a salad. According to Dr. Edward Palmer it is extensively cultivated 
in Mexico, where the natives pinch off the blossoms and seed pods, giving as a reason that if the seeds are allowed to mature the roots are not good. In Mexico the roots are much eaten raw, but are also pickled, boiled in soup, and cooked as a vegetable. As they come from the ground they are crisp, sweet, juicy, and of a nutty flavor. They are nourishing and at the same time quench the thirst, so that they are much liked by travelers. One way of preparing the raw roots is to cut them in thin slices and sprinkle sugar over them. They may also be boiled and prepared with batter in the form of fritters, and in Mexico they are often minced or grated, and with the addition of sugar, milk, and eggs, and a few fig leaves for flavoring, made into puddings.

The identity of the Mexican, Guam, and Philippine plants seems certain. Other forms of Cacara, which, like the present species, have been referred by authors to C. erosa, differ very much in the shape and size of the root. The Fijian species, identified by Seemann as Pachyrhizus trilobus DC., $a$ has roots 6 to 8 feet in length and the thickness of a man's thigh. Roots of Cacara bought in the Chinese market of San Francisco, and referred to C. erosa, were analyzed by Mr. Walter C. Blasdale and were found to contain an abundance of nutritive materials. Besides a large percentage of starch, considerable cane sugar was found, as well as protein. Long-continuer boiling of these roots failed to render them tender. Their principal use by the Chinese of San Francisco is for the preparation of starch, which is said to be of a superior quality. As far as could be learned, the Chinese obtain their comparatively large supply of roots entirely from Canton. $b$ From this description it is evident that the roots imported into San Francisco by the Chinese have very different properties from the crisp, succulent tubers of Mexico and Guam.

\section{REFERENCES:}

Cacara erosa (L.) Kuntze, Rev. Gen. 1: 165. 1891.

Dolichos erosus L. Sp. Pl. 2 : 726. 1753.

Dolichos bulbosus L. Sp. Pl. ed. 2. 2: 1021.,1763.

Pachyrhizus angulatus Rich.; DC. Prod. 2: 402. 1825.

Pachyrhizus bulbosus Kurz, Journ. As. Soc. Beng. 45²: 246. 1876.

\section{Cactus.}

There is no indigenous plant on the island belonging to the cactus family. The only introduced species which has established itself is a prickly pear, for which see Opuntia sp.

Cadena de amor (Guam).

"Chain of love," the name applied to Antigonon leptopus, probably on account of the rose-colored heart-shaped flowers.

Cadillo pata-de-perro (Porto Rico). See Urena sinuata.

Cadios, Cadius (Philippines). See Cajan cajan.

Caesalpinia bonducella Fleming. Same as Guilandina crista.

Caesalpinia crista L. Same as Guilandina crista.

Caesalpinia pulcherrima. See Poniciana pulcherrima.

Caesalpinia sappan. See Biancaea sappan.

Caesalpiniaceae.

Camsalpinia family.

Representatives of this family growing in Guam are Intsia bijuga, Cassia occidentalis, C. sophera, C. tora, Herpetica alata, Guilandina crista, Poinciana pulcherrima, Delonix regia, and Biancaea sappan.

Cafô, Cafû (Guam). See Pandanus fragrans.

$a$ Seemann, Flora Vitiensis, p. 63, 1865.

b Blasdale, Some Chinese vegetable food materials, U. S. Dept. Agr., Off. Exp. Sta., Bull. No. $68,1899$. 
Caguios (Philippines). See Cajan cajan.

Cahel (Mexico, Philippines). See Citrus aurantium and C. aurantium sinensis.

Cáhet, Káhet (Guam). See Citrus aurantium sinensis.

Cahuas (Mexico). See Capsicum annuum.

\section{Cajan cajan.}

Pigeon PeA.

Family Fabaceae.

Local names.--Lenteha fransesa (Guam); Cadios, Kad-yos, Cadius, Caguios (Philippines); Dhal, Dhol (India); Gandul (Porto Rico).

An erect shrub with 3 -foliolate leaves on slender gray silky branchlets; leaflets oblong-lanceolate, entire, subcoriaceous, thinly silky above, densely so beneath; stipules minute, lanceolate; flowers yellow, or the standard veined with red, growing in sparsely flowered racemes, often forming a terminal panicle; pod 5 to $7.5 \mathrm{~cm}$. long, finely downy, tipped with the lower half of the style.

This plant grows spontaneously in the Sudan, and is cultivated in India, Madagascar, New South Wales, Jamaica, Malabar, Brazil, and other warm countries. The seeds are nutritious and are eaten either green or dry, like peas. The plant will live several years, and in good soil begins bearing the first year. It was introduced into Guam in 1772 by the French ship Castries, whence its local name, which signifies "French lentil." It is planted at the beginning of the rainy season.

REFERENCES:

Cajan cajan (L.) Millsp. Field Col. Mus. Bot. Ser. 2: 53.1900.

Cytisus cajan L. Sp. Pl. 2: 739. 1753.

Cajanus indicus Spreng. Syst. 3: 248. 1826.

Cajanus indicus Spreng. See Cajan cajan.

Cajel, Kahel (Philippines) or Káhet (Guam). See Citrus aurantium and C. aurantium sinensis.

Calabash tree. See Crescentia alata.

Calabaza amarilla (Spanish). See Cucurbita maxima.

Calabaza blanca (Spanish). See Benincasa cerifera.

Calabaza vinatera (Spanish). See Lagenaria lagenaria.

Caladium colocasia.

Taro. Plate xxvi.

Family Araceae.

Local Names. - Suni, Sune (Guam); Songe (Marlagascar, Réunion); Gabi, Gave, Dagmai (Philippines); Talas, Talnes (Sunda); Talo, Taro, Kalo (Polynesia); Tao (Marquesas); Chaua (Carolines); Yautia (Porto Rico); Quequeste (Mexico); Otó (Panama); Edılo, Tania, Coco (British West Indies); Tadala, Gahala (Ningapore); Kachú (India, Bengal); Culcas, Kolkus, Qolkas (Egypt); Egyptian Arum (Italy); To-no-imo, Aka-imo, Midsu-imo (Japan).

A sncculent plant with edible, starchy, tuherous rootstock, cultivated in nearly all tropical countries of the world. Leares large, very stoutly peltately petioled, ovatecorlate or hastate, with a triangular basal sinus; spathe stoutly peduncled, persistent, mouth constricted, limb long, narrow, lanceolate; spadix shorter than the spathe, stipitate, terminal appendage variable, cylindric or subulate, or lacking; male and female inflorescences distant, male above the fenale with interposed flat neuters, male of densely packed cubical anthers or groups of anthers, with immersed cells opening by terminal slits; female of crowded, globose, 1-celled ovaries; stigma pulvinate; ovules many, orthotropous; berries obconic or oblong; seeds oblong, furrowed, endosperm copious, embryo axile.

Several varieties of taro are cultivated in Guan, some of which were growing on the island before its discovery. The petioles are stout, 90 to $120 \mathrm{~cm}$. long, green or violet; peduncles solitary or clustered and connate, much shorter than the petioles; spathe 20 to $45 \mathrm{~cm}$. long, caudate-acuminate, erect, pale yellow; female inflorescence 
as long as that of the neutral staminodes, male inflorescence longer. Like the sweet potato, ginger, and many other plants propagated by cuttings or suckers for the sake of their roots, the taro seldom flowers.

In one variety growing in wet places many suckers are sent out from the base of the stem, and the leaves and petioles are more or less purple; in another variety, growing in the ciénaga, or swamps, the petioles are green; in a third they are reddish. The favorite variety, planted in newly cleared land and on hillsides, has a purplish area at the junction of the petiole with the blade. It is called "suni Visaya." The natives recognize at least eight varieties of suni. The large-leafed, coarser, caulescent plants called "piga" are varieties of Alocasia, a genus which is distinguished from Caladium in having the terminal appendage of the spadix marked with reticulate furrows, and having few and basal ovules, while those of Caladium are many and parietal.

Suni was one of the prineipal food staples of the aboriginal inhabitants of Guam. Not only are the farinaceous tuberous rootstocks eaten, but also the young, tender leaves, which, when cooked, taste somewhat like asparagus. All parts, but especially the leaves, are extremely acrid, owing to the presence of sharp needle-like crystals of oxalate of calcium, called raphides (see Pls. XI, XII, and XIII), and to destroy this quality both leaves and rootstock must be thoroughly cooked.a

When the crop of taro is gathered the tops of the rootstocks are cut off and replanted at once. They quickly take root and mature in about a year. Taro is conked in various ways in Guam, but is never made into poi (fermented paste) as in Hawaii. Land taro, together with bananas and plantains, is the first thing to be planted in newly cleared ground. The climate of Guam seems to be admirably suited to its cultivation. Taro is a food staple in all island groups in the Pacific and in many other parts of the tropical world. In Samoa many savory dishes are prepared with both the rootstock and the young leaves of taro combined with the rich, creamy juice expressed from grated kernels of ripe coconuts, as well as with other ingredients.

The roots are characterized by a high percentage of carbohydrates, of which starch is the most important, and by a low percentage of fat, protein, and crude fiber. They have the consistency of a sweet potato, and a microscopical examination shows that the starch of which they are principally composed is in the form of very small grains. The crude protein of an albuminoid nature is in somewhat greater proportion than that found in the potato. Though offering no especial advantage over other farinaceous roots, taro is a very good substitute for them, and Europeans living in the Tropics soon acquire a taste for it, though at first it strikes them as insipid. In Hawaii taro prepared in the form of poi is very popular with the white residents. Taro is imported into the United States from Canton and the Hawaiian Islands, and is sold in large quantities in the Chinese markets of San Francisco. It is successfully grown in southern California, but it there requires an abundant artificial supply of water. The Florida Experiment Station has also succeeded in growing it, and reports satisiactory results. $b$ In tropical countries where potatoes can not be grown and where the cultivation of yams is attended with care and labor, taro in its various forms is a great blessing to the inhabitants. It grows almost spontaneously both in swamps and on dry land, and it yields an abundance of wholesome, nutritious food, which, with the occasional addition of meat, legumes, or other nitrogenous foods to supply protein, is quite sufficient to sustain life.

It is interesting to note that the Guam name of this plant reappears in Madagascar

a For full aecount see p. 69 , above.

b See Blasdale, Chinese vegetable food materials, Bull. No. 68, U. S. Dept. Agr., Off. Exper. Stations, pp. 13 to 15, 1899. Also, Florida Exper. Station Report, 1896, p. 9 . 
in the form of "songe," while its Philippine name is applied in Fiji, Samoa, and Rarotonga to the allied genus Alocasia.

REFERENCES:

Caladium colocasia (L.).

Arum colocasia L. Sp. PI. 2: 965.1753.

Colocasia antiquorum Schott in Schott \& Endl. Meletem. 1: 18. 1832.

The genus Caladium established by Ventenat, Description des plantes nouvelles et peu connues, cultivées dans le jardin de J. M. Cels, $t .30 .1800$, and Roemer, Archiv für die Botanik, 2:347. 1799-1801, is adopted from the Caladium of Rumph, Herbarium Amboinense, 5:313-318. 1747. The only species mentioned in common by the two authors is Caladium esculentum, which should therefore be considered as the type of the genus; and since this species is congeneric with, or, indeed, is sometimes considered merely a variety of Caladium colocasia, Caladium is restored as the correct name of the genus. The combination Caladium colocasia, eited in the Index Kewensis as having been published in Robert Wight's Icones for a different species, I find not to have been published there, and it is therefore a valid name in its present use.

The name Colocasia, on the other hand, even though Caladium was not to be applied to this genus, would be an untenable name, for it was proposed by Necker in 1790 for a genus the identity of which does not appear to have been definitely established, and again by Link in 1795 for still a different group. Either of these proposed uses would invalidate the application of the name as published by Schott in $1832 .-\mathrm{W}$. F. W.

Caladium esculentum. See Caladium colocasia.

Calamasa (Guam). Same as Kalamasa.

Calambit (Philippines). See Guilandina crista.

Calamismis (Philippines). See Botor tetragonoloba.

Calamus sp.

RATTAN.

Family Phoenicaceae.

Local rayes.-Behuko halom-tano (Guam); Bejuco cimarron (Spanish).

An indigenous climbing palm growing in Guam, of little economic value. An attempt was made to introduce the chair rattans, but it was unsuccessful.

Calophyllum inophyllum.

Palo Maria.

Family Clusiaceae.

LocAl XAMEs.-Daog or Daok (Guam); Dangkalan, Dinkalin, Bitaog, Bitanhol,

Tamauian (Philippines); Palo Maria, Palo de Santa Maria (Spanish); Tamanu (Rarotonga, Tahiti); Fetau (Samoa); Dilo (Fiji); Kamanu or Kamani (Hawaii); Foràha (Madagascar); Domba (Ceylon); Alexandrian Laurel (India).

A tree usually growing near the shore. Leaves opposite, shining, coriaceous, with innumerahle parallel veins at right angles to the midrib, oblong or obovate-oblong, ohtuse or emarginate; flowers polygamous, in axillary or terminal racemes, pure white, fragrant; sepals 4; petals 4, rarely 6 to 8 , like the inner sepals; stamens numerous, filaments in 4 bundles; ovary globose, stipitate; style much exceeding the stamens; stigma peltate, lobed; fruit $2.5 \mathrm{~cm}$. in diameter, glohose, smooth, yellow, pulpy.

This tree is widely spread throughout Polynesia and occurs on the tropical shores of Asia, Africa, and Australia. It is often planted near habitations and is valued for its wood, for an aromatic gum which exudes from incisions made in its trunk and limbs, and for a medicinal oil obtained from its nuts. Seeds of this species were among those collected by Doctor Guppy in the Solomon Islands in the drift of the beach, having probably been carried there by ocean currents.

When the leaves are put in water an oil rises to the surface. This is used in some parts of India as a remedy for sore eyes. In southern Polynesia and India the dark green fragrant oil expressed from the nuts, called dilo oil or domba oil, is used as a lamp oil and is an external remedy for bruises and rheumatic pains. The resin 
yielded by the trunk is one of the tacamahac gums of commerce; it is agreeably aromatic, and is used as a scent by the Tahitians. It is of a yellowish-green color and is soluble in alcohol.

Its wood is hard, strong, and cross-grained, and very hard to split. In Guam it is used for the solid wheels of the carts drawn by bullocks and carabao. It is durable in water, but is so rigid that it can not be bent. In Samoa it is much used for building large canoes. Its strong crooked branches furnish excellent knees for boats, and are used also for stem and stern posts.

REFERENCES:

Calophyllum inophyllum L. Sp. P1. 1: 513. 1753.

Caltrops. See Tribulus cistoides.

Calysaccion obovale. See Ochrocarpus obovalis.

Camachile or Kamachiles (Guam). See Pithecolobium dulce.

Camaluson (Philippines). See Botor tetragonoloba.

Camantigui (Philippines). See Impatiens balsamina.

Camatis (Philippines). See Iycopersicon lycopersicum.

Cambustera (Cuba). See Quamoclit quamoclit.

Camomile, false. See Chrysanthemum indicum.

Camote (Spanish) or Kamute (Guam). See Ipomoea batatas.

Camoting cahoi (Tagalog). See Manihot manihot.

Camphire. See Lausonia inermis.

Caña (Spanish). See Bambos and Trichoon roxburghii.

Caña espinas, Caña macho. See Bambos blumeana.

Caña de azúcar. See Saccharum officinarum.

Caña dulce. See Saccharum officinarum.

Cañafistula (Spanish). See Cassia fistula.

Caña hembra (Spanish). See Bambos sp.

Caña-pistola (Philippines). See Cassia fistula.

Cananga odorata. See Canangium odoratum.

Canangium odoratum.

ILANGILANG. YLANGYLANG.

Family Anonaceae.

Local Names. - Alangílang (Guam, Philippines); Moso'oi (Samoa); Moto-oi (Rarotonga).

A tree bearing a profusion of greenish yellow fragrant flowers, with long, fringelike petals, from which the perfume "ilangilang" is made. Leaves alternate, simple, entire, ovate-oblong, finely acuminate, puberulous beneath; sepals 3 ; petals 6 , in two series, narrowly linear; stamens many, linear, borne at the base of the ovary, the connective produced into a lanceolate, acute process; ovaries many; style oblong; ripe carpels about 12 , ovoid or obovoid, black, 6 to 12 -seeded.

Bark of tree smooth, ashy; trunk straight normally, but in Guam often twisted out of shape by hurricanes. Its wood is soft and white, and not very durable, but in Samoa the natives make small canoes of it, and the Malayans hollow out the trunks into drums or tomtoms. In Guam straight trunks of sufficient size for canoes are never found.

This tree is found in Java, the Philippines, and in many islands of the Pacific. It is widely cultivated in the Tropics. Its introduction into Guam is comparatively recent; but the fruit-eating pigeons are spreading it gradually over the island. The natives sometimes use its flowers to perfume coconut oil. In Samoa it is very highly esteemed. Its fringe-like flowers are there strung into wreaths and garlands by the natives, together with the drupes of Pandanus and the scarlet fruit of Capsicum.

$9773-05-14$ 
Ilangilang trees may be readily propagated either by cuttings or seeds. These should be planted in orchards or groves 8 meters apart. They thrive well on most tropical islands and countries with warm, moist climates. About the third year the flowers appear. They bloom continuously, so that flowers and fruit may be always found on the same tree.

From the flowers a pleasantly scented volatile oil is derived, known in commerce as the oil of ilangilang. In the Philippines and the East Indies this is sometimes adulterated with an oil extracted from the flowers of Michelia champaca. Ilangilang oil is obtained by steam distillation. In this process steam is generated in a small boiler and passed into a closed vessel containing the flowers. The mixed water and oil vapor as it leaves this vessel is condensed, and the oil separated from the water by decantation. In the Philippines German distillers have obtained it in the ratio of about 25 grams from 5 kilograms of flowers $(0.5$ per cent). It finds a ready market in Paris, Nice, and Grasse, and is used also by perfumers in London, Leipzig, Berlin, and Frankfort. The best quality of oil is perfectly clear and very fragrant. The second quality is yellowish and turbid. A perfume is also derived from the blossoms by the method known as enfleurage, as with jasmines and other fragrant flowers. By this process the fragrant oil is absorbed by refined fats, butter, or oil spread over trays, on the surface of which the flowers are sprinkled. These are changed at frequent intervals and the fat "worked" so as to present a fresh surface each time to the new flowers laid upon it. Finally it is scraped off the tray, melted, strained, and poured into jars in the form of a pomade. When oil is used in this process layers of cotton are steeped in it, spread upon trays, and the flowers sprinkled over the surface, after which the oil is pressed out. Care should be taken to use fresh oil. Coconut oil is liable to become rancid very soon.

The method used by the natives to extract the perfume is very simple. The flowers are put into coconut oil and allowed to remain there for a short time, after which they are removed and replaced by fresh ones. The process is hastened by heating the oil. To aroid excessive heat the vessel used for the process is partly filled with water and the oil poured upon it. This prevents the temperature rising above that of boiling water, and the lower specific gravity of the oil keeps it separate from the water. The "Macassar oil" of commerce is coconut oil, in which Ilangilang blossoms have been digested together with those of Michelia champaca.a

Ilangilang oil is becoming an important article of export from the Philippines. From the commercial monthly summary, published by the Bureau of Insular Affairs (May, 1904), it appears that the amount exported is steadily increasing. For the eleven months ending May, 1902, its value was $\$ 67,178 ; 1903, \$ 90,289 ; 1904, \$ 96,472$.

REFERENCES:

Canangium odoratum (Lam.).

Uvaria odorata Lam. Encyc. 1: 595.1783.

Cananga odorata Hook. f. \& Thom. Fl. Ind. 1: 130. 1855.

Cananga was proposed for a different genus by Aublet in 1775, and can not therefore be used as a valid name for the above genus. Baillon recognized this fact, and proposed Canangium, without, however, giving the species; but since there is no other name available it is adopted here.

Canarium indicum.

JAVA ALMOND.

Family Balsameaceae.

Local raues.-Brea blanca (Guam, Philippines); Pili (Philippines).

A large tree yielding an aromatic resin known in commerce as Manila elemi. Leaves alternate, odd pinnate; leaflets 7 to 9 , ovate or oblong elliptical, acuminate, glabrous; flowers in terminal puberulous panicles. Drupe ellipsoidal, subtrigonous,

$a$ Spons' Encyclopedia, vol. 2, p. 1422, 1882. 
with a hard, bony stone, which is trigonous or three-lobed, terminating at each end in a sharp point. The stone or nut is called "pili," or almond, in the Philippines.

This tree has been sparingly introduced into Guam. In his Islas Marianas (Manila, 1887) Don Francisco Olive y Garcia gives a catalogue of the trees growing on the island and mentions a single specimen of brea. This, however, is important, since it shows that the climate and soil of Guam are suitable for its propagation.

\section{REFERENCES:}

Canarium indicum Stickman, Herb. Amb. 1754; Amoen. Acad. 4: 143. 1759.

Canarium commune L. Mant. 1: 127. 1767.

\section{Canavali ensiforme.}

Sword BeAN. SABre BeAN.

Family Fabaceae.

Lgcal names.-Akankan (Guam); Palang-palang (Philippines); Horsebean (Jamaica); Jack bean (Brit. W. Indies).

A twining creeper; leaves pinnately trifoliolate, leaflets cordate-ovate, ovate-oblong, or ovate, rather acute; flowers in axiliary racemes, the peduncles and racemes each 7.5 to $15 \mathrm{~cm}$. long; corolla purplish or white, papilionaceous, more than twice as long as the calyx; calyx deep, the limb 2-lipped, the upper lip projecting, entire or emarginate, the lower shortly 3-toothed; pod 15 to $25 \mathrm{~cm}$. long, linear-oblong, flattish, with a distinct rib on each valve near the upper suture, 8 to 12 seeded; seeds white, ovoid-oblong, subcompressed.

Common in thickets and hedges everywhere in the Tropics. In Guam the racemes of purple flowers are conspicuous by the roadsides. The vernacular name Akankan signifies "molar teeth," from the appearance of the seeds. In some countries it is cultivated for the sake of its long esculent pods, the white-flowered and white-seeded varieties being considered the best for this purpose. It is a perennial. Though the pods are coarse in appearance, when sliced and boiled they are tender and scarcely inferior to French beans. $a$ The mature beans roasted and ground have been used in Texas as a substitute for coffee. They are indigestible unless deprived of their outer skin. Experiments have proved these beans to be unsuitable for stock food. $b$

REFERENCES:

Canavali ensiforme (L.) DC. Prod. 2: 404. 1825, as Canavalia ensiformis.

Dolichos ensiformis L. Sp. Pl. 2: 725. 1753.

\section{Canavali obtusifolium.}

Seaside bean.

Local names. - Akankan-tasi (Guam); Palang-palang (Philippines); Mata de la Playa (Porto Rico); Mata de Costa (Cuba).

A glabrous perennial creeper; leaves pinnately trifoliolate, leaflets thicker than those of the preceding species, obovate, obtuse, or sometimes emarginate; racemes fewflowered, usually overtopping the leaves; flowers in axillary racemes, corolla purplish; pod oblong, few-seeded, 10 to $12.5 \mathrm{~cm}$. long; seeds usually chestnut-colored, opaque, ovoid, subeompressed.

A strand plant widely distributed on tropical shores. In Guam, as in most places, it is associated with the goat's-foot convolvulus (Ipomoec pes-caprae). It is useful as a binder of loose sand.

REFERENCES:

Canavali obtusifolium (Lam.) DC. Prod. 2: 404. 1825, as Canavalia ensiformis. Dolichos obtusifolius Lam. Encyc. 2: 295. 1786.

\section{Canavalia. See Canavali.}

Canción (Guam).

A young coconut having a sweetish, edible rind.

Candlenut. See Aleurites moluccana.

$a$ Firminger, Man. Gardening for Bengal, ed. 4, p. 156.

b Lloyd and Moore. Feeding for beef. Mississippi Bull., No. 39, p. 166, Aug., 1896. 
Canna indica.

Canna. Indtan Shot.

Family Cannaceae.

Local Names.-Mañgo halom-tano (Guam); Fana-manu (Samoa); Aliipoe

(Hawaii); Caña de cuentas, Coyol (Mexico): Blumenrohr (German); Balisier de l'Inde (French).

A well-known plant cultivated all over the world for ornamental purposes and growing without cultivation in most tropical countries. Stem erect, about 90 to 120 $\mathrm{cm}$. high; leaves large, oblong-lanceolate, acuminate, clasping the stem; flowers red; sepals 3 , imbricate; petals 3 , narrow, subequal, with recurved tips; staminodes 3 , longer than the petals; ovary 3-celled, the cells with many ovules; style linear, flat, growing together below with the staminodial whorl, free above; stigma apical, often decurrent on one side; capsule warty; seeds round, black, very hard.

In India the seed are sometimes used for shot and are made into necklaces and other ornaments: They yield a purple dye, but it is not permanent. An allied species, Canna edulis, is cultivated in the West Indies for the sake of the starch derived from its fleshy rhizomes. In Colombia starch is obtained from Canna indica, but it is not so good as that of Canna edulis.

ReFERENCES:

Canna indica, L. Sp. Pl. 1:1. 1753.

Cannon-ball tree. See Xylocarpus granatum.

Capa de la reina (Guam).

The blue pea or "queen's cloak." See Clitoria ternatea.

Capayo (Philippines). See Carica papaya.

Caper. See Capparis mariana.

Capili (Philippines). See Aleurites moluccana.

Capoc (Philippines). See Ceiba pentandra; the silk-cotton tree.

Capparidaceae.

CAPER FAMILY.

This family is represented in Guam by Cleome viscosa and Capparis mariana.

\section{Capparis mariana.}

Marianne Caper.

Family Capparidaceae.

Local rames.-Alcaparro (Spanish, Guam); Alcaparro de Marianas (Philippines).

A shrub growing near the sea, with large, white, fragrant flowers, and large edible seed capsules. Trunk and limbs rough, covered with small protuberances, but not thorny; leaves alternate, subreniform, obtuse, emarginate, smooth, soft, and rather fleshy; petioles short; flowers solitary in the axils of the leaves, long-pedicelled; stamens numerous; fruit elongate, 6-ribbed; seeds many, embedded in pulp.

This plant is abundant on the island. The natives make very good pickles of the unripe capsules. It has been introduced into the Philippines, where it is known as the "caper of the Marianne Islands." The flowers are sometimes pink. It appears from the archives at Agaña that some of the early governors of Guam exported the fruit in considerable quantities, employing the natives to gather it.

References:

Capparis mariana Jacq. IIort. Schoenbr. 1: 57. t. 109. 1797.

Capparis spinosa mariana K. Schu. Engler's Jahrb. 9: 201. 1887.

\section{Capriola dactylon.}

BERMUDA GRASS.

Family Poaceae.

Local xames.-Grama (Guam, Cuba); Maníeníe (Hawaii); Mati (Rarotonga);

Doorba-grass, Doob-grass (Bengal); Bahama grass (West Indies).

A grass with prostrate stems, widely creeping and forming matted tufts with short ascending branches. Leaves short, subulate, glaucous; ligule hairy; spikelets minute, 
1-flowered, 1 or 2 -seriate, in 3 to 6 digitate slender unilateral spikes, not jointed at the base; grain laterally compressed.

This plant is distributed throughout all warm countries. In India it is an important forage plant and is much used for lawns. On account of its usefulness and beanty the Hindoos have celebrated it in their writings, and the native Hawaiians hold it in great esteem. It thrives where scarcely any other grass will grow, even in poor soil shaded by trees. It is useful in binding down the sand near the sea, and on the low sandy soil of Agaña, the capital of Guam, it forms beautiful soft turf. When once established in cultivated fields it is hard to eradicate. In India the young leaves are eaten by the natives and a cooling drink is made of the roots.

It is readily propagated by cuttings. When required for lawns a sufficient quantity can easily be collected from the roadside and waste places. The ground is dug and leveled and the rootstocks cut into small pieces set out at intervals of about 30 centimeters. The plat should be watered until the grass has established itself.

"A more expeditious and very successful plan of laying down a lawn is to pull up a quantity of grass by the roots, chop it tolerably fine, mix it well in a compost of mud of about the consistency of mortar, and spread it out thinly over the piece of ground where the lawn is required. In a few days the grass will spring up with great regularity over the plat." $a$ In establishing a pasture the grass should be planted at intervals of 50 centimeters in rows one meter apart.

REFERENCES:

Capriola dactylon (L.) Kuntze, Rev. Gen. 2: 764. 1891.

Panicum dactylon L. Sp. Pl. 1:58. 1753.

Cynadon dactylon Pers. Syn. 1: 85. 1805.

\section{Capsicum annuum.}

Red Pepper. CAyenne Pepper.

Family Solanaceae.

Local names.-Doni (Guam); Chile (Philippines); Cahúas, Chile (Mexico); Ají (Spanish America).

A plant of tropical American origin, but escaped from cultivation in many tropical countries of the Old World, where it was once supposed to be indigenous. Stem branching, glabrous or nearly so; leaves ovate or subelliptical, entire, acuminate; flowers white or greenish white, solitary, or sometimes in twos or threes; corolla rotate, usually 5-lobed; stamens 5 , rarely 6 or 7 , with bluish anthers dehiscing longitudinally; ovary originally 2 or 3 -celled; fruit a juiceless berry or pod, extremely variable in form and size, many-seeded, and with more or less pungency about the seeds and pericarp. Many varieties occur in cultivation. ${ }^{b}$ Among the forms usually assigned to this species are Capsicum annum grossum, the bell pepper, and Capsicum annuum cerasiforme, the cherry pepper. $c$

REFERENCES:

Capsicum annuum L. Sp. Pl. 1: 188. 1753.

Capsicum annuum cerasiforme.

Cherry pepper. Cayenne pepper.

A low, shrubby plant; leaves of medium size, orate or oblong, acuminate; calyx seated on base of fruit; corolla large, spreading; fruit spherical, somewhat heartshaped, or slightly elongated; flesh firm, very pungent. Of recent introduction on the island.

REFERENCES:

Capsicum annum cerasiforme (Mill.) H. C. Irish, Rep. Mo. Bot. Gard. 9: 92. 1898.

Capsicum cerasiforme Mill. Gard. Diet. no. 5. 1768.

a Bull. Bot. Dept. Jamaica, 1896, p. 30.

$b$ See Irish, Rev, genus Capsicum, Ninth Ann. Rep. Mo. Bot. Gard., p. 53, 1898.

$c$ See Tracy, W. W., Jr. A list of American varieties of peppers, U. S. Dept. Agr., Bureau Pl. Industry, Bull. No. 6, 1902. 


\section{Capsicum annuum grossum.}

BeLl PEPPER.

Local rayes.-Doni (Guam); Chile ancho (Mexico); Chile de Castilla (Philippines).

This plant has long been cultivated in Guam. Its flesh is not pungent, and the natives frequently prepare it for the table by stuffing it with minced meat and then cooking it. It grows here almost like a shrub to the height of $90 \mathrm{~cm}$., and bears prolifically. Fruit oblong or truncate, about $10 \mathrm{~cm}$. long by $4 \mathrm{~cm}$. in diameter, often lobed and usually with a basal depression. Cultivated in every garden on the island.

REFERENCES:

Capsicum annuum grossum (L.) Sendt. Mart. Fl. Bras. 10:147. 1846.

Capsicum grossum L. Mant. 1:47. 1767.

Capsicum baccatum. Same as Capsicum fmetescens baccatum; see under Capsicum frutescens.

\section{Capsicum frutescens.}

SPUR PEPPER. CAYENNE PEPPER.

Local Names,-Doni (Guam); Ají (Spanish).

A shrubby perennial, 90 to $180 \mathrm{~cm}$. high, with prominently angled or somewhat channeled stem and branches; leaves broadly ovate, acuminate; peduncles slender, often in pairs, usually longer than the fruit; calyx cup-shaped, embracing the base of the fruit; fruit red, obtuse or oblong-acuminate, very acrid. It is possible that the original form from which this plant has developed through cultivation is that known as Cupsicum minimum Roxb., to which, according to Engler, the allied varieties revert when left to themselves. The bird pepper (Capsicum frutescens baccatum) has round or ovate fruit about $6 \mathrm{~mm}$. in diameter. In the Philippines it is called "chileng bundok."

REFERENCES:

Capsicum frutescens L. Sp. Pl. 1: 189. 1753.

Capsicum grossum. Same as Capsicum annuum grossum.

Capúlao (Philippines). See Herpetica alata.

Carambola. See Averrhoa carambola.

Carapa moluccensis. Same as Xylocarpus granatum.

\section{Cardiospermum halicacabum.}

Balloon vine.

Family Sapindaceae.

Local rames. - Farolitos, Bombillas (Spanish).

A climbing herb, with wiry stem and branches, and alternate biternate leares; leaflets coarsely dentate; flowers irregular, polygamo-dioecious, in axillary racemes, white, very small; lowest pair of pedicels developed into spiral tendrils; sepals 4 , concave, the two outer ones small; petals 4 , in pairs, the 2 greater lateral ones usually adhering to the sepals; stamens 8, excentric; wrary 3-celled; style short, trifid; ovules solitary; fruit an inflated, broadly pear-shaped capsule.

This plant is widely distributed throughout the Tropics. Its root given in decoction is sail to be aperient. On the Malabar coast the leaves are administered in pulmonary complaints. In the Moluecas the leares are cooked as a regetable.

It was collected by Gaudichaud on the island of Rota.

REFERENCES:

Cardiospermum haticacabum L. Sp. Pl. 1:366. 1753.

\section{Carex densiflora.}

SEDGe.

Family Cyperaceae.

A sedge with numerous dense, lanceolate spikelets, arranged in a branching, Tracted spike: spikelets andrugynous, staminate above, pistillate below; srales tipped with a bristle, the female nearly round, the male ovate-lanceolate, bristles rough; ovary inclosed in an oblong, compressed, striate perigynium, contracted at the top, with a small bidentate opening through which protrudes the 2-cleft style; perigyn- 
ium rough-edged, longer than the scaly bract; culm (stem) 3 -sided, the sides channeled (triquetrous), smooth, shorter than the rough-edged broad leaves.

This species was described by Presl from specimens collected by Haenke in Guam.

REFERENCES:

Carex densiflora Presl, Rel. Haenk. 3: 204. 1828.

\section{Carex fuirenoides.}

Sedge.

A sedge with androgynous spikelets; male flowers with 3 stamens, female flowers with 3 styles; panicles spike-like, axillary and terminal, solitary, with long peduncles, clusters numerous; spikelets oblong-cylindrical, pistillate below, staminate above; scales many-nerved, male ovate-oblong, mucronate-subaristate, darkhyaline, female scales ovate-subrotund, with rounded apex, aristulate, veined, smooth, dark-hyaline; perigynia obovate-oblong, with attenuated beaks, slightly curved, ribbed, dark-brown, smooth, twice the length of the scale; beak rough on the upper margin, bidentate at the orifice. Immature achene obovate-oblong, trigonal, terminated by the persistent thickish base of the style.

This species, was described by Gaudichaud from specimens collected in Guam.

REFERENCES:

Carex fuirenoides Gaudich. Bot. Freyc. Voy. 412. 1826.

\section{Carica papaya.}

Papaw.

Family Caricaceae.

Local Names.-Papaya (Spanish); Lechoso (Mexico); Papai, Maneo, Mamerio (Brazil); Mamon (Paraguay); Papaya, Kapayo, Capayo (Philippines); Esi tane (male), Esi fafine (female) (Samoa).

A tree suggesting a palm in its habit of growth, bearing a crown of large palmatelylobed, long-stalked leaves on a slender, straight, fleshy trunk, which is normally unbranched. It is usually dioecious, the staminate (male) and the pistillate (female) flowers being borne on separate trees, the former funnel-shaped having 10 anthers inserted on the throat of the corolla; the latter larger, 5-petaled, with one pistil bearing a 5-rayed stigma. Occasionally trees are found with hermaphrodite flowers. All parts of the plant abound in milky juice, or latex, which has remarkable pepsin-like digestive properties. The melon-shaped fruit grows from the axils of the lower leaves, the normal fruit from the female flowers being sessile, while that from the hermaphrodite flowers is borne on long pedicels. The milky juice from the unripe fruit when rubbed on meat has the property of making it tender. By experiment it has been found that this juice is more efficacious than pepsin in dissolving albumen and muscular fibre. From the half-ripe fruits a proteolytic ferment has been derived which differs from pepsin in that its action on proteids goes on in neutral or alkaline solutions as well as in acid solutions.

From the seeds of the papaw a glucoside called caricin has been obtained; from the leaves an alkaloid called carpaine, the physiological action of which is similar to that of digitalis, a heart depressant. In commerce there are a number of preparations claiming to be the ferment of the papaw, sold under the name of papain, papayotin, caroid, papoid, etc. On examination of several of these substances they were found by Mr. F. B. Kilmer to be merely the dried and powdered latex of the papaw, bearing the same relation to the true separated ferment as the dried mucous membrane of the stomach might bear to purified pepsin. A series of experiments was carried on by Mr. Kilmer demonstrating beyond a doubt the digestive properties of the true papaw ferments. $a$

Papaws are very easily grown. They spring up spontaneously in open places and clearings in the forest, especially where the undergrowth has been burned, from seeds rlopped by birds. The tree grows rapidly, the leaves falling off as the trunk shoots

$a$ See Kilmer, The Story of the Papaw, American Journal of Pharmacy, vol. 73, pu. 272,336 , and $383,1901$. 
upward leaving the trunk marked regularly with scars. The leaf-stems are hollow, and in Guam are often used as trumpets by the natives, some of whom are skillful in sounding military bugle calls upon them. The root is turnip-shaped, the lower part extending deep into the earth seeking moisture and giving stability to the tree. The wood is soft, white, and, spongy, and decays rapidly. It is useless. The trunk of a tree can be cut through by a single stroke of a machete. Before ripening the fruits are green. On reaching maturity they become yellow and squashlike. They may be eaten either with salt or sugar. To a novice they are inferior in flavor to a musk melon. They vary in size and shape. Those growing in Guam are small and inferior to the varieties cultivated in countries where they are used as a food-staple. They contain a great number of dark-brown seeds, which turn black in drying and have a mustard-like pungent flavor. The fruit developes so rapidly that buds of flowers and ripe fruits are often seen on a tree at the same time.

The papaw is a native of tropical America, but it has become established throughout the entire tropical world. In Guam it appears spontaneously in waste places. Little attention is given to it by the natives. Though they eat it if other kinds of fruit be scarce, they do not appear to esteem it as an article of food.

REFERENCES:

Carica papaya L. Sp. Pl. 2:1036. 1753.

Caricature plant. See Graptophyllum pictum.

\section{Carinta herbacea.}

GROUNDBERRY.

Family Rubiaceae.

Local rayes.-Bejuco guara (Cuba); Naunau, Matamata-Aitu (Samoa); Kapukapu (Rarotonga); Karinta kali (Malay Archipelago).

A small, slender, creeping, perennial herb, bearing red, fleshy berries, somewhat like those of the partridge berry (. Witchella repens). Leaves long-petioled, more or less pubescent, orbicular, deeply cordate, stipules interpetiolar, ovate, obtuse; flowers small, white, growing in 1 to 6 -flowered peduncled umbels; bracts linear, lanceolate; calyx tube obovoid, segments 5 to 7 , slender, herbaceous, persistent; corolla salver-shaped, glabrous, throat hairy, lobes 4 to 7 , valvate in bud; stamens 4 to 7 , inserted on the corolla tube, included; stigma 2-fid; ovary 2-celled, the cells 1-ovuled; ovules erect; berry a fleshy drupe, with 2 plano-convex pyrenes; seeds plano-convex, not grooved ventrally.

This plant is widely distributed in the Tropics. It is common in the woods of Samoa, Fiji, and other islands of the Pacifie, in the Andaman Islands, Malay Arehipelago, Ceylon, South China, and in tropical America. It is said to possess medicinal properties similar to those of the allied Erea ipecacuanha of New Granada and Brazil, but of inferior quality. $b$

\section{REFERENCES:}

Carinta herbacea (Jacq.)

Psychotria herbacea Jacq. Enum. Pl. Carib. 16. 1760.

Geophila reniformis Don, Prod. Fl. Nep. 136. 1825.

Geophila was first proposed in 1803 for a genus of Liliaceae and is therefore not available for the rubiaceous genus so named by Don. Carinta is an adaptation of the Malayan name of this plant, Karinta kali.

Carmona heterophylla Cav. Same as Ehretia microphylla.

Carrizo (Spanish). See Trichoon roxburghii.

"Erea ipecucuanha (Brot.) Cullicocca ipecacuanha Brot. Trans. Linn. Soc. 6: 137. t. 11. 1802. Uragoga ipecacuanha (Brot.) Baill. Hist. Pl. 7: 281. 1880.

$b$ Watt, Dictionary of the Economic Products of India, vol. 3, p. $488,1890$. 
Family Myrtaceae.

Local Names.-Macupa, Makupa (Philippines and Guam); Kavika (Fiji); Nonu-fi'afi'a (Samoa); Ahia (Tahiti); Ohia (Hawaii).

A tree of medium size, bearing a profusion of white, purple, or red flowers, with tufts of stamens of the same color as the corolla. These are followed by an abundance of fruit having a fragrant, apple-like odor and a delicate flavor. Leaves large, glossy, ovate, elliptic or obovate-oblong, attenuate at each end; inflorescence centripetal with solitary axillary flowers, or in short racemes (leafless branches), or centrifugal in dense terminal cymes; calyx globose or more or less elongate, produced beyond the ovary, with 4 or rarely 5 rounded lobes; petals 4 , rarely 5 ; stamens many; ovary 2-celled, rarely 3 -celled, with several ovules in each cell; style filiform, stigma small; fruit nearly round, crowned by the scar of the calyx lobes; seed usually. 1 .

This tree occurs on nearly all the larger islands of the tropical Pacific and in the Malay Archipelago. It has been introduced into Guam comparatively recently and is by no means common. In Hawaii, Samoa, and Fiji it is very highly esteemed by the natives, more for its beauty than for its fruit. The ancient Hawaiians made their idols of its wood, and the tree figures in the myths of the Fijians. The etymological identity of the Fijian, Samoan, Tahitian, and Hawaiian names of this tree is interesting, indicating, as it does, an acquaintance with it before the separation of the various divisions of the Polynesians or its introduction from one group of islands to the others, together with its name.

\section{REFERENCES:}

Caryophyllus malaccensis (L.).

Eugenia malaccensis L. Sp. Pl. 1: 470. 1753.

Jambosa malaccensis DC. Prod. 3: 286. 1828.

The genus Caryophyllus was published by Linnæus in 1753 with a single species, C. aromaticus, which has since been referred to Jambos Adanson, or Jambosa, as written by many authors. Adanson's name, however, is of later date, and must therefore be displaced by the Linnæan name of the genus.

Casay (Philippines). See Adenanthera pavonina.

Cascabeles (Spanish). See Crotalaria quinquefolia.

Cashew. See Anacardium occidentale.

Casoy (Philippines). See Anacardium occidentale.

Cassava. See Manihot manihot.

Cassia alata. Same as Herpetica alata.

Cassia angustissima Lam. Same as Cassia mimosoides.

Cassia esculenta Roxb. Same as Cassia sophera.

Cassia fistula.

Pudding-PIPe tree.

Family Caesalpiniaceae.

Local names.-Cañafistula (Guam, Philippines, Mexico); Cañapistola (Philippines); Golden shower (Hawaii).

A tree with smooth, ashy-gray bark, bearing long, pendent, lax racemes of goldenyellow flowers, followed by very long, woody, cylindrical pods. Leaves large, evenpinnate, the leaflets in 4 to 8 pairs, ovate-acuminate, 5 to $15 \mathrm{~cm}$. long; calyx tube very short; sepals 5 , obtuse; petals 5 , veined, imbricated, obovate, shortly clawed, nearly equal; stamens 10; pod black or dark brown, 30 to $60 \mathrm{~cm}$. long, containing one-seeded compartments, marked with three longitudinal shining furrows, two of them close together and the third opposite them, marking the sutures; seed reddish brown, glossy, flattish, ovate, embedded in a blackish-brown sweet pulp; odor 
resembling that of prunes. When the wind blows the pendulous pods strike together and make a rattling noise.

This tree is said to be a native of upper Egypt and India, whence it has been introduced into nearly all tropical countries. It has been growing in Guam at least a century, but, like the tamarind, does not reproduce itself here spontaneously. The wood is hard and heavy, but the natives do not utilize it. It is found growing in many places on the sites of abandoned ranches. In Honolulu it is one of the principal shade trees and is highly prized for the beauty of its flowers.

The pulp is a valuable laxative, and is much used in medicine. It is apt to become sour if long exposed to the air, or moldy if kept in a damp place. It is extracted from the pods by bruising them and then boiling them in water, after which the decoction is evaporated. It may be obtained from fresh pods by opening them at the sutures and removing the pulp with a spatula. The pulp has a sweet, mucilaginous taste. It contains sugar, gum, a substance analogous to tannin, a coloring matter soluble in ether, traces of a principle resembling gluten, and a little water. It may be advantageously given in small doses in cases of habitual costiveness ( 4 to $8 \mathrm{gm}$.), and in doses of oné or two ounces ( 30 to $60 \mathrm{gm}$.) it acts as a purgative. $a$

REFERENCES:

Cassia fistula L. Sp. Pl. 1: 377. 1753.

\section{Cassia mimosoides.}

Tea senna.

Local Names. - Kōbo-cha, Nemu-cha, Ichinen-cha (Japan).

A low diffuse perennial, with slender, shrubby, finely downy branches. Leaves resembling those of the sensitive plant, 2.5 to $7.5 \mathrm{~cm}$. long, with a solitary sessile gland on the rachis below the leaflets; leaflets 60 to 100 , linear, rigidly coriaceous, 3 to $3.5 \mathrm{~mm}$. long, obliquely mucronate, with the midrib close to the upper border; stipules large, linear-subulate, persistent; flowers yellow, 1 or 2 in the axils of the leaves on short pedicels; sepals lanceolate-acuminate, bristly; corolla little exserted; stamens 10, alternately longer and shorter; pod strap-shaped, flat, dehiscent, 3.5 to $5 \mathrm{~cm}$. long by $3.5 \mathrm{~mm}$. broad, nearly straight, glabrescent or finely downy; septa more or less oblique.

In Japan, where it grows both wild and in cultivation, the young stem and leaves are cut and dried as a substitute for tea.

REFERENCES:

Cassia mimosoides L. Sp. PI. 1: 379. 1753.

Cassia occidentalis.

Coffee senna. Negro coffee.

Local Names.-Mumutun sable (Guam); Balatong aso (Philippines); Frijolillo (Panama); Hierba hedionda (Cuba); Hedionda (Porto Rico); Bantamare (Senegal); Herbe puante (French).

A glabrous, ill-smelling weed, 60 to $90 \mathrm{~cm}$. high, with abruptly pinnate leaves, having a single large ovate gland just above the base of the petiole. Leaflets 4 to 6 pairs, without glands between them, ovate-lanceolate or lanceolate, rounded at the base, acute, 2.5 to $7.5 \mathrm{~cm}$. long, glabrous on both sides, or finely pubescent; flowers yellow, pedicelled; racemes short, closely crowded, axillary; stamens 10, the upper 3 imperfect; calyx lobes oblong, obtuse, glabrous; pod linear, glabrous, 10 to $12.5 \mathrm{~cm}$. long by 2.5 to $7.5 \mathrm{~cm}$. broad, somewhat curved, its margins thickened.

This plant is of wide distribution in the Tropics, and in the warmer temperate regions of the globe. It was introduced into Guam more than a century ago, and is common in abandoned clearings, in waste places, and along the beach.

The seeds, sometimes called "negro coffee," are used in some parts of the world as a substitute for coffee and are said to be a febrifuge. In Senegambia an infusion of the roasted seeds having an agreeable flavor not unlike coffee is used by the natives. This plant has been used as a remedy for stomach troubles, nervous asthma, and 
typhoid fever. The root is especially active, and the leaves are used medicinally in many countries, especially in Dahomey, Africa, where they are one of the most important drugs used in the hospitals in the treatment of certain fevers. $t$ They are purgative and antiherpetic. Large quantities are received annually at Bordeaux and Marseille. In 1897 nearly 100 tons of the seed was imported into Europe. In 1898 the value of the export from Senegal amounted to 1,000 francs.

RËFERENCES:

Cassia occidentalis L. Sp. Pl. 1: 377. 1753.

Cassia sensitiva Roxb. Same as Cassia mimosoides.

Cassia sophera.

EDible SENNA.

LocAl Names. - Amot-tumaga, Amot-tomaga (Guam).

A plant resembling Cassia occidentalis, but of a more shrubby habit, and with more numerous, smaller, narrower leaflets and shorter, broader, more turgid pods. Leaf with a single large gland placed just above the base of the petiole; leaflets 6 to 12 pairs, lanceolate or oblong-lanceolate, acute, without glands between them; flowers yellow, racemes terminal or axillary, few-flowered; stamens 10, the upper 3 imperfect; pods glabrous, many-seeded, linear, turgid; suture keeled; seeds horizontal, with cellular partitions.

The leaves are variable in shape and size. A common variety in Guam has the leaves smaller and more obtuse than the typical form. The single gland on the petiole and the size and shape of the leaves will serve to distinguish this species from the others on the island.

Widely spread in the Tropics. In India the leaves are eaten by natives in their curries. An infusion of the bark has been given as a remedy for diabetes; and the bruised leaves and bark of the root, powdered and mixed with honey, are applied externally in ringworm and ulcers. As in the case of $C$. occidentalis, the smell of the plant is disagreeable.

\section{REFERENCES:}

Cassia sophera L. Sp. Pl. 1: 379. 1753.

\section{Cassia tora.}

Low SENNA.

Local NAMEs.-Mumutun adamelon, Mumutun palaoan (Guam).

An annual glabrous undershrub, with even pinnate leaves. Leaflets 2 to 4 pairs, a gland on the rachis between the lowest pair, and sometimes between the next pair, but never between the uppermost; stipules linear-subulate, at length deciduous; leaflets thin, obovate, obtuse; flowers yellow, small, in pairs or in short axillary fewflowered racemes; calyx lobes oblong, obtuse; stamens 10, the anthers of the upper 3 imperfect; pod linear, very slender, strongly curved, 15 to $2.5 \mathrm{~cm}$. long by 6 $\mathrm{mm}$. wide, membranous, the sutures very broad, the seeds flattened in the same direction as the pod.

Of world-wide distribution in the Tropics. In Guam it has been a common weed for more than a century. The leaves are mucilaginous and ill smelling. They are said to be aperient. In India they are fried in castor oil and applied to ulcers. The root, rubbed with lime juice, is a remedy for ringworm.

\section{REFERENCES:}

Cassia tora L. Sp. Pl. 1: 376. 1753.

\section{Cassytha filiformis.}

WIRE VINE. DODDER LAUREL.

\section{Family Lauraceae.}

Local Names.-Mayágas (Guam); Devil's guts (Australia).

A leafless, wiry, twining parasitic plant with the habit of Cuscuta, very common in thickets, adhering to branches of other plants by means of small protuberances or

$a$ Wildeman, Les Plantes Tropicales de Grande Culture, p. 72-73 (Brussels, 1902). 
suckers. Flowers small, white, remote, in small spikes; perianth with 3 inner equal obovate lobes and 3 outer minute ones; fertile stamens 9 , the 3 inner ones with 2 glands at the base, the filaments of the 3 outer ones petal-like, of the 6 others filiform; fruit round, one-seeded, inclosed by the perianth and crowned by its lobes; ovary free, style short, stigma depressed.

ReFerences:

Cassytha filiformis L. Sp. Pl. 1: 35. 1753.

Casta (Philippines). See Jatropha curcas.

Castor-bean. See Ricinus communis.

Casuarina equisetifolia.

Polynesian inonwood. Plate xít.

Family Casuarinaceae.

Local names. -Gago (Guam); Agoho (Philippines); Toa (Samoa, Rarotonga); Aito (Tahiti); Swamp oak, She-oak, Beef-wood (Australia).

A leafless tree with drooping branches, somewhat like a pine in general appearance. Branches 6 to 8-angled or terete, jointed like the stems of an Equisetum, with 6 to 8 sheath teeth at the joints. The genus to which the plant belongs, though formerly classed with the conifers, is now recognized as the only known genus of a distinct family. The flowers are unisexual, the staminate in cylindrical terminal spikes and the pistillate in dense heads borne in the axils and ripening into a cone, which is corky and buoyant and incloses winged seeds (see p. 75).

The wood is heary, strong, and very hard, of a red color when fresh, but turning a dark brown with age. It is excellent for fuel. In Samoa the natives make spears and war clubs of it. In Guam it is scarcely at all utilized, as it is hard to work. In the Hawaiian Islands it has been planted along the sea beach and grows rapidly and readily. It loves sandy soil, and will grow in brackish localities. The natives of Samoa prize it so highly that they often plant it near their dwellings. There a large tree is seldom seen, and the young trees are straight and spindling. At Waikiki, near Honolulu, there is a beautiful avenue of it, planted within comparatively recent time. There the trees grow straight. In Guam it is abundant along sandy beaches, especially on the east shore of the island. It also grows on the high "sabanas," where it is usually the only tree, but it never grows within the forest. All the Guam trees have twisted and gnarled trunks, from the effect of hurricanes.

The species is of wide tropical distribution. It is indigenous in Australia, on the Malayan Islands, and on the east side of the Bay of Bengal, and occurs on many islands of the Pacific, extending eastward to the Marquesas and northward to the Mariannes. It is cultivated in many warm countries, including the Hawaiian Islands, southern Florida, California, and Uruguay.

REFERENCES:

Casuarimu equisetifolia Stickman, Herb. Amb. 1754; Amoen. Acad. 4: 143. 1759.

Casúē (Guam). See Anacardium occidentale.

Cathartocarpus fistula Pers. Same as C'dssia fistula.

Cator (Philippines). See Jatropha curcas.

Catúrai (Guam, Philippines). See Agati grandiflora.

Cauayang tinic (Philippines). See Bambos blumeana

Caudolejeunia. See under Hepaticæ.

Caulerpa. See under Algr.

Cayam (Cebu). See Bocoa edulis.

Cayenne pepper. See Capsicum annum cerasiforme and C. frutescens.

Ceanothus asiaticus. Same as Colubrina asiatica.

Cebolla (Spanish). See Allium cepa.

Cebolla halom-tano (Guam). An orchid, Luisia teretifolia. 


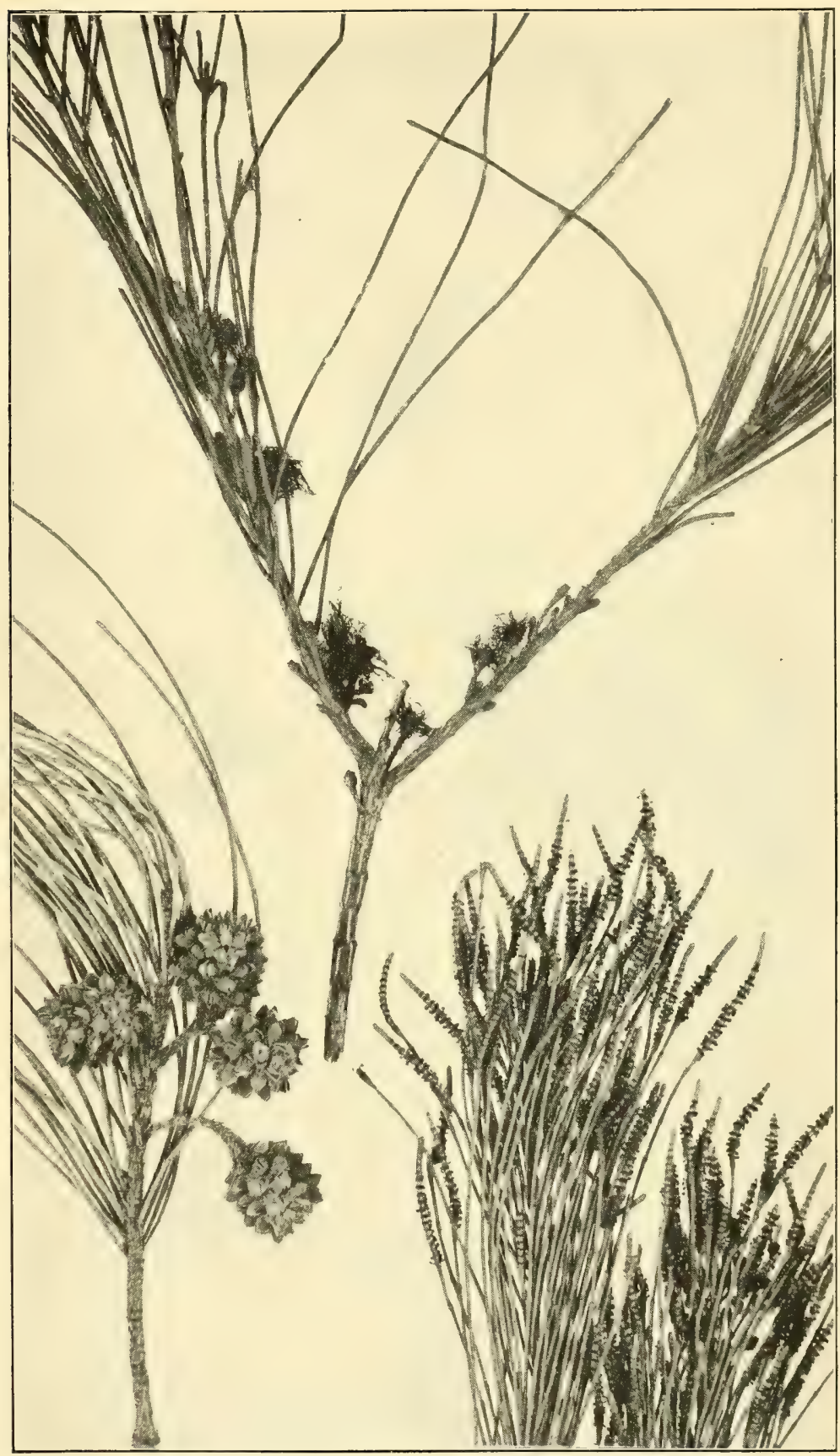

Casuarina equisetifolia. Male Inflorescence, Female Inflorescence, and Fruit. SLIGHTLY REDUCED. 




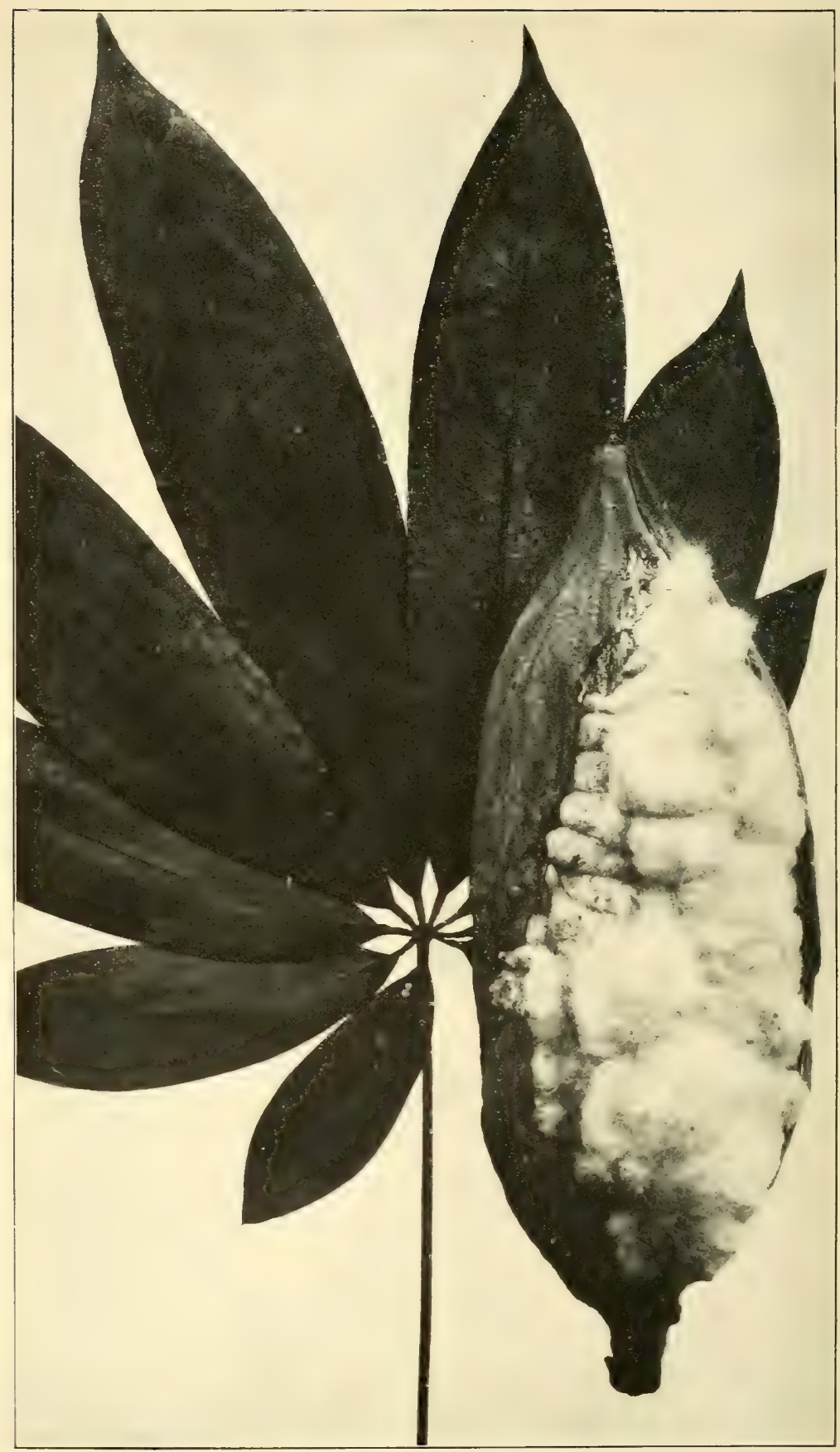

Ceiba pentandra, the Kapok tree. Leaf and Opened Pod, Showing Cotton-like floss. natural size. 
Ceboya (Philippines). See Allium cepa and Gardens.

Ceiba casearia. Same as Ceiba pentandra.

Ceiba pentandra.

Kapok. Plate xlif.

Family Bombacaceae.

Local vames.-Algodon de Manila (Spanish); Atgodon de Manila (Guam); Doldol, Capoc, Kapok, Bubui (Philippines); Kapok (Java); Imbul, Pulunimbul (Ceylon); Ceiba (Cuba, Central America); Silk-cotton tree (Brit. W. Indies).

A tall tree with a straight trunk, prickly when young, with whorls of horizontal branches, palmately compound, deciduous leaves, and mallow-like flowers appearing before the leaves, followed by pods containing silky floss. Leaflets 5 to 8, lanceolate, cuspidate, entire or serrulate toward the point, glaucous beneath; petioles as long as or longer than the leaflets; stipules small, deciduous; petals 5 , united at the base; stamens in 5 bundles; filaments joined at the base, each bearing 2 versatile anfractuose anthers; style crowned with a 5 or 6 -cleft stigma; capsule cucumber-shaped, woody when mature, 5-celled, 5-valved; cells many-seeded; seeds embedded in the flossy down.

The color of the flowers of this species varies. In Guam they are white, yellowish within; in the West Indies there is a variety with rose-colored flowers. There is some difference between trees growing in the East Indies and in the West Indies, and some botanists have regarded them as distinct species. The trunks of the young trees of both are armed with stout, sharp protuberances; but in the West Indian tree they are often swollen or ventricose in shape, while those of the East Indies are straight and tapering. No difference, however, can be discovered in herbarium specimens great enough to warrant their being separated. $a$

A common tree in Guam, growing near ranches and along the roadside, sometimes used for marking the boundary between adjacent farms. In Java the trees are grown along the roadsides for telephone poles. The wood is soft and white and is not utilized on the island. The silky floss can not be spun. In Guam it is used for stuffing cushions and pillows. It is brittle, elastic, and very inflammable. In India it is used in the manufacture of fireworks. In commerce it is known as "kapok," and was first brought to notice by the Dutch, who drew their supply from Java. It is now used in upholstery, and has the virtue of not becoming matted.

ReFERENCES:

Ceiba pentandra (L.) Gaertn. Fruct. 2: 244. t. 133. f. l. 1791.

Bombax pentandrum L. Sp. Pl. 1: 511.1753.

Eriodendron anfractuosum DC. Prod. 1: 479. 1824.

Cenchrus lappaceus. Same as Centotheca lappacea.

Cenizo (Spanish): See Chenopodium album.

Centella asiatica.

INDIAN PENNYWORT.

Family Apiaceae.

Local Naves.-Yahon-yahon (Philippines); Tono (Samoa); Yerba de clavo (Porto Rico); Ovate-leaved marsh pennywort (United States).

A perennial herb closely allied to Hydrocotyle, with prostrate stems, rooting and sending up tuits of long-petioled leaves at the nodes, together with 1 to 3 long-rayed umbellets of small white flowers, the true umbel sessile. Leaves not peltate, ovate, rather thick, rounded at apex, broadly cordate at base, repand-dentate; pedicels much shorter than the leaves; umbellets capitate, 2 to 4 -flowered, subtended by 2 ovate bracts; flowers pink, nearly sessile; fruit prominently ribbed and reticulated.

A plant growing in wet shady places, widely spread in warm countries. In India

$a$ For the synonymy of this species see Notes on Ceiba, by James Britten and Edmund G. Baker, Journal of Botany, April, 1896. 
the leaves, which are bitter, are toasted and given in infusion to children in bowel complaints and fevers, and they are applied as a remedy for bruises to check inflammation. On the Malabar coast the plant is one of the remedies for leprosy, for which it is said to be an excellent specific. $a$ In sonthern Africa and in India it is used as an alterative to purify the blood. It is said to be of value in syphilitic and serofulous affections.

ReFERENCES:

Centella asiatica (L.) Urban in Mart. Fl. Bras. 11'1:287.1879.

Hydrocotyle asiatica L. Sp. Pl. 1: 234. 1753.

\section{Centotheca lappacea.}

Burgrass.

Family Poaceae.

A tall perennial grass, with broadly lanceolate tessellately nerved leaves and a branched woody rootstock. Spikelets 1 or 2 -flowered, secund on the long branches of a lax subsimple panicle, not jointed on the very short pedicels; rachilla jointed at the base of and between the flowering glumes; glumes 5, the empty pair oblongovate, keeled, 3 to 5-nerved, persistent; flowering glumes oblong, acute, dorsally rounded, 7-nerved, naked or the upper bearing above the middle soft, erect, at length deflexed, tuberculate-based spines; palea shorter than the glume, its keels ciliolate; lodicules none; stamens 2 or 3, anthers short; styles free; grain ovoid, acute, terete, free. The leaves of this grass are 10 to $25 \mathrm{~cm}$. long by about $3 \mathrm{~cm}$. broad, manynerved, glabrous or sparsely hairy, midrib oblique, sheath glabrous or hairy, ligule short, lacerate; panicle 20 to $25 \mathrm{~cm}$. long and broad, branches smooth; spikelets 3.5 to $6 \mathrm{~mm}$. long, green; rachilla scaberulous; paleæ often decurrent on the rachilla below the glume. The upper palea is rather firm, very sharply 2-keeled, and even at the time of flowering bow-shaped and bent outward.

The species is of wide tropical distribution. It grows near the beach and in damp upland regions. It is an excellent fodder grass. It is common in central India and southward to Malacca, in the Andaman Islands and Ceylon, China, tropical Africa, and the Philippines. In the Pacific it has been collected in Samoa, Admiralty Islands, and the Caroline group.

REFERENCES:

Centotheca lappacea (L.) Desv. Nouv. Bull. Soc. Philom. 2:189. 1810.

Cenchrus lappaceus L. Sp. Pl. ed. 2. 2:1488, 1763.

Ceratopteris gaudichaudii. Same as Ceratopteris thalictroides.

Ceratopteris thalictroides.

WATER FERN.

LoCAL NAMEs. - Umug sensonyan (Guam); Midsu warabi (Japan).

An aquatic fern with divided fronds, eaten in Guam as a salad and in Japan as a pot herb. The divisions of the fertile fronds are linear and much narrower than those of the sterile ones.

REFERENCES:

Ceratopteris thatictroides (L.) Brogn. Bull. Soc. Philom. 1821: 186, pl. [1]. 1821.

Acrostichum thalictroides L. Sp. Pl. 2: 1070. 1753.

\section{Cestrum nocturnum.}

Night-BLOOMING CESTRUM.

Family Solanaceae.

Locıl xames.-Dama de noche (Guam and Philippines); Galan de noche (Cuba).

A glabrous shrub with greenish yellow tubular flowers which are very fragrant at night. Leaves alternate, entire, ovate or ovate-oblong, with a rather blunt point; racemes cymose, peduncled, exceeding the petiole; inferior pedicels often as long as the calyx; calyx 5-dentate, about one-third as long as the corolla-tube; teeth ovate, roundish, or deltoid; corolla-tube clavate, gradually tapering, glabrous; lobes ovate,

a Drury, Useful Plants, India, p. 257. 
blunt; stamens 5, included, inserted above the middle of the corolla-tube; filaments longer than the anthers, puberulous below, entire, or bearing a tooth above the base; berry ovoid-oblong.

The odor of the flowers is very penetrating. At a distance it resembles that of valerian, but at close range it is rank and overpowering, whence the name restrum foetidissimum applied to this species by Jacquin. This plant is of West Indian origin; it is widely cultivated in the Tropics. It was introduced into Guam many years ago from the Philippines. A large bush of it grows on each side of the door of the church at Agaña, the odor from which at night is diffused over the greater part of the city.

\section{REFERENCES:}

Cestrum nocturnum L. Sp. Pl. 1: 191. 1753.

\section{Cestrum pallidum.}

INKBERRY.

LOCAL NAMES. - Tintan-China, i. e., "Chinese-ink berry" (Guam).

A glabrous shrub 1.5 to 2.5 meters high. Branches terete; leaves alternate, elliptical-oblong or oblong-ovate, blunt-pointed, petiolate, green above, paler beneath, glabrous, 5 to $10 \mathrm{~cm}$. long by $3.5 \mathrm{~cm}$. broad; racemes cymose, with rather long peduncles, axillary and terminal; flowers nearly sessile, small, about $12 \mathrm{~mm}$. long; corolla tubular, clavate, the lobes very short, rounded, recurved; stamens 5 or 6 , included, alternating with the corolla lobes, inserted near the throat, filaments usually about as long as the anthers; pistil 1, style long and slender, slightly exserted, stigma capitate; berry ovoid, fleshy, about the size of a poke berry, filled with purple juice, few-seeded; calyx campanulate, 5-toothed, the teeth short and rounded, ciliolate.

I am not quite certain as to the identity of this plant. It corresponds very closely with the description given by Grisebach of Cestrum pallidum Lam. ${ }^{a}$ In Guam the flowers are white. They are day-blooming and have a slight fragrance of $C$. nocturmm. In De Candolle's Prodromus it is stated that the berries are poisonous, but this is probably a mistake, since they are an important article of food for the pigeons and other fruit-eating birds of Guam, by means of which the plant has been spread all over the island. It is of comparatively recent introduction. None of the early collectors mention it. The berries of the allied Cestrum lanatum of Mexico yield a black dye.

REFERENCES:

Cestrum pallidum Lam. Encye. 1: 688. 1783.

Ceylon moss. See Gracilaria confervoides under Algæ.

Cha. The name in Guam for tea.

Cha cimarron (Philippines). See Ehretia microphylla.

Chaca (Guam), Nephrolepis acuta. See under Ferns.

Chaetochloa glauca aurea.

GoLDen Foxtail.

Family Poaceae.

A pale-green, erect, annual grass, having a simple, dense, cylindrical, spike-like panicle. Spikelets articulated on very short pedicels, 1 or 2 flowered, ovate; glumes awnless; first empty glume short; flowering glume and palea obtuse, finally hard and shining or tranversely wrinkled; numerous involucral bristles under each spikelet. A cosmopolitan grass with flat leaves scabrous on the edges and often ciliate with a few long hairs, common in waste places and in the borders of cultivation; good for fodder. Collected in Guam by Lesson.

REFERENCES:

Chaetochloa glauca aurea (Hochst.).

Setaria aurea Hochst. A. Br. Flora. 24: 276. 1841.

Setaria glauca aurea K. Sch. in K. Sch. \& Laut., Fl. Deutsch. Schutzgeb. in der Südsee 180. 1901. 
Chagua (Guam).

General name for "plant" in the vernacular of the island.

Chaguan humátag (Guam). A sedge, Cyperus rotundus.

Chaguan lemae (Guam).

A sedge, Kyllinga monocephala; so called from the fancied resemblance of its heads to miniature breadfruits (lemae).

Chaguan-tais. See Halodule uninervis.

Chara (Guam). Sea purslane, Sesuvium portulacastrum.

Chara fibrosa. See Algæ.

\section{Charcoal.}

The principal trees which furnish wood for making charcoal are the lemoncito (Triphasia trifoliata), the mangrove (Rhizophora mucronata), the aában (Eugenia sp.), and an unidentified tree abundant on Orote Peninsula called "laláhag."

Chavica betle. Same as Piper betle.

\section{Chenopodiaceae.}

GooseFoot FAMILY.

This family is represented in Guam by the two following species:

\section{Chenopodium album.}

LAMBS-QUARTERS.

Family Chenopodiaceae.

Local Names. - Cenizo (Spanish); Quelites (Mexico); Kiletes (Guam).

An erect herbaceous weed, with rhombic-ovate or lanceolate, dentate, sinuate, or lobed leaves; flowers small, green, sessile; spikes terminal or axillary, often panicled; calyx segments usually inclosing the utricle, strongly keeled in fruit; seed horizontal, black, shining, firmly attached to the pericarp; embryo a complete ring.

Spread over the world in temperate and tropical regions, in Guam growing in waste places. The young shoots are cooked like spinach.

REFERENCES:

Chenopodium album L. Sp. Pl. 1: 219. 1753.

Chenopodium ambrosioides.

Mexican TEA.

Family Chenopodiaceae.

Local xayes.-Apasotes, Alapasotes, Pasotes (Guam, Philippines); Basote (Porto Rico); Epazote, Yepazotl (Mexico); Ambrosine, Thé du Mexique (France).

An erect puberulous, aromatic plant. Stem angled; leaves alternate, shortpetioled, oblong or lanceolate, obtuse, sinuately toothed, the upper ones entire; flowers minute, in slenderaxillary clusters and terminal simple or panicled spikes; sepals inclosing the utricle; seed horizontal, smooth, shining, the margin obtuse.

A species probably of Mexican origin, now widely spread over the warmer regions of the world. In Mexico a kind of tea is made of it. In France it is cultivated and is known as "thé du Mexique." In Guam it is found in many gardens together with manzanilla (Chysunthemum indimem), hierba de Santa Iaria (Artemisia vulgaris), anís (Foeniculum foeniculum), and hierba buena (Mentha arvensis).

REFERENCES:

Chenopodium ambrosioides L. Sp. Pl. 1: 219. 1753.

Cherry pepper. See Capsicum annum cerasiforme.

Chestnut, Polynesian. See Bocoa edulis.

Chichitun (Guam). Local name for Achyranthes aspera.

Chico (Guam, Philippines). Local name for the sapodilla (Sapota zapotilla).

Chile or Sile (Philippines). See Capsicum annuum and C. frutescens.

China dulce (Porto Rico). See Citrus aurantium sinensis. 
China-berry tree. See Melia azedarach.

Chinese-ink berry. See Cestrum pallidum.

Chocolate, chocolate bean or nut, chocolate tree. See Theobroma cacao.

Chopag (Guam).

One of the principal timber trees of the island, Ochrocarpus obovalis.

Chosgô or Chosgû (Guam).

A small-sized euphorbiaceous tree, Glochidion marianum, yielding very strong wood which is used by the natives of Guam for making cart shafts.

Chotda (Guam).

Vernacular name for banana plant or green banana; the ripe fruit is called "aga."

\section{Chrysanthemum indicum.}

Indian Chrysanthemum. False camomile.

Family Asteraceae.

Local Names.-Manzanilla (Guam, Philippines); Rosa de Japon (Philippines); Gúl-daoonde, Gúl daudi (Hindustan).

This well-known cultivated plant is used medicinally by the natives of Guam, who, like the Filipinos, erroneously apply to it the Spanish name for camomile. It is a perennial composite with alternate, divided leaves and blooms during the cold season. Involucre hemispherical, composed of imbricated seales which are membranous at the edges; receptacle naked; pappus none. It was described by Padre Blanco in the first edition of his Flora de Filipinas (p. 631) under the name of matricaria chamomilla.

The flowers in the form of an infusion are used as a remedy for intermittent fevers, and are valued by women as a remedy for hysteria and monthly irregularities.

REFERENCES:

Chrysanthemum indicum L. Sp. Pl. 2: 889. 1753.

Chrysodium aureum. Same as Acrostichum aureum. See under Ferns.

Chrysopogon aciculatus Trin. Same as Andropogon aciculatus.

Chupa (Guam). The vernacular name for tobacco.

Chuti or Chiute (Guam).

A shrub or small tree, baving white gamopetalous flowers, referred by Gaudichaud to the Apocynaceae. Not identified.

Cidra (Spanish).

The Citron. See Citius medica. The name is also sometimes incorrectly applied to large, thick-skinned, citron-like shaddocks (Citrus decumana).

Cinamomo (Guam, Philippines). The henna bush, Lawsonia inermis.

Citron. See Citrus medica.

Citronella oil. See Andropogon nardus.

Citrullus citrullus. See Gardens.

Citrus.

Oranges. Citrons. Lemons. Limes.

The existing classification of the fruits belonging to the genus Citrus is far from satisfactory. So many intergrading varieties of oranges, citrons, lemons, limes, pomelos, shaddocks, and their allies occur that it is difficult to delimit them and impossible to determine their origin. Thus the lemon, lime, and citron are by some authors considered distinct species and by others subspecies or varieties of the same species (Citrus medica L.). They are very different from one another and grow perfectly true to seed; so that, if they are simply varieties of the same species, they have probably developed under widely different conditions and in regions remote from one another. The cultivated forms of the true citron closely resemble the shaddock in their thick rind, while the acid lime, which is spherical in shape and smoothskinner more nearly approaches the orange, differing radically from the lemon which resembles the typical citron in its oblong shape and in having a nipple at the 
apex of the fruit. The acid lime (a fruit very distinct from the sweet lime, $C$. limetta W. \& A.) has been referred by Engler to Citrus hystrix DC., while Roxburgh a classifies it together with the sour lemons of India under the general name Citrus acida.

Whatever may be the correct botanical names of the forms of this genus, it is certain that the following fruits grow on the island of Guam:

1. The wild orange, with saponaceous leaves and fruit, identical with the indigenous "moli" of Samoa and Fíji. See Citrus aurantium saponacea.

2. The cultivated sweet orange. See Citrus aurantium sinensis.

3. The fragrant bergamot, which grows spontaneously on the island. See Citrus bergamia.

4. The tangerine orange, sparingly cultivated. See Citrus nobilis.

5. The citron, the thick rind of which is preserved by the natives. See Citrus medica.

6. The lemon, of oval shape, and terminating in a nipple, called "limon real" by the natives of Guam. See Citrus medica limon.

7. The acid lime, small, spherical, with a thin, smooth skin, called "limon" by the natives of Guam. See Citrus hystrix acida.

8. The shaddock, which often grows to a great size. See Citrus decumana.

For the citrus-like shrub called "lemoncito" see Triphasia trifoliata.

Citrus aurantium saponacea Safford, subsp. nov.

SOAP ORANGE.

Family Rutaceae.

Local names.-Káheĩ, Káhet (Guam); Kahél, Cahél, Cajel (Philippines); Naranjo agrio, Naranjo cimarron (Spanish); Moli, Moli-vao (Samoa); Moli, Moli-kurukuru (Fiji).

The wild orange of Guam is identical with the "moli" of Fiji and Samoa, and, as in those island groups, it is apparently indigenous or of prehistoric introduction. It is not edible. The saponaceous fruit is used by the natives of Guam not only for washing the hair, as in several other Pacific islands, but also as a substitute for soap in washing clothing. The macerated leaves also form a lather with water. They are fragrant, and may be used, as in Fiji, for washing the hair. Seemann $b$ designates this orange as Citms vulgaris Risso, and says that it is called the "bitter or Seville orange" by the white settlers. It can not, however, be identical with the cultivated variety known under this name, which is identified with Citrus bigaradia Duhamel, and called by Engler $c$ the subspecies amara of Citrus aurantium L. That recognized form, the pomeranze of the Germans, is the source of orange marmalade and of the fragrant Neroli oil, so extensively used in perfumery. In noting the distribution of the sulspecies amrra Engler does not mention the islands of the Pacific Ocean; and in Schumann and Lauterbach d the species is not mentioned, though the authors are careful to note other plants occurring in the Marianne Islands, and they could not fail to know of the occurrence of an indigenous orange identical with that recorded by Seemann from Fiji and by Reinecke from Samoa. $e$

The petioles of this wild orange are usually broadly winged and the leaves are aromatic. The fruit has very much the appearance of the cultivated sweet orange.

a Flora Indica, vol. 3, p. 391, 1832.

$b$ Flora Vitiensis, p. 32, 1865 to 1873.

c Nat. Pflanzenfamilien Teil 3, abt. 4, p. 198, 1896.

a Flora der deutschen Schutzgebiete in der Südsee, 1901.

e Citrus mlgaris Risso. Mächtige Bäume im Busch der Berge, Früchte mit fester, gelber Schale, die nach dem abfallen austrocknen und steinhart werden. Der Baum scheint auf den Inseln, wie auch auf Yiti heimisch da er auf allen Inseln bis hoch in die Berge hinaufstejgt. Der ausgepresste Fruchtsaft, sowie die macerirte Blätter, schäumen beim Reiben und werden als Kopfwaschwasser, sowie besonders zum Auswaschen des Kalkes aus den Haaren, von den Eingeborenen viel benutzt. (F. Reinecke, Die Flora der Samoa-Inseln, Engler's Jahrb., vol. 25, pp. 642-3, 1898.) 
It is of a light yellow color when ripe, and the skin hardens and becomes shell-like on drying.

In Guam it is a common sight to see scores of women and girls standing waist deep in the river with an oblong shallow wooden tray (batea) hefore them either afloat or resting on a rock. On this tray the linen is spread, rubbed with orange pulp, and vigorously scrubbed with a corncob. Often the entire surface of the river where the current is sluggish is covered with decaying oranges. In Samoa the name for the wild orange, "moli," has been applied to soap, and the introduced sweet oranges are distinguished as "moli-'aina," or "edible moli."

\section{Citrus aurantium sinensis.}

SWEET ORANGE.

Local Names.—Cáhet, Káhet (Guam); Cahél, Kahél, Dalandan (Philippines); Cajél (Mexico); Moli-'aina (Samoa); Moli in Tahiti (Fiji); China dulce (Porto Rico); Naranjo chino, Naranjo dulce (Spanish); Naranghi (Hindustan).

An introduced fruit tree. Young shoots and leaves glabrous; spines axillary, solitary; leaves alternate, 1-foliolate, coriaceous, persistent, leaflet elliptic or ovate, acute, obtuse, or acuminate; petiole often broadly winged, especially in young shoots; flowers white, sweet scented; ovary many-celled; style simple, stout deciduous; stigma capitate; ovules 4 to 8 in each cell; stamens 20 to 60 , inserted round a large disk, filaments variously connate; fruit globose, pulp sweet, yellow, or sometimes red.

Nearly all the orange trees in Guam are seedlings. The fruit usually supplied to visiting ships, grown in the vicinity of Agat and Sumay, is inferior. Good varieties are produced in Mataguak, Yigo, and Finaguayog, in the northern portion of the island, and in Yoña, on the highland near the east coast. They are apparently free from disease and insect pests. Navel oranges were imported by the writer from California, and were left by him in a thriving condition. The climate and the calcareous soil of the island seem to be very favorable for all varieties of citrus fruits. Oranges are easily propagated by cuttings or by layers, but the most satisfactory method is by budding. For this purpose seedlings of lemons or bitter oranges, which grow spontaneously on the island and are free from disease, may be used for stocks. They should be about a year old. February and March appear to be the best months for this purpose in countries with a climate like that of Guam. ${ }^{a}$ Two crops of oranges are usually produced each year. The blossoms of the first crop appear in February, and the fruit is fully ripe the first part of November. The tree again flowers at the beginning of the rainy season, in midsummer, and the fruit is ripe in March and April. Systematic orange culture has never been attempted on the island, but nearly every native has a tree or two on his ranch. There is now a ready market for all the good oranges that are grown. More extensive cultivation of this fruit would surely be profitable and would require little care and labor.

\section{REFERENCES:}

Citrus aurantium sinensis L. Sp. Pl. 2: 783. 1753.

Citrus sinensis Pers. Syn. 2:74. 1807.

\section{Citrus bergamia.}

LOCAL NAMES.-Limon china (Guam).

In Guam this variety grows to the size of an apple tree. Its fruit is somewhat smaller than that of the sweet orange, and has a smooth, pale yellow rind and acidulous pulp. The entire plant, leaves, rind, and pulp have the agreeable aroma of citronella. The leaves have winged petioles and are oblong in form; acute or obtuse. The flowers are white, very fragrant, and are smaller than those of the sweet orange.

The rind of the fruit is the source of the oil known in commerce as bergamot, which is so much used in the manufacture of perfumery. It is obtained by mechan-

a Journal of the Agro-Hort. Society, vol. 14, p. 199, quoted in Firminger's Manual of Gardening for Bengal and Upper India, p. 231, 1890. 
ical means with an instrument called the f́cuelle à piques. This is formed like a saucer, the bottom of which is covered with sharp projections and is deepened at its center into a tube, so that it has the shape of a funnel with its tube closed at the end. The peel is held in the hand and rubbed over the pins, by which the oil vessels of the entire surface are punctured; the liberated oil collects in the tube, and is emptied from time to time into another vessel, where it may be easily separated from the liquid accompanying it. $a$

In Guam the natives use the fruit only as a hair wash. It does not produce a lather like the bitter orange, but eleanses the hair, which is afterwards washed thoroughly with water, and imparts to it a pleasant fragrance. The tree bas spread all over the island and is common along the roadsides and at the edge of the woods.

\section{REFERENCES:}

Citrus bergamia Wight \& Arn. Prod. 98. 1834.

Citrus aurantium bergamia Duham. Arb. ed. nov. 7: 98. t. 26. f. 3. 1819.

\section{Citrus decumana.}

SHADDOCK.

Local NAMEs.-Lalanha, Lalañgha (Guam); Moli tonga (Samoa); Lucban, Lulsa (Philippines); Pompelmoes (Dutch); Pomplemousse (French); Pummelo (Brit. India).

The shaddock may possibly be a variety of the orange $b$ instead of a distinct species. It grows to the size of a tree. Young shoots pubescent; leaflets large, ovate-oblong, frequently emarginate and pubescent beneath; petiole broadly winged; flowers large, white; fruit large, pale yellow, globose or pyriform; rind thick; pulp pale, yellow-pink or red, usually sweet, sometimes acid, the vesicles distinct, easily separable from one another.

In Guam several varieties of shaddocks are to be found, varying in size and shape and in the color of the pulp. The natives make little or no use of them. They are eaten by Europeans, but their flavor is not especially good. Some of the varieties have a very thick skin like that of the citron, and are called "cidra," or "setla" by the natives. One variety has pink pulp. They are all inferior to the thinskinned forms sold in our markets as "grape-fruit" and "pomelos," which do not occur in Guam. This fruit owes its common English name to Captain Shaddock, who introduced it into the West Indies from China.

ReFerences:

Citrus decumana (L.) Murr. Syst. ed. 13. 580. 1774

Citrus aurantium grandis L. Sp. Pl. 2: 738. 1753.

Citrus aurantium decumana L. Sp. Pl. ed. 2. 2: 1101. 1763.

\section{Citrus hystrix acida.}

LIME.

Local nayes.-Limon (Guam); Dalayap (Philippines); Tipolo (Samoa); Lima (Ceylon); Lemon Nipis (Malayan).

A shrub or small tree with elliptic-oblong or oval leaflet, petiole winged, many times shorter than the leaflet; flowers white, fragrant, often 4-petaled; fruit usually small, globose or ovoid, yellow, with pale, sour pulp. Considered by Hooker $c$ to be a variety of Citrus medica, and by Englerd to be a subspecies of $C$. hystrix. In Guam the fruit is small and always globose, never having the terminal nipple characteristic of the lemons on the island.

The lime is especially well adapterl for hedges. It grows readily either from seed or from cuttings. It sends up stout vertical shoots from the roots and forms dense thickets if left undisturbed. It produces continuously in Guam, the bushes bearing both flowers and fruit at the same time The fruit is the principal source of the wellknown lime juice of commerce. In Guam it is very common. The natives use it

a See Spons' Encyclopædia, p. 1457, 1882.

$b$ Bonavia, Cultivated Oranges and Lemons, p. 223, 1890.

$c$ Flora, British India, vol. i, p. 515, 1872.

a Engler und Prantl, Die Natürlichen Pflanzenfamilien, Theil 3, Abt. 4, p. 200, 1897. 
for flavoring some of their dishes, squeezing a little of the juice on beef and venison, and sometimes scraping off the outer rind and preserving the fruit in sirup. The fruit is well suited to pickling. A pleasant drink is made of it with sugar and water, and a bit of the fresh aromatic peeling, squeezed so as to expel the oil, is a fine addition to an American "cocktail."

Lime juice is considered a valuable refrigerant, tonic, and antiscorbutic.

REFERLNCES:

Citrus hystrix acida (Roxb.) Engler in Engler \& Prantl. Nat. Pflanzenfam. $3^{4}: 200.1896$.

Citrus acida Roxb. Fl. Ind. 3: 390. 1832.

\section{Citrus medica.}

Citron.

Local Names.-Setlas (Guam); Cidro (Spanish); Citronnier (French); Moli'ovi'ovia, Moli-apatupatu (Samoa).

A shrub or small tree flowering and fruiting almost continuously throughout the year; young shoots glabrous, purplish; leaflet glabrous, oblong; petiole winged or not, short; flowers sometimes unisexual, numerous, petals sometimes pinkish; fruit large, oblong or obovoid, terminal nipple obtuse; rind usually warty, thick, tender, aromatic; pulp scanty, subacid.

The fruit of this plant, called "setlas" by the Chamorros in imitation of the Spanish "cidra," is not much used on the island. Sometimes, however, the rind is preserved in sirup, when it has the taste of the ordinary citron of commerce. In preparing it the outer surface is first scraped and the inner pulpy core removed.

This species takes its botanical name from ancient Media, where it was described as abundant three centuries before the Christian era. Perfumes are yielded both by the flowers and by the rind of the fruit, the former, resembling neroli, by distillation, and the latter, known as cedrat, both by distillation and by expression after the manner of bergamot.

REFERENCES:

Citrus medica L. Sp. Pl. 2: 782. 1753.

\section{Citrus medica limon.}

LEMON.

Local NAMES,-Limon real (Guam).

A small tree with glabrous young branches; leaflet ovate, petiole margined or winged; flowers white tinged with reddish, fragrant; fruit medium-sized, ovoid with nipple at the end; pulp abundant, acid.

This fruit is valuable for its acid juice and for the oil obtained from its rind, known as the "essence of lemon." The latter may be obtained by scraping and pressing or by distillation. The former, together with lime juice, is the source of citric acid. Lemon oil is of a pale vellow color, fragrant, and aromatic. It is used for flavoring and in the manufacture of perfumery, especially of eau de Cologne.

In Guam lemons are abundant and of excellent quality. They grow almost spontaneously, sending up shoots from the roots, and forming excellent, dense hedges. If left to themselves they grow into impenetrable thickets. They flower and bear continuously throughout the year, great quantities of them falling to the ground and going to waste. They are not used much by the natives except for lemonade and for seasoning meats. The fresh peel, like that of limes, is squeezed into "cocktails" for the sake of the aromatic flavor of the oil. Like the citron the rind is sometimes scraped and the fruit preserved in syrup.

REFERENCES:

Citrus limon (L.) Risso, Ann. Mus. Par. 20:201, 1813, as Citrus limonum.

Citrus medica limon L. Sp. Pl. 2:782. 1753.

\section{Citrus nobilis.}

TANGERINE.

LoCAL NAMEs.-Kahel na dikiki (Guam).

A moderate-sized tree introduced recently into Guam. It has small fruit of a reddish-orange color, spherical in shape and flattened on the top. The skin is very thin 
and is easily separated from the pulp. The pulp is reddish and of a peculiar odor which is shared by the rind and leaf. The leaves are small and usually pointed.

Several trees are now growing in the garden of Don José Herrero in San Ramon, near the southern edge of Agaña. The fruit, though not equal to the best tangerines of our markets, has a good flavor.

REFERENCES:

Citrus nobilis Lour. Fl. Cochinch. 2: 466.1790.

Citrus vulgaris Seeman. See Citrus aurantium.

\section{Cladium gaudichaudii.}

TWIG-RUSH.

Family Cyperaceae.

A leafy sedge with compressed two-edged culms; leaves (equitant) straddling, in two vertical ranks, linear, sword-shaped, rigid; peduncles bearing many spikelets, growing from the axils of the upper leaves in threes or more; panicle much branched; spikelets solitary, one-flowered; glumes few, disposed nearly in two vertical ranks, keeled, boat-shaped; hypogynous bristles or scales wanting; stamens 3, exserted; style 3-cleft, conically thickened at the base, silky-hirsute; achene sessile, bony, obovate-elliptical, obscurely 3 -angled, beaked with the persistent silky-hirsute base of the style.

This species was described by Gaudichaud from a specimen collected by him in in the Marianne Islands in 1819. He says that it closely resembles in habit "Tincentia angustifolia," of Hawaii, and the structure of the spike scarcely differs from that of Gahnia.

REFERENCES:

Cladium gaudichaudii.

Baumea mariscoides Gaudich. Bot. Freyc. Voy. 417. 1826.

Cladium mariscoides. Villar in Blanco, Fl. Philipp. ed. 3. 4: Nov. App. 309. 1880.

The genus Baumea has been merged by Hooker into that of Cladium on account of the affinities of certain Australian species with that genus. Hillebrand, writing on the Hawaiian species, thinks that Baumea and Vincentia might well be joined, but that both ought to stand apart from Cladium. The treatment here followed, however, is that of Hooker and other recent authors, but the transfer of Baumea muriscoides to Cladium necessitates a change in the specific name in order not to conflict with the name of another plant, Cladium mariscoides (Muhl.) Torr.

Cladium mariscoides F. Villar. Same as Cladium gaudichaudii.

\section{Claoxylon marianum.}

Claoxylon.

Family Euphorbiaceae.

Local names.-Panao (Guam).

A handsome tree having loose axillary racemes of small diceious flowers, followed by 3-coccous capsules. Branches rather stout, terete, smooth, densely leafy; leaves alternate, petioles firm, glabrous, 2 to 3 times shorter than the blade $(3$ to $5.5 \mathrm{~cm}$.); blade membranous, opaque, olivaceous, sabermlous, when young sparingly appressed-pubecent and dark violet, oblong-elliptical, shortly cuspidate-acuminate or somewhat obtuse, with the hase acute or subobtuse $\left(8\right.$ to $16 \mathrm{~cm}$. long, $4 \frac{1}{2}$ to $9 \mathrm{~cm}$. broad), margin distantly and obtusely denticulate, secondary nerves 7 to 10 on each side of the midrib, transverse veins lroarly reticulate, the smaller ones not conspicuous; inflorescence sparingly appressed-pubescent, of a waxy texture, bluish-green; racemes of moderate length, with fascicles growing from axils of bracts; male flowers with about 25 stamens, flaments distinct, anthers rather broad, 2-celled, erect, adnate to the top of the filament; pistillode absent; perianth divisions normally 3 , valvate in bud; female flowers with perianth divisions petal-like; ovary 3-celled, styles 3 , free at the base, not bifid, lacerately stigmatose. 
This tree was first described from specimens collected by Gaudichaud in Guarn. It closely resembles the manono, or anei, of Tahiti (Claoxylon taïtense).

ReFerences:

Claoxylon marianum Muell. Arg. in DC. Prod. 15²: 783. 1866.

Clavellina (Porto Rico). See Poinciana pulcherrima.

Cleome viscosa.

SPIDER-FLOWER.

Family Capparidaceae.

LoCAL NAMES.-Mongos paloma (Guam).

A common weed with clammy stems, 3 to 5 -foliolate leaves, and yellow 4-petaled flowers. widely spread in the Tropics. Stems covered with simple viscid-glandular hairs; leaflets ovate or obovate, equaling or shorter than the petioles, upper ones usually subsessile; flowers racemed, long-pediceled; sepals 4; petals imbricate in the bud, reflexed; stamens 12 to 20 , sessile on disk; ovary sessile with a short gynophore; style short or wanting; capsule glandular-pubescent, 5 to $8.5 \mathrm{~cm}$. long, striate, narrowed to the tip, the two valves separating from the seed-bearing placentas; seeds small, granular.

The seeds are sold in the bazaars of India, where they are used by the natives in their curries. They are also used medicinally, powdered and mixed with sugar, to expel intestinal worms, and externally as a rubefacient in the form of a poultice, bruised with vinegar, lime juice, or hot water, for the same purposes as a mustard plaster. The whole plant has a sharp taste not unlike mustard and in some parts of India is known as "wild mustard." It is sometimes eaten boiled with red peppers and salt.

In Guam the natives call it " pigeon pea," from its resemblance to Phaseolus mungo. It was first collected on the island by Lesson, botanist of the Astrolabe, in 1828.

REFERENCES:

Cleome viscosa L. Sp. Pl. 2: 672. 1753.

\section{Clerodendrum inerme.}

SEASIDE CleRodendron.

Family Verbenaceae.

Local Names.-Lodúgao (Guam); Baliskug (Visayan); Aloalo-tai (Samoa).

A branching, often rambling, evergeen shrub, common near the coast, bearing clusters of white, tubular, honeysuckle-like flowers with exserted stamens. Leaves opposite, rarely ternate, obovate or elliptic, subobtuse, entire, glabrate; cymes axillary with small linear bracts; calyx campanulate, minutely 5 -toothed, in fruit somewhat enlarged, subtruncate, closely embracing the base of the drupe; corolla white, tube long and slender, limb 5-fid, lobes oblong; stamens 4, anthers long-exserted, filaments usually reddish; ovary imperfectly 4-celled, 4-ovuled; drupe separating into 4 woody nutlets; seeds oblong.

This plant is widely spread in the Western Pacific, the Malay Archipelago, the Andaman Islands, India, Ceylon, and tropical Australia. Its Samoan name signifies "seaside Premna." The wood, the root, and the leaves are bitter, and are used by the natives of Guam, the Philippines, and Samoa as a remedy for intermittent fevers. The leaves, made into poultices, applied to swellings, prevent suppuration.

A second species or variety of Clerodendrum is found in Guam with narrower leaves, possibly Clerodendrum nereifolium Wall. The leaves of this plant are preferred by the natives to the above as a febrifuge.

REFERENCES:

Clerodendrum inerme Gaertn. Fruct. 1:271. 1788.

\section{Climbing plants.}

Growing without cultivation:

Abrus abrus.-Kolalis halom-tano, coral-pea vine, common in thickets.

Argyreia tiliaefolia.-Alálag (plant), Abubo (flower), twining among bushes, a lavender-flowered morning-glory. 
Climbing plants-Continued.

Cacara erosa.- Híkama, the yam bean, a leguminous plant having an edible tuber.

Calamus sp.-Behuko halom-tano, a climbing palm, like the rattan of commerce, but not utilized.

Canavali ensiforme.-Akankan, sword-bean, a forest climber.

Cassytha filiformis.-Mayagas, a wiry leafless parasite, common in thickets.

Clitoria ternatea.-Bukike, Capa de la reina, the blue pea.

Cyclophorus adnascens.-A climbing fern with small, simple, entire fronds.

Davallia solida.-Pugua machena, a fern with finely divided glossy fronds, climbing on tree trunks.

Dioscorea spinosa.-Gado, a wild yam, armed with wiry branching thorns, forming impenetrable thickets.

Dischidia puberula. - An asclepiad, growing on forest trees.

Guilandina crista.-Pakao, Uñas de gato, a rambling leguminous shrub, profusely branching, armed with recurved thorns.

Humata heterophylla. - A fern with simple fronds, the sterile entire, linearlanceolate, the fertile pinnately lobed.

Ipomoea spp. - Several species abundant, twining in thickets.

Lens phaseoloides.-Gagê (plant), bayog (seed), a giant climbing leguminous plant, common in forest.

Lygodium scandens. - Alambrillo, a delicate fern with wiry stems, common in marshes, twining about reeds and Acrostichum aureum.

Operculina peltata. - A morning-glory with peltate leaves, twining among undergrowth.

Phymatodes phymatodes. - A climbing fern with large, leathery, lobed fronds, growing on tree trunks, walls, and tiled roofs.

Quamoclit quamoclit.-Cabello del angel, scarlet-flowered cypress vine; escaped from cultivation, but well established on the island.

Stizolobium giganteum. - Sea-bean, a leguminous climber with papilionaceous flowers and brown pods.

Planted in gardens:

Antigonon leptopus.-Cadena de amor, an ornamental plant with rose-colored flowers growing in racemes.

Botor tetragonoloba. - Seguidillas, a leguminous plant with edible pods, which appear to be adorned with four longitudinal frills.

Cucurbita spp.-Kalamasas, gourds and squashes.

Dioscorea spp.-Dago, Nika, edible yams.

Dolichos spp.-Edible Fabaceae.

Lagenaria lagenaria. - Tagoa, the bottle gourd.

Momordica charantia.-Balsamina, the balsam pear.

Piper betle.-Pupúlo, the betel pepper, leaves chewed with Areca nut and lime by the natives.

Telosma odoratissima.-Mil leguas, a very fragrant asclepiad.

\section{Clitoria ternatea.}

Blue PEA.

Family Fabaceae.

Local Naues.-Bukike (Guam); Calocanting (Philippines); Capa de la Reina

(Spanish); Bejuco de Conchitas (Porto Rico).

A twining leguminous plant with pinnate leaves and large showy deep-blue flowers. Stems slender, downy; petioles short, leaflets 5 to 7 , ovate or oblong, obtuse, subcoriaceous; stipules minute, linear; flowers solitary, bracteoles large, roundish; calyx tubular, 5-fid, lobes lanceolate, half as long as the tube; standard of the corolla bright blue, with orange center; pod linear, pubescent, 6 to 10-seeded.

A plant widely distributed throughout the Tropies, common in the hedgerows of both the East and West Indies. It has established itself in Guam and is found near the sites of abandoned ranches. 'It bears transplanting, flowers profusely, and is one of the most showy plants of the garden. The seeds were first taken to England from the island of Ternate, one of the Holuccas, from which its specific name is taken.

The powdered ripe seeds act as an aperient and the root as a powerful cathartic.

REFERENCES:

$$
\text { Clitoria ternatea L. Sp. L. 2: 753. } 1753 .
$$

Club-rushes. General name for species of Fimbristylis. 


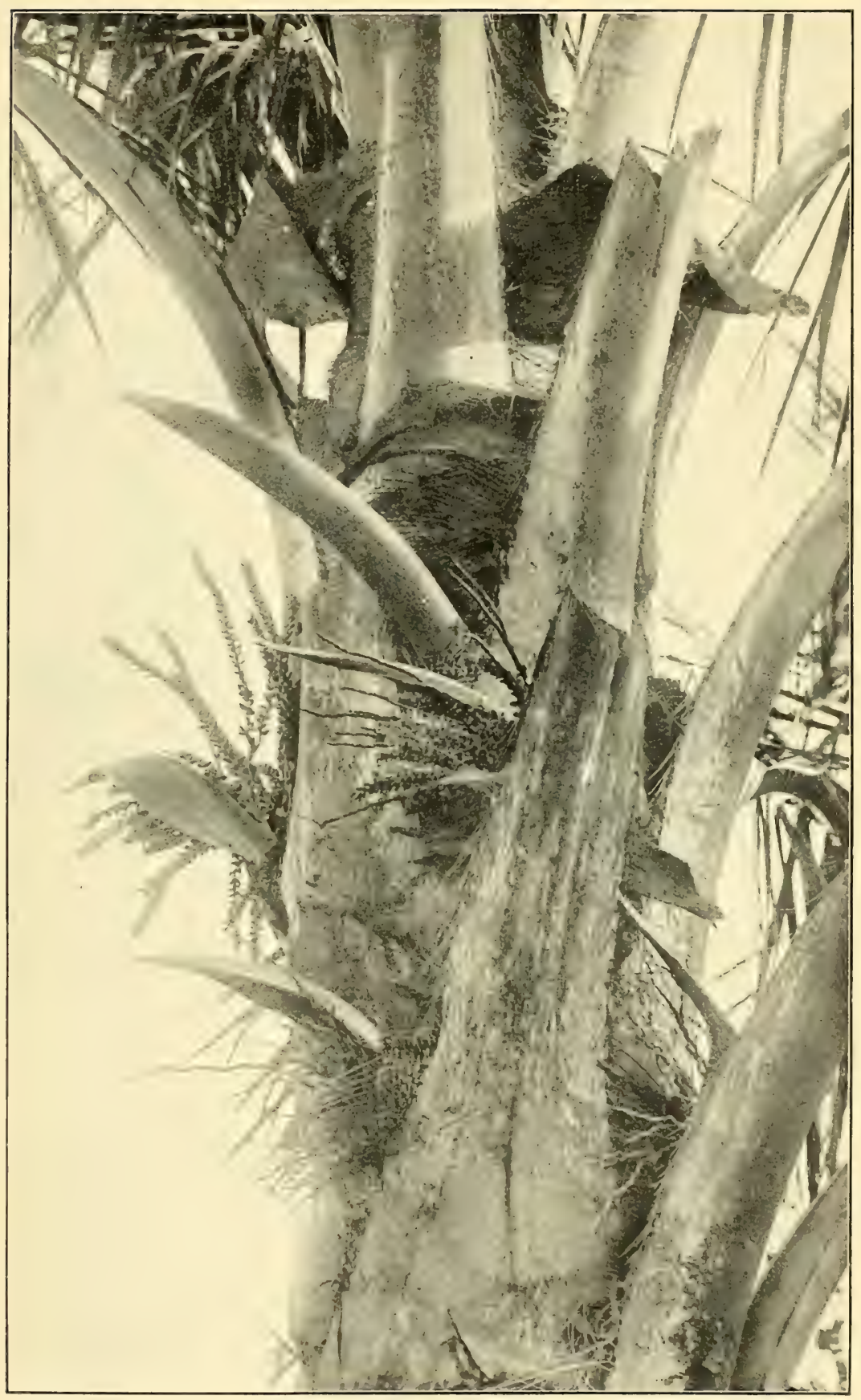

COCOS NUCIFERA, THE COCONUT, INFLORESCENCE, SHOWING UNOPENED, HORNLIKE SPATHE AND BRANCHING SPADIX. 




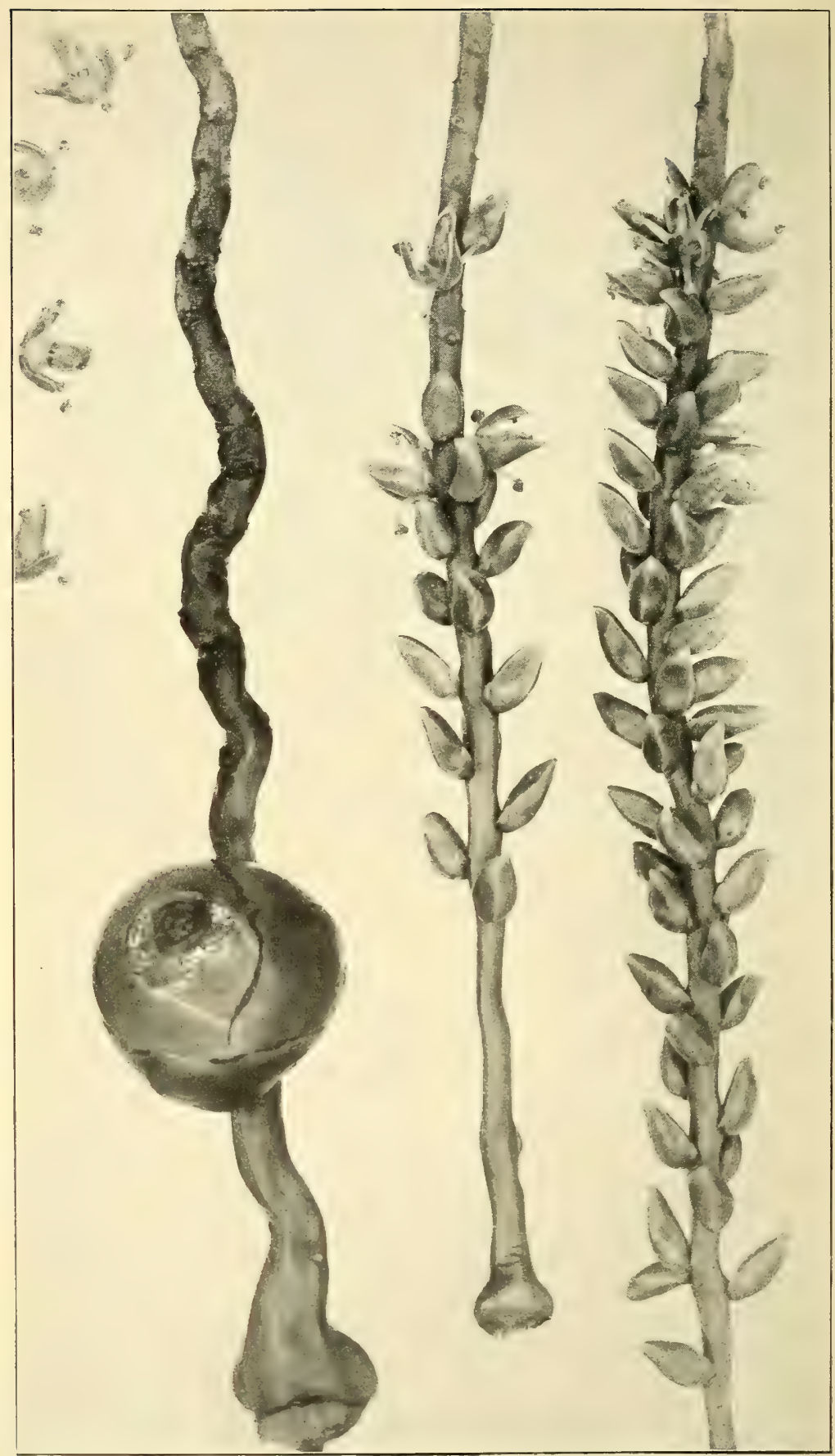

female flower and male flowers of the coconut Palm (Cocos nucifera). NATURAL SizE. 
Clusiaceae.

BALSAM-TREE FAMILY.

Representatives of this family growing in Guam are Ochrocarpus obovalis and Calophyllum inophyllum.

Coconut palm. See Cocos nucifera.

Cocos nucifera.

Coconut. Plates xliII, Xliv.

Family Phoenicaceae.

Local Names.-Niyog (Guam); Niog (Philippines); Nior, Nyor, Kalapa (Malay Archipelago); Niu (Polynesia); Coco (Spanish); Kokospalme (German).

A pinnate-leaved palm with a straight or curved trunk marked with ring-like leaf scars, which are not prominent, and rising from an inclined swollen base. Inflorescence a branching spadix, inclosed at first in a cylindrical sheath or spathe (Pl. XLIII) which splits longitudinally; branches of the inflorescence not subtended by additional spathes; flowers monoecious, the branches of the spadix bearing throughout the greater part of their length numerous small male flowers and near their base usually a single female flower much larger than the male (Pl. XLIV); male flowers 3 -petaled and 3-sepaled, with 6 stamens united at the base, and a rudimentary pistil or small central point; female flowers 6-petaled, usually accompanied by two adjacent male flowers; ovary 3-celled, but usually 2 of the cells becoming abortive; fruit more or less triangular, consisting of a hard endocarp (shell) perforated by three foramina, inclosing an endosperm (the kernel or "meat"), which is rich in oil and is covered by a thin, brown, closely adhering testa. The endosperm when young is of the consistency of the albumen of a soft-boiled egg and surrounds an opalescent fluid composed principally of water and sugar. As it grows older it becomes firmer and finally assumes a hard and almost horny consistency, the inclosed water thickening and becoming gradually absorbed. Outside of the shell there is a thick, fibrous mesocarp (husk), which yields the "coir" of commerce, the surface of which is covered with a smooth, thin, hard, tough epicarp.

In germinating, the inner end of the embryo, an extension of the cotyledon, is developed into a special absorbing organ (the "apple"). From the outer end of the embryo, situated below one of the openings at the apex of the shell, grow the plumule and the roots. The specialized cotyledon at first attacks and proceeds to digest the part of the kernel adjacent to the embryo. It continues to grow until it fills the entire cavity of the nut, the kernel of which becomes soft. The roots push forth and enter the soil before the kernel is totally absorbed, and finally the union between the young plant and the cotyledon is broken and it begins an independent existence. The function performed by the husk is protective. It is of low specific gravity and keeps the nut afloat if it falls into the sea, so that the nut may be transported from shore to shore by ocean currents. $a$

As shown by Cook, the coconut is, in all probability, of American origin, $b$ but it became widely distributed throughout the warmer regions of the Pacific, the Malay Archipelago, and the East Indies in prehistoric times. $c$ It is of very wide distribution in the Tropics. It flourishes best near the seashore and requires plenty of sunshine and free circulation of air. Dense plantations of coconuts have been growing for centuries in the same spots on the coast of Guam (PI. I), while groves planted in the interior sooner or later exhaust the soil and become spindling and unproductive. These seaside groves yield abundantly; and while good results are obtained from plantations in the interior, yet the soil will not continue to produce there indefinitely

a See Winton, anatomy of the fruit of the Cocos nucifera, Am. Journ. Sci., ser. 4, vol. $12,$, p. $265,1901$.

${ }^{b}$ Cook, origin and distribution of the Cocoa palm, Contr. Nat. Herb., vol. 7, p. 257, 1901.

$c$ Another interesting example of the wide dissemination of a plant belonging to an American genus is that of Osteomeles anthyllidifolia, all save one of whose congeners are indigenous to the Andes, but which occurs in the Hawaiian Islands, Piteairn, Rarotonga, the Bonin Islands, and the Liu-kiu group, near Formosa. 
unless artificially manured, and in such places renewals of old groves are unprofitable unless there is plenty of vacant space and the planter is prepared to devote several years to improvement of the soil. $a$

The first accurate description of the coconut was published by Dampier, from observations made by him in Guam in 1686. At the time of the discovery of the island, Magellan noted the occurrence of "cocchi," the oil of which, together with that of " giongioli," was used by the natives to anoint their bodies and their hair. (Pigafetta's Narrative.) Dampier compared the coconut palm with the "cabbage tree" (probably Roystonea oleracea) in its general appearance. He speaks of the large groves growing on the west coast of the island, and gives the following quaint description, which is marvelous for its accuracy:

The Nut or Fruit grows at the head of the Tree, among the Branches and Clusters, 10 to 12 in a Cluster. The Branch to which they grow is about the bigness of a Man's Arm, and as long, running small towards the end. It is of a yellow colour, full of Knots and very tough. The Nut is generally bigger than a Man's Head. The outer Rind is nearly two Inches thick, before you come to the Shell; the Shell it self is black, thick, and rery hard. The Kernel in some Nuts is very thick, sticking to the inside of the Shell clear round, leaving a hollow in the middle of it, which contains about a Pint, more or less, according to the bigness of the Nut, for some are much bigger than others.

This Cavity is full of sweet, delicate, wholesome and refreshing Water. While the Nut is growing, all the inside is full of this Water, without any Kernel at all; but as the Nut grows towards its Maturity, the Kernel begins to gather and settle round on the inside of the Shell, and is soft like Cream; and as the Nut ripens, it increaseth in substance and becomes hard. The ripe Kernel is sweet enough, but very hard to digest, therefore seldom eaten, unless by strangers, who know not the effects of it; but while it is young and soft like Pap, some Men will eat it, scraping it out with a Spoon, after they have drunk the Water that was within it. I like the Water best when the Nut is almost ripe, for it is then sweetest and briskest.

When the Nuts are ripe and gathered, the outside Rind becomes of a brown rusty colour; so that one would think that they were dead and dry; yet they will sprout out like Onions, after they have been hanging in the Sun 3 or 4 Months, or thrown about in a House or Ship, and if planted afterwards in the Earth, they will grow up to a Tree. Before they thus sprout out, there is a small spungy round knob grows in the inside, which we call an Apple. This at first is no bigger than the top of ones finger, but increaseth daily, sucking up the Water till it is grown so big as to fill up the Cavity of the Coco-nut, and then it begins to sprout forth. By this time the Nut that was hard, begins to grow oily and soft, thereby giving passage to the Sprout that springs from the Apple, which Nature hath so contrived, that it points to the hole in the Shell, (of which there are three, till it grows ripe, just where it's fastened by its stalk to the Tree; but one of these holes remains open, even when it is ripe) through which it creeps and spreads forth its Branches [leaves]. You may let these teewing Nuts sprout out a font and a half or two foot high before you plant them, for they will grow a great while like an Onion out of their own Substance.

After describing at length the products obtainable from the sap, the kernel of the nut, the fiber of the husk, and the shell, Dampier concludes:

I have been the longer on this sulject, to give the Reader a particular Account of the use and profit of a Vegetable, which is possibly of all others the most generally serviceable to the conveniencies, as well as to the necessities of humane Life. Yet this Tree, that is of such great use, and esteemed so much in the East-Indies, is scarce regarded in the West-Indies, for want of the knowledge of the benefit which it may produce. And 'tis partly for the sake of my Country-men, in our Anerican Plantations, that I have spoken so largely of it. For the hot Climates there are a very proper soil for it; and indeed it is so hardy, both in raising it, and when grown, that it will thrive as well in dry sandy ground as in rich land. I have found them growing very well in low sandy Islands (on the West of Sumatra) that are over-flowed with the Sea every Spring-tide; and though the Yuts there are not very big, yet this is no loss, for the Kernel is thick and sweet; and the Milk, or Water, in the inside is more pleasant and sweet than of the Nuts that grow in rich ground, which are commonly large indeed, but not very sweet. These at Guam grow in dry ground, are of middle size, and I think the sweetest that I did ever taste. $b$

$a$ See Lyon, The cocoanut, ete., Bureau of Agr. [Philippines], Bull. No. 8, 1903.

$b$ Dampier, A New Toyage Round the Torld, ed. 6, pp. 291-296, 1717. 
In the vernacular of the island a different name is applied to the coconut for every stage of its development:

Niyog, etymologically identical with its name throughout Polynesia, is its general designation.

Dádig, a young coconut the size of a betel nut.

Aplog, a young coconut in which water has begun to form.

Manha, a coconut full of water fit for drinking, called by the Spaniards "cocomudo."

Másôn, a coconut not quite ripe.

Gafo, a coconut perfectly ripe.

Pontan, a coconut which has fallen to the ground.

Nagao, a coconut in which the water has become entirely absorbed.

Jaiguie, or Haiguie, a coconut which has sprouted (pronounced very much like "highway").

Cancion, a variety of which the young nut has a sweet edible rind.

From experiments conducted by Kirkwood and Gies $a$ it was found that the fresh meat contains 35 to 40 per cent of oil, 10 per cent of carbohydrate, only 3 per cent of proteid, 1 per cent of inorganic matter, and nearly 50 per cent of water. The chief constituent of the "milk" of the central cavity, aside from water (of which there is 95 per cent), is sugar.

The meat of the ripe coconut, though agreeable to the taste, is seldom eaten by the Pacific islanders. It is fed to domestic animals of all kinds, even to cats and dogs, and is very fattening. In Guam it is rasped or grated and fed to chickens, but they do not lay so well when living upon a coconut diet as when fed with corn. From the grated meat a rich custard, or "cream," is expressed, which is extensively used throughout Polynesia as an ingredient for native dishes. One of the most savory of these, in which it is cooked with tender young leaves of Caladium colocasia, is in Samoa called "palu-sami." This cream contains much oil, as well as carbohydrate and proteid, and is consequently very nourishing as well as pleasant to the taste. In Guam the natives combine it with rice in various forms, and sometimes prepare it like a simple custard. It makes an excellent broth when boiled with a fowl or with other meat, and in the early days of long voyages nuts were carried to sea and used by the sailors for making rice-milk, a dish which they had learned from the natives to prepare. $b$

The water contained in the central cavity, though "sweetest and briskest" when the nut is almost ripe, as described by Dampier, is at that stage unwholesome, and can be drunk only sparingly, as it is strongly diuretic and is apt to produce an irritation of the bladder and urethra. The milk of young nuts, on the contrary, is harmless. On some islands it is the only beverage of the natives. From personal experience the writer can testify to its refreshing, grateful properties, and to a continued use of it throughout his stay in the island without disagreeable consequences of any kind. On the other hand, a number of cases came under his observation of the evil effects of drinking the milk of ripe coconuts. Immoderate use of the fruit is said to cause rheumatic and other diseases. $c$ This applies, in all probability, to the ripe nut, which the writer has never seen used as a food staple. The soft pulp of the young nuts, which furnish the natives with drink, is very delicate and is eaten like blancmange, with sugar and cream. The principal way of preparing the meat of the ripe nut for food is to grate it and combine it with sugar for sweetmeats and with custard for making cakes and other kinds of pastry. Another use to which the natives of Guam apply the meat of the coconut is the fattening of the "robber crab" (Birgus latro), which they keep in captivity until fit for the table. It has often been asserted that this singular animal climbs trees in quest of coconuts, detaches them with his claws,

a Chemical Studies of the Cocoanut, Bull. Torrey Bot. Club, vol. 29, pp. 321 ff., 1902.

5 Dampier, A New Voyage Round the World, p. 294.

$c$ Gies, Nutritive value and uses of the cocoanut, Journ. N. Y. Bot.Gard., vol. 3, p. $169,1892$. 
letting them drop to the ground, and then proceeds to tear off the husk and open them. On making inquiries among the natives, I was unable to find anyone who had seen an "ayuyu" climb a tree, but was told that the animal feeds upon nuts which have already fallen. It can not open a nut unassisted, but if an opening has been started it will succeed in getting at the kernel. Crab hunters carry coconuts to the sites frequented by the "ayuyu," and, after having made an incipient opening in each nut, leave it as bait. A crab soon discovers it, and is caught while engaged in opening it.

The primitive way of making coconut oil is to rasp the fresh or dry kernel into a pulp, macerate it in a little water, place it in bags, and subject it to pressure. The expressed juice is cooked and the clear oil which collects on the surface is skimmed off. The kernel may be boiled before it is rasped or grated. In Guam the rasp used consists of a flat iron blade set in a wooden footstool. The best oil is prepared from fresh kernels and is used in cooking. It is at first odorless, and with a slight flavor which is agreeable to the taste. It soon turns rancid, however, and in this condition is unfit for food. Coconut oil is perfumed by macerating in it the blossoms of the ilangilang (Canangium odoratum) or other fragrant flowers or substances. In the South Seas the natives, though preferring fresh and perfumed oil for anointing the head and body, do not hesitate to make use of rancid oil for these purposes. In Samoa certain kinds of tapa, or bark cloth, are always treated with oil before they are suitable for wearing as clothing, so that to those who have cruised among the islands of the Pacific the smell of rancid coconut oil always brings to the mind visions of brown-skinned natives and thatch-roofed huts nestling beneath groves of coconut palms.

The natives of Guam still use coconut oil for anointing the hair; but with the custom of wearing clothes that of anointing the body has died out, and the oil is used only for massaging the body in case of sickness. Though the use of petroleum is now general on the island, coconut oil is still sometimes used for illuminating. Until recently certain people paid their taxes partly in oil, which was used for lighting the tribunal. Nearly every house on the island has its little shrine, where before the patron saint a lamp of coconut oil is always kept burning. This lamp consists of an ordinary drinking glass half filled with water, upon which the oil is poured. A wick projecting from a float is fed by the oil, and the water keeps the glass cool.

In many of the Pacific islands the shell and the fiber of the husk play an important part in the daily economy of the inhabitants. In Samoa coconut shells are the only water vessels of the natives, and are used as vessels for oil. The open eye serves as an orifice, and a small grommet is passed through the other two eyes by which the nut is suspended. To remove the kernel, the natives, after having poured out the water through the open eye, immerse the nut in the sea, where the kernel soon putrefies and is eaten up by marine animals. It is then thoroughly cleansed and the outside is frequently polished. Both in Samoa and Hawaii the shells are made into cups, in which kava is served. $a$ These are often highly polished and become lined with a beautiful pearly enamel from the deposit gradually made by the kava. In many islands the natives also make spoons, dishes, beads, and finger rings of coconut shell, and use broken shells for keeping up the fires in their houses by night. In Guam the shells are not much used, joints of bamboo taking their place as water vessels. No use is made of the fiber in Guam, while in Samoa it is used universally to lash together the framework of native houses and the parts of canoes. At every council in Samoa the chiefs may be seen sitting in a large circle, each one engaged in braiding sinnet of coconut fiber; and it is only necessary to refer to a dictionary of the Samoan language to realize how important a part is played by "afa," as the sinnet is called, in the economy of the natives. Thus we have the word used to signify

a An infusion of the roots of the kava pepper (Piper methysticum). 
"to be fit only for plaiting sinnet," as applied to a rainy day; "to be neither too old nor too young," as applied to coconuts fit for making sinnet; "afa-afai," a verb signifying "to wind sinnet around the handle of a weapon to prevent it from slipping;" "afa-pala," "sinnet stained black by steeping it in the black mud of a swamp;" "afata ai," "a large roll of sinnet." a In every native house of Samoa there are large rolls of sinnet, and these are used in part as currency in paying a housebuilder, a canoe maker, or a tatooer for his work. Together with their fine mats they may be said to constitute the capital of the Samoans. In Guam in place of coconut sinnet the natives use the leaves of the "aggag" (Pandanus tectorius) for lashing together the framework of their houses, fences, and the like.

TODDY.

The custcm of making a fermented drink from the sap of the coconut palm, of which the Polynesians are ignorant, was introduced into Guam by the Filipinos brought by the Spaniards to assist in reducing the natives. Before the arrival of the Spaniards the aborigines had no intoxicating drink. The spathe of the young inflorescence is wrapped with strips of the green leaf to prevent its bursting and allowing the branches of the spadix to spread. The tip of the flower cluster is then sliced off with a sharp knife and gently curved, so that the sap may bleed into the joint of bamboo hung to receive it. This sap is collected at regular intervals, usually every morning and evening, and poured into a large bamboo, all of the septa but the lowest of which have been removed. The sap flows most freely at night. When the flow of sap becomes reduced owing to the healing of the wound, another thin slice is cut off the tip, and the flow of the sap begins afresh. Toddy, or "tuba," as this liquid is called in Guam, is very much like cider in taste and consistency. At first it is sweet and may be converted into sirup or sugar by boiling, but it soon begins to ferment and acquires a sharp taste, somewhat like hard cider, which is very agreeable if the receptacle has been kept thoroughly clean and free from insects. The natives, however, are apt to be careless and do not cleanse the bamboos each time they are emptied, so that the tuba is apt to have an offensive odor and flavor from putrefying organic matter. Care is taken in gathering the tuba not to spill it on the leaves and flower clusters of the tree, as this invites the attacks of insects. In some countries it is customary to coat the inner surface of the receptacles with whitewash of lime to prevent fermentation if the tuba is intended for sugar making. If tuba is desired for drinking purposes, the bamboo receptacles should be scalded out daily. The natives of Guam use fermenting tuba for yeast in making bread. This is made from imported wheat flour, and is snowy white and light. If the fermentation goes on unchecked the tuba is converted into vinegar, which is of an excellent quality. Under the usual conditions after having fermented four hours, tuba contains sufficient alcohol to be intoxicating.

\section{AGUARDIENTE.}

From the fermented liquid a kind of rum is distilled, called "aguayente" (aguardiente) by the natives of Guam and "arak" in the East Indies. The distilling of aguayente was the only industry in Guam up to the time of the American occupation. It has been prohibited by an official order on account of its evil effects upon our men. By double distillation almost pure alcohol was obtained. Good aguayente compares very favorably with Mexican mescal, and tuba is far more agreeable to the taste of the uninitiated than pulque, the fermented sap of Agave. Aguayente was seldom drunk to excess by the natives of Guam, but according to Padre Blanco its immoderate use by the Filipinos caused great harm, resulting in sleeplessness, loss of appetite, premature old age, extraordinary obesity, and diseases resembling dropsy and scurvy

a Pratt, Grammar and Dictionary of the Samoan Language, ed. 3, p. 65, 1893. 
Some of uhose who are addicted to it lose their intellectual faculties, are seized with trembling, or become stupid, absent-minded, or even insane. $a$

SUGAR. - In making sugar the fresh tuba is poured into kettles, beneath which a fire is kept burning, dried fronds, husks, and shells of coconuts being used for fuel, as well as mangrove and other hard woods. The sap soon turns brown and becomes thicker and thicker, until it assumes a semiviscid consistency, forming what is in the East Indies known as "jaggery" - a kind of coarse, moist, brown sugar. If the jaggery is allowed to drain in baskets the more fluid part will drain into pans placed to receive it, in the form of sirup or molasses. The remaining sugar is dried and the lumps broken up. In this form, combined with grated coconut meat, it can be made into sweetmeats. Coconut sugar is not made so extensively in Guam at the present time as formerly, before copra was in such great demand; but there are natives who still make it rather than buy imported sugar from the stores, and many families use the sirup ("almibar de tuba dulce") in their daily economy.

I.EAVES.

The roofs in the majority of houses in Guam (Pl. $\mathrm{xx}$ ) are thatched with coconut leaves (higae). These are split down the midrib, the two halves placed together end for end, and the leaflets braided diagonally. Long mats are woven (pupung) to cover the ridge of the roof, and secured in place by wooden pins passing through them below the ridgepole and projecting on each side. The higae are thoroughly dried before being lashed to the roof timbers. The pupung are put on green. Coconut thatch is not so durable as that of the nipa palm; a roof of coconut leaves lasting but four years, while one of nipa will last from ten to twelve. Neti thatch lasts even longer. $b$ In Samoa the sides of the houses are inclosed by coarse Venetian blinds made of coconut-leaf mats, which may be triced up or lowered at will. In Guam the walls of the houses are stationary and are sometimes composed of woven reeds (saguale) of Trichoon roxburghii ( $\mathrm{Pl} . \mathrm{XX}$ ), which are also used for ceilings and partitions. Coconut leaves are not sufficiently durable for this purpose. Baskets made of them are only serviceable when fresh, becoming dry and brittle in a few days. The whole leaves are used to keep the thatch from blowing in windy weather, by tying the tips together and allowing the heary petioles to hang suspended over the ridge. In Samoa, though the houses of the natives are thatched with wild sugar cane, coconut leaves are always used for the side mats.

The ribs of the leaflets are slender, strong, and somewhat elastic. They are frequently tied in bunches and used as brooms for sweeping about the fireplaces and orens, and in Samoa are used as forks in eating. Indeed, in those islands the word "tua-niu" (coconut leaflet rib) is applied to forks in general, and is also used for wire and as the name of certain pinnate ferns which have a slender stiff midrib. Skewers, knitting needles, and toothpicks are also made of tua-niu, and in the early days the oily kernels of the nuts of dleurites moluccum were strung on them, like pieces of meat on a brochette, and served the Samoans and other Polynesians as candles. On many of the Pacific islands tua-niu, neatly smoothed and pointed, were made into combs both for use and for ornament.

Throughout Polynesia dry coconut leaves are used as torches. It is a common occurrence when a boat is attempting a landing by night for the natives on shore to indicate the passage through the reef by holding up a burning coconut leaf; and on making a trip over a stony or difficult path after dark the traveler is preceded by a guide with a supply of these leaves, one after another of which he lights, as may be necessary. The natives of Guam often use these improvised torches for burning wasps' nests, with which the thickets of the island are infested. 
ROOT, CABBAGE, ETC.

In some countries the root is occasionally used instead of Areca nut by betel chewers, but in Guam, where the betel-palm grows spontaneously, there is never a dearth of nuts. The terminal bud, or " cabbage," like that of many other palms, is edible; but as the removal of the bud kills the tree, the natives of Guam indulge themselves in eating it only on occasions of festivity, when they prepare it as a kind of cabbage or raw salad. They either select for this purpose a tree which is comparatively sterile or one which too closely crowds a neighbor. The flowers of the coconut are frequented by several insectivorous birds, especially by "égige" (Myzomela rubratra), a pretty little red and black honey eater, with a slender, curved beak and a cleft, brush-tipped tongue. When the tree dies its crown is a favorite nesting place for the Guam starling, Aplonis kittlitzi, a bird with glossy black plumage, called "sali" by the natives. This bird also frequents the flowering spathes in quest of insects.

WOOD.

In many islands of Polynesia the strong elastic trunks of old coconut palms are used to bridge streams. For this purpose usually sterile trees are used. In commerce the wood is known under the name of "porcupine wood." It is hard, handsome, and durable, and is used for many purposes, for furniture, cabinetwork, walking sticks, and especially for veneering. $a$ In Guam the wood is used only for burning in limekilns.

COPRA.

From a commercial point of view the coconut is the most important product of Polynesia. Its dried meat, called "copra" or "coprac," is the only article of export from Guam. From this island the greater part goes to Japan. A hundred trees may be expected under favorable conditions to yield from 25 to 30 quintals per year. For every ounce of it there is a ready market, and traders vie with one another to secure their crops from the natives by advancing them goods or money beforehand. The current price is 4 pesos per quintal (102 English pounds). The nuts when fully ripe are split open and allowed to dry for a short while. Then the kernel is cut out and dried in the sun either on mats or on raised platforms. It is easily transported on the backs of animals or in carts and shipped in bulk by the traders. There are two regular harvests of copra per year, the principal one of which is in April, May, or June. If cocoanut oil were manufactured by the natives, great difficulty would attend its transportation, as the only receptacles on the island are bamboo joints and "tinajas," or earthenware jars, from Japan and China. There is not a cooper on the island, and the leakiness of barrels containing oil is proverbial. Another reason for transporting the product of the nut in the form of copra is the economic value of the refuse remaining after the oil is extracted.

For a description of the methods followed in Samoa in cultivating the coconut on an extensive scale and of preparing copra by means of drying apparatus, so that it remains perfectly white, assumes a hard, brittle consistency, and is free from rancidity, the reader is referred to Doctor Reinecke's work on Samoa, ${ }^{b}$ extracts from which have been published in the Journal d'Agriculture Tropicale in 1903 and 1904.

\section{PRODUCTS.}

Copra is used extensively in France, Germany, Spain, and England, chiefly in soap making, but also in the manufacture of certain food products resembling butter. This "cocoa butter," or "cocoaline," should not be confounded with the "cocoa 
butter" made from cacao (Theobroma cacao), the source of chocolate, which is also an important commercial product. $a$ The process of manufacture of coconut butter has been kept secret. The main difficulties to overcome were the tendency to rancidity of the fat and its liquid consistency. The credit for carrying on experiments which finally led to success is due to the firm of Rocca, Tassy \& de Roux, of Marseille, who have also erected a plant in Hamburg. Magnan Frères have more recently succeeded in making a satisfactory butter by independent experiments, and some German houses are now doing the same thing.

"The effort to extract an edible grease from an oil produced upon so vast a scale and formerly available only for the manufacture of soap gave promise of valuable returns if successful; and that this promise was not delusive may be judged from the circumstance that the factory of Rocea, Tassy \& de Roux, which produced 25 tons of butter per month in 1900, now (1902) turns out 600 tons per month. * * * The butter is not at all a by-product of the manipulation of the oil, as in the factory of Messrs. Rocca, Tassy \& de Roux, 7,200 tons of butter are obtained from 8,000 tons of oil per annum in a year of maximum results. The butter is styled 'vegetaline' and 'cocoaline,' the greater demand being for the former. The first named melts at $26^{\circ} \mathrm{C}$. and the latter at $31^{\circ} \mathrm{C}$, , being by that fact better suited for warm climates. * * * The activity of the manufacturers in trying to establish their private marks and in advertising their product as one of pure copra oil proves that the main object is to serve the constantly increasing public demand for comestible vegetable greases." $b$

In the United States the principal manufacturers of food products from coconut oil are the India Refining Company, of Philadelphia. They have a process by which the rancidity of the oil is eliminated, so that it is sweet, neutral, and adapted for family use and for manufacturing purposes by bakers, confectioners, and perfumers. One brand, called "kokoreka," consists of the stearin of the coconut oil, having a melting point of about $27.3^{\circ} \mathrm{C}$. This is used by manufacturing confectioners in combination with or in place of cacao butter. A lighter brand, called "ko-nut," is used for baking and domestic purposes in place of butter and lard. It has a melting point of about $23^{\circ} \mathrm{C}$. Specimens of these products, submitted to the Bureau of Chemistry of the Department of Agriculture for analysis, proved to be remarkably free from fatty acids, the "ko-nut" containing 0.13 per cent and "kokoreka," the harder substance, only 0.04 per cent. The material from which this company manufactures its products is East Indian coconut oil. Though they are prepared to press oil from copra itself and have a perfectly equipped oil mill, it lies idle for want of material. There is no reason why America should not offer a market for all the copra produced in Guam, the Philippines, and Samoa. In a letter from Albin Garrett, president of the India Refining Company, he says:

When we consider results of the development of the coconut industry in the island of Ceylon, with an area of 25,000 square miles and a production of coconut products of $76,210,370$ pounds in 1893 , and risen to $206,035,384$ pounds in $1903-\mathrm{a}$ period of ten years, it would seem that, with American methods and enterprise introduced into the Philippines, with 41,000 square miles of territory in the island of Luzon alone and 116,000 in the group, with a very enormous coast line, which is what counts in coconut production, a great field is open there for development. As we believe this city is the largest market in the world for manila hemp and has the only plant for handling copra in this country, it would seem that the lines will open if the button could be properly touched.

In consequence of tests made by Dr. Theodor Ternes, of the Royal Imperial Hospital of Tienna, an official report was made, stating that coconut butter meets all hygienic requirements; that it is superior to animal fat and butter; that it is

a See Listoe, Cocoa Butter in the Netherlands; and Skinner, Copra Products at Marseille; Advance Sheets of Consular Reports, October 15, 1902.

b Official Report of L. S. Consul-General Robert P. Skinner, September 18, 1902. 
easily digested and is particularly well adapted for the use of patients suffering from impaired digestion. $a$

The copra industry is becoming more important year by year. Thus far very little copra has found its way to the United States, but coconut oil is imported for various purposes, especially for soap making. The chief sources of coconut oil in this country are Ceylon and the Madras Presidency, India, especially the district of Cochin, where it is the principal product. Soap made from coconut oil is more soluble in salt water than that made from other oils or fats, and is consequently much used on seagoing vessels. One objectionable feature of soaps made from this oil is the disagreeable rancid odor which they usually leave on the skin after washing with them. The most serious difficulty encountered by soap makers is the elimination of fatty acids contained in it. To remove these the oil is heated with lye, an emulsion is made, and the oil extracted from the mixture by means of a separator and receiver. $b$ Coconut oil alone is not usually employed in soap making, but is added to other oils for the purpose of producing quickly solidifying soaps containing a large proportion of water. $c$

FIBER.

Coir, or the fiber of the husk of the coconut, is another product of commercial importance. It is imported into England and America in the form of coir yarn, coir fiber, coir rope, and bristle fiber, and is used principally in manufacturing matting and brushes. $d$ In Guam no effort is made to utilize it, and hundreds of tons go to waste each year. Fiber suitable for cordage must be taken from husks or nuts not yet thoroughly ripe, but the coarser, harder fiber of ripe nuts could be used for brushes. In Samoa, where the fiber plays so important a part in the economy of the natives, a particular variety ('ena, or niu afa) occurs having long nuts with fiber especially adapted for making sinnet (afa). This variety is rare, and is highly valued by the natives. $e$ The sources of the best coir of commerce are the Laccadive Islands and the neighboring district of Cochin, on the Malabar coast of British India. This coir is known commercially as Cochin or Madras coir. The primitive way of preparing the fiber is to soak the husks thoroughly in salt water, beat them with heavy wooden mallets, rub them between the hands, and remove the coir by hand. It is then twisted by hand into two-stranded yarns. $f$ This process has been replaced in many districts by improved methods, in which the fiber is extracted from the husk, either wet or dry, by means of machines. The husks are crushed in a mill, consisting of two adjustable fluted iron rollers. The pressure here exerted flattens them and prepares them for the "breaking down," or extraction of the fiber, performed in an "extractor" composed essentially of a drum or cylinder whose periphery is coated with steel teeth that catch in the fiber and tear it from the husk. The machine is covered with a wooden case to prevent the fiber being scattered. It is then "willowed" or cleaned, graded, and baled for shipment. $g$

PRODUCTION.

Nearly every family of Guam has its coconut plantation. The best sites are the lowlands, especially the sandy beaches of the west shore. The principal coconut

$a$ Kew Bulletin, No. 46, p. 235, 1890.

$b$ See Andés, Vegetable Fats and Oils, trans., pp. 203 and 244, fig. 76, 1897.

$c$ See Richardson and Watts, Chemical Technology, ed. 2, vol. 1, pt. 3, p. 683, 1863.

$a$ See monthly circulars of Ide \& Christie, fiber, esparto, and general produce brokers, 72 Mark lane, London, E. C., in which prices are quoted together with statistics regarding importations, etc.

eSee Powell, Thomas, On various Samoan plants and their vernacular names, Seemann's Journal of Botany, vol. 6, p. 282, 1868.

$f$ Watt, Economic Products of India, vol. 2, pp. 428-429, 1889,

$g$ Spon's Encyclopædia, vol. 1, p. 940, 1882.

$9773-05-16$ 
planters on the island are the Western Commercial Company, having its plantation in the district of Upe, in the northern part of the island (10,000 to 12,000 trees); Don Vicente Herrero, in Orunao, Retiyan, and Lalô (7,000 to 8,000 trees); the Japanese Oyama, in Hilaân (6,000 to 7,000 trees); Don Luis Torres, alias Cortez, in Gokñga and Lupog (5,000 to 6,000 trees), and Don José Dueñas Evarista, in Sinagósô (6,000 to 7,000 trees). There are also good plantations in the district of Yoña and in the vicinity of Agat. Though coconuts do not thrive in swampy places as a rule, yet there are good plantations near San Antonio, across the river from Agaña, and near Punta Piti, where the trees grow on hummocks almost on a level with the water's surface when the rivers are unobstructed. Coconuts are fond of sunshine and ocean breezes; but it is evident that they can not stand exposure to repeated hurricanes, from the fact that on the fine stretches of sandy beach along the east or windward coast of the southern portion of the island not a coconut tree is found, while near by, in more sheltered sites of Pago and the valleys of Ilig and Talofôfô, fine groves are met with. Great damage to the coconuts of the island is caused by baguios, or hurricanes. Both ripe and green fruits are whipped off and the leaves are destroyed. It is from the axils of the petioles of the old leaves that the young flower clusters issue; and when the leaves are killed these become aborted and it takes at least two years for the tree to recover. During the year which followed the hurricane of 1900 not a single ton of copra was exported from Guam. $a$

All enterprising natives on the island are now planting coconut trees, as there is a ready sale for all the copra that can be produced. Clearings are made in the forest, the undergrowth removed, and the tree trunks gradually gotten rid of with the aid of fire. (Pl. XXIII.) This requires hard work, and few white men coming to the island are either able or willing to clear land for themselves. Land taro and bananas may then be planted until the stumps are removed, after which coconuts are planted in regular rows. As the natives have plantations of their own they naturally prefer to work for themselves rather than for another; so that it is almost impossible to obtain laborers on the island. Moreover, the natives will not part with a coconut grove in good bearing condition or a thriving young plantation at any price. A fairly good yield for a coconut palm is 25 to 30 pounds of copra a year, though there are many trees on the island which produce double this amount. In the process of clearing, taro, yams, and bananas are often planted in the new ground. The nuts selected for seed are taken neither from very young nor very old trees, but from trees at least 15 years old. Many of the natives pay no attention to seed selection, but plant sprouting nuts indiscriminately; others, however, realize the advantage which results from planting seed taken from trees yielding the greatest amount of copra. The tendency is to plant large nuts; but these may have been produced by young trees or trees bearing few nuts and yielding less copra than trees bearing nuts of smaller size. Nuts selected for seed should be lowered to the ground, not thrown down or dropped. Nursery planting is not practiced in Guam. The ripe nuts are simply collected in piles in the shade of trees or in the corners of inclosures and left to sprout, without further care. When the sprouts are about $60 \mathrm{~cm}$. high they are ready for permanent planting. If the roots have in the meantime penetrated the ground and are broken off in removing the nuts, they should be neatly cut off with a sharp knife, so as not to leave ragged ends.

It is the practice in Guam to plant coconuts in rows 5 to 6 meters apart, but this is too close. From 7 to 10 meters is a good distance. Holes about $60 \mathrm{~cm}$. deep are first dug, and they are sometimes arranged so that the holes in one row will be opposite the intervals of the next. On some plantations coffee, cacao, or bananas are planted between the rows, but this custom is not recommended. The evil effects of crowd-

a See official report of Governor Seaton Schroeder to the Secretary of the Navy, 1901. 
ing are shown on the plantation of Dona Rufina Quítugua, in the district of Matáguag, while the benefits resulting from plenty of room and of cultivation of the ground are shown in that of Manuel Matanane, in the district of Yigo, where originally rows of cacao were planted alternately with those of coconuts. The cacao dir not thrive and was removed, but the coconuts grew with remarkable rapidity. The natives say that the trees are too far apart, but the fact that many of them began to bear when 3 years old, while in other good localities they do not bear until 4,5 , or 6 years old, speaks for itself. On the mesa, or table-land, coconut trees frequently are 8 to 10 years, or even 15 years, old before they begin to bear. In Yigo and Santa Rosa they begin to bear usually when 5 or 6 years old, and in Yona when 7 or 8 years. A coconut palm is in its best bearing condition from the age of 10 years on. It will continue to bear until 80 years old. Catch crops may be planted between the rows while the trees are young. These are far less exhausting than the weeds which would otherwise cover the ground, and the soil is benefited by the cultivation, especially if nitrogen-storing leguminous crops are grown. The common practice in Guam is to keep off the weeds from an area about 6 feet in radius about the trees by means of a thrust-hoe (fusiño or foziño), and throughout the rest of the plantation to cut the undergrowth from time to time with a machete. Attention is called by Lyon $a$ to the excellent methods of coconut cultivation practiced by the German colonists in German East Africa and in the South Pacific islands and by the French in Congo and Madagascar, who practice modern orchard methods. Mr. Lyon recommends planting coconuts at distances of not less than 9 meters, and, in good soils, preferably 9.5 meters. The former distance will allow for 123 and the latter for 111 trees to the hectare. He recommends annual plowing of the plantation and the cultivation of green manures and crops to keep up the fertility of the land. In Guam plowing is impracticable in many localities, owing to the thinness of the soil covering the coral substratum; and the prevailing system of keeping the plantations clear of weeds by means of the thrust hoe, by which the roots can not possibly be injured, seems to be a good one. Manuring is never practiced in Guam, and it is to this fact that the absence of the beetles which, in their larval stage, are so injurious to coconuts in other countries, should be attributed.

The boundaries between plantations on the island of Guam are usually indicated by lines of coconut trees, either single or double. It is the common practice to cut notches in the trunks to facilitate climbing. This practice is condemned by many writers, but in Guam the trees do not appear to be injured thereby. Sometimes a hole is cut near the base of the trunk to serve as a water reservoir. This seems to cause decay and should not be permitted. As a rule the natives do not plant coconut trees near their dwellings for fear of accidents during hurricanes. Every family selects one or two trees for a supply of toddy, and many of them keep small groves to furnish thatch for their houses, which must be renewed at intervals of about three years. The extraction of tuba does not injure the trees in any way, but the cutting of leaves causes injuries from which it takes years to recover. The inflorescence which forms in the axils of old leaves becomes aborted when these leaves are cut off. Young plantations are frequently injured by the deer with which the island abounds, and care must be taken to prevent cattle from entering them. To keep out the deer the natives simply inclose a field with a ribbon of pariti bark ( $P$. tiliacenm), through which they say the deer will not pass. Coconut trees are free from disease in Guam, and very little harm is done to them by insects.

REFERENCES:

Cocos nucifera L. Sp. Pl. 2:1188. 1753.

Codiaeum variegatum. See Phyllaurea variegata.

a Lyon, The cocoanut, etc. Bureau of Agr. [Philippines], Bull. No. 8, 1903. 
Coelococcus amicarum.

Caroline ivory-nut palm. Plate xly.

Family Phoenicaceae.

Local Nayes. - Och (Ponape); Palma de Marfil (Spanish); Steinnuss-palme (German).

A pinnate-leaved palm introduced into Guam from the Caroline Islands. The nuts are of an ivory-like texture and are exported from the Carolines to Germany for button making. The spheroid fruit, about 7 centimeters long and 8 centimeters in diameter, has a reddish brown, glossy, scaly shell. (Pl. XLVI.) The surface of the seed is glossy, black, and thickly striped, but not furrowed. The allied species of the Solomon Islands ( C. solomonensis) has a straw-colored shell, and that of C. vitiensis of Fiji, which is not used in the arts, is yellow. The inflorescence of this genus has not yet been described. In some of the Solomon Islands the natives prepare sago from the pith of the species growing there. It is said to keep well and not to be injured by salt water, so that it is a valuable food staple to take with them on their canoe voyages. $a$

ReFerences:

Coelococcus amicarum (Wendl.).

Sagus amicarum Wendl. Bot. Zeit. 36:115. 1878.

Coelococcus carolinensis Dingl. Bot. Centralbl. 32: 349.1887.

Coenogonium. See Lichenes.

Coffea arabica.

Coffee. Plate Xxx.

Family Rubiaceae.

Local names.-Káfe (Guam); Kahaua (Mindanao, Lolo, Philippines).

A shrub with glossy green leaves, fragrant, white, jasmine-like flowers and red berries, like small cherries, which contain two seeds, commonly called coffee. The leaves are opposite, rarely in threes, about $15 \mathrm{~cm}$. long by $6.5 \mathrm{~cm}$. broad, with wavy edges, and a long narrow point; flowers of short duration, with the fragrance of a tuberose, in dense clusters at the bases of the leaves; calyx tube short, limb 5-parted, persistent; corolla tubular, limb salver-shaped, 5-parted; stamens 5, fixed around the top of the tube and protrulling beyond it; ovary 2-celled; style filiform, smooth, 2-cleft; ovules 1 in each cell, peltately attached to the septum of the cell; seeds plano-convex, grooved ventrally.

In Guam coffee is one of the commonest plants, growing about most of the dwelling houses as lilac bushes grow in America, and nearly every family has its cultivated patch The climate and soil of the island seem well adapted to it, and it produces fruit abundantly from the level of the sera to the tops of some of the highest hills. Plants are obtained by planting seed at a depth of about $4 \mathrm{~cm}$. in beds, or by taking up seedling plants from under cultivated trees, where the seeds readily germinate without attention. They are easily transplanted, differing in this respect from the seedlings of cacao, which are often killed in transplanting. Seeds fresh from the pulp should be planted in the sementeras (nurseries) about $8 \mathrm{~cm}$. apart, in rows. In preparing the ground it is thoroughly pulverized and dry-brush is burned over it shortly after the weeds begin to sprout. This saves a great deal of subsequent weeding. Little watering is necessary in Guam. In transplanting crowding is avoided. The plants are set out in straight rows at a distance of from 1.5 to $2.5 \mathrm{~m}$. apart. On hillsides they may be closer, about 1.5 by $1.5 \mathrm{~m}$. Coffee trees planted too close together lose the use of their lower branches, which become interlaced and shade one another, so that only the top branches continue to grow and bear fruit. If the coffee is planted in newly cleared land the brush is either left to decay between the rows or burned. In places where the soil is shallow above the coral rock, holes are made and filled with good earth brought from the forest. The best time for trans-

a See Sadebeck, Die Kulturgewächse, etc., pp. 16 to 19, figs. 10, A, B, C, 1899; Guppy, Solomon Islands, p. 82, 1887; Tarburg, Berichte der Deutsch. Bot. Gesell., 1896, p. 133. 


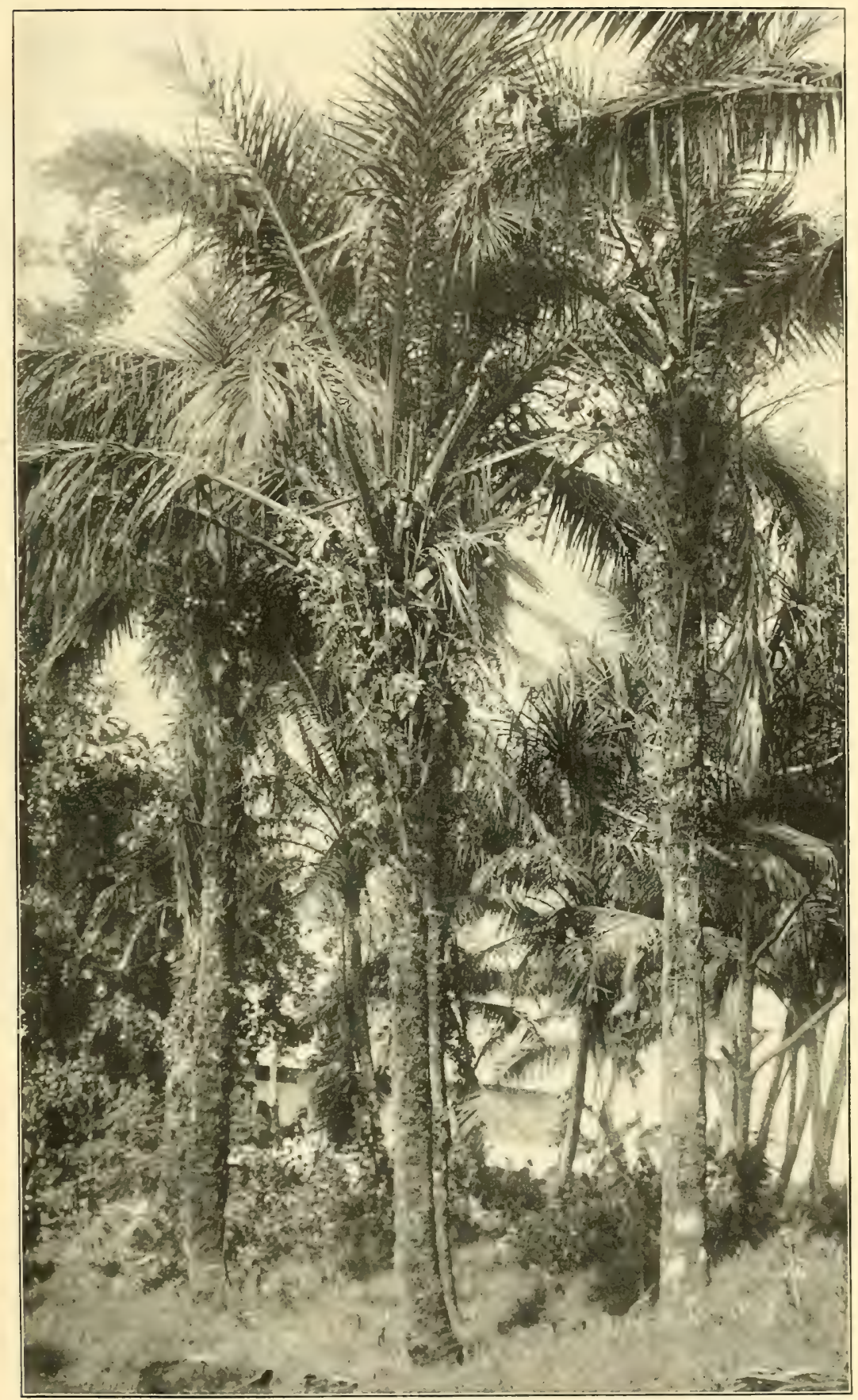

Coelococcus amicarum, the Caroline Island IVory Nut Palm. 



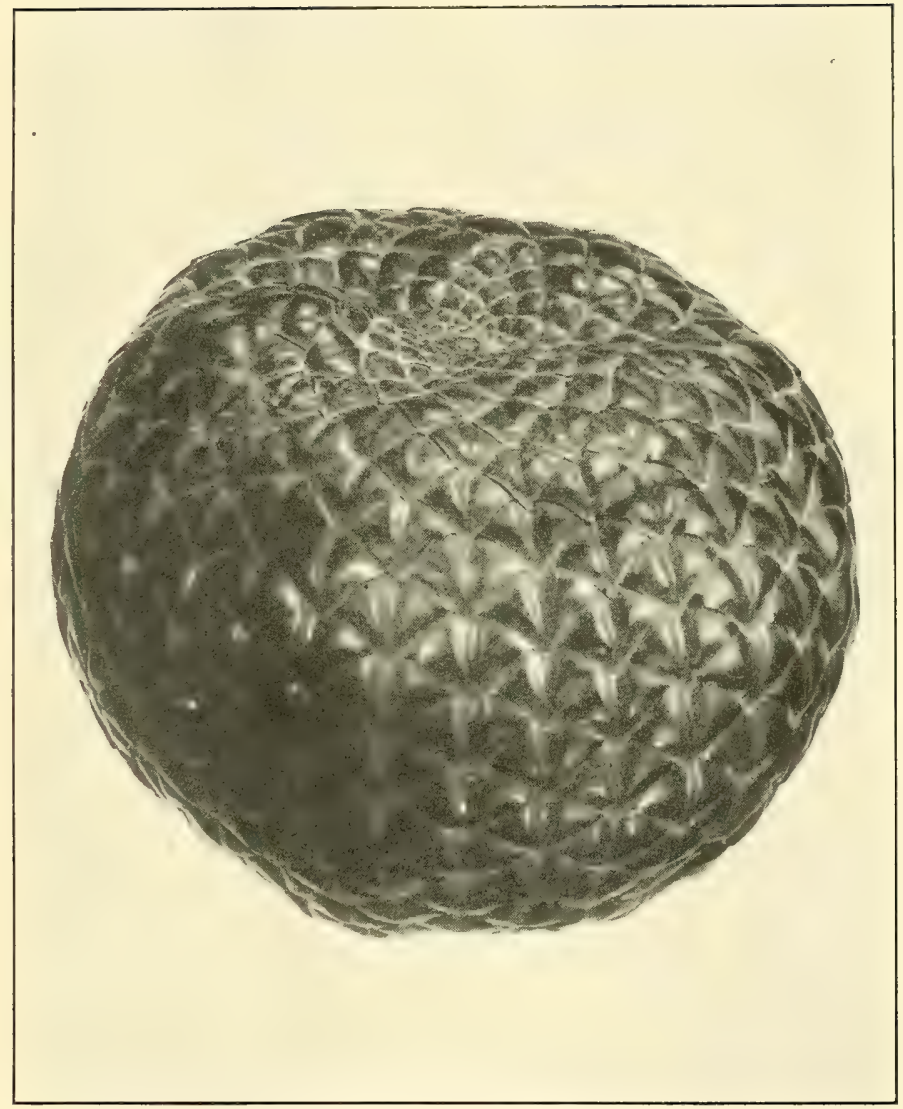

THE IVory Nut (Coelococcus amicarum). Slightly Reduced. 

planting is at the beginning of the rainy season. In moving them the roots should not be exposed to the sun. The plants are shaded at first by sections of coconut leaves stuck in the ground in a slanting direction. If rains are not sufficiently frequent after planting, the plants are watered every evening. In Guam it is not usual to plant shade trees to protect coffee. Sometimes the young plants are shaded by alternating rows of bananas, which easily take root and grow quickly. These are cut down when the plants are well established, as the mature coffee plant is a sun lover and becomes spindling in the shade. Catch crops of taro or maize may also be planted for the

st two years. As with other plants, the weeds must be kept down. They are aliowed to lie on the ground and rot, so as to enrich it. Weeding is accomplished by the fosiño, or thrust-hoe, an expert weeder being able to cover an area $1.5 \mathrm{~m}$. long and the width of his hoe at every thrust. In order that the trees may not grow too tall for convenience in gathering the berries, they are topped after reaching a suitable height. This causes them to spread out their branches and offers a smaller target for the heavy winds which sometimes prevail. The plants are kept free from shoots or suckers sprouting out from their stems, which are removed when young.

In Guam coffee seems to be remarkably free from disease. The berries are sometimes eaten by rats, which infest the island; but these animals are not so injurious to coffee as they are to cacao, of which they are immoderately fond.

As soon as the berries are ripe they are gathered. In Guam the whole family turns out to pick berries, and there is more or less jollification, as on the occasion of a picnic. The removing of the flesh from the seed or pulping is accomplished by band, and the sticky, mucilaginous material surrounding the seeds is removed by washing, after which the coffee is spread out on mats to dry in the sun. In this condition it is covered with a thin membrane or hull, which can be removed at will by pounding in large wooden mortars with wooden pestles. The coffee should be thoroughly dry before attempting to take off this hull. The chaff is gotten rid of by winnowing, which consists in pouring the seed from one receptacle to another in a current of wind.

Enough coffee is not produced in Guam for exportation; indeed, there is scarcely enough for the use of the natives, all of whom are coffee drinkers. The product is of excellent quality. In preparing it the beans are roasted, as with us, and ground on a stone "metate" with a cylindrical "mano," like a tapering rolling-pin of stone. $a$

REFERENCES:

Coffea arabica L. Sp. Pl. 1:172. 1753.

\section{Coffea liberica.}

LIBERIAN COFFEE.

A few plants of Liberian coffee were introduced quite recently into Guam from the Honolulu botanical garden. When I left the island several of them were in a thriving condition on a ranch near Sinahaña.

\section{REFERENCES:}

Coffea liberica Hiern, Trans. Linn. Soc. II. 1: 171. t. 24. 1876.

Coffee, negro. See Cassia occidentalis.

Coffee senna. See Cassia occidentalis.

Cogon (Philippines). See under Xipheagrostis floridula.

Coix lacryma-jobi.

Family Poaceae.

Local names.-Lagrinas de San Pedro (Spanish); Alimodias (Philippines); Tömugi, Judsu-dama (Japan); Maniumiu, Samasama (Samoa); Acayacoyotl (Mexico); Camandula (Porto Rico).

This grass, which furnishes the seeds known as "Job's tears," is common in Guam. The seeds are very hard, smooth, glossy, and of a gray color. They are 1897.

a For a history of coffee and its culture see Nicholls, Tropical Agriculture, p. 91, 
strung into rosaries and, according to Padre Blanco, " yield a nutritious flour, which is fed to convalescents. In Japan they are pounded in a mortar and cleaned and used as meal and mochi. An infusion of the parched and ground grains, called "kosen" by the Japanese, is used instead of tea. $b$

REFERENCES:

Coix lacryma-jobi L. Sp. Pl. 2: 972. 1753.

Colales or Kulalis (Guam). See Adenanthera pavonina.

Colales (Kulalis) halom-tano (Guam). See Abrus abrus.

Coló or Koló (Philippines). See Artocarpus communis.

Colocasia antiquorum. See Caladium colocasia.

\section{Colubrina asiatica.}

Family Rhamnaceae.

Local names. - Gasôsô (Guam); Kabatiti, Uatitik (Philippines); Fisǒa (Samoa); Vuso levu (Fiji: "much-foam"); Tutu (Tahiti).

A glabrous shrub with alternate leaves and axillary clusters of small greenish flowers having a fleshy disk in the calyx tube, suggesting the genus Euonymus or Ceanothus. Leaves $5 \mathrm{~cm}$. long by $2.5 \mathrm{~cm}$. wide, ovate, subacuminate, crenate-serrate, glabrous, membranous, 3-nerved at the base, the midrib pinnately branched; flowers growing in very short axillary cymes; calyx 5-parted, tube hemispherical; petals 5 , clawed, springing from the margin of the disk, hooded; stamens 5; disk fleshy, filling the calyx tube; ovary sunk in the disk and confluent with it, 3-celled, the cells 1-seeded, tardily dehiscent.

This plant is widely spread in Polynesia and is found in India, Ceylon, Java, Borneo, New Guinea, Australia, and southwest Africa. In Samoa and in Fiji the leaves are used for washing. They form a lather in water like soap. The vernacular name in Fiji signifies "much lather" or "big foam." The special use to which it is devoted in Samoa is the cleansing and bleaching of the white shaggy mats which the natives make of the fiber of an urticaceous plant, Cypholophus macrocephalus. The natives of Guam do not make use of it except for medicine, nor is it included by Watt in his list of the useful plants of India.

REFERENCES:

Colubrina asiatica (L.) Brongn. Ann. Se. Nat. I. 10: 369. 1827.

Ceanothus asiaticus L. Sp. Pl. 1: 196. 1753.

\section{Combretaceae.}

Mrrobalan FAMiLy.

This family is represented in Guam by the Malabar almond (Terminalia catappa) and the red-flowered mangrove (Lumnitzera littorea).

\section{Commelinaceae.}

To this family belong Commelina benghalensis and Commelina nudifora, creeping plants with small 3-petaled blue flowers from spathe-like bracts, and Zygomenes crisluta, with scorpioid cymes of blue flowers inclosed in large falcate, imbricating bracts. Commelina benghalensis.

DewFlower. DAYFlower.

Family Commelinaceae.

Local Names. - Anagálide azul (Spanish); Aligbañgon (Philippines).

A pubescent plant with stems 60 to $90 \mathrm{~cm}$. long, dichotomonsly branched from the base upward, creeping and rooting below; leaves short-petioled, 2.5 to $7.5 \mathrm{~cm}$. by 1 to $3.5 \mathrm{~cm}$., ovate or chblong, obtuse, pubescent or villous on both surfaces, unequal at base, cordate, rounded, or cuneate, the veins subparallel, 7 to 11 pairs; inflorescence inclosed in a spathe; spathes 1 to 3 together, short-peduncled, funnel-shaped or top-shaped, auricled on one side, pubescent or hirsute; upper cyme branched, 2 or 3 -flowered, lower 1 or 2 -flowered or without flowers; sepals 3, small, oblong,

a Flora de Filipinas, 689. 1837.

$b$ Agriculture Society of Japan, Useful Plants of Japan, p. 5. 1895. 
pubescent; petals 3 , two large, orbicular or transversely oblong, clawed, the third smaller, subsessile; stamens 3 , hypogynous, filaments slender, naked; anthers oblong, one larger than the others; staminodes 2 or 3 , like the stamens, but with deformed cruciform anthers; ovary 3-celled, 2 cells 2-ovuled, one 1-ovuler; capsule $6 \mathrm{~mm}$. long, hidden in the spathe by the decurving of the pedicel after flowering, pyriform, membranous, 5-seeded; seeds oblong, closely pitted.

Common, growing among grass; flowers bright blue, emerging from the spathe one by one. Widely spread in tropical Asia and Africa. Called in the Philippines by the Spanish name "anagálide azul."

REFERENCES:

Commelina benghalensis L. Sp. Pl, 1:41.1753.

\section{Commelina nudiflora.}

Dewflower. DAYFlower.

LOCAL NAMES.-Anagálide azul (Spanish); Aligbañgon (Philippines).

Similar to the preceding, but with the flower spathes ovate or ovate-lanceolate and acute; branches prostrate or subscandent, rooting at the rather distant nodes, tips ascending; leaves 3.5 to 7.5 by 1 to $1.5 \mathrm{~cm}$.; sessile, lanceolate or ovate-lanceolate, acute or acuminate, glabrous or puberulous, ciliate, sheath 1 to $2.5 \mathrm{~cm}$. long, loose, glabrous; spathes glabrous or pubescent, base cordate, lobes rounded; cymes 1 to few-flowered, shortly pedicelled; flowers 1 to $1.5 \mathrm{~cm}$. broad; two larger petals orbicular or cordate, third petal smaller subsessile; ovary 3-celled; capsule $6 \mathrm{~mm}$. long, broadly oblong, acuminate, coriaceous, 5-seeded; seeds oblong-cylindric, tubercled and reticulate brown.

A low weed growing in damp places among the grass; good forage; flowers of a bright cobalt blue.

REFERENCES:

Commelina nudiflora L. Sp. Pl. 1: 41. 1753.

Compositae. See Asteraceae.

Condol or Condor (Guam).

Local name for the wax gourd, Benincasa cerifera.

Condol (Philippines).

Name applied to several kinds of squash (Cucurbita).

Conferva. See under Algæ.

Convolvulaceae.

MORNING-GLORY FAMILY.

Among the Convolvulaceae growing on the island of Guam are the indigenous "alalag" ( Argyreia tiliaefolia), the lavender-colored flowers of which, called "abubo," are strung into necklaces by children; Ipomoea choisiana, a trailing plant with deeply cordate, denticulate leaves and purple flowers, growing on the strand and reappearing in the upper sabanas; Ipomoea pes-caprae, the "goat's-foot convolvulus," a plant with purple flowers and fleshy leaves notched at the apex growing on sandy beaches; Ipomoea mariannensis, with purple flowers; the "fofgu," with blue flowers, which turn purple in drying (Ipomoea congesta and Pharbitis hederacea), and the whiteflowered Operculina peltata. Among the introduced species are several varieties of the sweet potato (Ipomoea batutas) from Hawaii and from tropical America, and the common cypress vine (Quamoclit quamoclit), called by the natives "angel's hair" (cabello del angel), which has escaped from cultivation and grows in open places.

Convolvulus batatas L: Same as Ipomoea batatas.

Convolvulus coeruleus Spreng. Same as Pharbitis hederacea.

Convolvulus congestus Spreng. Same as Ipomoea congesta.

Convolvulus denticulatus Desr. Same as Ipomoea choisiana.

Convolvulus hederaceus L. Same as Pharbitis hederacea.

Convolvulus mariannensis Gaud. Same as Ipomoea mariannensis. 
Convolvulus nil L. Same as Pharbitis hederacea.

Convolvulus maritimus Desr. Same as Ipomoea pes-caprae.

Convolvulus peltatus L. Same as Operculina peltata.

Convolvulus pes-caprae L. Same as Ipomoea pes-caprae.

Convolvulus tiliaefolius Desr. Same as Argyreia tiliaefolia.

Convolvulus trilobatus Gaud. Same as Ipomoea congesta and Ipomoea mariannensis.

Coquillo (Panama). See Jatropha curcas.

Coraceae. See under Lichenes.

Coral plant. See Jatropha multifida.

Coral tree, East Indian. See Erythrina indica.

Coral-bead vine. See Abrus abrus.

Coral-bean tree. See Adenanthera pavonina.

Coralillo (Cuba). See Antigonon leptopus.

Corallopsis. See under Algæ.

Corazon (Porto Rico). See Annona reticulata.

\section{Corchorus.}

BROOMWEED.

Family Tiliaceae.

Local Names.-Masigsig lahe (Guam).

Corchorus tomentosus, a plant of Japanese origin, was included in Gaudichaud's list of Guam plants, but the name probably refers to Triumfetta tomentosa, or-some allied species of that genus. Corchorus differs from Triumfetta in having its fruit in the form of a 2 to 5 -celled capsule, the fruit of Triumfetta being indeniscent and spiny. Flowers 1 to 3 together, small, yellow, opposite the leaves; sepals 5 , distinct; petals 5 , distinct; stamens numerous, distinct; ovary 2 to 5 -celled, with numerous ovules; capsule loculicidal, 2 to 5 -valverl, with numerous seeds. C. acutangulus, having the capsule elongated, glabrous, strongly 3 -winged and 6 -angled, leaves ovate, rounded at base, acute, serrate, the 2 lowest teeth often prolonged into filiform tails, is a widespread tropical weed, found in the Solomon Islands and, possibly, in Guam. C. torresiums, collected by Gaudichaud on Rota, the island next to Guam, is not further known, and may prove to be identical with some other species.

Cordia subcordata.

Kou.

Family Boraginaceae.

Local Numes.-Banalo (Philippines); Kou (Hawaian Islands); Tou (Tahiti, Rarotonga, Marquesas); Nawanawa (Fiji); Tauanave (Samoa); Ikoik (Carolines).

A tree growing near the coast with large ovate leaves and orange or reddish funnel-shaped flowers. Leaves alternate, petioled, 7.5 to $15 \mathrm{~cm}$. long, obscurely 3-nerved, base ruunded or subcordate, glabrous; flowers in short terminal and lateral few-flowerel corymbs, nearly glabrous, polygamous; hermaphrodite corymbs fewerflowered than the male; calyx $12.5 \mathrm{~mm}$. long, 3 to 6 -parted, the teeth short, triangular, villous within; corolla tuhe $1.5 \mathrm{~cm}$. long, 5 to 7 -lobed, one lobe external, the lobes $15 \mathrm{~mm}$. long, rounded; stamens usually 6 ; anthers shortly exserted; ovary t-celled, glabrous; style terminal, long, 2-parted, its branches again 2-parted, linearspathulate; cells 1-ovuled; fruit an ellipsoid, acute, usually 1-seeded drupe, $2.5 \mathrm{~cm}$. long; seed coarsely muricate, subspinose.

Not common in Guam, several trees growing near the village of Agat. In Hawaii it is called "kou," etrmolugically the same as "tou" of Tahiti. The wood is rather soft, but durable. It is much prizer hy the natives of Hawaii, who make of it cups and poi calabashes, showing wayy hands of light and dark color when polished. The 
species ranges from the East Indies, Zanzibar, and Madagascar across the Pacific to Hawaii. Doctor Hillebrand thinks that its distribution throughout Polynesia has been due to human agency. $a$

REFERENCES:

Cordia subcordata Lam. Illustr. 1: 421. no. 1899. 1791.

\section{Cordyline hyacinthoides.}

Bow-STRING HEMP.

Family Liliaceae.

Local Names.-Tigre (Guam, Philippines)

A stemless plant with succulent, thick, fibrous, sword-shaped leaves, having a sheathing base and a straight spine at the apex. It takes its local name from the variegated coloration of the leaves. Flowers inconspicuous, greenish-white, disposed in the form of a raceme rising from the center.

The leaves yield an excellent, soft, silky, elastic fiber, from which in ancient times the Hindus made their bowstrings. In Guam the plant is cultivated for ornament, many of the natives having it growing in their gardens and in pots, but not otherwise utilized. In Manila a double line of it borders the walk approaching the palace.

REFERENCES:

Cordyline hyacinthoides (L.)

Aloe hyacinthoides L. Sp. Pl. 1: 321.1753.

Aloe hyacinthoides zeylanica L. Sp. Pl. 1: 321. 1753.

Aletris hyacinthoides zeylanica L. Sp. Pl. ed. 2. 1: 456. 1762.

Sanseviera zeylanica Willd. Sp. PI. 2: 159. 1799.

The earliest post-Linnæan use of the name Cordyline was by Adanson, Fam. Pl. 2: $54,543.1763$, who gives Royen as the authority for the name, but apparently does not use it in the same sense in which it was employed by that author. Royen included in his genus Cordyline two species of the Linnxean genus Yucca and a third cited by Linnæus under the latter's Asparagus draco, while the specific references given by Adanson, "Katukapel, H. M. 11:t. 42, Aloe Comm. H. 2. t. 20, 26, Pluk. t. 256. f. 5., and Lin. Sp. 321. No. 4.," are associable by citation with the species named by Linnæus Aloe hyacinthoides, or with one of its subspecies. The modern use of the name, however, appears to be in the sense in which it was mentioned by Jussieu, Gen. Pl. 41. 1789, and does not include any of the species included in it by either Royen or Adanson. "Cordyline" is accordingly here used as the name of the genus for which it was first properly published after 1753.-W. F. WIGHT.

Cordyline terminalis Kunth. See Taetsia terminalis.

Corkwood. See Pariti tiliaceum.

Cormigonus mariannensis.

TORCHWOOD.

Family Rubiaceae.

LOCAL NAMEs. -Gáusâli (Guam).

A small tree growing in rocky places, and especially abundant on the Peninsula of Orote and the island of Apapa, bearing a profusion of white trumpet-shaped flowers, appearing from a distance somewhat like morning-glories, but 4-parted. The wood ignites easily and is used for torches.

REFERENCES:

Cormigonus mariannense (Brongn.)

Bikkia mariannensis Brongn. Bull. Soc. Bot. Fr. 13: 42.1866.

The name Cormigonus Raf. 1820 is several years earlier than Bikkia.

Coromandel gooseberry. See Averrhoa carambola.

Cotorrera (Porto Rico). See Heliotropum indicum.

Cotorrera de la playa (Porto Rico). See Heliotropum curassavicum.

Cotton. See Gossypium arboreum and G. barbadense. 
Cotton-tree, silk. See Ceiba pentandra.

Cowhage or Cowitch plant. See Stizolobium pruriens.

Cowpea, twining (United States). See Vigna sinensis.

Crab's-eye seeds (West Indies). See Abrus abrus.

\section{Cracca mariana.}

GoAT'S-RUe.

Family Fabaceae.

An undershrub. Stem erect, terete, villous; leaves pinnate, with 4 pairs of leaflets, sessile; leaflets oblong, smooth above, silky-silvery beneath; stipules lanceolate, elongate, hairy; axillary flowers close together, subsessile, the terminal ones subracemose; pods narrow, upright, velvety-hairy, 10 to 12 -seeded. Type specimen from Marianne Islands, its leaflets nearly $5 \mathrm{~cm}$. long by 8 to $12 \mathrm{~mm}$. wide. Flowers not observed.

REFERENCES:

Cracca mariana (DC.) Kuntze, Rev. Gen. 1: 175. 1891.

Tephrosia mariana DC. Prod. 2: 253. 1825.

Crape myrtle. See Lagerstroemia indica.

Crescentia alata.

Crossleaf, Calabash tree.

Family Bignoniaceae.

Local Names.-Híkara (Guam); Jícara (Spanish, Mexico); Hojacruz (Manila); Xicali (Aztec).

A small tree with many wide-spreading branches and trifoliolate leaves with winged petiole, bearing gourd-like fruit upon the trunk and larger limbs. Branches angled, without thorns; leaves growing in threes from the axil, the middle one petiolate, 3 -foliate, the lateral ones simple, smaller, sessile; petiole of the 3 -foliolate leaf broadly winged, forming together with the 3 leaflets a cross-shaped leaf; leaflets linear-lanceolate or cuneate with crenate apex, membranous, sometimes 4 or 5 from end of petiole, but these probably abnormal; bark thin, greenish; flowers developing from buds on the trunk and the older limbs and branches, the tree therefore "cauliflorous," as in the case of Theobroma cacao and Averrhoa carambola. Flowers large, fleshy, purplish, usually solitary, with a very short pedicel; calyx 2-parted, deciduous; corolla campanulate, open-mouthed, tube curved, with a fold in the throat; limb unequally 5-parted; stamens 4, didymous; ovary 1-celled, stigma 2lamellate; fruit globose, hard, indehiscent, many-seeded, in Guam about $10 \mathrm{~cm}$. in diameter.

This species, first described from Acapulco, Mexico, has been introduced into the Philippines and Guam. It was described by Padre Blanco as Crescentia trifolia. $b$ "They call it 'cross-leaf' (hoja de cruz)," he says, "because the three leaflets with the winged petiole form a cross." Its spreading branches form good perches for fowls, and in building a rancho a site is often selected near one of these trees, so that it may serve for this purpose. The fruit is too small to serve as calabashes, and it is not used in Guam.

REFERENCES:

Crescentia alata H. B. K. 'Nov. Gen. \& Sp. 3: 158. 1818.

Crescentia trifolia Blanco. Same as Crescentia alata.

" Cauliflorie, d. h. Blüthenbildung am alten Holze in den immerfeuchten tropischen Wäldern nicht selten. Sie kommt dadurch zu Stande, dass ruhende axilläre Knospen sich nach mehreren bis vielen Jahren weiter entwickeln und die Rinde durchbrechend, ihre Blüthen frei entfalten. (Schimper, Pflanzen-geographie auf physiologischer Grundlage, p. 360, 1898.)

b Blanco, Flora de Filipinas, 489-490, 1837. 
Crinum asiaticum.

Antidote LiLY.

Family Amaryllidaceae.

Local Names.-Piga-palayi (Guam): Bakong (Philippines); Lautalatalo, Lautamatama (Samoa).

A lily-like plant with large white flowers and linear-lanceolate leaves, growing in sandy places near the sea. Bulb large, narrowed into a neck which is clothed with old leaf sheaths; leaves 90 to $150 \mathrm{~cm}$. long and 12.5 to $20 \mathrm{~cm}$. wide, shortly acuminate, flat, narrowed into the sheathing base; flower scapes rising from the axils of the old leaves, 45 to $90 \mathrm{~cm}$. long, compressed; bracts 2, spathiform, papery; bracteoles filiform; flowers growing in umbels of 10 to 50, fragrant at night; pedicels short; perianth tube 7.5 to $10 \mathrm{~cm}$. long, cylindric, slender, the segments linear, recurved; filaments slender; anthers reddish; fruit subglobose, beaked by fleshy base of perianth, usually 1 -seeded, rarely 2 -seeded. A widely spread strand plant. The large spongy, tuber-like seed of this species was collected in the drift on the strand of one of the Solomon Islands by Doctor Guppy, having evidently been carried there by ocean currents.

The bulb is bruised and the expressed juice used as an emetic. In some countries the bulb is chewed as an antidote for wounds of poisoned arrows and poisonous reptiles, and also as a remedy for sickness caused by eating poisonous fish. $a$

REFERENCES:

Crinum asiaticum L. Sp. Pl. 1: 292. 1753.

Crossleaf. See Crescentia alata.

Crotalaria quinquefolia.

Rattlebox. Rattlepod.

Family Fabaceae.

Local NAMes.-Cascabeles (Guam, Spanish).

An erect annual plant with 3 -foliate or 5-foliate leaves, yellow flowers, and inflated many-seeded pods. Leaflets subsessile, 2.5 to $3.5 \mathrm{~cm}$. long, oblong-linear, tapering to base, obtuse, thin, glabrous; flowers in very lax terminal racemes, bracts small, lanceolate, acuminate; calyx glabrous, segments narrowly triangular, acute; petals about twice the length of the calyx; pod oblong, glabrous, distinctly stalked, 30 to 40 -seeded.

A common weed in Guam. Widely distributed in the Tropics.

REFERENCES:

Crotalaria quinquefolia L. Sp. Pl. 2: 716. 1753.

Croton, variegated. See Phyllaurea variegata.

Cruciferae. See Brassicaceae.

Cuacuacohan (Philippines). See Abutilon indicum.

Cucumber. See Gardens.

Cucumis melo. Muskmelon. See Gardens.

Cucumis sativus. See Gardens.

Cucurbita cerifera. Same as Benincasa cerifera.

Cucurbita lagenaria L. Same as Lagenaria lagenaria.

Cucurbita maxima, C. pepo. Squashes and pumpkins. See under Gardens.

Cucurbitaceae.

Gourd FaMiLY.

Among the representatives of this family growing in Guam are Momordica charantia, Citrullus citrullus, Cucumis melo, C. satirus, Lagenaria lagenaria, Cucurbita maxima, C. pepo, and Benincasa cerifera.

Culasi or Kulasi (Philippines). See Lumnitzera littorea. 


\section{Cundeamar (Porto Rico). See Momordica charantia.}

Curcas purgans Medic. Same as Jatropha curcas.

\section{Curcuma longa.}

Family Zinziberaceae.

Local Names. - Mañgo (Guam); Añgo (Samoa); Thango (Fiji); Olena (Hawaii); Dilao (Philippines); Ukon, Kyō-ō (Japan); Azafran (Spanish); Yuquillo (Porto Rico).

A ginger-like, monocotyledonous plant, with long-petioled oblong leaves, rising from a fascicle of tuber-like roots, which differ in form, some being globose, others long and narrow. The ripe tubers yield the turmeric of commerce. Rootstocks perennial, stems annual; flowers in compound spikes with concave bracts; calyx tubular, 3-toothed; tube of corolla dilated above, with 5 of its lobes equal, middle one of inner row enlarged to a spreading lip; filament petaloid, 3-lobed at top, with a 2-spurred anther on the middle lobe; ovary 3-celled, many-ovuled; style filiform; stigma 2-lipped, the lips ciliate; capsule globose, membranous, finally 3-valved. Flower spikes crowned by a coma of enlarged pink bracts; flower bracts pale gı een, ovate; flowers pale yellow; leafy tuft 1.2 to 1.5 meters high.

This plant is widely spread in Polynesia. It grows wild in Guam, but is little used by the natives. In Fiji, Samoa, and other groups the natives used it to paint their bodies, and in Samoa it is used to paint siapo or bark cloth. In Japan its roots are collected in autumn and a yellow dye (turmeric) prepared from them. They are also used medicinally.

REFERENCES:

Curcuma longa L. Sp. Pl. $1: 2.1753$.

Custard-apple. See the species of Annona.

Custard-apple family. See Annonaceae.

Cyanopus pubescens. Same as Vernonia villosa.

Cyanotis cristata. See Zygomenes cristata.

Cyathea mariana Gaudich. Same as Alsophila haenkei. See under Ferns.

Cycadaceae.

CyCAD FAMILY.

The only representative of this family in Guam is Cycas circinalis. For the method of fecundation of the Cycads see p. 71.

Cycas circinalis.

East Indian Cycas. Plates viri, xiv.

Family Cycadaceae.

Local names.-Fadan, Fadang (Guam); Federico (Spanish); Bitogo, Pitogo, Patubo, (Philippines); Madu (Ceylon).

A low palm-like tree, with cylindrical trunk and a crown of glossy, fern-like, stiff, thick, pinnate leaves, bearing nuts which in their crude state are poisonous, but after having been macerated in water and cooked are used for food. Trunk clothed with the compacted woody bases of petioles, usually simple but often branching when the head has been cut off, or several new trunks springing up from the stump of an old one which has been cut down, sometimes the trunk bifurcated; besides the true leaves, modified leaves in the form of simple, short, sessile, subulate, woolly prophylla; true leaves 1.5 to 2.5 meters long, long-petioled; pinnules alternate, 25 to 30 $\mathrm{cm}$. long and quite narrow, linear-lanceolate, acuminate, subfalcate, midrib stout beneath, bright green, glabrous; petiole with short, deflexed spines near the base; inflorescence dioecious; the male inflorescence growing in the form of erect, woolly cones consisting of scales bearing globose pollen sacs on their under surface, the cone shortly peduncled and tipped with an upcurved spine; female inflorescence in the center of the crown of leaves, consisting of a tuft of spreading, buff, woolly, pinnatelynotched leaves (carpophylls), in the notches of whose margins the naked or uncovered ovules are placed; carpophylls about $30 \mathrm{~cm}$. long; ovules 3 to 5 pairs, borne 



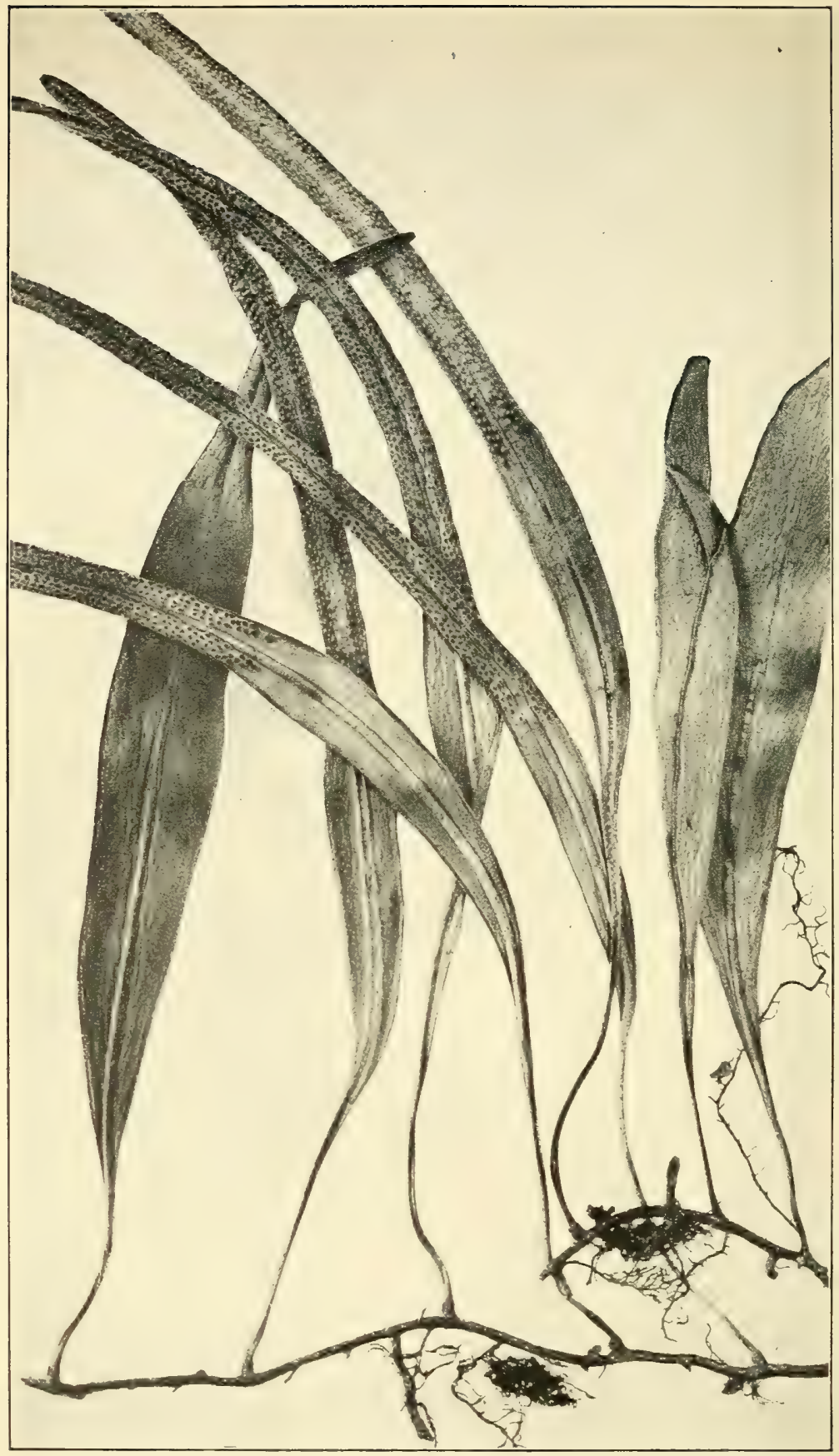

Cyclophorus adnascens, an Epiphytal fern. Natural Size, 
above the middle; seeds about the size of an English walnut, testa thinly fleshy, crustaceous within; endosperm copious, fleshy and farinaceous; embryo small, axile.

The cycads belong to a group of plants wonderfully interesting on account of the position they occupy intermediate between the flowering plants and cryptogams.

An account of their remarkable mode of fecundation has already been given. $a$

Both the fruit and the starchy pith of the trunks of many Cycadaceae are utilized for food. In Japan and in the Moluccas sago is obtained from the pith of Cycas revoluta and from that of Cycas circinalis; plants of the genus Encephalartos yield the "caffre-bread" of Africa; Dioon edule produces the "cabeza de chamal" of Mexico; in Central America, Florida, and the West Indies a kind of arrowroot is prepared from species of Zamia, and in Australia the nuts of Cycas media and of several species of Macrozamia are eaten after having been pounded, macerated for several days in water, and roasted. A gum resembling tragacanth exudes from wounds in Cycas circinalis and other Cycadaceae.

In Guam the seeds of Cycas circinalis, called "fadang" or "fadan" in the vernacular of the island, and "bitogo" or "federico" by the Filipinos and Spaniards, were an important food staple of the aboriginal inhabitants. As in other members of the family the trunk contains sago, but in Guam this has never been utilized. As prepared now by the natives, the endocarp of the seed is either grated or broken into small pieces and soaked for several days in water, which must be changed from time to time. When fresh the seeds are so poisonous that the water in which they are steeped is fatal to chickens if drunk by them. The poisonous principle contained in the seeds has not yet been ascertained. After having been thoroughly soaked the fadang is dried in the sun and put aside for use. In preparing it for food the natives grind it on a stone slab (metate) with a cylindrical stone rolling-pin (mano), mix it with water, make it into a thin cake, and bake it on a slab or griddle, like a tortilla of maize. If eaten continuously for any length of time it is injurious. The natives now resort to it only when maize is scarce, or in times of famine following hurricanes, when almost all other fruits are destroyed. In the old letter books at Agaña I find copies of reports of several Spanish governors to the captain-general of the Philippines, in which they complain of the unwholesomeness of this food and the injurious effects it has upon the natives. As far as my personal experience goes it is palatable and not injurious if eaten occasionally and in small quantities, although it is inferior to maize in every respect. Starch is sometimes made of the seed, but this is not very white and has a disagreeable odor. It is good for paste, however, and is avoided by insects. These seeds are used as food in the southern islands of the Philippine group, and the bracts and fruit are an excellent vulnerary.

Cycas circinalis is abundant in the woods of Guam, especially in rocky places. On the shores of Orote Peninsula, at the entrance to the bay of San Luis de Apra, the beautiful fern-like crests of this plant are distinctly visible to those on board ships entering the harbor and lend a peculiar charm to the landscape. Though usually only 1.2 to 1.5 meters high, the trunks reach the height of three meters in certain localities. On the promontory of As Kiroga, near 'Talofôfô, the growth of Cycas trees, with their cylindrical scarred trunks and luxuriant fronds, strongly recall ideal pictures of the vegetation of the Carboniferous age, in which the Cycadaceae formed so important a part.

REFERENCES:

Cycas circinalis L. Sp. Pl. 2: 1188. 1753.

\section{Cyclophorus adnascens.}

Creeping fern. Plate xlvit.

Family Polypodiaceae.

A creeping fern, with small, simple fronds, usually found growing on the trunks of trees. Rhizome firm, but slender, the scales linear, deciduous; fronds dimorphous, 
the sterile ones elliptical or spathulate, blunt, the fertile ones longer and narrower; texture coriaceous; upper surface naked, lower thinly coated with whitish tomentum in the sterile but more densely in the fertile part beneath; veins hidden; sori small, bright reddish brown, immersed, occupying the whole of the contracted upper part of the frond.

This species is spread throughout the islands of the Pacific Ocean. It is also found in India, Ceylon, and the Mascaren Isles.

REFERENCES:

Cyclophorus adnascens (Sw.) Desv. Berl. Mag. v. 300 (ex Luerssen).

Polypodium adnascens Sw. Syn. Fil. 25, 222. tab. 2. f. 2. 1806.

Cymbidium triste Willd. Same as Luisia teretifolia.

Cynodon dactylon Pers. Same as Capriola dactylon.

\section{Cyperaceae.}

SeDGes.

The following members of this family are known from Guam: Carex densiflora, Carex fuirenoides, Cladium gaudichaudii, Cyperus difformis, Cyperus pennatus, Cyperus rotundus, Eleocharis capitata, Eleocharis plantaginoidea, Fimbristylis complanata, Fimbristylis diphylla, Fimbristylis globulosa, Fimbristylis miliacea, Fimbristylis puberula, Fimbristylis spathacea, Fuirena umbellata, Kyllinga monocephala, Kyllinga monocephala subtriceps, Rynchospora corymbosa.

\section{Cyperus difformis.}

Family Cyperaceae.

A glabrous annual sedge often growing in rice fields; stem 10 to $50 \mathrm{~cm}$. high, acutely 3 -angled at the top; leaves usually somewhat shorter than the stem; spikes arranged in umbelled heads, the umbel either simple, compound, or reduced to one head, the rays up to $5 \mathrm{~cm}$. long, sometimes longer; bracts 5 to $25 \mathrm{~cm}$. long, lowest often suberect (umbel lateral); spikes globose, 8 to $12 \mathrm{~mm}$. in diameter; spikelets very small, linear-oblong, most densely crowded; glumes close-packed, concave, very obtuse, straw-colored, sides more or less red; stamens 1, rarely 2; anther small, oblong; nut subsessile, subequally trigonous, pale brown; style shorter than the nut; stigmas 3 , linear, short.

REFERENCES:

Cyperus difformis L. Cent. P1. 2: 6. 1756; Amoen. Acad. 4: 302. 1759.

Cyperus hexastachyos. Same as Cyperus rotundus.

\section{Cyperus pennatus.}

A sedge collected in Guam by Gaudichaud, with compound umbels of cylindrical sessile spikes. Stems 60 to $90 \mathrm{~cm}$. high; leaves longer than stem.

REFERENCES:

Cyperus pennatus Lam. Ill. 1: 144. 1791.

Mariscus albescens Gaudich. Bot. Freyc. Voy. 415. 1826.

\section{Cyperus rotundus.}

Nutgrass.

Loctl Xises.-Chaguan Humátag (Guam); Mootha, Mutha (India); Hamasage (Japan).

A sedge growing in sandy places, with aromatic tuberous rootstock, having the odor and taste of camphor. Very common in Guam, often growing in the yards of Agaña with grasses and near the shore. It is a most troublesome weed in garden patches. In Japan its roots are collected in the winter, dried, and used for medicine.

REFERENCES:

Cyperus rotundus L. Sp. Pl. 1: 45. 1753.

Cypress vine. See Quamoclit quamoclit.

Cytisus cajan. Same as Cajan cajan. 
Dabdap (Philippines, Malay Archipelago). See Erythrina indica.

Dactyloctenium aegyptiacum.

Goose Grass.

Family Poaceae.

LOCAL NAMES. - Salai maya (Philippines).

An annual grass spread throughout the warmer regions of the globe. Leaves distichous, flat, acute, ciliate; sheaths compressed; spikes digitate; spikelets at right angles to the rachis of the spikes; glumes rigid, cuspidate, glabrous, the lowermost ovate, the second broadly ovate, obliquely cuspidately awned as are the following, the cusps recurved; paleæ very broad, bifid, the keels hispid; grain globose, very rough, the pericarp evanescent.

Common in Guam, growing in damp sandy places. A coarse-looking grass rising above the general level of the "grama" (Capriola dactylon), with which it is associated, together with Eleusine indica. In the Philippines the vernacular name signifies "sparrow's nest."

REFERENCES:

Dactyloctenium aegyptiacum (L.) Willd. Enum. Hort. Berol. 2: 1029. 1809.

Cynosurus aegyptius L. Sp. Pl. 1: 72.1753.

Dádangsi or Dádanse (Guam).

Vernacular name signifying "bur" or something which sticks to something else; applied to Triumfetta rhomboidea, T. pilosa, and Urena sinuata, all of which have prickly fruit with hooked spines.

Dádig (Guam). Vernacular name for a small coconut of the size of a betel nut.

Dafau, Dafao (Guam). See Boerhavia diffusa.

Daffodil, seaside. See Pancratium littorale.

Dagmai (Philippines). See Caladium colocasia.

Dago (Guam). Vernacular name for one class of yams. See Dioscorea, D. alata, D. glabra, and, D. sativa.

Dalandan (Philippines). See Citrus aurantium sinensis.

Dalayap (Philippines). See Citrus hystrix acida.

Dalima (Philippines). See Punica granatum.

Dalinga or Dalingag (Philippines). See Dioscorea fasciculata.

Dalisay (Philippines). See Terminalia catappa.

Daltonia. See Neckera, under Mosses.

Dama de noche (Spanish). See Cestrum nocturnum.

Dampalit (Philippines). See Sesuvium portulacastrum.

Dangkalan, Dinkalin (Philippines). See Calophyllum inophyllum.

Dao (Philippines). See Zinziber zerumbet.

Daog or Daok (Guam). Vernacular name for Calophyllum inophyllum.

\section{Daphne.}

To this genus Freycinet referred a plant used by the natives for making a sort of noose to aid them in climbing trees, called "gapit atayake."

Date palm. See Phoenix dactylifera.

Date palm, wild. See Phoenix sylvestris.

Datura fastuosa.

THORNAPPLE.

Family Solanaceae.

A rank tropical plant growing in waste places, very much like the common $D$. stramonium, but with larger flowers and pods not regularly dehiscent. Its leaves are ovate, entire or deeply toothed, and smooth; corolla purple or white, limb shortly 5 or 6 -toothed. 
Common about Agaña, both the white-flowered and purple-flowered varieties. The leaves and seeds are sedative and narcotic. In India the seeds are often used as a poison.

REFERENCES:

Datura fastuosa L. Syst. ed. 2. 932. 1759.

Davallia heterophylla. See Humata heterophylla.

\section{Davallia solida.}

Glossy fern. Plate iit.

Family Polypodiaceae.

Local names.-Pugua machena (Guam).

A graceful fern, with glossy, divided fronds, climbing the trunks of forest trees and growing upon their limbs, associated with Polypodium phymatodes, Cyclophorus adnascens, and Nephrolepis spp. Rhizome stout, densely clothed with fibers; stipe slender, strong, erect; fronds deltoid, tripinnatifid; apex with a moderately broad undivided center; segments ovate-rhomboidal, deeply toothed, narrow and sharper in fertile frond; veins uniform; texture coriaceous; sori nearly or quite marginal; indusium semicylindrical.

This species is widely spread throughout Polynesia, the Philippines, and the Malay Peninsula. It has also been collected in Java.

REFERENCES:

Davallia solida Sw. Syn. Fil. 132, 375. 1806.

Trichomanes solidum Forst. f. Prod. n. 475. 1786.

\section{Dayflower. See Commelina.}

\section{Delonix regia.}

FLAME TREE.

Family Caesalpiniaceae.

Local Names.-Arbol del fuego (Philippines, Guam); Flamboyant; Peacock flower.

A rapid-growing tree with broad top and wide-spreading branches. Leaves gracefully bipinnate, 30 to $60 \mathrm{~cm}$. long with 10 to 20 pairs of pinnæe, each pinna with numerous small oval leaflets; flowers large, in large racemes, bright scarlet, the upper petal striped with yellow; calyx-segments valvate; petals 5 , clawed, obovate; stamens 10, free, exserted; pod flat, strap-like, 15 to $60 \mathrm{~cm}$. long.

This handsome ornamental tree is a native of Madagascar. It has become widely spread, and is now found in all tropical countries. It yields a yellowish or reddish brown mucilaginous gum containing oxalate of lime. It is not yet well established in Guam.

\section{REFERENCES:}

Delonix regia (Boj.) Raf. Fl. Tellur. 2: 92. 1836.

Poinciana regia Boj. in Hook. Bot. Mag. 56: t. 2884. 1829.

Desmodium australe. Same as Meibomia umbellate.

Desmodium gangeticum. Same as Meibomia gangetica.

Desmodium triflorum. Same as Meibomia triflora.

Desmodium umbellatum. Same as Meibomia umbellata.

Detergents, or plants used for cleaning.

Citrus aurantium saponacea (fruit used for washing clothes and for the hair).

Citrus bergamia (fruit used for washing the hair).

Colubrina asiatica (leaves used in Samoa and Fiji).

Lens phaseoloides (crushed stems saponaceous, used for washing).

Devil's guts. See Cassytha filiformis.

Dewflower. See Commelina.

\section{Dianella ensifolia.}

Family Liliaceae.

A plant with leafy stem and cymose panicles of small flowers. Leaves rigid, distichous, linear-lanceolate, the bases equitant or overlapping, the sheaths acutely 
angled; flowers nodding; pedicels short, slender, rigid, jointed at the top, panicle 1 to 2 feet long, cuneiform; bracts spathaceous; flowers odorless; perianth white, greenish, or bluish, the segments 6 to $8 \mathrm{~mm}$. long, the 3 inner reflexed; anthers linear, 2-porous; filaments much thickened at the top; anthers basifixed between the lobes, reflexed; ovary 3-celled; style filiform, stigma minute; berry blue; seeds few, testa black, shining. A plant widely spread in tropical Asia, Madagascar, Australia, and Polynesia. Collected in Guam by Haenke.

REFERENCES:

Dianella ensifolia (L.) DC. in Red. Lil. t. 1. 1802.

Dracaena ensifolia L. Mant. 1: 63. 1767.

Dianella nemorosa Lam. Encye. 2: 276. 1786.

Dianella nemorosa. Same as Dianella ensifolia.

Dictyonema. See under Lichenes.

Dilang usa (Philippines). See Elephantopus spicatus.

Dilao (Philippines). See Curcuma longa.

\section{Dimeria chloridiformis.}

Family Poaceae.

A grass growing in damp places. Spikelets 1-flowered, almost sessile, inserted singly in the alternate notches of slender unilateral spikes, which are either solitary or more frequently 2 or 3 together on a terminal peduncle; rachis not articulate; frequently a tuit of short hairs under each spikelet; glumes 4, 2 outer empty ones keeled, linear, rigid, not awned; the third empty, smaller, thin, hyaline, terminal glume with a slender awn twisted at the base and bent back at or below the middle; styles distinct; grain free, narrow, inclosed in the outer glumes. A slender branching annual with narrow ciliate leaves. Collected in Guam by Haenke. $a$

REFERENCES:

Dimeria chloridiformis (Gaudich.) K. Sch. \& Laut. Fl. Deutsch. Schutzgeb. in der Südsee 165. 1901.

Andropogon chloridiformis Gaudich. Bot. Freyc. Voy. 412.1826.

Dimeria pilosissima Trin. Mem. Acad. Petersb. VI. 2: 336.1833.

Dimeria pilosissima. Same as Dimeria chloridiformis.

Dioscorea.

YAMS.

Local nanes.-Nika, Dago, Gado (Guam); Tongô, Ubi, Tugui (Philippines); Álu (Hindustan); Kelengu (Malayan).

Yams formed one of the principal staples of food of the aborigines of Guam. They were among the provisions supplied to the early navigators visiting the group, many of whom designated them as "batatas," which has led some writers to the supposition that sweet potatoes were growing on the island before the discovery. Sweet potatoes, however, have no vernacular name in Guam. They are called "kamutes," a corruption of "camote," the name under which they are known to the Mexicans and the Spanish Americans of the Pacific coast of America. The natives divide the yams into two classes, which they call "nika" and "dago," respectively, the former having orbicular, acuminate, deeply cordate leaves, and the latter sagittate leaves. The leaves are sometimes quite variable, however, on the same plant, and much confusion exists in the classification of the various species and varieties, ${ }^{b}$ so that it is impossible to determine the species with any degree of accuracy. Gaudichaud, the botanist of Freycinet's expedition, counted seven kinds of "dago" and four of "nika." He referred the dago to Dioscorea alata, for the varieties of which the native names are such as "manila yam, bat yam, lizard yam, devil yam (not edible)," etc. The varieties of nika bear a general resemblance to $D$. aculeata $\mathrm{L}$.

$a$ Presl, Reliquiae Haenkeana, fasc. 4, p. 235, $t .38,1830$.

$b$ See Hooker, Flora Brit. Ind., vol. 6, pp. 288, 296, 1894.

$9773-05-17$ 
One thing is certain, the spiny wild yam called "gado" or "nika cimarron," which forms dense thickets in the forests of Guam and furnishes the natives with foor in the periods of famine which follow hurricanes, is not the Dioscorea aculeata of Linnaeus, as was supposed by Gaudichaud. D. aculeata L. is very probably the species described under that name by Seemann, a plant cultivated by the Fijians, in the description of which Seemam does not mention branching sharp spiny processes about the base of the stem, such as characterize the spiny yam of this island and which are features of the Dioscoren aculeata of Roxburgh. a According to Hooker, Roxburgh's Dinscorea aculeata is identical with D. spinosa Roxb., b the description of which corresponds to our gado.

The typical nika of Guam resembles $D$, aculeata L., and corresponds very closely with $D$. fasciculata lutescens, as described by Padre Blanco. $c$ Some of the varieties seem identical with $D$. papuana Warb.

In the list of yams given by Schumann and Lauterbach as occurring in the Bismark Archipelago and Kaiser Wilhelmsland, on the coast of New Guinea, are Dioscorea glabra Roxb.; D. papuanu Warb., perhaps the most extensively cultivated species; D. pentaphylla L., growing on the edge of the forests; D. sativa L., which "produces great tubers," growing in the woods, occurring also, according to Finsch, in Ponape, Kuschai, and Lalan, of the Caroline Group; and D. alata, which is cultivated. $l$

According to Hooker, a part of Linnæus' description of Dioscorea sativa $e$ applies to $D$. spinosa Roxb., to which should also be referred $D$. aculeata Roxb., $D$. tiliaefolia Kunth, and D. lanate Balf. Linneus' true $D$. satica is a glabrous piant, the stem terete, bulbiferous, the leaves broadly ovate-cordate, acuminate, cuspidate; and to it should be referred $D$. bulbifera $\mathrm{R}$. Br..$^{\prime} \quad D$. glabra is quite glabrous, with very variable, long-petioled, opposite, caudate-acuminate leaves, the youngest acute at the base, the older truncate or deeply curdate, the lobes sometimes $2.5 \mathrm{~cm}$. long, incurved and overlapping, orbicular, ovate-oblong, or hastate, strongly 7 to 9-nerved, and reticulate, subglaucous beneath. In the face of so many conflicting authorities it is hard to decirle as to the species or recognized varieties cultivated in Guam. A thorough study of the yams of this island is especially desirable, since most of the varieties were cultivated by the natives before the discovery. $g$

The species of Dioscorea can not be understood from herbarium specimens alone. The forl-yielding varieties must be studied in the locaities where they are cultivated, and should be represented in herlsaria by photographs of the growing plants, together with their tubers, and, if possible, by typical tubers of each rariety preserved in formalin or some other liquir. It is only in this way that specimens from Polynesia, India, the Malay Archipelago, Africa, Australia, and America can be compared.

Plant: belonging to the genus Diosourea are herbacenus perennials with fleshy tuherous roots and twining stems, which, as a rule, die down each year, allowing the plant $t$, rest through the dry seasm. Leaves having several longitudinal reins, wither entire, lobed, or digitately 3 to 5 foliolate, the petiole often angular and twisterl at the base. Fluwers small or minute, panicled, racemose, or spicate, rarely hisexual, the perianth superior, b-cleft. Male flowers with the perianth tubular or urn-shaped, its lohes shurtly spreading. Stamens inserted at the base of the perianth or $\mathrm{m}$ its lobes, 3 or 6 , or 3 perfect stamens and 3 staminodes, the filaments incurved or recurred, the anthers small, globose, oblong or didymous, or with the cells on

a Flora Indica, vol. 3, p. 800, 1832 .

${ }^{b} \mathrm{Ex}$ Wallich, Catalogue, No. 5703, A, B, C, D, E, F.

${ }^{c}$ Flora de Filipinas, ed. gran, vol. 4, p. 260, 1880.

d. Schumann uni Lauterbach, Flora deutschen schutzgebiete, pp. 223-224, 1901.

e Species Plantarum, ed. 1, vol. 2, p. 1033, 1753.

$f$ Prodromus Flora Novæ Hollandiæ, p. 294, 1810.

$g$ One of the tirst Je-nit missionaries to risit the island was killed br a native in ronseguence of a misunderstanding over some "nika" roots which the native failed to deliver as he had promised. 



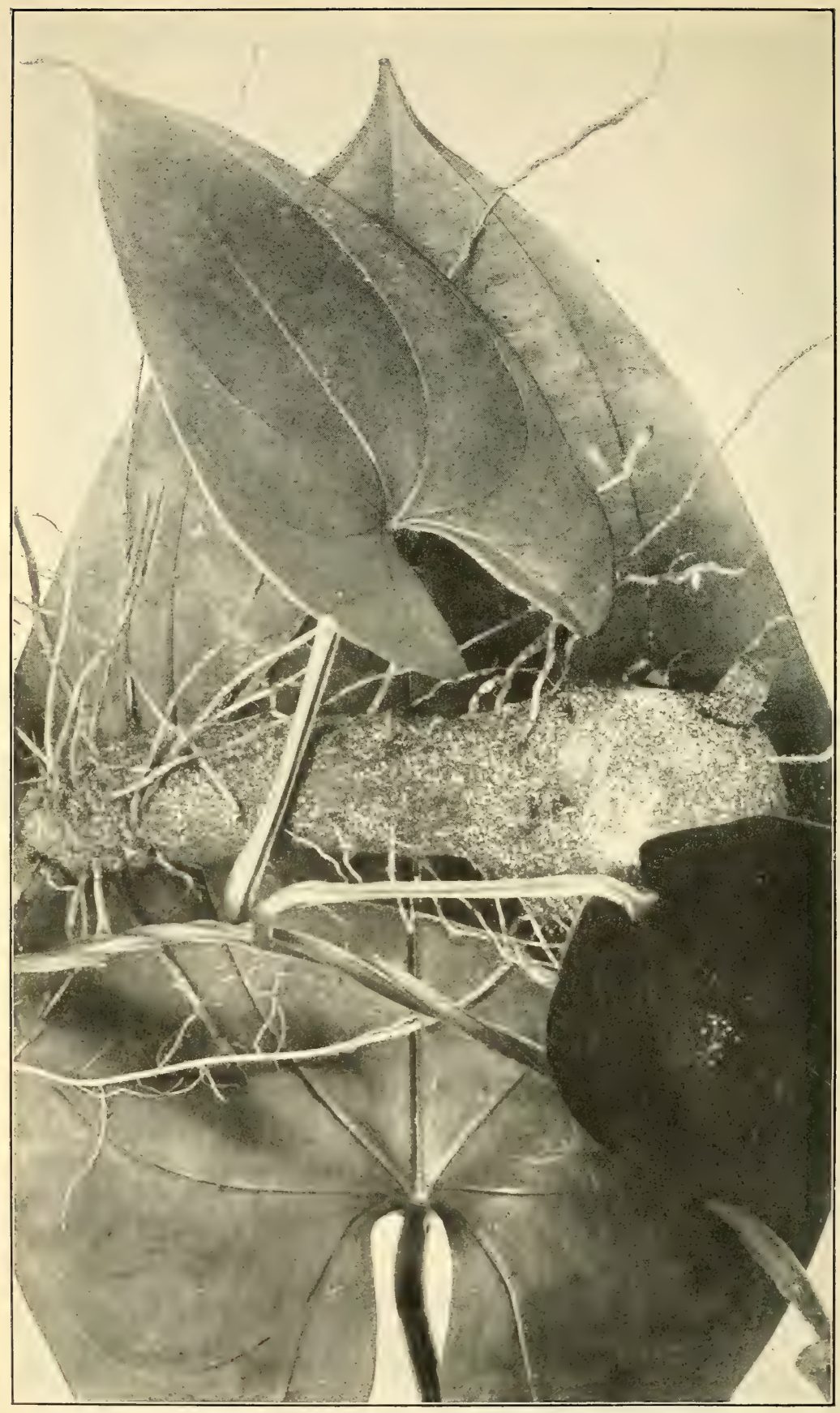

The Wing-stemmed Yam (Dioscorea alata). Leaves and ImMature Tuber. NATURAL SIZE. 
hranches of the filament, an imperfect pistil (pistillode) present or lacking. Female flowers with a perianth like that of the male, but smaller, imperfect stamens, or staminodes, 3 or 6 , or lacking. Ovary 3 -angled or 3-ribbed, 3-celled; styles 3, very short, the stigmas entire or 2-parted, recurved; ovules 2, superposed in each cell, pendulous. Fruit a berry or 3-valved capsule.

\section{Dioscorea aculeata.}

Guinea yam. Prickly yam.

Local Naues.-Nika (Guam); Baliácag (Philippines); Káttu kelángu (Malabar); Hoeï-trobong (Java); Kummara-baddu (Teloogoo).

Stem aculeate, terete; leaves alternate, cordate, acuminate, 7 to 9-nerved, transverse veins subsimple; male spikes panicled. $a$

This brief description corresponds with some of the varieties of the "nika" cultivated in Guam. Seemann attributes to it the yam called by the Fijians "kawai," which is in common cultivation on most of the islands of the group, and which differs from the wild spiny yam called "tivoli" (D. nummularia?) in having alternate instead of opposite leaves, and lacking the wiry spines about the base of the stem. Hooker identifies with it Rheede's "káttu keléngu." To this species 'also was assigned by Warburg the common cultivated yam of the Papuans, which he afterwards found to differ from Linnæus' description in having simple male inflorescences and sessile flowers; also in the broad, relatively not deep sinus of the base of the leaf, and which he afterwards described as Dioscorea papuana.b Warburg further remarks that the species $D$. aculeate is so insufficiently and badly described, that perhaps a series of species is included within it. $c$

REFERENCES:

Dioscorea aculeata L. Sp. Pl. 2: 1033.1753.

Dioscorea aculeata Roxb. (not L.). Same as Dioscorea spinosa Roxb.

Dioscorea alata.

White yam. Square-stemmed yam. Plate xlvir.

LocAl NAMEs.-Dago (Guam); Ubi, Ube (Philippines, Java, Malay Archipelago); Uvi (Fiji, New Zealand); Ovi, Oviàla (Madagascar); Ufi (Samoa); Uhi (Tahiti); Ui-parai (Rarotonga); Heeï-prataen (Java) ; Hoeï-lie lien (Sunda); Kap (Caroline Islands); Ñame (Panama).

A cultivated yam having a 4-angled or 4-winged climbing stem without prickles. Ronts very large; stem stout, often tuberiferous; leaves mostly opposite, varying from orbicular and deeply cordate to hastately ovate, 5 to 7 -nerved; male flowers in slender fascicled spikes, very much as in D. sativa; female flowers in much stiffer spikes; sepals narrowly oblong or lanceolate, subvalvate; capsule broader than long, 25 to $37 \mathrm{~mm}$. in diameter, very broadly obcordate, coriaceous; carpels rounded; seeds orbicular, broadly winged all round.

The natives of Guam distinguish a number of varieties all of which are known as "dagn," with roots of different sizes and shapes, varying in color from white to purple and differing in time of maturity. Yams are left in the ground for a short while after the vine has turned yellow and died down. The tops of the tubers are then cut off with the vines attached and buried in the ground, piling the earth up around the base of the vine. After several weeks another yam is produced which contains a number of eyes or buds. This is cut up into pieces each having an eye from which the new plant grows. Yams are usually planted in small hillocks arranged in a large circle, sumetimes with a tree or high pole at the center. In each hill a slender pole is thrust and inclined toward the center of the circle, the poles forming the shape of an Indian tent, or all are inclined against the central tree. The ground is kept free

a Flora Vitiensis, p. 308, 1865-73.

Ђ $)$. Warburg. Beiträge zur kenntniss der papuanischen Flora, Engler's Botanische Jahrbücher, Bd. 13, pp. 273-274. 1891.

$c$ See Dioscorea papuana below. 
from weeds and is hilled up from time to time around the base of the plants. In about eight or nine months the yams are ready for digging. They are dug and stored by the natives, who pick them over from time to time, taking out any that show signs of decay, so that the rest may not be affected by them. In the meantime the heads are forming new eyes and the ground is prepared for the new crop. As the cultivation of yams requires more labor and attention on the part of the natives than that of taro, they are not so extensively planted as the latter. They are very nutritious; more so, it is claimed, than the common potato. $a$ They are eaten either baked or boiled, and in many of the Pacific islands are combined with the rich creamy juice expressed from the meat of the coconut to form dumplings of various kinds. In the days when whaling vessels visited Guam in great numbers great quantities of yams and sweet potatoes were supplied to them in exchange for codfish, salt meat, sugar, flour, and textile fabrics.

REFERENCES:

Dioscorea alata L. Sp. Pl. 2: 1033. 1753.

Dioscorea bulbifera P. Br. (not L.). Same as Dioscorea sativa.

Dioscorea fasciculata.

KiDney yaM.

Local names.-Nika? (Guam); Soosni-aloo (Beng.); Bolót, Borót, Togui, Tugui, Dalinga or Dalingag (Philippines).

Tubers pendulous; stems annual, twining, round; prickles stipulary; leaves alternate, round, cordate, 5-nerved. Cultivated to a considerable extent in the vicinity of Calcutta, not only for food, but to make starch from the roots.

Root consisting of many tubers, about the size and shape of a pullet's egg, connected by slender filaments to the hase of the stems, covered with a pretty smooth, lightcolored, thin integument; internally they are white; stems several, about as thick as a pack thread, twining, round, smooth, except here and there a small prickle, and always two at the insertion of each leaf; these I call the stipules. Leaves alternate, long-petioled, round-cordate, entire, pointed, from 3 to 7 -nerved, venose, slightly villous. I have not met with the flowers of either sex. $b$

To this species is assigned, in the last edition of the Flora de Filipinas, Padre Blanco's earlier D. tugui, called "togui" by the Filipinos, which in the first edition he describes as follows: $c$

Male. Root with many tuhers; stem climbing, somewhat angled, hairy and prickly; leares alternate, broadly cordate, abruptly acuminate, concave, somewhat hairy beneath, and with 7 prominent nerves; petioles very long, minutely and sparsely prickly; flowers in axillary spikes; 2-bracteolate, unisexual; perianth 6-cleft, in 2 series, the 3 inner divisions narrower; the 3 outer ones fleshy and hairy without; corolla absent; stamens 6 , of equal length; pistillode prominently 3 -lobed. In some plants 3 .bifid styles are seen; fruit not observed.

These plants, which are cultivated, are climbers, on which account the Indians place stakes so that they may climb upon them. Their root, which is the part most valued in them, forms inany tubers, some of which reach $5 \mathrm{in.}$ or more in thickness. This root is not poisonous, nor needs any anterior preparation to be eaten boiled or fried in olive oil or lard. The flavor is very good, and on that account it is more esteemed than the sweet potato. Blooms in May and June.

REFERENCES:

Dioscorea fasciculata Roxb. Fl. Ind. 3: 801. 1832.

\section{Dioscorea fasciculata lutescens.}

YeLLOW YAM.

Local Nayes.-Nika (Guam); Toguing polo (Philippines).

This variety has the ruot as in the preceding species, only it differs in the color, which inclines to yellow. Stem with a greater number of prickles; leaves mostly heart-shaped, the new ones approaching the shape of a kidney, full of wool, especially beneath; petioles very long and with 2 prickles at the base. Used like the preceding, but the root not so savory; found everywhere. $d$

a Nicholls, Tropical Agriculture, p. 284, 1897.

$b$ Roxburgh, Flora Indica, vol. 3, p. 801, 1832.

$c$ Flora de Filipinas, p. 800, 1837.

d Blanco, Flora de Filipinas, ed. 1, p. 801, 1837. 
One variety of nika cultivated in Guam very closely corresponds with this description. The species is very close to D. papuana of Warburg. Hooker $a$ was unable to identify any of the Indian yans examined by him with $D$. fasciculata Roxb.

\section{REFERENCES:}

Dioscorea fasciculata lutescens Fernandez-Villar, Blanco Fl. Philipp. 4: Nov. App. 280. 1880.

\section{Dioscorea glabra.}

Chinese yam.

Local names.-Dago (Guam).

Quite glabrous. Stems stout, somewhat flattened; leaves opposite, long-petioled, extremely variable, 7.5 to $20 \mathrm{~cm}$. long by 2.5 to $11 \mathrm{~cm}$. broad, caudate-acuminate, orbicular, ovate-oblong, or hastate, strongly 7 to 9 -nerved and reticulate, the youngest acute at the base, the older truncate or deeply cordate, the lobes sometimes $2.5 \mathrm{~cm}$. long, incurved and overlapping, subglaucous beneath; margins not thickened or cartilaginous; petiole 2.5 to $8 \mathrm{~cm}$. long; male spikes $2.5 \mathrm{~cm}$. long, rarely longer, spreading; flowers scattered, rather large, globosely 8-lobed, often coarsely dotted; sepals ovateoblong, petals cuneately obovate; pistillode minute; capsule $3.7 \mathrm{~cm}$. in diameter, very variable in shape, subquadrate, broadly obcuneate or obcordate, retuse at the tip and base, valves very thin; seeds irregularly orbicular.

A plant occurring in the Bismarck Archipelago and Kaiser Wilhelmsland, near the coast of New Guinea, the Philippine Islands, and the Malay Peninsula. It is probable that some of the varieties of the dago of Guam should be referred to this species.

\section{References:}

Dioscorea glabra Roxb. Fl. Ind. 3: 804. 1832.

\section{Dioscorea papuana.}

Papuan yam.

LOCAL NAMES.-Nika ? (Guam).

The following is a translation of Warburg's description and discussion of this species:

Stems climbing, terete, finely ferruginous-villous, sparsely prickly, the prickles commonly erect, small; leaves long-petioled (the petiole angled, pubescent), broadly cordate, with the sinus at the base deep and very broad, the apex shortly acuminate, above smooth, below lighter-colored, sparsely whitish-hairy, 7 to 11-costate, with the basal costae commonly bifid or trifid; male racemes simple, axillary, many-flowered, as long as the leaf or longer, the peduncle pubescent, the bracts small, acutely ovate, hairy; flowers solitary, subsessile, campanulate, hairy without, the lobes 6 , subequal, obtusely ovate, longer than tube; stamens 6 , glabrous, shorter than the divisions of the perianth, the filaments attached to the base of the divisions, the anthers all fertile, introrse; rudiment of the style (pistillode) smooth, short, irregularly subpyramidal.

The petioles are 5 to $6 \mathrm{~cm}$. long, the leaves themselves 7 to $8 \mathrm{~cm}$. long and 9 to $10 \mathrm{~cm}$. broad. The prickles differ very much in length. They are sometimes triangular and sometimes slender; at the base of the leaf there are prickles almost twice as long, somewhat curved. The male inflorescences vary between 10 and $40 \mathrm{~cm}$., but are never branched; the bracts are $1.5 \mathrm{~mm}$., the perianth nearly $3 \mathrm{~mm}$. long, the style scarcely perceptible.

This hitherto overlooked species stands very near to $D$. aculeata L., but differs above all in the simple male inflorescences and the sessile blossoms; also, the broad, relatively not deep sinus of the base of the leaf is noteworthy.

The plant grows wild on Little Key. I also found sterile branches evidently of the same species in Ceram-Laut and Hatzfeldhafen.

This is probably the species of yam which is chiefly cultivated there by the natives, and which, together with Colocusia antiquorum [Caladium colocasia], even to the present day represents the most important cultivated plant of Papuasia. As I held the above plant to be $I$. aculeata, I unfortunately did not take care to procure for myself female flowers and fruit; nor do I remember to have seen the plant in bloom, as the yam planting of the year had just begun; it is of great importance, in the future, to 
take note of it. In connection with this it is remarked that the $D$. aruleata $\mathrm{L}$. is described so insufficiently and badly that perhaps a series of species is included within it. $a$

\section{REFERENCES:}

Dioscorea papuana Warb. Engler's Bot. Jahrb. 13: 273. 1891.

\section{Dioscorea sativa.}

Round-stemmed yam. Negro yam. Common yam.

Local Names.-Dago (Guam); Bayog cabayo, Bâong, Baliácag (Philippines);

Hoi (Tahiti, Hawaii); Oi (Rarotonga); Pua-hoi (Marquesas); Hoei-oepas (Sunda); Kaile (Fiji).

Closely allied to $D$. alata, but with round instead of 4 -winged stems. Quite glabrous; stem sometimes prickly below, bulbiferous, slender, green or purple; tubers large, variable in form, white or yellowish within, soon decaying when taken from the ground; leaves opposite or alternate, very variable in size, sometimes attaining $35 \mathrm{~cm}$. in length and breadth, membranous, dark green, usually very deeply cordate, but sometimes with only a shallow, broad sinus, acuminate, cuspidate, or caudate, 7 to 9-costate; male spikes slender, panicled, almost capillary, 2.5 to $10 \mathrm{~cm}$. long; flowers crowded or scattered, very variable in size, green or purplish; sepals narrow, linear or linear-lanceolate, 2.5 to $6 \mathrm{~mm}$. long, fleshy; petals rather narrower; filaments much shorter than the perianth; anthers minute, didymous; pistillode 3-lobed; female spikes axillary, solitary, or fascicled, 10 to $25 \mathrm{~cm}$. long, pendulous; flowers 3 to $6 \mathrm{~mm}$. long; sepals as in the male; capsule quadrately oblong, 16 to $25 \mathrm{~mm}$. by 8 to $13 \mathrm{~mm}$. long, membranous; seeds with a broad basal wing. This species is regarded by Hooker and by Bentham as the true $D$. sutire of Linnæus. The capsule is rather broader upward, the top truncate or abruptly acute, the base truncate or subcordate.

REFERENCES:

Dioscorea sativa L. Sp. Pl. 2: 1033. 1753.

\section{Dioscorea spinosa.}

Spiny yam. Wild yam. Plate xlix.

Local Names.-Gado, Nika cimarron (Guam); Tuñồ Toñồ (Philippines); Mou-aloo (Calcutta).

Tubers very large; hase of stem beset with long woody, rigid fibers, bearing lateral spines $12 \mathrm{~mm}$. long;" glabrous or tomentose; stem round, very spinous at the base; leaves orbicular-cordate or reniform-cordate, $20 \mathrm{~cm}$. long and broad; acuminate or cuspidate, 5 to 7 -nerved, rather memhranous, hasal lobes rounded; male flowers in simple or nearly simple axillary spikes, 15 to $45 \mathrm{~cm}$. long, distant or in distant clusters; flowers $3 \mathrm{~mm}$. in dianeter, often in very dense cymules, sessile or shortly pediceled; bracteoles very broad; perianth lobes remote from the large oblong pistillode; sefals broadly oblong or orbicular; stamens 6, all having anthers; anthers large; female raceme rather short; capsule broader than long, $2.5 \mathrm{~cm}$. in diameter, broadly obcordate.

To this species should be referred $D$. aculeata of Roxburgh (not L.). Linnæus' species of that name is Rheede's "káttu kelingu," which has panicled male spikes. In Fiji a thorny yam, "alled "tivoli" by the natives, grows in the woods, which Seemann considers to be $I$. nummuluriu Lam.c This plant differs from D. aculeata, according to Seemann, in having opposite instear of alternate leaves. The base of its stem is spiny; leaves ovate or oval, searious-mucronate, with the base subcurdate or rather rotundate, 5-nerved, glaucescent below; spikes axillary; wings of the capsule hemispherical. Hooker does not recognize $D$. nummuluria among the Indian yams.

The gado, or spiny yam, is very abundant in Guam. Its vernacular name is identical with the Malayan "gadong", applied to D. hirsute. It is the only species growing

a Warburg, Beitrïge zur Kenntniss der papuanischen Flora, Engler's Botanische Jahrbücher, Bd. 13, pp. 273, 274, 1891.

$b$ See p. 68 .

c Encyc., vol 3, p. 231, 1789. 


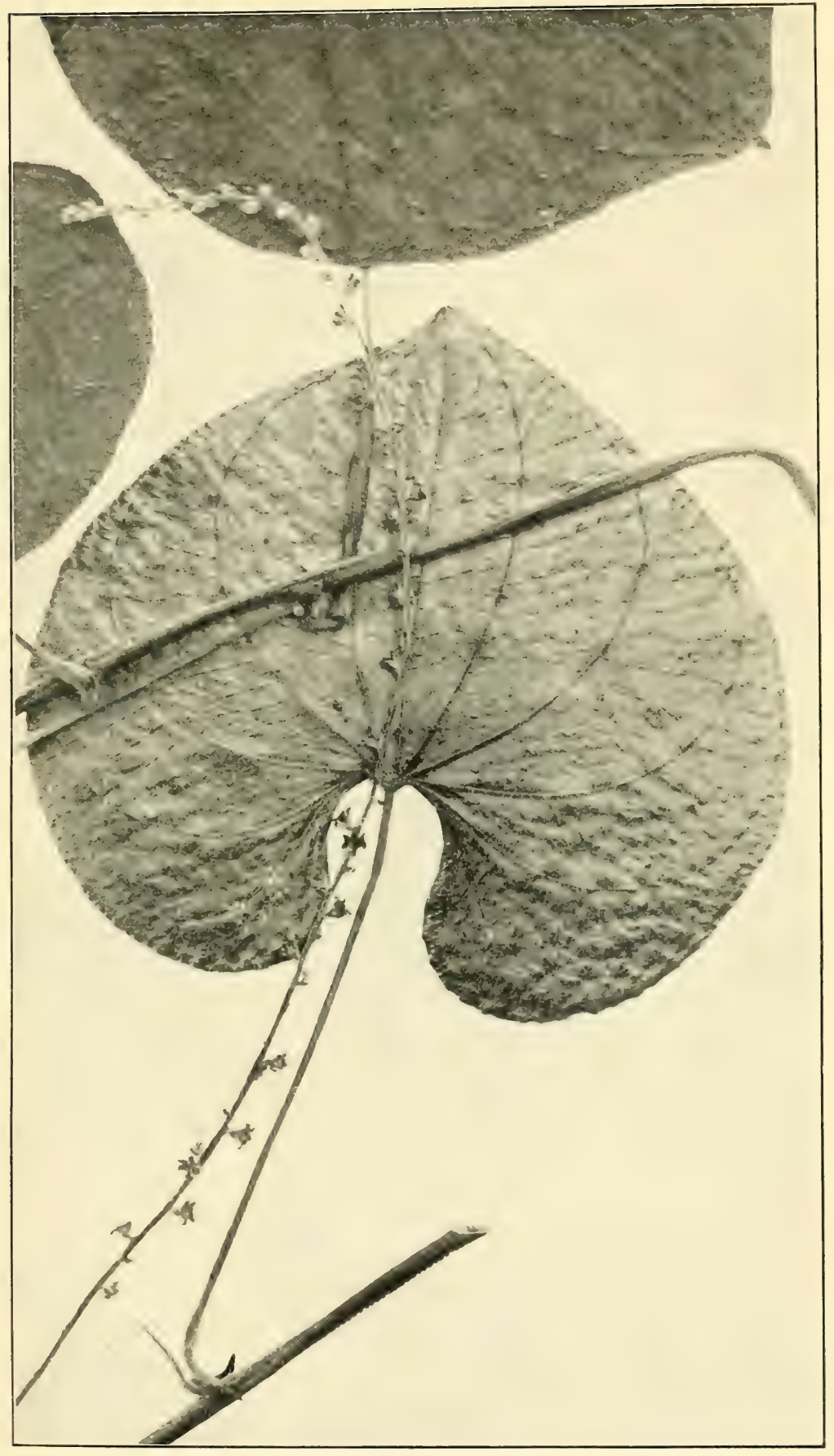

The Spiny yam (Dioscorea spinosa). Leaves and Flower Spike. NATURAL SIZE. 

wild, forming dense matted thickets, under which the deer often make paths impassable to man. Like the Bengal wild yam described by Roxburgh (mon-aloo), its roots are white, and are dug up in the woods during the cool season, for it is not cultivated; and as the wild yam of Bengal resembles in habit the cultivated species, Lroscorea fasciculata Roxb., so does the gado, or nika cimarron of Guam resemble the cultivated nika. In December the leaves turn yellow, then brown, and then fall off, at which time the tubers are ready for digging. These weigh about 2 pounds, and are in shape like a sweet potato, but have little fibers growing from them. They are more solid and sweeter than cultivated yams.

As considerable work is necessary to dig the wild yam, the Guam people do not eat it when there is enough of other food. The Caroline Islanders, however, who until recently have been living on the island of Guam, and who are in no sense an agricultural people, resorted to the forest habitually for it, and often brought it to the houses of the Chamorros to exchange for other things. After the severe hurricanes, which sweep the island from time to time, the natives are obliged to resort to the woods for food, and are fortunate to find a good reserve of gado, fadang nuts (Cycas circinalis), Caladium, and Alocasia. Yams form an important food staple in November, after the breadfruit has gone and before the sweet potatoes are rearly for digging.

REFERENCES:

Dioscorea spinosa Roxb.; Wall. Cat. n. 5103. 1828 (ex Index Kew.), without description.

This name appears to be untenable for the above species, but in the present state of our knowledge of the genus it is impossible to give the correct name.

\section{Dioscoreaceae.}

YAM FAMILY.

This family is represented only by the genus Dioscorea (which see).

Diplazium nitidum. Same as Asplenium nitidum. See Ferns.

Dischidia bengalensis. Same as Dischidia puberula.

Dischidia puberula.

Family Asclepiadaceae.

A herbaceous plant climbing over the trees of the forest. Leaves ovate, acute, short-petioled, opposite, thick, fleshy, glaucous; flowers very small, growing in axillary umbels; calyx 5-parted; corolla urceolate, 5-parted, the divisions obtuse, pilose; stamens 5, connate, anthers with a membranous tip, pollen masses 1 in each cell, compressed, pendulous coronal processes adnate to stamens, erect, bifid above; flowers on a short peduncle in twos or threes; divisions of staminal crown subreniform at apex.

This species was described from specimens collected in Guam by Gaudichaud in 1819.

\section{REFERENCES:}

Dischidia puberula Deene. in DC. Prod. 8: 631. 1844.

Distreptus spicatus. Same as Elephantopus spicatus.

\section{Dodder laurel. See Cassytha filiformis.}

\section{Dodonaea viscosa.}

Family Sapindaceae.

SwITCH-SORREL.

LoCal names._Lampuaye (Guam); Alipata (Philippines); Lala-vao, Tongo-vao

(Samoa); Apiri (Tahiti); Aalii (Hawaii); Ake (Rarotunga).

A shrub or small tree, with numerous erect, twiggy branches, the bark longitudinally cracked and striate, young parts scurfy-puberulous. Leaves simpie, nearly sessile, 5 to $9 \mathrm{~cm}$. long, linear-lanceolate, very tapering at base, subacute or obtuse, entire, the margin often slightly revolute, glabrous, more or less viscid, with a shining resinous exudation; flowers small, polygamous or dicecious, on long, slender pedicels, 
nodding, in lax axillary panicles shorter than the leaves; sepals 5, distinct, ovate, acute, glabrous; petals lacking; stamens generally 8, filaments very short, inserted outside disk; anthers oblong-linear, very large; disk very small; ovary pilose, 3-celled, with. 2 ovules in each cell; style very long, conspicuous; fruit a trigonous winged capsule over $12 \mathrm{~mm}$. long, the angles with a broad, membranous, veined, rounded wing, glabrous, viscid with resin, orange-brown; seed black.

A seacoast plant of wide tropical distribution, growing in rocky places and in open waste ground in patches. Flowers yellowish. The leaves have a sour-bitter taste and are said to have febrifugal properties. The plant is good for hedges. The wood ignites readily and is used for fuel.

REFERENCES:

Dodonaea viscosa Jacq. Enüm. Pl. Carib. 19. 1760.

Dogbane family. See Apocynaceae.

Dogdog (Guam). See Artocarpus communis.

Dog's-foot bur-weed. See Urena sinuata.

Dolichos bulbosus. Same as Cacara erosa.

Dolichos catjang. Same as Vigna sinensis.

Dolichos ensiformis. Same as Canavali ensiforme.

Dolichos giganteus. See Stizolobrum giganteum.

Dolichos lablab.

Hyacinth BEAN.

Family Fabaceae.

Local Names.-Batao (P̀hilippines); Frijoles caballeros (Porto Rico); Sim (India); Pien-tau (China).

A twining plant cultivated in Guam for the sake of its pods, which are eaten green. Leaves pinnately trifoliolate; leaflets broadly ovate, as broad as long, entire, acute; stipules lanceolate; flowers in axillary racemes; calyx tube campanulate, teeth short, deltoid; bracteoles oblong, sometimes as long as the calyx; corolla commonly purple, but in some varieties white or red, with a narrow, beaked keel, which is not spirally twisted; pedicels short; stamens diadelphous; ovary nearly sessile, many-ovuled; legume flat, broad, curred, tipped with the hooked persistent base of the style; seeds longitudinally oral, usually dark brown or white with a conspicuous white hilum, not usually eaten when ripe.

The green pods are dressed and cooked after the manner of French string beans. The red-flowered variety is much esteemed by the natives of India. The stems and ripe seers are eaten with relish by cattle. In Guam, where so much forage is gathered for cattle, this plant would be useful to alternate with corn and would at the same time be valuable as a nitrogen storer. It grows commonly by the native houses, running along the garden fences in company with Botor tetragonoloba.

REFERENCES:

Dolichos lablab L. Sp. Pl. 2: 725. 1753.

Dolichos sinensis. Same as Tigna sinensis.

Dolichos tetragonolobus. See Botor tetragonoloba.

Doni (Guam). General name for red pepper. See Capsicum annum and C. frutescens.

Dracaena terminalis. See Taetsia terminalis.

Dugdug (Guam). See Artocarpus communis.

Dranu (Fiji). See Alocasia indica.

Dryopteris. See under Ferns.

Dye plants.

Acacia farmesiana. - A decoction of the pods with salts of iron yields a black dye, used in Mexico for ink.

Averrhoa carambola. - Unripe fruits astringent, used as an acid in dyeing, probably as a mordant. 
Dye plants-Continued.

Bixa orellana. - Pulp surrounding seeds reddish orange; prepared for market it is called arnatto or annatto; used for coloring cheese and butter, and sometimes for dyeing silk, but it is not permanent. In Guam the natives put it in soup and with rice.

Biancaea sappan.-Bark, wood, and roots yield yellow and red dye; red intensified by alkalies; pods with protosulphate of iron yield a black dye. Sometimes used by natives of Guam for dyeing, but supplanted by introduced aniline dyes.

Casuarina equisetifolia.--Bark yields a dye, reddish alone, blue-black with salts of iron; in some countries used to dye fishing nets.

Curcuma longa. - Old rhizomes may be used for dyeing yellow without mordants; color deepened to reddish orange by alkalies, with carbonate of soda bright yellow, with indigo green; color not lasting.

Indigofera anil and Indigofera tinctoria.-Abundant on island in abandoned fields, but not utilized.

Intsia bijuga.-Fresh wood yields a brown dye; not utilized.

Lawsonia alba. - The "henna" of the Egyptians. Leaves yield a red stain for nails and hair. Not used in Guam.

Morinda citrifolia.-Wood, small roots, and root bark.

Ochrocarpus obovalis.- Heartwood of tree yields a red dye.

Pithecolobium dulce.-Bark yields a yellow dye.

Rhizophora mucronata.-Bark yields a brown dye.

Tamarindus indica.-Leaves yield a red dye; flowers and fruit acid, acting as a mordant.

Terminalia catappa.-Bark and leaves yield a black dye with salts of iron; in some parts of India used to blacken teeth and make ink.

Thespesia populnea.-Bark and wood yield a red coloring matter; capsules and flowers a yellow dye; little used.

Dyeweed. See Eclipta alba.

Earthnut. See Arachis hypogaea.

Echinochloa colona.

JUNGLE RICE.

Family Poaceae.

An annual grass, often growing as a weed in cultivated places, closely allied to the common barnyard or cockspur grass (Echinochloa crus-galli). Stem erect or decumbent, rather slender, leaves flat, narrowly linear, smooth or scaberulous; spikelets in 3 rows, globose or ovoid, acute, crowded on the under surface of the racemed spikes; raceme contracted; spikes 5 to 12 , distant, suberect or appressed, 2.5 to 3.5 $\mathrm{cm}$. long, usually distant, rachis pilose; glumes and lower palea hispid on the nerves, pointed; fertile flower barely pointed.

The typical form of this grass differs from $E$. crus-galli, but there is a gradual transition from one to the other. It is widely distributed throughout the warmer regions of the world. It is found in the United States in Virginia, Florida, Texas, and southern California. It was first collected in Guam by Gaudichaud. The type locality is East Indian. The cultivated form yields a grain which forms a food staple in many parts of northern India. A paste, or mush, is made of it, called "bát" or "phat," and eaten with milk. This preparation constitutes the chief food of the natives of some districts. " It is an excellent fodder grass, both before and after it has flowered, the abundant grain adding to its nutritive value.

REFERENCES:

Echinochloa colona (L.) Link, Hort. Berol. 2: 209. 1833.

Panicum colonum L. Syst. ed. 10. 870. 1759.

\section{Echinus sp.}

Family Euphorbiaceae.

LOCAL NAMES.-Alōm, Alūm (Guam).

A tree growing in marshy or damp places, with linden-like leaves. Flowers small, monoecious, apetalous, greenish, the males clustered, the female solitary in the bracts; male flower with globose or ovoid calyx, 3 to 5-parted; stamens 20 or more, 
crowded on a central receptacle; anther cells globose, attached by a connective; pistillode minute or wanting; female flowers with 2 to 4-celled ovary; styles free or growing together below; ovules 1 in each cell; fruit a capsule. Leaves lobed like those of a Vitis or of an Acer.

The wood of this tree is soft and is used in Guam for making shoe lasts. The vernacular name is applied in the Philippines to another species of Mallotus. The present species is possibly E. tilicefolius (Mallotus tiliaefolius (Lam.) Muell. Arg.), which extends from southern Asia to the Fiji Islands. In Guam it is used medicinally.

\section{Eclipta alba.}

DYEWEED.

Family Asteraceae.

LOCAL Names. - Tinta-tinta (Philippines).

A branching annual composite with inconspicuous white flowers, usually prostrate or creeping, sometimes ascending or erect, 1 foot long or more, sprinkled with closely appressed short, stiff hairs; leaves shortly petiolate, from nearly ovate to oblong-lanceolate or almost linear, 2.5 to $5 \mathrm{~cm}$. long, coarsely toothed or nearly entire; peduncles in the upper axils solitary or two together, very variable in length, bearing a single flower head about $6 \mathrm{~mm}$. in diameter; involucre of about 2 rows of uvate, obtuse, herbaceous bracts; scales of chaffy receptacle narrowly linear; ray florets female, small, shortly ligulate, narrow, white; disk florets hermaphrodite, usually fertile, tubular, 4-toothed; achenes of the disk with thick, almost corky margins, the pappus either quite abortive or reduced to a border of 4 minute obtuse teeth, conspicuous chiefly at the time of flowering.

This plant is widely spread in the Tropics. In India a bluish-black dye is obtained from the juice of its leaves, and in some places it is used for tattooing. In Ceylon it is employed as an alterative medicine by the natives. It was first collected in Guam by Chamisso (1817) and afterwards by Lesson, the botanist accompanying Dumont D'Urville in the Astrolabe. It is found growing in wet places.

\section{REFERENCES:}

Eclipta alba (L.) Hassk. Pl. Jav. Rar. 528. 1848.

Verbesina alba L. Sp. Pl. 2: 902. 1753.

Eclipta erecta L. Mant. 2: 286. 1771.

Eclipta erecta. See Eclipta alba.

Eclipta prostrata. Same as Eclipta alba.

Eddoes. See Caladium colocasia.

Edible senna. See Cassia sophera.

Eggplant. See Solanum melongena.

Egyptian privet. See Lawsonia inermis.

Ehretia buxifolia. Same as Ehretia microphylla.

Ehretia microphylla.

BASTARD CURRANT.

Family Boraginaceae.

Local Names.-Cha cimarron, Alañgitñgit (Philippines),

A bush 90 to $120 \mathrm{~cm}$. high, branches rery numerous, slender, divaricate, the bark reddish brown, eracked; leaves small, 6 to $25 \mathrm{~mm}$. long, very numerous, sessile, fasciculate on suppressed branchlets, obovate-cuneate, acute at base, truncate with a few obtuse crenatures at apex, otherwise entire, slightly rough above with short bristly hairs (with a white spot round each when dry), shining and polished, paler beneath with conspicuous venation; Howers solitary or two together, on very short puhescent pedicels, axillary; calyx hairy, 5-parted, segments oblong-spathulate, acute, leafy; corolla canpanulate-rotate, 6 to $9 \mathrm{~mm}$. in diameter, lobes 5 , ovate, subacute, spreading or recurved; stamens 5 , erect, exserted, inserted on corolla tube; ovary "-elled with 2 orules in each cell; styles 2 , longer than stamens, undivided; drupe small, $6 \mathrm{~mm}$. long, globose, apiculate, shining, scarlet, pyrene 4-celled. Flowers white. Collected in Guam by Luis Née, 1792. 
In India the root is used as a remedy for syphilis. The Mohammedans regaril it as an antidote to vegetable poisons. In Leyte and other Visayan Provinces of the Philippines the natives drink an infusion of the leaves and call the plant "wild tea" (cha cimarron).

\section{REFERENCES:}

Ehretia microphylla Lam. Tabl. Encyc. 1: 425. 1791.

Cordia retusa Vahl, Symb. 2: 42. 1791.

Ehretia buxifolia Roxb. Pl. Corom. 1: 42. t. 5\%. 1795.

\section{Elatostema pedunculatum.}

STRAWBERRY-NETTLE.

Family Urticaceae.

An herbaceous plant or undershrub growing on rocks or trunks of dead trees. Leaves of two forms differing greatly in size, alternate, arranged in two rows, a large leaf on one side with a small leaf on the opposite side; the large leaves lanceolate or oblong-lanceolate, oblique, feather-veined, acuminate, acute at the base, entire or obscurely sinuate-serrate at the tip; the small leaves bract-like, subsessile, lanceolate; stipules axillary; male flowers in cymes, with peduncles 1 to $2 \mathrm{~cm}$. long; female flowers sessile, crowded in heads; heads white at first, growing to the size of a small strawberry, and turning red on ripening. " First collected on the island of Guam by Gaudichaud.

REFERENCES:

Elatostema pedunculatum Forst. Char. Gen. 105. t. 53. 1776.

Procris pedunculata (Forst.) Wedd. in DC. Prod. 16 ${ }^{1}: 191.1869$.

This is Forster's first species and the one he figured, and should therefore be taken as the type of the genus. Procris was proposed as a name for this genus in 1789.

Elder, wild. See Premna gaudichaudii.

Elemi, Manila. See Canarium indicum.

Eleocharis atropurpurea Presl. Same as Eleocharis capitata.

Elocharis capitata.

Spike-RUsh.

Family Cyperaceae.

An annual sedge with fibrous roots, growing in moist places. Culms densely tufted, nearly terete, almost filiform; leaves reduced to sheaths; upper sheath truncate, 1 toothed; spikelet solitary, ovoid, much thicker than the culm, many-flowered, not subtended by an involucre; scales concave, spirally imbricated all around, broadly ovate, obtuse, firm, brown with a greenish midvein, narrowly scariousmargined, persistent; stamens mostly 2 ; style 2-cleft; bristles 5 to 8 , slender, downwardly hispid, as long as the achene; achene obovate, jet black, smooth, shining, nearly $1 \mathrm{~mm}$. long; base of style persistent on summit of achene, forming a tubercle; tubercle depressed, apiculate, constricted at the base, very much shorter than the achene.

Collected by Haenke in Guam.

REFERENCES:

Eleocharis capitata (L.) R. Br. Prod. 225. 1810.

Scirpus capitatus L. Sp. Pl. 1: 48. 1753.

Eleocharis plantaginoidea.

SPIKE-RUSH.

Local NAMEs.-Uchaga lahe (Guam); Boru-pun (Ceylon); Harefo (Madagascar).

A glabrous, leafless sedge. Stems simple, erect, without nodes; sheaths few, cylindrical, truncate or with a small unilateral subapical tooth, barren leaf-like stems often present; inflorescence a single terminal spikelet; glumes imbricated on all sides, obtuse; lowest "bract" (not always empty) not longer than the spikelet; lowest flower nut-bearing, perfect; many succeeding glumes, usually nut-bearing,

a Engler, Nat. Pflanzenfamilien, Teil 3, Abt. 1, p. 109, fig. 79, 1894. 
upper tabescent; hypogynous bristles 5 to 8 , rarely fewer; stamens 1 to 3 , anterior; anthers linear-oblong, not crested; style linear, as long as nut, 2 or 3 -fid; style base dilated, constricted, or apparently articulated on nut, but usually persistent. Nut obovoid, plano-convex (when style is bifid), or trigonous (when style is trifid).

The stem is robust, terete, transversely septate when dry, spikelet dark strawcolored, hardly wider than stem, elongated, many-flowered. Plant stoloniferous, stolons long, $4 \mathrm{~mm}$. in diameter; stems 30 to $90 \mathrm{~cm}$. high, slender; sheaths membranous, soon torn.

In Ceylon sleeping mats are made of the culms of this species, specimens of which are preserved in the Kew Museum. In Madagascar the natives braid them into mats, baskets, and hats. $a$

\section{REFERENCES:}

Eleocharis plantaginoidea (Rottb.).

Scirpus plantaginoides Rottb. Desc. et Ic. Pl. 45. t.15. f.2. 1773.

Scirpus plantagineus Retz. Obs. 5: 14. 1789.

Eleacharis plantaginea R. Br. Prod. 224. 1810.

\section{Elephantopus scaber.}

BLUE ELEPHANT'S-FOOT.

\section{Family Asteraceae.}

Local names.-Lengua de vaca (Porto Rico); Erva da Collegio (Brazil).

A stiff hairy herb, 30 to $90 \mathrm{~cm}$. high, with wrinkled, crenate, cuneate radical leaves. Stem dichotomously branching; cauline leaves lanceolate, floral ones broadly cordate, acuminate, canescent; heads very numerous, sessile, closely packed, forming a large flat-topped terminal inflorescence nearly $2.5 \mathrm{~cm}$. wide, and surrounded at the base with 3 large, stiff, broadly ovate, conduplicate, leafy bracts; involucral bracts 8 , in two rows, linear, acuminate, the outer ones half as long as the inner and scarious, flowers exserted; corolla tube long, very slender, lobes widely spreading; style very much exserted, tapering, pubescent. its branches recurved; achene truncate, nearly glabrous.

Widely distributed in the Tropies. Introduced into Guam. Flowers bright pale violet; a small amplexicaul acute leaf at each bifurcation of the scabrous flowering stem. Used as a remedy for asthenic fever.

REFERENCES:

Elephantopus scaber L. Sp. Pl. 2: 814. 1753.

Elephantopus spicatus.

WHITE ELEPHANT'S-FOOT.

Local Names. - Dilang usa, Habal (Philippines).

A branched, rigid, perennial herb of American origin, but now widely spread in the Tropics. Glomerules 2 or 3 -bracteate, in interrupted, sprearling, compound spikes; Howers white; heads few-flowered, discoid, 1 to 3 in a glomerule; pappus 1-serial, uneyual, with several of the stouter bristles bent upward and downward below the summit. The inferior leaves are spathulate-oblong, variable in breadth, subentire or crenate; superior leaves lanceolate; heads long-linear, 3 or 4-flowered.

A common, troublesome weed, growing usually by roadsides and in waste places. Collected in Guam by Chamisso.

ReFerences:

Elephantopus spicatus Aubl. Pl. Gui. 2: 808. 1775.

Eleusine aegyptiaca. Same as Dactyloctenium aegyptiacum.

Eleusine indica.

YARD GRASS.

Family Pocaeae.

Local Names.-Umog (Guam); Pata de gallina (Cuba).

A tufted grass with flat leaves and digitate spikes at the summit of the culm. Spikelets several-florered, sessile, closely imbricated in two rows on one side of the

a Baron, Economic plants of Madagascar, Kew Bull., vol. 45, p. 211, 1890. 
rachis, which is not extended beyond them; flowers perfect or the upper staminate; scales compressed, minutely keeled, scabrous on the keel, the 2 lower empty, the others subtending flowers or the upper empty; stamens 3 ; styles distinct; stigmas plumose; grain loosely inclosed in the scale and palet.

Common in Guam, growing in sandy places, associated with Dactylocteninm regyptiamm and Capriola dactylon. A grass distributed widely in the tropical and temperate regions of the world. Common in North America.

\section{REFERENCES:}

Eleusine indica Gaertn. Fruct. 1: 8. 1788.

Enredadera (Spanish).

A general name for climbers. See Climbing plants.

Entada pursaetha. Same as Lens phaseoloides.

Entada scandens. See Lens phaseoloides.

Enteromorpha. See Algæ.

Eperua decandra. Samé as Intsia bijuga.

Epidendrum fasciola. Same as Taeniophyllum fasciola.

Epidendrum triste. Same as Luisia teretifolia.

Epiphytal plants:

Cyclophorus adnascens. - A climbing fern, with small simple, linear-lanceolate fronds.

Davallia solida. - A climbing fern, with glossy green divided fronds.

Dischidia puberula.-An asclepiad, with small fleshy leaves.

Humata heterophylla.-A creeping fern.

Luisia teretifolia. - An orchid with inconspicuous flowers.

Lycopodium phlegmaria.-Growing in graceful pendent tassels.

Neottopteris nidus. - The bird's-nest fern.

Nephrolepis acuta. - A fern with long, slender, simply pinnate fronds.

Ophiodermis pendulum. - Hanging like ribbons from the branches.

Piper sp.?.-A pepper called "podpod" by the natives, mentioned by Gandichaud.

Phymatodes phymatodes. - A climbing fern, with leathery, lobed fronds, like an oak leaf.

Taeniophyllum fasciola.-An orchid.

Vittaria elongata. - Ribbon fern growing in grass-like tufts.

\section{Eragrostis.}

A genus of grasses distinguished by having the inflorescence in compound or decompound panicles, spikelets 4 to 10 -flowered; glumes imbricated in two ranks, the upper reffexerl, with the edges turned back; stamens 2 or 3 ; styles 2, with feathery stigmas; seeds loose, 2-horned, not furrowed. Three species have been collected in Guam: Eragrostis pilosa, E. tenella, and E. plumosa, the last regarded by Hooker as a variety of the preceding species. $a$ See under Grasses.

Eranthemum sp. See under Acanthacex.

Erianthus floridulus. Same as Xipheagrostis floridulus.

Eriodendron anfractuosum. Same as Ceiba pentandra.

\section{Erythrina indica.}

East Indian coral tree.

Family Fabaceae.

Local XAMEs. - Gabgab, Gapgap, or Gaogao (Guam); Dapdap (Philippines, Malay Archipelago); Gatae, Ngatae (Rarotonga, Samoa); Piñon (Cuba).

A moderate-sized, quick-growing tree with straight trunk, which is usually armed with prickles when young, pinnately trifoliolate leaves and dense racemes of large scarlet blossoms; leaflets membranous, glabrous, the end one round-cuspidate, truncate, or broadly rhomboidal at the base; calyx oblique, spathaceous, minutely 5 -toothed at the very tip, finally split to the base down the back; petals very unequal,

"See Flora Brit. Ind. vol. 7, pp. 315, 323, 1897, where these species are described. 
standard much exserted and exceeding the keel and wings; wings and keel subequal, not more than half as long as the calyx; upper stamen free down nearly to the base, anthers uniform; ovary stalked, many-ovuled; style incurved, beardless; stigma capitate; pod linear, contracted at intervals.

In Guam the light soft wood of this tree is used for making troughs. Stakes thrust into the ground readily take root, so that the natives use them for making inclosures about their gardens.

In Samoa the natives often use the wood for the outriggers of their canoes, and, when dead and dry, for keeping fire in their houses, as it will smolder a long time without going out.

In India an ointment is made by boiling the leaves with ripe coconut, which is applied to venereal buboes and pains in the joints. The leaves are fed to cattle, and, when young and tender, are eaten in curry.

In Samoa and in other islands of the Pacific the natives reckon the change of seasons by the flowering of this tree.

\section{REFERENCES:}

Erythrina indica Lam. Encyc. 2: 391. 1786.

Escoba (Central America). See Sida rhombifolia.

Escobang-haba (Philippines). See Sida rhombifolia and S. acuta.

Escobilla (Guam). See Sida rhombifolia and S. acuta.

Escobilla papagu (Guam). See Sida glomerata.

Esi (Samoa). See Carica papaya.

Esi fafine (Samoa). The female papaya.

Esi tune (Samoa). The male papaya.

Eugenia spp.?

To this genus were referred two plants collected by Gaudichaud in Guam: A tree called by the natives "aahan," or "aabang," with fine-grained hard wood, yielding $\operatorname{logs} 30 \mathrm{~cm}$. in diameter and $4.5 \mathrm{~m}$. long; and "agatilon," or "agatelang," the wood of which is strong and is used in the construction of houses and ranchos. Neither of these trees has been identified.

Eugenia malaccensis. Same as Caryophyllus malaceensis.

Eulalia. See under Xiphagrostis.

Euphorbia atoto.

SPURGE.

Family Euphorbiaceae.

LoCAL NAMES. - Atoto (Tahiti).

A dwari shrub of wide tropical distrihution, in the Pacific extending eastward to Tahiti and northward to the Marianne Islands. Stem shrubby, usually prostrate or decumbent, stout, much-branched, glabrous and shining, thickened at nodes; leaves opposite, shortly petiolate, 18 to $25 \mathrm{~mm}$. long, oral or oblong-oval, obtuse at both ends, entire, glabrous, the upper ones not imbricating; flower heads axillary or in small terminal 'ymes, stalked; flowers monceious, small, numerous, without a perianth, many male and one female arranged in a common perianth-like involucre, with glands at the mouth, these with rery narrow appendages; male flower, stamen 1, perliceled; female Hower, ovary pediceled, 3-celled with one orule in each cell; styles 3: capsule glahrous, of 3 nutlets separating from a central axis, and each splitting both ventrally and dorsally; capsule glabrous; seed smooth.

Usually growing near the shore.

REFEREXCES:

Euphorbia atoto Forst. f. Prod. 36. 1786.

Euphorbia gaudichaudii.

GAUDICRAUD'S SPURGE.

The entire plant (under the lens) crisply relvety; stem erect, usually simple; leaves petiolite, subcurlate at the base, linear-lanceolate or linear, rather acute, sharply 
denticulate; stipules small, reddish, linear; cymes in the uppermost axils and terminal, subsessile, corymbose-capitate, dense; involucre sparsely hairy without, densely hairy within; lobes triangular-lanceolate; glands substipitate, orbiculate, with a white oborate-oblong appendage much wider than themselves; style bifid, young capsule hairy.

Type specimen, collected in Guam by Gaudichaud, in the herbarium of De Candolle. Stem $30 \mathrm{~cm}$. high; leaves $18 \mathrm{~mm}$. long, 8 to $10 \mathrm{~mm}$. wide; branches of the cymes provided with linear leaves. The plant is rarely smooth. It is closely allied to Euphorbia sinensis (Euphorbia serrulata Reinw. not Thuill.), but its involucre is smaller than in that species.

\section{REFERENCES:}

Euphorbia gaudichaudii Boiss. Cent. Euph. 7. 1860.

\section{Euphorbia hirta.}

Asthma herb.

Local Names.-Golondrina (Guana); Batabotonis (Philippines).

An annual hispid weed with acute leaves, minute flowers, and small round fruit. Stem 15 to $30 \mathrm{~cm}$. high, decumbent, ascending or erect, cylindrical, rather stout, with more or less copious spreading, crisped, bristly hair; leaves opposite, 18 to $37 \mathrm{~mm}$. long, on very short petioles, lanceolate-oblong, very unequal-sided, acute or subacute, serrate, sparingly hairy on both surfaces, pale glaucous, sometimes pinkish, with prominent veins beneath; stipules pectinate, soon falling; flower heads minute, numerous, shortly stalked, crowded in small rounded pedunculate axillary cymes; involucre very small, glands obscure or absent; capsule minute, adpressed-hairy, the lobes keeled; seeds ovoid-trigonous, transversely wrinkled, bright light brown.

Common in cultivated ground and in waste places. Flowers greenish, blooming constantly. A plant widely spread in the Tropics. It has been used as a remedy for bronchitis and asthma, and in Australia it is known as "Queensland asthma herb."

REFERENCES:

Euphorbia hirta L. Sp. Pl. 1: 454. 1753.

Euphorbia pilulifera L. Sp. Pl. 1: 454. 1753.

Euphorbia hirta has place priority.

Euphorbia pilulifera. Same as Euphorbia hirta.

Euphorbiaceae.

SPurge FAMiLy.

This family is represented in Guam by the genera Glochidion, Phyllanthus, Echinus, Acalypha, Ricinus, Aleurites, Jatropha, Manihot, Phyllaurea, Excoecaria, and Euphorbia.

\section{Excoecaria agallocha.}

Blinding tree. Mrlky mangrove.

Family Euphorbiaceae.

Local vames.-Buta-buta, Alipata (Philippines); Siak (Visayan); Sinu-gaga

(Fiji); River poisonous tree, Blind-your-eyes (Australia).

An evergreen tree with glossy, oblong leaves, spikes of small green flowers and acrid, milky sap, growing in mangrove swamps or near the seabeach. Flowers usually monoecious, the female flowers, few in number, growing at the base of the spikes; both sexes without disk or petals; calyx 3-parted; male flowers without rudimentary ovary; stamens 2 or 3 , anthers free; female flowers with 3 -celled ovary; style undivided; floral bracts densely imbricated.

When the tree is cut or bruised the milky juice flows copiously from the wound and soon hardens like rubber. It is so acrid that it will blister the skin and is almost blinding if it gets into the eyes. The smoke of the burning wood is also very irritating; in Fiji it is thought to be a remedy for leprosy. The wood is white, soft, and spongy. In India fishing floats are sometimes made from the roots.

\section{References:}

Excoecuria agallocha Stickman, Herh. Amb. 1754; Amoen. Acad. 4: 122. 1759.

Excoecaria cammettia. Same as Excoecaria agallocha. 
Fabaceae.

BEAN FAMILY.

Among the species growing in Guam included in this family of leguminous plants are the following:

Abrus abrus. - Kolales halom-tano, coral-bead vine.

Aeschynomene indica.-Indian joint-vetch.

Agati grandiflora.-Katúrai.

Arachis hypogaea.-Kakaguate, peanut.

Bocoa edulis.-Polynesian chestnut, recently introduced.

Botor tetragonoloba. - Seguidillas.

Cacara erosa.-Hícamas, turnip bean.

Cajan cajan.-Pigeon pea.

Canavali ensiforme.--Akankan, sword-bean.

Canavali obtusifolium.-A kankan-tasi, seaside bean.

Clitoria ternatea.-Capa de la reina, blue pea.

Cracca mariana.-Marianne goat's-rue.

Crotalaria quinquefolia.-Cascabeles, rattle-box.

Dolichos lablab.-Hyacinth bean.

Erythrina indica.-Gabgab, coral tree.

Indigofera anil.-Añilis, indigo.

Indigofera tinctoria.-Añilis, indigo.

Meibomia gangetica.-Atis-aniti.

Meibomia triflora.-Agsom.

Meibomia umbellata.-Palaga hilitai.

Phaseolus lunatus inamoenus.-Habas, lima bean.

Phaseolus mungo.-Moñggos, gram.

Sophora tomentosa.-Sea-coast laburnum.

Stizolobium pruriens.-Cowhage.

Stizolobium giganteum.-Ox-eye or horse-eye sea-bean.

Vigna lutea. - Yellow-flowered seaside bean.

Vigna sinensis.-Chinese asparagus bean, twining cowpea.

Fabronia. See Bartramia under Mosses.

Faca or Faka (Guam).

A leguminous tree, not identified, with large bipinnate leaves; wood used in the construction of small boats.

Fadan or Fadang (Guam). See Cycas circinalis.

Fàe, Fài, Faai, or Farai (Guam). See Oryza sativa.

Fago (Guam). See Ochrosia mariannensis.

Fa'i (Samoa). See Musa paradisiaca.

Fairy lily (United States). See Atamosco rosea.

Fala (Samoa). See Pandanus tectorius.

False camomile. See Chrysanthemum indicum.

False elder. See Premna gaudichaudii and $P$. mariannarum.

False sandalwood. See Ximenia americana.

Fala (Samoa). See Nothopanax fruticosum.

Fan-flower. See Lobelia koenigii.

Fangu (Samoa). See Lagenaria lagenaria.

Fañog (Guam).

A tree growing in Guan mentioned by Governor Olive in his report to the captaingeneral of the Philippines. Not identified.

Farolitos (Spanish). See Cardiospermum halicacabum.

Fau (Samoa). See Pariti titiaceum; in Hawaii called "hau."

Fau-sonḡà (Samoa). See Pipturus argenteus.

Fau-uta (Samoa). See Mussaenda frondosa.

Federico (Spanish). See Cycas circinalis. 


\section{Fence and hedge plants.}

The following are the most common plants used in Guam for inclosing garden patches. Large fields and plantations are seldom inclosed, but are defined by rows of coconuts, or by lines of physic nut bushes (Jatropha curces) or textile screw-pines (Pandanus tectorius). A prickly pear (Opuntia) and an Agave have heen introduced, but they have not established themselves. On the other hand, the orange berry (Triphasia trifoliata), sappan wood (Biancaea suppan), and the lead tree (Leucaena glauca) have in places spread into thickets. Lawsonia alla, the Egyptian privet, or henna, a favorite hedge plant in some countries, grows well in Guam, but the natives do not use it for hedges. See under Gardens.

Acacia farnesiana.-Aromo; used occasionally.

Agati grandiflora. - Sometimes used; large flowers and long legumes edible; in Guam called "katúrai." (Pl. VI.)

Bambusa sp.-Piao; if placed in the ground green, the stems root at the nodes.

Biancaea sappan.-Sibukao; often used.

Citrus hystrix acida.-The lime (called "limon"); often used, forms dense hedges; always full of fruit.

Citrus medica limon.-The lemon (called "limon real"); fine for hedges; always full of fruit.

Erythrina indica.-The coral tree (called "gabgab"); green stakes root readily; flowers bright red.

Jatropha curcas. - Physic nut (called in Guam "tubatuba"); very often used; green branches root readily. (Pl. LV.)

Leucaena glauca. - The acacia-like lead bush, or lead tree (called in Guam "tangantangan"); one of the commonest hedge plants; cattle will not eat it.

Pithecolobium dulce. - Kamachiles; pods eaten by cattle, bark used for tanning.

Triphasia trifoliata. - Orange berry (in Guam called "lemoncito"); forms dense, thorny hedges.

Fennel. See Foeniculum foeniculum.

\section{Ferns.}

Among the true ferns, or Filicales, the Ceratopteridaceae are represented by the widely spread aquatic Ceratopteris thalictroides (L.) Brogn., the fronds of which in Japan are eaten as a pot herb; the Schizaeaceae by the climbing marsh fern Lygodium scandens Swartz, called also alambrillo, or wire fern, which reappears on the undrained, treeless, savanna lands, and Lygodium circinatum (Burm.) Swartz, the stems of which are braided by the Filipinos into hats; the Gleicheniaceae by Gleichenia dichotoma (Hook.), (Pl. L) (see in place); and the Cyatheaceae, or tree-ferns, by Alsophila haenkei Presl, which grows along the banks of streans in the forests. In the family Polypodiaceae the Acrosticheae are represented by the great simply pinnate marsh fern Acrostichum anrentm L. "lagngayao") (Pl. IV) and by Belvisia spicata (L.) Nirbel, a species with simple fronds, on the contracted apex of which the spores are horne; the Vittarieae by the simple-fronded, plantain-like Antrophyum plantagineum Kaulf., and by Vitteria elongata Swartz, which grows like tufts of grass on the limbs and trunks of trees; the Polypodieae by the climbing Phymatodes phymatodes (L.) Maxon (Pl. LXIII), called "kahlau" or "kahlao," with fronds like huge lobed oak leaves, Cyclophorus adnascens (Sw.) Desv. (Pl. XLVII), also climbing, but with small linear-lanceolate or linear fronds, and Microsorium irioides (Lam.) Fée., a terrestrial species with large broadly linear or sword-shaped fronds dotted with sori on the back; the Pterideae by Pteris marginata Bory, Pteris quadriaurita Retz., and Pteris biaurita L.; tne Asplenieae by Blechnum orientale L., Asplenium falcatum Lam., A. laserpitiifolium Lam., A. monanthemum L., A. nitidum Sw., and the great epiphytal "bird's-nest fern," Nerttopteris nidus (L.) J. Sm., in Guain called "galak" or "galag," the sword-like simple fronds of which are called "sables" by the Filipinos; the Dryopterideae by Dryopteris dissecta (Forst.) Kuntze, and D. parasitica (L.) Kuntze; and the Davallieae by Odontosoria retusa (Cav.) J. Sm. and Schizoloma ensifolium (Sw.) J. Sm., which grow on the savannas, the epiphytal Nephrolepis acuta (Sw.) Presl and the closely allied N. hirsutula (Sw.) Presl, the long, narrow, simply pinnate fronds of which 
hang in graceful tufts from the limbs of forest trees, the curious climbing Humata heterophylla (Sm.) J. Sm. (Pl. LIII), with simple sterile fronds and prettily lobed and crenated fertile ones, and the glossy, divided Davallic solida Swartz (known as pugua machena) (PI. III), which also climbs the trunks of forest trees and perches upon the limbs, associated with the species of Nephrolepis and with Phymatodes phymatodes (L.) Maxon.

No Hymenophyllaceae have been observed in the Marianne Islands.

\section{Fern allies.}

The Ophioglossales are represented in Guam by Ophioderma pendula (L.) Presl, an epiphytal species which hangs from the limbs of forest trees like broad green ribbons, by the natives called "leston." The only representative of the Marattiales recorded from the island is Angiopteris evecta Hoffm. (Pl. XXXIII), which grows in the woods in damp places, usually on the margins of streams.

The Lycopodiales are represented by the epiphytal Lycopodium phlegmaria and the terrestrial $L$. cernuum. No Selaginella has been collected nor have any Equisetales or Salviniales been found on the island.

Fetau (Samoa). See Calophyllum inophyllum.

Fever-nut. See Guilandina crista.

Fiafiatuli (Samoa). See Portulaca quadrifida.

Fianiti (Guam).

A climbing plant with slender, pliable stems, used for lashing together the framework of houses; not identified.

\section{Fiber plants.}

Among the fiber-yielding plants growing in Guam are the following; those marked with an asterisk $\left(^{*}\right)$ are the most important:

Abutilon indicum. - Stem yields a fiber suitable for cordage; not utilized in Guain.

Agave vivipara?.-Called by the natives "lirio de palo" or "tree-lily;" leaf fiber used to wrap cigars and for thread.

* Ananas ananas. - The pineapple; leaf fiber, twisted by hand, used for fine fishing nets.

Annona spp.-Custard-apples; bark of young twigs tough, resembling that of the allied "papaw" of North America (Asimina trilota); fiber utilized in the West Indies, but not in Guam. The strips of bark of Annonu reticulata, which grows wild on the island, are used for temporary lashings.

* Artocarpus communis. - The breadiruit; bark tough and leathery; inner bark utilized in several islands of Polynesia, and probably by the aborigines of Guam, for making bark cloth.

Areca cathecu. - Betel-nut palm; in some countries the flower sheath used for caps and dishes and the leaf sheath for cups and bags; in Ceylon strong and durable water vessels made of it; not utilized for these purposes in Guam.

Bambusa spp.-The shoots yield a fiber of which the Chinese make paper; in several countries matting is nade of the split stems; not utilized in Guam for fiber.

* Boehmeria tenacissima. - The rhea plant, called "amahadyan" by the natives of Guam; grows wild in rocky places; not utilized by the natives for fiber.

Ceiba pentandra.- Kapok tree; the flossy down surrounding the seeds used for stuffing pillows and cushions.

*Cocos nucifera. - The fiber of the husk, called "coir" in commerce, so much used for sennit and cordagra by the Samoans and other Pacific Islanders, is little used in Gram, enormons quantities which could be utilized going to waste each year.

Erythrina indica. - Called "gabgah" by the natives; bark yields a fiber suitable for cordage; not utilized in Guam.

Gossypium spp. - Cotton was introduced about 1866 by the Sociedad Agricola de la Concepcion, and laborers were brought from Japan to cultivate it, but the project proved a failure. It is now found in places by the wayside growing as a weed. 
Fiber plants-Continued.

Lygodium scandens. -Called "alambrillo" (Spanish for "wire") by the natives; in some countries the glossy, wiry stipe is split and woven into hats, mats, etc.; not utilized in Guam.

Musa paradisiaca and Musa sapientum.-Bananas and plantains yield a fiber which has been used in making cordage and textiles. In Guam the natives when in need of a string frequently peel off a strip from the stalk or petiole of the leaf of a banana plant, which is very strong and pliable. The Caroline Islanders weave fine strips from the petiole into the mats which the women wear for aprons.

* Musa textilis.-A Aacà, or "manila hemp;" introduced into Guam about 1866 by the Sociedad Agricola de la Concepcion; clumps of it still growing at the upper end of the Ciénega, but the natives have never learned how to extract the fiber.

* Nypa fruticans. - A stemless palm with giant pinnate leaves growing on the edge of brackish water; introduced into Guam as thatching material. In some countries excellent mats are made of the leaves.

*Pandanus tectorius. - The "aggag" of the natives; hats, bags, and mats of very fine quality are made of its leaves, out of which the aborigines also made the triangular sails for their wonderful "flying praos." Only one sex of this plant grows on the island. The leaves are glaucous and are very tough. Branches readily take root wherever they may happen to be placed. The leaves stripped of the spiny median keel are used for lashing together the framework of houses, taking the place of the coconut sennit so much used by the Polynesians.

* Pariti tiliaceum. - The chief source of cordage in the island.

Saguerus pinnatus. - Cabo-negro palm; yields a strong black fiber; not utilized in Guam, where it is of recent introduction.

Sida rhombifolia. - Called "escobilla" by the natives; yields a fiber suitable for cordage, but utilized by the natives of Guam only for brooms for sweeping their houses.

Taetsia terminalis. - Leaves yield a fiber; stripped into shreds they are used as fringe-like skirts by the Samoans; in Guam, where the plant was introduced about a century ago, the plant is not utilized. The natives call it "Baston de San José," or St. Joseph's wand.

Thespesia populnea.-Called "kilulu" by the natives; yields a bast-fiber.

Trichoon roxburghii.-A marsh reed called "karriso" by the natives, growing in the Ciénega and in other wet places; woven into mats by the natives for ceilings, partitions, and sides of houses, and often covered with a coat of lime or mud.

Ficus sp.

Banyan. Plate vili.

Family Moraceae.

Local nayes.-Nunu (Guam); Nonok, Lonok, Baliti(Philippines); Aoa (Samoa; Rarotonga; Tahiti); Aio (Caroline Islands).

Among the species of Ficus indigenous to Guam is a giant banyan, belonging to the section Urostigma and allied to Ficus indica, Ficus benghalensis, and Ficus religiosa. Like its allies, the Guam species usually begins its life as an epiphyte from seeds dropped by birds on the limbs of other trees. It sends down snake-like, aerial roots, which embrace the host and ultimately strangle it. After entering the ground the roots enlarge into what looks like a compound trunk. The branches also send down roots, at first thread-like and swinging, but at last entering the ground and becoming thick supporting props, so that a single tree often resembles a dense grove.

These trees were considered by the ancient Chamorros sacred to the aniti, or spirits of the departed, and they are still regarded with superstitious dread by the natives. It is interesting to note that the Tahitians and Samoans have the same superstitious awe of the allied aoa trees of their islands, which in ancient times were sacred to the aitu, or wood spirits. Even at the present time few natives of Guam will linger near a nunu tree after dark.

The latex of the nunu is astringent, and is used for stopping the flow of blood. The wood is useless.

Ficus spp.

WILD FIGS.

Two other species of Ficus are called "hoda," or "hodda," and "tagete," or "takete." The hodda has prop-like branching aerial roots, growing from near the base 
of the trurk into the ground, and herries, like small red crab apples in appearance, but fibrous within, like the fruit of a rose. These berries are much relished by the starling-like sali. The tagete, or taguete, as it is written by the Spaniards, is somewhat like the nunu, but its large aerial roots grow exclusively from the trunk. The wood of both is used for fuel.

\section{Ficus carica.}

Fig.

Local Names.-Higo (Spanish).

The edible fig grows in Guam, but for some reason it does not thrive well and is not abundant. It sheds its leaves in the cold season. It is interesting to note that in Bengal, where the climate resembles that of Guam, its culture has not met with success.

\section{REFERENCES:}

Ficus carica L. Sp. Pl. 2: 1059. 1753.

Fig. See Ficus carica.

Filices. See Ferns.

\section{Fimbristylis.}

A genus of Cyperaceae, usually known as "club-rushes." Leaves all toward the base of the stem, narrowly linear or filiform, rarely reduced to sheaths; inflorescence terminal, umbelled or capitate, bracteate, the bracts long or short; spikelets terete, angular, or compressed, many-flowered; glumes imbricated all around the rachilla, or the lower distichous, very rarely all distichous, glabrous, very rarely pubescent, deciduous, lower 1 to 3 , and sometimes the upper empty; flowers bisexual without bristles; stamens 1 to 3 ; filaments flat; anthers linear, obtuse, acute or tipped with a subulate process; nut obovoid, biconvex or trigonous, very rarely cylindric; style long, flattened or slender, deciduous with its dilated base, leaving no scar on the nut; stigmas 2 in the biconvex nuts, 3 in the trigonous, usually filiform and elongate. This genus embraces many tropical species. The following have been collected on the island of Guam.

\section{Fimbristylis affinis. Same as Fimbristylis diphylla.}

\section{Fimbristylis complanata.}

A sedge growing in low moist places to a height of 2 or 3 feet, with a leafy stem and a decompound effuse umbel of compressed spikelets. Rootstock small, hard, creeping, leafy, wiry; stem flattened, 2-edged, deeply furrowed and ribbed, quite smooth; leaves very many, crowded round the base of the stem, and shorter than it, erect, flat, linear, coriaceous, tip obliquely narrowed, obtuse or subacute, margins scaberulous, sheath coriaceous; branches of umbel bearing many small, shortly pedicelled, brown spikelets; bracts one-half as long as the umbel, one leaf-like, erect, the rest subulate; spikelets oblong or oroid-oblong, few-flowered, lower glumes more or less distichous, lowest narrower, subulate or cuspidate, empty, rachilla short, wings deciduous; glumes oblong, obtuse, mucronate, sides appressed together; stamens 3 , anthers very long, obtuse; nut stipitate, 3-gonous, minutely warted, pale; style twice as long as nut, slender, glabrous, base conical, stigmas usually 3 , long.

A plant widely distributed throughout the warmer regions of the globe.

\section{REFERENCES:}

Fimbristylis complanata (Retz.) Link, Hort. Berol. 1: 292.1827.

Scirpus complanatus Retz. Obs. 5: 14. 1789.

Isolepis complanata Roem. \& Schult. Syst. 2: 119. 1817,

\section{Fimbristylis diphylla.}

Collected by Haenke, Gaudichaud, and Lesson. Stigmas 2; spikelets umbelled or capitate, glabrous; glumes mucronate; leaves many.

\section{REFERENCES:}

Fimbristylis diphylla (Retz.) Vahl, Enum. 2: 289. 1806.

Scirpus diphyllus Retz. Obs. 5: 15.1789. 
Fimbristylis globulosa.

A perennial having 3 stigmas, the spikelets terete or polygonal (not 2-sided), the leaves either lacking or very minute.

\section{REFERENCES:}

Fimbristylis globulosa (Retz.) Kunth, Enum. Pl. 2: 231. 1837.

Scirpus globulosus Retz. 6:19, 1791.

Fimbristylis glomerata. Same as Fimbristylis spathacea.

Fimbristylis littoralis. Same as Fimbristylis miliacea.

Fimbristylis marianna. Same as Fimbristylis diphylla.

Fimbristylis miliacea.

An annual with 3 stigmas, the spikelets terete or polygonal (not 2-sided), the style glabrous.

REFERENCES:

Fimbristylis miliacea (L.) Vahl, Enum. 2: 287. 1806.

Scirpus miliaceus L. Syst. ed. 10. 868. 1759.

Fimbristylis puberula. Collected by Gaudichaud.

REFERENCES:

Fimbristylis puberula (Michx.) Vahl, Enum. 2: 289. 1806.

Scirpus puberulus Michx. Fl. Bor. Am. 1: 31. 1803.

\section{Fimbristylis spathacea.}

Collected by Haenke. Stigmas 2; similar to $F$. diphylla, but the glumes with a rounded hyaline tip.

REFERENCES:

Fimbristylis spathacea Roth, Nov. Pl. Sp. 24. 1821.

Fimbristylis torresiana. Same as Fimbristylis globulosa.

Fimbristylis wightiana. Same as Fimbristylis spathacea.

Fish poison. See Barringtonia speciosa.

Fiso (Samoa). See Xiphagrostis floridulus.

Fisoa (Samoa). See Colubrina asiatica.

Flamboyant. See Delonix regia.

Flame tree. See Delonix regia.

Fleurya interrupta. Same as Schychowskya intermuta.

Fleurya ruderalis. See Schychowskya ruderalis.

Flor de Mariposa (Guam.) Same as Bauhinia.

Flower-fence. See Poinciana pulcherrima.

Foeniculum foeniculum.

Fennel.

Family Apiaceae.

Local Names.-Anis hinoho (Guam); Anis hinojo, Haras (Philippines).

An aromatic herb often planted in gardens of the natives. Leaves 3 or 4-pinnate, finely dissected; leaflets divided into linear segments. Bracts wanting; petals yellow, emarginate; fruit oblong or ellipsoid, not laterally compressed; carpels half-terete, ridges prominent, subequal; carpophore 2-parted. Seed somewhat dorsally com- pressed, inner face slightly concave. A widely distributed plant, cultivated in India, the Philippines, and many other tropical and temperate countries. The anise-like seeds have a sweet taste. They yield by distillation an aromatic volatile oil resembling oil of anise.

REFERENCES:

Foeniculum foeniculum (L.) Karst. Deutsch. Fl. 837. 1880-83.

Anethum foeniculum L. Sp. Pl. 1: 263. 1753.

Foeniculum vulgare Gaertn. Fruct. 1: 105. t. 23. f. 5. 1788. 
Foeniculum vulgare. Same as Foeniculum foeniculum.

Fofgu (Guam).

See Pharbitis hederacea, Ipomoea mariannensis, and $I$. congesta.

Fomes. See under Fungi.

Forage plants. See page 150 .

Four-o'clock. See Mirabilis jalapa.

Foxtail, golden. See Chatochloa glauca aurea.

Frijoles caballeros (Porto Rico). See Dolichos lablab.

Frijolillo (Panama.) See Cassia occidentalis.

Frullania. See Hepaticx.

Fuefue-tai (Samoa). See Ipomoea pes-caprae.

\section{Fuirena umbellata.}

Sedge.

Family Cyperaceae.

A sedge, growing in damp places, belonging to the tribe Scirpeae, with dark-brown, dense clusters of sessile spikelets and leafy triangular stems, which are glabrous except at the tomentose inflorescence. Plant perennial; rootstock hard; stoloniferous or shortly creeping with filiform root fibers; stolons hardening into rhizomes, clothed with ovate-lanceolate striate scales; stem 30 to $120 \mathrm{~cm}$. tall, stout or slender, ribbed; leaves variable, 15 to $30 \mathrm{~cm}$. long, up to $14 \mathrm{~mm}$. broad, linear-lanceolate, obtusely acuminate, 3 to 5 -reined, glabrous or ciliate toward the base, margins smooth or nearly so, sheaths long, closed, mouth with a ciliolate brown ligule; spikelets 5 to 8 $\mathrm{mm}$. long, oroid or oblong, sessile, crowded in simple or compound, axillary, peduncled and terminal, sometimes subpanicled clusters 12 to $25 \mathrm{~mm}$. in diameter, dark brown, the peduncle tomentose or villous, rachilla slender; bracts under the clusters short, cuspidate; glumes closely imbricated, at length deciduous, $3 \mathrm{~mm}$. long, membranous, broadly obovoid, retuse or 2-lobed, glabrous or puberulous and ciliate, keel stout, of 3 reins meeting in a stuut scabrid cusp half as long as the glume; scales obovate-quadrate, upper margin thickened, cuspidate; stamens 3, anthers rather stout, apiculate; nut 1.5 to $2 \mathrm{~mm}$. long, stipitate, trapezoidal, trigonous, long-beaked, the angles acute, obscurely 3-ribbed dorsally, smooth, pale; style as long as the nut.

A plant of wide distribution in moist tropical regious. Growing in Guam in swampy places and on the borders of rice fields. Collected here by Haenke and Lesson.

\section{REFERENCES:}

Fuirena umbellata Rottb. Desc. et Ic. Pl. 70. t. 19. f. 3. 1773.

\section{Fungi.}

Very little is known of the Fungi of Guam. Among the few species collecterl by Gaudichaud on the island are Auriculariu uuricula-judue (L.) Schröt, belonging to the Auriculariaceae; Fomes scabrosus (Pers.) Fr., Polyporns kamphoeventri Fr. (P. mariannus Pers.), Polystictus sanguineus (L.) Mey., P. xanthopus Fr. ( $P$. sarmulus Pers.), belonging to the Polyporaceae; and Schizophyllum alneum (L.) Schröt, belonging to the Agaricaceae. From the results of observations on other islands it is certain that a collector of Fungi would have a fine field in the Marianne Islands. Fungi abound everywhere, on the ground, on decaying wood, on tree trunks, on the leaves of water plants, grasses, and forest trees, and upon rotting fruit. Some of them are like great solid masses of gingerbread, others are as delicate as coral, and others appear as microscopic rusts, molds, or mildew. One of the most common is brightly luminous in the dark.

Futu (Samoa, Tonga). See Barringtonia speciosa. 
Gabgab, Gapgap, or Gaogao (Guam).

Vernacular name for a tree, Erythrina indica, and for Tace pinnatifida, the Polynesian arrowroot.

Gabi (Philippines). See Caladium colocasia.

Gado (Guam). See Dioscorea spinosa.

Gafau (Guam). See Melastoma marianum.

Gafo (Guam).' Local name for a fully ripe coconut.

Gadyê or Gayê (Guam). See Lens phaseoloides.

Gafus (Guam). See Medinilla rosea.

Gago (Guam). See Casuarina equisetifolia.

Galag or Galak (Guam).

The bird's-nest fern, Neottopteris nidus.

Gallito (Panama.) See Poinciana pulcherrima.

Gamot sa buni (Philippines). See Herpetica alata.

Ganda (Philippines). See Allium sativum.

Gandul (Porto Rico). See Cajan cajan.

Gaogao (Guam). See Gabgab.

Gaogao uchan (Guam). A species of Phyllanthus.

\section{Gardens.}

Settlers in tropical islands are apt to be disappointed in their first attempts at horticulture. Many take with them a supply of seeds of vegetables and fruits which grow in temperate regions, and plant them only to find that the seed fail to germinate, or that the plants, though apparently thriving, fail to produce fruit. The causes of disappointment in many cases are the loss of vitality of the seeds and not planting at the proper time of the year. There are, however, certain plants which require a cool temperature and can not possibly be propagated in a tropical climate at the level of the sea. Thus it is useless to expect Irish potatoes or cauliflower to grow, and apples, pears, plums, and quinces are out of the question.

All tomatoes, introduced eggplants, and beans should be planted toward the end of the rainy season or at the beginning of the dry season, say November or December. Introduced watermelons, muskmelons, pumpkins, and squashes should be planted after the dry season has set in, and watered if necessary. The red peppers, Leguminosae growing naturally in the Tropics, bananas, plantains, and the perennial eggplant found in the island of Guam may be planted in the rainy season, which is also the time for transplanting cacao, coffee, orange, and other trees, for setting out hedges, and planting maize on the uplands.

During the summer months the rainfall is sometimes so excessive that the surface of the land remains inundated for a day or two, so that such plants as squashes, melons, tomatoes, and lima beans are killed outright. Provisions should be made for drainage. During the rainy months the atmosphere is frequently saturated with moisture and all organic substances, including living succulent plants, are subject to decay. Tomatoes planted by the writer at the beginning of the rainy season grew well at first, but the fruit rotted while still green, and melons planted at the same time were attacked by some fungus disease and failed to reach maturity.

Certain plants appear to thrive best if planted first in boxes raised from the earth and protected from insects. Beets, collards, and lettuce should be planted in this way, and set out in the garden when they have four or six leaves. Tobacco is invariably planted first in sementeras (seed beds), then transferred to larger beds, shaded with muslin or branches, where the individual plants have room to grow, and finally set out in the fields. Plants with a taproot, like radishes and beets, must be 
transplanted while very small. To prepare the ground for a garden it is cleared of brush and weeds. When new weeds begin to spring up the dry brush is spread over the surface and burned, which kills the young seedlings and at the same time enriches the ground with the ashes.

The only implement used by the natives, a scuffle or thrust hoe, called "fusiño," or "foziño," is well adapted for clearing the ground and keeping it free from weeds. It consists of a broad transverse blade provided with a socket into which a long handle is fitted. The iron part is T-shaped, with the socket in the stem of the T and with one arm of the letter longer than the other. In Guam it is usually made by the village blacksmith from a musket barrel-an almost literal example of beating "swords into plowshares and spears into pruning hooks" - a practice which was undoubtedly carried out among primitive people in more than one region of the world. All the natives-men, women, and children-are skilled in the use of this tool.

Many plants will grow in almost pure sand; otbers require the ground to be enriched. For manure cow dung is best. The soil is also benefited by turning under weeds, by planting velvet beans and oth $\bullet r$ nitrogen-gleaning leguminous plants, which may either be fed to cattle or turned under as green manure. An occasional crop of peanuts is recommended, which may be utilized either as forage for animals or as food for man. Wood ashes are always available, and are recommented for the sake of the potash they contain. Nitrate of soda, if it can be obtained, makes an excellent fertilizer; but care must be taken not to apply it too strong; half an ounce to a gallon of water is recommended for potted plants and one ounce per gallon for garden patches.

Hedges are the most economical inclosures. They may be made of lemoncito, lime, lemon, physic nut, or lead tree. The lemon, lime, and lemoncito grow densely, sending up sprouts from their roots. They have the advantage of yielding fruit, but they need to be trimmert and held in check. The physic nut and Leucaena take root readily when freshly cut stakes are thrust into the ground. Both are poisonous and are immune from attacks of animals. Henna is also recommended. It grows readily from cuttings; but the odor of its flowers, though delightful from a distance, is too rank at close range to he agreeable. For surrounding large garden patches remote from dwellings sappan wool and lemoncito are recommended.

Among the animal pests which infest garilens are white ants, mole crickets, and in sume localities land (crahs, which are herbivorous. The field adjacent to the palace at Agaña is riddled with their burrows. Insects are held in check by the use of scalding water. Crabs are often caught by the natives in traps of bamboo placed at the entrance to their burrows.

In the climate of Guam seeds are apt to die if left unprotected for any length of time. Ordinary garden seeds should be thoronghly dried before storing and should be kept in glass jars or tin cans sealed with parattin or soldered. The same precautions should he taken in the transportation of seeds. Corn, onion seed, and seed of lettuce sent from the United States to Manila in paper wrappers were found to be quite dead after having been kept for a few months; and the failure of the seed of lettuce, onions, and of several other vegetables brought by us to Guam may have been owing to carelessness in packing. On the other hand, certain seeds must be kept fresh, as they lose their vitality in drying. This is true of the mango, avocado, mangosteen, and many other tropical fruits, the seeds of which are usually packed for transportation in moist charcoal, to prevent drying and the attacks of fungus. $a$

The regetables arailable for cultivation in Guam and their proper treatment are shown in the following list:

Artichokes.- Not sucessfully grown in Guam. When planted they grow coarse and weedy.

a See Duvel, The Vitality and germination of seeds, U. S. Dept. Agr., Bureau Plant Industry Bull. No. 58. 1904. 
Asparagus. - Can not be cultivated in Guam. As a substitute the young shoots of Chenopodium album and of Amaranthus viridis are eaten.

Beans. - Lima beans will grow, but they do not thrive well. Introduced varieties should be planted at the beginning of the dry season. The purpleflowered Dolichos lablab grows in nearly every garden, together with an interesting bean called "seguidillas" (Botor tetragonoloba), the pods of which are winged with four longitudinal frills and are eaten when green. They are tender and succulent and are free from stringiness. Another bean, Vigno sinensis, which furnishes long, succulent pods, is found growing in nearly every garden. The pods are quite tender when young and are cooked likestring beans. The mature seeds are edible, but are inferior to those of the common phaseolus, or French bean, which is also sometimes cultivated on the island. The yam-bean, Cacara erosa, a plant of Mexican origin, is cultivated chiefly for the sake of its sweetish, turnip-like roots, which may be eaten either raw, made into salad, cooked as a vegetable, or grated and made into puddings. For list of bean species see Beans.

Beets. - The climate of Guam is too moist and warm to be favorable to beet culture. They can, however, be grown. It is recommended to plant the seed in pans and transplant them into beds when the plants have four leaves. They should be planted at the beginning of the cold season. There are several distinct types. One, with the root of a whitish color and cylindrical form, is called "acelga." Another, of a deep red color and turnip-shaped, or fusiform, is called "remolacha." The tops may be eaten as a pot herb.

Cabbage. - Can not be cultivated. As a substitute several kinds of mustard are now grown from seed from Japan brought to Guam by the little schooners of the Japanese commercial company which has established a store at Agaña. All attempts to grow cauliflower have proven failures. Georgia collards are recommended. Tender seedlings of crucifers are subject to the attacks of termites and other insects. Attempts should be made to grow them in pans supported on benches with their legs standing in water. When they have four or six leaves they can be transplanted.

Carrots. - Attempts to cultivate carrots have failed.

Celery.-Will not grow.

Chick peas. - Grow well.

Cress. - There is a species of Nasturtium or Cardamine which grows spontaneously. It has the taste of the common water cress and makes an excellent salad. Peppergrass (Lepidium sativum) may be cultivated. The seed should be sown at the end of the rainy season in shallow pans filled with good light soil.

Cucumbers. - A variety of Cucumis sativus grows spontaneously in waste places. The natives usually eat it cooked. Attempts to grow plants from American seed have proved failures. They germinate, but soon sicken and die. Introduced seed should be planted at the beginning of the dry season.

Eggplant. - This is one of the most important garden vegetables of Guam. The fruit is large, of a dark purple color, and of excellent quality. The plants grow vigorously and with little care, almost like the common Datura. It is usually prepared for the table by stuffing it with chopped meat and roasting it. It is called by its Spanish name "berenhena."

Garlic.-Grown with difficulty and only in small quantities.

Grams or "Monggos."-Grow well. They form the principal pulse-crop of the natives.

Grapes.-Only a few vines grow on the island. It would be well to introduce varieties from the low regions of Peru and Mexico.

Ground Cherry.-Physalis angulata grows spontaneously; the fruit is eaten uncooked as a salad or in the form of sweet preserves.

Horse-radish. - Will not grow,

Lentils. Do not thrive.

Lettuce.-Grown with great difficulty. Seed subject to the attacks of insects. Should be sown in pans and transplanted when four leaves have developed. See Lactuca sativa.

Melons.-A melon of quality inferior to our own grows spontaneously on the island. Seeds of canteloupes or muskmelons brought from the United States germinated, but the fruit did not reach maturity. To insure the best results they should be planted late in the dry season and watered.

Mustard.--Bressica junceu, or Indian mustard, is cultivated in Guam and has escaped in many places. The young leaves are used for "golae," or greens, and take the place of spinach and cabbage. They are also good for salad. Largeleaved varieties from Japanese seed are grown by some of the natives. The leaves are not amplexicaul, the lower ones are stalked and often lyrate or pinna- 
tifid, the margin often hispid when young, upper leaves nearly sessile, linearlanceolate; flowers bright yellow, small; pods slender, 1 or 2 inches long, beak about one-third the length of the pod. This plant is largely cultivated in tropical countries and takes the place of black mustard. In Bengal the seed is of commercial importance as a source of oil used for food. Mustard should be planted at the beginning of the dry season (November).

Okra. - Grows fairly well in Guam. It should be planted at the beginning of the rainy season. The green mucilaginous pods are used in soups and are also cut into slices and fried.

Onions. - The onions grown by the natives are small and rank. Attempts to introduce varieties grown in the United States have not been successful. Seed kept for any length of time should be thoroughly dried and protected from moisture in air-tight jars. It will not retain its vitality long; seeds brought to Guam from San Francisco and kept for three months were found to be quite dead. Onions should be obtained from visiting ships and planted for seed at the end of the rainy season. When the seed matures it should be gathered, dried, and stored in bottles sealed with paraffin, to be planted the following October, November, or December. If trouble is experienced when planting the seed in the garden, sow it in seed pans and transplant. The introduction of Bermuda onions is recommended.

Parsley.- The natives of Guam esteem parsley very highly and often have a few plants growing in pots, like flowers, pinching off a few leaves from time to time as they may be needed. It does not succeed well when sown in the garden. It should be planted in seed pans, sheltered from the sun and heavy rains, and planted out in a shaded bed when about 3 inches high. The transplanting should take place immediately after a good rain, and the plants should be watered frequently until they are well established.

Parsnips.- Will not grow.

Peas (guisantes).-Grow with difficulty; seldom mature. They should be planted at the beginning of the dry season.

Peanuts (kakhuates.).-Common in gardens; grow well and need little care.

Pepper, black. - Will grow, but is not cultivated by the natives; grew in my garden by the side of the betel pepper, which it closely resembles.

Pepper, red.- Several kinds cultivated in the gardens; called by the vernacular name "doni." The favorite variety, a large "bell-pepper," often stuffed with meat and roasted; a smaller variety with pungent pods used for seasoning. All of them flourish and grow with little care; sometimes found in waste places.

Potatoes, Irish.-Will not grow.

Potatoes, sweet.- Several varieties are cultivated. Theygrow well. The natives seldom eat them, but sell them to passing ships, contenting themselves with yams and taro.

Pumpkins and squashes (calamasa, kalamasa, kalabasa).--Several kinds of Cucurbita are grown, incluling varieties of $C$. maxima and C. pepo. Benincasa ceriferc, often called the "wax gourd," and known in Guan as "kondot," is one of the principal cucurbitaceous plants. All should be planted after the beginning of the dry season and watered if necessary.

Radishes.-Grow pretty well; best varieties from Japanese seed; some of them grow quite large.

Rhubarb. - Will not grow on the island.

Sesame.-Grows well.

Spinach.-Does not grow on the island; but its place is taken in a measure by Chenopodium album, which is eaten as golue or greens. A species of Amaranthus is also eaten in the same way. The tender young leaves of taro are also cooked like spinach.

Sweet corn.--Can not be cultivated.

Taro.-Grown extensively in marshy places, on dry hillsides, and on newlycleared land. See Caladium colocasia and Alocasia macrorrhiza.

Tomatoes. - Two rarieties of small size grow with little or no cultivation. Seed from the I'nited States planted in my garden grew well, but the fruit decayed before it reached maturity and was attacked by the larva of some lepidopterous insect. Tomatoes should be planted at the beginning of the dry season.

Turnips.-Do not grow on the island.

Velvet beans. - May be grown to renovate the soil. They should be fed green to cattle.

Watermelons.--These should be planted at the end of the rainy season. Too much moisture is apt to make the fruit decay before ripening, and the vines may be killed outright by a heavy rain which tloods the surface of the garden. 



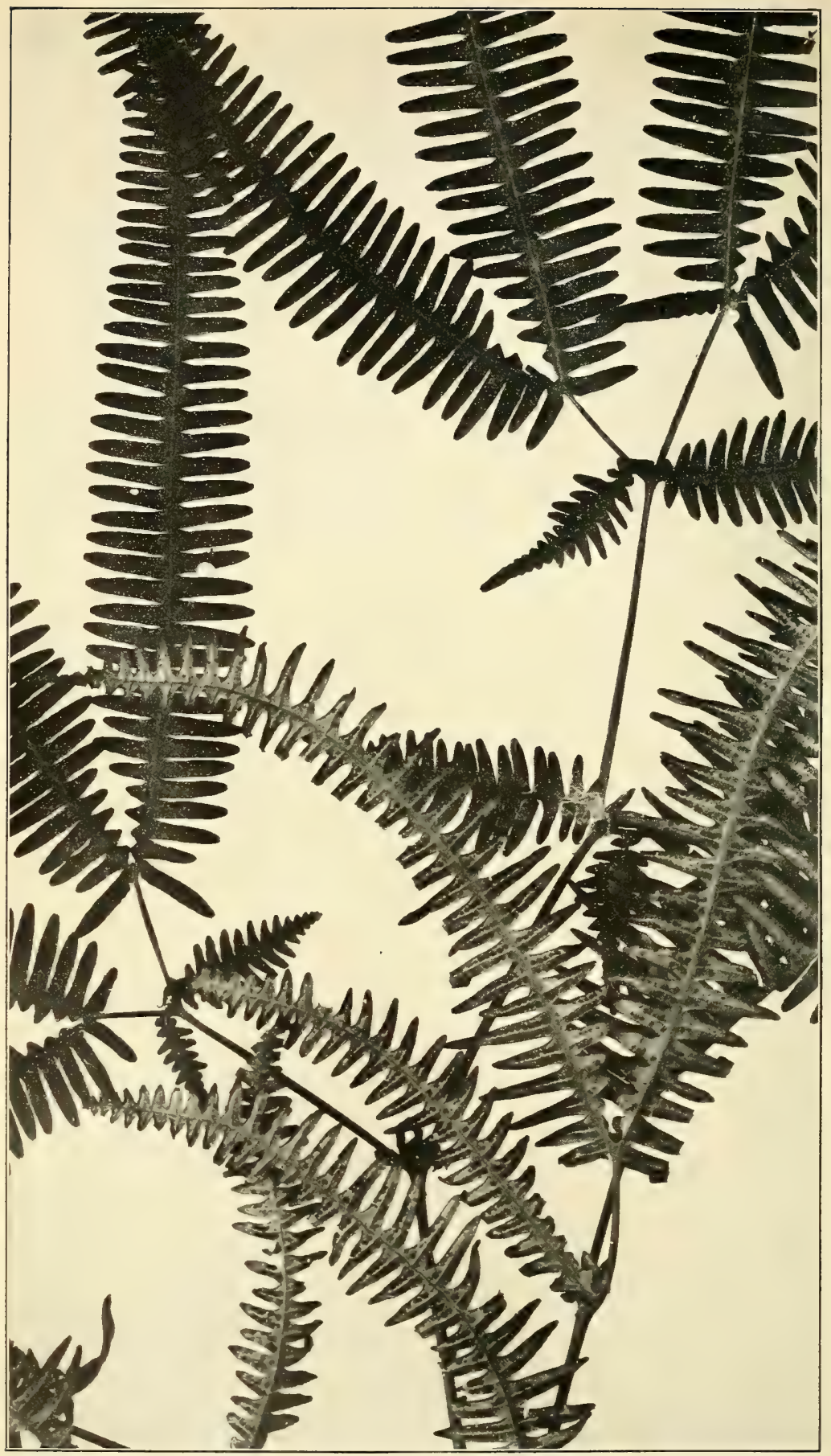

Gleichenia dichotoma, a Fern Growing on the Savannas. Natural size. 
Yams (Dioscorea spp.).--Several varieties are cultivated by the natives; one species grows wild. They are planted in April, the soil having been previously dug deeply. The crop will be ready about December. The maturity of the tubers is indicated by the turning yellow of the leaves. Yams are left in the ground, to be dug as required for use. They will not keep like sweet potatoes, and are therefore not suitable for taking on long voyages. For methods of propagation see under Dioscorea alata.

Yam-beans. Grow readily.

Garlic. See Gardens.

Gasôsô (Guam). See Colubrina asiatica.

Gatae or Ngatae (Rarotonga, Samoa). See Erythrina indica.

Gauay (Philippines). See Lycopodium cernuum.

Gánaygánay (Philippines). See Agati grandiflora.

Gáusâli (Guam). See Cormigonus mariannensis.

Gavo (Philippines). See Caladium colocasia.

Gayê, Gadyê, or Gayi (Guam). See Lens phaseoloides.

Gégé (Guam). See Ambulia indica and A. fragrans.

Geophila reniformis. See Carinta herbacea.

Gingelly, Gingelly oil. See Sesamum orientale; in Guam called "ajónjoli" or "ahónholi."

Ginger. See Zinziber zingiber.

Ginger, wild. Zinziber zerumbet.

Gingili. See Sesamum orientale.

Gleichenia dichotoma.

Local names.-Mana (Guam); Asaua (Samoa).

Savanna fern. Plate L.

A fern growing on the sabanas, or upland, grassy regions. In some islands of Malanesia the wiry stipes are split and braided into baskets and into armbun's or other ornaments. In places where the sabanas have been burned over the stiff, erect stipes project a few inches above the surface, and often cause wounds in the feet of the natives, even when the latter are protected by leather sandals.

REFERENCES:

Gleichenia dichotoma Hook. Sp. Fil. 1: 12.1846.

Globe amaranth. See Gomphrena globosa.

Glochidion marianum.

Chosgo.

Family Euphorbiaceae.

Local names.-Chosgô, Chosgu (Guam).

A smooth evergreen shrubby plant with alternate, oblong-elliptic, entire, shortly petioled leaves arranged in two rows, closely veined beneath and shortly pointed at each end. Flowers small in axillary clusters, shortly pedicelled, apetalous, without disk scales or glands; calyx of both sexes of 2 large and 3 minute sepals, that of the female flower larger than that of the male; male flower without pistillode; anther: 3 , growing together in an oblong sessile column; female flower with 5-celled, globose, smooth ovary; styles growing together in an elongated, subcylindrical column, gradually narrowing from the base to the apex, 3 or 4 times as long as the ovary, the apex shortly 5-toothed; capsule depressed globular, finally 5-lobed. This species has also been collected in Samoa and in the Aru Islands. $a$ Its wood is fine-grained and very strong, and is used by the natives for cart shafts.

The type specimen of this species is from the island of Guam, where it was collected in 1819 by Gaudichaud. It was described by Müller of Aargau, first in Lin-

a Warburg, Beiträge sur Kenntniss der Papuanische Flora, Engler' ' Bot. Jahrl., vol. 13 , p. $355,1890-91$. 
naea $a$ and afterwards in Flora, ${ }^{b}$ where he placed the genus under Phyllanthus and changed the name of the plant to Phyllanthus gaudichaudii, so as not to confuse it with $P$. marianus, $c$ a valid species.

I follow Hooker in recognizing the validity of the genus Glochidion. $d$

References:

Glochidion marianum Muell. Arg. Linnaea 32: 65. 1863

\section{Glossogyne tenuifolia.}

SPANISH NEEDLES.

Family Asteraceae.

A perennial, glabrous composite closely resembling Bidens, but having pistillate ray flowers instead of sterile ones. Stock tufted, sometimes almost woody, with ereet dichotomousstems, 15 to $30 \mathrm{~cm}$. high and often almost leafless, or sometimes elongated decumbent, and leafy at the base; leaves alternate, chiefly radical, or nearly so, the lowest sometimes cuneate and 3-lobed, all the others pinnately divided into 5 or 7 stiff linear segments, either entire or 2 or 3 -lobed; flower heads small, on long slender terminal peduncles; involucre campanulate, not 2 lines long, the bracts few, in about 2 rows, narrow and nearly equal; receptacle chaffy; ray florets pistillate, small, yellow, spreading, ligulate, fertile, or sometimes wanting; disk florets tubular, hermaphrodite, 4 or 5 toothed; anthers obtuse at the base; style branches ending in subulate points; achenes linear, flattened, striate, with 3 or more ribs on each face, crowned by 2 erect or slightly diverging awns.

This plant is common along the roadsides. A preparation made from the root of the very elosely allied Glossogyne pinnatifida is used in India as an application for scorpion stings.

REFERENCES:

Glossogyne tenuifolia (Labill.) Cass. Dict. Sc. Nat. 51: 475. 1827.

Bidens tenuifolia Labill. Sert. Austr. Caled. 44. t. 45. 1824.

Glueweed. See Boerhaavia diffusa.

Goat's-foot convolvulus. See Ipomoea pes-caprae.

Goatweed. See Ageratum conyzoides.

Goat's-rue. See Cracca mariana.

Gogo (Guam). See Lens phaseoloides.

Gogong bakai (Visaya). See Lens phaseoloides.

Golae (Guam).

The vernacular name for greens or leafy esculents (Spanish "verdura"). See Pot herbs.

Golden shower (Hawaii). See Cassia fistula.

Golondrina (Guam). See Euphorbia hirta.

Gomphrena globosa.

Globe amaranth.

Family Amaranthaceae.

Local Names.-Amor seco (Spanish).

In general cultivation; occasionally found in waste places, escaped from cultivation.

REFERENCES:

Gomphrena globosa L. Sp. Pl. 1: 224. 1753.

Gomuto palm. See Saguerus pinnatus.

Goodeniaceae.

Goodenia Family.

The only representative of this family in Guam is Lobelia koenigii.

Goosefoot, white. See Chenopodium album.

Goose grass. See Dactyloctenium aegyptiacum.

$a$ Vol. 32, p. 65, 1863.

$b$ Vol. 48 , p. $379,1865$.
${ }^{c}$ Linnæa, vol. 32, p. 17, 1863.

d Flora of British India, vol. 5, p. 306, 1890. 
Family Malvaceae.

Local Names.-Atgodon (Guam); Algodonero (Spanish); Bulak riga Visaya (Philippines).

A shrub or low tree with purple pilose branches and palmately lobed leaves. Leaves with a nectar gland near the base of the midrib on the lower surface; lobes 5 to 7 , linear-oblong, mucronate, contracted at the base; stipules sword-shaped; flowers purple, rarely white; peduncles axillary, 1-flowered, jointed; bracteoles cordate, ovate, acute; sepals 5 , leafy; petals 5, spreading; staminal tube as in Hibiscus, anther-bearing throughout its whole length; ovary 5-celled; style clavate, 5 -grooved at the apex, with 5 stigmas; ovules many in each cell; capsule about 2.5 $\mathrm{cm}$. long, oblong-pointed; seeds free, covered with white wool overlying a dense green down.

An introduced plant sometimes planted near houses, but never cultivated for its cotton.

REFERENCES:

Gossypium arboreum L. Sp. Pl. 2: 693, 1753.

\section{Gossypium barbadense.}

Sea-island Cotton.

Local names.-Atgodon (Guam); Algodon (Spanish); Bulak Pernambuco or

Fernambuco (Philippines); Vavai (Tahiti).

A shrub or tall herb, the herbaceous portions of which are nearly smooth and are sprinkled with black dots, the branches purplish; leaves usually 1-glandular (see illustration of gland, Pl. X), cordate, deeply 3 to 5-lobed; lobes oblong-lanceolate, acuminate; bracteoles very large, deeply gashed; petals spreading, convolute, yellow, with a crimson spot; capsule oval, acuminate; seeds black, covered with easily separable white or brownish wool.

This introduced plant is the species which furnishes the American varieties known as Bourbon, New Orleans, and Sea-island cotton.

The natives of Guam are ignorant of spinning and weaving. They utilize cotton only for stuffing pillows and cushions. In 1866 an agricultural company called "La Sociedad Agricola de la Concepcion" a attempted the cultivation of cotton, together with that of abaká (Musa textilis), sugar, and rice. Though these products grew well, the company failed for lack of labor.

REFERENCES:

Gossypium barbadense L. Sp. Pl. 2: 693. 1753.

Gourd, bottle. See Lagenaria lagenaria.

Gourd, wax. See Benincasa cerifera.

Gourd-tree. See Crescentia alata.

Gracilaria. See Algæ.

Graciola. See Bacopa monniera.

Gram, green. See Phaseolus mungo.

Grama. See Capriola dactylon.

Gramineae. See Grasses.

Granada. See Punica granatum.

Granatum littoreum. Same as Xylocarpus granatum.

Grape. See Gardens.

Graptophyllum hortense. Same as Graptophyllum pictum.

Graptophyllum pictum.

Caricature plant.

Family Acanthaceae.

Local NAMes. -San Francisco (Guam); Balasbas, Sarása, Lovas (Philippines). 
A variegated-leaved shrub quite common in gardens and often planted in rows near the houses, so as to receive the drippings from the thatched roofs. Leaves glabrous, petioled, opposite, ovate-lanceolate or broadly elliptic, narrowed at both ends, entire, usually variegated with white irregular patches, which frequently resemble a profile of the human face; flowers crimson, pedicelled, clustered in terminal thyrses, with very small, narrow, curved bracts and bracteoles, calyx small, sub-5-partite; segments equal, linear-lanceolate, corolla tube curved; limb 2-lipped, upper lip shortly 2-fid, lower 3-lobed; stamens 2, with 2 minute staminodes; anthers oblong, 2-celled; cells parallel, without points; ovary with 4 ovules; style filiform, scarcely bifid; capsule oblong, hard, contracted into a long stalk; seeds usually 2, orbicular or subquadrate, flat, lacunose-rugose.

This plant is probably a native of Java, but has been spread widely and is found in gardens in nearly all tropical countries. There are varieties having the leaves of a dark-claret color and other with green leaves. In some parts of India the natives use the leaves as soap.

REFERENCES:

Graptophyllum pictum (L.) Griff. Notul. 4: 139. 1854.

Justicia picta L. Sp. Pl. ed. 2. 1: 21. 1762.

Graptophyllum hortense Nees in Wall. Pl. As. Rar. 3: 102. 1882.

\section{Grasses.}

Andropogon aciculatus. - Awned beardgrass. A species widely spread in the Tropics; good pasture, but disagreeable on account of its adherent spikelets and awns.

Andropogon nardus.-Lemon grass. A fragrant, lemon-scented grass, planted by the natives near their houses; said to have been introduced into the island from the Carolines.

Bambos blumeana.-Thorny bamboo. A handsome species, with hard, durable stalks, which resist the attacks of insects; used by the natives for making inclosures, and in the construction of their houses and ranchos; also as water vessels and receptacles for cocoanut sap.

Bambos sp. - An unarmed bamboo, called by Gaudichaud B. ammdinacea, possibly a species of Schizostachyum; inferior to the preceding in strength and durability; subject to the attacks of insects.

Capriola dactylon. - The well-known Bermuda grass, common in the lawns about the houses of the natives; grows well and without care in sandy soil.

Centotheca lappacea. - A broad-leaved robust grass, known as bur grass, growing near the sea and in damp upland regions; good fodder for cattle; found also in Samoa, the Caroline Islands, Philippines, Andaman Islands, and the East Indies.

Chaetochloa glauca aurea.-Golden foxtail. A grass with its inflorescence in spike-like clusters.

Coix lachryma-jobi.-Job's tears. Seeds hard, stony; sometimes strung into necklaces or rosaries.

Dactyloctenium aegyptiacum.-Goose grass. Growing in yards and waste places; a coarse grass with creeping habit of growth; naturalized in the United States.

Dimeria chloridiformis. - A grass with ciliate leaves growing in damp places.

Echinochloa colona. - Jungle rice. A grass allied to our barnyard grass ( $E$. crusgalli), but with awnless scales.

Eleusine indica. - Yard grass; a tufted grass with flat leaves and digitate spikes at the summit of the culm; common in yards; naturalized in the United States. In Guam called "umog."

Eragrostis pilosa. - A grass with erect, tufted, slender-branched culms; common in yards and damp places; naturalized from Europe in the United States; eaten by buffaloes and cattle.

Eragrostis plumosa. - A slender annual grass common in sandy soils and often found in yards of natives; eaten by buffaloes and cattle.

Eragrostis tenella.-An annual grass with stiff, rather brittle, flowering stems, and capillary branches bearing minute spikelets, which are often tinged, when mature, with red; often found in cultivated fields; eaten by cattle; possibly identical with the preceding. 
Grasses-Continued.

Isachne minutula. - A small grass allied to the Panicums, with its inflorescence an open pyramidal panicle with slender branches; spikelets small, obtuse, continuous with the pedicel, articulate above the 2 sterile glumes, 2 -flowered.

Ischaemum digitatum polystachyum.-A grass growing in damp places with inflorescence of 3 to several digitate spikes; branches and pedicels shortly and rigidly ciliate on the external angle.

Ischaemum chordatum.-A grass with spreading culms 60 to $120 \mathrm{~cm}$. high, with sessile lanceolate leaves and with 3 to 6 subdigitate spikes.

Oryza sativa.-Rice. Introduced before the discovery of this island by Europeans.

Panicum gaudichaudii.-An erect grass growing in tufts with undivided eulms, flat leaves, and a fascicle of spikes.

Panicum distachyum. - A decumbent or creeping grass with the stems rooting at lower nodes; eaten by cattle.

Paspalum scrobiculatum.-Kodo millet. An erect or ascending annual grass, bearing a grain which, after special treatment, is eaten by the poor in India.

Trichoon roxburghii.--The common reed. Abundant in the swamps.

Saccharum officinarum. - Sugar cane. Introduced into the island and cultivated before the discovery.

Stenotaphrum subulatum. - Shore grass. A creeping strand grass valuable for lawns and for forage.

Xiphagrostis floridula.-Sword grass, "nete" or "neti." A stiff, erect, perennial reed-like grass, covering large areas called "sabanas." The leaves have cutting edges, owing to the presence of minute sharp teeth along their margins. For uses, ete., see Xiphagrostis floridula.

Zea mays.-Maize or Indian corn. Introduced from Mexico; now the principal food staple of the island.

Greens. See Pot herbs.

Grewia guazumaefolia. Same as Grewia multiflora.

Grewia multiflora.

Family Tiliaceae.

Local Names.-Añgilao, Anilao (Guam).

A shrub or small tree with slender, sparingly hairy branches, and distichous leaves variable in shape and size. Leaves shortly petioled, glabrescent, usually lanceolate, glandular-serrate, the apex sometimes acuminate, the base 3-nerved; petiole pilose; stipules linear-subulate; peduncles half the length of the leaves, pilose; pedicles dilated upward; peduncles axillary, 3-flowered; flower-buds oblong-clavate, petals 5 , entire, half the length of the sepals; stamens many on a raised torus; ovary 2 to 4-celled; drupe fleshy, the size of a small pea, didymous, purplish, glabrescent; stones 1-seeded.

In the Philippines the name Angilao is applied to the allied Columbia anilao Blanco. The fruit of Columbia is in the form of 3 to 5 -winged nutlets. The flowers resemble those of Grewia as to the stamens, 5 distinct sepals, and petals glandular at the base.

REFERENCES:

Grewia multiflora Juss. Ann. Mus. Par. 4: 89. t. 4\%. f. 1, 1804.

Groundberry. See Carinta herbacea.

Ground-cherry. See Physalis angulata and P. minima.

Groundnut. See Arachis hypogaè.

Guaguáot (Guam).

A tree, not identified, the wood of which is used in the construction of houses and is said to be proof against the attacks of insects.

Gumachil, or Guamachi (Mex.). See Pithecolobium dulce.

Guanábano (Spanish America and Philippines). See Annona muricata. 
Guava. See Psidium guajava.

Guayaba, guayava (Spanish). See Psidiun guajara; in Guam called "ahas."

Guegue (Guam). See Ambulia indica and A. fragrans.

Guettarda speciosa.

ZEBRAWOOD.

Family Rubiaceae.

Local NaMes.-Balangigan (Philippines); Zebrawood, Tambari-barisa (Madagascar); Buabua (Fiji); Puapua (Samoa).

A small evergreen tree with fragrant white, jasmine-like flowers, growing near the seabeach. Branchlets stout, short; petioles, leaves beneath, and usually the infloresence pubescent; leaves opposite or 3 in a whorl, with ovate, pubescent, deciduous stipules between the petioles, broadly obovate, 12 to $25 \mathrm{~cm}$. long by 10 to $18 \mathrm{~cm}$. broad, tip acute, obtuse, or rounded, the base obtuse or cordate, petiole $3.5 \mathrm{~cm}$. long; cymes usually from the axils of fallen leaves, long-peduncled, with spreading dichotomous few-flowered branches; calyx velrety, truncate limb deciduous; corolla imbricate, $3.5 \mathrm{~cm}$. long, softly pubescent; limb $2.5 \mathrm{~cm}$. in diameter, segments 4 to 9 , oborate; stamens 4 to 9 , inserted in the mouth of the corolla, subsessile; drupe woody, globose or depressed; endocarp 4 to 9-celled, with as many grooves and angles, perforated at the top opposite the cells; cells curved, 1-seeded.

A plant of wide distribution in the Pacific and on the tropical shores of Australia, India, and Eastern Africa. In Samoa and Fiji the natives string the fragrant flowers into necklaces. In India a perfume is extracted from them. They bloom in the evening and drop to the ground before morning.

It is interesting to note that the seeds of this species are among those collected by Doctor Guppy in the drift on the beach of islands in the Solowon group. Its wide distribution on tropical shores is evidently the result of the fact that the seeds are carried by ocean currents.

REFERENCES:

Guettarda speciosa L. Sp. Pl. 2: 991.1753.

Guilandina bonducella. Same as Guilandina crista.

\section{Guilandina crista.}

Molucca bean. Nickernut. Plate li.

Family Fabaceae.

Local names.-Pacao, Pakao (Guam); Uñas de gato (Spanish); Guacalote príeto (Cuba); Anaoso (Samoa); Tataramoa (Rarotonga $\left.)^{\prime}\right)$ Kakalaioa (Hawaii); Bayag cambing, Calambit (Philippines).

A shrub with climbing or loosely spreading branches, armed with numerous scattered sharp, recurved prickles, especially on the petiole and rachis of the leaves, pubescent or villous in all its parts. Leaves abruptly bipinnate; common petiole 30 to $45 \mathrm{~cm}$. long, pinnae in 4 to 6 distant pairs, spreading nearly at right angles, each 10 to $15 \mathrm{~cm}$. long; leaflets 5 to 8 pairs to each pinna, oblong, often mucronate, 2 to 2.5 cm. long; stipules deciduous; racemes 10 to $15 \mathrm{~cm}$. long, simple or branched in the upper axils; flowers shortly pedicellate and crowded in the upper part; bracts with a long recurved point, deciduous; calyx about 4 lines long; sepals united at the base into a short tube lined by the disk, bearing at its margin the petals and stamens; petals 5 , oblanceolate, yellow, little exserted; stamens 10, free; ovary sessile, with 2 ovules; pods in crowded clusters, short-stalked, broadly ovate-oblong, 5 to $7.5 \mathrm{~cm}$. long, coriaceous, covered with very sharp prickles; seeds, mostly 2 , large, of a bluishgray or lead color, smooth, glossy, nearly round and very hard. The cotyledons are closely appressed and do not fill the shell, but leave an air space which gives buoyancy to the seed. (See Pl. XV.)

a The Rarotongan name signifies "cockspur;" the Hawaiian name "thorny." 


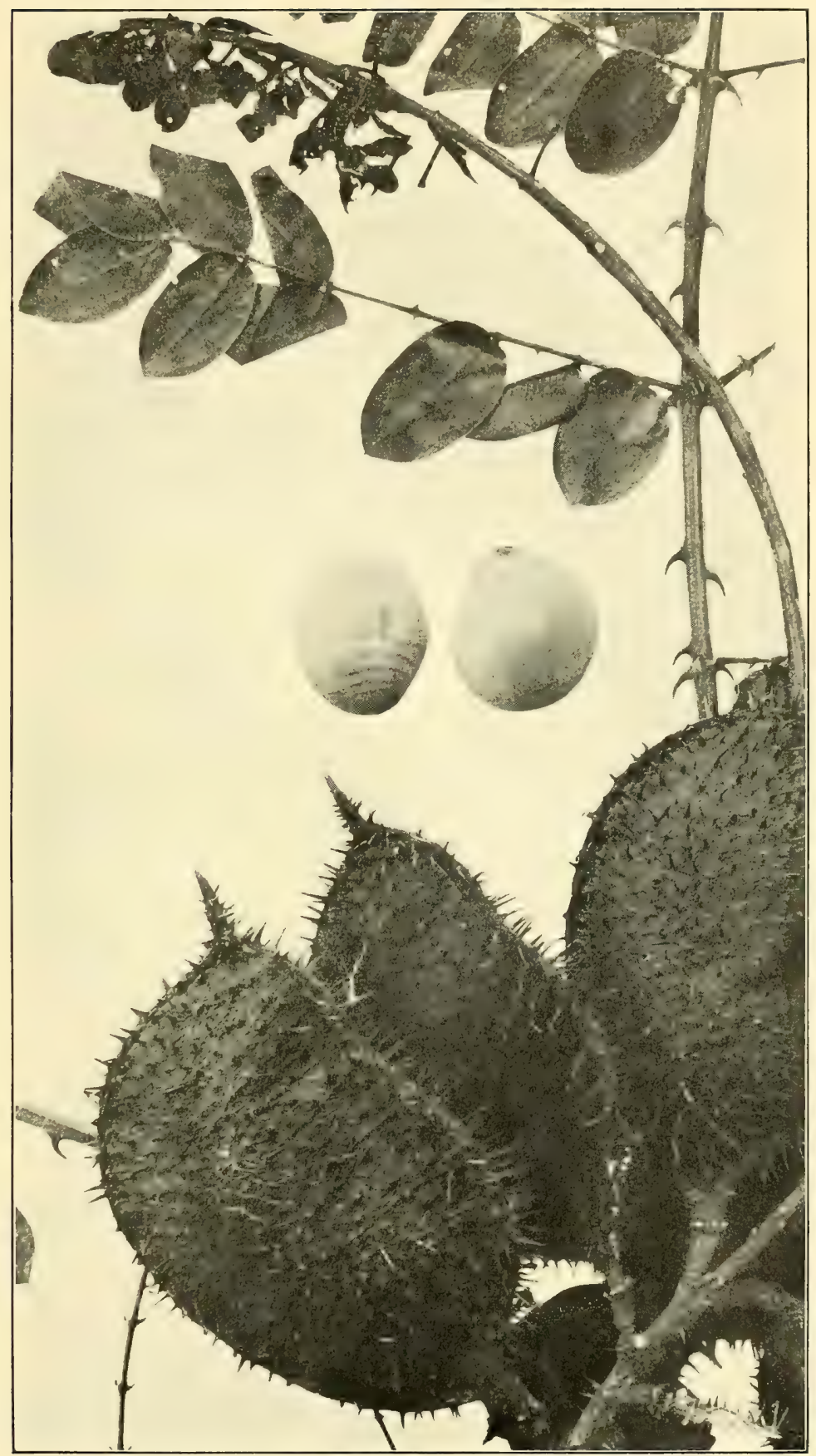

guilandina crista, the nicker nut. Pods and Seeds. Natural size. 

The bitter kernels of the seeds are used as a remedy for malarial fevers; from which fact the seeds are sometimes called "fever nuts."

ReFERENCES:

Guilandina crista (L.) Small, Fl. Southeastern U. S. 591. 1904.

Caesalpinia crista L. Sp. Pl. 1 : 380.1753.

Guilandina bonduc L. Sp. Pl. 1 : 381.1753.

Guilandina bonducella L. Sp. Pl. ed. 2. 1: 545.1762.

Guingambo (Porto Rico). See Abelmoschus esculentus.

\section{Gum and resin plants.}

Acacia farnesiana.-Aromo; yields a gum like that of gum arabic, used by the natives as a mucilage

Anacardium occidentale.-Kasué; yields "cashew gum," used as a varnish to guard against attacks of insects.

Artocarpus communis. - Breadfruit; yields a milky latex, used as a sizing for whitewash and a medium for mixing paint; becomes stiff on exposure to air, and is used for paying seams of canoes and troughs.

Calophyllum inophyllum. - Palo maria; the source of a resin, sometimes called tacamahac, soluble in spirits.

Ochrocarpus obovalis.-Chopag; yields a resin somewhat like that of the palo maria, to which it is closely related.

Ochrosia mariannensis. - Yellow-wood; yields a latex like rubber; not utilized in Guam.

Gulamán (Guam, Philippines). See Gracilaria confervoides, under Algæ.

Gulos (Guam).

An unidentified tree. Leaves abruptly pinnate, the leaflets in two pairs, the terminal pair much the larger; fruit eaten by bats (Pteropus keraudreni); seeds edible, said to be somewhat like almonds. Tree common on the east coast near Pago.

Gumbo (Louisiana). See Abelmoschus esculentus.

Gumamela (Guam). See Hibiscus rosa-sinensis.

Guttiferae. See Clusiaceae.

Gynopogon torresianus.

MAILE.

Family Apocynaceae.

LOCAL NAME.-Nanago (Guam).

A low glabrous evergreen shrub with aromatic, glossy leaves arranged in whorls of three or four. Leaves elliptical or narrowly obovate, obtuse, subemarginate, coriaceous, tapering to the base, short-petioled or nearly sessile; flowers small, salvershaped, white, in axillary clusters with the peduncle exceeding the short petiole; peduncle usually 2-flowered; calyx 5-parted; corolla tube cylindrical, slightly swollen around the anthers and the throat usually somewhat dilated; lobes 5, spreading, contorted in the bud, the throat without scales; stamens 5, inserted in the tube, alternating with the corolla lobes; anthers erect, turned inwards, 2-celled, inclosed in the tube; ovary of 2 distinct carpels, united by a single style; ovules few in each carpel, in 2 rows; fruit an elliptical or nearly round drupe or berry.

This species was collected in Guam by Gaudichaud, who obtained only imperfect specimens of it. Leaves 24 to $36 \mathrm{~mm}$. long, 10 to $20 \mathrm{~mm}$. wide; lateral veins close together, rather distinct; petioles 2 to $4 \mathrm{~mm}$. long. In specimens collected by the writer many of the leaves were sessile. Common on rocky cliffs, especially on the promontory between Asan and Tepungan, at the base of which the road passes aiong the edge of the sea. The plant has the coumarin-like fragrance of the allied species in Hawaii and Samoa, which are called maile or lau-maile by the natives of those islands. In Hawail Gynopogon olvvaeforme is highly esteemed. It is made into garlands by the natives and its fragrance is celebrated in their songs. Its spe-

$9773-05-19$ 
cific name was given it by Gaudichaud in honor of Don Luis de Torres, sarjentomayor at the time of De Freycinet's visit to the island.

REFERENCES:

Gynopogon torresianus (Gaudich.) K. Sch. \& Laut. Fl. Deutsch. Schutzgebiete. in der Südsee 504.1901.

Alyxia torresiana Gaudich. Bot. Freyc. Voy. 451.1826.

Habal (Philippines). See Elephantopus spicatus.

Habas (Spanish, from faba, Latin). See Phaseolus lunatus inamoenus.

Haiguie (Guam). A coconut which has sprouted.

Hala (Hawaii). See Pandanus tectorius.

Halimedia. See under Algæ.

\section{Halodule uninervis.}

Family Potamogetonaceae.

LOCAL NAMEs. - Chaguan-tasi.

A plant somewhat resembling eelgrass (Zostera) in miniature, growing in salt water. It is diceious; the flowers, arranged in pairs, have no perianth; the pistillate ones reduced to an ovary with a short style and a long, thread-like stigma; the staminate consisting of two anthers growing together aiong their backs, with two parallel cells opening outwards by longitudinal slits.

This genus is closely allied to Cymodocea, but differs in haring the male flowers at slightly different heights on the flower stem and in having one instead of two stigmas. The fruits are roundish-oral and scarcely appressed; leares narrowly linear, with distinct midrib and two marginai veins and without definite finer venation, the margins each proionged into a tooth at the apex, between which the apex of the leaf projects.

REFERENCES:

Halodule uninervis (Forsk.) Boiss. Fl. Orient. 5: 24.1884.

Zostera uninerva Forsk. Fl. Aegypt. Arab. 157. 1775.

Diplanthera tridentata Steinheil, Annai. Sc. Nat. II. 9: 98. t. 4. f. B. 1838.

Halom (Philippines). See Amaranthus oleraceus.

Halophila ovata. Same as Halophita ovalis.

Halophila ovalis.

Family Vallisneriaceae.

A plant growing in the sea, often near low-water mark or deeper, and at the mouths of streams. Stems creeping and rooting under water, having at each node a pair of ovai or oblong-elliptical, thin, feather-reined leares with entire margins and long petioles; at the base of the petioles 2 broad, thin, colorless, hyaline scales, within which are the orate sessile inrolucres or double spathes inclosing the flowers; male flowers on perlicels emerging from the involucre; perianth of 3 segments; anthers 3 , sessile, alternating with the segments, erect, 2-celled, the cells opening outward; pollen confervoic; female flowers without perianth, sessile within the involucre; ovary single, tapering into a filiform style with a short stigma, either entire or dirided into 3 to 5 filiform segments; ovules several, erect, attached to the sides of the carity; fruit membranous, opening irregularly; seeds nearly globular, with a thin testa.

This species was first collected in Guam by Gaudichaud. It is often washed up on the beach with algae. $a$

REFERENCES:

Halophila ovalis (R. Br.) Hook. Fl. Tasm. 2: 45.1860.

Caulinia ovalis R. Br. Prod. 339. 1810.

Halophila ovata Gaudich. Bot. Freyc. Voy. 430. t. 40. f. 1. 1826.

a Bot. Freycinet Exp. 430, 1826. 
Handaramai (Guam). See Pipturus argenteus.

Haplachne pilosissima Presl. Same as Dimeria chloridiformis.

Haras (Philippines). See Foeniculum foeniculum.

Hasmín (Guam). See Jasminum grandiflorum.

Hasmín dikike (Guam). See Jasminum officinale.

Hayo or Hayu (Guam). Vernacular word for tree or wood (Malayan "Kayı").

Hayun-lago (Guam).

The name of an introduced tree, mentioned by Freycinet, signifying "foreign wood;" not identified, but evidently belonging to the Fabaceae.

Hayun-mananas (Guam).

A tree given in the list of woods forwarded by Governor Olive y Garcia to the captain-general of the Philippines; not identified.

Hayun-palaoan (Guam).

Name of a tree in Olive's list, signifying "female tree" or "shewood;" used in house building; not identified.

Hedge acacia. See Leucaena glauca.

Hedge plants. See Fence and hedge plants.

Hedionda (Porto Rico). See Cassia occidentalis.

Hediondilla (Porto Rico). See Leucaena glauca.

Hedysarum diphyllum L. Same as Zornia diphylla.

Hedysarum gangeticum L. Same as Meibomia gangetica.

Hedysarum triflorum L. Same as Meibomia triflora.

Hedysarum umbellatum L. Same as Meibomia umbellata.

Heleocharis. A modified spelling of Eleocharis.

Heliotrope, cultivated. See Heliotropium peruvianum.

Heliotrope, Indian. See Heliotropium indicum.

Heliotrope, beach. See Heliotropium curassavicum.

Heliotropium curassavicum.

BeACH HELIOTROPE.

Family Boraginaceae.

Local nayes.-Hunig-tasi (Guam); Cotorrera de la Playa (Porto Rico); Alacrancillo de Playa (Cuba).

A much-branched, prostrate, glabrous, and glaucous perennial, often somewhat succulent, spreading sometimes to 60 or $90 \mathrm{~cm}$. Leaves linear-oblanceolate or oblong, usually obtuse and narrowed into a short petiole, or the upper sessile, rarely obovate, rather thick, inconspicuously veined; scorpioid spikes dense, bractless, mostly in pairs; flowers sessile, calyx segments acute; corolla white with a yellow eye, or changing to blue; stigma umbrella-shaped; anthers acuminate; fruit globose.

A common weed on sandy seashores.

REFERENCES:

Heliotropium curassavicum L. Sp. Pl. 1:130. 1753.

Heliotropium indicum.

Scorpion WEED.

Local Names.-Berbena (Guam); Cotorrera (Porto Rico); Trompa de elefante (Manila); Alacrancillo (Cuba, Mexico); Flor del alacran (Panama).

An annual, hirsute, herbaceous weed with dense, elongate, scorpioid spikes of small blue flowers. Stems 15 to $45 \mathrm{~cm}$. long; leaves alternate or subopposite, 2.5 to $10 \mathrm{~cm}$. long; petioled, ovate, subserrate, more or less woolly; spikes 2.5 to $20 \mathrm{~cm}$. long; sepals linear; corolla tube narrow-cylindric; lobes small, round, crenate; stigma conoidinear; fruit $3.5 \mathrm{~mm}$. long, ovoid, ribbed, soon separating into 2 miter-like nutlets, each nutlet with 2 cavities in addition to the seed-bearing cells. 
Collected in Guam by Chamisso and by Lesson. In Bombay the leaves are used as a local application to boils, sores, and the stings of insects and reptiles.

REFERENCES:

Heliotropium indicum L. Sp. Pl. 1: 130. 1753.

\section{Heliotropium peruvianum.}

Heliotrope.

The cultivated heliotrope, common in the gardens of the natives.

REFERENCES:

Heliotropium peruvianum L. Sp. Pl. ed. 2. 1:187. 1762.

Hemionites plantaginea Cav. Same as Antrophyum plantagineum. See under Ferns. Hemp, bowstring. See Cordyline hyacinthoides.

Hemp, Manila. See Musa textitis.

Henna. See Lawsonia inermis.

Hepaticæ.

LIVERWORTS.

The liverworts of Guam have never been systematically collected. Among those hitherto recorded from the island are Hygrolejeunea sordida (Nees) Schiffn., growing on damp tree trunks, Caudolejeunea recurvistipula (Gottsche) Schiffn., and Frullania gaudichaudii Nees \& Mart., belonging to the Jungermanniaceae. a Frullania nodulosa (R. Bl. \& N.) Nees $b$ was collected by the writer. It is a widely distributed species in the eastern Tropics.

Heritiera littoralis.

Looking-glass tree. Plate lit.

Family Sterculiaceae.

Local names.-Ufa, Hufa (Guam); Chaiping, Chaping (Ponape); Pipilusu (Solomon Islands); Looking-glass tree (India).

A tree growing near the sea, especially in the vicinity of mangrove swamps. Leaves very shortly petiolate, oval or oblong, the larger ones 20 by $10 \mathrm{~cm}$., but often much smaller, entire, feather-veined, coriaceous, glabrous above, silvery underneath with a close scaly tomentum; flowers small, numerous, unisexual, in loose tomentose, panicles in the upper axils much shorter than the leaves; calyx 5-toothed or 5-cleft, about $4 \mathrm{~mm}$. long; petals none; in the male flowers staminal column slender, hearing on the outside below the summit a ring of 5 anthers with parallel cells, shorter than the calyx; in the female flowers, carpels of the ovary 5, nearly distinct, 1-ovuled; style short, with 5 rather thick stigmas; fruit carpels sessile, ovoid, 5 to $7.5 \mathrm{~cm}$. long, thick, and almost woody, with a slight projecting inner edge, and a strong, projecting, almost winged keel along the outer edge; seeds without albumen, cotyledons very thick, the radicle next the hilum.

The wood is durable, hard, and tough. In Guam it is used for spokes of wheels, knees of boats, and especially for plows. The seeds of this tree were among those collected by Doctor Guppy in the drift on the beach of some of the islands of the Solomon group, evidently transported by ocean currents from other shores. The East Indian name, "looking-glass tree," comes from the silver-like appearance of the lower surface of the leaves.

REFERENCES:

Heritiera littoralis Dryand. in Ait. Hort. Kew. 3: 546. 1789.

Hernandia peltata.

JACK-IN-THE-BOX.

Family Hernandiaceae.

Local xames.-Nonag, Nonak (Guam); Puka (Rarotonga); Pu'a (Samoa); Buka (Tonga); Yeruyeru (Fiji); Tia nina (Tahiti); Koli (Solomon Islands); Kolongkolong (Philippines).

"See Schumann und Lauterbach, Flora deutsch. Schutzgeb. in der Südsee, pp. 75 and $76,1901$.

${ }^{b}$ Determined by Dr. A. W. Evans. 


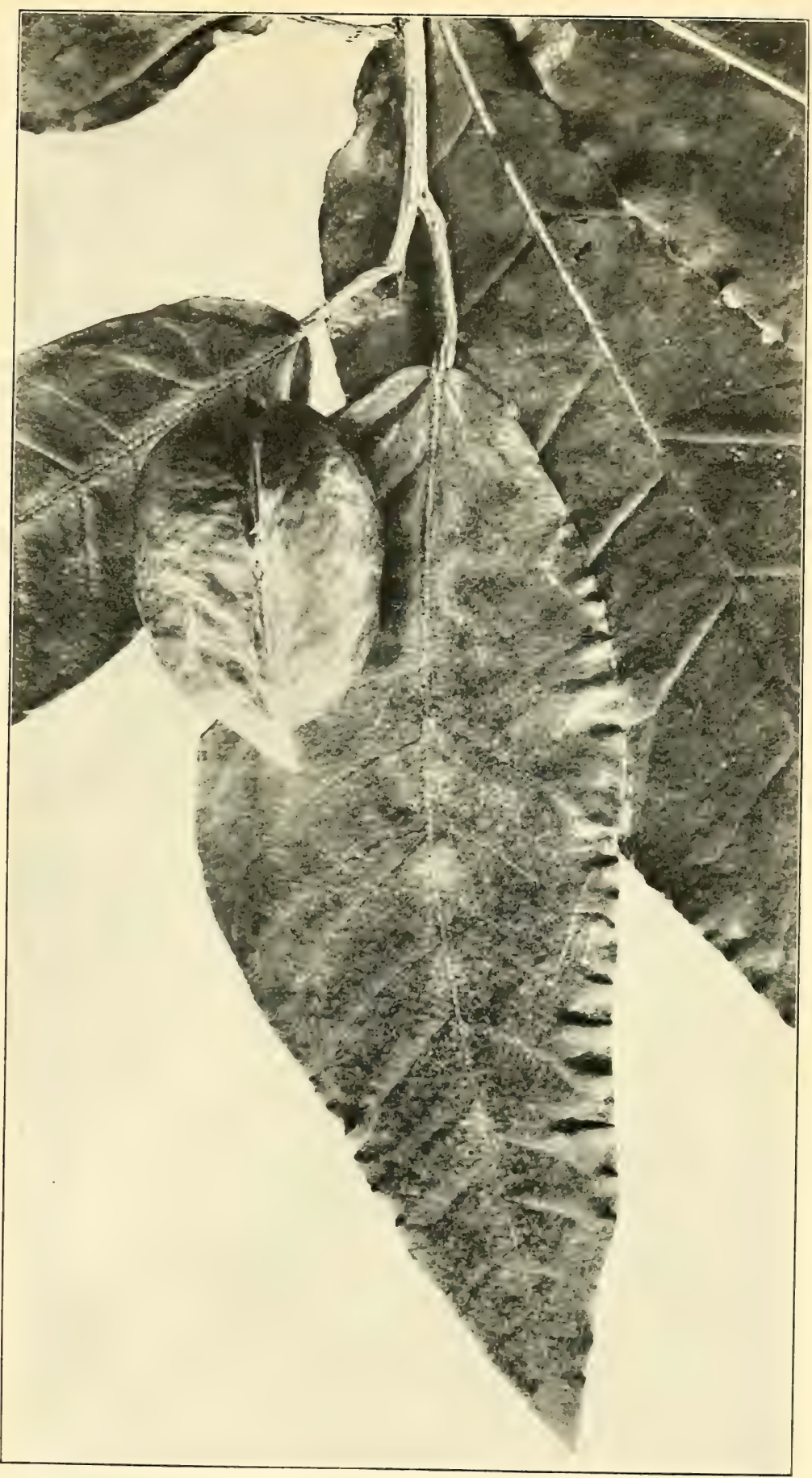

heritiera littoralis, a strand tree. foliage and fruit. natural size. 

A tree with peltate, ovate, acuminate leaves, bearing fruit inclosed in an inflater, globular involucel, having a circular orifice, which gives to it its Samoan name, signifying "iris" (of the eye). Leaves on long petioles marked with a red or a white area at the point of attachment of the petiole, which is near the base, 5 to 9-nerved and remotely feather-veined, the larger ones nearly $30 \mathrm{~cm}$. long, the upper ones much smaller; flowers unisexual, in panicles shorter than the leaves, almost clustered on the branches, one terminal female between two males within a whorl of 4 bracts, and sometimes one or two males lower down with a small bract under each pedicel; perianth-segments in two rows, slightly pubescent, in the male flowers 3 in each row, almost petal-like, veined, about two lines long; stamens 3 , shorter than the segments, with short filaments; female flowers with a cup-shaped, entire, truncate involucel a little below the ovary, $3 \mathrm{~mm}$. long at the time of flowering, but soon enlarged and growing over the ovary or perianth tube; perianth tube of female flowers from the first completely adnate to the fleshy ovary, the segments 4 in each row, the outer ones ovate, the inner ones narrow; glands or staminodia 4, large and nearly globular, opposite the outer perianth segments; style short, thick, with a dilated irregularly lobed stigma, the whole style deciduous with the perianth lobes; fruit completely inclosed in the involucel, which has become inflated, globular, smooth, and fleshy, above $3.5 \mathrm{~cm}$. in diameter with a circular entire orifice of about $12 \mathrm{~mm}$. in diameter; fruit about $2.5 \mathrm{~cm}$. in diameter marked with eight broad raised longitudinal ribs, with a raised terminal umbo; seed very hard, about $19 \mathrm{~mm}$. in diameter; embryo divided into 4 or 5 thick fleshy lobes.

The wood is very light and soft and takes fire readily from a flint and steel. It has been used in Guam for making eanoes, but they soon become water-logged and useless if unpainted and left exposed to the weather. The bark, seed, and young leaves are slightly purgative, and the juice of the leaves is a depilatory, destroying hair without pain. ${ }^{a}$ Distributed in tropical Asia, Africa, and Australia, and eastward in the Pacific as far as Tahiti.

\section{REFERENCES:}

Hernandia peltata Meissn. in DC. Prod. 15 1 : 263. 1864.

Hernandia sonora Endlicher, not L. Same as H. peltata.

Herpestis monniera. Same as Bacopa monniera.

\section{Herpetica alata.}

RiNGWORM BUSH.

Family Caesalpiniaceae.

Local Names. - Acapulco (Guam); Capúlao, Gamot sa buni (Philippines); Laureño (Panama); Guacamaya francesa (Cuba); Talantala (Porto Rico); Taratana (Mexico).

A shrub 2 to 3 meters high with terminal racemes of showy yellow flowers. Branches thick, finely downy; leaves devoid of glands, subsessile, abruptly pinnate, 30 to $60 \mathrm{~cm}$. long; stipules deltoid, persistent; leaflets 6 to 14 pairs, oblong, obtuse, 5 to $15 \mathrm{~cm}$. long, minutely mucronate, rigidly subcoriaceous, glabrous or obscurely downy beneath, broadly rounded, oblique at the base; rachis narrowly winged on each side of the face; racemes peduncled, 15 to $30 \mathrm{~cm}$. long; bracts large, membranous, caducous; corolla yellow, distinctly veined; stamens very unequal; pod membranous, with a broad wing down the middle of each valve; straight, glabrous, 10 to $20 \mathrm{~cm}$. long by 12 to $14 \mathrm{~mm}$. broad; seeds 50 or more.

This shrub was introduced into Guam from Acapulco, whence it takes its local name. Its leaves are used by the natives as a remedy for skin diseases, and especially for ringworm.

References:

Herpetica alata (L.) Raf. Sylva Tellur. 123, 1838.

Cassia àlata L. Sp. Pl. 1 : 378.1753.

$a$ Watt, Economic Products of India, vol. 4, p. 225, 1890. 
Hialoa (Hawaii). See Waltheria americana.

Hibiscus esculentus. Same as Abelmoschus esculentus.

Hibiscus mutabilis.

Changeable rose-mallow.

Family Malvaceae.

Local Names. - Mapola (Guam); Amistad (Mexico); Maravilla (Porto Rico).

A shrub or small tree which has flowers that change in color, almost white in the morning and red at night. Leaves downy, cordate, 5 -angled, $10 \mathrm{~cm}$. in diameter, petiole $7.5 \mathrm{~cm}$; peduncles axillary, nearly as long as the leaf, jointed near the top; bracts shorter than the calyx; flowers 7.5 to $10 \mathrm{~cm}$. in diameter; sepals ovate-lanceolate, connate below the middle; capsule depressed-globose, hairy; seeds reniform, hispid.

Planted in many gardens in Guam. The bark yields a strong fiber, but this has never been used for cordage.

References:

Hibiscus mutabilis L. Sp. Pl. 2: 694. 1753.

Hibiscus populneus. Same as Thespesia populnea.

Hibiscus rosa-sinensis.

SCARLET ROSE-MALLOW,

Local Names.-Gumamela (Guam); Tapuranga (Philippines); Kaute (Rarotonga); Aute (Samoa); Shoe-flower (India); Fu-sang (China).

An ornamental shrub planted by the natives near their houses. In Guam only the crimson-flowered varieties, single and double, are found. Leaves ovate, acuminate, entire at the base, coarsely toothed at the apex, nearly glabrous; stipules sword-shaped; peduncles axillary, as long as or longer than the adjoining leaf; bracteoles 6 or 7 , linear, half the length of the bell-shaped calyx; sepals lanceolate, connate below the middle; staminal tube exceeding the corolla; capsule rounded; many-seeded. Seldom seeds in cultivation.

In India the flowers are used to black shoes, and paper colored with the petals is used in the place of litmus for testing. The plant is easily propagated by cuttings. These should be removed with a piece of the old wood adhering, placed in water until roots begin to make their appearance, and then planted. In this way it is possible to have a fine hedge under way in a very short time, which begins to bloom immediately if flowering twigs have been selected for cuttings.

REFERENCES:

Hibiscus rosa-sinensis L. Sp. Pl. 2: 694. 1753.

Hibiscus tiliaceus. Same as Pariti tiliaceum.

Hierba buena (Spanish). See Mentha arvensis.

Hierba de pollo (Spanish). See Portulaca quadrifida.

Hierba de Santa Rosa (Mexico). See Antigonon leptopus.

Higo (Spanish). See Ficus carica.

Híkamas (Guam). See Cacara erosa.

Hikara (Guam). See Crescentia alata.

Hinaxamai (Philippines). See under Piptums argenteus.

Hinegsa (Guam). See under Oryza sativa.

Hoda or Hodda (Guam). See Ficus spp.

Hogweed. See Boerhaavia diffusa.

Hoja de bouja (Cuba). See Bryophyllum pinnatum.

Hombronia edulis. Same as Pandanus dubius.

Horse bean. See Canavali ensiforme.

Horse-radish tree. See Moringa moringa.

Huamachil (Mexico). See Pithecolobium dulce. 



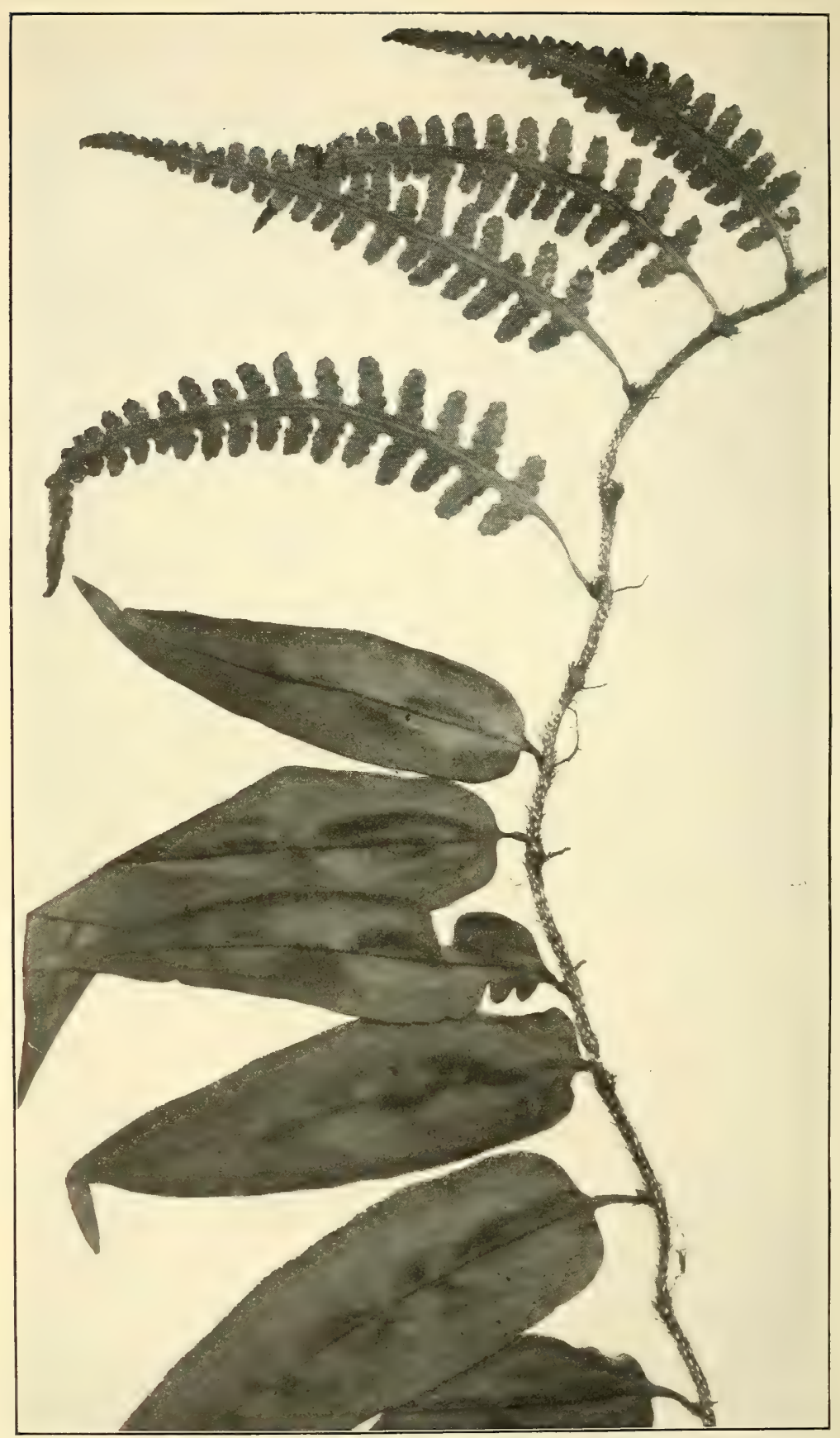

humata heterophylla, the Umata fern. Natural Size. 
Hufa (Guam). See Heritierc littoralis.

Huisache (Texas). See Acasia farnesiana.

Humata heterophylla.

Umata fern. Plate lim.

Family Polypodiaceae.

A creeping fern with dimorphous fronds, the sterile ones ovate-lanceolate or lanceolate, entire or slightly lobed at the base, the fertile ones narrower, deeply sinuate-pinnatifid, the lobes coarsely crenate; sori 2 to 10 to a lobe; involucre ample, coriaceous, suborbicular or reniform, attached by a broad base, the apex and sides free. This genus was founded by Cavanilles on specimens collected by Née, who visited Guam in company with Haenke with the Malaspina expedition. It was named for the village of Humata (or Humátag), now called Umata, on the west coast of the island south of the peninsula of Orote.

REFERENCES:

Humata heterophylla (Sm.) J. Sm. Hook. Journ. 3: 416. 1841.

Davallia heterophylla Sm. Act. Taur. 5: 415. 1793.

Humata pinnatifida Cav. Prael. no. 679, 1801.

Humata pinnatifida. Same as Humata heterophylla.

Hunig or Hunik (Guam). See Tournefortia argentea.

Hunig-tasi (Guam). See Heliotropium curassavicum.

Hydrocotyle asiatica L. Same as Centella asiatica.

Hygrolejeunea. See Hepaticæ.

Hymenocallis littoralis. Same as Pancratium littorale.

Hypnum. See Mosses.

Hypoxis aurea.

Golden STAR-GRASS.

Family Amaryllidaceae.

A small hairy plant with grass-like leaves and yellow, star-like flowers. Rootstock tuberous; leaves radical, narrowly linear; scape filiform, hairy, with one or two flowers; bracts setaceous; perianth rotate, 6-parted, yellow within, sessile on the top of the ovary, persistent; ovary and perianth lobes externally hairy, 3 outer lobes green on the back; flowers diøecious; stamens 6 on the base of the segments, filaments short, anthers sagittate; ovary clavate; capsule at length 3-valved, crowned with the erect perianth-lobes; seeds black, tuberculate.

Common in Guam on the treeless sabanas, especially on Mount Makahna near Fonte, back of Agaña.

The species is widely spread in the Philippines, India, Java, China, and Japan.

REFERENCES:

Hypoxis aurea Lour. Fl. Cochinch. 200. 1790.

Hyptis capitata. Same as Mesosphaerum capitatum.

Hyptis pectinata Poit. Same as Mesosphaerum pectinatum.

\section{Icacorea sp.}

Family Myrsinaceae.

LoCAL NaMes. - Otot, Otud, Utud, Utug (Guam).

A low shrub with simple, alternate, lanceolate leaves, bearing racemes of small, red, globose berries of a pleasant acid flavor like that of tamarinds. The berry contains a single hard globose seed, flattened at the base, with its envelope covered with longitudinal or radiating striations.

The berries have a pleasant acid flavor like barberries. Birds are fond of them, but they are not usually eaten by the natives.

If (New Guinea), Ifi (Samoa). See Bocoa edulis。

Ifi-lele (Samoa). See Intsia bijuga. 
Ifil or Ifit (Guam). Intsia bijuga; in the Philippines called "ipil."

I'i (Samoa). See Oxalis corniculata.

Ilangilang (Guam, Philippines). See Canangium odoratum.

\section{Illuminating oils.}

The following plants yield oils used for lighting: Aleurites moluccana, Calophyllum inophyllum, Cocos nucifera, Jatropha curcas, Ricinus communis, Sesamum orientale, Xylocarpus granatum.

\section{Impatiens balsamina.}

GARDEN BALSAM.

Family Impatientaceae.

Local nayes. - Belen (Mexico); Sulangga, Camantigui (Philippines); Touchme-not (United States).

This well-known garden plant is found in most gardens of Guam, and in places has escaped from cultivation. In the Philippines, according to Mercado, the women and girls make use of it to dye their finger nails. In Chamba, northern India, the seeds are eaten by the natives, and an oil is expressed from them which is used as food and also for burning.

REFERENCES:

Impatiens balsamina L. Sp. Pl. 2:.938. 1753.

Imumu (Guam). Name of a poisonous tree; not identified.

Indian almond. See Terminalia catappa.

Indian corn. See Zea mays.

Indian joint-vetch. See Aeschynomene indica.

Indian licorice. See Abrus abrus.

Indian mallow. See Abutilon indicum.

Indian mercury. See Acalypha indica.

Indian mulberry. See Morinda citrifolia.

Indian pennywort. See Centella asiatica.

Indian shot. See Canna indica.

Indigo. See Indigofera anil and $I$. tinctoria.

Indigofera anil.

INDIGO.

Family Fabaceae.

Local names. - Añilis (Guam); Añil (Spanish); Tagum (Philippines).

Low shrub very common in abandoned clearings, slightly pubescent with odd pinnate leaves and axillary sessile racemes of many small greenish purplish fiowers. Stipules awl-shaped; calyx lobes triangular; standard roundish; keel spurred; leaflets 3 to 7 pairs, spatbulate-oblong; pod oblong-linear, cylindrical, not torulose, much thickened along the dorsal line, 3 to 6 -seeded.

This, like the next, is a well-known dye plant, introduced into the island more than a century ago.

REFERENCES:

Indigofera anil L. Mant. 2: 272.1771.

Indigofera tinctoria.

INDIGO.

Local names. - Añilis (Guam); Añil (Spanish); Tagum (Philippines).

Low shrub like the last and in similar places. Leaflets 4 to 6 pairs, oval or obovateoblong; pods many-seeded, slightly torulose or swollen at intervals, and somewhat thickened along the line of dehiscence.

Like the last, a dye plant introduced long ago. Neither is utilized by the natives.

REFERENCES:

Indigofera tinctoria L. Sp. Pl. 2:751. 1753 .

Inga dulcis. Same as Pithecolobium dulce. 


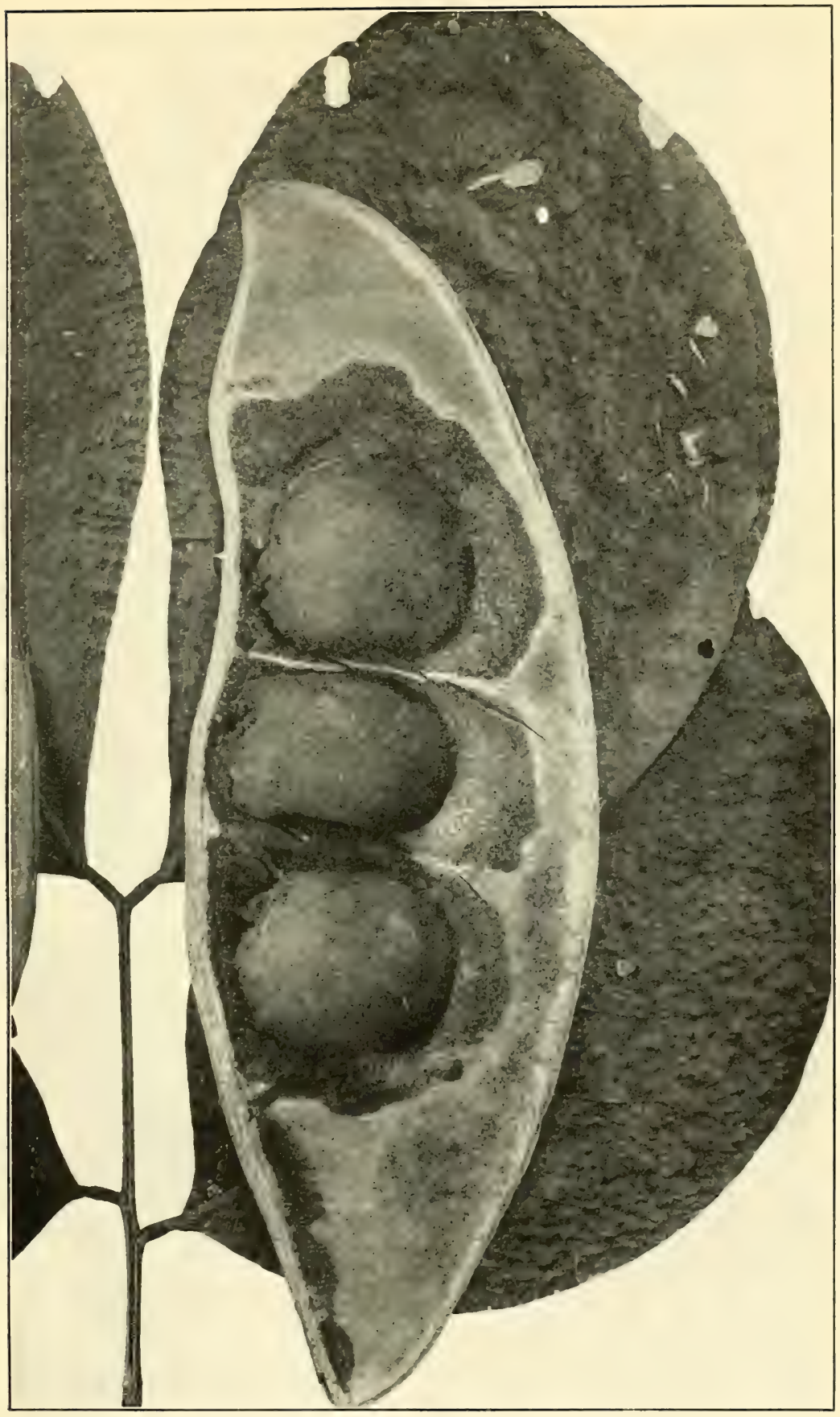

intsia bijuga, the Ipil tree. Natural Size. 

Inifut or Inifuk (Guam).

Vernacular name of a purplish grass, which sticks to the clothing.

Inkberry. See Cestrum pallidum.

Inocarpus edulis. Same as Bocoa edulis.

Intsia bijuga.

Ipil. Plate liv.

Fan.ly Fabaceae.

Local xames.-Ipil (Philippines); Ifil, Ifit (Guam); Ifi-lele (Samoa); Vesi (Fiji).

The most important timber tree of Guam. Leaves abruptly pinnate; leaflets 2 pairs (rarely 1 pair), obliquely oblong, glabrous, inclined to be leathery; flowers in a dense terminal corymbose panicle; calyx-tube cylindrical; sepals 4; corolla consisting of one developed petal, which is exserted and is round in form, with a long claw; fertile stamens 3 , sterile 7 ; filaments more than $2.5 \mathrm{~cm}$. long, anthers small; pod rigid, flat, oblong, opening with difficulty; seeds 1 to 5 .

The heartwood of this tree is very hard and heavy, but not elastic. It is crossgrained and hard to work. It is very durable and is used for the posts of the best houses. The pillars of the church of Agaña are the trunks of ifil trees cut very near the site of the building. At first the wood is yellowish, then it turns rust-color, and assumes a dark color with time, resembling that of black walnut. Although of rather coarse grain, it takes a very fine polish. Nearly all the better houses of the island have tables and settees made of it, and even floors, which are kept beautifully polished by rubbing them with grated coconut wrapped in a cloth, through which the oil oozes. The wood has the virtue of resisting the attacks of termites or white ants. Trunks 9 meters long and 1 meter in diameter are sometimes found, but they usually vary from 2.5 to 5 meters in length and from 30 to $60 \mathrm{~cm}$. in diameter. Houses made of newly sawn ifil are not whitewashed or painted until the wood has had time to dry and season, on account of the brown coloring matter, which discolors the surface. When old the wood becomes so hard that holes must be bored in it for nails. The trees are becoming scarce in the vicinity of Agaña, but are still comparatively abundant in the forests of the northern part of the island.

\section{REFERENCES:}

Intsia bijuga (Colebr.) Kuntze, Rev. Gen. 1: 192. 1891.

Afzelia bijuga Gray, U. S. Expl. Exped. 1:467. 1854, not Afzeliam bijuga Spreng. 1827.

Macrolobium bijugum Colebr. Trans. Linn. Soc. 12: 359. 1818.

Ipecac, wild (Hawaii). See Asclepias curassavica.

Ipil (Philippines). See Intsia bijuga.

Ipomoea batatas.

SWEET POTATo.

Family Convolvulaceae.

Local Names.-Camotic (Mexican); Camote (Spanish); Kamote, Kamute (Guam); Kumara (Rarotonga, New Zealand); 'Umala (Samoa and other Polynesian groups); Uala (Hawaii); Cumar (Quichuas of Ecuador); Ubicastela (Malayan).

There are several varieties of sweet potato growing in Guam, differing from one another in shape, color, and quality of the root, and in the shape of the leaves. One of these was brought to the islands from Hawaii and is still called by the natives "kamutes de Guahú" (Oahu). Some of the earliest navigators mention "batatas" among the supplies received from the natives of Guam, but it is certain that they applied this name to the yam. In picturing the privations of the first missionaries in establishing themselves in Guam, Padre Francisco Garcia mentions that they were obliged to eat certain roots like sweet potatoes, but without the flavor of the Camotes of Mexico. Sweet potatoes were introduced, however, at a very early date by the 
Jesuits. They were much more to the taste of Europeans than the yams of the island and were among the supplies most prized by the whalers visiting the island. The natives seldom grew them for their own use, but contented themselves with yams, exchanging the sweet potatoes for fabrics and other things brought by the ships.

Sweet potatoes grow very well in Guam. They are among the crops which will thrive on the high land or "mesa" in places where the soil is too much exhausted ("cansado") for other things.

REFERENCES:

Ipomoea batatas (L.) Poir. Encye. 6: 14. 1804.

Convolvulus batatas L. Sp. Pl. 1: 154. 1753.

Ipomoea biloba. Same as Ipomoea pes-caprae.

Ipomoea choisiana.

PURPLe MORNing-GLORY.

Local names.-Pipa (Rarotonga); Tangā-mimi (Samoa).

Stems trailing, somewhat twining; leaves variable, not fleshy, 2 to $7 \mathrm{~cm}$. long, cordate or hastate at the base, acute or obtuse, mucronate, entire or more or less dentate, or deeply 3 or 5-lobed, glabrous; petiole usually longer than the leaves; flowers rather large, purple, on rather long glabrous pedicels, solitary or 2 or 3 from a short common peduncle; bracts inconspicuous; sepals $7 \mathrm{~mm}$. long, oboyate-oblong, obtuse, mucronate, glabrous; corolla widely funnel-shaped; limb $3.5 \mathrm{~cm}$. in diameter, lobes apiculate; ovary 2-celled; capsule globose, glabrous; seeds smooth.

A tropical seashore plant of wide distribution. First observed in Guam by Gaudichaud.

\section{REFERENCES:}

Ipomoea choisiana.

Convolvulus denticulatus Desrouss. in Lam. Encyc. 3: 540. 1789.

Ipomoea denticulata Choisy, Mem. Soc. Phys. Genev. 6: 467. 1833, not R. Br. 1810.

The binomial published by Choisy is preoccupied by the Ipomoea denticulata of Robert Brown, and the specific name is therefore untenable, even though it be of earlier date in combination with a different generic name.

Ipomoea congesta.

ISLAND MORNING-GLORY.

Family Convolvulaceae.

Local Names.-Fofgu (Guam); Koali, Koali awahia (Hawaii); Wa wuti (Fiji).

A stout twining plant, with cordate, acuminate leaves and azure blue flowers, turning purple or reddish on drying. Lower part of stem wcody, leaves with broad rounded sinus at the base and auricles, 7.5 to $11 \mathrm{~cm}$. long, when young silky pubescent on both faces; petioles 5 to $10 \mathrm{~cm}$. long; peduncles bearing 2 or more flowers; sepals herbaceous, acuminate; corolla tubular-campanulate, 5 to $7.5 \mathrm{~cm}$. long, ciliate at the bottom of the tube, as are also the bases of the style and stamens; stamens one-half as long as the corolla; style as long as the stamens, the stigma entire, globose; ovary supported by a campanulate disk; capsule globose, about the size of a small cherry, splitting into halves, the two seeds dark brown, glabrous.

The leaves of this plant are sometimes 3 -lobed and the apex less acuminate than in the typical form. It grows on the island of Apapa, in the harbor of Apra, and was referred to by Freycinet as Coniolvulus trilobatus. It climbs among thickets. The root is a powerful cathartic.

It was first collected in Guam by Gaudichaud. It occurs in Hawaii, Fiji, Tonga, Samoa, Tanna, Norfolk Island, and on the east coast of Australia.

REFERENCES:

Ipomoea congesta R. Br. Prod. 485. 1810.

Ipomoea denticulata. Same as Ipomoea choisiana.

Ipomoea insularis Steud. Same as Ipomoea congesta. 
Ipomoea littoralis Thw. Same as Ipomoea choisiana.

Ipomoea mariannensis.

MARIANNe MORNING-GLORY.

Local Names.-Fofgu (Guam); Tugui-tuguian (Philippines).

Smooth, striate, prostrate-trailing plant. Leaves cordate-acuminate, sometimes entire, sometimes 3-lobed or trifid, dark-colored, acutely mucronulate, 12 to 25 $\mathrm{mm}$. long, the auricles obtuse, entire or lobed; median lobe dilated at the base; peduneles 3 or 4 -flowered, longer than the petioles; sepals lanceolate, very acute, ciliate-hirsute, 4 to $6 \mathrm{~mm}$. long; corolla tubular, scarcely 3 times as long as the calyx; capsule hairy. Collected in Guam by Gaudichaud and described from his specimen in the herbarium of the Paris Museum by Choisy.

REFERENCES:

Ipomoea mariannensis Choisy, Mem. Soc. Phys. Genev. 6: 468.1833.

Ipomoea maritima R. Br. Same as Ipomora pes-caprae.

Ipomoea pes-caprae.

Goat's-Foot Convolvulus.

Family Convolvulaceae.

LOCAL NAMES.-Alalag-tasi, Alaihai-tasi (Guam); Lambayong, Lagairai, Katangkatang (Philippines); Lawere (Fiji); Pohuehue (Hawaii); Pohue (Rarotonga); Fuefue-tai (Samoa); Bejuco de vaca (Porto Rico); Boniato de Playa (Cuba).

A common tropical strand plant, growing on sandy beaches in most warm countries. Stem very long, fleshy, smooth, prostrate, not twining nor rooting; leaves long-petioled, rounded, notched at the apex or deeply 2-lobed, subcoriaceous, glabrous, the venation conspicuous, pellucid, the midrib terminating in a mucro between the 2 lobes, the petiole 5 to $10 \mathrm{~cm}$. long, erect, glabrous, with 2 glandular spots at the summit; peduncles axillary, erect, 1 to 3 -flowered; flower very large; bracts lanceolate, soon falling; sepals broadly oval or oblong, subacute; corolla widely funnel-shaped, $7.5 \mathrm{~cm}$. in diameter, bright rose-purple, ever-blooming; filaments dilated and hairy at the base; capsule 2-celled, cells 2-seeded; seeds covered with dark-brown pubescence.

An important sand-binding plant. The root is large, long, and covered with a thick brown bark. It contains starch and is used medicinally. The whole plant is mucilaginous. In India the leaves are applied externally in rheumatism and colic, and the juice is given as a diuretic in dropsy. " The Fijians use the scorched leaves for calking the seams of canoes.

REFERENCES:

Ipomoea pes-caprae (L.) Roth, Nov. Sp. Pl. 109. 1821.

Convolvulus pes-caprae L. Sp. Pl. 1: 159. 1753.

Ipomoea biloba Forsk. Fl. Aegypt. A rab. 44. 1775.

Inomoea quamoclit L. Same as Quamoclit quamoclit.

Ironweed. See Vernonia.

Ironwood, Polynesian. See Casuarina equisetifolia.

Isachne minutula. See Grasses.

Ischaemum chordatum and I. digitatum polystachyum. See Grasses.

Ivory-nut Palm of the Caroline Islands. See Coelococcus amicurum.

Jacinto (Panama). See Melia azedarach.

Jack-in-the-box. See Hernandia peltata.

Jaiguie or Haiguie (Guam). (Pronounced very much like the English word "highway.")

A coconut which has begun to grow.

Jamaica mignonetté tree. See Lawsonia inermis.

$a$ Drury, Useful Plants of India, p. 266, 1858. 
Jasmine. See Jasminum, all species.

Jasminum grandiflorum.

SPANISH JASMine.

Family Oleaceae.

Local Nayes.-Hasmín (Guam); Jasmin (Spanish); Jasmin de olor (Mexico).

A glabrous shrub with drooping anguiar branches and very fragrant white flowers. Leaves odd-pinnate, leaflets 2 or 3 pairs, rhomboid-oblong, elliptic, or round-elliptic, usually ending in a small point; calyx teeth linear, about $6 \mathrm{~mm}$. long, rarely half as long as the corolla tube; corolla star-shaped, lobes sometimes attaining $12 \mathrm{~mm}$. Common in Guam gardens.

The flowers of this plant are the source of a very highly esteemed extract which enters into many manufactured perfumes. In India a medicinal scented oil is prepared from them, which is applied externally, and is said to be "cooling." The leaves are chewed as a remedy for ulceration of the mucous membrane of the mouth.

REFERENCES:

Jasminum grandiflorum L. Sp. Pl. ed. 2. 1: 9. 1762.

\section{Jasminum marianum.}

Marianne Jasmine.

Local rames.-Panágo, Banágo (Guam); Silisíli, Laióklaiók (Philippines).

A shrub or small tree with terete branches. Leaves unifoliolate, opposite, featherveined, elliptical, acuminate at the apex, petiole articulate below the middle with the base persistent; flowers in terminal trichotomous corymbs; calyx teeth 5 or 6 , awl-shaped, as long as the tube; corolla with the tube 4 times as long as the calyx, lobes linear-lanceolate. First collected in Guam by Gaudichaud, who applies to it the rernacular name "banágo;" probably identical with "panágo" of Governor Olive's list, the wood of which, he says, is used for making plows and outriggers of canoes. The tube of the corolla is 8 to $10 \mathrm{~mm}$. long, lobes 6 to $8 \mathrm{~mm}$. long.

REFERENCES:

Jasminum marianum DC. Prod. 8: 307. 1844.

\section{Jasminum officinale.}

COMMON JASMINE.

Local Names. - Hasmín dikike (Guam); Jasmin blanco (Spanish).

A slender shrub requiring support, bearing small white fragrant flowers. Glabrous or nearly so; leares opposite, odd-pinnate; leaflet 2 or 3 pairs, rhomboid-oblong, acute, the terminal leaflet the longest; flowers 2 to 10 , in terminal more or less leafy clusters; calyx teeth linear, long; corolla lobes 8 by $6 \mathrm{~mm}$.

Common in the gardens of the natives, and highly esteemed for the fragrance of the flowers. These yield a fragrant oil similar to that of the preceding species and used for the same purposes. The root is a remedy for ringworm.

REFERENCES:

Jasminum officinale L. Sp. Pl. 1: 7. 1753.

Jasminum sambac.

Arabian Jasmine.

Local rames. - Sampagita (Guam); Sampagas (Philippines); Gran duque (Mexico).

A climbing shrub with angular pubescent branches and very fragrant white flowers. Leaves opposite or in whorls of 3 , with a single shining leaflet, the petiole short and abruptly curved upward, elliptic or broadly ovate, entire, either rounded at the apex or prominently acute; flowers in clusters of 3 to 12 , white, often turning purplish on drying; calyx lobes linear and prominent, usually hirsute on edges; lobes of corolla oblong or orbicular, tube $12 \mathrm{~mm}$. long, corolla often double.

A fragrant oil is obtained from the flowers of this plant by the enfleurage process, i. e., by forming alternate layers of fat and flowers. The fat absorbes the odor and after standing for some time is melted at as low a temperature as possible and strained. Coconut oil may be scented in the same way by steeping cotton cloths in the vil and al ernating them with layers of the Howers. In India crushed Sesamum seeds are used instead of fat or oil. 



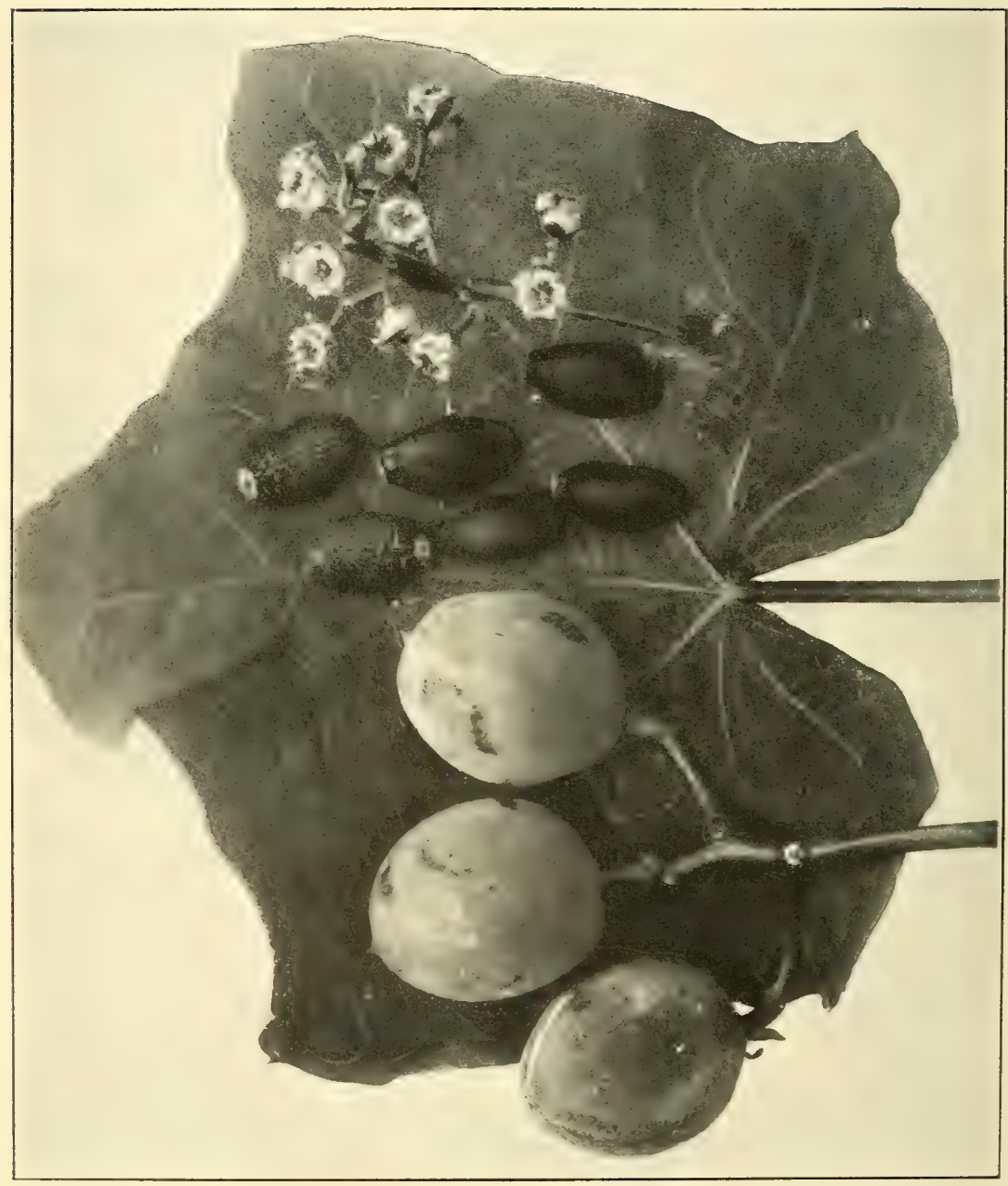

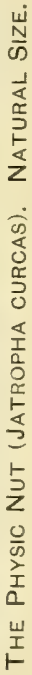


Poultices made of the flowers applied over the mammæ suppress the secretion of milk.

\section{REFERENCES:}

Jasminum sambac (L.) [Soland. in] Ait. Hort. Kew. 1: 8. 1789.

Nyctanthes sambac L. Sp. Pl. 1: 6. 1753.

\section{Jatropha curcas.}

Physic nut. Plate liv.

Family Euphorbiaceae.

Local names. - Tubatuba (Guam); Tuba, Casta, Tavatava, Cator, Kator (Philippines); Tartago (Porto Rico); Piñon botija (Cuba); Puăvai (Samoa); Avellanes purgantes, Sangregado (Mexico); Coquillo (Panama).

An introduced evergreen shrub or small tree, very much used in Guam, the Philippines, Samoa, and other tropical countries for hedges or fences. Leaves smooth, broad-cordate, entire or 5-angled, long-petioled; panicles terminal or from the axils of the leaves, cymose, many-flowered, the male flowers at the extremities of the ramifications on short articulated pedicels, the female flowers in the forks with pedicels not articulated, flowers yellow or greenish; calyx with 5 sepals, which are often petaloid; petals 5, cohering as far as the middle; corolla tube of male flower hairy within; stamens many; perianth of female flower similar to that of male; ovary 2 to 4 -celled; styles cohering below, 2 -fid; ovules 1 in each cell; capsule divided into 2-valved cocci; seeds very oily.

The branches of this shrub take root very quickly when stuck in the ground. For this reason and from the fact that cattle will not eat the leaves it is a favorite hedge plant in many tropical countries. The seeds, though agreeable to the taste, are purgative, and, if eaten in considerable quantities, poisonous. The taste is very much like that of beechnuts. They are more drastic than the seeds of the allied castor-oil plant and milder than croton-oil seeds. The oil is used in the Philippines and in India for illuminating. Padre Blanco says it lasts longer than cocoanut oil used for this purpose. The viscid juice of the plant, when beaten, foams like soapsuds. Children often blow bubbles of it with a joint of bamboo. On evaporation it yields a reddish-brown resin. The juice is applied to wounds and ulcers. It prevents bleeding by forming a film like that of collodion. A decoction of the leaves is used as a wash in eczema and for ulcers. In the Philippines the plant is sometimes used for stupefying fish; hence, according to Padre Blanco, its vernacular name "tuba," signifying liquor which intoxicates; but for this purpose it is inferior to Barringtonia speciosa.

The oil has been used in England for soap making, as a lubricant, and as a medium for mixing paint. The Chinese boil the oil with oxide of iron and use the preparation for varnishing boxes. $a$

\section{REFERENCES:}

Jatropha curcas L. Sp. Pl. 2: 1006. 1753.

Jatropha manihot. Same as Manihot manihot.

Jatropha moluccana. Same as Aleurites moluccana.

\section{Jatropha multifida.}

Local NAMEs.-Mana (Philippines).

An introduced ornamental plant with umbel-like clusters of scarlet flowers and palmately divided orbicular leaves. Leaves long-petioled, the divisions pinnatifid; stipules many-parted, the divisions bristly. Cultivated in many gardens of the natives.

REFERENCES:

Jatropha multifida L. Sp. Pl. 2: 1006. 1753.

$a$ Drury, Useful Plants of India, p. 277, 1858. See also Kirtikar, Journ. Bombay Nat. Hist. Society, vol. 15, p. 56, 1903. 
Java almond tree. See Canarium indicum.

Jayi (Guam). See Lens phaseoloides.

Jequirity beans. See Abrus abrus.

Jícama (Spanish). See Cacara erosa.

Jicara (Spanish). See Crescentia alata.

Job's tears. See Coix lachryma-jobi.

Jogâ. See Yogâ.

Jujube tree. See Zizyphus jujuba.

Jungle rice. See Echinochloa colona.

Junig (Spanish). See Tournefortia argentea.

Junquillo oloroso (Spanish). See Andropogon nardus.

Justicia picta L. Same as Graptophyllum pictum.

Kabaikabai (Philippines). See Sophora tomentosa.

Kabatiti (Philippines). See Colubrina asiatica.

Kadius or Kad-yos (Philippines). See Cajan cajan.

Kafo, Kafok, or Kafu (Guam). See Pandanus and $P$. fragrans.

Kahana (Philippines). See Coffea arabica.

Kahel or Kahet (Guam). See Citrus aurantium and C. anrantium sinensis.

Kahlau or Kahlao (Guam). See Phymatodes phymatodes.

Kakaguate, Kakahuate (Guam). See Arachis hypogaea.

Kakao (Guam). See Theobroma cacao.

Kalabasang pula (Philippines).

A red or orange squash, according to Padre Blanco, Cucurbita maxima.

Kalamasa (Guam).

The general name in Guam for the rarious forms of pumpkins and squashes (Cucurbita spp.). See under Gardens.

Kalamismis or Kamaluson (Philippines). See Botor tetragonoloba.

Kalubai (Philippines). See Lagenaria lagenaria.

Kalumpag-sa-lati (Philippines.) See Xylocarpus granatum.

Kamachiles (Guam).

A name derived from the Mexican "guamachil," applied in Guam to Pithecolobium dulce.

Kamalindo (Guam). See Tamarindus indica.

Kamani, Kamanu (Hawaii). See Calophyllum inophyllum.

Kamas (Philippines). See Cacara erosa.

Kamote or Kamute (Guam).

A name of Mexican origin used in Guam for the sweet potato (Inomoea batatas), which was introduced from Mexico and the Hawaiian Islands.

Kamoting-kahoi (Philippines). See Manihot manihot.

Kamuku nanofe (Guam). See Taeniophyllum fasciola.

Kansion (Guam).

Vernacular name for a young coconut having a sweet edible rind.

Kape (Easter Island, Rarotonga). See Alocasia macrorrhiza.

Kapok (Philippines, Java). See Ceiba pentandra.

Karampalit (Philippines). See Sesuvium portulacastrum. 
Karriso (Guam). See Trichoon roxburghii.

Kasói (Philippines). See Anacardium occidentale.

Kasoy, Kasue (Guam). See Anacardium occidentale.

Katang-katang (Philippines). See Ipomoea pes-caprae.

Katjang (Malayan).

General name in the Malay Archipelago for beans and other leguminous plants, the origin of the name "cajan" and "catjang."

Katjang-tana (Java).

"Ground-bean," a name applied to the peanut, Arachis hypogaea.

Kator (Philippines). See Jatropha curcas.

Katudai (Philippines). See Agati grandiflora.

Katurai (Guam, Philippines). See Agati grandiflora.

Kau ni alewa (Fiji.) See Sophora tomentosa.

Kauai (Philippines). See Sophora tomentosa.

Kelites, Kiletes, or Kuletes (Mexico, Guam).

A general name for pigweeds and other pot herbs growing spontaneously, applied especially to plants of the genera Amaranthus and Chenopodium. See under Pot herbs.

Ki (Hawaii). See Taetsia terminalis.

Kilulu (Guam). See Thespesia populnea.

Kodo millet. See Paspatum scrobiculatum.

Kolales or Kulalis (Guam). The coral-bean tree, Adenanthera pavonina.

Kolales halom-tano (Guam).

"Wild or inland coral." The coral-bead vine (Abrus abrü).

Kolo (Philippines). See Artocarpus communis.

Kolongkolong (Philippines). See Hernandia peltata.

Kondol (Philippines). See Benincasa cerifera.

Kondor or Kondot (Guam).

The local name for Benincasa cerifera, the wax gourd.

Kou (Hawaii). See Cordia subcordata.

Kukui (Hawaii). See Aleurites moluccana.

Kulasi (Philippines).

The red-flowered mangrove, Lumnitzera littorea.

Kyllinga monocephala.

ButTon SEDGF。

Family Cyperaceae.

LocAL Names.-Chaguan lemae, Botoncillo (Guam); Bolobotones, Barubatones (Philippines); Kaluja (Hawaii).

A sedge with a single globose, compact head, creeping rhizome, and aromatic roots; involucre 3-leaved. Common in low grassy places in Guam. Its native name comes from the resemblance of its head to a miniature breadfruit (lemae). The natives say it is used for medicine. It is widely spread throughout the Tropics of the world.

REFERENCES:

Kyllinga monocephala Rottb. Desc. et Ic. 13. t. 4. f. 4. 1773.

La'au-lopá (Samoa). See Adenanthera pavonina.

Lablab cultratus DC. Same as Dolichos lablab.

Lablab vulgaris Savi. See Dolichos lablab.

Labnis (Philippines). See Boehmeria tenacissima. 
Laburnum, seacoast. See Sophora tomentosa.

Lactuca sativa.

LETTUCE.

Family Cichoriaceae.

Local NAMES.-Lechuga (Spanish); Chisa, Chishana (Japan).

This plant is difficult to grow in Guam. Seed brought from the United States was repeatedly planted, but without success. In Bengal, where the climatic conditions are very similar to those of Guam, the seed is sown at the beginning of October. It sometimes remains in the ground a month or two before all of it germinates. As it is liable to be destroyed by insects it should be sown in large shallow seed pans, supported on flower pots standing in vessels of water. The soil is kept moist and shaded by muslin or by an inverted pan of the same size as that containing the earth. Firminger recommends that the plants be pricked out when four leaves have formed and planted in beds at about eight or ten inches apart. "If two or three plants be reserved and allowed to run to seed, the seed thus saved may be sown almost immediately and a supply of plants secured which, if grown in a spot tolerably sheltered from the sun and excessive wet, will come into use during the hot and rain seasons." a In Guam the best plants grown thus far have been Japanese varieties. These are upright in shape and are sometimes cooked as pot herbs. They grow to the height of 3 feet. $b$

REFERENCES:

Lactuca sativa L. Sp. Pl. 2: 795. 1753.

Lada, Ladda (Guam). See Morinda citrifolia.

Lagairai (Philippines). See Ipomoea pes-caprae.

Lagenaria lagenaria.

BOTTLE GOURD.

Family Cucurbitaceae.

Local NAMES.-Tagoa (Guam); Calabaza rinatera (Spanish); Vango (Fiji); Opo, Upo, Opu, Sicoi, Tabayag, Kalubai (Philippines); Fangu (Samoa; Futuna); c Ipu (Hawaii); Hue (Tahiti); Ue (Rarotonga); Kapop kapop, Kabo Kabole (German New Guinea); Kaddú (India); Laoki-kudu (Bengal); Labo (Macassar); Diya labu (Ceylon); Hu-lu (China); Acocote, Alacate (Mexico); Marimbo (Porto Rico).

This well-known and widely spread plant has been cultivated in Guam from time immemorial. It is easily distinguishable from other gourds by its white flowers. The hard mature shell is used as a dipper or bottle, the green fruit cut into strips as a vegetable, and the seeds as medicine.

The plant is annual and is planted in June. It often springs up spontaneously and may be seen climbing over walls and the roofs of native dwellings. Unless seasoned well the fruit is insipid. It acts as a laxative and is likely to purge if eaten in any quantity.

REFERENCES:

Lagenaria lagenaria (L.) Cockerell, Bull. Torr. Bot. Club 19: 95. 1892.

Cucurbita lagenaria L. Sp. Pl. 2: 1010. 1753.

Lagenaria vulgaris Ser. Mem. Soc. Phys. Genev. 31: 16. 1825.

Lagenaria vulgaris Ser. Same as Lagenaria lagenaria.

$a$ Firminger, Manual of Gardening for Bengal, ete., ed. 4, p. 172, 1890.

$b$ Useful Plants of Japan, p. 13, 1895.

"The samoan name "fangu," identical with the Fijian "vango," is applierl to gourds used to holl oil and also to all bottles and jugs. The same word is thus user in the island of Futuna. In Samoa "fue," identical with the Tahitian "hue" and the Rarotongan "ue," is used generally to designate all creeping plants, whether Cucurbitaceae, Leguminosae, or Convolvulaceae. In Samoa "ipu," identical with the Hawaiian "ipu," is the word for "cup," which may be made of a gourd, of coconut shell, or of tin or porcelain. 
Lagerstroemia indica.

Crape myrtle.

Family Lythraceae.

Local Names.-Melindres (Guam; Philippines); Astronomica (Mexico).

This shrub is cultivated in many gardens of Guam for the sake of its beautiful rosecolored flowers. It is widely spread throughout the Tropics and the warmer temperate regions of the globe.

ReFerences:

Lagerstroemia indica L. Syst. ed. 10. 1076. 1759.

Lagñ

Lagrimas de San Pedro (Spanish). See Coix lacryma-jobi.

Laguaná (Guam).

The vernacular name for the sonr-sop, Annona muricata, called in Central and South America la guanávana.

Lagūn (Guam). See Operculina peltata.

Laguncularia coccinea Gaud. Same as Lumnitzera littorea.

Laguncularia haenkei Endl. Same as Lumnitzera pedicellata.

Laguncularia purpurea Gaud. Same as Lumnitzera littorea.

Lagundi (Guam, Philippines). See Vitex negundo and V. trifolia.

Laiók laiók (Philippines). See Jasminum marianum.

Lala (Samna). See Meibomia umbellata.

Laláhag or Lalahâ (Guam).

The name of a small tree not identified, especially abundant on Orote Peninsula, and used by the natives for making charcoal. Wood white, brittle, and coursegrained.

Lalangha or Lalanha (Guam).

The shaddock, Citrus decumana.

Lalányug or Lalányog (Guam). See Xylocarpus granatum.

Lala-vao (Samoa). See Dodonaea viscosa.

Lama (Samoa). See Aleurites moluccana.

Lama-papālangi (Samoa). See Ricinus communis.

Lambayong (Philippines). See Ipomoea pes-caprae.

Lamb's-quarters. See Chenopodium album.

Lampuage (Guam). See Dodonaea viscosa.

Laña (Guam).

An unidentified tree with fine-grained, yellow wood, which is sometimes used for making handles of tools.

Lañgaasag, Lañgāsat, or Lañgat (Guam).

Vernacular names for Barringtonia racemosa.

Lañgis (Philippines). See Sesamum indicum.

Lañgiti (Guam).

An unidentified tree, the wood of which is used in the construction of houses and for making furniture. Referred by Gaudichaud to the genus Rauwoltia. Probably Ochrosia mariannensis.

Laññngaya (Guam). See Acrostichum aureum under Ferns.

Lansina (Philippines). See Ricinus communis.

Las-ága (Guam). See Stenotaphrum subulatum.

Lasona (Philippines). See Allium cepa and Gardens.

Idau-fala (Samoa). See Pandanus tectorius.

$9773-05-20$ 
Lau-hala (Hawaii). See Pandanus tectorius.

Laumapapa (Samoa). The bird's-nest fern, Neottopteris nidus. See under Ferns.

\section{Lauraceae.}

LAUREL FAMILY.

This family is represented in Guam by Cassytha filiformis.

Laureño (Panama). See Herpetica alata.

Lausa'ato (Samoa). Acrostichum aureum. See under Ferns.

Lautalatalo (Samoa). See Crinum asiaticum.

Lau tefe-ule (Samoa). See Achyranthes aspera.

\section{Lawns and lawn making.}

In Guam the best grass for lawns is the introduced Bermuda grass (Capriola dactylon). Another grass, Slenotaphrum subulatum, which is indigenous and grows either on the sandy seashore, on the edge of the forest, and even in the shade, is also good. It has creeping rootstocks and a prostrate creeping habit of growth, and never becomes coarse or hard. Both of these grasses are excellent for fodder and are especially useful for covering bare land and binding drift sand and river banks. They also successfully compete with most of the tropical weeds. They are easily propagated by cutting into small pieces the creeping rooting stems.

The most expeditious method of preparing a lawn of Bermuda grass is to clear and level the plot of ground selected for the purpose, plow it up, or spade it, and prepare it as for a garden. Then spread over it a layer of wet earth, of the consistency of mortar, with which the chopped-up grass has been mixed. Each little joint will take root, and in a short time a lawn will be established. Throughout the greater part of the year there is sufficient rain to water the plot, but it is best to prepare it at the beginning of the rainy season. In drier climates the plot must be watered from time to time until the grass has established itself. Only a few tufts of Bermuda grass are necessary to cover a large area. It will grow either on low, moist, sandy soil near the sea or on the upland regions of the island. Once established it is hard to eradicate, and it is apt to become a pest in cultivated fields. In establishing a pasture the grass should be planted at intervals of $50 \mathrm{~cm}$. in rows 1 meter apart. It spreads rapidly and in a short time will cover the entire surface.

In Guam it is cut and ferl to cattle as green forage. It can, however, be dried, if necessary, and made into excellent hay.

Lawsonia alba. Same as Lawsonia inermis.

Lawsonia inermis.

Henna.

Family Lythraceae.

Local xames. - Cinamomo (Guam, Philippines); Chí-kiah-wah (China); Reseda (Central America); Jamaica mignonette (West Indies); Broad Egyptian privet (England); Henna (Persia); Khenna (Egypt); Al khanna (Arabic).

A shrub bearing very fragrant flowers, with round branches, sometimes armed with spines, and opposite entire lanceolate leares. Flowers rather small, white, rosecolored, or greenish; calyx-tube very short, limb with 4 ovate lobes; petals 4 , oborate, wrinkled, inserted at the top of the calyx-tube; stamens usually 8 , inserted in pairs between the petals, sometimes 4 only or 8 not paired; orary free, 4-celled; style very long, stigma capitate; orules many; capsule leathery, globose, breaking up irregularly, ultimately 1-celled; seeds many, angular, pyramidal, smooth, packed on a central placenta.

Introduced into Guam on account of the fragrance of its flowers. It is readily propagated from cuttings, grows in the form of a bush sending up shoots, and is suitalle for helges. When kept clipped it is not unlike privet. Its odor at short range is rank and overpowering, but from a distance it is like that of mignonette. On the shores of Central America the land hreezes frequently waft the odor out to sea. This species is the "sweet-smelling camphire" of Solomon. It is a native of western Asia, Egypt, and the African coasts of the Mediterranean, and now grows 
wild in some parts of India. It is also cultivated in many countries. It has been a favorite garden plant in the East from the time of the ancient Egyptians to the present day. The Egyptians used the flowers for perfuming the oils and ointments with which they anointed the body and for embalming the bodies of their dead. The Jews also derived a perfume from the flowers, which they employed in their baths, and in religious ceremonies, and they sprinkled the flowers on the garments of the newly married.

From the most ancient times the leaves have been used in the East for staining the fingers, nails, hands, and feet, and for dyeing the hair. Egyptian mummies have been found with their nails stained by it. In India its use is still universal among Mohammedan women and has spread among the Hindoos. In southern China, where it is common, it is also used for the same purpose. To dye the nails, the freshly gathered leaves and young twigs are pounded with lime or catechu, mixed with hot water, and applied to the fingers over night. For dyeing the hair a paste of the powdered leaves is applied to it and it is bound up with leaves, wax cloth, or oilskin. After a half hour or more the preparation is washed off and the hair is found to be of a bright red color. A second application is then made of the powder of the indigo plant made into a paste with water and allowed to remain three hours. This turns the hair a jet black. Ointments are used to make it glossy. The process must be repeated frequently, as with other dyes, on account of the growth of the hair. By certain classes of Mohammedans the process is stopped at the first stage, leaving the hair and beard red; and in Persia, Arabia, and northern India the manes and tails of horses are sometimes colored red by the same process. $a$

REFERENCES:

Lawsonia inermis L. Sp. Pl. 1: 349. 1753.

Layâl (Philippines). See Zinziber zingiber.

Lead tree (West Indies). See Leucaena glauca.

Lechuga (Spanish). See Lactuca sativa.

Lecideaceae. See under Lichenes.

Lecythidaceae.

BRAZIL-NUT FAMILY.

This family is represented in Guam by Barringtonia speciosa, and B. racemosa.

Leguminosae. See Mimosaceae, Fabaceae, and Caesalpiniaceae.

Lemae, Lemay, or Lemai (Guam).

Names of the sterile breadfruit (Artocarpus communis); modified to "rima."

Lemon. See Citrus medica limon.

Lemon-grass. See Andropogon nardus.

Lemoncito. See Triphasia trifoliata.

Lengnga (Philippines). See Sesamum orientale.

Lengua de Vaca (Guam).

Local name for a species of introduced prickly-pear (Opuntia sp.).

Lens phaseoloides. Snuff-Box Sea-bean. Plate lvi.

Family Fabaceae.

Local NaMes.-Gayê, Gadyê, Gayî, Lódısong, Bayog (Guam); Gogo, Gogong bakai, Bayogo, Balones (Philippines); Cacoon (West Indies); Boja (Cuba); Tupe (Samoa); Kaka (Rarotonga); Match-box bean (Queensland).

A giant climber with snake-like branches, bipinnate leaves, minute flowers growing in long slender spikes, and an enormous flattened woody, jointed pod like a sword-scabbard, the margins of which consist of a strong woody suture, which persists

"Drury, Useful Plants of India, p. 285; Smith, Dict. Economic Plants, p. 81; Watt, Economic Products of India, vol. 4, pp. 559, 601; Treasury of Botany, vol. 2, p. 66i5. 
after the segments of the pod have been detached. Leaves with two or three pairs of pinnæ, sometimes with a single pair, rachis ending in a bifid, spiral tendril, by which the plant climbs; pinnæ with 3 or 4 pairs of leaflets; leaflets obovate-oblong, acute at base, rounded, often emarginate at apex, glabrous, paler beneath, with the lateral veins conspicuous; flowers sessile, very small, with 5 petals and 10 stamens, polygamous (male and bisexual), crowded in long, narrow, pedunculate axillary spikes; pod 60 to $90 \mathrm{~cm}$. long, often curved, sometimes twisted, compressed, hard, indented on both sutures between the seeds, joints (Pl. XV) 6 to 12, turgid, 1-seeded, indehiscent, brown, readily detached from the surrounding tough, woody suture and from one another, so that each forms a water-tight cell inclosing the large, smooth, shining brown, orbicular, compressed seed, which does not completely fill it, but leaves a large air space. Testa of the seed hard, thick, and woody. Cotyledons inclosing an air space between them, which gives buoyancy to the seed and enables it to be transported by ocean currents. (See Pl. XV.)

In Guam the seeds are called "bayog" or "badyog." The stems often grow to the thickness of a man's arm and to a length of a hundred feet. When green it is tough, but on drying it loses its strength. Fish traps are often made of the green stems. The stems are saponaceous and when crushed are used for washing clothes. In India the seeds are used for washing the hair, and as a remedy for fever. In Java they are used as an emetic. In Samoa the seeds, called "tupe" by the natives, are used in playing certain games. This name has now been applied to money.

REFERENCES:

Lens phaseoloides Stickman Herb. Amb. 1754; Amoen. Acad. 4: 128. 1759.

Mimosa scandens L. Sp. Pl. ed. 2. 2: 1501. 1763.

Entada scandens Benth. Hook. Journ. Bot. 4: 332. 1842.

The name Lens was published for this genus in 1754, while Entada was not published until 1763.

\section{Lenteha fransesa (Guam).}

The local name for Cajan cajan, so called because it was introduced by the French ship Castries (1772).

Leston (Guam).

Vernacular name for Ophioglossum pendulum, signifying "belt," or "ribbon." See under Ferns.

Lettuce. See Lactuca sativa.

Leucaena glauca.

HEDGe ACACIA.

Family Mimosaceae.

Local Names. - Tangantañgan (Guam); Agho (Philippines); Santa Helena (Spanish); Hediondilla (Porto Rico); Aroma blanca (Cuba); Lead tree (West Indies).

An unarmed Acacia-like shrub, or small tree, with globular heads of flowers, much used in Guam for fences or hedges. Leares bipinnate, with glands on the petioles; pinnae 4 to 6 pairs bearing 10 to 20 pairs of leaflets; leaflets oblong-linear, acute, very oblique, slightly curved, pale or glaucous underneath; peduncles solitary or two or three together in the upper axils, 2.5 to $3.5 \mathrm{~cm}$. long, the upper ones forming a terminal raceme; heads about $2.5 \mathrm{~cm}$. in diameter, flowers whitish, turning brown on dying, not fragrant; calyx cylindrical-campanulate, shortly toothed; petals valvate, free; stamens 10 , free, much exserted; ovary stalked, many ovuled; style filiform, stigma minute terminal; pod flat, coriaceous, straight, strap-shaped, dehiscent, 15 to 20 -seeded. This plant resembles a Mimosa in having 10 stamens, but differs from that genus in having strap-shaped pods like an Acacia.

Branches or stakes of this plant when stuck in the ground take root readily, and fur this reason, together with the fact that cattle do not relish its leaves, it is a favorite 


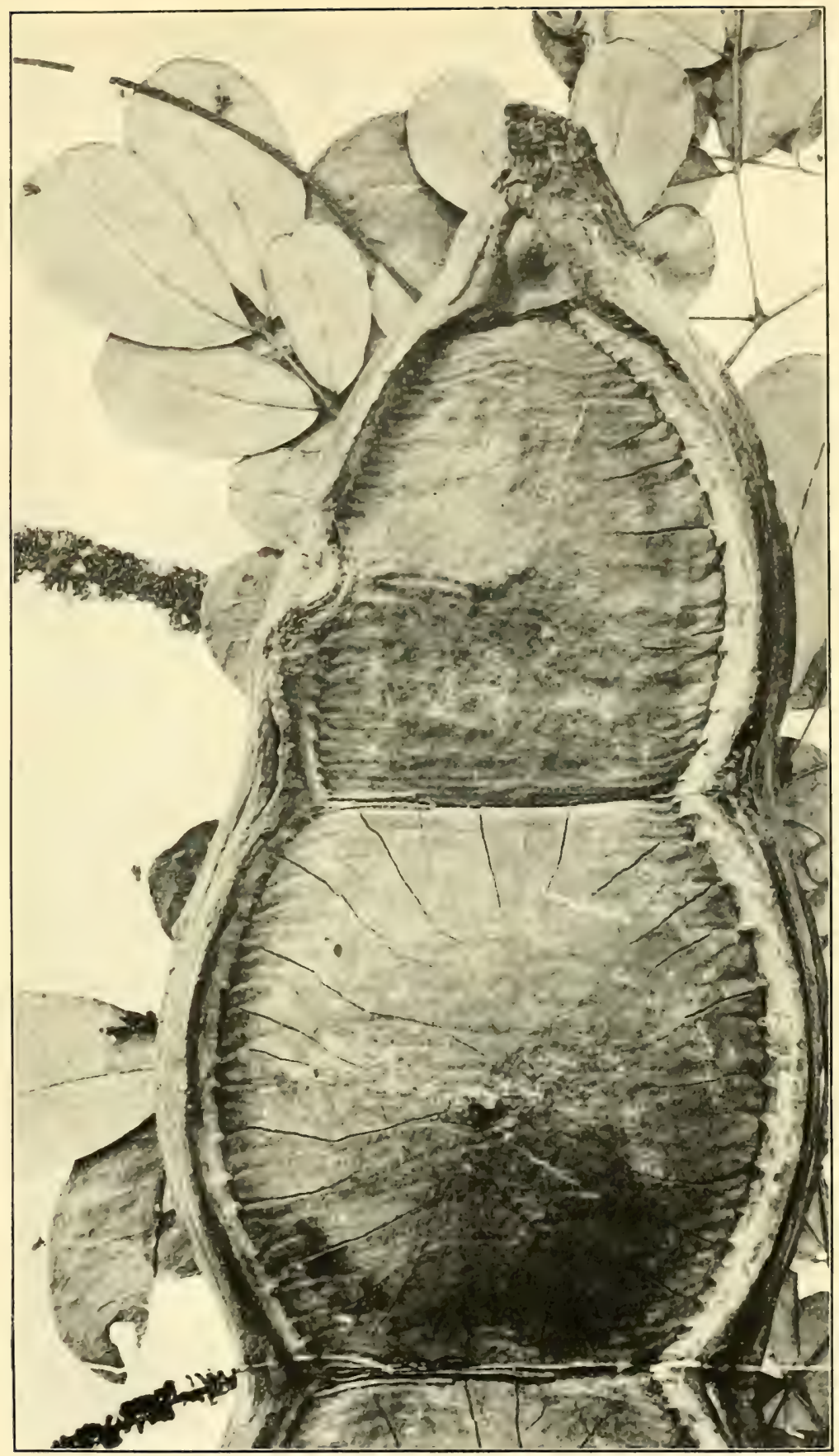

Lens phaseoloides, the Snuffiox Sea Bean. Pod and Inflorescence. NATURAL Size. 

hedge plant in many countries. When fer to animals it causes their hair to come out." It is indigenous to tropical America, but has spread throughout India, tropical Asia, and Africa. It will bear the winter in the warmer parts of the Mediterranean region, where it is occasionally planted. In Guam it is one of the most common hedge plants, and on the sites of abandoned clearings it forms dense thickets, like Jatropha curcas, Tripleasia trifoliata, and Brancaea sappan.

REFERENCES:

Leucaena glauca (L.) Benth. Hook. Journ. Bot. 4: 416. 1842.

Mimosa glauca L. Sp. Pl. 1: 520. 1753.

Acacia glauca Moench, Meth. 466. 1794.

Libato-pula (Philippines). See Xylocarpus graratum.

Lichenes. Scarcely anything is known of the lichens of Guam. The only species recorded from the island are Dictyonema membranaceum Agardh and Coenogonium linckii Ehrenb. (C. controversum Pers.), belonging to the Coraceae; and Ramalina subfraxinea $\mathrm{Nyl}$, belonging to the Lecideaceae.

Licorice, Indian (Australia). See Abrus abrus.

Licorice, wild (India). See Abrus abrus.

Lifeplant. See Bryophyllum pinnatum.

Liliaceae.

LILY FAMILY.

The only representatives of this family in Guam are Taetsia terminalis, Cordyline hyacinthoides, and Dianella ensifolia.

Lily. See Taetsia, Pancratium, Crinum, and Atamosco.

Lima bean. See Phaseolus lunatus inamoenus.

Lime. See Citrus hystrix acida.

Limeberry or Lime myrtle. See Triphasia trifoliata.

Limnophila fragrans Seemann. Same as Ambulia fragrans.

Limnophila gratioloides. Same as Ambulia indica.

Limnophila serrata. See Ambulia fragrans.

Limodorum fasciola Ser. Same as Taeniophyllum fasciola.

Iimon (Guam). The sour lime, Citrus hystrix acida.

Limon China (Guam). The bergamot, Citrus bergamia.

Limon de China, Lemoncito (Guam). See Triphasia trifoliata.

Limon real (Guam).

Local name for the lemon (Citrus medica limon).

Limoncitos (Philippines). See Triphasia trifoliata.

Limonia trifoliata Burm. Same as Triphasia trifoliata.

Limu (Samoa, Hawaii). See Algæ.

Lindsaea. See under Ferns.

Liñga (Philippines). See Sesamum indicum.

Lipay (Philippines). See Stizolobium giganteum.

Lirio (Guam).

The local name for Pancratium littorale.

Lirio de palo (Guam). See Agave vivipara.

Liverworts. See Hepaticæ.

Lizard's bush. See under Meibomia umbellata.

Loa (Samoa). See Bixa orellana. 
Lobelia koenigii.

FANFlower.

Family Goodeniaceae.

Local Names.-Nanaso (Guam); Nano (Solomon Islands); Bokíbok, Balókbalók, Bosbóron, Panabólong (Philippines); To’ito'iāve'a (Samoa); Naupaka (Hawaii); Taccadia (India, Ceylon).

A shrub growing on the strand, widely spread throughout the tropical islands of the Pacific and Indian oceans and on the shores of tropical Asia and Australia. Stem branching extensively from the base, thick and succulent and full of pith when young, but later becoming hard and woody. Leaves and inflorescence generally silky-pubescent, rarely glabrescent; leaves fleshy, obovate, tufted in the axils, with long silky hairs, alternate, entire or rarely obscurely crenate, rounded at the top or even emarginate, narrowed at the base into a short petiole, the nerves hidden; cymes axillary, shorter than the leaf; bracts small; corolla white, often with purple streaks, slit to the base on the upper side, its lobes margined, spreading somewhat like a miniature fan; calyx tomentose, 5 -fid, the lobes linear-lanceolate, enlarging in fruit; stamens 5, inserted at the base of the corolla, alternate with its lobes; anthers free; style simple, with a cup-shaped ciliate indusium including the stigma; fruit a round, succulent drupe, with a bony endocarp.

Common near the shore, and like several other shore plants reappearing on the treeless sabanas of the island. In India the young leaves are eaten as a pot herb. The soft, snow-white pith, an inch in diameter or more, is sometimes cut into thin paper-like flakes by the Siamese, Malayans, and Chinese and made into artificial flowers, butterflies, and other objects. The wood is coarse, fibrous, and useless.

REFERENCES:

Lobelia koenigii (Vahl).

Scaevola koenigii Vahl, Sym. Bot. 3: 36. 1794.

Lobelia sericea koenigii Kuntze, Rev. Gen. 2: 377. 1891.

The genus Lobelia as established by Linnæus in the Species Plantarum 2:929.1753 and Genera Plantarum ed. 5. 401.175t, contained 25 species, only one of which belonged to the Lobelia of Plumier from whom Linnæus adopted the name. This species, Lobelia plumierii, was the first to be referred to a new genus, Scaevola, under the name Scaerola lobelia, proposed by Linneus in 1771, and thus became its type species. This treatment has been followed by most modern authors, but in the application of the names in accordance with the principle of generic types the course of several well-known authors who wrote soon after the appearance of the species Plantarum seems to indicate a more careful regard for the correct application of generic names. Yotable among these was Miller, who, in the seventh edition of the Gardener's Dictionary, wisely restricted the name Lobelia to the original of Plumier and the type species of the genus as established by Linnseus, and adopted the Tournefortian name Rapuntium for the species which modern authors (Otto Kuntze, I think, alone excepted) have allowed to remain under the name Lobelia.

Lochnera rosea.

OLD MAID.

Family A pocynaceae.

LoCAL NAMES. - Vicaria, Dominica (Cuba); Madagascar periwinkle.

A plant growing in cultivation and in waste places with pretty salver-shaped rosecolored flowers (sometimes white with a crimson eye). Leaves spoon-shaped, oblong; flowers subsessile in pairs from the same node of the stem; calyx 5-parted, segments lanceolate, acuminate, much shorter than the slender corolla tube; corolla callous at the pubescent, narrow throat; stamens inserted upon the upper part of the tube; ovaries 2, slightly cohering, alternating with 2 oblong disk glands, which exceed the ovaries. This genus differs from Vinca in having the filaments thin and the anthers and stigma not hairy. 
The plant is probably of West Indian origin, but is now widely apread throughout the warmer regions of the world. It is used medicinally in some parts of India, and is often planted about pagodas.

REFERENCES:

Lochnera rosea (L.) Reichenb. Consp. 134. 1828.

Vinca rosea L. Syst. ed. 10. 944. 1759.

Lodúgao (Guam). See Clerodendron inerme.

Lóduson or Lódusong (Guam). See Lens phaseoloides.

Lomaria spicata. Same as Belvisia spicata. See Ferns.

Loñga (Philippines). See Sesamum indicum.

Lonok (Philippines). See Ficus sp.

Looking-glass tree. See Heritiera littoralis.

Low senna. See Cassia tora.

Luluhut or lulujut (Guam).

The name of a small tree, not identified, sometimes used for stakes for inclosures and for fuel. It is referred by Gaudichaud to the Rhamnaceae. Common on the shore of Rota.

\section{Luisia teretifolia.}

Family Orchidaceae.

Local Names.-Cebollo halom-tano (Guam).

A tuited epiphytal orchid with cylindrical leaves 10 to $15 \mathrm{~cm}$. long; flowers drooping, small, growing in a spike; petals not much longer than the lateral sepals, linear-oblong, obtuse; lateral sepals subacute, keel winged; the basal portion of the labellum almost square, sack-like, the upper portion broadly cordate.

Collected in Guam by Gaudichaud. An accurate drawing of the living plant is desirable, as there is much confusion in the various descriptions of the coloration of the flowers.

\section{REFERENCES:}

Luisia teretifolia Gaudich. Bot. Freyc. Voy. 427. t.3\%.1826.

Lumbang (Guam).

The Philippine name for the candle-nut (Aleurites moluccana).

Lumnitzera coccinea W. \& A. Same as Lumnitzera littorea.

\section{Lumnitzera littorea.}

RED-FLOWERED MANGROVE.

Family Combretaceae.

Local nayes.-Ñaña (Guam); Culasi, Kulasi, Sagása (Philippines).

A small tree growing in salt-water swamps, associated with mangroves. Leaves clustered toward the ends of the branches, alternate, thickly leathery, subsessile, narrow-obovate, 2 to $9 \mathrm{~cm}$. long; flowers growing in racemes; racemes dense, terminal, sometimes 2 or 3 forming a small corymb; calyx tube with 2 adnate bracteoles near the base, oblong, narrowed at both ends, produced above the ovary, lobes 5 , persistent; petals 5 , oblong, scarlet, $6 \mathrm{~mm}$. long; stamens 5 to 10 , usually 7 ; twice as long as the petals, filaments crimson; ovary inferior, 1-celled; style awl-shaped, simple; ovules 2 to 5 , pendulous from the top of the cell; fruit woody, elliptic-oblong, 12 to $24 \mathrm{~mm}$. long including the calyx limb, longitudinally striate or nearly smooth; seed 1 , cotyledons convolute.

The following species should possibly be referred to this one, which was described and figured under the name of Laguncularia purpurea by Gaudichaud in 1826 (Toy. Uranie 481, t. 104), from specimens collected by him in Guam in 1819. The good, heavy, yellowish-brown, fine-grained wood is used in boat building by the natives of Kaiser Wilhelmsland. On the Malay Peninsula it is used for axles of carts. It 
is spread from Malacca to Polynesia, and is recorded by Guppy from the islands of Bougainville Strait, Solomon Group.

REFERENCES:

Lumnitzera littorea (Jack) Voight, Hort. Suburb. Calc. 39. 1845.

Pyrrhanthus littoreus Jack, Malay. Misc. 2: 57. 1822.

Laguncularia purpurea Gaudich. Bot. Freyc. Voy. 481. t.104. 1826.

Lumnitzera purpurea Presl, Rep. Bot. 1: 155. 1834.

Lumnitzera coccinea Wight \& Arn. Prod. 1: 316. 1834.

\section{Lumnitzera pedicellata.}

RED-FLOWERED MANGROVE.

LOCAL NAMES. - Ñaña.

A small tree growing in salt-water swamps, with clusters of crimson flowers. Branches terete, dark-colored, wrinkled, alternate, leafy, marked with scars of fallen leaves, and bearing spikes of flowers at their tips; leaves $7.5 \mathrm{~cm}$. long and $16 \mathrm{~mm}$. broad, alternate, without stipules, obovate-cuneate, emarginate, entire, attenuate into a short petiole, rery smooth, leathery, rather fleshy, having a rather prominent midrib, which reaches the apex; spikes of flowers terminal, occasionally inclining to grow in pairs, with the primary branch aborted, and the lateral branches approximate, 10 to 15 -flowered, simple, erect; rachis scarcely $15 \mathrm{~cm}$. long, smooth, scarred where flowers and fruits have fallen off; bracts $1.5 \mathrm{~mm}$. long, ovate, acute, concave, ciliate, smooth, colored, fugacious; flowers approximate, alternate, 12 to $14 \mathrm{~mm}$. long, smooth, crimson; calyx superior, persistent, 5-parted, divisions leathery, ovaterounded, not veined, ciliate; calyx tube with 2 bracteoles near the base; petals 5 , three times longer than the calyx, cordate-ovate, obtuse, spreading, alternating with the divisions of the calyx, deciduous after flowering; stamens 10,5 opposite the petals and 5 opposite the lobes of the calyx, filaments thread-like, equal, twice as long as the petals, anthers cordate-subrotund, attached by the back, 2-celled, longitudinaliy dehiscent; ovary obconical, terete, attenuate into the pedicel so that the line of separation of the two is not apparent; style slightly shorter than the stamens, simple, cylindrical, erect, thicker at the apex; stigma truncate; drupe $16 \mathrm{~mm}$. long, oblong, many-reined, in the middle two-angled and with two bracteoles, the angles decurrent at the base, crowned by the calyx, narrowing into the compressed pedicel, woody, dark-brown, nearly smooth, glossy, 1-celled, 1-seeded; seed oblong, terete, pendulous, twice shorter than the drupe; cotyledons convolute.

This species was described by Presl from specimens collected in Guam by Haenke in 1792. It is also recorded by Finsch from Tarawa Island, Gilbert Group.

\section{REFERENCES:}

Lumnitzera pedicellata Presl, Rel. Haenk. 2: 23. 1830.

Lumot (Philippines). See Algæ.

Lumut (Guam, Malay Archipelago). See Algæ.

Lupinus angustifolius Blanco. Same as Zornia diphylla.

Luya (Philippines). See Zinziber zingiber.

Luyaluya (Philippines). See Zinziber zerumbet.

Luyos (Philippines). See Areca cathecu.

Lycopersicon lycopersicum.

Томато.

Family Solanaceae.

Local xayes.-Tomate (Spanish); Camatis (Philippines); Xitómatl, Gitomate (Mexico).

The tomato has escaped from cultivation in Guam and is found growing wild in waste places and on the sites of abandoned clearings. Two forms occur, one globular, or nearly so, and the other oval, each about $2.5 \mathrm{~cm}$. in diameter. Our best varieties do not thrive if planted at the beginning of the rainy season, having a tendency to 



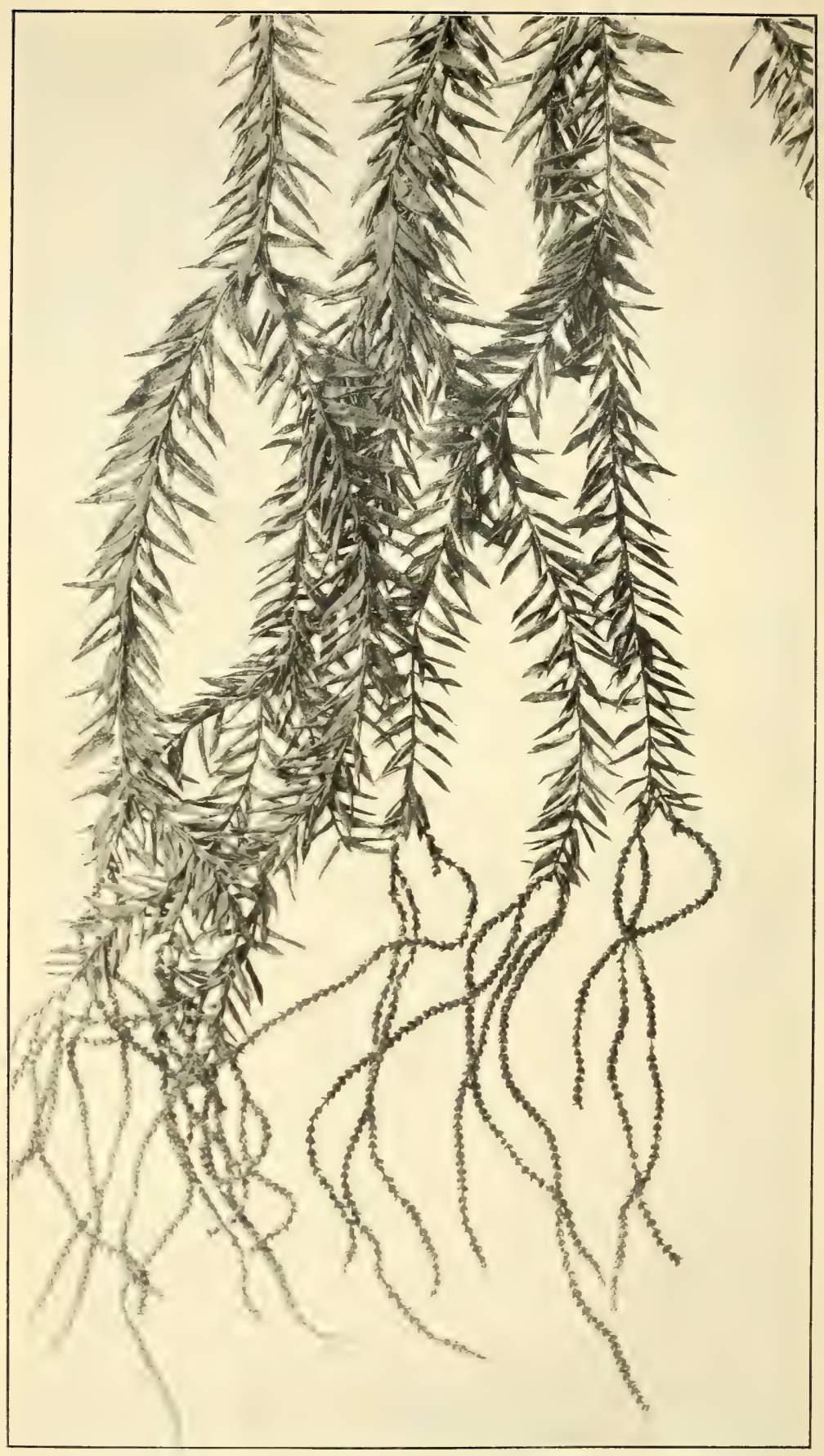

Lycopodium phlegmaria, an Epiphytal Clubmoss. Natural Size. 
grow weedy and rank. They should be planted toward the end of the rains (October) so as to be well established when the dry season sets in.

\section{REFERENCES:}

Iycopersicon lycopersicum (L.) Karst. Deutsch. Fl. 966. 1880-83.

Solanum lycopersicum L. Sp. Pl. 1: 185. 1753.

Lycopersicon esculentum Mill. Gard. Dict. ed. 8. 1768.

Lycopersicum esculentum. Same as Lycopersicon lycopersicum.

\section{Lycopodium cernuum. \\ Savanna lycopodium. Plate v.}

Family Lycopodiaceae.

Local Names. Amigos, Gauay (Philippines); Wawae iole (Hawaii); Azufre vegetal (Cuba).

A lycopodium growing on the ground; especially common on the treeless highlands of Guam called "sabanas." Stem erect, hard, stiff, terete, about $60 \mathrm{~cm}$. high or more, with numerous spreading, flexuose, repeatedly forking branches, each branchlet at last terminating in a sessile, cylindrical, mostly nodding spike; leaves awlshaped, 2 to $4 \mathrm{~mm}$. long, those of the stem irregular in 8 ranks, erect and appressed in the lower portion, those of the branches crowded, incurved; bracts in 8 ranks, appressed, ovate, $2 \mathrm{~mm}$. long, contracting below, denticulate, cuspidate, much longer than the capsules; capsules minute, globular, without a basal incisure; spores smooth.

Common throughout the Tropics, often associated with Gleichenia dichotoma. Its Hawaiian name signifies "rat's-foot." It was first collected in Guam by Haenke. The form occurring in Guam is called by Baker variety marianum.

\section{REFERENCES:}

Lycopodium cernum L. Sp. Pl. 2: 1103. 1753.

Lycopodium marianum Willd. Same as Lycopodium cernuum.

Lycopodium mirabile Willd. Same as Lycopodium phlegmaria.

Lycopodium, pendant. See Lycopodium phlegmaria.

\section{Lycopodium phlegmaria. Pendant lycoponium. Plate livit.}

Local Names. - Cordon de San Francisco (Spanish).

A Lycopodium usually growing on the trunks and branches of trees, in long, pendulous tufts. Leaves mostly lanceolate, spreading, $6 \mathrm{~mm}$. or more long, sometimes elliptical or oblong and obtuse; spikes slender, at the ends of the branches, usually several, often forked several times; bracts imbricated, usually in 4 rows, broad, scarcely exceeding the capsules in common forms, but sometimes pointed and longer.

Very common in the forests of Guam, associated with Nephrolepis acuta, Davallia solida, Polypodium phymatodes, Asplenium nidus, and other epiphytal ferns. Gaudichaud states that the natives considered it a symbol of fecundity, but I could find no evidence that this idea prevails at the present day.

In referring to the specimen obtained by him in Guam, Gaudichaud says:

I owe this plant to the kindness so often put to proof of Don Luis de Torres, the most estimable man of the Marianne Islands, not only through his birth, his distinguished rank in this country, but also on account of his intellect, his education, and the rare philanthropic virtues which characterize him. This excellent old gentleman broke off the fragment which I possess from an enormous branch which he carefully preserved at the head of his bed, near his holy-water font.

The species is very widely spread throughout the islands of the Pacific and the East Indies.

REFERENCES:

Lycopodium phlegmaria I. Sp. Pl. 2:1100. 1753.

Lycopodium, savanna. See Lycopodium cernuum.

Lygodium microphyllum R. Br. Same as Lygodium scandens microphyllum. 


\section{Lygodium scandens.}

Family Schizaeaceae.

Local Names.-Alambrillo (Guam); Nito (Philippines); Ngiungiu (Yap).

A climbing fern common in the swamps of Guam, where it twines among the reeds and Acrostichum aureum. Stems wiry, slender, twining, glabrous, or slightly pubescent; fronds pinnate, inserted on the common stem in divaricate pairs; pinnules 5 to 10 or more, varying in shape from cordate-ovate to oblong-lanceolate or hastate, 12 to $36 \mathrm{~mm}$. long, often shortly lobed at the base, and always articulate on a slight thickening of the apex of the petiolule, which persists on the common rachis after the pinnules have fallen off. Veins forked, free, radiating from the petiolule, with a more or less distinct central nerve; sori protruding from the margins of pinnules similar to the barren ones, sometimes all very short, with 3 to 6 pairs of spore cases; sometimes in the same specimen 8 to 10 lines long, with 12 to 15 pairs of spore cases.

This species is widely distributed in the Tropics. The form in Guam, described as Lygodium microphyllum $\mathrm{R}$. Br., is referred to this species as a variety ( $L$. scandens microphyllum) and is recorded from New Pomerania, Bismarck Archipelago, by Schumann and Lauterbach, the natives there making baskets of the wiry stems. ${ }^{a}$ In the Philippines the natives make from them hats and bags for their betel nuts. $b$ Other species of Lygodium recorded from Guam are $L$. dichotomum $\mathrm{Sw}$. and $L$. longifolium, which is referred by Baker to $L$. pinnatifidum $\mathrm{Sw}$.

\section{REFERENCES:}

Lygodium scandens (L.) Sw. Schrad. Journ. Bot. 1800²: 106. 1801.

Ophioglossum scandens L. Sp. Pl. 2: 1063. 1753.

\section{Lythraceae.}

LOOSESTRIFE FAMILY.

This family is represented in Guam by Pemphis acidula, Lawsonia inermis, Ammannia coccinea, and Lagerstroemia indica.

Macromitrion. See Mosses.

Macupa or Makupa (Philippines, Guam). See Caryophyllus malaccensis.

Madagascar periwinkle. See Lochnera rosea.

Maguay, Maguey (Philippines). See Agave vivipara.

Mahlog-hayo or Majlok-hayo (Guam).

A tree, not identified, the wood of which is used for fuel.

Mai (Rarotonga). Fermented breadfruit. See Artocurpus communis.

Maigo-lalo, Maigu-lalo (Guam).

"Fly-roost." The vernacular name for Phyllanthus niruri, "maigo" signifying sleep and "lalo" flies.

Maile (Polynesian). See Gynopogon torresianus.

Maisa ulu (Guam). See Nervilia aragoana.

Maiz (Spanish). See Zea mays.

Maize. See Zea mays.

Majagua (Panama). See Pariti titiaceum.

Makupa. See Caryophyllus malaccensis.

Malabar almond. See Terminalia catappa.

Malay apple. See Caryophyllus malaccensis.

Malbas or Matbas (Guam). See Abutilon indicum.

a Schumann und Lauterbach, Die Flora der Deutschen Schutzgebiete in der Südsee, p. 146, 1901 .

b Padre Ignacio de Mercado; Declaracion de los Arboles y Plantas que están en esta Tierra, p. 50, in Blanco's Flora de Filipinas. 
Mallotus. See Echinus sp.

Malunggai (Philippines). See Moringa moringa.

Malva (Guam). See Abutilon indicum.

Malva blanca (Cuba). See Waltheria americana.

Malvabisco (Porto Rico). See Waltheria americana.

Malvaceae.

Mallow Family.

This family is represented in Guam by the following genera: Abelmoschus, Abutilon, Gossypium, Hibiscus, Pariti, Sida, Thespesia, and Urena.

Mamaka (Guam). See Polygonum sp.

Mamaon (Guam). See under Piper betle.

Mampalam (Mindanao). See Mangifera indica.

Mana (Guam). See Gleichenia dichotoma.

Mana (Philippines). See Jatropha multifida.

Mandioka or Mandiuka (Guam). See Manihot manihot.

Manga (Tagalog). See Mangifera indica.

Mañgeso (Samoa). See Schychowskya interrupta.

Mañgga (Guam). See Mangifera indica.

Mangifera indica.

Mango. Plate xxviri.

Family Anacardiaceae.

Local names.-Mañgga (Guam); Manga (Tagalog); Mampalam (Mindanao).

The mango tree is not well established in Guam. There are few trees on the island, but these produce fruit of the finest quality. Guam mangoes are large, sweet, fleshy, juicy, and almost entirely free from the fiber and the flavor which so often characterize the fruit. The trees grow to great size and appear to be thrifty; but nearly all on the island have been blown down by baguios, or hurricanes, and continue to grow, as it were, resting on their elbows. The cause for this, I think, is the shallowness of the soil, the hard coral rock not allowing the roots to penetrate to any great depth. Those which remain standing are in low, protected places, where the soil is comparatively deep. The natives value the fruit more highly than any other food product of the island. Indeed, the presence of a mango tree on a rancho enhances its value. During some seasons no fruit is produced. The natives frequently cut gashes in the trunk and build fires beneath the limbs, thinking that the tree will be induced thereby to produce a goud crop. Frequently one portion of the tree will bloom or send out fresh foliage, which is reddish and tender when new, while the rest of the tree remains dormant, and it often happens that the fruit is perfectly ripe on certain limbs, while on others it is still green. The trees are propagated by seed, and the fruit of the seedlings appears, in Guam, to be identical with that of the parent tree. The seeds must be planted when quite fresh. The young plants are tender, and are killed in transplanting if the root be injured. Grafting and inarching is not practiced, though it could be done with good advantage from limbs of mature trees producing especially fine fruit, $a$ and it could be carried on with especial facility with the prostrated trees, which still continue to grow vigorously and bear fine fruit. The tree is in Guam entirely free from disease or injurious parasites. In view of the excellent quality of its fruit and the danger of bringing diseases and parasitic insects with specimens from abroad, importation of living mango plants should be forbidden. The failure to produce crops each year is probably owing to the fact that the dry season in Guam is not sufficiently marked to cause the trees to

a Grafting should not be performed during the rainy season nor in the midst of the hottest part of the year. Inarching of the herbaceous parts is most successful. See Baltet, L'art de greffer, p. 297, 1892. 
bear, or it may be that pollination is prevented by rains. In Burma the earth around the tree is removed each year and the roots left exposed for a space of two or three weeks, so as to create a dry season artificially. This is done in November. In December the roots are supplied with manure and covered with new earth. During the month of April, when the fruit is swelling, copious drenchings of the soil around the stem with water or liquid manure is of great advantage. When continued wet weather prevails during the time of flowering, the flowers are apt to drop off without setting fruit.

REFERENCES:

Mangifera indica L. Sp. Pl. 1: 200. 1753.

\section{Mangle.}

The Spanish name for mangroves in general.

Mangle hembra (Spanish). See Rhizophora mucronata.

Mangle macho (Spanish). See Bruguiera gymnorhiza.

Mañgo. See Mangifera indica.

Maño (Guam). See Curcuma longa.

Mañgo halom-tano (Guam).

"Wild turmeric," the local name for Canna indica.

Mangosteen, wild. See Sandoricum indicum.

Mangrove. See Bruguiera gymnorhiza and Rhizophora mucronata.

Mangrove, Milky (Australia). See Excoecaria agallocha.

Mangrove, red-flowered. See Lumntzera littorea and L. pedicellata.

Manha (Guam).

The vernacular name for an unripe coconut which is full of water, in Spanish called "coco mudo."

Maní (Panama). See Arachis hypogaea.

Manieníe (Hawaii). See Capriola dactylon.

Manihot manihot.

Cassava. Plate xxyi.

Family Euphorbiaceae.

Local NaMes,-Mandiuka, Mendiuka, Mandioka, Mendioka, Yuka (Guam); Camoting cahvi, Kamoting kahvi (Tagalog); Yuca (Spanish); Huacamotl (Mexico).

This plant, which is of tropical American origin, is cultivated by many of the natives of Guam, but it is not of much importance in the economy of their daily life. It grows as a shrub, with knotty stems containing pith, palmately divided, longpetioled leaves without glands, and fleshy tuberous roots (Pl. XXVI, p. 145). In Guam it is not known to flower. It is very easily propagated by cuttings made of the thicker branches, which take root readily and grow with little care. There are two prineipal varieties recognized, which though not having distinct specific characters are very different in the properties of the root. The first, called "sweet cassava," may be used as a vegetable without special treatment; the second, called "bitter cassara," contains an abundance of prussic acid, which renders the juice very poisonous, but which is fortunately volatile and is rendered harmless by heat. The roots are gathered at maturity and must be immediately utilized, as they will not keep like sweet potatoes.

As the climate of Guam seems well adapted to the cultivation of this plant, and as it is very productive, it would well repay more extensive cultivation. The roots yield meal, starch, and cassava, or tapioca. The meal or harina (called "farinha" in Brazil) is made by peeling and grating the root, expressing the juice, drying the pulp, removing the fibrous matter by sifting, and dissipating any vestiges of prussic acid by heating. In preparing meal from sweet cassava the root is peeled, sliced or 
grated, dried in the sun, and ground into powder. In this state it may be used for thickening soups, making gruel, and as an ingredient in puddings.

Starch is made from cassava very much in the same way as from potatoes. The roots are rasped or grated to a fine pulp, mixed with water in a tub or vat and run through strainers to separate the solid particles from the milky liquid. This liquid is allowed to stand for some time and the starch settles at the bottom. The water is then drawn off without disturbing the sediment. Fresh water is poured upon this sediment and after vigorous stirring it is passed through a finer sieve, allowed once more to settle and the clear liquid drawn off. The starch is then spread out in thin layers and dried in the sun. Cassava will yield nearly double the percentage of starch obtained from an equal weight of potatoes, ${ }^{\prime}$ and in a country like Guam, where potatoes will not grow and the climate and soil are well adapted for cassava, its culture can not fail to be profitable. It is now cultivated in Florida and other Southern States and factories have been established for the manufacture of cassava starch. The starch produced has been sold to cotton factories for sizing. For laundry purposes the starch is said to be better than that made from corn or potatoes, "giving a smoother surface and a finer gloss than can be obtained by the use of either." $b$

Tapioca is made by washing and peeling the roots, grating them to a fine pulp and expressing the milky juice. This is collected into a flat-bottomed tub or vat and allowed to stand for eight hours. A considerable quantity of very fine starch will be deposited. The clear liquid is carefully drawn off and the starch is spread upon wicker frames and dried for two or three hours in the sun. It is then placed upon sheets of tin or in flat iron pans and well stirred with an iron rod to prevent scorching. The starch grains swell up and burst and become agglutinated together into small, irregular, transparent, jelly-like lumps, which harden on cooling, and which form the tapioca of commerce ${ }_{3}$ one of the most important exports from Brazil.

The roots of sweet cassava are much relished by cattle, horses, hogs, and poultry. In a country like Guam, where animals are always kept confined and where food must be gathered for the majority of them, it would be profitable to raise cassava for forage. The greater part of the cassava grown in our Southern States is fed to animals, which are said to thrive on it much better than when confined to dry feed. It is less watery than potatoes, yams, sweet potatoes, or turnips, while its yield is much greater. The roots must be fed in a fresh condition, but they will keep for a long time if left undisturbed in the ground; so that during the periods of famine which invariably follow hurricanes in Guam, when nearly all vegetation and all crops are blasted and destroyed, they would be especially valuable. In the farmers' bulletin already referred to $c$ cassava roots are specially recommended as food for milch cows and for fattening stock. It does not affect the flavor of the milk or butter and imparts a richer color to both. In feeding to cattle the roots are cut or broken into small pieces to prevent choking, but this is not necessary when feeding to horses or hogs. It is the custom of some farmers to crush the roots with a mallet before feeding, and as the fresh roots are crisp and brittle, this can be easily done. Others put them in a box and chop them with a spade. In feeding to hogs the animals are sometimes turned into the field and allowed to gather the erop for themselves. This, however, is wasteful. It is a good plan to turn hogs into a field where cassava has been grown and gathered, as many broken roots will be found remaining. Cassava is very fattening. It is too carbonaceous to be fed exclusively to animals, and with it there should be some nitrogenous food to form bone and muscle. This is also the case

aSee Wiley, The Manufacture of Starch from Potatoes and Cassava, U. S. Dept. of Agr., Div. of Chemistry, Bull. No. 58, p. 44, 1900.

$b$ Tracy, Cassava, U. S. Dept. of Agr., Farmers' Bull. No. 167, p. 31, 1903.

cTracy, Idem., p. 24. 
with poultry. Hens fed on cassava roots are said to become fat and not to lay well. It is not advisable to feed it to growing chickens or laying hens, but it is an excellent and inexpensive food for fattening chickens for the table. $t$ The mots are so succulent and tender that they can be eaten readily without further preparation than chopping them up, and they are apparently relished as much by poultry as by cattle and hogs. $b$

REFERENCES:

Manihot manihot (L.) Karst. Deutsch. Fl. 588. 1880-83.

Jatropha manihot L. Sp. Pl. 2: 1007. 1753.

Manihot utilissima Pohl, PI. Bras. Ic. 1: 32. t. 24. 1827.

Manila hemp. See Musa textilis.

Manila tamarind (India). See Pithecolobium dulce.

Maniuniu (Samoa). See Coix lachryma-jobi.

Mankit (Philippines). See Meibomia gangetica.

Mantofa (Samoa). See Urena sinuata.

Manzanas (Guam).

Spanish name for apple, applied in Guam to the introduced jujube tree, Zizyphus jujuba.

\section{Manzanilla.}

A name applied in Guam and the Philippines to Chrysanthemum indicum, the flowers of which are used medicinally like those of Camomile.

Manzanitas (Philippines). See Zizyphus jujuba.

Mapola (Guam). The local name for Hibiscus mutabitis.

Mapuñao (Guam). A small tree used for fuel and for fence stakes.

Marañon (Panama). See Anacardium occidentale.

\section{Maranta arundinacea.}

Arrowroot. Plate XXV.

Family Marantaceae.

Local vames.-Arorú, Aruru, Sagu (Guam); Araró, Araráo, Ararú (Philippines); Sagú cimarron (Mexico).

An introduced plant of American origin, the tuberous rhizomes of which (Plate $\mathrm{XXV}, \mathrm{p}, 145$ ) are the source of the well-known arrowroot of commerce. Herbaceous, branched; leaves alternate, orate-oblong, pointed, puberulous, with a cylindrical knob between the blade and the sheathing petiole; inflorescence loose, spreading; bracts in two vertical ranks; flowers small; calyx of 3 sepals; corolla white, tube obliquely tubular, equaling the calyx, club-shaped, about twice as long as the lobes; petal-like staminodes arranged so that the two exterior form an upper lip and the two interior form a lower lip, those of the upper lip exserted, exceeding the lateral staminodes, another free from the petaloid filament; ovary 1-ovuled by abortion; style incurved; stigma 3-angular; capsule membranaceous; seed ovoid-oblong, tubercled; embryo curved.

This plant is propagated from the tubers, very much after the manner of potatoes. They are planted just before the rainy season sets in, and the rhizomes are dug in the dry season. The smaller ones and the pointed tips of the larger ones, at the extremities of which the eyes are situated, are reserved for planting. $c$

To prepare the fecula or arrowroot from the rhizomes they are washed clean, put into a wooden mortar and pounded to a pulp. The pulp is then put into a large vessel of water, which will become turbid and milky, a portion of the pulp remaining suspended as a fibrous mass. This fibrous portion is rinsed and put once more

a Tracy, Cassava, U. S. Dept. Agr., Farmers' Bull. No. 58, p. 29, 1903.

$b$ See also Morong, Iandioca, Bull. Pharmacy, vol. 5, p. 260, 1891.

$c$ Firminger, Manual of gardening for Bengal, p. 125, 1890. 
into the mortar and pounded, after which it is put back into the vat or tub as before, left awhile, lifted out, rinsed, and thrown away. The milky liquid is then strained through a coarse cloth, to remove the finer solid particles of the root, and the strained liquid allowed to stand until the starch has settled. The water is then poured off gently without disturbing the sediment, and clean water is poured upon it. It is then well stirred up and strained through a fine cloth, allowed to stand until the starch is deposited and then the water is gently drained off as before. The sediment, which is the pure arrowroot of commerce, is then spread out on sheets of clean paper, or on banana leaves and dried in the sun. $a$

REFERENCES:

Maranta arundinacea L. Sp. Pl. 1:2. 1753.

Marattiales. See Fern-allies.

Maravilla (Guam). See Mirabilis jalapa.

Maravilla (Porto Rico). See Hibiscus mutabilis.

Marianne Betel pepper.

De Candolle calls the Guam betel pepper, Piper betle variety marianum. See Piper betle.

Marianne Caper. See Capparis mariana.

Marianne jasmine. See Jasminum marianum.

Marianne maile. See Gynopogon torresianus.

Marianne morning-glory. See Ipomoea mariannensis.

Marianne tree-fern. See Alsophila haenkei, under Ferns.

Marianne yellow-wood. See Ochrosia mariannensis.

Marimbo (Porto Rico). See Lagenaria lagenaria.

Mariposa, flor de (Guam). See Bauhinia sp.

Mariscus albescens (Gaud). See Cyperus pennatus.

Marunggai (Guam). See Moringa moringa.

Marrubio-boton (Porto Rico). See Mesosphaerum capitatum.

Marvel-of-Peru. See Mirabilis jalapa.

Masi (Samoa). Fermented bread fruit. See Artocarpus communis.

Masigsig (Guam). See Stemmodontia biflora.

Masigsig hembra (Guam). See Triumfetta procumbens.

Masigsig lahe (Guam). See Triumfetta procumbens, and T. tomentosa.

Masoã (Samoa). See Tacca pinnatifida.

Másôn (Guam). A coconut not quite ripe.

Mastophora. See under Algæ.

Mata de la Playa (Porto Rico). See Canavali obtusifolium.

Mata-pavo (Spanish). See Boerhaavia diffusa.

Matamata-aitu (Samoa). See Carinta herbacea.

Matamata-Moso (Samoa). See Abrus abrus.

Matbas (Guam).

Local name for Abutilon indicum; derived from "malva."

Matricaria chamomilla Blanco. Same as Chrysanthemum indicum.

Mautofu (Samoa). See Urena sinuate and Sida rhombifolia. Applied also to other similar species of Sida.

Mautofu-tai (Samoa). See Triumfetta procumbens. 
Mayagas (Guam). See Cassytha filiformis.

Medicago sativa.

Alfalfa.

Attempts have been made to introduce alfalfa into Guam, but they have been unsuccessful. See Forage plants, p. 151.

\section{Medicinal plants.}

Anacardium occidentalis. - An acrid oil is obtained from the pericarp or shell of the cashew nut. It is used in India as a remedy in the anæsthetic variety of leprosy, and as a blister in the treatment of warts, corns, and ulcers. By macerating the shell in alcohol an oil is obtained which is a very good remedy for the cracking of the skin of the sole of the foot. The kernels of the nut yield a fixed oil. For other uses see name.

Arachis hypogaea. - Peanut oil is used as a substitute for olive oil in the preparation of ointments and plasters.

Artemisia vulgaris. - Infusion of leaves used in treating ulcers.

Calophyllum inophyllum. - Fresh seed yield a green oil used externally for rheumatism and for lamps. A resin exudes from the fruit and branches, used in India in treating sore eyes.

Cassia fistula. - Pulp of the fruit is used as a purgative.

Cassia occidentalis and Cassia sophera.-Paste made of fresh leaves used as a remedy for wounds and ulcers. Ointment made of bruised leaves, sulphur, and ripe seeds a remedy for ringworm and itch.

Cassia tora.-Leaves used as an aperient and externally for ringworm and itch. Seeds roasted and made into a decoction resembling coffee.

Chrysanthemum indicum.-Flowers used for fevers and female complaints.

Clerodendron inerme. - The bitter leaves used in intermittent fevers.

Clitoria ternatea. - Roots and seeds are cathartic.

Ficus spp.- Juice of banyan trees astringent, used to check the flow of blood.

Guilandina crista. - Powdered seeds used in intermittent fevers and as a tonic.

Herpetica alata. - Leaves used as a remedy for ringworm and for other skin diseases.

Jatropha curcas.-Seeds purgative. The juice is applied to foul ulcers.

Lawsonia inermis. - An ointment made of the leaves is used for wounds, bruises, and ulcers.

Mangifera indica.-Gum of trunk and branches mixed with lime juice or oil used in cutaneous diseases.

Melia azedarach. - Poultices of leaves and bark used in leprosy and scrofulous ulcers. Paste of flowers used to destroy lice and for eruptions of the scalp.

Ricinus communis.-Purgative.

Tamarindus indica.-Tamarinds are used as a remedy and preventive of scurvy. The pulp mixed with water is given to children as a laxative.

Medinilla rosea.

Medinilla.

Family Melastomataceae.

Local names.-Gafus (Guam).

A smooth shrubby plant with round branches, entire 3-nerved leaves growing in whorls of three or four, and axillary cymes of rose-colored, 4-petaled flowers. Leaves obovate-oblong, the 2 lateral nerves near the margin; peduncles of the umbellike flower-clusters bearing at their tips 6 to 8 flowers; pedicels articulate at the base; calyx ventricose-ovate, adnate to the ovary, its limb free, tubular, truncate, entire, persistent; the 4 petals inserted at the margin of the epigynous disk, dolabriformovate, widely spreading, equal; stamens 8 , inserted in the same way; filaments filiform; anthers linear-subulate, subarcuate, bilocular, opening by a terminal pore, bilohate at the base and shortly spurred at the produced connective, the alternate ones (opposite the petals) longer, and more slender; style terete, erect, somewhat curved at the apex; stigma simple, obtuse; berry ovate-globose, rose-colored, crowned by the limb of the calyx, 4-celled, cells with many seeds; seeds falcate-ellipsoid, smooth; raphe not excurrent.

This plant was collected by Gaudichaud in Guam and referred to in the narrative of the Freycinet expedition as Melastoma medinillana. It was afterwards made the 
type of a new genus ledicated to Don José de Merlinilla y Pinerla, "who was governor of the Marianne Islands at the time of Freyeinet's visit. Somewhat diagrammatic figures of the plant, flower, and fruit are given in plate 106 of the atlas of the Botany. The species is recorded hy Hooker in his Flora of British India as occurring in Malacea, and is recognized hy Naudin in his monograph of the Melastomaceae. "s

\section{REFERENCES:}

Medinilla rosea Gaudich. Bot. Freyc. Voy. 484. t. 106. 1826.

Melastoma medinillana is merely mentioned by Gaudichaud in the text and not properly published. The specific part of the name is therefore not recognized as having place priority.

\section{Meibomia gangetica.}

TICK-TREFOIL.

Family Fabaceae.

LoCAL NaMes.-Atis-aniti (Guam); Mankit (Philippines); Salpani (Bengal).

A suberect weed, 90 to $120 \mathrm{~cm}$. high; stems woody, slightly angular, upwardly clothed with short gray down; leaves 1-foliolate, the leaflet oblong, entire, glabrescent on the upper surface, thinly clothed beneath with appressed hairs, membranous or subcoriaceous, 7.5 to $15 \mathrm{~cm}$. long and one-third to one-half as broad, rounded at the base, narrowed gradually upward to an acute point; stipules distinct; petiole 12 to $24 \mathrm{~mm}$. long; flowers small, in long ascending, lateral and terminal racemes, purple or yellowish white; calyx less than $2.5 \mathrm{~mm}$. long, campanulate, finely downy, the teeth lanceolate; corolla 3 to $3.5 \mathrm{~mm}$. long; standard broad, wings adhering to the keel; upper stamen free, the other 9 stamens united; porl subsessile, compressed, 6 to 8 -jointed, 12 to $18 \mathrm{~mm}$. long, glabrescent or clothed with minute hooked hairs.

Common on the island of Guam; probably introduced. The vernacular name, signifying "devil's sweet-sop," is probably given it on account of the similarity of its leaves to those of the "atis" (Annona squamosa). This shrub is one of the most highly prized of the medicinal plants of India. It is one of the ten roots (dasha mulu) of the Hindu Materia Medica. It is regarded as a febrifuge and anticatarrhal. It is of very wide tropical distribution.

References:

Meibomia gangetica (L.) Kuntze, Rev. Gen. 1: 196. 1891.

Hedysarum gangeticum L. Sp: Pl. 2: 746. 1753.

Desmodium gangeticum DC. Prod. 2: 327. 1825.

Meibomia triflora.

Creeping TICK-TREFoIL.

Local names. - Agsom, Apson (Guam); Pakpak lañgao (Philippines).

A small, much-branched, slender creeping or trailing plant, often not more than 5 cm. long, with trifoliolate leaves and small pink flowers arranged 2 or 3 together opposite the leaves. Stems clothed with fine spreading hairs; leaves small, with lanceolate stipules; petiole 3 to $6 \mathrm{~mm}$. long; leaflets obovate, 3 to $12 \mathrm{~mm}$. long, truncate or emarginate, with a few appressed hairs below; calyx pubescent, teeth very long, inclosing the corolla; porl sessile, 8 to $12 \mathrm{~mm}$. long, $3 \mathrm{~mm}$. broad, 3 to 6 -jointed, the upper suture straight, the lower slightly indented.

A plant widely distributed in the Tropics. It is good for forage, taking the place of clover and alfalfa, and will grow in all kinds of soil and situations. The leaves are sometimes marle into poultices and applierl to aloscesses and wounds. In Gram it grows in waste places and in ahandoned fields, often forming a fine thick turf. Sometimes improperly called "agsom," which see.

REFERENCES:

Meibomia triflora (L.) Kuntze, Rev. Gen. 1: 197. 1891.

Hedysarum triflorum L. Sp. Pl. 2: 749. 1753.

Desmodium triflorum DC. Prod. 2: 334. 1825.

a"Hommage de reconnoissance à D. José de Medinilla y Pineda, gouverneur des îles Mariannes, yui nous a prorligué les soins et les secours les plus empressés." (Gaudichaud, Freyc. Voy. Bot., pp. 484-485, 1826. )

b Ann. Sci. Nat. ser. 3, vol. 15, p. 286, 1849.

$9773-05-21$ 


\section{Meibomia umbellata.}

LoCAL NAMes. - Palaga hilitai (Guam); Lălă (Samoa).

A shrub 1 to 2 meter high growing on the seabeach, with densely downy young branches, 3-foliolate leaves, and axillary umbels of whitish papilionaceous flowers. Branches terete; petioles $2.5 \mathrm{~cm}$. or less long, slightly furrowed; leaflets subcoriaceous with raised costate reins, green and glabrous above, thinly gray-canescent or nearly glabrescent beneath, end leaflet larger than side ones, roundish, or broadoblong, 5 to $7.5 \mathrm{~cm}$. long; umbels 6 to 12 -flowered; pedicels short, unequal; calyx 4 $\mathrm{mm}$. long, densely silky, t-parted, 2-bracted; bracts minute, deciduous; standard of corolla obovate, keel blunt; stamens monadelphous; pod jointed, 3.5 to $5 \mathrm{~cm}$. long, the joints 3 to 5, thick, glabrescent or silky, indented at both sutures.

A strand shrub of wide tropical distribution. Common near the beach in Guam. Samoa, Fiji, and the Malay Archipelago. In Samoa it is used for perches for pet fruit pigeons. The Guam name means "lizard's bush."

REFERENCES:

Meibomia umbellata Kuntze, Rev. Gen. 1: 197. 1891.

Hedysarum. umbellatum L. Sp. PI. 2: 747. 1753.

Desmodium umbellatum DC. Prod. 2: 325. 1825.

Melastoma denticulata. Same as Melastoma mariannum.

Melastoma marianum.

Melastoma.

Family Melastomataceae.

Local rames.-Gafau (Guam).

A low, hairy shrub growing on the coast, described by Charles Naudin in his monograph of the Melastomataceae from specimens collecter near Agana by Hombron and Le Guillou. It is injurious to chickens. Where it grows they can not be raiser. It is erect and branching with flowers comparatively small for this genus, short stamens usually corresponding in number with the petals; branches rust-colorer, with appresserl tiff hairs and scurfy scales at last falling off; leaves oblong-ovate, acuminate, acute, almost entire, 5-nerved with a marginal nerve on each side, the blade on both surfaces covered with small stiff appressed sharp hairs; flowers at the apex of the branches, subcorymbose, 5 -merous; anthers obtuse, the connective of all with a simply articulate filament.

This plant at first glance resembles $M$. denticulatum; it is different, however, on account of the structure of the connective of the anthers and some other characters. The stem sometimes almost simple, more frequently branching, those examined by Naudin a half meter long; leaves 4 to $7 \mathrm{~cm}$. in length; calyx covered with chaffy hairs, with 5 ovate lobes almost equal in length to the tube, with minute teeth between the divisions; petals hroadly orate, somewhat notched at the apex, about $12 \mathrm{~mm}$. long and hroad; anthers very short for this genus, oblong-ovoid, obtuse; the connective of the larger ones beneath the cells short, not very much curved, not manifestly thickened nor hiloberl at the insertion of the filament; that of the sualler ones scarcely perceptihle; fruit a berry, 5-celled and of nearly the size of a pea."

REFEREXCES:

Melastoma marianum Naud. Ann. Sc. Nat. III. 13: 276. 1849.

Melastoma medinillana Gaudich. Same as Medinilla rosea.

Melastomataceae.

Melastoma Family.

This family is represented in Guam hy Melustoma marmmm and Medinilla rosea.

Melia azedarach.

Pride of India. Chinaberry.

Family Meliaceae.

Local xuss - Paraiso ((iuam: Mexico; Philippines); Jacinto (Panama); Arbol de Paraiso (spanish): Persian Lilac (India); Syrian Bead Tree (Mediterranean).

"Charles Naudin, Munograph of the Melastomataceae, Ann. Sci. Nat., ser. 3., vol. 13, p. 276,1849 . 
A small tree bearing clusters of small lavender-colored, honey-scenterl flowers with purple staminal tubes. Trunk short; leaves bipinnate, occasionally tripinnate, leaflets 3 to 12 on the ultimate divisions, opposite or alternate, ovate or lanceolate, serrate or entire, acuminate, base more or less oblique; flowers usually 5-merous; ralyx deeply loherl, lobes lanceolate-oblong; petals puherulent; anthers nearly equaling the linear-lanceolate teeth of the purple staminal tube; ovary 5-celled; fruit an indehiscent drupe with 5 or fewer cells and seeds.

The inner bark, especially that of the root, is used as a remedy for intestinal worms. It is also cathartic and emetic, and has been used as a remedy for cholera morbus and other intestinal troubles. It must be used fresh. A decoction of the bark is sairl to be narcotic and causes a dilation of the pupil of the eye, but its effects soon pass away. The wood is bitter and resists the attacks of white ants. There are several varieties of it, one of which is of a reddish color and another white. In China and Japan it is user for cabinetwork, but that grown in the West Indies does not appear to be highly esteemed and is used only for fuel. Owing to its graceful foliage and its pretty clusters of pale lavender blossoms with their violet staminal tubes the tree is a favorite in most tropical countries, and the flowers are much used for making funeral wreaths. It is probably a native of the Himalayas, where it is found growing wild at a height of 2,000 to 3,000 feet, but it has now found its way all over the warmer regions of the globe. A variety grown in the southern United States is known as the "umbrella tree" from the dome-like crown and drooping branches. The berries are poisonous. A decoction prepared from them is sprinkled on plants to protect them from the attacks of insects. The seeds are strung into necklaces and rosaries, and in some countries are supposed to act as a charm against disease when worn or when hung above the door of a house during epidemics.

Though introduced into Guam more than a century ago the tree has not spread itself spontaneously over the island as in the case of other introduced plants with edible berries:

Mr. Oudenampsen, who has made a careful study of the properties of this plant has arrived at the following conclusions: $a$

The bark of Melia azedarach contains a substance which is stupefying to fishes. This substance is soluble in water, but loses its qualities when boiled. The bark contains a resin which is saponified with difficulty; phytostearin or vegetable fat; azedarachic acid; a tannin which yields a green precipitate with perchloride of iron; saponin, from which the plant derives its narcotic properties, and a bitter substance. Notwithstanding the evidence furnished by various authors, Mr. Oudenampsen doubts the efficacy of the bark of this plant as an anthelmintic. $b$

REFERENCES:

Melia azedarach L. Sp. Pl. 1: 384. 1753.

\section{6 liaceae.}

MAHOGANY FAMILY.

This family is represented in Guan by the introduced Melia azedarach, Sandoricum indicum, and the indigenous seaside tree Xylocarpus granatum.

Melindres (Guam; Philippines).

The local name for the crape myrtle, Lagerstroemia indica.

Melon. See Cucumis melo, under Gardens.

Mendioka, Mendiuka (Guam). See Manihot manihot.

Mentha arvensis.

Chinese mint.

Family Menthaceae.

LOCAL NAMES.-Yerba buena (Guam); Hierba buena (Spanish).

An herb with a pleasant scent and flavor very much like our common mint. Hairy

a Oudenampsen, Bydrage tot de Kennis van Melia Azedarach L., 1892.

b) See Wildeman, Melia Azedarach, Revue des Cultures Coloniales, vol. 13, p $75,1903$. 
or smooth; leares shortly petioler or sessile, oblong-ovate or lanceolate, serrate; flowers in axillary capitate whorls; bracts acute, shorter than the flowers; calyx hairy, teeth triangular or lanceolate; corolla hairy without and within, subequally 4-lobed; stamens 4; stigma bifid, style branches short.

Cultivated in Guam, often grown in pots. It is used for making mint juleps.

ReFERENCES:

Mentha arvensis L. Sp. Pl. 2: 577. 1753.

\section{Menthaceae.}

Mint Fanily.

This family is represented in Guam by the genera Colens, Mentha, Mesosphaerum, and Ocimum. The author of the name Menthaceae, which is here published for the first time, is Prof. Lester F. Ward, who has presented the following statement regarding it:

"Permit me to propose the name Menthaceae for the mint family as the most suitable substitute for the name Labiatae, given it by Bernard Jussieu in Hort. Trianon, 1759 , and used by most botanists since that date, but which has not the proper termination and is not formed from the name of any genus of the family. Being baser on Mentha, the most typical genus of the family, it has better claims, except in the matter of priority, than Lamiaceae (Lindley, 1836), Nepetaceae (Horaninow, 1843), or Salviaceae (Drude, 1879)."

\section{Mesosphaerum capitatum.}

Family Menthaceae.

Local Names.-Batunes (Guam); Marrubio-boton (Porto Rico); San Diego cimarron (Cuba).

A stout glabrescent weed growing to a height of 1.5 to 2 meters; leaves petioled, ovate-oblong, pointed, unequally and coarsely serrate; floral leares oblong-linear, at length reflexed, shorter than the head; flomers sessile, capitate; heads globose, axillary, shorter than their peduncles; calyx equally 5-toothed, teeth awl-shaped, bristle-tipped, erect at length one-third as long as the tube; corolla 2-lipped, inferior lobe deflexed; stamens 4, deflexed; leaves 5 to $13 \mathrm{~cm}$. long, peduncles 2.5 to $5 \mathrm{~cm}$. long; heads in fruit 20 to $25 \mathrm{~mm}$. in diameter; nutlets devoid of a concave margin. A weed of American origin, widely spread through the Tropics.

REFERENCES:

Mesosphaerum capitatum (Jacq.) Kuntze, Rev. Gen. 2: 525. 1891.

Hyptis capitata Jacq. Coll. 1: 102.1786.

\section{Mesosphaerum pectinatum.}

Local NaMes.-Alhucema (Cuba).

slender, wand-like, puberulous or glabrescent; leares petioled, orate, unequally crenate-serrate (or serrate), hoary-pubescent beneath or glabrescent; floral leares hristle-like; flowers in one-siled, contracted, short, arched, recurved cymes; cymes racemose or paniculate: calyx shortly perlicellate, 10-striate, subequal; tuho shortly campanulate, densely villous at the truncate throat; teeth bristle-like, shorter than the tube, suberect.

A tropical weed; collected in Guam by Lesson and Gaudichaud.

REFERENCES:

Mesosphaerum pectinatum (L.) Kuntze, Rev. Gen. 2: 525. 1891.

Nepeta pectinata L. Syst. ed. 10. 1099. 1759.

Hyptis pectinata Poit. Ann. Mus. Par. 7: 474. t. 30. 1806.

Mexican creeper. See Antigonon leptopus.

Mexican tea. See Chenopodium ambrosioides.

Mignonette tree (British West Indies). See Lawsonia inermis.

Mil-leguas (Guam, Philippines). See Telosmu odoratissima.

Milkweed, Curaçao. See Asclepias curassavica. 
Milkweed family. See Asclepiadacene.

Milky mangrove (Australia). See Excoccaria agallocha.

Millet, Kodo. See Paspalum scrobiculatum.

Milo (Samoa, Hawaii). See Thespesia populnea.

Mimosa scandens L. Same as Lens phaseoloides.

Mimosaceae.

Mimosa Family.

This family is represented in Guam by Acacia farnesiana, Adenanthera paronina, Lens phaseoloides, Leucaena glauca, and Pithecolobium dulse.

Mint, Chinese. See Mentha arvensis.

\section{Mirabilis jalapa.}

Four-o'clock. Marvel-of-Peru.

Family Nyctaginaceae.

Local Names.-Maravilla (Guam); Trompetilla, Don Diego de Noche (Mexico);

Buenas tardes (Panama); Wunderblume (German); Belle de Nuit (French).

A glabrescent herbaceous plant bearing showy trumpet-shaped flowers of various colors. Leaves ovate or subcordate; flowers apetalous, the perianth consisting of a 5-lobed corolla-like calyx encircles by a 5-lobed involucre; stamens 5; ovary 1-celled, ovule solitary, style simple.

The flowers expand in the afternoon and wither the following morning. In Guam they are often seen in the gardens of the natives; crimson, scarlet, white, yellow, and variegated. Some of them are very fragrant, and some are odorless. In Japan the powdered seeds are used as a cosmetic.

REFERENCES:

Mirabitis jalapa L. Sp. Pl. 1: 177. 1753.

Miscanthus floridulus. Same as Xiphagrostis floridula.

Miscanthus japonicus Anders. See under Xiphagrostis floridula.

Mitracarpum hirtum.

Family Rubiaceae.

A herbaceous annual introduced from tropical America. Stem simple or fewbranched, hairy at the summit; leaves oblong or lanceolate, subsessile or shortly petioled, opposite, connected by stipules divided into bristles; flower whorls and heads many-flowered; calyx limb 4-parted, persistent, 2 of its segments rigid, subulate-lanceolate, longer than the capsule, the other 2 shorter; flowers small; corolla funnel-shaped, with 4 lobes; stamens 4 , inserted on the margin of the tube; ovary 2-celled, adherent to the calyx tube, capsule membranaceous or leathery, circumcissile. $a$

To this species should be referred Mitracarpum torresianum Cham. \& Schlecht., collected in Guam by Chamisso in 1818.6

References:

Mitracarpum hirtum (L.) DC. Prod. 4: 572. 1830.

Spermacoce hirta L. Sp. Pl. ed. 2. 1: 148. 1762.

Mitracarpum torresianum Cham. \& Schlecht. Same as Mitrucarpum hirhm.

Moli (Samoa). See Citrus aurantium saponacea.

Moli-tai (Samoa). See Ximenia americana.

Momordica charantia.

BALSAM-PEAR.

Family Cucurbitaceae.

Locul Names.-Balsamina, Amargosa (Spanish); Ampalia (Philippines); Cundeamar (Cuba, Porto Rico).

A climbing gourd-like vine with palmately 5-lobed leaves and warty, yellow,

"Schumann, in Engler und Prantl, Die Natürlichen Pflanzenfamilien, Teil f, Abt. 4, pp. 142, 146, fig. 46 U., 1891.

"Legimus in insula Guajan en insulis Marianis." Limæea, vol. 3, p. 360. 1828. 
oblong fruit containing seeds surrounder loy a red aril. Stems more or less hairy; lobes of leaves sinuate-toothed, more or less hairy on the under side when young; peduncles slender with a kidney-shaped bractenle, which in the male ones is above the middle and in the female near the base; flowers of medium size, pale yellow; fruits bursting open when ripe, showing the red aril.

Cultivated in Guam, running along fences, etc. The fruit is bitter, but not unwholesome. In India it is eaten in curries. Before cooking it must be steeped in salt water. The plant is used as an external remedy in leprosy and malignant ulcers. REFERENCES:

Momordica charantia L. Sp. Pl. 2: 1009. 1753.

Monggo (Philippines). See Phaseolus mungo.

Moñggos (Guam). See Phaseolus mungo.

Monggos paloma (Guam). Local name for Cleome viscosa.

Monkey-pod (Honolulu). See Pithecolobium saman.

Monkey-pod, sweet. See Pithecolobium dulce.

\section{Moraceae.}

MUlberRy Family.

This family is represented in Guam by the genera Artocarpus and Ficus.

\section{Morinda citrifolia.}

Indian Mulberry.a Plate xvi.

Family Rubiaceae.

Local Names.-Ladda, Lada (Guam); Nino (Philippines); Nona (Malay Archipelago); Núna (Southern India); Nono (Rarotonga, Tahiti); Nonu (Samoa); Noni (Hawaii); Urati (Solomon Islands); Kura (Fiji).

A suall tree widely spread over the Pacific, the Malay Archipelago, southem India, and the west coast of Africa; in India yielding the ál dye of commerce, for which purpose it is there cultivated. Branchlets t-angled; leaves large, glussy, urate, attenuate at each end, short-petioled, with broarl, membranous stipules, connate below into a loose sheath inclosing the peduncle; peduncles solitary, opposite the leaves, rarely binate, or ternate at the ends of the branches; flowers 5-merous, growing in globose heads, white, the calyx tube short; corolla tuke $12 \mathrm{~mm}$. or less long, lobes glabrous, fusiform in hul, thruat pubercent; fruit of nany drupes coalesrent into a fleshy globose or oroid head, inclosing many cartilaginous or bony 1-seeded pyrenes.

The seets of this species are especially interesting, owing to their possession of a distinct air chamber or resicle, which renclers them bungant and capable of being transported to great distances by ocean currents." Not only have they been found in the clebris cast ${ }^{\prime}$, at the high-water mark along tropical shores, but experiments have been made which demonstrate the great length of time they will float in salt water. $c$

In (iuan the tree is used for dyeing, though, owing to the trouble of preparing it, the dye is not now so extensively used as hefore the introduction of coal-tar dyes into the island. Both a red and a vellow color are olutainable, the bark of the root being the source of the best red dye, the root itself yielding a yellow dye.

The fruit is eaten in many of the Pareific islancls, bat it is insipial and rery full of seceds. In India it is gathered green and forms an ingreslient in the eduries of the natives.

ReFERENCES:

Morinda citrifolia L. Sp. Pl. 1: 176. 1753.

$a$ Watt, Economic Products of India, vol. 5, p. 261, 1891.

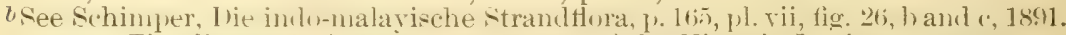

"Guppy, The dispersal of plants, etc., Trans. of the Vietoria Institute, lsyo. 



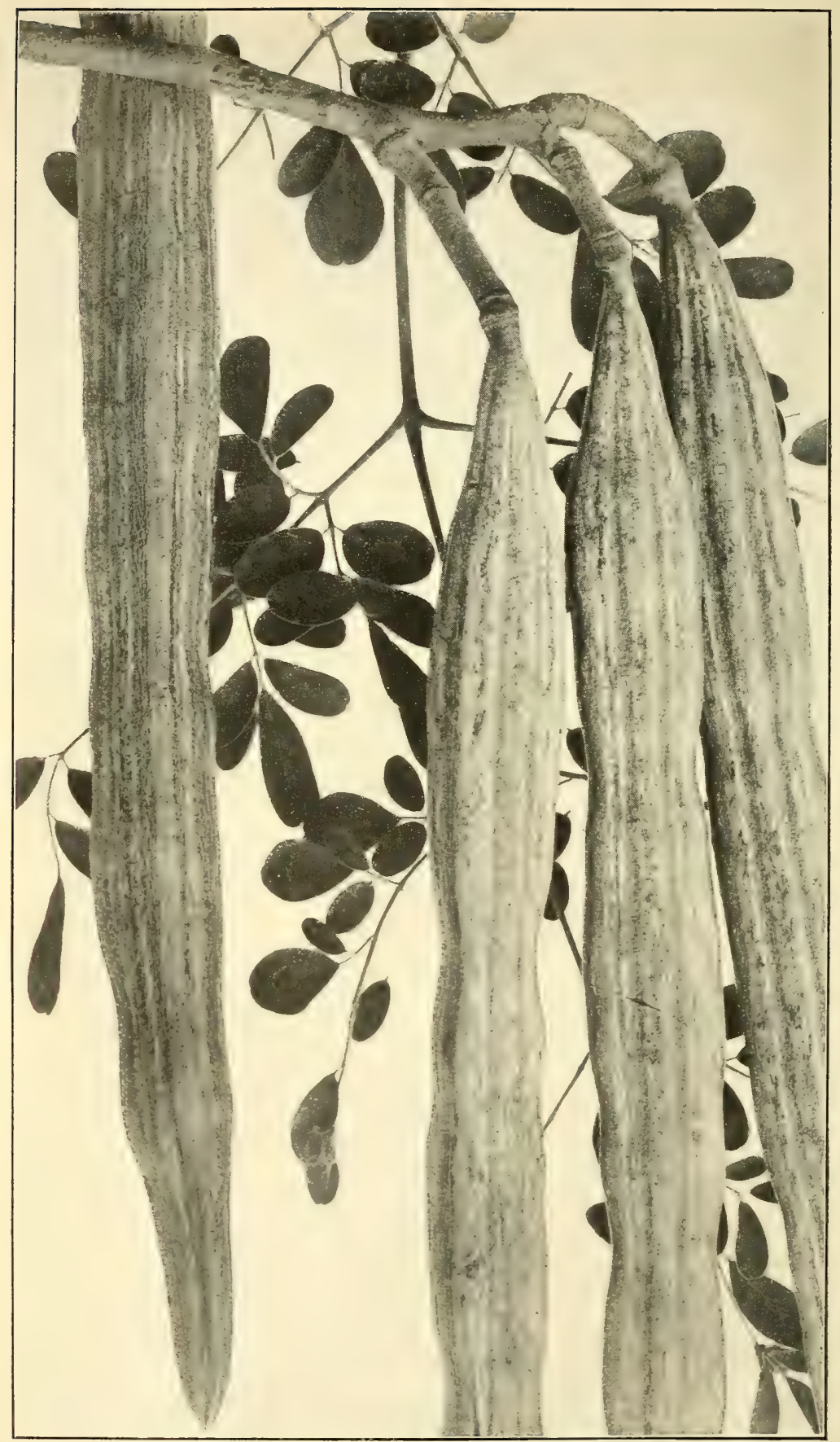

Moringa moringa, the Horse-radish Tree. Natural Size. 
Family Moringaceae.

Local xayes.-Marunggai (Guam); Maluñggai, Balunggai, Balonggai, Arongay, Arungay (Philippines); Murungai, Murunga (Tamil); Murinna (Malayan); Palo jermga (Cuba).

A small tree with corky bark, soft wood, and pungent root having the taste of horse-radish. Leaves pinnately compound, usually tripinnate; petiole slender, sheathing at the base; pinnae 4 to 6 pairs; leaflets 6 to 9 pairs, opposite, pale beneath, caducous as well as the pinnules, glandular at the base; petiolules slender; glands linear, hairy; panicles axillary, spreading; bracts linear; flowers white, honeyscented, irregular, bisexual, pediceled, $2.5 \mathrm{~cm}$. in diameter; calyx cup-shaped, 5-cleft; segments unequal, petaloid, linear-lanceolate, reflexed; petals 5, unequal, narrowly spathulate, upper smaller, lateral ascending, anterior larger; stamens inserted on the edge of the disk, declinate, 5 perfect opposite the petals, alternating with 5 which are reduced to antherless filaments; ovary stipitate, 1-celled; style slender, tubular; stigma perforated; ovules numerous, in 2 series on 3 parietal placentas; pod long, slender, pendulous, 9-ribbed; seeds 3-angled, winged at the angles.

The seeds of this tree yield the "ben" oil of commerce, which is highly valued as a lubricant by watchmakers. The young leaves, young pods, and flowers are used as food in West Bengal; they are antiscorbutic; the root is used in place of horse-radish, and medicinally as a rubefacient and counterirritant, like a mustard plaster. The leaves and young branches are much relished by cattle and horses. In Nicaragua they are cut for forage.

Plants are easily raised from seed and are of rapid growth. The unripe seed-pods are used in India for curries. When cut into pieces and cooked like asparagus or string-beans they form a savory dish, but they are too fibrous to be a popular vegetable. In Bengal and upper India the seeds are planted in June and July, at the beginning of the rainy season. $a$

REFERENCES:

Moringa moringa (L.) Millsp. Field. Col. Mus. Bot. Ser. 1: 490. 1902.

Guilandina moringa L. Sp. Pl. 1: 381. 1753.

Moringa pterygosperma Gaert. Same as Moringa moringa.

Morning-glory. See Ipomoea, Argyreia, Pharbitis, and Operculina.

Moso'oi (Samoa). See Canangium odoratum.

\section{Mosses.}

The following mosses are recorded from the island of Guam, all of them collected hy Gaudichaud and determined by Schwaegrichen and Walker-Arnott. They were first sent by Gaudichaud to Sehwaegrichen, but many of the specimens were incomplete or without fruit, so that they could not be identified with absolute certainty. Afterwards they were carefully examined by Walker-Amott, who published a paper on the "Disposition méthodique des espèces de Mousses," $b$ in which were included with a few changes the mosses of Schwaegrichen's list.

Bartramia uncinata Schwaeg. Freyc. Voy. Bot. 227.

Hypnum cupressiforme Schwaeg. Freyc. Voy. Bot. 229.

Hypnum delicatulum Schwaeg. Freye. Voy. Bot. 229.

Hypnum recurvans Schwaeg. Freyc. Voy. Bot. 229.

Hypnum scaturiginum Schwaeg. Freye. Voy. Bot. 228.

Macromitrion urceolatum Schwaeg. Freyc. Voy. Bot. 224.

Neckera undulata Schwaeg. Freyc, Voy. Bot. 228.

Octoblepharum albidum Schwaeg. ex Walker-Arnott, p. 1t. Freyc. Voy. Bot. 226. Syrrhopodon rigescens Schwaeg. Freyc. Voy. Bot. 226.

a Firminger, Manual of Gardening for Bengal, ed. 4, p. 140, 1890.

$b$ Mem. de la Soc. d'Hist. Nat. de Paris, 1825, p. 249. 
Mostaza. See Brassicr juncea.

Mucuna gigantea. Same as Stizolobium giganteum.

Mrucuna pruriens. Sante as stizolobinm pmiens.

Mudu-murunga (Ceylon). See Sophoru tomentosa.

Mugwort. See Artemisia vulgaris.

Mulberry, Indian. See Morinda citrifolia.

Múmutun (Guam).

A general name in the island vernacular for rank-growing weeds. Cassia tora is called mumutun palaoan (female weed) or mumutun adaiselon. Thename mumutun chiva (goat weed) is applied to a low, snuall-flowered composite; mumutun lahe (male weed) to an ill-smeiling hispid, blue-flowered labiate, with cordate leaves; and mumutun sable (sword weed) to Cassia occidentalis.

Irung (India). See Phaseolus mungo.

Muñggo (Philippines). See Phaseolus mungo.

\section{Musa paradisiaca. \\ Plantaix. Banana. Plate xim.}

Family Musaceae.

LocAL NAMES. - Chotda (Guam, for the plant and green fruit); Aga (Guam, for the ripe fruit); Platano (Spanish); Saguing, Pisang (Philippines); Fa'i (Samoa).

Bananas were growing in Guam before the discovery of the island by Magellan. Pigafetta describes them in his narrative as "figs a palm long." a Usually the numerous varieties are grouped under two heads. Those of smaller size, which are sweet and which may be eaten raw, are called bananas and have often been considered a distinct species, Musa sapientum; the larger ones, which are less sweet and more starchy, and which must be cooked before they are fit to eat, are called plantains, and are considered by some to constitute the species Musa paradisiaca. At least eleven varieties are recognized in Guam, some of which were undoubtedly introduced after the discovery. Schumann, in his monograph, regards $M$. sapientum as a subspecies of M. paradisiaca. ${ }^{2}$

Among the varieties noticed by Gaudichaud were chotdan c patgon, a small banana of fine flavor; chotdan lago ("foreign banana"); chotdan tontuke, a giant plantain, probably introduced from the Philippines, where it bears the name of "tondok," having few fruits on a raceme, but these of great size, and having also a strong fiber which is used for cortage and for weaving into fabrics; and three forms of aga, as the ripe fruit is called: Aga Sumay (a variety cultivated first in the village of that name), aga mahalang, and aga langüi. In the last edition of Blanco's Flora Filipina the large plantain called tondok is called Musa comiculate magma. Its fruit is often more thin a foot long and when cookerl has a fine apple-like flavor.

Bananas are easily propagated by suckers, which spring up from the base of the old plant when the fruit begins to ripen. When two or three bananas at the top of the bunch turn yellow the bunch should be eut off and hung up by a string in the

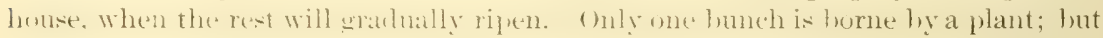
as suckers spring up from the underground rootstalk, the life of the banana may be saicl to be continums. In Guam bananas grow almost spontaneously. In Plate XXII is shown a plantation of then along the road leading from Agaña to the port.

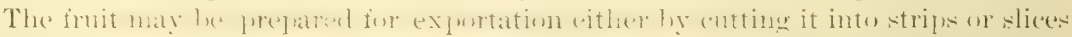

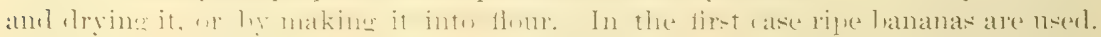

a Primo Viaguio intorno, 1800.

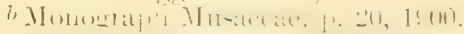

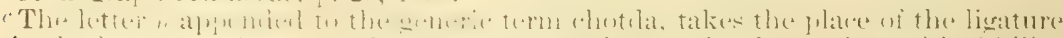

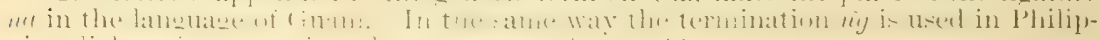

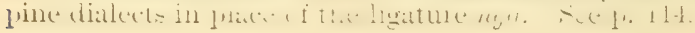


They are peeled and sliced either longitudinally or transversely and dried first in the oven and then in the sun. They are then parked in boxes or wrapped in dry leaves for exportation. In this form they are quitesweet and sugary and have a delightful flavor. In Tahiti and the neighboring islands belonging to France bananas preserverl in this way are called "piéré."

Buncence flour. - This is made from unripe bananas, which are first put into scalding water so as to facilitate peeling, sliced, dried in vacuum or in the sun, powdered and sifted. In British Guiana it is called by the natives "conquintay." It has a fragrant odor, acquired in drying, somewhat resembling fresh hay or ted. The fruit is gathered green, before its starch is converted into sugar. The flavor of the meal is enhanced by quick drying. Steel knives must not be used in slicing the fruit, since they discolor the meal. Knives with silver or nickel blades are preferable. The flour may be used in a measure as a substitute for arrowroot. Samples fit for exportation contain about 15 per cent of water. The flour is packed in boxes or barrels lined with paper. It is of a yellow color and has an agreeable sweetish taste. It combines readily with water, milk, or broth. It can not be made into bread, but is a fine ingredient for biscuits or cakes. ${ }^{a}$

In a country like Guam, where hurricanes, followed by scarcity of food, are liable to occur at any time, it would be of the greatest advantage to the natives to keep on hand a supply of banana flour, as well as of dried breadfruit and fadang meal. $b$

\section{REFERENCES:}

Musa paradisiaca L. Sp. Pl. 2: 1043. 1753.

Musa sapientum L. See under Musa paradisiaca.

Musa textilis.

Abacá.

Local Names.-Abaká (Guam, Philippines).

This plant has been introduced into Guam, and attempts were made to cultivate it on the island by several governors and by the Sociedad Agrícola de la Concepción, in 1867, during the administration of Don Francisco Moscoso y Lara. It grows well; a fine patch of it may still be seen on the border of the "Ciénaga," near Matan-hanom, the sonrce of the Agana River; but the preparation of its fiber required too much work on the part of the natives. They have other plants suitable for cordage, which require little trouble to prepare them for their uses; and the cultivation of this species, though quite possible in Guam, has never been an industry of the island.

Unlike the allied hanana and plantain, the fruits of Musc textilis are fertile. The plant may be propagated from the seed, but it is usually propagated from suckers, as in the case of the banana and plantain. When the plants are cut down at maturity they are replaced by suckers which spring up from the root, so that the plantation is constantly renewing itself. When the flower bud makes its appearance the plant is rearly for the harvest. The stalk is cut cluse to the ground. The fiber is contained in the long leaf sheaths which surround the stem. These are split into strips two or three inches wide. The inner portion of the middle parts, which are thicker than the marginal, is pulpy and comparatively useless, so that only the outer portion is used. The fiber should be extracted while the strips are still fresh, since they become quickly discolored if left in the sum, and the quality of the fiber is injured if they are allowed to ferment. In the Philippines the fiber is extracted by drawing the prepared strips of the leaf-sheath between the edge of a large knife or machete and a block of hard wood. This is usually done under a tree or a thatch-covered shed. Two posts are set upright in the ground, to which a horizontal pole is lashed with rattans (in Guam Pandanus leaves or cords of Hibiscus bark would answer).

"Neish, Leuscher's methorl of preparing banana flour, Journ. Jamaica Agr. Soc., Tov. $190: 3$, p. 440 . See also species and principal varieties of Musa, Kew Bull. Misc. Inf., 1894 , p. 228 to 314.

b. See Artocurpus communis and Cycus circinulis. 
On the upper face of this pole a strong knife with a wooden handle is firmly attached by means of a pivot. The handle is attached by a spring to the roof above or the branch of a tree, and by a line or rattan to a treadle below, which can be worked by the foot of the operator. The spring ahove holils the edge of the knife against the pole or a block with a uniform pressure, while the strip is drawn between it and the pole or block. By means of the treadle the pressure is released. The fineness and whiteness of the fiber is enhanced by drawing the strips several tines. This is accompanied by considerable waste, which is in part compensated for by an increase in value of the fiber.

REFERENCES:

Musa textilis Née, Anal. Cienc. Nat. 4: 123. 1801.

\section{Mussaenda frondosa.}

Family Rubiaceae.

Local names. - Agboy (Philippines); 'Uto'uto, Aloalo-sina, Fau-uta (Samoa); Bovu (Fiji).

A handsome shrub, with yellow flowers, having one of the divisions of the calyx expanded into a white, leaf-like, petioled appendage. Leaves oblong or ovateacuminate, opposite or in whorls of three; stipules solitary or in pairs between the petioles; flowers in terminal cymes; bracts and bracteoles deciduous; calyx-tube oblong or turbinate; calyx-teeth 5, deciduous almost immediately after flowering, one modified into a large, white, petioled leaf; corolla tubular, funnel-shaped above, tube silky, throat hairy; lobes 5 , broadly ovate, acute or acuminate; stamens 5 on the throat of the corolla, filaments short, anthers linear; ovary 2-celled; style filiform; stigmas 2, linear; ovules numerous on peltate fleshy placentas; berry obovoid, glubrous, fleshy, with a broad areole on the top; seeds minute, testa pitted.

This plant is of wide tropical distribution, being found in Polynesia, Melanesia, the Malay Archipelago, and India. In Bombay the white leaf-like segment of the calyx is eaten as a vegetable. The white leaves are given in milk as a remedy for jaundice in India, and the root is used as a remedy for leprosy.

References:

Mussaenda frondosa L. Sp. Pl. 1: 177. 1753.

Mustard (Indian). See Brassica juncea.

Mutha (India). See Cyperus rotundus.

Myrobalan family. See Combretaceae.

Nagao (Guam).

The vernacular name for a ripe coeonut in which the water has becone absorbed.

$\widetilde{\mathbf{N}}$ aju (Panama). See Abelmoschus esculentus.

Ñame (Panama). See Dioscorea alata.

Namulenga (Samoa). See Titex trifolia.

Ñaña (Guam). See Limnitzera littorea and L. pedicellata.

$\widetilde{\mathbf{N}}$ aña (Guam). See Lumnitzera pedicellata.

Nanago (Guam). See Gynopogon torresianus.

Nanaso (Guam). See Lobelia koenigii.

Nangka (Guam).

The Phillipine name for the Jak-fruit (Artocarmes integrifolice); in Guam applied tw the edible seed of the fertile breadfruit, Artocarpus communis, or "dugdug."

Naranjo (Spanish). See Citrus aurantium, and its variety sinensis.

Nardo (Guam). Name applied in the island to Atamosco rosea.

"See Gilmore, Commercial fihers of Philiphines, Isur. Igr. [ I'hilippines], Farmers" Bull. No. 4, pp. 11-12, 1903. 
Naunau (Samoa): See Carinta herbacea.

Neckera. See Mosses.

Negro coffee. See Cassia occidentalis.

Nephrodium dissectum. Same as Iryopteris dissecta. See Ferns.

Nephrodium parasiticum. Same as Dryopteris purtsitira. See Frrus.

Nephrolepis. See Ferns.

\section{Nerium oleander.}

The well-known oleander, an introduced plant enltivated by the natives tor the sake of its flowers and called in Guam "adelfa" or "rosa laurel."

REFERENCES:

Nerium oleander L. Sp. Pl. 1: 209. 1753.

\section{Nervilia aragoana.}

W ATER-ROOT.

Family Orchidaceae.

Local NAyes. - Sevaíhagon or Sedyaíhagon, Maisa ulu, "single head," (Guam).

An orchid closely allied to Pogonia, collected by Gaudichaud in Guam and named by him for Arago, the draftsman of Freycinet's expedition. Leaves subrotundcordate, repand, of uniform color, many-nerved, smooth, plicate when young, with deep basal sinus and acute apex, usually solitary, sometimes in pairs, rising from a spheroid tuber about $12 \mathrm{~mm}$. or more in diameter; flowers arranged in form of a raceme on an erect leafless scape 17 to $30 \mathrm{~cm}$. high, greenish, shortly pedicelled, at first erect, afterwards nodding; perigonium half-open, persistent, divisions lanceolatelinear, actiminate, subequal; median lobe of the three-lobed lip broader than the lateral, obtusely crenulate, slightly villous within; stigma broader and lower than in Pogonia, column elongated.

The natives of Guam frequently chew the firm, fleshy, juicy tuber as they walk through the woods, to quench their thirst, especially in the northern part of the island, where there are no springs nor streams. This species is figured in the Botany of the Uranie. A detailed deseription is given by Blume in Flora Javæ, Orchidaceae, p. 130, tab. 56, under the name of Pogonia nervilia.

Nervilia ovata Gaudich. is a species collected by Gaudichaud on the adjacent island of Rota, or Luta.

References:

Nervilia aragoana Gaudich. Bot. Freyc. Voy. 422. t. 35. 1826.

Nervilia ovata. See under Nervilia aragoana.

Nete or Neti (Guam). See Xiphagrostis floridula: also under Grasses.

Nettle family. See Urticaceae.

Ngatae (Samoa). See Erythrina indica.

Nickernut. See Guilandina crista.

Nicotiana tabacum.

Toвacco。

Family Solanaceae.

Local NaMes.-Chupa (Guam); Tabaco (Spanish).

Tobacco was introduced into Guam by the Jesuit missionaries very shortly after their arrival. The natives soon became very fond of it, learning to smoke the leaves in the form of cigars, and some of them chewing it either alone or in combination with their areca nut and betel pepper. So popular was its use that the wages of the natives working for the missionaries and for the government were paid in tobaceo leaves, as the archives at Agaña will show.

Though it is cultivated in a variety of situations, on the lowlands, on the coral platform or mesa, and in alluvial valleys, yet the natives recognize that the best results are obtained from tobaceo planted on recently cleared land. The regions known as Santa Rosa, Yigo, Yoña, Matáguag, Finaguáyog, and Magî are all celebrated fur their 
fine tobacco crops. Both the soil and the climate of the island seem well adapted to its culture.

After a spot of land has been cleared for a "semillero," or seed bed, the brush is allowed to dry, and when the weeds have sprung up it is spread over the surface and burned, thus destroying weeds and injurious insects and larve, and euriching the ground with the ashes. The seed is planted during the months of August and September in small beds. It is sown over the surface of the finely pulverized ground and raked in. They soon sprout and in Guam require little watering. The beds are carefully weeded and the seedlings are ready for transplanting in a few weeks, generally in October and November. They are then planted in nurseries, in parallel rows, near their ultimate destination, and are usually shaded with canopies of muslin or interlacing branches or cocoanut leaves. This gives the roots a chance to grow without too great crowding, as would be the case if they were left to develop in the seed beds. Finally, in the months of December, January, or February, they are flanted in the field, the time selected for this purpose being after a good rain. Care is taken not to injure the roots of the young plants in transplanting. They must be watered at intervals, if the rain is not sufficient and must be protected from the sun by segments of cocoanut leaves set in the ground at an angle and the ends of the leaflets tied together so as to form a sort of cone. The natives take great care to keep their fields free from weeds and go over the plants daily to destroy the larva of a sphinx moth which feeds upon them.

About one month after planting in the field the flower buds make their appearance and are immediately pinched off, leaving only a few of the finest plants to Hower in order to secure seed for the next season. Tobacco is so prolific that the seed from one plant is sufficient to plant a field of considerable size. Suckers or side branches are removed as fast as they appear, as the nourishment must go to developing large leaves. When the leaves are sufficiently mature the whole plant is eut off near the base, and the leaves are allowed to dry on the stem. The plants are tied in bundles and taken under cover. For cutting a dry day is selected, and the plants are allowed to wither before being taken under cover. In drying two or three plants are hung together, the bunches being far enough apart so as to leave space for free circulation of the air. When the midribs are perfectly dry the process is finished. After undergoing a slight fermentation the tobaceo is male up either in the form of loosely rolled cigars wrapped with pineapple or agave fiber, or in bundles ("palillos") of ten leaves each.

The use of tobacco is general among the natives, both male and female, of the luwer classe, hut very few ladies of the better class make use of it, and these appear ashaned if seen smoking. So necesary is it to most of the people that they appear to suffer as much from its lack as from a dearth of food. As a rule they prefer their own tobaceo to imported kinds; but when their supply gives out they will use what they can obtain from the storekeepers. On such occasions they will bring eggs or chickens to give in exchange, when they refuse to sell these for money.

\section{REFERENCES:}

Nicotiana tabacum L. Sp. Pl. 1: 180. 1753.

Nigas (Guam). See Pemphis acidula.

Night-blooming cestrum. See Cestrum nocturnum.

Nika (linam). See IDisscoren, D. uculeulu, D. fusriculatu, D. fusciculutulutescens, and D. papuana.

Nika cimarron (Guam). See Dioscorea spinosa.

Nimo (Guam).

Local name of a tree mentioned in a list compiled by Governor Olive y Garcia. Not identitied. 
Ninayag (Guam).

Local name of a tree mentioned in a list sent by Governor Pablo Perez to the captain-general of the Philippines. He describerl it as having soft wood and growing near the beach. It is sometimes used for furniture. Not identified.

Nino (Philippines). See Morinda citrifolia.

Niog (Philippines). See Cocos nucifera.

Nipa (Guam, Philippines). See Nypa fruticans.

Nipay (Philippines). See Stizolobium giganteum and S. pruriens.

Niphobolus adnascens Kaulf. Same as Cyclophorus adnascens.

Nito (Philippines). See Lygodium scandens.

Niu (Samoa, Hawaii). See Cocos nucifera.

Niyog (Guam). See Cocos nucifera.

Ñolon (Guam).

Name of a tree not identified, included by Governor Olive in a list sent by him to the captain-general of the Philippines.

Nona (Malay Archipelago). See Morinda citrifolia.

Nonag or Nonak (Guam). See Hernandia peltata.

Noni (Hawaii). See Morinda citrifolia.

Nono (Rarotonga, Tahiti). See Morinda citrifolia.

Nonok (Philippines), See Ficus sp.

Nonu (Samoa). See Morinda citrifolia.

Nonu-fi'af'a (Samoa). See Caryophyllus malaccensis.

Nostoc. See $A \lg x$.

Nuna (Southern India). See Morinda citrifolia.

Nunu (Guam). A large banyan tree. See Ficus sp.

Nothopanax cochleatum.

SAUCER-LeAf. SHELl-LeAF.

Family Araliaceae.

Locıl xayes._Platitos (Guam, Philippines); Rauparoro (Ternate); Daun papeda (Java).

An introduced ornamental shrub, growing in many of the gardens of Guam, with sancer-like or shell-like concave leaves, which are petioled, simple, round-cordate, and spinulose-ciliate and dentate. Flowers small, growing in dense paniculate umbels; calyx-tube obconical, with adherent ovary, the limb minutely 5 -toothed, persistent; petals 5 , valvate; stamens 5 , alternating with the petals; ovary 2 -celled; styles 2 ; fruit 2 -seeded.

This plant is a native of the Malay Archipelago. In Java it is much planted about dwellings and in the villages. It has been introducer into south America. The leaves serve as rlishes, also as greens. Together with the root, according to Rumphius, they are mixed with parsley and act as a diuretic. ${ }^{a}$

\section{REFERENCES:}

Nothopanax cochleatum (Lam.) Miq. Fl. Ind. Bat. 1' $: 766.1855$.

A ralia cochleata Lam. Encye. 1: 224. 1783.

Panax cochleatum DC. Prod. 4: 253. 1830.

Nothopanax fruticosum.

Cut-leated panax.

Local Nayes.-Papúa (Guam, Philippines); Daun papeda papoea (Java); Tanetane (Samoa); Danidani (Fiji).

An introduced ornamental shrub with tripinnate leaves. Leaflets lanceolate, bristly-

a Miquel, Flora Indiæ Bataviæ, vol. 1, p。 766, 1855. 
serrate or inciscel, often irregular in shape; flowers small, in panicled umbels; pedicels jointed close under the flowers; panicles 7.5 to $15 \mathrm{~cm}$; bracts minute, deciduous; styles 2 ( rarely 3 ), persistent on the laterally compressed fruit, recurved.

Widely spread in India, the Malay Archipelago, and the islands of the Pacific. Cultivated in villages and planted near houses. In Java it is used in the place of celery and parsley and as food. The root has an agreeable and strongly aromatic smell, tastes like parsley, and is used as a diuretic. In Fiji the bark is scraped off and is used medicinally by the natives. $a$

REFERENCES:

Nothopanax fruticosum (L.) Miq. Fl. Ind. Bat. 1': 765.1855.

Panax fruticosum L. Sp. Pl. ed. 2. 2:1513. 1763.

Nupe (Guam).

A climbing plant, not identified, the stems of which are used for lashing together the framework of houses and sheds. When required for use they are rendered flexible by heating. After the lashing is wrapped they contract and become rigid and hard, so that they can not be unbent but must be cut if it is desired to remove them. They are durahle if kept dry. Another plant with a more slender stem, used in the same way, is called "fianiti."

Nutgrass. See Cyperus rotundus.

Nyctaginaceae.

Four-o'clock FAMILY.

This family is represented in Guam by Mirabilis jalapa and Boerhaavia diffusa.

\section{Nypa fruticans.}

NIPA PALM.

Family Phoenicaceae.

Local Names.-Nipa (Guam, Philippines); Parran (Ponape); Ballang (Sulu Archipelago).

An interesting, stemless, marmed palm with pinnate leaves often growing to a length of 20 feet. Flowers monoecious, axillary, inclosed in a spathe; fruit a oneseeded drupe growing in clusters as large as a man's head.

This plant was introduced into Guam from the Philippines for the sake of its leaves, which make excellent thatch. It has established itself at the month of nearly every stream in the island where the water becomes brackish, its graceful giant leaves rising from the water's edge forming a striking feature of the landscape. The plant is of interest to the geologist from the fact that fossil nuts of an allied species are fouml in England in the tertiary formations at the month of the Thames, where they unce floated abont and embedded themselves in the mud as they now do in Guam and the Philippines.

For thatching, the leaflets are stripped from the rachis and formed into a thick iringe ( $\operatorname{tag}(n)$ ) on at reed. After having been thoroughly dried the thatch is secured to the framework of the rus by lashings of pandanus leaves split up the middle and deprived of their stiff keel. Two men work at a time on each reerl, beginning at the eaves and working toward the ridge, which is covered with a sort of braided matting secured in place hy pins fassing under the ridge-pole and projecting on each side. The nipa is far superior to and more durable than cocoanut thatch, and is used for the better houses of the island.

Preparations are made for thatching very much as for a corn-husking with us. The housewite hegins saving up dulces and other good things months beforehand. The nipa leaves are collected, made into fringe, and allowed to dry. Pandanus leaves are collected and cured and stripped of their spiny-keeled midrib. When all is ready relatives and neighbors are invited to assist, a pig or a hullnck is killerl, and the work goes on amid feasting, tuba drinking, and

$$
\text { c: Seemann, Flora Vitiensis, p. 115, 1865-1873. }
$$





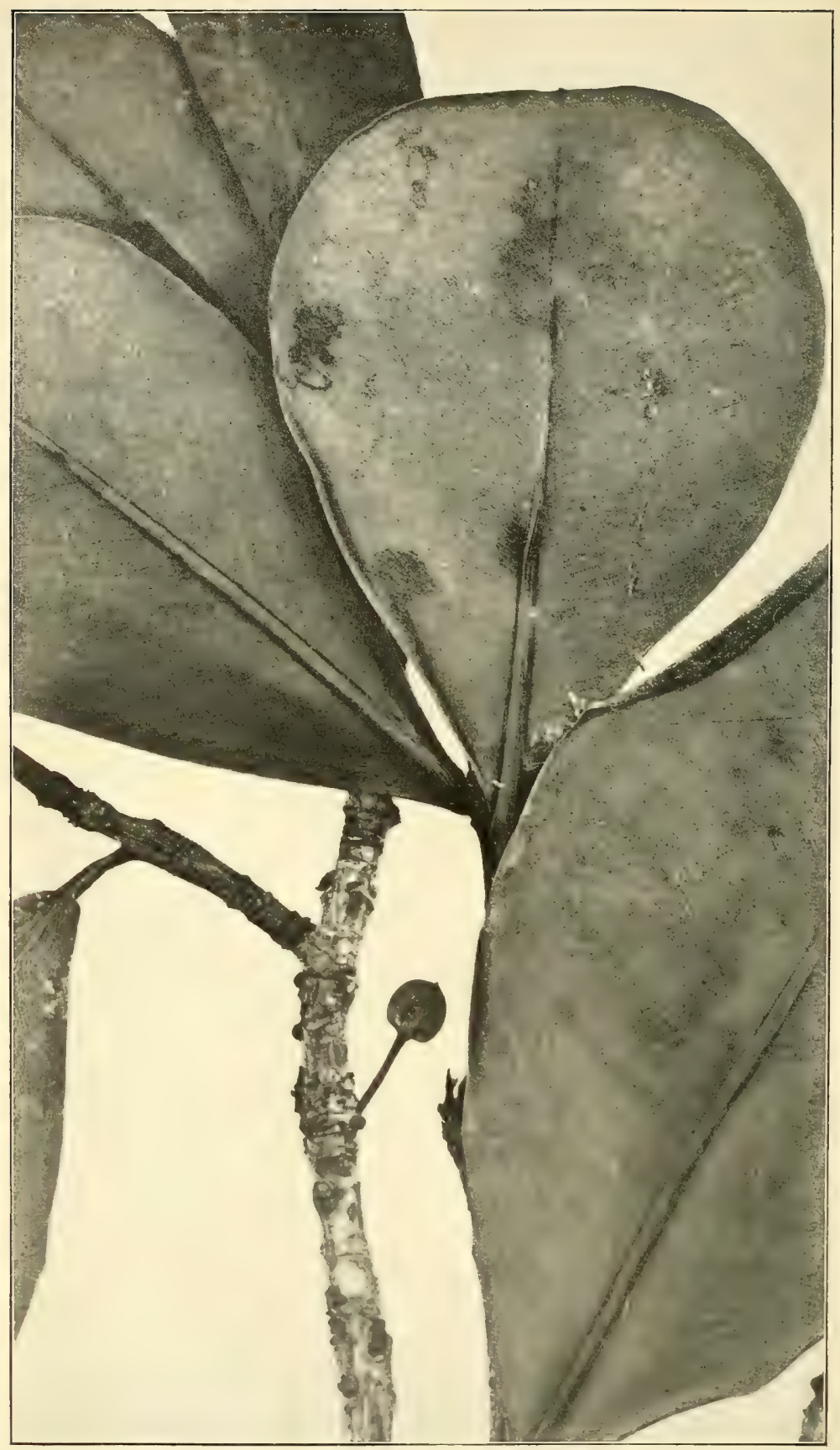

Ochrocarpus obovalis, an Important hard-wood tree. natural Size. 
langhter, with ocasional pauses during which Areca nuts, fresh betel leaves, and lime are passed around on a tray, and the host dispenses cigars, marle by the ladies of his family, of tobacco leares in the form of a cylindrical bundle kept together by a wrapping of pineapple fiber or thread.

In the Philippines toddy or "tuba" is made of the sap of the nipa, obtained as in the cocoanut from the flowering spadix. This is not done in Guam, where coconuts are much more abundant. Padre Blanco mentions nipa as a remedy for the bites of rentipedes and a cure for ulcers. The kernel is edible, but very hard and only eaten occasionally in Guam as an experiment.

\section{REFERENCES:}

Nypa fruticans Wurmb, Verh. Batav. Gen. 1: 350. 1779.

Ochra. See Abelmoschus esculentus.

Ochrocarpos obovalis.

Chopag. Plate lix.

Family Clusiaceae.

LOCAL NAMES.-Chopag (Guam).

A medium-sized tree with leaves resembling those of Calophyllum and Clusia. Branches rigid, warty, with light-colored bark; leaves opposite, short-petioled, narrowed to the base, obovate or oblong-obovate, broadly rounded at apex, entire, smooth, coriaceous, 10 to $18 \mathrm{~cm}$. long by 6 to $8 \mathrm{~cm}$. wide, finely pinnate-veined and delicately reticulate, with broad, prominent midrib; petioles stout, grooved, scarcely $13 \mathrm{~mm}$. long; flowers fragrant, polygamons, lateral, single or clustered; peduncles single-flowered with a few short bracts at the base; calyx closed in the bud, splitting into two persistent sepals, which are $12 \mathrm{~mm}$. long, broadly ovate and pointed; petals b, white, oblong, about $13 \mathrm{~mm}$. long; stamens numerous, filaments slender, united at hase; anthers elongated, fertile only in male flowers; female flowers with sterile stamens, a single pistil, and peltate, subsessile stigma; fruit large, hard, and of an oblong shape.

The wood is hard, heavy, fine-grained, and durable. It is very highly prized by the natives of Guam, who use it for posts and beams in the construction of their houses. Sometimes the trunks yield logs 5 meters long and $30 \mathrm{~cm}$. in diameter. As the tree grows old red heart-wood is developed which at length takes up a great part of the trunk. From this a dye somewhat like that obtained from sappan-wood is obtainerl, but at the present time, when imported dyes are easily obtainable, the natives do not go to the trouble to prepare it for use.

The tree usually grows in rocky places near the shore. It is especially abundant on the Peninsula of Orote and also on A papa Island. Vast quantities have been cut down for the use of ressels touching at the island, but as it multiplies rapidly from the seed it has not become rare.

In the Index Kewensis Calysaccion obovale of Miquel is given as a synonym for Ochrocarpos ovalifolius (Chois.) T. Anders. The Guam species corresponds accurately with Miquel's description, but not with that of $O$. ovalifolius, the leaves of which are "oval, obtuse at each end, or subcordate at the base," while those of our species narrow gradually to the base.

This tree was mentioned under its vernacular name by Gaudichaud in the botany of the Freycinet expedition, but he did not know to what genus to refer it, calling it in one place a species of Rauwolfia and in another Plumiera. He described the wood correctly, but evidently did not see the flowers nor leaves. He probably confused it with Ochrosia mariannensis, a tree with glossy coriaceous leaves belonging to the Apocynaceae.

REFERENCES:

Ochrocarpos obovalis (Miq.) Safford.

Calysaccion obovale Miq. Fl. Ind. Bat. Suppl. 1: 500. 1860. 
Ochrosia mariannensis.

Marianne Yellow-WOJD.

Family A pocynareae.

LocAL NAMES.-Fago?, Lañgiti? (Guam).

A forest tree of medium size, with glossy coriaceons leaves and milky sap, resembling Cerhera. Leaves in whorls of three, oblong, narrowing to the hase, ohtuse at the apex, very smooth, renose beneath; calyx 5-parted, lobes elliptical, very obtuse, smooth; corolla salver-shaped, 4 lines long, smooth without, pubescent within, 5lobed, the tube without scales at the constricted throat, the lobes turning toward the right; stamens 5, inserted at the middle of the tube, inclucled, the lanceolate anthers longer than the filaments; disk wanting; ovaries 2, appressed; orules small, 2 to 6 in each carpel; drupes 2 (or 1 by abortion), with woody endocarp; seeds 2, large and compressed, with thin testa, separated by the thin placenta; embryo straight, with plane cotyledons and a superior radicle.

This species was referred by Gaudichaud, who first collected it in Guam, to the genus Rauwolfia. The branches are cylindrical and smooth; leaves 7 to $10 \mathrm{~cm}$. long, 16 to $20 \mathrm{~mm}$. wide, approximate to the apex of the branches, gradually narrowing to the petiole, the lateral veins almost at right angles to the midrib. (De Candolle Prod. 8: 357). Ochrosia commutata described by K. Schumann from New Guinea is possibly identical with this species.

The wood is fine-grained and of a yellow color. It is sometimes used in Guam for making furniture. It does not soon decay and it resists the attacks of insects, but it is not strong. It takes a fine polish and has the advantage of lightness, but the natives seem to prefer the "ifil" to it. On being wounded a thick milky juice exudes from the branches and green fruits, which coagulates and resembles rubber.

References:

Ochrosia mariannensis A. DC. in DC. Prod. 8: 357.1844.

\section{Ocimum basilicum.}

SWEET BasiL.

Family Menthaceae.

Local Names. - Albahaca (Spanish); Atbahakat (Guam).

A cultivated aromatic plant, herbaceous, erect, glabrous or pupescent; leaves petiolate, wate or oblong, narrowed at the base, toother or entire; petioles ciliate; hracts petiolate; flowers in simple raceme; calyces longer than pedicels, ovoid or 'ampanulate, deflexed in fruit, upper tooth lroadest, decurrent, 2 lower ovatelanceolate, awned, longer than the rounded upper; corolla white, pink, or purplish, 8 to $12 \mathrm{~mm}$. long; tube short, upper lip subequally 4-fid, lower entire; stamens 4 , exserted, declinate.

This plant is found growing in many of the native gardens. It has a pleasant ofor and is used medicinally and for culinary purposes as a seasoning. In India it is used in perfumery and the small black seeds, which become mucilaginous when steeped in water, are used by native doctors in the treatment of gonorrhea.

ReFERENCEs:

Ocimum basiticum L. Sp. Pl. 2: 597. 1753.

\section{Ocimum canum.}

HAIRY BASIL.

LOCAL NAMES. - Albahaca (Spanish); Atbahakat (Guam).

This plant clisely resembles the preceding, hut is smaller in all its parts; corolla white, smaller than that of preceding, half as long as filanents, which are hairy at the knee; nutlets jet black; flowers nearly sessile; bracts orate, awned, not so large as the nearly smooth calyx, ciliate; leares pubescent, narrowly ovate.

This plant is used by the nativer like the preceding. It was first collected in Guam by Craudichaut.

REFERENCE:

Ocimum canum Sims, Bot. Mag. 51: t. 2452. 1824. 
Ocimum sanctum.

Local Names. - Albahaca morada (Spanish); Tulsí (India).

Somewhat similar to the preceding, but with very small corolla, which scarcely exceeds the calyx in length. Plant hairy, often purplish; leaves oblong, obtuse or acute, entire or slightly serrate, floral ovate-lanceolate or cordate; racemes very slender; calyx short, 2 lower teeth very long-awned, longer than the broadly oblong upper, lateral broadly ovate, shorter than the lower; flowers pale purple, fruiting calyx $4 \mathrm{~mm}$. long, on a slender pedicel, broadly campanulate, membranous; nutlets nearly globose, slightly compressed, nearly smooth, pale red-brown.

Sometimes found in waste places in Guam, where it was first collected by Gaudichaud. In India it is grown in gardens and near pagodas. The juice of the leaves is there used by the native doctors in catarrh and bronchial affections. The seeds are mucilaginous when steeped in water, and are used as a remedy for disorders of the genito-urinary system. This plant is held sacred by the Hindus.

\section{ReFERENCES:}

Ocimum sanctum L. Mant. 1: 85. 1767.

\section{Octoblepharum. See Mosses.}

Odontosoria. See under Ferns.

\section{Oil-yielding plants.}

Aleurites moluccana.-Recently introduced and not yet well established.

Anacardium occidentale. - The seeds yield the light-colored acajou oil, which has a pleasant flavor and is used for food.

Arachis hypogaea.-Introduced from Mexico; cultivated.

Barringtonia speciosa.-On expression the seeds yield a lamp oil.

Calophyllum inophyllum. - The source of the dark-green fragrant dilo or domba oil of commerce.

Ceiba pentandra. - An introduced tree of American origin. The seeds yield oil somewhat like that of cotton seed.

Cocos nucifera.-Oil used in the island for illuminating and cooking, and for anointing the hair and body.

Guilandina crista. - The seeds yieltl bonduc-nut oil, used medicinally and for burning.

Jatropha curcas. - Seeds yield curcas oil or "oleum infernale," used as a purgative.

Moringa moringa.-The source of ben-oil.

Ricinus communis. - The source of castor oil, common in waste places.

Sesamum indicum. - Seeds yield sesame oil.

Terminalia catappa. - Seeds yield myrobalan oil, or catappa oil, an excellent foor oil, which does not easily turn rancid.

Xylocarpus granatum. - Seeds yield on expression a semisolid fat called carapa oil, used for burning and as a hair oil.

Ojo de venado (Spanish). See Stizolobium gigunteum.

Okra. See Abelmoschus esculentus.

Olacaceae.

Ximenia FAMILY.

The only representative of this family in Guam is Ximenia americana.

Old Maid. See Lochnera rosea.

Oldenlandia paniculata.

Family Rubiaceae.

An annual glabrous plant of the madder family allied to Houstonia, with panicled cymes of minute white salver-shaped 4-parter flowers, followed by capsules borne on slender pedicels. Branches erect or ascending, succulent; leaves bright green, soft, elliptic-orate or oblong, acute, narrower into the short or long petiole; stipules truncate, with median points or bristles; cymes in the upper axils, short, 3 to 8 -flowered; calyx teeth short, broadly triangular, very small in fruit; corolla tube short, lobes 4, valvate; ovary 2-celled; style filiform; stigmas 2, linear; ovules numerous; $9773-05-22$ 
capsules variahle, turbinate-dilymous or hemispheric, terete or t-ribhed, membranous; crown usually exceeding the calyx teeth, loculicidal at the top, many-seeded; seeds subglobose, testa deeply coarsely pitted.

A variable plant often having the habit of chickweed. Growing in waste places on the island of Guam. Widely spread throughout the Pacific islands, the Philippines, China, and the East Indies. The allied Oldenlandia umbellatr L., which grows in India, both wild and cultivated, is the source of the chaya root, which with alum yields a beautiful red dye.

References:

Oldenlandia paniculata L. Sp. PI. ed. 2. 2: 1667.1763.

\section{Oleaceae.}

The Olive family.

This family is represented in Guam by Jasminum marianum and the cultivated Jasminum officinale and $J$. sambac.

Oleander. See Nerium oleander.

Olena (Hawaii). See Curcuma longa.

Onion. See Allium cepa and Gardens.

\section{Operculina peltata.}

Shield-LeAved MoRNing-GLORY.

Family Convolvulaceae.

Local NAMEs.-Lagŭn (Guam); Wa bula (Fiji).

A climbing plant with long, tough, woody stem, large dark-green leaves, and milky juice. Glabrous or the veins of the leaves hairy beneath; leaves broadly ovate, shortly acuminate, more or less peltate, or the upper ones cordate with a narrow sinus, 15 to $25 \mathrm{~cm}$. long; flowers large, usually white (they have also been describerl as purplish and sulphur-colored), in loose cymes on a common peduncle usually shorter than the petiole; sepals broad, obtuse, coriaceous, nearly equal, about $18 \mathrm{~mm}$. long when in flower, larger when in fruit; corolla broadly campanulate, at least $5 \mathrm{~cm}$. long; anthers large.

Common in Guam in rocky places along the coast, especially on Orote peninsula, and Apapa Island in the harbor of San Luis de Apla, spreading over bushes and covering the rocks with its lark-green foliage. The species is found in Tahiti, Fiji, Java, Amboina, and the islands on the east coast of tropical Africa.

\section{REFEREACES:}

Operculina peltata (L.) Hallier f. Engler's Bot. Jahrb. 16: 549. 1892.

Convolvulus peltatus L. Sp. Pl. 2:1194. 1753.

Ipomoea peltata Choisy, Mem. Soc. Phys. Genev. 6: 452. 1833.

Ophioglossales. See Fern-allies.

Ophioglossum penduIum. Same as thhiodemn pendulu. See Fern-allies.

Opo, opu (Philippines). See Lagenaria lagenaria.

Opoponax (Southern United States). See Acacia farnesiuna.

Opuntia sp.

Prickly pear.

Family Cactaceae.

Local rames.-Lengua de vaca (Spanish, merning "cow's tongue").

A plant probably introduced from Mexico. Flowers yellow; fruit sweetish; not common on the island. The natives do not care for the fruit.

Oramai (Ponape). See Boehmeria tenacissima.

Orange. See Citrus aurantium.

Orange-berry. See Triphasia trifoliata.

Orchidaceae.

ORCHID FAMILY.

The following species of urchirls have thus far been collected in Guam: Verrilin

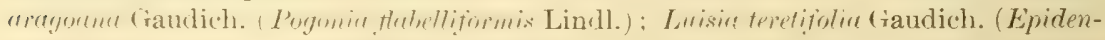
drum triste Forst.): Tueniophlullum fesciolu (Forst.) Reichenb. (Vunilla jasciolu 
Spreng., Limodorum fusciolu Sw.). On the neighhoring island of Rota, Gaudichaud collected Nervilia ovata Gaudich. (Pogonia ovata Lindl.).

\section{Oryza sativa.}

RICE.

Family Poaceae.

Local xayes.-Fāi, Fāe, Farai (Guam); Bai (Java); Paré, Pari (Sunda); Padi (Malay); Halai, Hala, Pala (Bouru); Fala (Ceram, Amblaw); Fáha (Matabello); Fas (Mysol); Palai (Philippines); Paddy (British East Indies). $a$

Rice was a food-staple of the natives before the discovery of Guam. It is among the products of the island mentioned by Magellan (1521), Legazpi (1565), Oliver van Noort (1600), and others. According to the accounts of the early navigators it was cultivated in many places on the island by the natives, who sold it to visiting ships in parcels weighing 70 to 80 pounds each. The Dutch complained that the natives were dishonest in their dealings, for not one parcel of rice bought from them was found which had not been increased in weight by the addition of stones and sand.

The aborigines had three kinds of rice, red (agaga), coarse-grained (basto), and a fine fragrant variety, brought from the island of Rota, called by the Spanish settlers "palay aromático." According to Don Antonio Martinez, one of the principal ricegrowers on the island, rice was formerly cultivated both in the flooded marshes and on dry land. Now it is cultivated only in the marshes. In addition to the three kinds already mentioned two Philippine varieties are now planted, called "palay blanco" (white paddy) and "malaquid."

It is interesting to note the identity of the Guam name for rice with names used throughout the Malay Archipelago, which is shared by the East Indian word "paddy." Cooked rice is called "puga," or when preceded by the definite article, "piga." This word is probably allied to "buas" of the sea-gypsies called Bajau, $b$ a roaming tribe of fishermen met with in all parts of the Malay Archipelago.

At present rice is cultivated in Guam very much as in the Philippines. The land is generally prepared during the month of August or September or in the early part of October, and at the same time the seedlings are grown and gotten ready for transplanting. Transplanting takes place in October, November, or December and the grain matures about five months later. As the water supply comes from rain-fed streams the cultivation of rice is attended with considerable uncertainty. It is not unusual for droughts or blasting winds to cause the loss of the entire crop. As the time of the harvest approaches the prevailing winds are from the north, and they sometimes cause great damage to the rice fields which are exposed to them. Near Inalahan they are protected by the mountains to the northward. On the Inalahan rega the planting may be postponed even until January, so that the grain may form at the end of March, when the northerly winds have somew'at subsided.

The fields are leveled by means of a scraper (rastra). It is unnecessary to puddle the soil, as it will retain the water without difficulty. The area to be cultivated is divided into small fiels separated by banks about a half meter high, to confine the water. Where the land slopes it is formed into terraces, arranged in such a manner as to govern the flow of water.

The seed is soaked in water for twelve hours, after which it is taken out and left three or four days, when it begins to sprout. It is then planted in a semillere, or nursery, which is surrounded by a diteh of water to protect it from ants and other crawling insects. When the seedlings are about 6 or 8 inches high they are transplanted into the fields, or syuares, prepared for them. The plants are set out

"The vernacular names here given are applied to the unhuskerl rice. Throughout the Malay Archipelag, and in Inclia distinct names are applied to rice after it is husked and to cooked rice, just as in English we distinguish between maize, hominy, and pone.

b See Wallace, Malay Archipelago, pp. 621 and 607, 1869. 
in groups of 3 or 5 in straight rows about a foot apart. Rice is never sown broadcast in Guam. About two kabanes of seed are required for each hectare of land. The weeding is done by hand. The weeds are buried in the mud. They soon decay and serve to enrich the soil. In Guam the fields are kept flooded until the grain is completely developed and well filled out. The water is then trawn off the fields.

As there is no provision in Guam for storing water in reservoirs for irrigation or pumping it from wells, the season for rice growing depends upon the water supply from the streams. As a rule there is but one rice harvest per year. The plants are not pulled up, but are cut with a sickle at a convenient height, leaving the stalks, which sometimes produce a second crop. The gathered crop is exposed to the sun only while the reaping is going on. It is carried to sheds the evening of the same day and placed under cover.

Rice is thrashed either by treading it under foot or by beating the stalks over a pole or bamboo grating. The grain is separated from the straw rery easily by the latter process, which, in Guam, is preferred to the former. It is then winnowed. It is kept in store in its unhulled condition, small quantities being hulled as requirerl in a large wnoden mortar (pilon) made of a log with a carity at the upper end holding from a half ganta to a ganta of grain. The pestle is also of wood, having an oblong thickening at each end and slenter in the middle, so as to be easily grasped by the hand. As a rule rice grown in Guam is inlerior to that imported from other countries. The best rice brought to the island comes from Japan, selling at 10 pesos (\$5) a picul. American rice sells for 10 cents a pound. Rice was formerly brought to Guam from the Philippines and from Saigon, Cochin China, but impurtation from these sources has stopperl. When the rice harvest of the island has heen fairly good the unhulled paddy is sold at 6 pesos a kaban. In the time of Don Felipe de la Corte its usual price was 3 pesos a kaban. (See value of picul and kaban under "Measures," p. 139.) In time of scarcity Japranese and American rice is sold as high as 20 pesos a sack ( $\$ 10)$ containing 1 picul.

Unsuccessful attempts have been made to cultivate rice in the large marsh near Agaña, called "la Ciénaga," and Don Felipe de la Corte trierl to cultivate upland rice on the island, Int failed." The labor required to keep the rice fields free from weeds is so great and so exacting, and failures of the crop are so frequent, that rice culture is gradually heing ahandoned in Guam, except in sites especially farored. The natives are lirecting their attention more and more to maize, their principal forl staple, and to creoanut planting, the only commercial industry of the island.

According to Don Antonio Martinez, the yield of rice per hectare of land is, in wroud rears, as much as 100 kabanes. Laborers in rice fields are subject to sickness which they call "fremm manengheng," especially those working in drainert fields. This is probalbly of a malarial mature ("manengheng" signifies cold). Land varies greatly in fertility. In some places the same field is cultivater for a number of years in sucesion; in whers the coil som hecomes exhausted. In the latter case it is allowed to lie fallow for one or two years. Weeds grow up, and their leaves falling and decaying serve to enrich the fielis anew. When the rice is ripe the fields are visiterl ly dores and wild dueks, which cause considerable loss to the farmer.

REFEREXCES:

Oryza sativa L. Sp. Pl. 1: 333.1753.

Otaheite apple. See Caryophyllus malaccensis.

Otó (Panama). See Caladium colocasia.

Otud or Otot (Guam). See Icacorea sp.

Oxalidaceae.

OXALIS FAMILY.

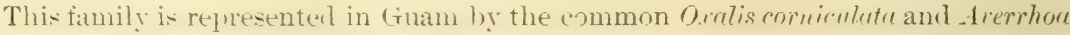
carambola, a small tree with sensitive foliage, planted for the sake of its fruit.

a See De la Corte, Memoria descr. é hist. de las islas Marianas, p. 60, 1875. 
Oxalis corniculata.

WOONSORREL.

Family Oxalidaceae.

Local names.-Agsom, Apson (Guam); I'i (Samoa); Koki (Rarotonga); Vinagera (Cuba); Vinagrillo (Porto Rico).

A procumbent, herbaceous plant, usually pubescent with appressed hairs, freely branching from the base, often creeping. Leaves trifoliolate, leaflets obcordate, minutely reticulated; stipules united to base of petals; flowers yellow, growing in umbel-like cymes; peduncles 1 to 5 -flowered but mostly 2-flowered, pedicels pubescent, reflexed; sepals 5, pubescent; petals 5, emarginate; stamens 10, monadelphous at base, 5 longer and 5 shorter; ovary 5 -celled; ovules several in each cavity; styles 5 , separate, persistent, stigmas terminal; capsule oblong, appressed-pubescent; seeds compressed, transversely ridged.

Common in waste places and fields on the island. The plant is antiscorbutic and is used in India as a remedy in dysentery. The Chamorro name signifies "sour" and is also applied to Meibomia triflora (see agsom). It was first collected in Guam by Freycinet, who recorded it as Oxalis repens.

Widely distributed in the warmer regions of the earth.

REFERENCES:

Oxalis corniculata L. Sp. Pl. 1: 435.1753.

Ox-eye bean. See Stizolobium giganteum.

Pacao or Pakao (Guam). See Guilandina crista.

Pachyrhizus bulbosus. Same as Cacara erosa.

Pachyrhizus jicamas. Same as Cacara erosa.

Pacpac or Pakpak (Guam).

A small tree mentioned by Governor Olive in his list, from which pikes and handles of garden implements are made; not identified.

Paddy (British East Indies). See Oryza sativa.

Padi (Malayan). See Oryza sativa.

Pago (Guam). See Pariti titiaceum.

Pahong or Pahon (Guam). See Pandanus and $P$. dubius.

Paingot (Guam). See Pandanus sp.

Paipay (Guam).

A tree included in the list of Don Felipe de la Corte, yielding timbers 4 meters long and $15 \mathrm{~cm}$. in diameter, used for the framework of roofs of houses and handles for fusiños or thrust hoes. It is subject to the attacks of termites, and therefore not so extensively used in Guam as other woods which are immune; not identified.

Pajon (Spanish). See Pandanus dubius.

Pajuil (Porto Rico). See Anacardium occidentale.

Pakpak langao (Philippines). See Meibomia triflora.

Palaga-hilitai or Quelitai (Guam). See Meibomia umbellata.

Palai or Palay. The Philippine name for uncooked rice. See Oryza sativa.

Palang-palang (Philippines). See Canavali ensiforme and C. obtusifolium.

Palilalia (Guam). See Schychowskya interrupta.

Pal-lam or Pallang (Philippines). See Botor tetragonoloba.

Palm, betel-nut. See Areca cathecu.

Palm, black-fiber. See Saguerus pinnatus.

Palm, coconut. See Cocus mucifera.

Palm, date. See Phoenix dactylifera.

Palm, gomutu. See Saguerus pinnatus. 
Palm, Ivory-nut. See Coelococcus amicarum.

Palm-lily. See Taetsia terminatis.

Palm, Nipa. See Nilpa fruticans.

\section{Palm, Rattan.}

A species of climbing Calamus, not identified, called "behuko halom-tano" by the natives.

Palm, sago. See Coelococcus amicarum.

Palm, screw.

General name for the species of Pandanus. (More commonly known as screwpines, but allied to the palms.)

Palm, sugar. See Saguerus pinnatus.

\section{Palma.}

This name is applied generically by many Spanish writers to the varions species of Pandanus growing on the island.

Palma brava (Guam).

A small, graceful, pinnate-leaved palm with a strong, slender, elastic trunk, of which carrying sticks and shafts of carts are made. Introduced, but now widely spread on the island; not identified.

Palma de Marfil (Spanish). See Coelococcus amicarum.

Palmeae. See Arecaceae.

Palo de jagueca (Porto Rico). See Thespesia populnea.

Palo del Brazil. See Biancaea sappan.

Palo Maria (Spanish).

See Calophyllum inophyllum.

Panabólong (Philippines). See Lobelia koenigii.

Panago or Banago (Guam). See Jasminum marianum.

Panao (Guam).

A tree mentioned by Governor Olive which furnishes boards for construction. Unidentified; referred by (xamdichaud to the genu Clawylon. In the Philippines this name is applied to Dipterocarpus hispidus.

Panax cochleatum. Same as Nothopanax cochleatum.

Panax conchifolium Roxb. Same as Nothopanax cochleatum.

Panax, cut-leaved. See Nothopanax fruticosum.

Panax fruticosum. Same as Nothopanax fruticosum.

Pancratium littorale.

SPIDER LILY.

Family Amaryllidaceae.

Local Names.-Lirio (Guam); Ahos-ahos nga mapotî (Philippines); Seaside daffodil (English).

A bulbous plant growing along the seashore and in moist sandy places, with umbels of fragrant white flowers. Perianth with a cylindrical tuthe and 6 linear segments; stamens 6 , the filaments free above, but webberl and united into a funnelshaped cup below; anthers narrow, versatile; orary 3-celled with 2 ovules in each cell, bearing a long slender style and capitate stigma; leaves star-shaped.

This plant is of comparatively recent introduction into Guam. It has spread rapidly and covers acres of coast near Agaña. The flowers burst into bloom at alunt half past $4 o^{\prime}$ clock in the afternoon.

Referexces:

Pancratium littorale Jacq. Select. Stirp. Amer. 99. 1763.

Hymenocallis littoralis Salisb. Trans. Hort. Soc. 1:338. 1812.

The genus Pancratiun as estahlished l,y Limnat in Species Plantarum 1: 290. 175: and crenera Plintarnm ed. 5. 141. 175t, was atopted from the Pancratimn of 
Dillenius, whose only species is included in the Linnæan genus under the binomial name $P$. mexicanum. This species, although since referred to Hymenocallis, should be considered as the type of Pancratium and the latter name retained for the group to which its type species belongs.

Pandan (Philippines). See Pandanus tectorius.

\section{Pandanaceae.}

SCREwPine Family.

Local Nayes (generic).-Palma (Spanish); Fala (Samoa); Hala, Lauhala (Hawaii); Ara, Rau-ara (Rarotonga); Pandan (Java); Vakoàna, Hôfa (Madagascar); Páhong, Kafô Aggak. (Guam); Pangdang (Philippines).

Iuch confusion exists in the nomenclature of the Pandanaceae, owing to insufficient material in herbaria. In this genus the male and the female flowers are borne on separate plants. The leaves are long and narrow, tough and leathery, and are armed along the keel of the midrib and on the edges with sharp recurved prickles. They are arranged in triple spirai series toward the ends of the branches, forming dense tufts or crowns; it is from their resemblance to the leaves of the pineapple that the name of the screw pine is derived. The trees are remarkable for their prop-like aerial roots, with large, cup-like spongioles on their tips. The male inflorescence consists of a compound spadix, made up of a number of short eatkin-like spikes, each of which bears an immense number of little naked flowers with indefinite stamens. The female inflorescence is a globular or oblong head consisting of rery numerous, closely packed ovaries, each containing a single ovule. The fruit consists of a number of wedge-shaped clusters of drupes, congregated into oval or cone-like heads. $a$

At least three species of Pandanus occur in Guam, the most important of which, the "aggak," is represented by only one sex, and must be propagated by cuttings. It is probably Pandanus tectorius Parkinson ( $P$. littoralis Jungh.); but it can not be identified with certainty, as there are many closely allied species.

\section{Pandanus dubius.}

KNOB-FRUITED SCREWPINE.

Local vames.-Pahong, Pahon (Guam); Pajon (Spanish); Bangeóang bóndôk (Philippines); Uom (New Lanenburg group).

A tree growing to the height of 3 to 7 meters, with very broad, stiff, long, coarse leaves, which are crowded at the ends of the branches. The drupes composing the large head each terminate in a point at the apex, giving to the fruit the appearance of the head of an enormous Fijian war club, studded with many blunt projections. The leaves are not strong. They are normally stiff, but may be made more flexible by heat, and may be woven into coarse mats, but they are inferior in every way to those of the aggak. The kernels of the seeds are sometimes eaten by the natives as a relish, but they are not a food staple. Collected in Guam by Chamisso and by Gaudichaud, by the latter of whom it was named Hombronia edulis.

This species occurs only east of the Moluccas. It has been collected on Mioko and Kerawara, of the New Lauenburg group, Bismarck Archipelago. $b$

REFERENCES:

Pandanus dubius Spreng. Syst. 3: 897. 1826.

\section{Pandanus fragrans.}

Fragrant-fruted screwpine. Plate lx.

Local Names.-Kafô, Kafû, Kafok, Cafô, Cafû (Guam).

A small tree, 3 to 7 meters high, with glossy, green leaves having no textile value. In open places the trunk is short and soon begins to branch dichotomously; in the forest it sometimes grows vertically $t$ meters before branching. (Pl. VIII.) Numerous straight aerial roots grow from the trunk up to a distance of 90 to $120 \mathrm{~cm}$. from the base, extending obliquely downward to the ground, serving as sustaining props. (Pl. XXIII.) These roots as well as the trunk and limbs are whitish or ash-colored, 
ancl when old are coverel with short, sharp protuherances, like stout spines; leaves crowded at the ends of the branches, green, not glaucous, 90 to $150 \mathrm{~cm}$. long, about $7.5 \mathrm{~cm}$. broad at the base, prickly on the margins and along the keeled midrib, coriaceous, coarse, not rery pliable nor strong; drupes arranged in a solid round or oral head, somewhat resembling a pineapple about the size of a man's hear, numerous, top-shaped, blunt at the apex, angular, 3.5 to $7.5 \mathrm{~cm}$. long and 2.5 to $3 \mathrm{~cm}$. broad at the end, each composed of several carpels, of which one is central and the others grouped around it; the top divided hy shallow grooves into as many parts as there are carpels; fruit fragrans when ripe, often bursting open when falling to the ground; sides of drupes yellow or orange.

The ripe fruit is much eaten by flying foxes (Pteropus keraudreni) and rats (Mu: decumanus), which abound on the island, but it is not a food staple of the natives. The kernel of the seed is almonl-like in shape, of the consistency of beechmuts, and the flavor of otto of roses. It is occasionally eaten by the natives as a relish, but is too small to repay one for the trouble of picking it out. The trunks are often used for building temporary ranches or farm dwellings; they are not rery durahle. Advantage is taken of the dichotomous branching of the limbs to make supports for platforms. Water tronghs are made of straight trunks of specimens from the forest, but they soon decay. Along the roadsiles and near drelings trees of kafo are seen with their trunks notched in such a manner as to make a reservoir for the rain water which is caught by the leaves and drains down the trunk. Often the presence of a good tree of this kind determines the place where a ranch shall be built. The limbs are also fine chicken roosts, not an unimportant matter in the domestic economy of the natives. In the forests the trumk sometimes rises to a height of 7 meters, straight and smooth, hefore hranching. The heartwood of the old trees is hard and palm-like. It is made into walking sticks.

REFEREXCES:

Pandanus fragrans Brongn. Ann. Sci. Nat. VI. 1: 274. t. 15. f. 10. 1875.

\section{Pandanus tectorius.}

Textile scrempine. Plate vir.

Locıl ximes._-Aggag, Aggak, Akgak (cruam); Pamlan, Sahotan (Philippines); Fala, Lau-fala (Samoa); Hala, Lau-hala (Hawaii).

A small tree with a trunk, which usually begins to branch very low, the branches often bending elownwarl nearly to the gromul; leaves long, sworl-shaped, armed with spines on the matein and keel, differing in color and texture from those of the other species w the island, heing glancons and of great textile sirength. Only one sex occurs on the island, so that it must be promgaterl hy cuttings. These take root readily; indeed, a loranch lying on the surface will often send sut roots which penetrate the gromel. The natives frepuently plant this species in hedges, which serve the doulde purpose of defining their hommlaries and of furnishing material for cordage and for mats, hats, and bags.

Dried leaves stripued of the rigil, spinr keel, are lised either in their simple form or twisted together as lawhing for the framework of holldings and for securing thatch to the rouf. For making nats, hats, and hags the leaves are steeped in hot water, scraped and split into strips of various widths according to the fineness of the

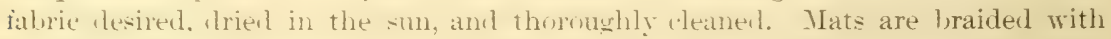
the strips coseing diagonally, as in the nate of the eastern Pulynesians, not woven with warp and wow as are the mats of many of the Mieronesians. Some of the hats and small bags are very fine. In the early days the natives of Guam made their sals of aggals leaves. The plant was undunbtedly introlucerl into the island in pre-

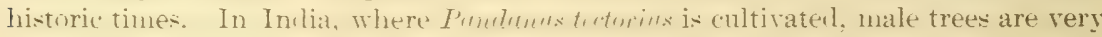
common, but female trees are of very rare occurrence. "

a Solms-Laubach, Monographia Pandanacearum, Linnea, vol. 42, p. 38, 1878. 


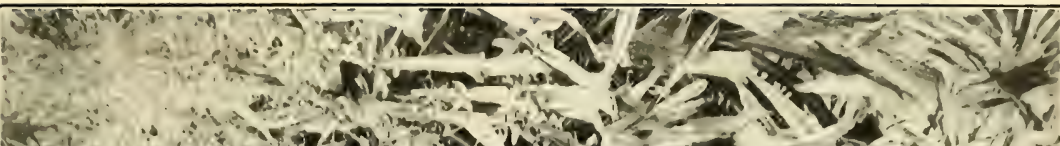

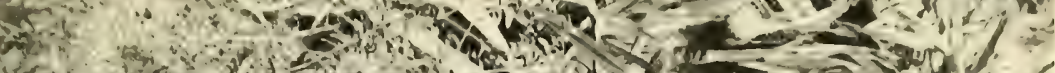

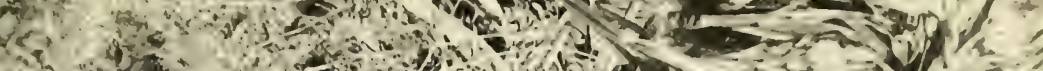

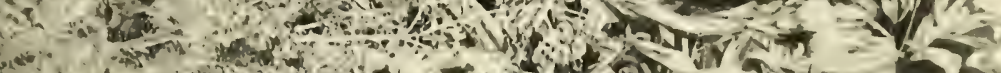

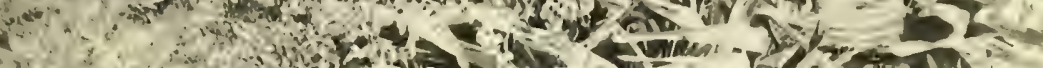

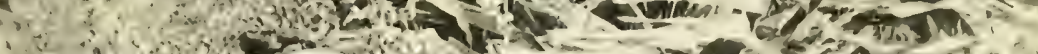

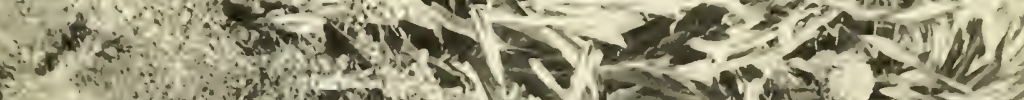

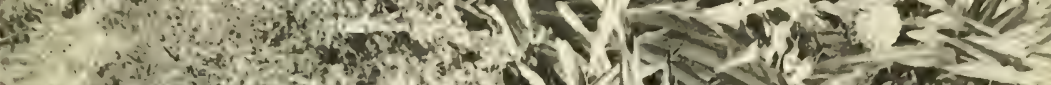

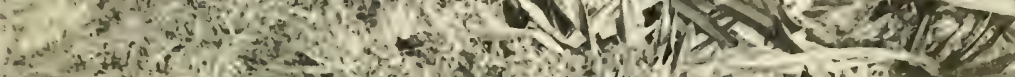

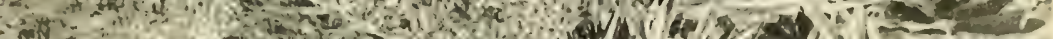

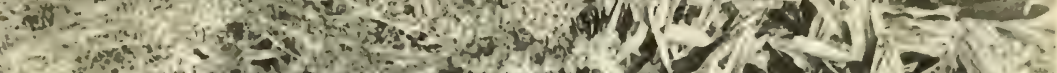

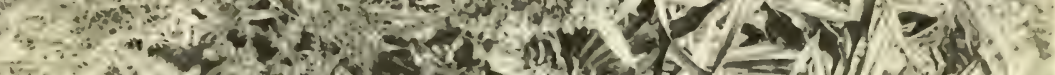

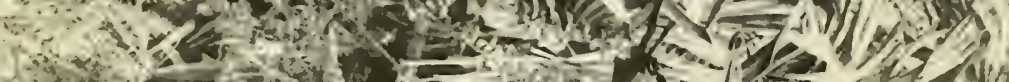

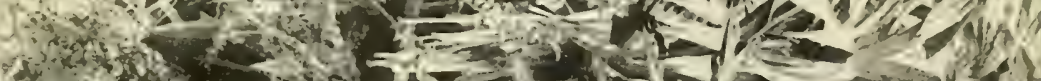

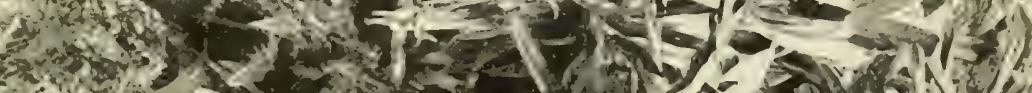

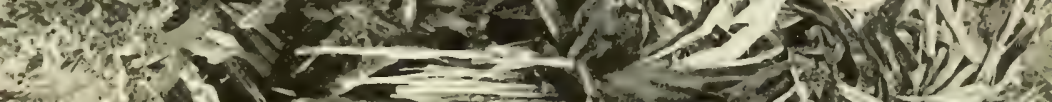

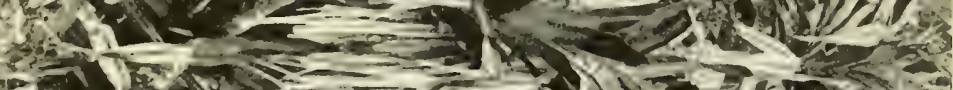

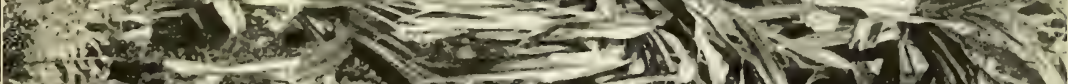

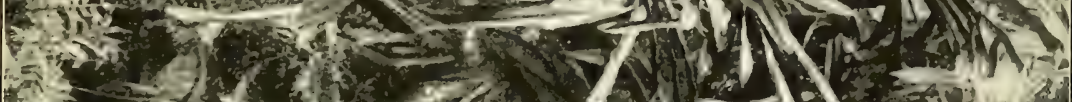

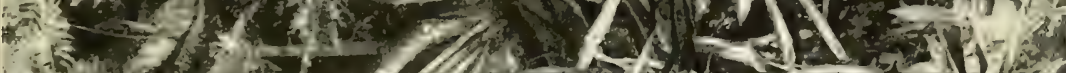

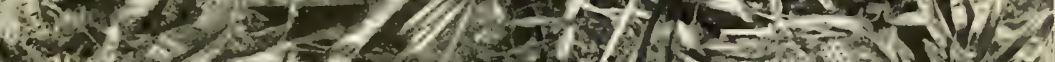

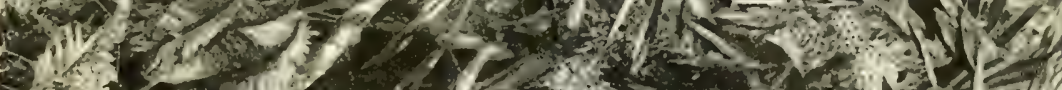

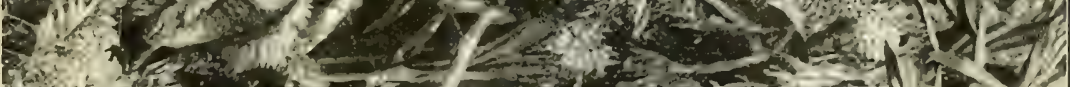

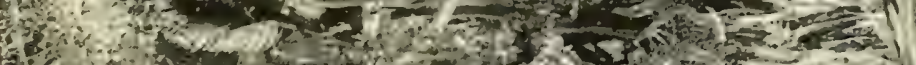

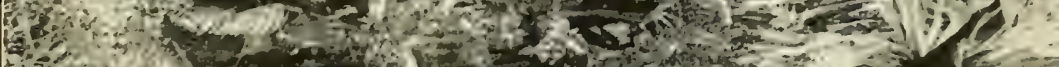

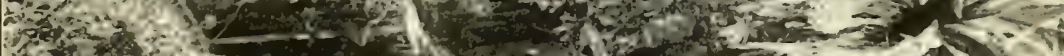

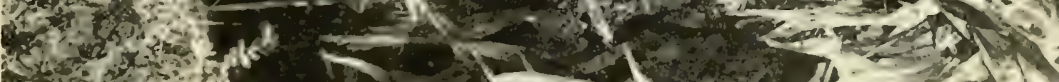

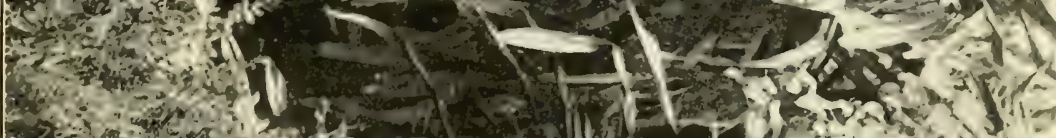

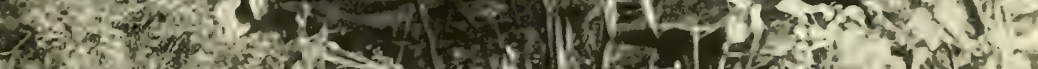

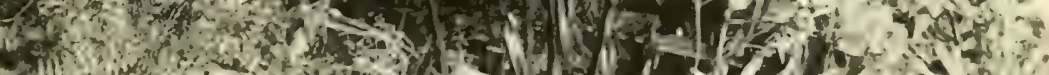
f W.

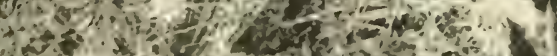

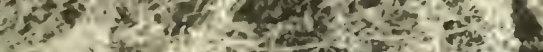

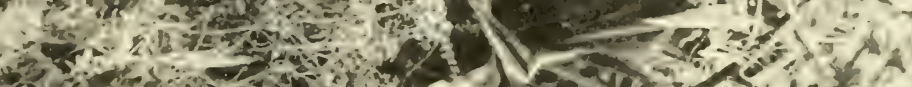

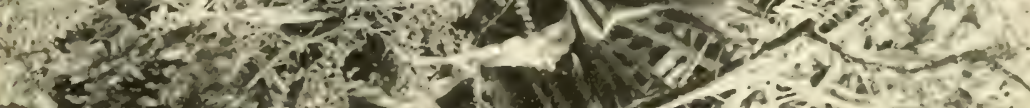

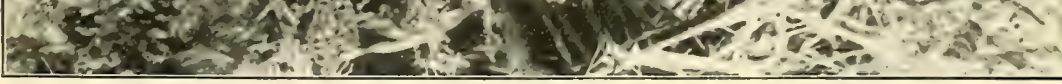



I am not sure of the identity of the Guam plant. Its glaucous leaves exceed in strength the simnan and Hawaian screwpines referred to this species. There is also "onsiderable difference between the Samoan "fala" and the Hawaiian "hala," both in the texture of the leaves and the color of the drupes.

References:

Pandanus tectorius Parkinson, Journ. Voy, to the South. Sea in H. M. S. Endeavor, 46. 1773.

Keura odorifera Forsk. Fl. Egypt. Arab. 172. 1775.

Pandanus odoratissimus L. f. Suppl. 424. 1781.

Pandanus fascicularis Lam. Encye. 1: 372. 1783.

\section{Pandanus sp.}

Local Names.-Paingot (Guam).

A species of Pandanus grows in Guam in cutivation, the tender young leaves of which are nsed by the natives as a pot herb, and as a Havoring for various dishes. They taste very much like artichokes.

Par̃gas (Philippines). See Zinziber zingiber.

Pangdang (Philippines). See Pandanus.

Pañgi (Philippines). See Pangium edule.

\section{Pangium edule.}

Family Flacourtiaceae.

Local Names.--Rauál, Rauwél (Guam, Yap); Pañgi (Malayan, Philippines); Boenger iSumatra); Ani (Amboina).

A large tree, introduced int, Guam from the island of Yap, bearing large, round, pulpy, edible fruit with numerous large seeds. Leaves large, alternate, entire or inclining to he 3-lobed, long-petioled, cordate or round-ovate, acuminate, smooth above, hairy below along the veins; flowers of different sexes; calyx roundish, dividing into 2 or 3 unequal segments; petals 5 or 6 , each bearing a seale on the inner surface at the base; male flowers with an indefinite number of stamens, having leaflike filaments and oval anthers; female flowers with 5 or 6 staminodes alternating with the petals; ovary elongate-oroid, 1-celled, with 2 to 4 placentas, each bearing an indefinite number of seeds; stigna sessile; fruit a large, rounded or oval capsule, which does not split open, with a moderately hard, brown rind; seeds numerous, large, embedded in a mass of pulp, transverse, egg-shaped or 3-cornered, with a hard shell, covered with conspicuous branching veins, and a long and large hilum. They grow readily when planted fresh; cotyledons very large, leaf-like.

The sweetish yellow pulp has an onion-like flavor. The seeds contain prussic acid and are poisonous if eaten fresh. They are edible after the poisonous principle has been removed by continued steeping in water. In the Malay Archipelago they form an important food staple of the natives. The crushed seeds are antiseptic and are used to preserve fish; the bark is used for stupefying fish. The wood is hard."

\section{ReFERENCES:}

Pangium èdule Reinw. Syll. Ratisb. 2: 12. 1828 (ex Ind. Kew.).

Panicum colonum. Same as Echinochloa colona.

\section{Panicum distachyum.}

Family Poaceae.

A grass with branched straggling stems, creeping below, slender, quite glabrous or panicle sparsely hairy. Leaves linear or lanceolate, with rounded base, flat; margins of sheath sometimes ciliate, mouth hairy; spikes rarely more than 4 , erect, at length syrearling; rachis slender, smooth; spikelets solitary, subsessile in 1 or 2 rows, ellipsoid, glabrous, variable in size, pale green.

"Warburg, Flarourtiaceae, in Engler und Prantl Nat Pflanzen familien, Teil 3, Abt. 6a, p. 23, 1895. 
This grass is eaten hy cattle. It was first collected in Guam by Chamisso.

REFERENCES:

Panicum distachyum L. Mant. 1: 183. 1767.

\section{Panicum gaudichaudii.}

Family Poaceae.

LOCAL NAMES. - Umog, Uuma (Guam).

A grass with digitate spikes. Smooth; culms growing in tufts, upright, undivided; leaves flat; spikes 12 to 16, fasciculate, crowded, ascending; spikelets solitary, biseriate, hispidulo-scabrous. This species was described from a plant collected on the island of Guam by Gaudichaud.

REFERENCES:

Panicum gaudichaudii Kunth, Rev. Gram. 2: 385. t. 106. 1830.

Digitaria stricta Gaudich. Bot. Freyc. Voy. 409. 1826, not Roth, 1821.

Panoche (Guam). See under Saccharum officinamum.

Papau or Papao (Guam).

Caulescent aroids (Alocksia spp.) with cordate leaves growing along the borders of streams on the island of Guan. The natives distinguish two varieties, papau ápaka or "white papau," and papau pinto. Their stems, which are very acrid, grow to a height of 1 to 2 meters. In early times they were eaten by the natives during the periods of famine which followed huricanes.

Papaw. See Carica papaya.

Papaya (Spanish, Philippincs). See Carica papaya.

Papúa (Guam, Philippines). See Nothopanax fruticosum.

Paraiso (Spanish, Guam). See Melia azedarach.

\section{Parasites.}

Among the parasitic plants are Cassythu filiformis, a leafless, wiry plant growing in thickets, and adhering to the branches by root-like tubercles by which they derive their nourishment; and a species of Balanophora, a low, fleshy, leafless, red plant growing on the roots of other plants, common in thickets, especially on the hill above San Ramon.

\section{Pariti tiliaceum.}

Corkwood. Plate lixi。

Local ximes.-Pago (Guam); Balibago (Philippines); Bìro, Vìro (Madagascar); Fau (Sanora, Tahiti, Fiji); Lu (Rarotonga); Hau (Hawaii); Mahagua, Mahne (W. Indies); Emajagna (Porto Rico); Mahagua, Masagua, Masahua (Mexico); Majagua (Panama); Kalau, Kala-hau (Ponape); (Kili-fau (Mortlocks); Kal (Yap).

A common seacoast tree with spreading branches, yellow flowers with dark centers, and bark which yields a tiber valual, le for cordage. Leares on long petioles, orbicular-cordate, shortly acuminate, "entire or crenulate, white or hoary underneath with a close, short tomentum, nearly glabroms alore, 7 to $13 \mathrm{~cm}$. in diameter; midril, with an elongated raginate nectar glanm near its hase on the lower surface; stipules large, broadly ollong, deciluous; forrers on short perduncles in the upper axils or at the ends of the branches; involucre camplanulate, divided to about the middle into 10 to, 12 lohes, about half the length of the calyx; calyx 5-loherl, nearly 2.5 ('m. long, with lanceolate 1-nerred lobes; staminal column bearing numerous filanents on the outside helow the summit; ovary 5-cellerl, with 3 or more ovules in each cell; style lranches 5, spreading, with terminal capitate stignas; (apsule membranous or coriaceous; seeds nearly globular, with granular surface.

In Guam this species is abuntant. The natives make cordage of its inner bark, nearly every family being provited with rope-making appliances. The ropes are used for halters and lines for tethering cattle and carabaos, for harnews, and for cables for ferrying the bambou balsas, or rafts, across the mouths of the rivers on the 


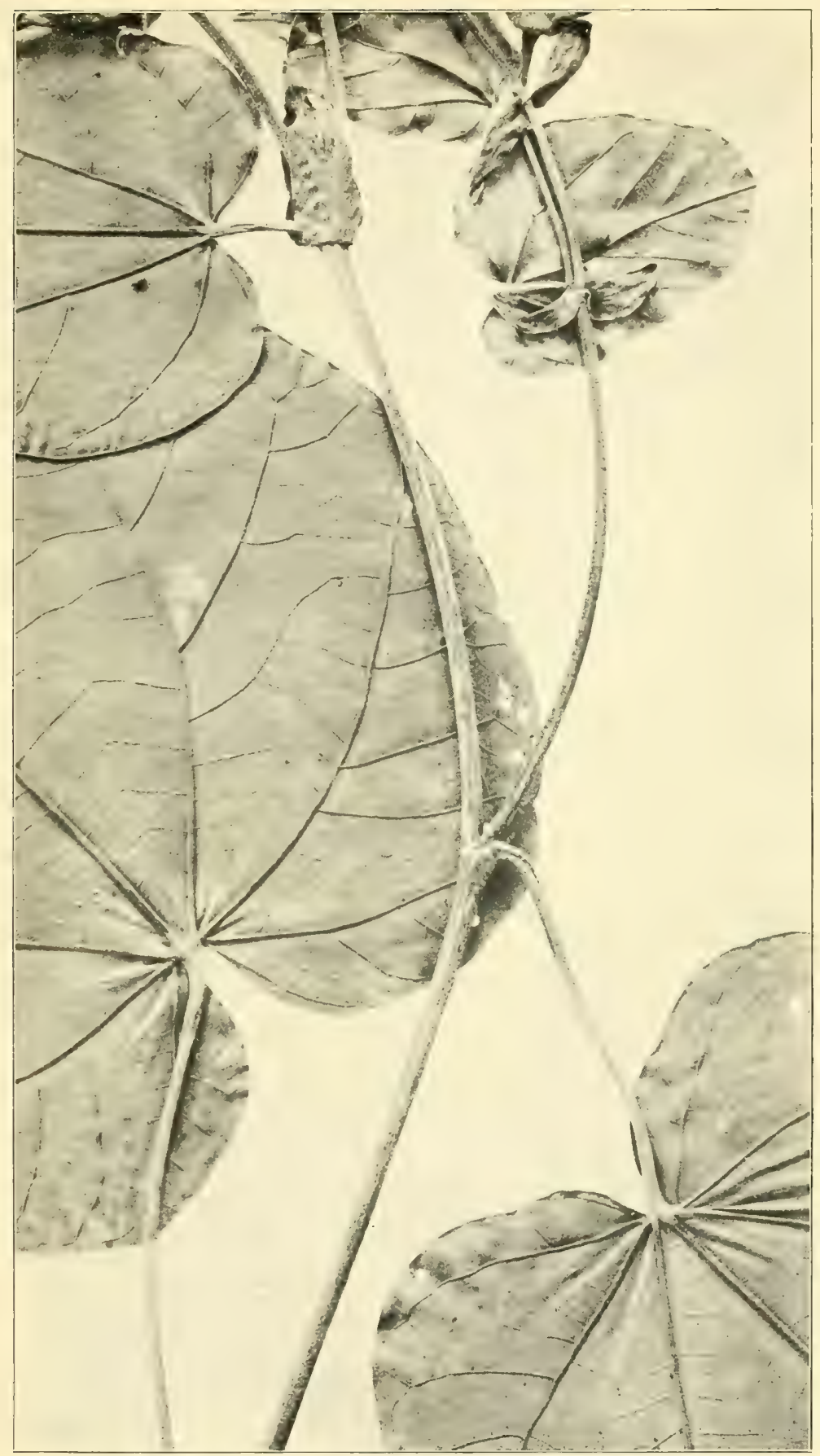

Pariti tillaceum, the Only Source of Cordage on the Island. NATURAL SIZE. 

east coast of the island. The strength and durability of the ropes are much increaser l,y tarring. If they are not thus treated and are left uncared for they are soon ruined by attacks of insects. The Caroline Islanders split the inner bark into narrow strips, which they soak and scrape, and weave into breechcloths or aprons worn by the women. In Tahiti also mats are made of it. The wood is light, durable, and flexible, so that it can be readily bent into any required shape. This renders it suitable for frames of boats, and the lightness of the woorl fits it for outriggers of canoes. In Samoa most of the outriggers are of fau wood.

REFERENCES:

Pariti tiliaceum (L.) A. St. Hil. Fl. Bras. Mer. 1: 256. 1825.

Hibiscus tiliaceus L. Sp. Pl. 2: 694. 1753.

Paritium tiliaceum. Same as Pariti tiliaceum.

Parmentiera alata Miers. Same as Crescentia alata.

Parra (Spanish). See Vitis.

Parsley. See Petroselinum petroselinum.

Pasotes (Guam, Philippines). See Chenopodium ambrosioides.

Paspalum cartilagineum. Same as Paspalum scrobiculatum.

Paspalum scrobiculatum.

KoDO MiLLeT.

Family Poaceae.

An erect annual grass, millet-like; leafy, gla rous, rarely hairy; leaves acuminate; ligule short, membranous; peduncle rather : nder; spikes 2 to $8,8 \mathrm{~mm}$. long, alternate, erect or spreading, rachis 2 to $2.5 \mathrm{~mm}$. broad, margins ciliate or serrulate; spikelets in 2, rarely in 3 or 4 rows, imbricate, glabrous or sparsely pubescent, sometimes geminate on a common pedicel.

This grass was first collected in Guam by Haenke. It often grows on the savannas associated with Gleichenia dichotoma. It is widely distributed in the warmer regions of the world, and in India is cultivated for food. The grain, however, can not be considered wholesome. Unless special precautions are taken it is apt to act as a narcotic poison, producing delirium and vomiting. Although every part of the grain is poisonous, the husk and testa are especially so, the natives separating the light from the heavy grain by means of water. It is a common article of food with all the poor people of India. They prepare it by macerating it for three or four hours in a watery solution of cow dung, throwing away the scum and chaff which rise to the surface, and spreading out the good grain in the sun to dry. Boiling does not entirely destroy the poison. $u$ Cattle and carabaos eat the grass when it is young, but they should not be allowed to feed on it when it is ripening.

References:

Paspalum scrobiculatum L. Mant. 1: 29. 1767.

Pasotes (Guam, Philippines). Name of Mexican origin for Chenopodium ambrosioides.

Patani (Philippines). See Phaseolus lunatus.

Pau-dedo (Guam).

A shrub with opposite leaves and with flowers having a disgusting fetid odor, growing in terminal and axillary umbels. Not identified.

Pea, pigeon. See Cajan cajan.

Peacock-flower (India, Ceylon). See Poinciamu pulcherrima and Delonic regia.

Peanut. See Arachis hypogaea.

Pega-pollo (Spanish). See Boerhactia diffusa.

$a$ Watt, Economic Products of India, vol. 6, pt. 1, p. 113, 1892. 


\section{Pellionia divaricata.}

Family Urticaceae.

A plant collected by Gaurlichaud in the Marianne Islands but nerer described aciequitely, possibly identical with Pellioniu nigrescens Warburg. " The plants of this genus are succulent herbs with leaves distichously subopposite, often in unequal pairs, one large, the other minute, unequal-siderl, 3-veined; stipules persistent; flowers monoecious, in axillary, long-peduncled, contracterl, dichotomously branched cymes; male flowers, sepals 4 or 5 , obtuse, imbricate, dorsally spurred below the tip; stamens 5, filaments inflexed in bud; pistillode conic; female flowers sessile in axillary hearls; sepals 4 or 5 , subequal; staminodes inflexed; ovary oval, shorter than the sepals; stigma sessile, penicillate, orule erect; achene embraced by the sepals, compressed, tubercled, endosperm very scanty, cotyledons rounded, radicle conic.

\section{ReFERENCES:}

Pellionia divaricata Gaudich. Bot. Freyc. Voy. 494. 1826.

Polychroa Lour., 1790, is sometimes cited as a synonym of Pellionia, but there appears to be too much doubt of its identity to warrant its substitution for a wellestablished name.

\section{Pemphis acidula.}

Family Lythraceae.

Local Names. - Nígas (Guam); Bantigui (Philippines).

A shrub or small tree growing on ihe strand, with numerous ascending branches densely clothed with gray pubescen , small, crowded, sensile leaves, and small pink or white flowers. Leaves opposite, oblong, entire, thick, fleshy; flowers axillary, solitary, peduncles with two bracts at them hase; calyx tube campanulate, with 12 or more ribs; teeth 6 , whort, with 6 shorter accessory teeth; petals 6 , inserted at the top of the calyx tube, nearly as long as it, sxinkled, white or rose; stamens 12 , inserted in two series toward the middle of the calyx tube; ovary free, at the bottom of the calyx tube, :3-celled at the hase; style long; stigma capitate; ovules many, ascending, placentas 3 , subbasal; capsule coriaceons, obovoid or nearly globose, included in the (alyx tube or exserted nearly half its length, circumscissile somewhat irregularly, ultimately 1-celled; seeds very many, long cumeate-obovoid, angular, smooth, standing out in all directions from what appears to be a free central placenta.

Branchlet, young leaves, and inflorescence with short gray hairs. ${ }^{h}$ In Guam the wood is used for fuel, for fence stakes, and sometimes for walking sticks.

REFEREXCES:

Pemphis acidula Forst. Char. Gen. 68. t.34.1776.

\section{Pengua (Guam).}

A tree with many branches, given in the list of Don Felipe de la Corte. The wood is durable in salt water and yields planks for building purposes. A resin-like rethlish gum exules from the tree, which may be used for gluing together partis of furniture. Not identified.

\section{Pennywort, Indian or Marsh. See Centella asiatica.}

\section{Peperomia mariannensis.}

Family Piperaceae.

A smooth, erect. succulent, aromatic herb with minute flowers growing in slender, (atkin-like-pikes. Leares petioled, elliptical-ovate, membranous, glabrous on both sides or cilinlate toward the apex, subpelucid, with pelucid dots, 5 -nerved, the midwe nerve reaching to the alrex, the lateral ones to the middle, the nervules converging tuward the margin of the apex; petiole smooth; flowers hermaphrodite; spikes dense-flowered, slender, terminal, equaling the leaf, peduncle smooth, equal- 
ing the petiole; bracts round, peltate, subsessile at the center, perianth lacking; stamens :2, short; ovary compressed-ovate, stigma obliyuely inserter, brush-like; ovule 1, erect; fruit minute, indehiscent; seed with membranous testa.

Type species in the Berlin herbarium, collected by Gaudichaud in Guam.

Grows on the banks of streams.

REFERENCES:

Peperomia mariannensis C. DC. in DC. Prod. 16¹: 442.1869.

Pepitio (Tahiti). See Abrus abrus.

Pepper. General name for the species of Piper.

Pepper, beil. See Capsicum annuum grossum.

Pepper, betel. Piper betle.

Pepper, black. See Piper nigrum.

Pepper, Cayenne. General name for the species of Capsicum.

Pepper, cherry. See Capsicum annuum cerasiforme.

Pepper, Guam. See Piper guahamense.

Pepper, Indian wild. See Titex trifolia.

Pepper, red. See Capsicum annurm and other species.

Pepper, spur. See Capsicum frutescens.

Peppermint, Chinese. See Mentha arvensis.

Pergularia odoratissima. Same as Telosma odoratissima.

Periwinkle, Madagascar. See Lochnera rosea.

Peronia (Porto Rico). See Abrus abrus.

Petroselinum petroselinum.

Parsley.

Family Apiaceae.

Parsley is cultivated by the natives. It does not grow very well. The natives often have one or two plants growing in a pot, taking off a leaf or two when required for seasoning certain dishes.

References:

Petroselinum petroselinum (L.) Karst. Deutsch. F1. 831. 1880-83.

Apium petroselinum L. Sp. Pl. 1: 264. 1753.

Pharbitis congesta. Same as Ipomoea congesta.

Pharbitis hederacea.

IVY-LEAVED MORNING-GLORY.

LOCAL NAMES.-Fofgu (Guam).

A twining plant with azure blue or pink flowers. Stems twining, slender hirsute with deflexerl hairs; leaves 5 to $12.5 \mathrm{~cm}$. long, usually broader than long, cordate at the hase, palmately 3 -lobed, the lobes deep, acute, middle one the largest, slightly hairy on both sicles, especially on the veins beneath, petiole a little shorter than the blade; flowers large, on short stout peduncles, either solitary or in threes; bracts linear, persistent; peduncle usually shorter than the petiole; sepals equal in length, 18 nm. long, linear, dilated below, acute, hairy; corolla tubular, funnel-shaped, limb 5 $\mathrm{cm}$. in diameter; ovary 3-celled; capsule $12 \mathrm{~mm}$. long, surrounderl by the much longer enlarged sepals, glohose, 3-valved; seeds usually 6, $6 \mathrm{~mm}$. long, ovoid-triangular, glabrous, dull black.

The seeds are strongly purgative and in India are used as a drug under the name of kaladana. a The plant is probably of American origin.

References:

Pharbitis hederacea (L.) Choisy, Mem. Soc. Phys. Genev. 6: 440. 1833.

Convolvulus hederaceus L. Sp. Pl. 1: 154. 1753.

Ipomoen hederacea Jacq. Coll. 1: 124. 1786.

a Trimen, Handbook Flora of Ceylon, vol. 3, pp. 212, 213, 1895. 
Pharbitis insularis Choisy. Same as Ipomoea congesta.

Pharbitis nil. Same as Pharbitis hederacea.

Phaseolus lunatus inamoenus.

LIMA BEAN.

Family Fabaceae.

Local Names.-Habas (Spanish); Patani (Philippines).

Lima beans will grow in Guam, but our common varieties do not appear to flourish here. They should be planted toward the end of the rainy seascn. In India fresh seed is imported annually from America.

REFERENCES:

Phaseolus lunatus inamoenus (L.).

Phaseolus inamoenus L. Sp. Pl. 2: 724. 1753.

Phaseolus macrocarpus Moench, Meth. 1: 155. 1794.

\section{Phaseolus mungo.}

Green GRAM.

Local vames.-Monggos (Guam); Muñggo, Monggo, Balatong (Philippines); Mung (India).

The most extensively cultivated leguminous plant in Guam. A low suberect annual, more or less densely clother with loose deflexer hairs, leaves 3-foliolate, stipellate; leaflets membranous, entire, rarely faintly lobed; stipules ovate; flowers in axillary capitate racemes at the end of the peduncles; bracteoles ovate or lanceolate; calyx campanulate; corolla yellow, much exserted; keel prolonged into a complete spiral; pedicels very short; pod 3.5 to $6 \mathrm{~cm}$. long by 4 to $.5 \mathrm{~mm}$. in diameter, clothed with deciduous silky hairs, subcylindrical, slightly recurved; seeds small, green.

Tn the agricultural statistics of one year I find that in the district of Agana there were planted 131 chupas of monggos (102 pints), and 1,149 gantas ( 455.3 pecks) were gathered, making the yield more than seventyfold. $a$

This plant is widely distributed in the Tropics. It is extensively cultivated in many warm countries, especially in the Philippines and on the plains of India. The seeds are largely imported into San Francisco, Cal., by the Chinese. In Guam it is grown as a rotation crop after maize. It thrives best apparently on the highland during the rainy season. Cattle are very fond of the seeds, stems, and leaves. In India and in the Philippines the seeds are ground into flour and used as a substitute for soap for washing delicate fahrics. They are wholesome and nutritious and have a pleasant taste. They may he eaten as a porridge or parched. The green pods are sometimes eaten as a vegetable. An analysis of the seed has been made by W. C. Blasdale. $b$

REFERENCES:

Phaseolus mungo L. Mant. 1: 101. 1767.

\section{Phoenix dactylifera.}

DATE。

Family Phoenicaceae.

I know of only one tree of this species in Guam. It grows in the garden of the rectory back of the church of Agaña. As the species is dicecious, of course the tree bears no fruit. It is probable that the climate is too moist for the culture of dates, though the trees could be propagated without trouble.

References:

Phoenix dactylifera L. Sp. Pl. 2: 1188. 1753.

\section{Phoenix sylvestris.}

WILD DATE.

Sereral specimens of this palm obtained by me from Mr. David Haughs, of the

"Olive y Garcia, Islas Marianas, App. no. 4, 1887.

7. Blaslale, some (hinese vegetable food materials, ete, L. S. Dept. Agr., Off. Exp. Sta., Bull. No. 68 , p. 37, 1899. 
Honolulu Botanical Gardens, were planted in Guam, and were thriving at the time of my departure from the island.

REFERENCES:

Phoenix sylvestris (L.) Roxb. Hort. Beng. 73. 1814 (ex Ind. Kew.); Fl. Ind. 3: 787.1832.

Elate sylvestris L. Sp. P1. 2: 1189. 1753.

Phragmites communis. Same as Trichoon phragmites. See under Trichoon roxburghii.

Phragmites karka Trin. Same as Trichoon roxburghii.

Phragmites phragmites. See under Trichoon roxburghii.

Phragmites roxburghii. Same as Trichoon roxburghii.

Phyllanthus gaudichaudii. Same as Glochidion marianum.

Phyllanthus marianus.

Phyllanthus.

Family Euphorbiaceae.

A shrub with leaves arranged in two vertical rows; branches compressed, wrinkled; leaves subsessile, ovate, unequal at the base, acute at the apex, membranous, prominently net-veined; flowers in axillary clusters, shortly pedicelled, very minute, numerous; glands of male flowers free; stamens 3 , filaments united in a column; staminal column entire, anthers erect with vertical slits, free from one another; female flowers with three bifid styles; capsule of three crustaceous 2-valved cocci; seeds on the back coarsely, transversely undulate-ribbed.

The type specimen of this species was collecterl on the island of Guam in 1819 by Gaudichaud and placed in the herbarium of De Candolle. The plant is used medicinally by the natives of Guam.

\section{References:}

Phyllanthus marianus Muell. Arg. Linnæa 32: 17. 1863.

Tot to be confused with Phyllanthus (CIlochidion) morianus Müll. Arg. Flora 48: 379, 1865, also from Guam, which was first described by Müller in Linnea, 32: 65, as Glorhidion marianum, a genus which is now recognized as distinct from Phyllanthus. $a$

\section{Phyllanthus niruri.}

FLY-Roost.

Local NAMEs.-Maigo-lalo, Maigu-lalo (Guam).

An annual, herbaceous, glabrous weed of wide tropical distribution; stem angular, glabrous, 15 to $45 \mathrm{~cm}$. high, often branched from the base, with slender leafy angular branchlets above. Leaves variable, pale gretn, 6 to $18 \mathrm{~mm}$. long, often imbricated in two rows, glaucous beneath, elliptic-obovate, oblong, or linear, the tip rounded, obtuse, or acute; petiole minute; stipules subulate; flowers very numerous, males solitary and in pairs, almost sessile; female twice as large; sepals of male orbicular, of female narrowly obovate-oblong with broad white margins, spreading; disk of male of minute glands; anthers 3, sessile on a short column; disk of female annular, lobed; styles minnte, very short, free, 2-lobed; capsule minute, depressedglobose, smooth; seeds with equal parallel slender ribs and faint cross striæ.

This plant is very common in Guam, growing everywhere in waste places. The native name, signifying "sleeping flies," or "fly-roost," is probably applied to it from the appearance of the plant when the leaves closing together have the appearance of a number of two-winged insects clinging to the stem.

The milky juice of this plant is a good remedy for offensive sores. The bruised bitter leaves are applied externally as a cure for the itch and for scabby sores of the scalp, and the fresh root is an excellent remedy for jaundice. $b$

ReFERENCES:

Phyllanthus niruri L. Sp. Pl. 2: 981. 1753.

Hooker, Flora British India, vol. 5, p. 306, 1890.

$b$ Watt, Economic Products of India, vol. 6, pt. 1, p. 222, 1892. 


\section{Phyllanthus nivosus.}

ROSY-LEAVED PHYLLANTHUS.

A shrub used extensively in the tropics as an ornamental hedge-plant, in its cultivated form (variety roseopictus) having variegated green, white, and pink leaves. Leaves arranged in 2 lateral rows on small branchlets which have the appearance of pinnately compound leaves; flowers small, greenish, apetalous, discoid, hanging by their pedicels from the leaf-axils.

A number of plants obtained from Mr. David Haughs, of the Honolulu Botanical Gardens, were introduced into Guam by the writer. They grew well and were left in a flourishing condition. In Honolulu beautiful hedges are made of this Phyllanthus. They are easily kept in a good compact condition by clipping, and the light pinkish foliage offers a pleasing contrast with darker-leaved shrubs.

REFERENCES:

Phyllanthus nivosus Bull. Cat. 9. 1873; W. G. Smith, Flor. Mag. N. S. t. 120. 1874.

\section{Phyllanthus urinaria.}

Phyllanthus.

A diffusely branched erect or decumbent herb (sometimes perennial), glabrous or nearly so, the stem and branches angled. Leares variable in size, 4 to $16 \mathrm{~mm}$. long, sessile, distichously imbricate (in 2 rows), lanceolate, oblong or linear-oblong, tip rounded or apiculate, stipules peltate; flowers very minute, male smaller than female, axillary, subsessile; sepals ciliolate; filaments very short, free; ovary densely granulate; styles short, free, 2-fid; fruit echinate; seeds transversely furrowed.

Collected in Guam by Gaudichaud. Its medicinal properties are the same as those of $P$. niruri.

\section{REFERENCES:}

Phyllanthus urinaria L. Sp. Pl. 2:"982. 1753.

\section{Phyllaurea variegata.}

VARIEGATED CROTON.

Family Euphorbiaceae.

Local Names.-San Francisco, Buena Vista (Guam, Philippines); Saguilalá (Philippines).

An ornamental plant with bright-colored leaves rarying greatly in form and coloring. Flowers monweious, usually in racemes of one sex, rarely a female at the base of a male raceme; males small, clustered, females solitary; males with small petals and many stamens; females without petals, calyx 5-lobed, ovary 3 -celled.

Much planted by the natives in a line near their houses, so as to receive the drippings from the eares. The commonest form is one having rariegated green and yellow leaves. Other forms occur with red and orange coloring.

\section{REFERENCES:}

Phyllaurea variegata (L.)

Croton variegatum L. Sp. Pl. 2: 1199. 1753.

Phyllaurea codiaeum Lour. Fl. Cochinch. 2: 575. 1790.

Codiaeum variegatum Blume, Bijdr. 606. 1825.

\section{Phymatodes phymatodes.}

Oak-leaved fern. Plate lxiti。

Family Polypodiaceae.

Local Naves.-Kahlau (Fuam); Lau mangamanga (Samoa).

A climbing fern, with pinnatifid or deeply lohed fronds resembling great oak leaves. Rhizome wide-creeping, woody, the scales dark brown, fibrillose; stipes firm, erect, glossy; fronds varring from simple oblong-lanceolate to pinnately lobed, often cut down to a broadly-winged rachis into numerous entire acuminate lanceolate-oblong lobes; texture coriaceous; both siles naker; no distinct main veins; areolse fine, with copious free veinlets; sori large, more or less immerserl, 1 or 2-serial or scattered.

Common in the forests of Guam and growing on stone walls and the tiled roofs of 


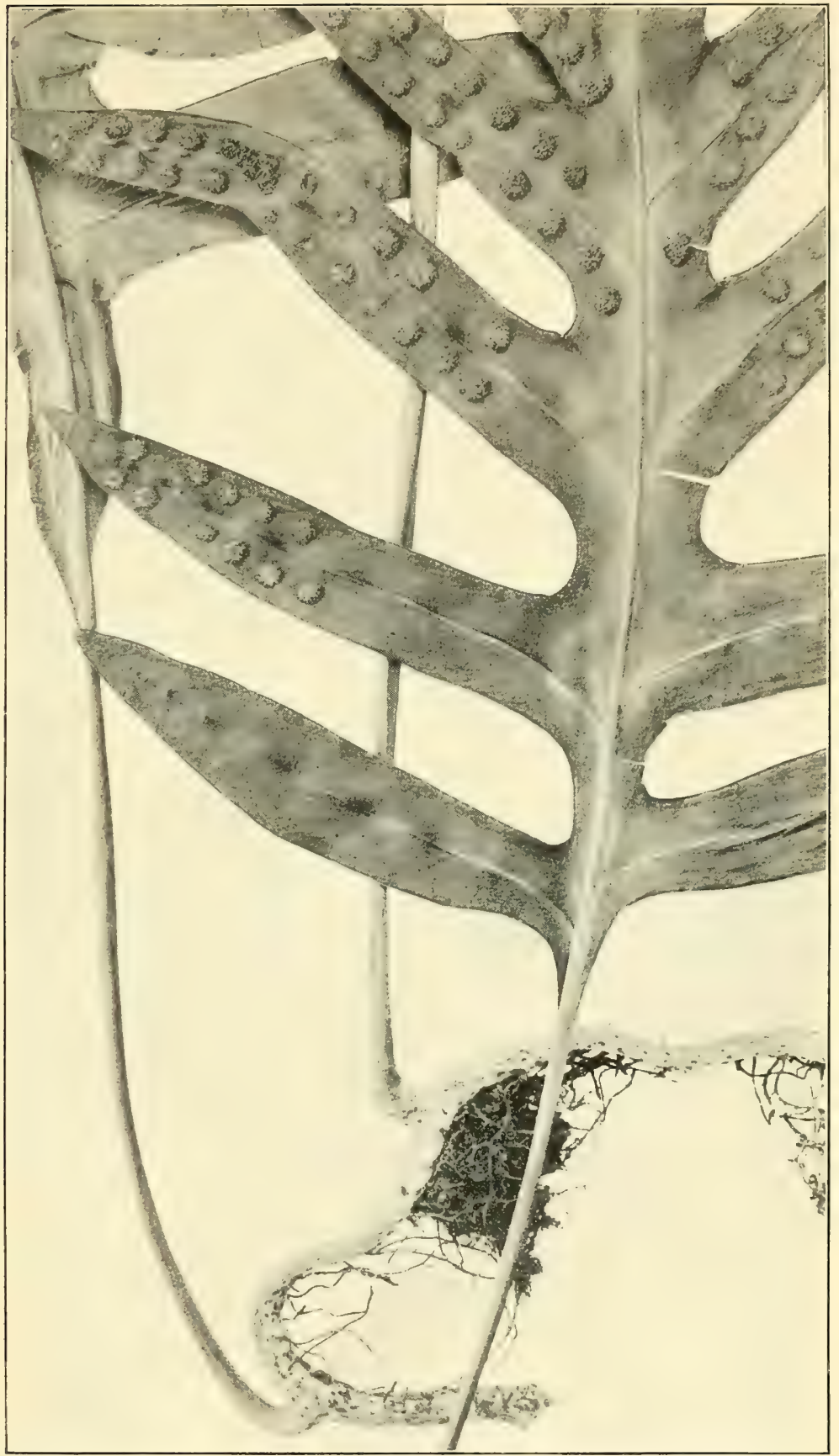

Phymatodes phymatodes, the Oak-leaf fern. Natural Size. 

houses. Spread throughout Polynesia, Formosa, Malaysia, North Australia, Ceylon, etc.

\section{REFERENCES:}

Phymatodes phymatodes (L.) Maxon.

Polypodium phymatodes L. Mant. 306. 1771.

\section{Physalis angulata.}

GROUND-CHERRY.

Family Solanaceae.

Local Names.-Tomates de Brihuega (Spanish); Sisio, Asisio (Philippines).

An annual glabrous weed, with angled stem. Leaves ovate, with cuneate base and long-acuminate teeth, or subentire; calyx $\tilde{\jmath}$-parted, inflated like a bladder around the included berry; calyx-lobes deltoid; bladder sharply 5-angular; corolla pale; stamens 5, anthers violet; stigma capitate; berry 2-celled, turning yellow when ripe and nearly filling the calyx.

Widely spread in the warmer regions of the world. In Guam it grows in waste places. Fruit eaten occasionally by the natives.

REFERENCES:

Physalis angulata L. Sp. P1. 1: 183. 1753.

\section{Physalis minima.}

GROUND-CHERRY.

Local Names.-Tomate chaka, i. e., "Rat tomato" (Guam); Tomates de Brihuega (Spanish); Sisio, Asisio (Philippines).

An annual pubescent plant. Leaves ovate, sinuate, angular, or scarcely lobed; calyx inflated, enlarging after flowering, 5 or 10-ribbed; corolla yellow; berry 12 $\mathrm{mm}$. in diameter. Abundant on cultivated land. Fruit eaten by the natives, forming a good salad, when raw, or made into a dulce. Chickens are fond of it.

REFERENCES:

Physalis minima L. Sp. Pl. 1: 183. 1753.

Physic-nut. See Jatropha curcas.

Pia (Samoa). See Tacca pinnatifida.

Piao (Guam). General name for bamboo.

Piao lahe, Piao tituka (Guam). See Bambos blumeana.

Piao palaoan (Guam). See Bambos sp.

Piga (Guam).

General name for Alocasia spp., giant aroids with acrid starchy stems, eaten in times of famine.

Piga-palayi (Guam). See Crinum asiaticum.

Pigeon pea. See Cajan cajan.

Pigweed, green. See Amaranthus viridis.

Pigweed, spiny. See Amaranthus spinosus.

Piipii (Hawaii). See Andropogon aciculatus.

Pili (Philippines). See Canarium indicum.

Pilikai (Hawaii). See Argyreia tiliaefolia.

Piña (Guam, Philippines, Spanish). See Ananas ananas.

Pineapple. See Ananas ananas.

Píod or Piut (Guam). See Ximenia americana.

Piper betle.

Betel pepper. Plate lixiI.

Family Piperaceae.

Local names.-Pupúlo, Pupúlu (Guam); Tambula (Sanscrit); Tambol (Persian); Tanbol (Arabic); Bulat-wel, Bulat woela (Ceylon); Buyo (Philippines); Kolu (Solomon Islands); Hurung, Huglong (Kaiser Wilhelmsland); Pán (Bengal).

$9773-05-23$ 
A perennial climbing plant with smooth bright green, ovate-cordate leaves, having a pungent, aromatic taste. Leares large, coriaceous, petioled, obliquely ovate-oblong or rounded orate-cordate, entire, 5 to 9 -nerved, often unequal at the base; flowers in solitary spikes, diœcious, with orbicular peltate bracts; male spikes 7.5 to $15 \mathrm{~cm}$. long: female long-peduncled, in fruiting stout, 2.5 to $12.5 \mathrm{~cm}$. long, pendulous; fruit fleshy, often confluent into a cylindrical fleshy red mass. The leaves resemble those of Piper nigrum, but the fruit is more compact.

This plant, like many other cultirated species, is variable. Piper siriboa and $P$. melamiri are forms which were described by Linnæus as distinct species. Specimens collected in Guam by Haenke were described by Opiz as Piper marianum, $₫$ but were later called by C. De Candolle Piper betle mariannum. ${ }^{b}$ In the Guam variety the leaves have longer petioles than in the typical form; are smooth on both sides, membranous, rather stiff, with fine pelucid dots, 5-nerved, the central nerve sending forth on each side one nerve from above the base and another from the base, opposite to each other.

In Guam it is very extensicely cultirated. Cuttings take root readily. An old lady, who made a business of selling betel leares, brought the writer several cuttings and planted them in his garden. She removed all the leaves but two or three, twined the lower part of the cutting into a hoop-like loop, and covered it with a few inches of soil upon which she laid a flat stone to retain the moisture, leaving the tip of the cutting projecting from beneath the stone. Following her directions I watered my cuttings daily for about a week. New leaves soon began to push forth, and in a short time I had fine vigorous plants climbing up my lemon and lime trees and running over my garden wall.

The fresh green leaves (mamaon) are chewed by the natives wrapped about a fragment of Areca nut together with a pinch of quicklime. They are agreeably pungent and aromatic, the nut and leaves together tasting somewhat like nutmeg, and giving a spicy odor to the breath. In Guam the betel takes the place of Piper methystimm, the roots of which, after having been chewed or grated, are made by the Polynesians into the infusion called "kava" or "ava." The kava pepper does not grow in Guam. In islands where it does occur its leaves are occasionally used in place of those of the betel pepper for chewing.

For the effects of betel chewing and the ceremony attending it see notes under Areca cuthecu. It is interesting to observe the resemblance of "pupúlu," the Guam name of the hetel pepper, to "pipul" and "pipulmul," the names applied in India and Bengal to Piper longum.

References:

Piper betle L. Sp. Pl, 1: 28. 1753.

Piper guahamense.

GUAM PEPPER.

A plant resembling the kara pepper (Piper methysticum) of Polynesia. Diøecious; stems erect; leares long-petioled, round or round-ovate, with the apex shortly protracted-acuminate, the point rather sharp, deeply cordate at the base, smooth above, yellowish-puberulous along the veins on the under surface, membranous, rather stiff, sub naque, finely pelucid-dotted, 9 to 11-nerved; nerves rather prominent below, the middle one reaching to the apex, the two next nearly to the apex, the remaining ones finer; yetiole sheathing for one-fourth of its length with linear wings attenuated toward the apex into the petiole; spikes of the female plant axillary, solitary, densely flowered, nearly equaling the leaves, the peduncle a little shorter than the petioles, sparsely puberulous, the rachis puberulous; bracts roundpeltate, petiolate at the center; ovary ovate, glabrous; stigmas 3 , rather fleshy, ses- 


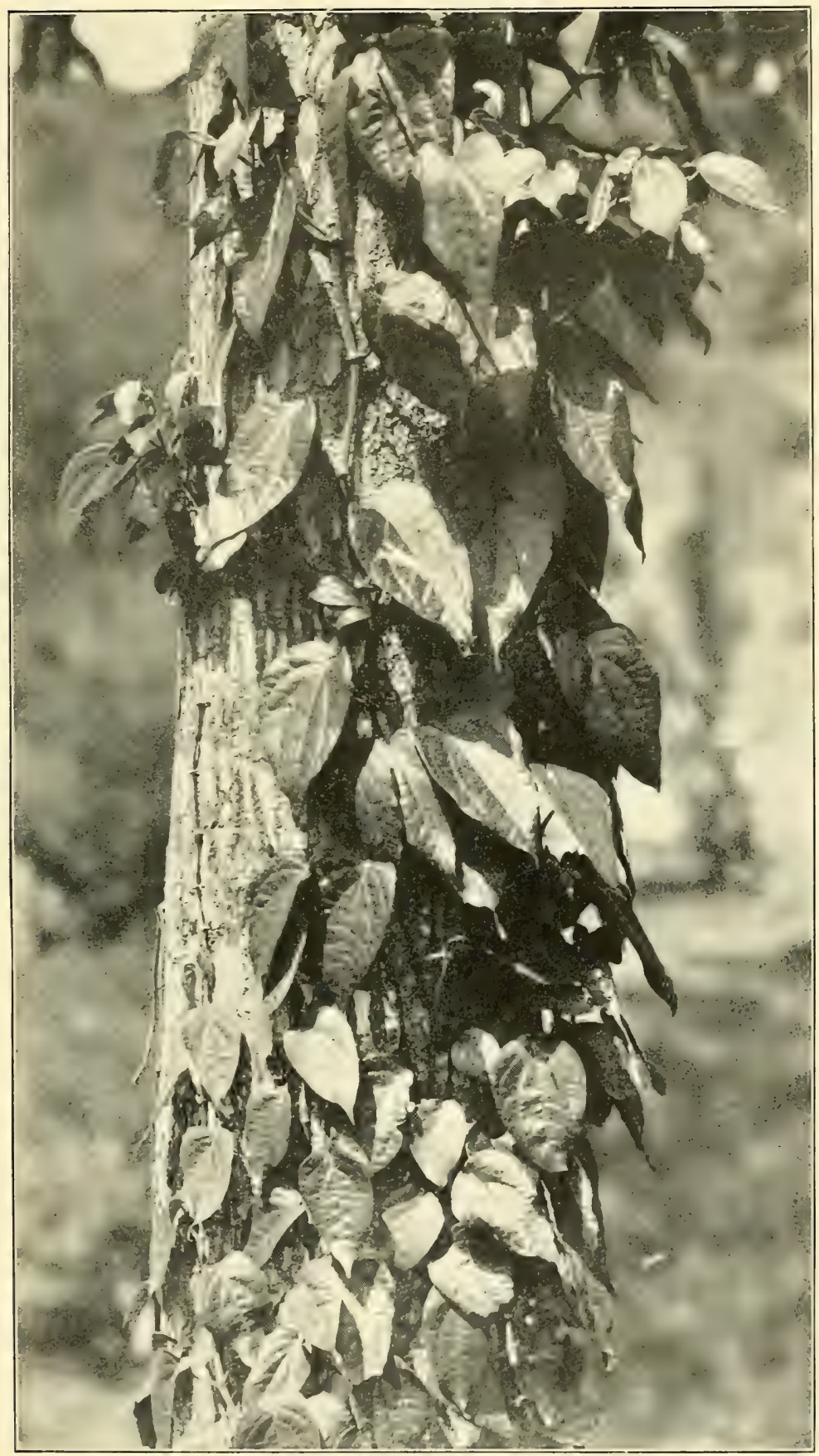

Piper betle, the Betel Pepper. 

sile; male plants with smooth petioles, leaves more membranous; spike (solitary?) dense-flowered, rachis puberulous; stamens 3.

A common plant in Guam, growing in shady woods in moist situations and near the banks of streams. Its leaves have an aromatic taste much like those of the closely allied kava pepper.

This species was described by C. De Candolle from a female plant collected in Guam by Chamisso, the type now in the herbarium of Berlin, and from a male plant, perhaps a distinct species, collected by Haenke in Mexico, also in the same herbarium. It was referred by Miquel to Macropiper methysticum and Macropiper latifolium.a

\section{REFERENCES:}

Piper guahamense C. DC. Prod. 16': 336. 1869.

Piper marianum. See Piper betle.

Piper nigrum.

BLACK PEPPER.

A few plants of black pepper given me by Mr. David Haughs, of the Hawaiian Botanical Garden at Honolulu, were planted by me in Guam. They seemed to be well established in my garden when I left. The climate is evidently adapted to the cultivation of this species.

\section{REFERENCES:}

Piper nigrum L. Sp. Pl. 1: 28. 1753.

\section{Piper potamogetonifolium.}

A diøecious plant with flower-spikes opposite the leaves. Leaves petioled, cordateorate, with acuminate apex and equal base, lobes approximate, coriaceous, smooth, glossy, net-veined; petiole sheathing, much shorter than the leaf, smooth; spike cylindrical, much shorter than the leaf, mucronate; peduncle smooth. An undershrub collected by Haenke on the island of Guam.

\section{ReFERENCES:}

Piper potamogetonifolium Opiz in Presl, Rel. Haenk. 13: $^{3}$ 156. 1828.

Macropiper potamogetonifolium Miq. Syst. Pip. 221. 1843.

\section{Piper sp.}

Besides the above species, an epiphytal piper is mentioned by Gaudichaud, called "podpod" in the vernacular of the island. This I have been unable to identify.

\section{Piperaceae.}

Pepper family.

This family is represented in Guam by Piper betle, $P$. guahamense, $P$. potamogetonifolium and Peperomia mariannensis.

\section{Pipturus argenteus.}

\section{Silvery Pipturus.}

Family Urticaceae.

Local NaMes.-Handaramai, Hinaramai (Philippines); Fau songä (Samoa); Kongangu, Queensland Grass-cloth Plant (Australia).

A shrub or small tree, allied to the mamake of the Hawaiian Islands. Young branches covered with whitish wool or pubescence; leaves alternate, petioled, unequal in size and length of petiole, 3-nerved, ovate or elliptical-lanceolate, rarely cordate, acuminate or gradually attenuate and acute; petioles varying in length, longer and shorter ones alternating on the branches; old leaves glabrate and smooth on the upper face, crenulate or finely serrulate or nearly entire, unlike in color on the two faces; stipules axillary, deeply bifid; flowers small, growing in axillary clusters of two sexes; male perianth, 4 or 5-lobed, with 4 or 5 stamens and the woolly rudiment of a pistil; female ventricose, 4 or 5 -toothed, with filiform stigma; ovule 1 , erect; achene nut-like, closely invested by perianth. The inflorescence is arranged either in axillary clusters or in simple interrupted spikes sometimes leafy at the tip. 
From the fibrous inner bark of this species the Samoans make their red, shaggy, rug-like mats and their nets and fishing lines. The fiber is of fine texture and great strength, but difficult to prepare. In Australia it is known as the Queensland grass-cloth plant, or native mulberry. It was first collected on Guam by Gaudichand. The fiber is not utilized on this island. From the allied mamake the Hawaiians made bark-cloth or "tapa." The bark yields a brown dye.

REFERENCES:

Pipturus argenteus (Forst.) Wedd. in DC. Prod. 16 ${ }^{1}: 235^{19} .1869$.

Urtica argentea Forst. Prod. 65. 1786.

Pipturus propinquus. Same as Pipturus argenteus.

Pisang (Philippines). See Musa paradisiaca.

Pisonia brunoniana. Same as Pisonia excelsa.

Pisonia excelsa.

Family Nyctaginaceae.

Local names.-Umumu, Umumo (Guam); Tak-an (Philippines); Buatea (Tahiti).

A shrub or tree, glabrous or nearly so; leaves opposite or growing in whorls at the ends of the branches, more or less coriaceous, oblong or oval, obtuse or pointed at the tip, slightly cordate, usually attenuate at the base (15 to $20 \mathrm{~cm}$. or more long by 4 to $6 \mathrm{~cm}$. wide). Flowers diøecious, growing in terminal or lateral clusters (10 to 15 $\mathrm{cm}$. long); clusters in pairs or in fours on the extremities of the branches, sometimes covered with reddish hairs, or on nodules on the lower parts of the branches; peduncles smooth or pubescent, like the rest of the inflorescence, often elongated and with short ramifications or shortened and with longer ramifications. Perianth funnel-shaped, 5 to $6 \mathrm{~mm}$. long, 5-toothed, the fruiting clusters larger than the flowering ones; fruiting perianth, 4 to $5 \mathrm{~cm}$. long by 3 to $4 \mathrm{~mm}$. wide, oblong, with 5 ribs either smooth or armed with tiny spines, attenuate at the base, claviform at the top, exuding a viscous juice; stamens 6 to 10, of unequal length, protruding: female flowers having a 1-celled ovary more or less elongated, with a single erect ovule; style often exserted with a 2-lobed stigma; stigma-lobes pectinate; style of male flowers when present often shorter than the stamens, its stigma lateral, oval, entire, spongy; fruit angular, inclosed in the persistent tube of the perianth, the angles frequently armed with prickly glands, which are sometimes scarcely perceptible.

This species is quite variahle and has been described under several names. It is widely distributed throughout the Pacific and in tropical Asia.

RefERENCES:

Pisonia excelsa Blume, Bijdr. 735. 1826.

Pisonia umbellifera Seem.; Nadeaud, Enum. Pl. Tahiti, 46. 1873.

Pisonia mitis. Same as Pisonia excelsa.

Pisonia umbellifera. Same as Pisonia excelsa.

Pisum sativum.

Peas (Spanish "alverjas") will not grow in Guam.

References:

Pisum satioum L. Sp. Pl. 2: 727. 1753.

\section{Pithecolobium dulce.}

Guamachil.

Family Mimosaceae.

Local Nayes.-Kamachiles, Camachile (Guam, Philippines); Guamachil, Huamachil, Guamachi (Mexico); Manila Tamarind (India).

A medium-sized tree introduced into Guam from Mexico, via the Philippines, bearing heads of small yellowish-green flowers followed by pods containing seeds embedded in a sweet, white, edible pulp or aril. Branches glabrous, pendulous; leaves abruptly bipinnate, composed of a single pair of pinnæ, each of which has a single pair of 
leaflets; stipules spinose, the spines minute, pointing upward; leaflets approximate, oblique, very unequal-sided, ovate-oblong, rigidly subcoriaceous, obtuse, $12 \mathrm{~mm}$. long; petiole shorter than the leaflets; flowers sessile in heads; heads dense, with short peduncles, on elongated branches; calyx 5-parted, funnel-shaped, gray-downy, very small; corolla funnel-shaped, the petals united below the middle; stamens monadelphous, much exserted; style filiform; stigma minute, capitate; pod irregularly swollen and curled at the end, 10 to $12.5 \mathrm{~cm}$. long by $12 \mathrm{~mm}$. wide, 6 to 8 -seeded, both sutures indented between the seeds, which are half embedded in the aril.

In many tropical countries the pulp of the pod is eaten by the poorer classes, and the pods are good fodder for animals. The tree, which has now spread all over the island of Guam, was probably introduced for the sake of its bark, which contains 25 per cent of tannin. $a$ In Mexico it is one of the principal sources of tan bark. Though widely cultivated in India, it is apparently not used in that country for tanning, as no mention is made of it as a tan bark in Watt's Dictionary of the Economic Products of India. Its wood is used in India for making carts, paneling of doors, and packing boxes. In Guam it is used only for fuel.

References:

Pithecolobium dulce (Roxb.) Benth. Hook. Lond. Journ. Bot. 3: 199. 1844.

Mimosa dulcis Roxb. Pl. Corom. 1: 67. t. 99. 1795.

\section{Pithecolobium saman.}

RAIN TREE.

LoCal NaMes.-Monkey-pod (Hawaiian Islands); Zamang (Venezuela).

A handsome tree with spreading branches and bipinnate leaves. Pinnæ 2 to 6 pairs; leaflets 2 to 7 pairs, obliquely ovate or obovate-oblong; corolla yellowish; stamens light crimson; flowers growing in globose clusters like crimson pompons. Its pods contain a sweetish pulp and are relished by cattle and horses. In Honolulu it is one of the favorite shade trees. A number of plants obtained from Mr. David Haughs were taken by me from Honolulu and planted in Guam. When I left the island they were in a thriving condition.

\section{REFERENCES:}

Pithecolobium saman (Jacq.) Benth. Hook. Lond. Journ. Bot. 3: 216. 1844.

Mimosa saman Jacq. Fragm. 15. t, 9. 1800-1809 (ex Ind. Kew.).

Inga saman Willd. Sp. Pl. 4: 1024. 1805.

Plantain. See Musa paradisiaca.

Plantain-leaf Fern. See Antrophyum plantagineum under Ferns.

Plátano (Spanish). See Musa paradisiaca.

Platitos (Guam, Philippines).

An ornamental shrub. See Nothopanax cochleatum.

Plum, seaside. See Ximenia americana.

Poaceae. See Grasses.

Podpod (Guam). See Piper sp.

Pogonia flabelliformis. Same as Nervilia aragoana.

Pogonia nervilia. See Nervilia aragoana.

Poinciana regia. See Delonix regia.

Poinciana pulcherrima.

Flower-Fence.

Family Caesalpiniaceae.

Local Names.-Caballero (Guam); Clavelina (Porto Rico); Gallito (Panama); Flor de Camaron, Chacalxochitl (Mexico); Peacock flower (India, Ceylon); Barbadoes Pride (West Indies).

A shrub 2.5 to 3 meters high, often used as a hedge plant, with terminal racemes of showy orange and crimson flowers. Branches with a few scattered prickles;

a See Reichel, Gerbstoffrinde aus Saipan, Tropenpflanzer, vol. 8, p. 687, 1904. 
leaves abruptly bipinnate; leaflets sessile, close, membranous, oblique-oblong; stamens much exserted; petals broadly spreading, on long claws; pod thin, flat, smooth, 6 to 8 -seeded.

Universally cultivated in the Tropies; its native country not clearly known. In Guam it is common in gardens and growing along fences. It remains in bloom all the year. The leaves are said to be purgative and have been used as a substitute for senna. In the West Indies a decoction of the leaves and flowers is used as a remedy in fevers. The wood makes excellent charcoal. In India ink is made from the charred wood.

References:

Poinciana pulcherrima L. Sp. P1. 1: 380. 1753.

Caesalpinia pulcherrima Swartz, Obs. 166. 1791.

\section{Poisonous plants.}

Among the plants containing poisonous prineiples may be mentioned the following:

Abrus abrus.-Kolales halom-tano; seeds.

Annona muricata.--Laguaná; root a fish poison, leaves anthelmintic.

Annona reticulata.-Anonas; leaves anthelmintic.

Annona squamosa.-Atis; seeds, leaves, and unripe fruit kill insects.

Areca cathecu. - Betel nut; active principle of nut anthelmintic.

Asclepias curassavica.-A suncion; juice anthelmintic.

Barringtonia racemosa. - Lañgāsat; seeds a fish intoxicant.

Cacara erosa.-Híkama; seeds stupefy fish.

Crinum asiaticum.-Piga-palayi; juice used in the East Indies as antidote for snake and arrow poisons, and after eating poisonous fishes.

Cycas circinalis. - Fadan; fresh seeds poisonous.

Erythrina indica.-Gabgab; juice of leaves anthelmintic.

Herpetica alata.-Acapulco; leaves and flowers used as a remedy for ringworm.

Jatropha curcas. - Tubatuba; seeds poisonous.

Lens phaseoloides. - Gogo; in Ceylon crushed leaves used for stupefying fish.

Leucaena glauca. - Tangantangan; when eaten by animals causes hair to fall out.

Manihot manihot.-Mandiuka; fresh root contains prussic acid:

Melia azedarach. - Paraiso; anthelmintic and insecticide.

Pancratium littorale.-Lirio; juice of bulb poisonous.

Pangium edule.-Rauél; seeds poisonous when fresh.

Polanisia icosandra. Same as Cleome viscosa.

Polanisia viscosa. Same as Cleome viscosa.

Polianthes tuberosa.

TuBerose.

Family Amaryllidaceae.

Local names.-Azucena, Amiga de noche (Guam); Nardo, Amiga de noche (Mexico).

Cultivated in pots and in the gardens of many of the natives.

ReFerences:

Polianthes tuberosa L. Sp. Pl. 1: 316. 1753.

Polygonaceae.

BuCKWHEAT FAMILY.

This family is represented in Guam by the following species and by Antigonon leptopus.

Polygonum sp.

A species of Polygonum called "mamaka" by the natives grows along the banks of streams and in marshy places. It is possibly $P$. barbatum $\mathrm{L}$.

Polypodium adnascens. Same as Cyclophorus adnascens.

Polypodium irioides. Same as Microsorium irioides. See Ferns.

Polypodium punctatum. Same as Microsorium irioides. See Ferns.

Polyporus. See Fungi.

Pomegranate. See Punica granatum 
Pomelo. See Citrus decumana.

Pondweed. General name for the species of Potamogeton.

Pontan (Guam).

Vernacular name for a coconut which has fallen to the ground.

Portlandia tetrandra. Same as Cormigonus mariannensis.

Portulaca oleracea.

Purslane.

Family Portulacaceae.

LOCAL NaMes.-Verdolaga (Spanish); Osuberi-hiyu (Japan).

This common weed is spread all over the world. It is sometimes eaten as a pot herb and is used medicinally. It is said to be antiscorbutic. Flowers inconspicuous, several together in terminal heads; sepals 2, fleshy. In Japan there is a variety (sativã) cultivated by the natives, which attains the height of $30 \mathrm{~cm}$. In the spring and summer months the leaves and stalks are eaten either raw or scalded.

REFERENCES:

Portulaca oleracea L. Sp. Pl. 1: 445. 1753.

Portulaca quadrifida.

Four-Leaved pUrslane.

Local Names. - Hierba de pollo (Spanish); Fiafiatuli (Samoa).

A small, delicate, prostrate, much-branched annual, creeping and rooting at the nodes, with numerous slender, glabrous stems; leaves numerous, opposite, $6 \mathrm{~mm}$. long or smaller, very nearly sessile, oval, subobtuse, fleshy; stipular appendages a ring of long white hairs; flower solitary, terminal, sessile, surrounded with long white hairs and an involucre of 4 leaves; sepals oblong-oval, obtuse, thin; petals 4 , lemonyellow, oval, ohtuse; stamens 8; style filiform, 4-cleft at apex; capsule acute; seeds twice the size of those of $P$. oleracea, rough, with small firm excrescences.

A delicate creeping plant, often minute, in dry situations, growing in cultivated ground; flowers open in the middle of the day only. Common on the sabanas of Guam. Sometimes used as a pot herb, either for food or as an antiscorbutic.

REFERENCES:

Portulaca quadrifida L. Mant. 1: 73. 1767.

\section{Portulacaceae.}

Purslane family.

The only representatives of this family in Guam are the two preceling species of Portulaca.

\section{Pot herbs.}

Among the plants used in Guam for golae (greens or pot herbs, Spanish "verdura)," are severel species of Amaranthus called "kelites," "kuletes," or "bledos;" Chenopodium album, also called "kelites" or "cenizo;" Indian mustard (Brassica juncea); purslane or "verdolaga" (Portulaca oleracea), and "chara" (Sesuvium portulacastrum).

The value of pot herbs or "greens" as a preventive and cure for scurvy has long been recognized, and there can be no question that such food is necessary from time to time to keep the human body in good condition. The value of this element in diet has been discussed in a paper by Mr. Frederick V. Coville. ${ }^{a}$

In addition to the plants above mentioned the natives of nearly all the islands of the Pacific eat the young leaves of the taro (Caladium colocasia), which must be thoroughly cooked to remove the acridity of their natural state. $b$ These leaves are either boiled like spinach or they are prepared with the expressed creamy juice of the coconut and baked in native ovens. In Samoa this dish is called "palusami."

Among the trees which furnish edible pods, leaves, and flowers are the marunggai, or horseradish tree (Moringa moringa), and the leguminous katúrai (Agati grandi-

"Coville, Some Additions to our Vegetable Dietary, Yearbook, U. S. Dept. Agr., 1895, p. 206.

$b$ See p. 69 . 
fora), the leaves and pods of which must be gathered when young and tender, and, like other green foods, must not be indulged in too freely, owing to their cathartic properties. The chemical composition of several green vegetables, including species of Brassica and Amaranthus, has been published by Mr. Walter C. Blasdale, who shows that the species of Amaranthus analyzed by him contains a much higher percentage of protein than the crucifers. $\alpha$

Several varieties of Amaranthus are cultivated in Bengal, the tender succulent tops of the young stems and branches of which are served as a substitute for asparagus. ${ }^{b}$

\section{Potamogetonaceae.}

PONDWEed FAMILY.

This family is represented in Guam by Potamogeton natans mariannensis, P. zizii, Ruppia maritima, and Halodule uninervis.

Potamogeton fluitans Gaudich., not Roth. Same as Potamogeton natans mariannensis. Potamogeton gaudichaudii Cham. \& Schlecht. Same as Potamogeton zizii.

Potamogeton mariannensis. See Potamogeton natans mariannensis.

Potamogeton natans mariannensis.

Floating PONDWEed.

Family Potamogetonaceae.

A submerged water plant with creeping rootstock; upper leaves floating, elliptical, somewhat pointed at each end, $5 \mathrm{~cm}$. long, one-half as broad, many-nerved, longpetioled; petiole flat; nerves conspicuous on both sides, but neither prominent nor sunken; peduncle terete, slender; flower spike cylindrical, slender, with flowers of the size of those of $P$. oblongus.

In rivulo aquae dulcis urbem Agana insulae Guajan e Marianis irrigante a celeberrimo Gandichaud lectus, ad $P$. nutantis tribum pertinet. (Chamisso \& Schlechtendal, Linnæa, vol. 2, p. 228.)

REFERENCES:

Potamogeton natans mariannensis (Cham. \& Schlecht.) Nolte; K. Schu. \& Laut.

Fl. Deutsch. Schutzgebiet. in der Südsee 162. 1901.

Potamogeton mariannensis Cham. \& Schlecht. Linnæa 2: 228. 1827.

Potamogeton zizii.

SHINING PONDWEED.

A species closely allied to $P$. Tucens and $P$. mucronatus. Stems slender, branching; floating leaves elliptic, many-nerved; petioles mostly short; submerged leaves mostly lanceolate or oblanceolate, thin, acute or cuspidate; stipules obtuse, 2-keeled; peduncles thicker than the stem; fruit obliquely obovoid, the face dorsally 3 -keeled; style short, blunt, facial.

This plant was collected by Gaudichand in the Agaña River. The growth of Potamogeton and other water plants is here so vigorous as to check the flow of the river, and it must be cleaned out periodically.

In rivulo dulcis aquae urbem Agaña in insula Guajan percurrente legit amicissimus Gaudichaud. (Chamisso and Schlechtendal, Linnaea, vol. 2, p. 200, 1827.)

REFERENCES:

Potamogeton zizii Koch; Roth, Enum. Pl. Germ. 2: 531. 1827.

Potat (Philippines). See Barringtonia racemosa.

Potato, sweet. See Ipomoea batatas.

Potato, white or Irish. See Solanum tuberosum.

Premna gaudichaudii.

FALSE ELDER.

Family Verbenaceae.

Local Names.-Ahgao, Ahgap, Ajgao (Guam); Sauco (Spanish). A shrub or small tree with puberulent young branches and flower panicles. Leaves

a Some Chinese regetable food materials, U. S. Dept. Agr., Off. Exp. Sta, Bull. No. $68,18: 9$.

${ }^{b}$ Firminger, Manual of Gardening for Bengal, ed. 4, p. 151, 1890. 
long-petioled, broadly ovate, shortly acuminate, quite entire, smooth on both sides; veins of young leaves puberulent at their axils on upper face, woolly on lower surface; terminal panicles corymbose, many-flowered; calyx short, cupuliform, subbilabiate, upper lip obscurely bidentate or entire, the lower distinctly acutely bidentate; corolla subequally 4 -fid, equaling the calyx tube; leaf $12.5 \mathrm{~cm}$. long, petiole $3.5 \mathrm{~cm}$. long; flowers small, calyx $2 \mathrm{~mm}$. long, stamens 4, didynamous; limb of corolla reflexed, stamens and pistil slightly exserted; drupe small, surrounded below by the calyx. Type specimen collected by Gaudichaud in Guam. Leaves imperfect. The wood of the ahgao is hard and durable, but knotty and often crooked. It is much used in construction by the natives of Guam. It is very much like the molave, or molavin, of the Philippines (Vitex geniculata), a large forest tree belonging to the same family. Like many other Verbenaceae the ahgao has medicinal properties. In Guam its bark steeped in water is used as a remedy for neuralgia. The tree grows in rocky places, and sometimes yields logs 4 meters long by $45 \mathrm{~cm}$. in diameter. Its inflorescence somewhat resembles that of the elder.

\section{REFERENCES:}

Premna gaudichaudii Schau. in DC. Prod. 11: 631. 1847.

\section{Premna mariannarum.}

FALSE ELDER.

A shrub or small tree. Leaves short-petioled, oval and subrotund, obtuse and very shortly acuminate or quite obtuse, rounded at base or somewhat cordate, entire, smooth on both sides, axils of the veins woolly on the lower surface, $5 \mathrm{~cm}$. long; petioles $12 \mathrm{~mm}$. long; flowers in small terminal, corymbose, panicles; calyx cupuliform, bilabiate, the upper lip very shortly truncate, the lower rounded, entire; corolla subequally 5-cleft, bearded, equaling the calyx tube; stamens exserted; calyx $2 \mathrm{~mm}$. long; branchlets, panicles, petioles of leaves, and veins on both sides subcanescent.

\section{REFERENCES:}

Premna mariannarum Schau, in DC. Prod. 11: 632. 1847.

Prickly pear. See Opuntia sp.

Pride of India. See Melia azedarach.

\section{Procris candolleana.}

Family Urticaceae.

Collected by Gaudichaud in Guam. Not further known; it is possibly Pipturus argenteus. $a$

Procris divaricata. Same as Pellionia divaricata.

Procris paniculata. Same as Schychowskya muderalis.

Procris pedunculata. Same as Elatostema pedunculatum.

Procris torresiana Endl. Same as Elatostema pedunculatum.

Psidium guajava.

Guava.

Family Myrtaceae.

Local NAMEs.-Abas (Guam); Bayabas (Philippines); Guayava, Guayaba (Spanish).

An introduced shrub or small tree, bearing the fruit from which the well-known guava jelly is made. Young branches pubescent; leaves short-petioled, opposite, entire, ovate or oblong, usually acuminate, glabrous or nearly so above, softly pubescent beneath, and with the principal nerves prominent; flowers large, white, 1 to several on a common peduncle, which grows from the axils of the leaves; calyx undivided at first, separating into 4 or 5 lobes when in flower; petals 4 or 5 , free; stamens many, forming a brush-like tuft; ovary 2 or more-celled with many ovules in each cell; fruit globose or pear-shaped, many seeded, seeds with hard testa. 
Indigenous to Mexico and other parts of tropical America, now spread throughout the warmer regions of the globe. In Guam, as in the Hawaiian Islands, it forms extensive thickets or patches of scrubby growth on abandoned fields and open places. It will not grow in the shade of the woods. The fruit is of good quality, but owing to scarcity of sugar on the island the natives do not utilize it much for making dulces. The wood is sometimes used for making tool handles and for fuel.

\section{REFERENCES:}

Psidium guajava L. Sp. Pl. 1: 470. 1753.

Psophocarpus tetragonolobus. Same as Botor tetragonoloba.

Psychotria herbacea. Same as Carinta herbacea.

Psychotria mariana.

Aploghating.

Family Rubiaceae.

Local NAmes.-Aploghating, Aplokhating (Guam).

A glabrous shrub or small tree with compressed branchlets and peduncles; leares ovate-oblong or obovate, rather obtuse, attenuate at the base, subcoriaceous, turning purplish on drying; stipules caducous; terminal cymes peduncled, shorter than the leaves, twice 3-divided; flowers sessile on the divisions of the inflorescence and terminating the branches; calyx with limb campanulate, truncate or obtusely dentate, or sometimes irregularly split; corolla short-campanulate, the hud obovate; berries red. Collected on the island of Guam by Haenke and described from type specimen in Haenke's collection. The wood is durable and is used in the construction of houses. It is included in the list sent by Governor Olive y Garcia to the captaingeneral of the Philippines.

REFERENCES:

Psychotria mariana Bartl.; DC. Prod. 4: 522. 1830.

Pteris. See Ferns.

Pua (Banda). See Areca cathecu.

Pu'a (Samoa). See Hernandia peltata.

Puah (Amboina). See Areca cathecu.

Puapua (Samoa). See Guettarda speciosa.

Puāvai (Samoa). See Jatropha curcas.

Pudding-pipe tree. See Cassia fistula.

Puga (Guam). See under Oryza sativa.

Pugua (Guam). See Areca cathecu.

Pugua machena (Guam). A climbing fern, Davallia solida.

Pummelo. See Citrus decumana.

Punica granatum.

Pomegranate.

Family Punicaceae.

Local Names. - Granada (Spanish); Dalima (Philippines).

A shrub or snall tree with oblong, obovate, or lanceolate entire leaves; cultivated in all warm countries for the sake of the refreshing pulp of its fruit. Flowers usually bright scarlet, with a leathery top-shaped calyx divided at the top into 5 or 7 valvate lobes; petals as many as the divisions of the calyx and alternating with them, or in double-flowered varieties numerous; stamens many, inserted around the mouth of the calyx; style long, hent, stigma capitate; fruit usually the size of an apple, globose, bearing the persistent calyx, many-celled, containing very many angular seerls, with coriaceous testa and watery outer coat containing a pelucid red juice of a pleasant acid flavor. A cooling sherhet is made from the juice which is greatly appreciated by those living in warm countries.

The hard rind of the fruit is astringent and in some countries is used in tanning and in dyeing. The bark is used as a tan and dye for leather, and the astringent 
root-bark as a specific for intestinal worms. The powdered rind is an excellent remedy in chronic diarrhea and dysentery.

Cultivated in many of the gardens of the natives.

REFERENCES:

Punica granatum L. Sp. Pl. 1: 472.1753.

Pupúlo, Pupulu (Guam). See Piper betle.

Pursaetha scandens. Same as Lens phaseoloides.

Purslane. See Portulaca oleracea and P. quadrifida.

Purslane, sea or seaside. See Sesuvium portulacastrum.

Putat (Malay). See Barringtonia racemosa and B. speciosa.

Puting (Guam). See Barringtonia speciosa.

Pyrethrum indicum and P. sinense. Same as Chrysanthemum indicum.

Pyrrhanthus littoreus. Same as Lumnitzera littorea.

Quamoclit quamoclit.

Cypress vine.

Family Convolvulaceae.

Local Names.-Cabello del angel (Guam); Cambustera (Cuba).

This pretty scarlet-flowered twining plant has escaped from cultivation and grows in many places on the island far from human habitations. It is also planted by the natives in their gardens and allowed to run along the fences of their inclosures.

References:

Quamoclit quamoclit (L.) Britton in Britton \& Brown, Ill. Fl. 3 : 22. 1898.

Ipomoea quamoclit L. Sp. Pl. 1: 159. 1753.

Quelites, Quiletes (Mexico, Guam). Same as kelites, kiletes, kuletes.

Quílulu (Guam). Same as kilulu; see Thespesia populnea.

Raguar (Guam, Caroline Islands). See Aleurites moluccana.

Rain tree. See Pithecolobium saman.

Ramalina. See Lichenes.

Ramie. See under Boehmeria tenacissima.

Rattan. See Ćalamus sp.

Rattlebox or Rattlepod. See Crotalaria.

Rauál or Rauwél (Yap, Caroline Islands). See Pangium edule.

Rauwolfia. See Ochrosia mariannensis.

Red-flowered Mangrove. See Lumnitzera littorea and L. pedicellata.

Red pepper. See Capsicum annuum.

Redwood, Red sandalwood (India). See Adenanthera pavonina.

Reed. See Trichoon roxburghii.

Reseda (Central America). See Lawsonia inermis.

Resin.

The principal resin-yielding tree on the island is the daog, or tacmahac tree (Calophyllum inophyllum). See last name.

Rhamnaceae.

BUCKTHORN FAMILY.

This family is represented in Guam by the indigenous gasôsô (Colubrina asiatica) and the introduced jujube tree or manzanas (Zizyphus jujuba).

Rhizoclonium. See under Algæ.

Rhizophora mucronata.

Four-Petaled mangrove. Plate lixiv.

Family Rhizophoraceae.

Local naves.-Mangle hembra (Guam); Tongo (Samoa); Dongo (Fiji); Bakao, Bakauan, Bakawan (Philippines). 
A large shrub or moderate-sized tree growing on tidal muddy shores and saltwater estuaries, with a spreading head and aerial roots descending -into the mud from the stem and branches. Branchlets marked with close scars of fallen leaves and stipules; leaves opposite, entire, thick, with large interpetiolar, deciduous stipules inclosing the buds, oval, acute at both ends, usually with a strong brown point at the apex, glabrous, bright green, pale beneath and dotted with minute red spots, 11.5 to $12.5 \mathrm{~cm}$. long; petiole 12 to $75 \mathrm{~mm}$. long, stout; stipules $5 \mathrm{~cm}$. long, glabrous, soon falling; flowers moderate-sized on short, very thick peduncles, usually 2 pairs together at the end of stout peduncles from axils of leaves of the same year, each flower supported by two hard, thick connate bracts; calyx segments 4, persistent, enlarged in fruit, pale yellow; petals 4 , white, narrow, obtuse, curved, thick, induplicate, hairy within; stamens 8 (or 12), anthers nearly sessile, with numerous cells: ovary half-inferior, 2-celled, with two ovules in each cell; fruit ovate-conical, pendulous, slightly rough, dark brown, crowned by the reflexed limb of the calyx, 1-seeded by abortion; seeds germinating on the tree, the radicle elongating and perforating the apex of the fruit, attaining a length of $45 \mathrm{~cm}$. or more before falling into the mud.

The fruit of this species is not eaten in Guam. In some countries it is prepared by boiling, and ashes are applied to neutralize the bitter taste, after which it is baked and eaten. The bark is used for tanning, and yields a chocolate-colored dye. The sap is used for preserving fish nets. The wood is excellent for fuel, especially for baking. On the Malay peninsula mangrove swamps are sometimes leased to woodcutters, who supply fuel to steamers and factories. The heartwood is of a dark red color, with dark rings of growth, and is durable, very hard, and heavy. It is, however, very brittle, and warps and cracks so easily as to unfit it for cabinet use. The sapwood is of a bright yellow color. The wood is durable in water and underground, and would be suitable for foundations of bridges and wharves.

Mangrove swamps occur in Guam at the mouths of many streams, especially on the shores of the harbor of San Luis de Apra. The native name as given by Gaudichaud, "tonbog" or "tounboug," is obsolete and only the Spanish name as given above is applied to it. It is interesting to note that the Visayan name of an allied species given by Padre Blanco, "tontog," is practically identical with the vernacular name for this species, "tongo," on the remote islands of Samoa, where in like manner we have "niu" for "niyog" (coconut), and "ifilele" for "ifil" (Intsia bijuga). This species is easily distinguished from Bruguier gymorhiza by its 4-parted flowers.

REFERENCES:

Rhizophora mueronata Lam.; Poir. Encyc. 6: 189. 1804.

\section{Rhizophoraceae.}

MANGROVE FAMILY.

The true mangroves are represented by Bruguiera gymmorhiza and Rhizophoru mucronata.

Ribbon fern. See Vittaria elongata.

Rice. See Oryza sativa.

Ricinus communis.

CAstor-Bean.

Family Euphorbiaceae.

LoCAL XAMEs._-Agaliya (Guam); Tañgantañgan, Lansina (Philippines); Lamapapālangi (Samoa).

This well-known plant was introduced in early times. It has spread over the island and is now well established. The oil obtained from its seeds is used medicinally as a purgative and is much milder in its action than the allied tubatubu (Jatropha curcas), which is very drastic. The best oil is expressed from decorticated seeds without the assistance of heat. In India a lamp oil is made from a large-seeded rariety by boiling or slightly roasting the seed, drying in the sun, remoring the 


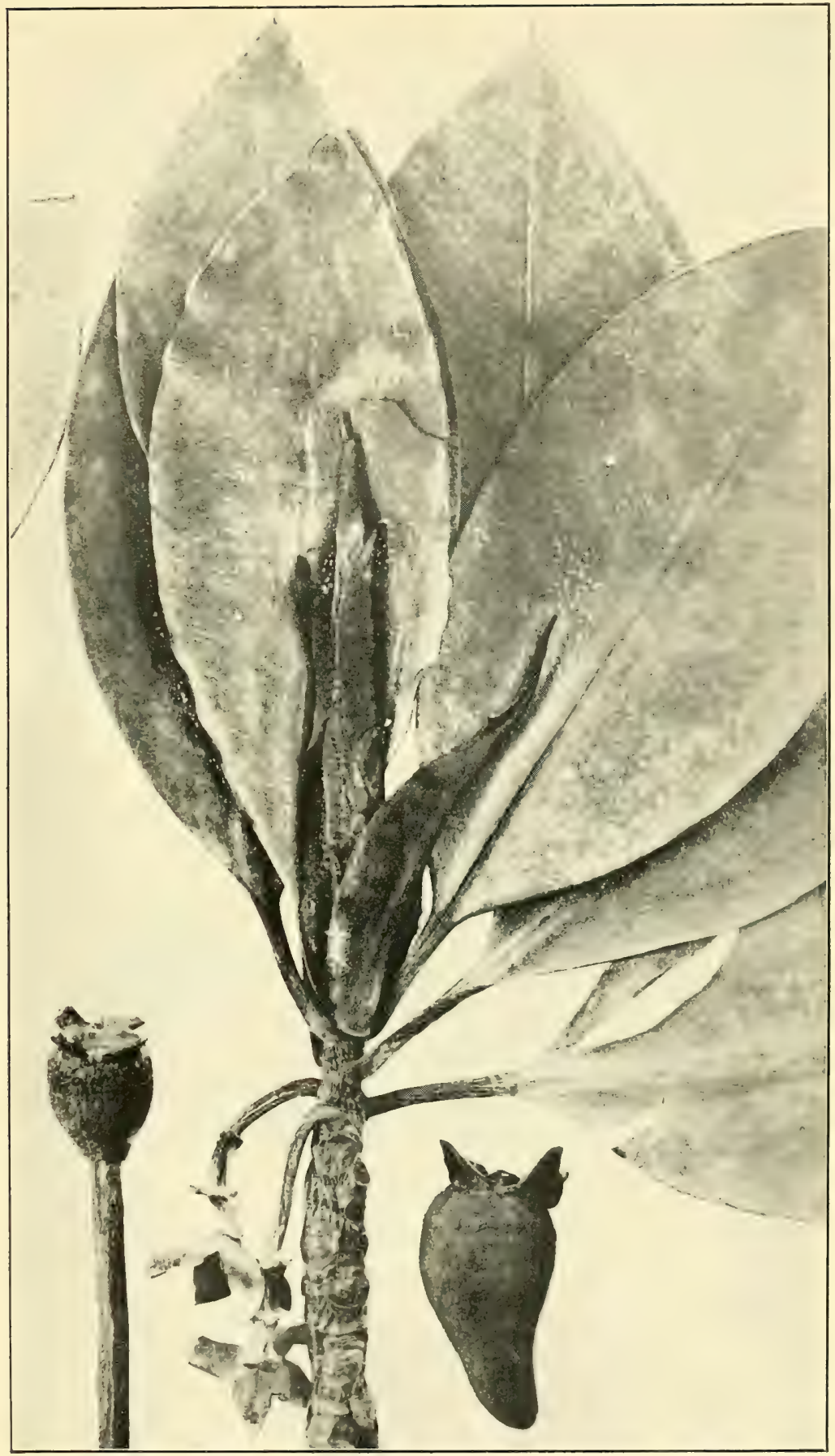

Rhizophora mucronata, the four-petaled mangrove. Natural size. 

husks, pounding it in a mortar, and removing the oil by absorbing it with a cloth placed in the pulp and then squeezed into a pot, or by boiling the pulp in water and skimming off the oil. Oil prepared in this way is also used as a lubricant." The seeds of commerce are sometimes confused with those of the physic nut, Jatropha curcas

\section{REFERENCES:}

Ricinus communis L. Sp. Pl. 2:1007. 1753.

Rima (Guam, Philippines). See Artocarpus communis.

Ringworm bush. See Herpetica alata.

Rosa de Francia (Philippines). See Asclepias curassavica.

Rosa de Japon (Spanish). See Chrysanthemum indicum.

Rosa laurel (Spanish). See Nerium oleander.

Rosaceae.

Rose FAMILY.

With the exception of two introduced roses, Rosa damascena and $R$. indica, cultivated in the gardens of the natives, this family is without representatives in Guam. It is interesting to note that the rose-aphis and the rose-beetle, which infest roses in so many countries, are thus far absent from Guam. The small Rosa indica is a constant bloomer. Plants raised by me from cuttings and kept in pots were seldom out of bloom. They were, however, scarcely at all fragrant. The other species, which grows to a height of 120 or $150 \mathrm{~cm}$., having stout, rigid stems, is delightfully fragrant and belongs to the same division as our magnificent "American Beauty."

Rose. See under Rosaceae.

Rose-mallow, changeable. See Hibiscus mutabilis.

Rose-mallow, scarlet. See Hibiscus rosa-sinensis.

Rosewood, Polynesian.

A name sometimes applied to Thespesia populnea, a common strand tree in Guam.

Rubber.

Among the plants producing milky juice of the nature of rubber may be mentioned the breadfruit, Artorarpus communis, the fertile variety of which, called "dugdug," grows to an enormous size in the forests of Guam, and the fago (Ochrosia mariannensis), a medium-sized tree belonging to the Apocynaceae, growing near the strand. The latex of the breadfruit soon hardens on coming in contact with the air. From prehistoric times it has been used by the natives for paying the seams of their canoes and for stopping leaks in water troughs. For other uses see under Artocarpus communis.

\section{Rubiaceae.}

MADDER FAMILY.

Among the indigenous Rubiaceae are Morinda citrifolia, which yields an important dyestuff, Cormigonus mariannensis, a small tree with large white flowers, Psychotria mariana, and Carinta herbacea, a low, creeping forest plant, having white flowers and red berries. Coffee has been introduced and grows in perfection.

Ruellia fragrans. Same as Ambulia fragrans.

Ruppia maritima.

SeA-Grass.

Family Potamogetonaceae.

A plant growing in brackish water, like fine, fibrous grass. The stem is filiform, branched, submerged; leaves capillary, sheathing at the base; flowers 2 or several, near the tip of the axillary peduncles; minute, naked, bisexual; stamens 2 , of 2 anther-cells, distinct; ovaries 4 (3 to 6 ) at length stalked on a large carpophore; embryo ovoid.

\section{REFERENCES:}

Ruppia maritima L. Sp. Pl. 1:127. 1753.

$a$ See Hicks, Oil-producing seeds, Yearbook U. S. Dept. Agr. 1895, p. 190. 
Rutaceae.

RUE FAMILY.

There are no indigenous Rutaceae. In addition to the various species of Citrus, the "lemoncito" (Triphasia trifoliata) has been introduced, and in many places forms dense, impenetrable thickets.

Rynchospora aurea. Same as Rynchospora corymbosa.

Rynchospora corymbosa.

BEAK RUSH.

Family Cyperaceae.

A sedge widely distributed in the Tropics, collected in Guam by Haenke in 1792 and Lesson in 1828. Common in moist places, especially on the borders of rice fields. It has a leafy 3-cornered stem 60 to $90 \mathrm{~cm}$. high and very many clustered spikelets at the ends of the branches of large decompound umbels.

REFERENCES:

Rynchospora corymbosa (L.)

Scirpus corymbosus L. Cent. Pl. 2: 7.1756 (ex Ind. Kew.); Amoen. Acad. 4: 303.1756.

Rynchospora aurea Vahl, Enum. Pl. 2: 229. 1806.

Sabana vegetation. See Savannas.

Saber bean. See Canavali ensiforme.

Sables (Philippines). See Asplenium nidus under Ferns.

Sabotan (Philippines). See Pandanus tectorius.

Saccharum floridulum. Same as Xiphagrostis floridula.

Saccharum officinarum.

Sutgar cane.

Family Poaceae.

Local Names.-Caña dulce, Caña de azúcar (Spanish); Tupu, Tupo (Guam); Tubó, (Philippines); Tubu, Tibu mirá (Malay Archipelago); Tébu (Java); Dovu (Fiji); Tolo (Samoa); To (Tahiti, Easter Island); Fari (Madagascar).

Sugar cane was one of the food staples of the aborigines before the discovery of Guam. Its vernacular name is etymologically identical in many islands of the Malay Archipelago, the Philippines, and Polynesia; and the variety in Guam from which the natives make sugar, with short intemodes and of a yellow color, is like that found by Captain Cook in Tahiti. Another variety, called "caña morada" by the Spaniards, of a purple color, is also grown on the island, but it is too watery and not sweet enough for sugar-making. The variety "amarilla" grows to the height of 7 or 8 feet; the "morada" grows much higher.

The cultivation of sugar cane is not now carried on so extensively as formerly, as the manufacture of sugar demands no little labor, and requires the use of animals and machinery, and imported sugar can be bought of the traders at a comparatively low price. There are families, however, who retain the customs of their ancestors, holding it to be wrong to buy anything which they themselves can make. These not only make their sugar from cane or from the sap of the cocoanut, but evaporate sea water in iron kettles to get their salt, counting as nothing the labor of their families or the value of the fuel consumed.

The climate of Guam is well adapted to the cultivation of sugar cane, and in many low-lying situations, where it is not very wet, the soil seems well suited to it. Though the cost of a sugar mill is considerable, yet one mill would answer for the crops of many farms, and the natives could carry their cane to the mill just as with us the farmers carry their wheat or corn.

The cane is propagated by cuttings, consisting of two or three joints of the upper part of the stem. These are selected from vigorous, healthy plants. They are placed in the ground with only an inch or two of the cutting projecting above the surface. In about two weeks from planting the "eyes" at each node will seurl forth shoots, and roots will grow from the nodes themselves. As the shoots develop, the parent 
stem decays and the young plants produce roots of their own. In Guam the plants mature in about nine months, when they are cut close to the ground and the leaves stripped off, spread over the surface of the field, and burned. Ratoons (retonos) spring up from the old stoles, or "stools," which yield more abundantly than the original plants. The operation is repeated, and a third crop, perhaps a little less liberal than the second, is gathered. After the third crop, when the cane shows evidence of deterioration, the old stalks are uprooted and burned and the land cleared. As sugar cane soon exhausts the soil, the land would become "cansado," or barren, if measures were not taken to restore its fertility. It is therefore allowed to lie fallow for several years. In some countries the planters grow indigo or other leguminous plants between the rows when the canes are first planted and turn them under while they are still green and succulent. $t^{\text {Th }}$ This process has a very beneficial effect. It could easily be practiced in Guam, where indigo grows spontaneously, together with a number of cassias and other nitrogen-gleaning leguminous plants. In Mauritius rotation of crops is practiced. In that island, after the land has produced cane for two seasons, it is planted in maize, arrowroot, mandioca, or peas, allowing a period of three years between the cane crops. In Guam monggos (Phaseolus mungo) may be used for this purpose.

Cane does not thrive either on the elevated mesa or in situations where only pure sand is found. This is owing, in the former case, to the porosity of the coral which forms the subsoil, allowing the water to filter through immediately after each rain. Don Felipe de la Corte, who, during his administration as governor, tried earnestly to develop the resources of the island, hoped to succeed on the mesa with the "morada" variety, thinking that it might there "prove less watery and sweeter, as in the case of the sweet potato and other plants grown there, as compared with the same plants grown on the lowlands." $b$ He accordingly started a cane plantation on the mesa, on the finca (farm) belonging to the Colegio de San Juan de Letran; but his experiment proved a failure. Its site is now occupied by cornfields, and the foundations of the sugarhouse alone remain as a monument to the zeal of this good governor.

After the cane has been gathered and stripped of its leaves it is carried to the mill (trapiche), in which it is crushed between rollers. The juice is then strained and lime is added to purify it. The lime nentralizes any acils resulting from fermentation and combines with any carbonates present, forming an insoluble precipitate, which carries down with it the impurities in the juice. The juice is then boiled in kettles, as in the case of the sugar made of coconut sap, and the scum is removed as it rises to the surface. Only the crude, brown, moist sugar, called "panoche," is made in Guam. The natives are very fond of it and use it in various ways to make sweetmeats. The sirup which drains from the panocha is used as molasses, or "almibar," and serves instead of sugar for preserving fruit.

Notwithstanding the advantages which Guam offers as to soil and climate and the absence of enemies of sugar cane, it is not probable that the production of sugar on the island would be profitable from a commercial point of view. For, in order to compete with sugar produced in other parts of the world, its cultivation and manufacture would have to be carried on on a large scale, and would necessitate the employment of labor which it is impossible to get on the island.

REFERENCES:

Saccharum officinarum L. Sp. Pl. 1:54. 1753.

Sadyiafi. See Sayiafi.

Sagása (Philippines). See Lumnitzera littorea.

Sagasaga (Philippines). See Abrus abrus. 
Sago. See Coelococeus amicarum and Cycas circinalis.

Sagu (Guam). See Maranta arundinacea.

Saguerus gamuto. Same as Saguerus pinnatus.

\section{Saguerus pinnatus.}

BLACK-FIBER PALM.

Family Phoenicaceae.

Local Names.-Cabo negro (Guam, Philippines); Gomuto (Malay Archipelago).

A large palm with unequally pinnatisect leaves and a stout trunk, which is clothed above with the fibrous sheaths of dead leaves. Segments of the leaves grouped in fascicles of 4 or 5 , linear, sword-shaped, 2-lobed, or variously dentate at the apex, white or silvery beneath; mid-veins prominent; nerves parallel; margins recurved at the base, and one or both of them auricled, the lower auricle the longer; petiole plano-convex with spiny margin; sheaths short, reticulate-fibrous, the margin crenate; spadix large, with short, reflexed peduncle and elongated, slender, pendulous branches; spathes numerous, attached to the peduncle, deciduous; bracts and bractlets broad; flowers brownish, fruit a yellowish brown 3-seeded drupe, of the size of a small apple, very acrid. The stem, when young, is entirely covered with sheaths of fallen leaves, and black horse-hair like fibers, which issue in great abundance from their margins; but as the tree increases in age, these drop off, leaving a columnar stem or trunk. In the Malay Archipelago the thickest fibers are used by the natives as styles for writing on other palms. The finest fibers are known in Eastern commerce as "gomuto" or "ejoo" fiber, and are much used for making strong cordage, particularly for cables and standing rigging of ressels, whence the name "cabo negro," applied to the tree in the Philippines. They are not pliable enough for running rigging or for fine cordage. They need no preparation but spinning or twisting. No ropes of vegetable fiber are so imperishable when subjected to repeated wetting as those made of cabo negro fiber. At the base of the leaves there is a woolly material used in calking ships and stuffing cushions.

The saccharine sap of this palm in the Malay Archipelago is used for making toddy and sugar. This is obtained in great abundance by cutting the spadices of the flowers in the same way as those of the coconut palm are cut in Guam for the same purpose. (See Cocos nurifera). When fresh the sap is like sweet cider; by fermentation it becomes intoxicating, and is then distilled into a rum or brandy resembling the aguardiente of Guam.

The cabo negro has been introduced into Guam from the Philippines. It grows well, but it has been planted in only one or two spots on the island. At Aniguag, a village between Agaña and Punta Piti, there is a fine specimen on the inland side of the road.

REFERENCES:

Saguerus pinnatus Wurmb, Verh. Batav. Gen. 1: 351. 1779.

Arenga saccharifera Labill. Mem. Inst. Par. 4: 2091801 (ex Ind. Kew.).

Saguilalá (Philippines). See Cordyline terminalis and Phyllaurea variegata.

Saguing (Philippines). See Musa paradisiaca.

Sagus amicarum. Same as Coelococcus amicarum.

Sakate (Guam). General name applied to grasses and foreign plants.

Salai maya (Philippines). "Sparrows-nest." See Dactyloctenium aegyptiacum.

Sambag, Sambagui, Sambalagui (Philippines). See Tamarindus indica.

Sampagas (Phllippines). See Jasminum sambac.

Sampagita (Guam). See Jasminum sumbac.

Sampalok (Philippines). See Tamarindus indica.

Sandalwood, false. See Ximenia americana.

Sandalwood, red. See Adenanthera pavonina. 
Sand-binding plants. See Strand plants.

Sandia (Spanish). See Citrullus citrullus under Gardens.

\section{Sandoricum indicum.}

Santor. Wild MANGOSTEEN.

Family Meliaceae.

Local NaMes. - Santol (Guam, Philippines, Singapore); Santor (Malayan); Wild mangosteen (India); Thitto (Burma).

An evergreen tree growing in the Philippines, the Malay Archipelago, and the East Indies. The young shoots and panicles are tawny-velvety; leaves trifoliolate; leaflets tawny-pubescent along veins on lower surface, elliptic, or ovate-orbicular, shortly acuminate or apiculate, base unequally obtuse; flowers clustered, subsessile in ample, much-branched axillary panicles, small, yellowish, sweet-scented; calyx 5-toothed, short, pubescent; petals 5, linear; stamens 10, combined into a tube; stigma divided into 5 lobes; fruit about the size of an orange, containing 5 one-seeded nuts.

The fruit has a fleshy acid pulp. It may be eaten raw and makes very good dulces, but has a peculiar odor. In Manila it is sold on the streets and served at hotel tables. The root, bruised with vinegar and water, is said to be a good remedy in diarrhea and dysentery. $a$

This tree has been introduced into Guam from the Philippines, but has not yet become well established. A fine tree is growing on the ranch of Don José de Leon Guerrero, in the locality called Lalo. It is a native of Burma and has spread through southern India, the Philippines, and many other tropical countries. The wood when burned gives forth an aromatic odor. It is durable and is suitable for the construction of houses and boats. The heartwood is red and close-grained, and takes a fine polish.

\section{REFERENCES:}

Sandoricum indicum Cav. Diss. 7: 359. t. 202, 203. 1789.

San Francisco (Guam, Philippines).

Name applied to several ornamental foliage plants. See Phyllaurea variegata and Graptophyllum pictum.

Sansevieria zeylanica. Same as Cordyline hyacinthoides.

Santa Helena (Spanish). See Leucaena glauca.

Santa Maria, Palo de (Spanish). See Calophyllum inophyllum.

Santa Maria, Yerba de (Spanish, Guam, Philippines). See Artemisia vulgaris.

Santa Rosa, hierba de (Mexico). See Antigonon leptopus.

Santol (Guam, Philippines, Singapore). See Sandoricum indicum.

Santor (Malayan). See Sandoricum indicum.

Sapindaceae.

SOAPBERRY FAMILY.

The only representatives of this family in Guam known to me are the introduced balloon vine (Cardiospermum halicacabum) and Dodonaea viscosa, a plant widely spread in the Tropics.

Sapodilla or Sapodilla plum. See Sapota zapotilla.

Saponaceous plants. See Detergents.

Sapota zapotilla.

SAPODILLA.

Family Sapotaceae.

Local Names. - Chico (Guam); Chico, Zapote chico, Zapotillo chico (Philippines); Níspero (Spanish West Indies); Nis-berry, Nees-berry, Nase-berry (British West Indies); Brei-apfel (German); Sapotille (French).

A handsome evergreen tree with milky juice bearing a fruit shaped like an apple, cultivated extensively in the Tropics. Leaves thick and glossy, clustered at the

a Watt, Economic Products of India, vol. 6, Pt. 2, p. 458, 1893,

$9773-05-24$ 
extremities of the branches, elliptic-oblong, acute; primary veins thick, petioles downy; flowers whitish, pedicellate in the axils; calyx segments 6 , in 2 distinct series; corolla 6-lobed. The fruit is a little larger than an egg. It is covered by a rough brown skin and contains a yellowish pulp with 4 or 5 black seeds. It is not eaten until thoroughly ripe, when it is sugary and very sweet.

This species is allied to the star-apple of the West Indies (Chrysophyllum crinito). It was introduced into Guam about thirty years ago. The few trees now growing on the island appear to thrive, but they seldom bear fruit. A fine tree grows in San Ramon, near the southern boundary of Agaña, opposite the house of Don José Herrero. In the markets of Manila the fruit is common. In the United States the cultivation of this tree is limited to southern Florida. The tree yields a latex, which is boiled down until it assumes the consistency of gutta-percha, to which it is allied. It is called chicle in Mexico, and is the basis of the chewing gum so widely used in the United States.

References:

Sapota zapotilla (Jacq.) Coville.

Achras sapota L. Sp. Pl. ed. 2. 1: 470. 1762. Not Achras zapota L. Sp. Pl. 2: 1190. 1753.

Achras zapota zapotilla Jacq. Select. Stirp. Am. Hist. 57. 1763.

The genus Achras (L. Sp. Pl. 2: 1190. 1753; L. Gen. Pl. ed. 5.497.1754) was based by Linnæus on Plumier's genus Sapota, but only one of Plumier's two species was enumerated by Linnæus in 1753. This species, Achras zapota, being the only Achras in the first edition of Linnæus' Species Plantarum, is the type of that genus. An unfortunate confusion of names was introduced by Linnæus in the second edition of his Species Plantarum, in 1762, when he changed the name of his Achras zapota of 1753 to Achras mammosa, transferring the former name, Achras zapota, to another species under a modified spelling - tchras sapota. The nomenclatorial misunderstandings thus originated are easily and definitely dispelled by an application of the rule of priority and the principle of generic types. The name Achras zapota is restored to its original use, and since the serond species, called Achas sapota, does not belong to the same genus as the first, a new generic name must be found. This nomenclatorial racancy is filled by Sapota, published by Miller, Gard. Dict. ed. 7. 1759, who includes both species, hut his first and the type of the genus is the one described above. The specific name, sapota, is not tenable on account of the earlier Achras zapota of 1753 , and as Miller did not propost a hinomial name for the species, the subspecific name zapotilla, proposed by Jacquin in 1763, is adopted.-Frederick V. Coville.

Sapotilla plum. See sopota zrpotilla. In Guam and the Philippines it is called "chico."

Sappan-wood. See Biancaea sappan.

Sarása (Philippines). See Graptophyllum pictum.

Saromo (Philippines). See Achyranthes aspera.

Saucer leaf. See Nothopanax cochleatum.

Sauco (Spanish). See Premna gaudichaudii.

Savanna plants.

The upland regions deroid of forest growth are known in Guam as "sabanas" or "savannas." The highest mountains of the island scarcely exceed 1,000 feet in height, and there is no distinctive vegetation on the high land. The soil consists chiefly of red clay, which is impervious to water and is incapable of drainage. Among the plants gruwing there are a number of strand plants and marsh plants which love the smu and will not grow in shaded localities. MIost of the savannas are covered with a growth of sword-grass or "neti" (Xipheagrostis floridula), with a 
sparse sprinkling of ironwood (Casuarina erpuisetifolia). Among the ferns are Cileichenia dichotoma, Blechnum orientale, Odontosoria retusa, Pteris biaurita, Pteris marginata, and Lygodium scandens. The coarse labiate Hesosphatum capitatum ("batunes"); Clossigyne tenuifolia, a composite like Bidens; and the yellow-flowered stemmodontia biflora and S. canescens occur, the last with thickly canescent leaves. Among the shrubs are Lobelia koenigii and Pemphis acidula, and the grasses include Dimeria chloridiformis, a small variety of Echinochloa colonem, Panicum distachyum, and Centotheca leppaced. The little yellow-flowered Hypoxis aurea grows on the mountains back of Agaña, and on Santa Rosa are patches of Lycopodium cernuum.

Sayafi or sayiafi.

An urticaceous shrub or small tree resembling Boehmeria. Collected by Gaudichaud but not identified. Also written "i sedyiafi," "i seyafi."

Scaevola koenigii. Same as Lobelia koenigii.

Scaevola velutina. Same as Lobelia koenigii.

Schizophyllum. See Fungi.

\section{Schychowskya interrupta.}

\section{Family Urticaceae.}

Local names.-Palilalia (Guam); Mangeso (Samoa); Salato-nithoro (Fiji).

An annual nettle-like herb with deep green, long-petioled alternate leaves, which are 3 -veined at the base, and clusters of small green unisexual flowers borne on long slender peduncles. Stem 60 to $120 \mathrm{~cm}$. high, erect, flexuous, branched, furrowed; whole plant more or less covered with scattered stinging hairs; leaves 6 to $9 \mathrm{~cm}$. long, broadly ovate, acuminate, coarsely crenate-serrate, membranous, base cuneate, rounded or cordate, 3 to 5 -veined, lateral veins 3 to 5 pairs; petiole long, very slender; stipules connate in pairs; flowers in cymes or spikes which are very variable, 25 $\mathrm{cm}$. long, bearing rather distant pedicelled clusters of minute flowers; flower branches short, or long and very slender; male sepals 4, concave; pistillode minute; female flower with pedicel decurved, swollen above; achene cordate, compressed, keeled on one side, the keel decurrent on the pedicel. Common in cultivated fields and waste places. A weed widely distributed throughout the East Indies, China, Abyssinia, and the Pacific islands. Easily distinguished from the following species by its acuminate leaves and the hairs on the stem and leaves. Although this plant bears a bad reputation in Fiji, and in Samoa, where its common name signifies "stinging," yet in Guam it is comparatively harmless. It bears a close resemblance to $S$. aestuans (Fleurya aestuans Gaudich.), which in Porto Rico is called "picapica."

\section{REFERENCES:}

Schychouskya interrupta (L.).

Urtica interrupta L. Sp. Pl. 2: 985.1753.

Fleurya interrupta Gaudich. Bot. Freyc. Voy. 497. 1826.

The type species of Fleurya belongs to the earlier genus Urticastrum, and the name Fleurya must therefore be abandoned.

\section{Schychowskya ruderalis.}

An annual glabrous herb with leaves 3 -veined at the base. Leaves alternate, obtuse, truncate, or subcordate at the base, ovate, scarcely acuminate, coarsely crenate-serrate or crenate, 2.5 to $10 \mathrm{~cm}$. long; flowers unisexual, in androgynous clusters which are shorter or longer than the petiole; tufts loosely flowered, approximate; pericels not dilated; male flowers 3 to 5 -sepaled; stamens 3 to 5 , inflexed in bud; pistillode small; female flowers with 4-lobed or 4-parted perianth, posticous lobe largest; ovary oblique, decurved, style subulate, very short, ovule erect; achene half inclosed in the persistent perianth, obliquely ovate, compressed, gibbous, pericarp membranous, endosperm scanty, cotyledons broad, radicle short, straight. 
Collected in Guam by Gaudichaud. This plant is also found in Java, Celebes, New Guinea, Kaiser Wilhelmsland and the Marshall Islands.

REFERENCES:

Schychowskya ruderalis (Forst.) Endl. Ann. Wien. Mus. 1:187. t. 13.1836.

Urtica ruderalis Forst. f. Prod. 66. 1786.

Fleurya ruderalis Gaudich. Bot. Freyc. Voy. 497. 1826.

Scimitar pod. See Lens phaseoloides.

Sciophila torresiana. Same as Elatostema pedunculatum.

Scorpion weed. See Heliotropium indicum.

Screwpine or screwpalm. General name for the species of Pandanus.

\section{Scrophulariaceae.}

Foxglove Family.

This family is represented in Guam by three low, herbaceous, water-loving plants, the fragrant Ambulia gratioloides and A. fragrans, called "guegue" or "gégé" (pronounced "gaygay"), and the fleshy creeping, blue-flowered water-hyssop, Bacopa monniera (Herpestis monniera).

\section{Sea-beans.}

Those found in Guan are: Lens phaseoloides, the scimetar-pod bean called "gayê," "lóduson," or "bayog;" Stizolobium giganteum, the ox-eye bean of the Pacific; Canavali obtusifolium, a sncculent, glabrous creeper growing on the strand; and Guilandina crista, the gray nicker-nut, or "pakao" of the natives. See the scientific names.

Sea-coast laburnum. See Sophora tomentosa.

Sea daffodil. See Pancratium littorale.

Sea-grass. See Ruppia maritima.

Sea-island cotton. See Gossypium barbadense.

Sea purslane. See Sesuvium portulacastrum.

Seaside bean. See Canavali obtusifolium.

Seaside plum. See Ximenia americana.

Seaweeds.

See Algs and Halophila ocalis, the latter a flowering plant collected in Guam and figured by Gaudichaud.

Seboyas (Guam). See Allium cepa and Gardens.

Sedges. See Cyperaceae.

Sedyiafi, Seyafi, or Sedyafo.

Improper sivelling of the name of an urticaceous plant, "Sayafi," or "Sayiafi."

Sedyaíhagon or Seyaíhagon (Guam). See Nervilia aragoana.

Seguidillas (Spanish). See Botor tetragonoloba.

Senna. See Cassia.

Sensitive joint vetch, Indian. See Aeschynomene indica.

Sensitive plants.

The only plant remarkable for its irritability is Averrhoa carambola, a tree belonging to the Oxalidaceae, called "bilimbines" by the natives.

Sesame. See Sesamum orientale.

Sesamum indicum. Same as Sesamum orientale.

Sesamum orientale.

Sesame. Benne.

Family Pedaliaceae.

Local xımes.-Ajónjoli (Spanish); thónholi (Guam); Liñáá, Loñgá, Lañgis, Leñgnga (Philippines); Gingili, Gingelly (E. Indies); Til (Bengal).

An anmual plant which has been introduced into Guam, and is cultivated in some 
of the gardens of the natives for the sake of its oily seeds. The axillary tubular flowers have a 5-cleft calyx and a 5-parted corolla, the lowest lobe of which is prolonged; stamens 4 (2 pairs of unequal length), with the rudiment of a fifth; capsule oblong, quadrangular, 2-valved, many-seeded.

In Guam this plant is not of much economic importance. The seeds yield an abundance of fixed oil, which is clear and nearly tasteless, and may be used like olive oil. The best oil for food purposes is expressed from the cold seed. $\iota$ The parched seeds are used in many countries to give a flavor to cakes, sweetmeats, and salads, and when parched and pounded they are made into a savory soup.

One of the chief advantages of this plant consists in its quick return of produce. It does not thrive so well in moist tropical countries where the rainfall is continuous as in regions where the rainfall is regular and not excessive, or where the crop can be irrigated. It will not grow in localities incapable of drainage, but thrives in alluvial sandy soil. The seed is sown at the beginning of the rainy season. The plant blooms in two months and at the end of three or four months the seed is ripe. The plants are then cut or pulled up and piled in heaps until the leaves have shriveled and fallen off. They are then hung up to dry in the sun. The pods burst open and the seeds are allowed to fall on mats or cloths placed to catch them. The bunches are also beaten so as to cause the remaining seed to fall. The seeds may be hulled by gently pounding them in a wooden mortar with a wooden pestle. The hulls contain a yellow coloring matter. The kernels are white and tasteless. When parched they have a nutty flavor. A very good candy is made by melting sugar, as for peanut brittle, pouring it in shallow pans, and sprinkling over it sesame seed. The heat of the melted sugar is sufficient to parch the seeds and to give them a rich aromatic flavor. In South Carolina, where sesame is cultivated by the negroes as a catch crop in cotton fields, candy of this kind is made by the confectioners.

Three varieties are recognized, distinguished by the color of the seeds. Yellow and white sesame seeds are used in Japan for oil-making, while the black seeds are used for cooking, either whole or ground into a coarse powder. $b$

REFERENCES:

Sesamum orientale L. Sp. PI. 1: 634.1753.

Sesban or Sesbania grandiflora. See Agati grandiflora.

Sesuvium portulacastrum.

SEASIDE PURSLANE.

Family Aizoaceae.

Local Nanes.-Chara (Guam); Tarampulit, Karampalit, Dampalit, Bilangbilang (Philippines); Verdolaga de Costa (Cuba).

A succulent, branching, prostrate, strand plant of wide tropical distribution, sometimes forming mounds on the sandy beach. Leaves opposite, entire, nearly veinless; flowers axillary; without petals; calyx 5-parted, green outside, purplish or rosecolored within; stamens many; styles 3 to 5 ; capsule 3 to 5 -celled, circumscissile through the middle, the upper part like a lid, falling away when ripe, and leaving the lower part attached to the plant; seeds black, shining; smooth.

The entire plant is eaten cooked like spinach. It is rather salty. In some parts of India it is cultivated as a pot herb.

REFEREXCES:

Sesuvium portulacastrum Stickman, Herb. Amb. 1754; Amoen. Acad. 4: 136. 1759.

Setaria aurea Hochst. Same as Chaetochloa glauca aurea.

Setaria glauca aurea K. Sch. Same as Chaetochloa glauca aurea.

$a$ See Hicks, Oil-producing seeds, Yearbook U. S. Dept. Agr., 1895, p. 197.

b See Descriptive Cat. Agr. Prods. Japan, World's Columbian Exposition, p. 52, 1893. 
Setlas (Guam). See Citrus medica.

Seyaihagon (Guam). See Nervilia arragoana.

Shaddock. See Citrus decumana.

Shell-leaf. See Nothopanax cochleatum.

She-oak, Australian. See Casuarina equisetifolia.

Shore grass. See Stenotaphrum subulatum.

Siak (Visayan). See Excoecaria agallocha.

Sibucao or Sibukao (Guam). See Biancaea sappan.

Sicoi (Philippines). See Lagenaria lagenaria.

Sida acuta.

BROOMWEED.

Family Malvaceae.

Local Names.-Escobilla (Spanish); Escobang-haba, Wawalisán (Philippines); Malva de caballo (Cuba).

A much-branched, semi-shrubby, perennial, its branches erect, smooth, or slightly rough with minute stellate hairs. Leaves 1.5 to $6.5 \mathrm{~cm}$. long, lanceolate-oblong, rounded at base, acute or obtuse, sharply serrate or crenate-serrate, glabrous, pale beneath, petioles $6 \mathrm{~mm}$. long, thickened at top, slightly stellate-hairy; stipules linearsubulate, exceeding petioles, veined, ciliate; flowers yellow, $1.5 \mathrm{~cm}$. long, peduncle 6 to $12 \mathrm{~mm}$. long, stellate-pubescent; calyx nearly glabrous, the segments very broadly triangular, acute or acuminate; petals twice as long as calyx; ripe carpels 5 to 11 , rugose on the back, black, with 2 sharp erect beaks. Collected in Guam by Lesson.

Common in waste places. The stems yield a good fiber. The natives make brooms, with which they sweep, their houses, of the stems of this and allied species, gathering them afresh each morning. In the Philipjines, according to Padre Blanco, poultices are made by boiling the leaves and are applied to ulcers and other sores. In India a tonic is made of the plant, which is said to be a good appetizer.

REFERENCES:

Sida acuta Burm. f. Fl. Ind. 147. 1768.

Sida carpinifolia. Same as Sida acuta.

\section{Sida glomerata.}

This species is said by Gaudichaud to occur in Guam, where, according to his notes, the natives call it "escobilla papagu," "papagu" meaning "poil à gratter" (hair for scratching). It is given by Endlicher in his list of South Sea Island plants as occurring in Guam, ${ }^{a}$ where it was collected by Lesson. According to Cavanilles's description, the sprecies has orate-lanceolate, serrate, tomentose leaves, axillary 1flowered very short pedicels, and five 2-beaked carpels. Calyx ciliate.

REFERENCES:

Sida glomerata Cav. Diss. 1:18. t. 2. f. 6. 1785.

Sida indica. Same as Abutilon indicum.

\section{Sida maura.}

In Endlicher's list of South Sea Island plants, cited above, this species, attributerl to Link, is said to have been collected by Chamisso in the Marianne Islands. It is not further known. In Link's Enumeratio plantarmm horti regii botanici berolinensis, $b$ I find not S. maura but S. mauritiana, which has the leaves "praesertim subtus incana. caps. longe birostres." To locality given. Leaves cordate, crenate, often angled.

REFERENCES:

Sida maura Endl. Fl. Südseeinseln, Ann. Wien. Mus. 1: 182. 1836. 
Sida rhombifolia.

Broomweed.

Local Names. - Escobilla (Guam, Panama); Escoba (Spanish Central America);

Malva de cochino (Cuba); Mautofu (Samoa); Ilima (Hawaii); Burume

(Tahiti); Silhigon, Escobang-habá, Báseng-báseng (Philippines); Svet-berela

(India); Kotikan-bévila (Ceylon).

A half-shrubby weed growing by the roadsides and in open places, having yellow flowers which open at about half-past 10 o'clock in the morning and soon fade to a whitish color. Branches rough with stellate hairs; leaves 2.5 to $5 \mathrm{~cm}$. long, rhomboirlanceolate, obtuse at the base, acute, entire below, dentate-serrate above, glabrous above, more or less densely stellate-hairy beneath, petioles $6 \mathrm{~mm}$. long, stellatehairy, stipules setaceous, longer than petioles; flowers $2 \mathrm{~cm}$. long, peduncles axillary, 1-flowered, 1.5 to $4 \mathrm{~cm}$. long, stellate-hairy; calyx-segments broadly triangular, very acute or apiculate; ripe carpels 8 to 10 , with or without beaks.

This plant varies greatly with its environment, and it may be that forms described as distinct species may be nothing more than varieties caused by differences of light, moisture, soil, etc.

It yields a good fiber, which in Australia is known as Queensland hemp. This is fine, strong, white, and lustrous, and is easily extracted. It is softer and finer than jute, but shorter. Experiments made with this fiber show that a cord $12.5 \mathrm{~mm}$. in circumference will sustain a weight of 400 pounds. In Guam fresh plants are gathered each morning and made into bundles which serve as brooms.

REFERENCES:

Sida rhombifolia L. Sp. Pl. 2: 684. 1753.

Siempre-viva (Spanish).

Local name for Bryophyllum pinnatum, which grows in Guam as a common roadside weed.

Silhigon (Philippines). See Sida rhombifolia.

Silisíli (Philippines). See Jasminum marianum.

Silk-cotton tree. See Ceiba pentandra.

Silk leaf. See Tournefortia argentea.

Sincamas (Philippines). See Cacara erosa.

Single head. See Nervitia arragoana.

Sisio (Philippines). See Physalis angulata and P. minima.

Sitae (Philippines). See Vigna sinensis.

Soap orange. See Citrus arrantium saponacea.

\section{Solanaceae.}

NightShade FAMiLY.

This family is represented in Guam by the following species:

Capsicum annuum.-Doni, Cayenne pepper.

Capsicum frutescens.-Doni, spur pepper.

Cestrum nocturnum.-Dama de noche, night-blooming Cestrum.

Cestrum pallidum.-Tintan China, "Chinese inkberry."

Datura fastuosa, Purple-flowered thornapple.

Iycopersicon lycopersicum. - Tomato.

Nicotiana tabacum.-Chupa, tobacco.

Physalis angulata. - Tomates de brihuega, ground-cherry.

Physalis minima. - Tomates de brihuega, ground-cherry.

Solanum melongena.-Berengenas, eggplant.

Solanum melongena.

Family Solanaceae.

Local Names.-Bereñghenas (Guam); Berengena (Spanish); Tálong. (Philippines).

The eggplant is one of the principal vegetables cultivated in Guam gardens. It thrives best in sandy soil. The fruit is large, oval in shape, and purple. A favorite method of cooking it is to stuff it with minced meat and bake it.

References:

Solanum melongena L. Sp. Pl. 1:186. 1753. 
Solanum tuberosum.

Potato. IRish potato.

The potato can not be successfully cultivated in Guam.

REFERENCES:

Solanum tuberosum L. Sp. Pl. 1: 184. 1753.

\section{Sophora tomentosa.}

Seacoast laburnum.

Family Fabaceae.

Local names.-Bañgil, Tambalisa, Kabaikábai, Káuai, Ya bag (Philippines); Kau ni alewa, "Woman's Tree" (Fiji); Mudu-murunga (Ceylon).

A shrub or small tree growing on the strand with gray velvety branches, yellow flowers, and necklace-like pods with joints separated by narrow necks. Leaves oddpinnate with 7 or 8 pairs of leaflets, which are shortly stalked and often alternate, $4 \mathrm{~cm}$. long, broadly oval, obtuse and rounded at both ends, pubescent; flowers rather large, pedicels as long as the calyx, jointed near the top, rather closely arranged in stout, erect, stalked racemes about $15 \mathrm{~cm}$. long; needle-like bracts deciduous; calyx somewhat inflated, velvety, segments very small; pod covered with velvety down, 5 to $15 \mathrm{~cm}$. long, long-stalked; seeds nearly globular, pale brown, $9.5 \mathrm{~mm}$. in diameter.

This plant is not common in Guam. It grows sparingly on the windward side of the island on the sandy beach between Pago and Talôfôfô. It is widely spread on tropical shores. The natives had no vernacular name for it and said that it had recently appeared on the island.

All parts of the plant, but especially the bark of the root and the seeds, are bitter and yield a poisonous alkaloid called sophorine. In the Malay Archipelago the pulverized seeds are used as a specific for dysentery and cholera and as an antidote after having eaten poisonous marine animals. Padre Blanco says that the seeds are purging. $a$ Two of them are almost too drastic for a dose in tertian fever. They are a common remedy among the natives of the Philippines for disorders of the stomach and were at one time a popular remedy for cholera morbus.

REFERENCES:

Sophora tomentosa L. Sp. Pl. 1: 373. 1753.

Sorrel. See Oxalis corniculata.

Soursop. See Annona muricata.

Spanish needles. See Glossogyne tenuifolia.

Spider-flower. See Cleome viscosa.

Spider lily. See Pancratium littorale.

Spiderwort. See Commelina nudiflora and Zygomenes capitata.

Spike-rush, capitate. See Eleorharis capitata.

Spike-rush, plantain-like. See Eleocharis plantaginoidea.

Spur pepper. See Capsicum frutescens.

Spurge. General name for the species of Euphorbia.

Star-grass, golden. See Hypoxis aurea.

Starch-yielding plants.

Among the plants yielding starch are:

Alocasia indica and A. macrorhiza.-Piga, acrid taro.

Artocarpus communis.-Lemae and dugdug, breadfruit.

Cacara erosa.-Híkamas, yam-bean.

Caladium colocasia. - Suni, taro.

Canna indica.-Mañgo halom-tano.

Cycas circinalis.-Federico or fadang.

Dioscorea spp.-Dago, nika, and gado, yams.

Ipomoea batatas.-Kamute, sweet potatoes.

Manihot manihot.-Mandiuka, cassava plant.

Musa paradisiaca.-Chotda, bananas and plantains. 



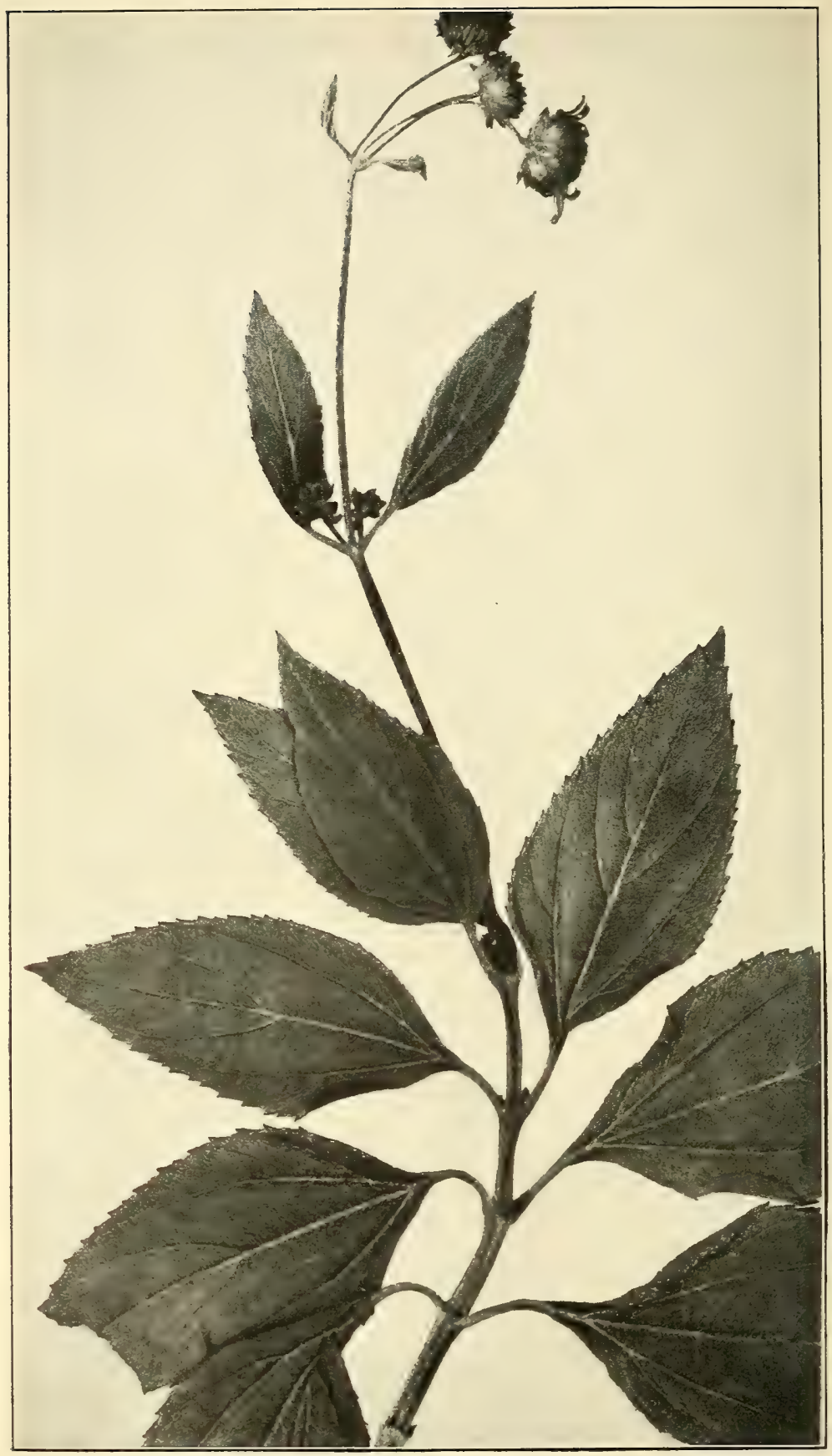

Stemmodontia canescens, a Strand Plant. natural size. 
Starch-yielding plants-Continued.

Oryza sativa.-Fa'i, or palai, rice.

Tacca pinnatifida. - Gabgab, or gaogao, Polynesian arrowroot.

Zea mays. - Maeis, maize or Indian corn.

Stemmodontia biflora.

ROUGH-LEAVED TICKSEED.

Family Asteraceae.

LoCal NAMEs.-Masigsig (Guam); Ateate (Samoa).

A yellow-flowered composite. Leaves opposite, rough, petioled, 3-nerved, ovate, acuminate, serrate; heads axillary or terminal, 1 to 3 , peduncled; ray-flowers pistillate, fertile, ligule spreading, entire; involucre bracts 2 -seriate, oblong or ovatelanceolate often recurved, equaling or exceeding the disk, achenes shortly cuneate, 3 or 4-angled, rough, the tip broad, truncate; disk flowers hermaphrodite, fertile, or the central sterile, tubular, limb elongate, 5-toothed; anther base entire or subsagittate; style-branches of hermaphrodite flowers with acute hairy tips.

A plant widely spread on tropical shores of eastern Asia and on many Pacific islands.

References:

Stemmodontia biflora (L.)

Verbesina biflora L. Sp. Pl. ed. 2. 2:1272. 1763.

Wedelia biflora DC.; Wight, Contrib. 18. 1834.

Stemmodontia canescens.

Hoary tickseed. Plate lixv.

LOCAI Names.-Masigsig chunge (Guam).

A yellow-flowered composite similar to the preceding, but hairy-canescent. Leaves ovate or elliptical-lanceolate, serrate, acuminate, hairy-canescent, panicles subcorymbose, involucre with two series of hirsute acuminate scales, and achenes blunt.

Common on the island of Guam.

REFERENCES:

Stemmodontia canescens (Gaudich).

Verbesina canescens Gaudich. Bot. Freyc. Voy. 463. 1826.

Wedelia chamissonis Less. Linnaea 6:161. 1831.

\section{Stenotaphrum subulatum.}

SHORE GRASS.

Family Poaceae.

LOCAL NAMEs. - Las-ága.

A broadly creeping strand-grass, rooting at the lower nodes with the broad rachis of the spike-like panicle notched or pitted to receive the spikelets; spikelets convex within, fitting into the alternating pits and flat on the outside; leaves many, lanceolate-acuminate, spreading; axis of rachis with a chaff-like prolongation; spikelets 2 -flowered, the first empty glume small. Described and figured by Trinius from a specimen collected on the island of Guam.

Common along the beach and in damp places. Allied to Stenotaphrum secundatum Kuntze (S'. americanum Schrank, S. glabrum Trin., and S. dimidiatum Trin.), which might be introduced with advantage into the island. The present species is valuable for lawns and for forage, and is a good sand binder. It is easily propagated by cuttings and will grow in the shade. It never becomes coarse or hard, but remains succulent. Cattle are very fond of it. See Lawns and lawn making.

\section{References:}

Stenotaphrum subulatum Trin. Mem. Acad. Petersb. VI. Sc. Nat. 3: 190. 1835.

\section{Sterculiaceae.}

CACAO FAMiLy.

This family is represented by the indigenous ufa (Heritiera littoralis), a tree growing near the shore; the introduced cacao (Theobroma cacao), which is successfully cultivated in sheltered places; and Waltheria americana, a widely spread tropical weed. Kleinhovia hospita, a tree apparently indigenous on many islands of the Pacific, has not been observed in Guam, but may possibly occur in the forests of the northern part of the island. 
Stizolobium giganteum.

Sea-bean. Great ox-eyil bean.

Family Fabaceae.

LOCAL Nayes.-Akankan dáñgkulo (Guam); Nipay, Lipay (Philippines); Tu tai buaa (Tahiti); Faso-gasuga (Solomon Island); Kakatea (Rarotonga); Kaeëë (Hawaii); Ojo de venado (Spanish):

A woody climber with slender glabrous branches, compound tendrils, and trifoliolate leaves with long petioles; leaflets subcoriaceous, glabrous, the terminal one oblong-cuspidate, 12 to $15 \mathrm{~cm}$. long by $8 \mathrm{~cm}$. broad, the lateral ones very oblique; flowers pale greenish yellow, 12 to 30 in long-peduncled, drooping, elose racemes; pedicels $2.5 \mathrm{~cm}$. long; calyx-tube campanulate; two upper teeth connate, truncate; lowest longer than the middle ones; corolla $3.5 \mathrm{~cm}$. long; standard reflexed, not more than half as long as the rostrate keel; keel not abruptly inflexed at the end; stamens diadelphous, the upper one free, the rest united; anthers dimorphous; pod broadly winged down both sutures, but not plaited on the faces, 8 to $15 \mathrm{~cm}$. by $5 \mathrm{~cm}$., flat on the faces, copiously clothed with abundant deciduous yellow-brown irritating bristles, 2 to 6 -seeded; seeds large, orbicular, hard, bony, uniformly brown or with black lines, the raphe extending over three-fourths of the circumference.

The seeds are sometimes used as watch charms; powdered, they are used as an aphrodisiac. This plant is widely spread in Polynesia, tropical Asia, and eastern Australia. It was first collected in Guam by Gaudichaud. Grows on the edge of the forests and in thickets along the roadside, sometimes climbing over high trees.

References:

Stizolobium giganteum (Willd.) Spreng. Syst. Ant. 4: Cur. Post. 281. 1827.

Dolichos giganteus Willd. Sp. Pl. 2:1041. 1801.

Mucuna gigantea DC. Prod. 2: 405. 1825.

\section{Stizolobium pruriens.}

Cowhage. Cowitch.

Local Names.-Picapica (Spanish); Nipay (Philippines).

The pods of this species are devoid of plaits or wings, but have a longitudinal rib along the whole length of each valve, and are densely covered with orange-brown, brittle, irritant hairs pointing backward and easily detached. They are 6 to $8 \mathrm{~cm}$. long and about $1.5 \mathrm{~cm}$. broad, linear, blunt and curved at both ends. They are 4 to 6-seeded with partitions between them; seed small (about $6 \mathrm{~mm}$. in diameter) ovoid, compressed, brownish mottled with black, the hilum short, oblong, not half the length of the seed. The plant is a seniwoody twiner with large trifoliolate leaves and purplish papilionaceous flowers growing in slender racemes. Branches usually clothed with short white, deflexed hairs; leaflets on short thick, hairy stalks, rachis 8 to $13 \mathrm{~cm}$. long, sparingly deflexed-hairy, stipules linear, setaceous-hairy; terminal leatlet smallest and rhomboid-oval, lateral ones very obliquely deltoid, all acute, mucronate, covered with silvery hair beneath.

The hairs of the pod, known as cowhage in medicine, are mixed with honey or molasses and given as a rermifuge. The powdered seeds are used in India as an aphrodisiac, and the young green pods are cooked and eaten as a vegetable.

ReFERENCES:

Stizulobum piruens (Stickman) Medic. Torles. Churpf. Phys. Ges. 2: 399. 1787.

Dolichos pruriens Stickman, Herb. Amb. 1754; Amoen. Acad. 4: 132. 1759.

Mucuna pruriens DC. Prod. 2: 405. 1825.

\section{Strand plants.}

The principal species growing on the shore of the island are the following:

Barringtonia racemosa.-Lañgaásag.

Barringtonia speciosa.-Puting.

Bruguiera gymnorhiza.-Mangle macho.

Canavali obtusifolium. - Seaside bean.

Casuarina equisetifolia.-Sago.

Cocos nucifera.-Niyog 
Strand plants-Continued.

Cormigonus mariannense.-Gáusâli.

Crinum asiaticum.-Piga-palayi.

Heritiera littoralis. - Ufa.

Hernandia peltata. -Nonag.

Ipomoea pes-caprae.-Goats-foot convolvulus.

Lobelia koenigii.-Nanaso.

Lumnitzera purpurea.-- Nanã, or red-flowered mangrove.

Ochrosia mariannensis.-Fago.

Pancratium littorale.-Lirio.

Pariti tiliaceum.--Pago.

Pemphis acidula.-Nigas.

Rhizophora mucronata.-Mangle hembra.

Sesuvium portulacastrum.-Chara.

Terminalia catappa.-Talísai.

Thespesia populnea.-Kílulu.

Tournefortia argentea.-Hunig.

Stemmodontia biflora.-Masigsig.

Stemmodontia canescens.-Masigsig.

Ximenia americana.-Píod.

Xylocarpus granatum.-Lalányug.

Strawberry-nettle. See Elatostema pedunculatum.

Sugar-apple. See Annona squamosa.

Sugar cane. See Saccharum officinarum.

Sulangga (Philippines). See Impatiens baisamina.

Sumag or Sumak (Guam).

A tree mentioned in the list of Don Felipe de la Corte, the wood of which is used for the framework of roofs of native houses. The wood is flexible and elastic and is not subject to the attacks of white ants. The leaves are said to have medicinal properties. Species not identified.

Sumág-lada or Sumáklada (Guam).

A tree used in the construction of houses mentioned by Don Felipe; not identified.

Sune, Suni (Guam).

Vernacular name for taro (Caladium colocasia); also called by its Philippine name, "gabi."

Swamp-oak, Australian. See Casuarina equisetifolia.

Swamp plants.

Among the plants growing in marshy places and on the banks of streams are the following:

Acrostichum aureum.-Lagñgayas.

Alocasia indica and A. macrorhiza.-Baba, piga, papao.

Alsophila haenkei. - A tree fern.

Ambulia fragrans.-Gégé sensonyan.

Ambulia indica.-Gégé.

Bacopa monniera.-Water hyssop.

Bambos sp.-Piao palaoan.

Bambos blumeana.-Piao lahe, piao tituka.

Caladium colocasia.-Suni (Guam), gabi (Philippines).

Ceratopteris thalictroides.-Umug sensonyan.

Echinus tiliifolius.-Alūm.

Lygodium scandens.-Alambrillo.

Pariti tiliaceum.-Pago.

Trichoon roxburghii.-Kaliso.

Xipheagrostis floridula.-Nete.

Sweet acacia. See Acacia farnesiana.

Sweet potato. See Ipomoea batatas.

Sweetsop. See Annona squamosa.

Switch-sorrel. See Dodonaea viscosa. 
Sword bean. See Canavali ensiforme.

Sword grass. See Xiphagrostis floridulus.

\section{Synedrella nodiflora.}

Family Asteraceae.

An introduced weed of tropical American origin with ineonspicuous sessile axillary and terminal heads of flowers. Plant erect, dichotomously branched; stem and branches terete, glabrous; leaves ovate-lanceolate, short-petioled, serrate, scaberulous, 3-nerved; heads small; inner involucre of bracts linear-lanceolate, shining; ray flowers 1 or 2-seriate, fertile, ligule short, broad, 2 or 3-toothed; disk-flowers hermaphrodite, fertile, tubular, limb 4-toothed; achenes slender, black; spines 2 to 3 times as long, ereet, very stout.

Hitherto unknown from Guam; but of wide tropical distribution. Common near cultivation.

REFERENCES:

Synedrella nodiflora (L.) Gaertn. Fruct. 2: 456. t. 171. 1791.

Verbesina nodiflora L. Cent. Pl. 1: 28. 1755; Amoen. Acad. 4: 290. 1759.

Syrrhopodon. See Mosses.

Ta'amū (Samoa.) See Alocasia indica.

Tabaco (Spanish). See Nicotiana tabacum.

Tabayag (Philippines). See Lagenaria lagenaria.

Tabing (Philippines). See Abutilon indicum.

Tabunak (Philippines). See Trichoon roxburghii.

Tacamahac. See Gums and resins, and Calophyllum inophyllum.

Tacca pinnatifida. Polynestan arrowroot. East INdAN arrowroo?? Family Taccaceae.

Local names.-Gabgab, Gapgap, Gaogao (Guam); Pannirien (Ilocos); Gaogao (Philippines); Mamago (Bougainville Straits); Yabia (Fiji); Pia, Masoa (Samoa); Pia (Tahiti, Hawaii); Pombwaú (Burna).

An interesting, monocotyledonous plant having edible starchy tubers resembling young potatoes, which yield the Polynesian or East Indian arrowroot. It has 3parted irregularly pinnatifid leaves which are all radical and an umbel of drooping greenish flowers with a leafy involucre and a number of very long filiform bracts resembling flower-pedicles. Scape leafless, tapering, longer than the petiole, striped with dark and light green; flowers 10 to 40, subglobose, fleshy, $1.5 \mathrm{~cm}$. in diameter, 6 -lobed in two series, lobes greenish edged with purple; leaves of involucre lanceolate, recurved, striped with purple; filiform bracts very numerous; stamens 6 , at the base of the perianth lobes, filaments very short, base dilated or with an appendage on each side and dilated above into an inflexed hood with 2 ribs or horns on the inner surface; anthers sessile within the hood; ovary 1-celled; style short, included, stigmas 3 , hroad or petaloid and reflexed like an umbrella over the style; ovules many, on 3 parietal placentas; fruit the size of a pigeon's egg, 6-ribbed, yellow.

As with the yams, the tubers are mature when the plants die down. They are then dug up and are ready for conversion into starch or arrowroot. They are rasped or grated into a fine pulp which is put into a tub of water. This becomes milky and is strained through a coarse cloth or sieve to remove the coarser particles. On standing for some time the starch settles on the bottom and the clear liquid is carefully poured off. The fresh root is very bitter, but by repeatedly pouring off the water and replacing it by fresh water the bitter principle is removed. When the starch is thoroughly washed it is dried in the sun after the manner of common arrowroot and cassava starch. In Ilocos and Zambales, of the Philippine group, where it is abundant, the natives prepare the starch by rasping the roots on a rough stone in water. The starch finds a ready sale in Manila, where it is mixed with 
sugar and made into sweetmeats. ${ }^{b}$ In Fiji the natives use graters of mushroom coral (Fungia). As formerly made by the Fijians the starch was frequently of a grayish color, owing to the fact that the tubers were not first peeled and the starch was not sufficiently washed. When it became an article of export from the Fiji Islands the natives were taught to prepare it more carefully. For their own use they did not dry it but buried it in the ground, wrapped in leaves, so that it might ferment after the manner of breadfruit. $b$ In Samoa the fresh starch is always used for pasting together the thin layers of beaten bark of the paper mulberry (Broussonetia papyrifera) in making tapa, or "siapo," as bark cloth is there called. In Guam it is used for starching clothes and for making sweetmeats called "buñuelos." The root itself is not used as a vegetable.

As a food for invalids the arrowroot made from Tacca is said to be superior to all others. "It is invaluable when taken in cases of dysentery and diarrhea." $b$

From the petioles and flower scapes the natives of Tahiti get an excellent straw for braiding hats, which they prepare by splitting into narrow strips, curing, and drying. Hats made from this straw were purchased by the officers of the U. S. S. Mohican in 1886. They were white and glossy and of light weight. It is said that the late Queen Victoria had a bonnet made of this material. $b$

The plant is found growing wild in Guam and is also cultivated. It is widely spread in Polynesia, and is found in Australia, the German colonies in the Solomon Islands and Bismarck Archipelago, and in the East. Indies. The natives of the island of Cheduba, on the coast of Burma, make arrowroot from it; but on the neighboring mainland it is not utilized. $c$ In the State of Travancore, near the southern point of India, the plant is cultivated and forms an important article of trade. The root here grows to a large size, and is much eaten by the natives, who mix with it agreeable acids to overcome its pungency. $d$

\section{REFERENCES:}

Tacea pinnatifida Forst. Char. Gen. 70. t. 35. 1776.

\section{Taeniophyllum fasciola.}

OrChID.

Family Orchidaceae.

Local NaMES. - Kamuke nanofe (Guam); Uramaore (Tahiti).

A small stemless, epiphytal orchid, with the habit of Polyrrhiza, apparently leafless after the first growth; roots flattened, fasciculate, interlaced; leaves 2 or 3 or absent, linear, fleshy, veinless; peduncle radical, filiform; flowers very minute, spicate; sepals and petals nearly alike, together with lip connate in a 6-toothed perianth; lip boatshaped, the margins free, fleshy, the base produced into a saccate spur; dorsal side of spur continuing the base of the column; column very short, broad, foot lacking; anther 2-celled, pollinia 4, in superposed pairs, pyriform, waxy, sessile on the gland; adventitious roots spreading, flexuose, elongate, and lying flat on the bark of the tree on which the plant grows, $20 \mathrm{~cm}$. long and 2 to $3 \mathrm{~mm}$. wide. Flowers green, soft, minute, not conspicuous.

Collected in Guam by Gaudichaud and by him called Vamilla fasciola. This plant occurs also in the Society Islands and in Fiji.e In Endlicher's Flora der Südseeinseln it is called Limodorum fasciola. $f$

\section{REFERENCES:}

Taeniophyllum fasciola (Forst. f.) Reichenb. f. in Seem. Fl. Vit. 296. 1868.

Epidendrum fasciola Forst. f. Prod. 60. 1786.

Vanilla fasciola Gaudich. Bot. Freyc. Voy. 427. 1826.

a Blanco, Flora de Filipinas, p. 262, 1837.

$b$ Seemann, Flora Vitiensis, p. 101, 1865-1873.

c Williams, On the Farina of the Tacca pinnatifida, Pharmaceutical Journ. and Trans., vol. 6 , p. $383,1846-1847$.

d Drury, Useful Plants of India, p. 423, 1858.

$e$ Seemann, Flora Vitiensis, p. 296, 1865-1873.

$f$ Ann. des Wiener Museums, vol. 1, p. 163, 1836. 
Taetsia terminalis.

PalM-Lily.

Family Liliaceae.

Local names. - Bastón de San José (Guam); Saguilala (Philippines); Tī (Samoa, Raratonga, Tahiti); Ting (Ponape); Ki (Hawaii); Qui, Masawe (Fiji).

A plant with an erect stem bearing a cluster of simple leaves, often of a redclish color, rising from a large tuberous, saccharine root, and with terminal panicles of small flowers. Stem erect, 1.5 to 3 meters high, marked with leaf scars; leaves lanceolate, 30 to $60 \mathrm{~cm}$. long, 8.5 to $10 \mathrm{~cm}$. broad at the middle, contracting to a petiole of 5 to $7.5 \mathrm{~cm}$. long, with many longitudinal nerves diverging from a short rib; flowers sessile on the alternating branches of the panicle, 3-bracted; perianth jointed with the short pedicel, split to the middle into 6 equal lobes; stamens 6 , inserted at the throat; ovary 3-celled, ovules numerous; style filiform, stigmas 3-lobed or nearly entire; berry round, 4 to $6 \mathrm{~mm}$. in diameter, often few-seeded; seeds obovoid, compressed, often curved; testa black, shining; embryo axile, curved.

This plant is widely distributed in the Pacific; but it did not find its way to Guam until after the discovery, and at present has no Chamorro name. Its Spanish name, signifying "St. Joseph's staff," has been applied to it evidently on account of its slender, straight stem and its graceful terminal tuft of leaves. It is now abundant on the sides of the road leading from Agaña to Pago. In Hawaii it is held in high esteem by the natives, who plant it around the tombs of their dead. The aboriginal Hawaiians made a fermented drink out of the fleshy, sweet roots. The modern Hawaiians distill from them a highly intoxicating liquor, somewhat like rum. In Samoa the natives make fringed skirts (turti) of the leaves, which they wear in fishing on the reef and in rainy weather. The leaves are also much used by the Polynesians for wrapping fish and other food before putting it into the native ovens to bake. The leaves are free from any pronounced taste. They are excellent for fodder for animals, and are often used in native feasts, together with leaves of bananas and plantains, as plates or trays upon which food is spread.

In Guam the natives use it only as an ornamental plant.

REFERENCES:

Taetsia terminalis (L.)

Asparagus terminalis L. Sp. Pl. ed. 2. 1: 450. 1762.

Dracaena terminalis L. Syst. ed. 12.246. 1767.

Cordyline terminalis Kunth, Abh. Acad. Berl. 30. 1820.

The name Cordyline, as shown in the discussion under that name on an earlier page in this work, is an untenable name for this genus, and Taetsia, proposed by Medicus in 1786 and based on the species ferrea, is accordingly reinstated.

Tagete or Taguete (Guam).

Vernacular name for a species of Ficus allied to the banyan, but without aerial roots from the branches, common in the forests and growing to great size. Wood used only for fuel.

Tagoa (Guam). See Lagenaria lagenaria.

Tagum (Philippines). See Indigofera anit and I. tinctoria.

Takan (Philippines). See Pisonia excelsa.

Takete (Guam). See Ficus spp.

Talamtala (Porto Rico). See Herpetica alata.

Talie (Samoa). See Terminalia catappa.

Talisai (Guam, Philippines). See Terminalia catappa.

Tálong (Philippines). See Solanum melongena.

Tamanu (Polynesia). See Calophyllum inophyllum.

Tamarind. See Tamarindus indica. 



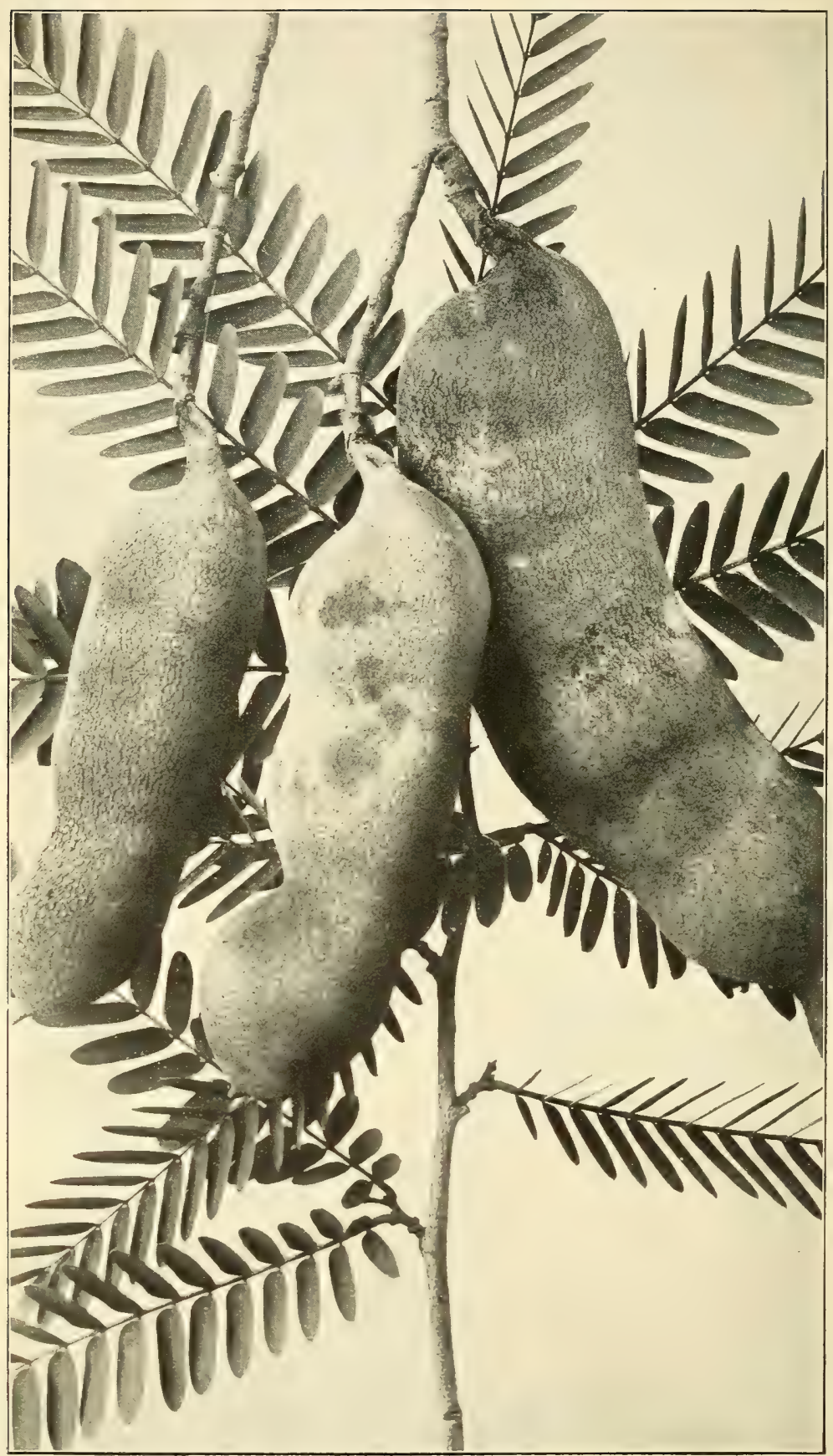

Tamarindus indica, the Tamarind. Foliage and Fruit. Natural Size. 


\section{Tamarind, Manila.}

Name in India for Pithecolobium dulce.

\section{Tamarindo (Philippines). See Tamarindus indica.}

\section{Tamarindus indica.}

Tamarind. Plate lXvi.

Family Caesalpiniaceae.

Local Nayes.-Kamalindo (Guam); Sampalok, Sambalagui, Sambag, Sambagui, Tamarindo (Philippines).

An introduced tree with spreading branches and beautiful foliage, bearing pods containing seeds surrounded by an acid pulp of pleasant flavor. Leaves abruptly pinnate, with 20 to 40 glabrescent, close, obtuse, opposite, oblong leaflets; flowers few together, in copious lax racemes at the end of the branchlets; pedicels articulated at the base of the calyx; bracts boat-shaped, inclosing the buds, caducous; calyx tube top-shaped, the disk produced some distance above its base; teeth lanceolate, much imbricated, the lowest 2 connate; only the 3 upper petals developed, the 2 lateral ovate, the upper hooded, $12 \mathrm{~mm}$. long, yellow striped with red, the 2 lower petals reduced to scales; stamens monadelphous, only 3 developed, the others reduced to bristles at the top of the sheath; ovary many-ovuled, with a stalk adnate to the calyx tribe; style filiform, stigma capitate; pod 5 to $15 \mathrm{~cm}$. by $2.5 \mathrm{~cm}$. or more, 3 to 10 -seeded, with a thin crustaceous epicarp and a thick pulpy mesocarp.

The acid pulp makes a very pleasant, cooling drink when mixed with water and sweetened. In India it is a favorite ingredient of curries and chutneys, and the seeds are eaten by the natives, the outer skin being first removed by roasting or soaking, and the seed then boiled or fried. They are also made into a flour after being dried and ground. The tender seedlings are eaten as a vegetable, and the leaves and flowers are also eaten. Nearly every part of this tree is utilized in India, and it plays an important part in the economy of the natives. The wood is highly prized, but is hard to work. It is used for mallets, rice pounders, wheels, etc. The leaves, flowers, and fruit are used as mordants in dyeing; and the fruit is a valuable laxative and antiscorbutic. $a$

In Guam the trees grow well, but as they do not spread spontaneously they are found only near villages and houses where they have been planted, and on the sites of abandoned ranchos.

\section{REFERENCES:}

Tamarindus indica L. Sp. PI. 1: 34. 1753.

\section{Tamauian (Philippines). See Calophyllum inophyllum.}

Tambalisa (Philippines). See Sophora tomentosa.

Tambo (Philippines). See Trichoon roxburghï.

Tamo (Philippines). See Zinziber zerumbet.

Tanetane (Samoa). See Nothopanax fruticosum.

Tangā-mimi (Samoa). See Ipomoea congesta.

Tañgantañan (Guam). See Leucaena glauca.

Tangantangan (Philippines). See Ricinus communis.

Tangerine orange. See Citrus nobitis.

Tanglad (Philippines). See Andropogon nardus.

\section{Tanning.}

Among the plants yielding tan stuffs are the following:

Anacardium occidentale.-Kasóe, the cashew tree.

Bruguiera gymnorhiza.-Mangle macho, the many-petaled mangrove.

Ficus sp.-Nunu, the banyan; bark astringent.

Heritiera littoralis.-Ufa; free from coloring matter. 
Tanning-Continued.

Lens phaseoloides.-Gaye or bayog; a forest liana.

Pithecolobium dulce. - Kamachiles; most extensively used of all.

Psidium guajava. - Abas, the guava; leaves and bark.

Punica granatum.-Granada; rind of fruit excellent.

Rhizophora mucronata. - Mangle hembra, four-petaled mangrove; aerial roots crushed and soaked in water, good for curing fish nets.

Terminalia catappa. - Talisai; bark and leaves.

Tapioca. See Manihot manihot.

Tapuranga (Philippines). See Hibiscus rosa-sinensis.

Taro. See Caladium colocasia.

Taro, acrid. See Alocasia indica and A. macrorrhiza.

Taro, giant. See Alocasia indica and A. macrorrhiza.

Tartago (Porto Rico). See Jatropha curcas.

Tarumpalit (Philippines). See Sesuvium portulacastrum.

Tauanave (Samoa). See Cordia subcordata.

Tausunu (Samoa). See Tournefortia argentea.

Tavatava (Philippines). See Jatropha curcas.

Tea.

An attempt was made to cultivate tea in Guam, but it was unsuccessful, the plants. growing too high and rank.

Tea, Mexican. See Chenopodium ambrosioides.

Tea senna. See Cassia mimosoides.

Telosma odoratissima.

Thousand leagues.

Family Asclepiadaceae.

Local Names.-Mil-leguas (Guam, Philippines); Liane Tonquin (Mauritius); Malati tunkat (Java); Yé-lan-hiang (China).

A twining shrub of East Indian origin, with very fragrant, aromatic, greenish flowers growing in umbel-like cymes. Leaves opposite, ovate-cordate, membranous; calyx 5-parted; corolla salver-shaped, tube pubescent within, swollen at the base; lobes oblong, overlapping at the right; stamens growing together so as to form a short fleshy column bearing a ring of seales caller the staminal corona, scales membranous, growing to the back of the anthers, erect, double, the inner with a long point; pollen masses one in each cell; stigma capitate; fruit a pod having one suture, lanceolate, about $7.5 \mathrm{~cm}$. long; pericarp thick, glabrous; seeds $8 \mathrm{~mm}$. long, broadly ovate.

This plant is a great favorite with the natives. They plant it in their gardens, propagating it by cuttings, which readily take root. I have never seen it form fruit on the island. It takes its local name from the great distance to which the aromatic odor of its flowers is carried. On going home I could always tell at a distance of two blocks whether or not there was a boquet of mil-leguas in my bouse.

REFERENCES:

Telosma odoratissima (Lour.) Coville.

Cynanchum odoratissimum Lour. Fl. Cochinch. 1: 166. 1790.

Pergularia odoratissima Sm. Ic. Pict. $t$. 16. 1790-93.

Tone of the species currently referred to the genus Pergularia was contained in the original Pergularia of Linnæus. That author described two species in the genus, one of which was subsequently made by Burmann the type of the Apocynaceous genus Vallaris, while the other also was removed from Pergularia by Robert Brown and, with Cynanchum ertcrsum of Jacquin, erected into the genus Daemia. Pergularia can not therefore properly be used as the genus name for those plants to which 
it has currently been applied, and the name Telosma ( $\tau \eta \bar{\eta} \lambda \varepsilon$, far, and $\dot{\sigma} \sigma \mu \dot{\eta}$, odor) is here proposed, the type species being $T$. odoratissime as above cited.-Frederick $\mathrm{V}$. Coville.

\section{Tephrosia mariana. Same as Cracca mariana.}

\section{Terminalia catappa. Indian ALMOND. MaLABAR ALMOND.}

Family Combretaceae.

Local nuyes.-Talísai (Guam); Talisai, Dalisai (Philippines); Talie (Samoa); Kaorika, Kauarika (Karotonga); Tavola (Fiji); Kamani (Hawaii); Almendro (Spanish America); Badamier (French); Saori (Solomon Islands); Tipop, Tipapop (Ponape, Caroline Islands).

A handsome deciduous tree with branches in horizontal whorls, large leaves, which usually turn scarlet before falling, and an edible almond-like fruit. Leaves alternate, clustered toward the ends of the branches, short-petioled, obovate from a cordate but very narrow base, 15 to $20 \mathrm{~cm}$. long, usually softly hairy when young, glabrous or hairy when adult, with 2 glandular depressions near the base of the midrib on the under side which are often obscure or wanting; petiole 6 to $19 \mathrm{~mm}$. long; flowers small, spicate; spikes solitary, axillary, simple, gray or rusty tomentose, the upper flowers male, the lower hermaphrodite, the bracts minute at the base of each flower, soon deciduous; calyx tube produced above the ovary with a campanulate mouth, limb of 5 short valvate triangular lobes, deciduous; petals none; stamens 10 inserted on the calyx tube; epigynous disk within them densely hairy; ovary 1-celled, inferior; style long, simple; fruit 2.5 to $3.8 \mathrm{~cm}$. long, ellipsoid, slightly compressed so as to show two ridges, finally glabrous.

A very common tree in Guam, often growing near the shore, but also found inland. The kernels of the fruit are of a fine almond-like consistency and flavor. The crows (Comus kubaryi) are very fond of them, and the natives eat them as delicacies either fresh or candied. The bark and leaves are astringent and contain tannin. In India they are mixed with iron salts to form a black pigment, with which the natives in certain localities color their teeth and make ink. This species is an excellent shade tree. It is of wide tropical distribution and is often planted for ornament and for the sake of its nuts. It has been introduced into Hawaii and the natives have applied to it the Polynesian name for Calophyllum inophyllum (kamanu, or kamani) owing to the appearance of its foliage, which from a distance looks somewhat like that of the latter species. It is easily propagated from the seed.

The wood is hard and of a reddish color, the sapwood lighter colored than the heartwood. In Guam it is used for troughs, carts, and posts, and if "daog" wood (Calophyllum inophyllum) can not be obtained it is used for making cart wheels, though it is inferior to that species in toughness and durability. The Fijians and Samoans make drums of the hollowed trunks.

ReFerences:

Terminalia catappa L. Mant. 1: 128. 1767.

\section{Thatch plants.}

The principal materials used for thatching are the leaves of Cocos nuciferc and fringes of sword grass or neti (Xipheagrostis floridula) and of the leaflets of the nipa palm (Nypa fruticans). See p. 148.

\section{Theobroma cacao.}

Cacao. Chocolate tree. Plate lxvil.

Family Sterculiaceae.

Local Names.-Cacao (Spanish); Kákao (Guam).

The seeds of this plant are the "chocolate beans" or "chocolate nuts" of commerce. It is a small tree with a bare stem which generally rises to a height of about 2 meters before branching, and reaches a height of 5 or 6 meters. Sometimes, however, under good conditions of moisture, soil, and situation it grows higher. The tree is cauliflorous; that is, the flowers spring forth from the trunk and older branches.

$9773-05-25$ 
Leaves large, undivided, smooth, broad, pointed, and of a thin texture; of a reddish color and hanging limp from the branches when young, but soon turning green and becoming firm; flowers produced from adventitious buds under the bark, usually at the "eyes," or points marked by the scars of fallen leaves, small, growing in clusters or solitary, usually only one of a cluster developing into fruit; calyx 5-parted, often of a pinkish color; petals 5 , yellowish, concave at the base and having a strap-like appendage at the tip; stamens 10 , united at the base into a cup, 5 without anthers and the other 5 alternating with them bearing 2 double-celled anthers each; style thread-like, terminating in a 5-cleft stigma; fruit somewhat like a cucumber in shape, 15 to $25 \mathrm{~cm}$. long, yellow or reddish, longitudinally ribbed, the rind thick and warty, leathery and tough, not splitting when ripe, 5-celled, and containing many seeds in a soft butter-like pulp of a pleasant sweetish-acid flavor; seeds compressed, somewhat almond-shaped, with a thin, pale, reddish-brown, fragile skin or shell, covering an oily, aromatic, bitter kernel, which consists mostly of the crumpled cotyledons.

If taken from the pod the seed soon loses its vitality. It is consequently difficult to transport it to distant countries unless in a germinating condition or in ripe pods, which, if kept cool, will last ten days or perhaps two weeks.

Cacao must be grown in sheltered situations. The best soil is that of valleys made by the decomposition of volcanic rocks and containing organic matter, as at Santa Rosa, Yigo, and Matáguag in the northern part of the island of Guam, and alluvial deposits along the banks of streams, as in the valleys of Ilig and Tarofôfô, on the east coast. Considerable depth is necessary, as the tree has a long taproot. The trees will not bear exposure to the brisk trade winds, which are almost constantly blowing in Guam. Whole plantations are sometimes blasted by the baguios, or hurricanes, which visit the island.

The seeds are planted fresh from the pods in sementeras, or nurseries. They are taken from the best and largest pods, which are picked from the best-bearing trees perfectly ripe and kept for a week or ten days. On opening the pod it is not unusual to find that the seeds have already begun to germinate. The best pods are those growing on the trunk, and from them the largest seed should be selected. They are placed in the ground about 1 inch below the surface, so that the point where each seed was attached to the placenta is lowermost, thus avoiding a crooked stem and taproot, which are very delicate and easily injured in transplanting. The rows are about $25 \mathrm{~cm}$. apart, with the seed set at intervals of about $10 \mathrm{~cm}$. They sprout in a few days and in a few weeks' time they are ready for transplanting. The best time for transplanting is the beginning of the rainy season. Great care must then be taken, as a slight injury to the taproot will kill the plant. The plants given to the writer by Mr. David Haughs in Honolulu were grown from seed planted in pots. A very good way to propagate them is to plant them in bamboo joints, which may be filled with good fine earth and sunk in the ground. When ready for transplanting the bamboo is split and the hall of earth surrounding the tender roots left intact. Sometimes the seeds are planted on the site chosen for the plantation, so that transplanting will not be necessary. In this case the ground is cleared and straight rows 4 to 5 meters apart marked out by lines. The rows may be a little closer together than this in places where the cacao does not send out very long brunches, and 6 meters apart where the soil is deep and rich, taking care to plant the seeds in one row opposite the middle of the interval of the row next to it. The position of each hill is indicated by a stake, around which 3 or 4 seeds are planted about 20 cm. apart. All the seeds may grow, yet only the most thrifty one is allowed to remain, the rest being either pulled up and thrown aw ay or carefully removed with a ball of earth attached to the roots and planted in the places where seeds have failed to sprout or set out in another field, as in the case of plants grown in sementeras.

In clearing land for planting cacao a few trees are sometimes left for shade, except in moist valleys, where they are not necessary. 



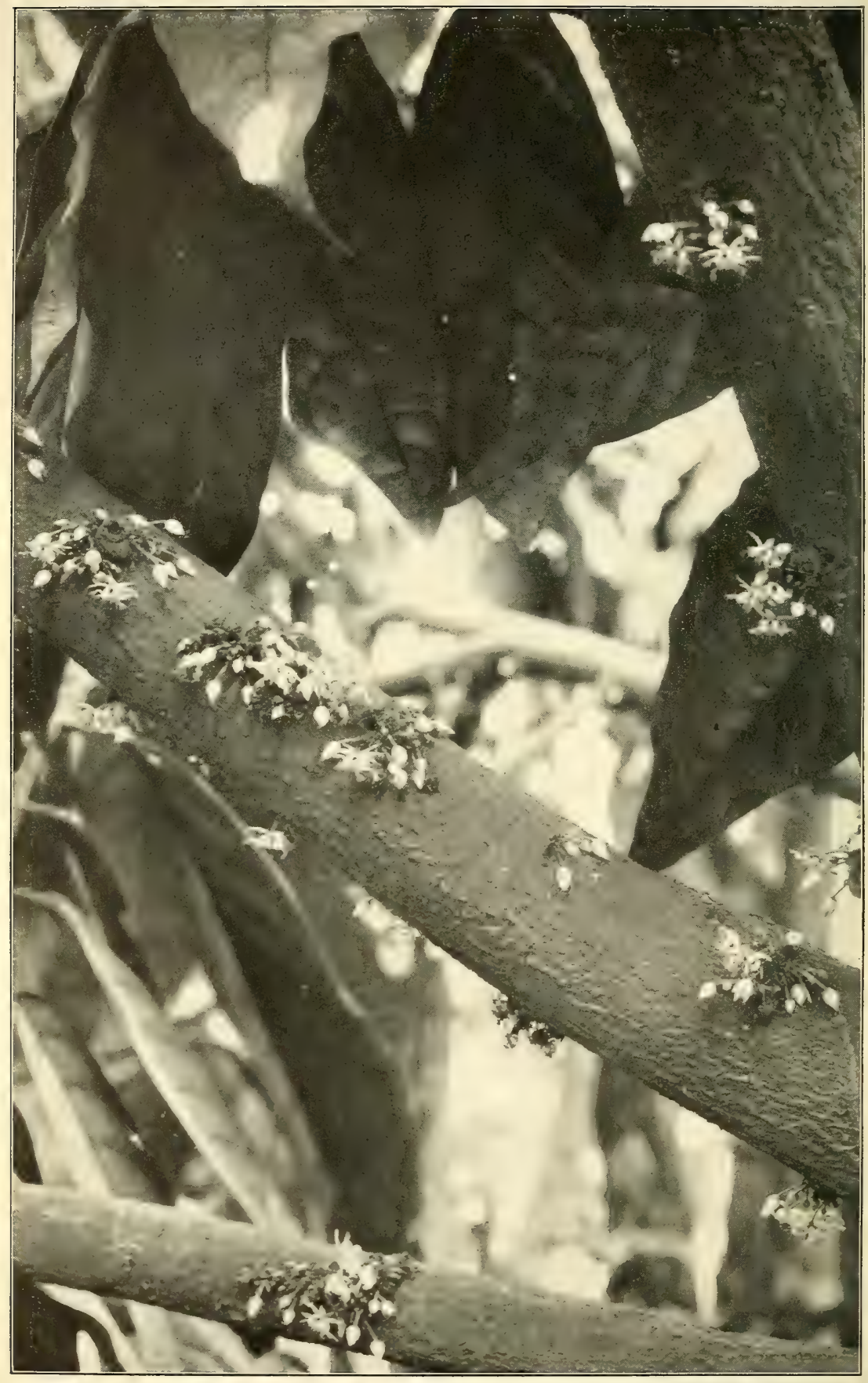

Theobroma cacao, the Chocolate Plant. inflorescence. Slightly Reduced. 
In Guam sappan wood (Biancaea sappan) grows readily, and soon forms hedges or thickets of a good height, which serve as excellent wind-breaks. The plantation must be kept free from weeds, especially while the plants are still young. Jn Guam the weeds are kept down with a thrust hoe, or fusiño. $a$ Rows of taro or bananas are often planted between those of the cacao, and left while the plants are still young. The bananas not only produce fruit, but, growing readily and rapidly, they act as shade plants to the tender young cacao. As the cacao matures, these plants are removed. The custom of planting shade trees, called "madre-cacao," is not so prevalent in Guam as in America; $b$ but in exposed situations trees of gabgah (Erythrina indica), lemae, or breadfruit, and dugdug, or fertile breadfruit-all quick-growing trees-may be planted to shade the plants, care being taken to keep the lower boughs cut off, so as not to interfere with the growth of the cacao.

In many parts of the island where the soil is thin, with a substratum of coral, or where the soil is poor, the cacao should be planted in holes 2 feet in depth and in diameter, filled with good rich soil. This method is called "holing," and is used in many tropical countries for other plants as well as for cacao. Dead weeds and the refuse from the pods after the seeds have been taken out form an excellent manure, and should be placed about the trees or buried near their roots. This practice, however, should not be followed if any pods show evidence of disease. In such an event all infected pods should be carefully burned.

Only one stem is allowed to grow until the tree has reached the height of a meter, after which three main branches are allowed to remain. The plant should be kept free from suckers, which sometimes sprout out even after the main branches have appeared. In about three years from planting the trees will flower, but it is best to remore the flowers from young trees, as it is injurious to them to bear fruit before the fourth or fifth year. In Guam the trees bear fruit almost continuously, but there are two principal crops each year. The fruit is then gathered in quantities, some of the best pods selected for seed, and the rest of the seeds are dried and stored or made at once into chocolate. No cacao is exported, except, perhaps, a little sent by natives to friends in Manila or given to people leaving the island, as is the custom in Guam.

In gathering the pods the stalks should be cut halfway between the pod and the tree, care being taken not to tear the bark, as is often done if the pod be removed by twisting; for it is in the bark, at the base of the old peduncle that the adventitious buds push forth which produce the crop of the following year. The beans are freed from pulp and gummy matter, dried in the sun, parched, and ground on stone slabs called "metates" with a cylindrical stone rolling-pin called a "mano," just as maize is ground for making tortillas. The ground paste is formed into balls or lozenge-shaped disks, each large enough to make one cup of chocolate. Chocolate as made in Guam is thickened with flour or arrowroot. It is of fine flavor and is not arlulterated in any way, except by the ardition of sugar and flour. The natives scorn imported chocolate, saying that it tastes like medicine. The custom of chocolate drinking is universal among them. They drink it in the late afternoon, serving it rquite hot, and offering it to visitors as a matter of etiquette, often accompanying it with sponge cake or poundcake, which they have been taught to make by foreigners, and which they call "kéke."

Cacao beans are sometimes kept in jars and allowed to "sweat" or undergo a sort of fermentation, which improves their flavor, but this custom is not universal. IIany families, after having dried the beans in the sun, keep them until required for use, when they toast them as we do coffee, grind them on the family metate, and make them into chocolate. Chocolate made from the newly ground bean is especially rich and aromatic.

$b$ See Cook, Shade in Coffee Culture, U. S. Dept. Agr., Div. Botany, Bull. No. 25, p. 8,1901 . 
The cacao plantations of Guam suffer greatly from the ravages of the brown, or Norway, rat (Mus decumanus), which overruns the island and is a great pest. These animals are immoderately fond of the beans, and sometimes destroy whole crops. The trees are comparatively short-lived, often beginning to die at the top when 10 years old, and are subject to the attack of boring insects. On this account and on account of the sensitireness of the trees to hurricanes, which are not rare in Guam, cacao is not cultivated extensively, the natives preferring to devote their energies to clearing land for the longer-lived and hardier coconuts, which yield good and certain returus. In places where conditions of soil and moisture are favorable for cacao culture, it is recommended that belts of forest be left as a protection from wind. Where the forest has been destroyed, artificial wind-breaks may be formed by planting trees and wild yams, which quickly form a solid matting of vegetation. If leguminous trees are planted they will undoubtedly be a benefit to the soil as storers of nitrogen.

REFERENCES:

Theobroma cacao L. Sp. PI. 2: 782.1753.

\section{Thespesia populnea.}

MrLo.

Family Malvaceae.

Local Names.-Kílulu, Quílulu (Guam); Bulakan, Bubui gubat (Philippines); Mulo (Fiji); Milo (Tonga, Samoa, Tahiti, Hawaii); Miro (Rarotonga); Bonabeng (Yap); Pona, Pena, Pana (Ponape); Bengibeng (Gilbert Islands); Kaikaia (Bougainville Straits); Suriya-gas (Ceylon); Umbrella tree, Tulip tree (British India); Majagua de Florida (Cuba); Palo de jagueca (Porto Rico).

A tree growing near the coast, with showy yellow flowers which change to a purplish-pink color on withering. Branches spreading; young twigs covered with peltate scales; leaves 7 to $12 \mathrm{~cm}$. long, broadly ovate, entire, acute, or acuminate, cordate at base, palmately 7 -veined, more or less covered on both sides with minute peltate scales, sometimes with a glandular pore beneath between the bases of the veins; petioles 2.5 to $7.5 \mathrm{~cm}$. long, stipules subulate, deciduons; flowers axillary, solitary, campanulate, 5 to $7.5 \mathrm{~cm}$. in diameter; peduncles 2.5 to $3.5 \mathrm{~cm}$. long, bracteoles lacking or very early deciduous; calyx cup-shaped, truncate, the teeth obscurely marked; petals 5; stamens indefinite, filaments forming a tube; capsule about 2.5 cm. long, depressed globose, somew hat loberl, 4 or 5 -celled, surrounded at the base by the persistent calyx, more or less covered with peltate scales, indehiscent or irregularly dehiscent; seeds woolly, large, compressed. As in many species of Hibiscus, the 5 styles are connate, or grow together; ovary 4 or 5 -celled, with many ovules in each cell; stigma club-shaped.

d favorite shade tree, growing wild and often planted about villages in Polynesia. The heartwood is hard, smooth, durabie, and of a dark-red color. The Hawaiians sometimes make poi calahashes of it, and it has been called "Polynesian rosewood." The bark is tough and fibrous, but for cordage is inferior to that of Pariti tilinceum. It is one of the commonest trees of Guam. This tree is of very wide distribution. It ranges from tropical Asia, Africa, and Madagascar across the Pacific to Hawaii and Easter Island, and also occurs in tropical America and the West Indies. The identity of its name in islands so widely separated as Rarotonga and Hawaii is interesting.

REFERENCES:

Thespesia populnea (L.) Soland; Correa, Ann. Mus. Par. 9: 290. t. 8. f. 2. 1807.

Hibiscus populneus L. Sp. Pl. 2: 694. 1753.

Malvaviscus populneus Gærtn. Fruct. 2: 253. t. 135. f. 3. 1791.

Thorea gaudichaudii. See $-1 \lg x$.

Thornapple. See Datura fastuosa. 
Thorny bamboo. See Bambos blumeana.

Thousand leagues. See Telosma odoratissima.

Ti (Samoa). See Taetsia terminalis.

Tiaridium indicum. Same as Heliotropium indicum.

Ticamas (Philippines). See Cacara erosa.

Tickseed. See Stemmodontia.

Tick-trefoil. General name for the species of Meibomia.

Tick-trefoil, Creeping. See Meibomia triflora; also Agsom, a name improperly applied to this plant.

Tick-trefoil, Ganges. See Meibomia gangetica.

Tick-trefoil, umbelled or shrubby. See Meibomia umbellata.

Tigre (Guam, Philippines). See Cordyline hyacinthoides.

Tiliaceae.

LINDEN FAMILY.

To this family belong the following Guam plants:

Grexia guazumaefolia, añgilao; Triumfetta pilose, masigsig lahe; Triumfetta rhomboidea, dadangse, or burweed; Triumfetta procumbens, masigsig hembra.

Tintan China (Guam).

"Chinese ink;" a name applied in Guam to a recently introduced Cestrum which has been spread all over the island, probably by the fruit-eating pigeons, which are very fond of its dark purple berries. It is very closely allied to, if not identical with, the tropical American Cestrum pallidum.

Tinta-tinta (Philippines). See Eclipta alba.

Tipolo (Philippines). See Artocarpus communis.

Tipolo (Samoa). See Citrus hystrix acida.

Toa (Samoa). See Casuarina equisetifolia.

Tobacco. See Nicotiana tabacum.

Toddy. The fermented sap of the coconut, in Guam called "tuba." See Cocos nucifera.

Toguing polo (Philippines). See Dioscorea fasciculata lutescens.

To'ito'iāve'a (Samoa). See Lobelia koenigii.

Tolo (Samoa). See Saccharum officinarum.

Tomate (Spanish). See Lycopersicon tycopersicum.

Tomate chaka (Guam). See Physalis minima.

Tomato. See Lycopersicon lycopersicum.

Toñgo (Philippines). A prickly yam. See Dioscorea spinosa.

Tongo (Samoa). See Rhizophora mucronata.

Tongo (Philippines). See Dioscorea and D. tiliaefolia.

Tor go-vao (Samoa). See Dodonaea viscosa.

Tono (Samoa). See Centella asiatica.

Torchwood. See Cormigonus mariannensis.

Totopo.

Name of a grass eaten by cattle, with long, narrow leaves and creeping rootstock.

Tournefortia argentea.

Velvetleaf. Plate lxvit.

Family Boraginaceae.

Local Names.-Junig (Spanish); Hunig, Hunik (Guam); Tahenu (Tahiti);

Tauhinu (Rarotonga); Tausunu (Samoa); Diave (Bongainville Straits); Karan (Ceylon).

A small tree, 3 to 4 meters high, growing on the strand, with large silky-pubescent, leaves and scorpioid branched cymes of small white flowers with black anthers. 
Trunk short, bark deeply furrowed, pale; branchlets thick, marked with scars of fallen leaves; twigs dencely silky-pubescent; leaves closely placed at the end of branches, 10 to $20 \mathrm{~cm}$. long, oval or obovate-oval, much-tapering to base, rounded or obtuse at apex, fleshy, densely covered with close silky, white, appressed hair; petiole stout, short and obscure; flowers numerous, sessile, cymes peduncled, spreading, with long branches, silky; buds globose; sepals ovate-rotund, imbricate, densely silky-hairy; corolla rotate, over $6 \mathrm{~mm}$. in diameter, lobes rotundate, spreading; anthers sessile, large, at throat of corolla; ovary glabrous; stignia subsessile, obscurely 2-lobed; fruit the size of a small pea, depressed-globose, minutely apiculate, smooth, brown; nutlets corky.

The tree is of little economic value. Shoe lasts are sometimes made of the wood. It is widely distributed in the Malay archipelago, the Indian and Pacific oceans. The Polynesian names, signifying "scorched leaf," are applied to it on account of the shriveled appearance of the dead leaves.

REFERENCES:

Tournefortia argentea L. f. Suppl. 133. 1781.

Tree-cotton. See Gossypium arboreum.

\section{Tree ferns.}

The only tree fern thus far known in Guam is Alsophila haenkei Presl, a species growing on the hanks of streams, first collected by Haenke in 1792, and afterwards by Gaudichaud, who called it Cyathea mariana."

Tree mignonette. See Lawsonia alba.

Trefoil, tick. General name for the species of Meibomia.

Tribulus cistoides.

Caltrops.

Family Zygophyllaceae

A trailing strand plant with yellow flowers resembling those of Cistus. Branches procumbent or ascenting; leaves silky, stipulate, abruptly pinnate; leaflets about 8 pairs, oblong, subequal; stipules falcate, acuminate; flowers solitary; sepals 5 , caducous, acuminate, silky; petals 5, obovate; disk annular, 10-lobed; stamens 10, inserted on the base of the disk, 5 longer opposite the petals, 5 shorter with a little gland outside; filaments filiform, naked; ovary sessile, hirsute; style short, stigmas 5 ; cocci almost woody, tubercled and hairy, usually 2-horned, partitioned internally into several 1-seeded compartments.

A widely spread strand plant, easily identified by its conspicuous yellow flowers and horned wooly cocei. Not common in Guam, where, according to the natives, it is of recent introduction. A few plants observed on the sandy beach on the east shore of the island between Pago and Talôfôfô.

REFERENCES:

Tribulus cistoides L. Sp. Pl. 1: $387.1^{1753}$.

\section{Trichoon roxburghii.}

Reed. Marsh ReEd.

Family Poaceae.

Local names.-Karriso (Guam): Caña, Carrizo (Spanish); Tambo, Tabunak (Philippines); Yoshigo, Yoshi-dsuno (Japan); Nal, Nar, Karka (India); Nalagas (Ceylon); Lú, Tih, Wei (China).

A tall perennial grass with stems 2 to 4 meters high, common in marshes and along the banks of streams. The inflorescence forms large spreading lax panieles, with the flowers enveloped with long silky hairs. The plant is gregarious, having creeping, stoloniferous rootstocks: stems stout, hollow, smooth, covered with the leaf sheaths; leares close together, growing in 2 vertical ranks, sword-shaped, without ligule, but with a ridge of short hairs instead; panicle decompound, erect, more

"Presl, Reliquiae Haenkeanae, vol. 1, p. 6s, 1825. Gaulichaud, Freycinet's Voyage, Botany, p. 365, 1826. 


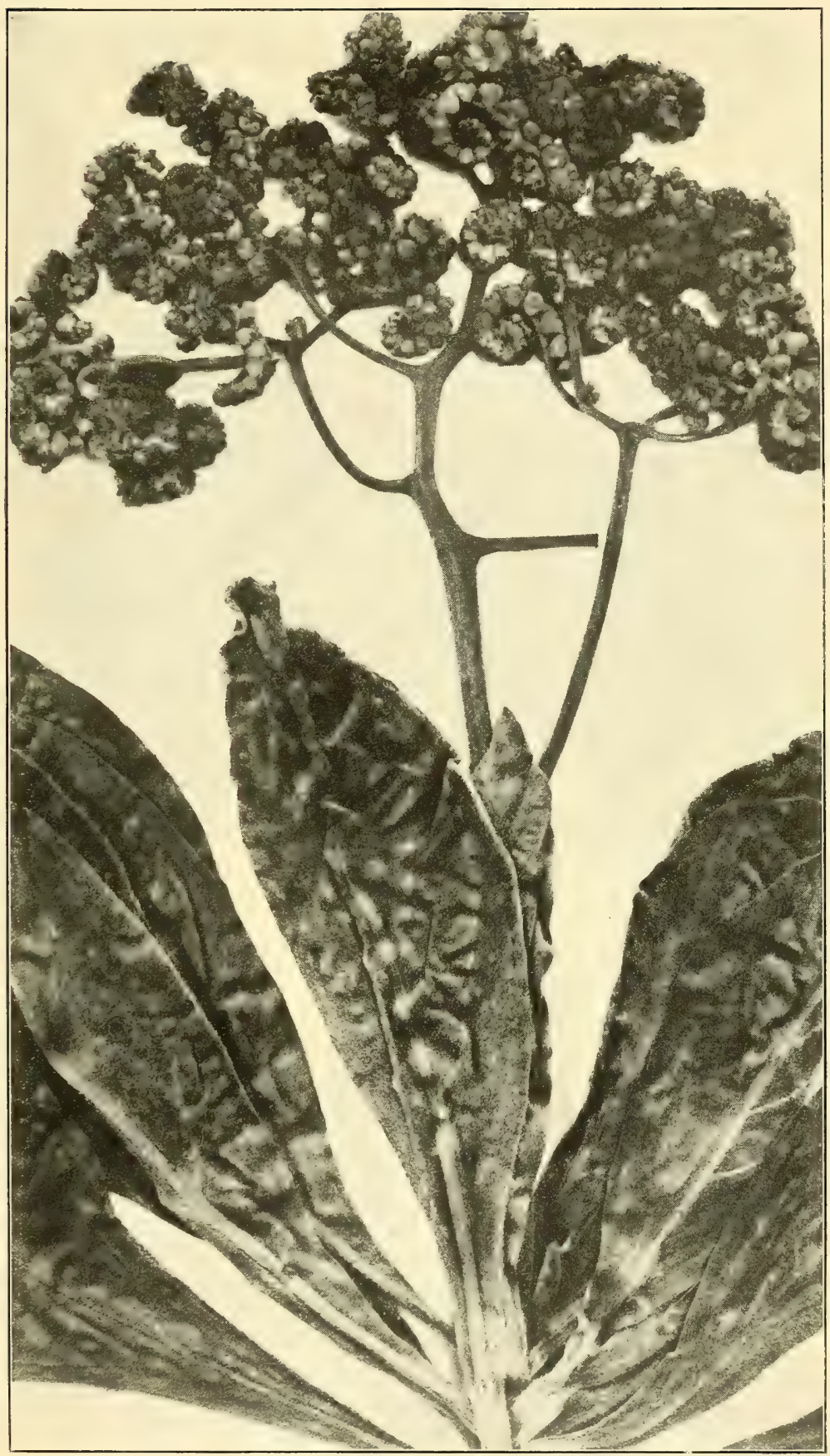

Tournefortia argentea, Velvetleaf, a Characteristic Strand Shrub. NATURAL SIZE. 

spreading than in the typical Trichoon phragmites the common reed; branches of panicle filiform, pedicels capillary, quite smooth; spikelets when fully expanded. about $12 \mathrm{~mm}$. broad across the glumes, 3 or more flowered, fan-shaped, the first flower often staminate, the others perfect; rachilla articulated between the flowering glumes, long-pilose, the two lower glumes empty; the third glume empty or subtending a staminate flower; flowering glumes glabrous, long-acuminate, much exceeding the short palets; stamens 3 ; styles 2, distinct, short; stigmas plumose; glumes spreading in fruit, exposing the long silky hairs of the rachilla; grain free, loosely inclosed in the glume and palet. This plant is quite variable, and it is possible that it is only a variety of Trichoon phragmites. Hooker could find no important differences between herbarium specimens of the two. In both forms dwarf or slender states occur, with slender leaves and greatly reduced panicles. $a$ The species is spread from Japan and India through Malaysia and the Philippines, and oceurs in the Caroline Islands, Bismarck Archipelago, New Caledonia, and other islands of the Pacific, but not in Fiji, Samoa, nor Hawaii.

In Guam the stems are split and woven into coarse matting for covering the sides of houses (Pl. XX), for partitions, and for ceilings, often covered with whitewash or mud, and serving as laths for plastering. It is from this species that the durma mats of Bengal are made. Padre Blanco first described it in the Philippines under the name Amondo tecto. In Japan the young shoots are eaten cooked like asparagus or bamboo sprouts. In China they are taken out of their sheaths and preserved by drying with a coating of salt on them, to be stored for cooking purposes. $b$ This reed is said to have proved poisonous to cattle in India, but in Guam the young shoots are used as fodder and are not considered harmful. In China the banks, marshes, and shoals of the Yangtze River are covered with great beds of it, the people cutting down the reeds on the subsidence of the floods. They form the fuel for a large portion of the people in certain districts, who also use them for building hovels and making mats and hurdles, and eat the young shoots as food.c

\section{REFERENCES:}

\section{Trichoon roxburghii (Kunth).}

Arundo roxburghii Kunth, Rev. Gram. 1: 79. 1829.

Phragmites roxburghii (Kunth) Steud. Nom. ed. 2. 2:324. 1841.

The earliest post-Linnæan use of the name Phragmites appears to be by Adanson in 1763 , but for a different genus from that to which it has been applied by modern authors. Trinius proposed the name for the present genus in 1820 , but it is antedated by Trichoon, published by Roth in 1798. The common reed, Trichoon phragmites (Arundo phragmites of Linnæus), is widely known under the name Phragmites communis Trin.

\section{Triphasia aurantiola Lour. Same as Triphasia trifoliata.}

\section{Triphasia trifoliata.}

ORANGE-BERRY.

Family Rutaceae.

Local maxes.--Lemoncito, Limon de China (Guam); Limoncitos (Philippines; Lime myrtle (West Indies); Limeberry (East Indies).

A glabrous, spiny shrub, with evergreen branches and leaves, small fragrant white flowers, and orange-red berries about the size of a cherry. Leaves alternate, sessile, 3 -foliate; leaflets obtuse, thick and soft, crenulate, coriaceous, almost nerveless, the terminal one shortly petioled, 2 to $4 \mathrm{~cm}$. long, ovate, with a cuneate base and rounded notched tip; lateral ones smaller, more rounded, oblique; flowers very shortly peduncled, axillary, solitary or in 3-flowered cymes; calyx 3-lobed; petals 3, free, imbricate, linear-oblong; stamens 6 , inserted around a fleshy disk; ovary oroid,

a Hooker, Flora British India, vol. 7, pp. 304, 305, 1897.

$b$ See Useful Plants of Japan, Agricultural Society of Japan, p. 29, 1895.

cSmith, Materia medica, etc., of China, p. 171, 1871. 
3-celled, narrowed into a slender deciduous style; stigma obtuse or capitate and 3-lobed; ovules solitary in each cell; berry ovoid, 1 to 3-celled, 1 to 3-seeded, glanddotted; seeds oblong, immersed in mucilage, testa coriaceous.

This plant should not be confused with Citrus trifoliatu of Japan. The fragrance of the flowers suggests that of the hyacinth. The fruit is bittersweet and has the flavor of Curaçao liqueur, or orange marmalade. It is agreeable if eaten in small quantities, but is mucilaginous and astringent, and one soon tires of it. The natives make very good dulces of it, which are said to be constipating if eaten in any quantity. In the East Indies a liqueur is made by soaking the berries in brandy for several years. Fruit pigeons (Ptilinopus roseicapillus and Phlegoenas xanthonura) are very fond of the berries. The plants send up shoots from the root very much after the manner of lemons and limes. They consequently make excellent hedges and have a tendency to spread. The spines are straight and rigid. Where hedges have been abandoned the lemoncito forms dense, impenetrable thickets. The wood is very hard and is difficult to cut, so that several hours may be necessary to open a path a few meters in length through such a thicket. Although the plant grows usually in the form of a shrub about a meter and a half high, yet on the east side of the island there are thickets in which it assumes the form of trees 3 to 4 meters high. Tool handles are sometimes made of the wood, and it is excellent for fuel. The natives make fagots of the stems and branches, which are very convenient for the earth-covered cooking benches of the island.

REFERENCES:

Triphasia trifoliata (L.) DC. Prod. 1: 536. 1824.

Limonia trifoliata L. Mant. 2: 237. 1771.

Triumfetta fabreana Gaudich. Same as Triumfetta procumbens.

Triumfetta lappula Gaudich. Same as Triumfetta rhomboidea.

Triumfetta pilosa.

GREAT BURWEED.

Family Tiliaceae.

Local NaMes.-Masigsig lahe, Dadangsi, Dadanse (Guam).

A herbaceous, hairy or bristly weed with yellow flowers in dense cymes. Lower leaves 3-lobed, stellate-hairy on both sides; upper leaves 9 or $10 \mathrm{~cm}$. long by $6 \mathrm{~cm}$. broad, ovate or ovate-lanceolate, unequally toothed; petiole $2 \mathrm{~cm}$. long, villous; stipules subulate-aristate, shorter than the petiole; peduncles shorter than the petiole; flowers $2 \mathrm{~cm}$. long; sepals 5, linear, apiculate; petals 5 , oblong, spathulate, scarcely shorter than the sepals, ciliate at the base; stamens about 10; fruit globose, tomentose, covered with long, hooked spines, which are glabrous along the upper and hispid along the lower edge, about the size of a cherry (including the spines), 4-celled, 4 or 8 -seeded.

The bur-like fruits readily adhere to objects which come into contact with them. The vernacular name signifies "to stick," or "anything which adheres."

REFERENCES:

Triumfetta pilosa Roth, Nov. Pl. Sp. 223. 1821.

\section{Triumfetta procumbens.}

SeAside BURWEed.

Local NaMes.-Masigsig hembra (Guam); Mautofu-tai (Samoa).

A procumbent weed usually growing near the strand, with tomentose-woolly ascending branches and small yellow flowers. Leaves subrotund-cordate, subtrilobed, obtusely serrate, tomentose-hairy; peduncles axillary, 3-fid; sepals 5, linear; petals 5 , oblong, obtuse, attenuate at the base; stamens numerous; capsule echinate, 3 or 4-celled, 2-ovuled.

This plant was collected in Guam by Gaudichaud and figured in the botany of Freycinet's expedition as a ner species, T. fabreana." It is also found in the Admir- 
ralty, Marshall, and Solomon groups, in Fiji, Tahiti, and Samoa. The Samoan vernacular name signifies "seaside burweed," in contradistinction to Urena lobutu, which is simply called "mautofu" or burweed.

\section{REFERENCES:}

Triumfetta procumbens Forst. f. Prod. 35. 1786.

\section{Triumfetta rhomboidea.}

SMall BURWEed.

Local Names.-Dádangsi, Dádanse (Guam); Pegapega (Spanish).

A pubescent or glabrous weed with small yellow flowers growing in dense cymes. Leaves ovate, rhomboid, or cordate, 3 to 7 -nerved, apex acute or somewhat 3-lobed, serrate, variable in amount and quality of pubescence; flowers $6 \mathrm{~mm}$. long; pedicels short; flower-buds oblong, club-shaped, apiculate; sepals oblong, apiculate; petals oblong, ciliate at the base; stamens 8 to 15; capsule the size of a small pea, whitishtomentose between the spines; spines hooked, glabrous or ciliated. The species of this genus are so variable according to the various conditions of light and moisture and nature of the soil, that it is possible forms of the same species may be mistaken for distinct species. In making collections a series of plants should be gotten growing in different situations.

I have referred to this species the plant mentioned by Gaudichaud as Triumfetta lappula, as that species is West Indian and is not further recorded from the Pacific.

The plant yields a soft, glossy fiber, and like the allied species is mucilaginous, but it is not utilized in Guam.

\section{REFERENCES:}

Triumfetta rhomboidea Jacq. Enum. Pl. Carib. 22. 1760.

\section{Triumfetta tomentosa.}

WOOLLY BURWEED.

Local names.-Masigsig lahe (?) (Guam).

A widely spread tropical weed. It is possible that Gaudichaud referred to this species in giving in his list of Guam plants Corchorus tomentosus, which is a Japanese species. T. tomentosa differs from other species of the genus in having the spines of its fruit not hooked. It is an erect, branched, perennial herb, with softly hairy stems, often found.near cultivated ground, with numerous small yellow flowers in clusters opposite the leaves. Leaves 7 to $12 \mathrm{~cm}$. long, passing gradually into bracts in upper part of stem, ovate or ovate-lanceolate, slightly cordate at the base, acute, serrate, densely stellate-tomentose on both sides; petiole 1.2 to $5 \mathrm{~cm}$. long; stipules 6 $\mathrm{mm}$. long, setaceous; flowers on slender pedicels, clusters forming interrupted, spicate, terminal panicles, buds linear-clavate; sepals 5, narrowly linear, apiculate, densely stellate-hairy; fruit globose, about $5 \mathrm{~mm}$. in diameter, glabrous, covered with numerous straight, sharp spines equaling its diameter, and bristly for lower half. Flowers opening only in the afternoon. $a$

REFERENCES:

Triumfetta tomentosa Boj. Hort. Maurit. 43. 1837; Bouton, Rapp. Ann. Maur. 19. 1842 .

Trompa de elefante (Philippines). See Heliotropium indicum.

\section{Tronkon setlas (Guam). See Citrus medica.}

Tuba (Guam).

The vernacular name for toddy, made from the sap of the coconut. See Cocos nucifera.

Tuba (Philippines). See Jatropha curcas.

Tubatuba (Guam). The physic nut. See Jatropha curcas.

Tuberose. See Polianthes tuberosa.

Tubó (Philippines). See Saccharun officinarum. 
Tugui, Togui (Philippines). A yam. See Dioscorea and D. fasciculata.

Tugui-tuguian (Philippines). See Ipomoea mariannensis.

Tulip tree, Indian. See Thespesia populnea.

Tungô (Philippines). The spiny yam. See Dioscorea spinosa.

Tupe (Samoa). See Lens phaseoloides.

Tupo, Tupu (Guam). Sugar cane. See Saccharum officinarum.

Tupun ayuyu (Guam).

"Robber-crab's sugar cane," a succulent plant with leaves having 3 longitudinal nerves, not identified; said to be eaten by the ayuyu.

Tupun-neti (Guam). See Xiphagrostis floridula.

Turmeric. See Curcuma longa.

Turnip-bean. See Cacara erosa.

Twig-rush. Cladium gaudichaudii.

Ube, Ubi (Philippines, Java, Malay Archipelago). See Dioscorea, D. alata.

Uchaga lahe (Guam). See Eleocharis plantaginoidea.

Ufa (Guam). Vernacular name for Heritiera littoralis.

Ufi (Samoa). See Dioscorea alata.

'Ulu (Samoa, Hawaii). See Artocarpus communis.

'Ulu-ma'a (Samoa). See Artocarpus communis, seeded variety.

'Umala (Samoa). See Ipomoea batatas.

Umbrella tree. See Thespesia populnea.

Umog (Guam).

A name applied to sereral grasses with digitate spikes, including Panicum gaudichaudii and the introduced Eleusine indica.

Umog sensonyan, "swamp grass," (Guam). See Ceratopteris thatictroides.

Umumo, Umumu (Guam).

A tree mentioned by Governor Olive in his report to the captain-general of the Philippines, from the trunks of which sugar troughs are sometimes made. Called "umumu" by Gaudichaud, who referred it to Pisonia mitis. Growing in Tinian on rocks. See Pisonia excelsa.

Uñas de gato (Spanish).

"Cats-claws;" a name applied in Gnam to the nickernut (Guilandina crista) on account of the sharp, recurved spines of the branches and leaves.

Uom (New Lanenberg). See Pandanus dubius.

Upo. (Philippines). See Lagenaria lagenaria.

Urena sinuata.

DOG'S-FOOT BURWEED.

Family Malvaceae.

Local Xames. - Darlangsi, Dadanse (Guam); Cadillo pata-rle-perro (Porto Rico); Bondenkiva (Japan); Mautofa (Samoa).

An erect branched hairy weed, growing to a height of about a meter, with palmately lohed downy leaves, small pink mallow-like flowers, and bur-like fruit. Stem and branches covered with spreading stellate hairs; leaves very variable, 4 to $8 \mathrm{~cm}$. long, usually deeply palmately cut into 5 lobes, which are again lobed or pinnatifid, serrate, stellate, hairy on linth sides, and having a gland beneath on the milvein near its hase and sometimes similar glands on 2 lateral nerves; flowers clustered; lurateoles 5, alnate to the 5-cleft calyx, linear-oblong, nearly as long as the calyx; petals 5 , united to the base of the tube formed by the stamens; anthers nearly seswile; ovary 5 -relled, cells $1-0$ vulerl; stigmatic branches 10 ; stigmas capitate; ripe carpels covered with pubescence and set with hooked bristles. 
This plant varies in the shape of its leaves and the amount of pubescence. It is closely allied to Urena lobata, the "mautofu" of the Samoans. The stem yields a good fiber, of which cordage is made in Japan, but this is not utilized in Guam.

A common plant in open places; of wide tropical distribution. It blooms the latter part of October.

REFERENCES:

Urena sinuata L. Sp. Pl. 2: 692. 1753.

\section{Urticaceae.}

Nettle family.

Among the indigenous urticaceous plants are the "amahayan," Boehmeria tenacissima, which in cultivation produces the celebated rhea fiber; an allied plant with fulvous pubescence called "sayiafi" (not yet identified); Pipturus argenteus, the "Queensland grass-cloth plant," called in Samoa "fau-songia," Elatostema pedunrulata, a plant of the forest, which bears sessile red spherical fruit; the nettle-like Schychouskya interrupta, with coarsely toothed acuminate leaves; the glabrous schychowskya mideralis; and Pellionia divaricata.

Urtica argentea Forst. Same as Pipturus argenteus.

Urtica interrupta L. Same as Schychowskya interrupta.

Urtica ruderalis Forst. Same as Schychowskya ruderalis.

Urtica tenacissima Roxb. Same as Boehmeria tenacissima

Uto (Fiji). See Artocarpus communis.

Uto-sori (Fiji). See Artocarpus communis; seeded variety.

'Uto'uto (Samoa). See Mussaenda frondosa.

Utud or Utug (Guam). See Icacorea sp.

Uuma or Ououma. A name referred by Gaudichaud to Panicum gaudichaudii; more correctly "umog."

Uvi (Fiji). See Dioscorea alata.

Vallisneriaceae.

TAPEgRASS FAMILY.

The only representative of this family in Guam is Halophila ovalis.

Vanilla fasciola Gaudich. Same as Taeniophyllum fasciola.

Velvetleaf. See Tournefortia argentea.

Verbenaceae.

VERBENA FAMILY.

This family is represented in Guam by the genera Clerodendron, Vitex, and Premna.

Verbesina alba L. Same as Eclipta alba.

Verbesina argentea.

In the botany of the Voyage de l'Uranie, Gaudichaud mentions among the plants growing on the hills back of Agaña and Umata, in places where the vegetation was scant, a "Verbesina with silver leaves." This is included in Endlicher's list of South Sea Island plants as "Terbesina? argentea Gaudich. ad Freyc. 464.-Guam archipelagi Mariannae (Gaudich.)."a The plant is not further known. In the locality referred to I have collected two species of yellow composites, both of which are allied to Verbesina, one of them, Stemmodontia canescens, with silvery canescent leaves. It is probable that this is the plant referred to by Gaudichaud as the "silvery-leaved Verbesina."

REFERENCES:

Verbesina argentea Gaudich. Bot. Freyc. Voy. 463. 1826.

Verbesina biflora L. Same as Stemmodontia biflora.

Verbesina canescens Gaudich. Same as Stemmodontia canescens.

a Annalen des Wiener Museums, vol. 1, p. 169, 1836. 


\section{Verbesina nodiflora L. Same as Synedrella nodiflora.}

Verdolaga (Spanish). Purslane. See Portulaca oleracea.

Verdolaga de Costa (Spanish, Cuba). Sea purslane. See Sesuvium portulacastrum. Verdura (Spanish).

The general name for greens or pot-herbs; in Guam called "golae."

\section{Vernonia cinerea.}

Gray ironweed.

Family Asteraceae.

A pubescent annual composite with small rayless heads of pinkish-violet flowers. Stem 15 to $60 \mathrm{~cm}$. high, erect, stiff, cylindrical, grooved and ribbed, sometimes hoarypubescent, slightly branched; leares distant, the lowest $5 \mathrm{~cm}$. long but gradually smaller upwards, broadly oval to linear-lanceolate, tapering to base, subobtuse, apiculate, coarsely and shallowly crenate-serrate, more or less hairy on both sides; petiole 6 to $18 \mathrm{~mm}$. long; heads of flowers small on long stalks, in lax divaricate terminal corymbs; involucre bracts linear, mucronate, silky, flowers 20 to 25 ; achene not ribbed, hairy; pappus white, outer row very short.

A common weed in waste places and on abandoned clearings, flowering all the year. Widely spread throughout the Tropics. It varies according to conditions of light, moisture, and character of soil.

RefERENCES:

Vernonia cinerea (L.) Less. Linnæa 4: 291. 1829.

Conyza cinerea L. Sp. Pl. 2: 862. 1753.

Vernonia parviflora Reinw. Same as Vernonia cinerea.

\section{Vernonia villosa.}

WOOLLY IRONTEED.

A puberulous or woolly composite with rayless heads of flowers $8 \mathrm{~mm}$. in diameter. Branches slender-cylindrical; leaves sessile or petioled, ovate, elliptic, or elliptic-lanceolate, sulsserrate; heads 20 to 30 -flowered, scattered or binate or ternate; involucre bracts pubescent, lanceolate, mucronate; achenes 4 or 5-ribbed, glabrous, glandular; pappus white.

This species was collected in Guam by Haenke and afterwards by Chamisso. It is widely distributed in the Tropics, occurring in southern Asia, the Philippines, and on several islands of Polynesia.

Referexces:

Vernonia villosa (Blume).

Conyza chinensis Lam. Encyc. 2: 83. 1786, not L. Sp. Pl. 2: 862 . 1753.

Centrathemum chinense Less. Linnæa 4: 320. 1829.

Vernonia chinensis Less. Linnæa 6: 105, 67t. 1831.

Cyanthillium villosum Blume, Bijdr. 889. 1826.

Via (Fiji Islands). See Alocasia indica.

Vigna sinensis.

Chinese asparagus bean.

Family Fabaceae.

Local NaMes. - Sítao (Philippines); Twining cowpea (United States).

A twining variety of the well-known " compea," bearing long slender legumes which the natives eat as a regetahle. Leaves pinnately 3 -foliolate, stipules large, attached ahove the have; leaflets membranous, ovate-rhomboidal, entire or slightly lobed, terminal leaflet 5 to $15 \mathrm{~cm}$. long, long-stalked; racemes axillary, few-flowered, long-peduncled; calyx campanulate; corolla much exserterl; keel truncate; stamens diadelphous; anthers uniform; pod very long, many-seeded.

Commonly cultivated in the gardens of Guam, trailing along the fences of inclosures. Flowers large, white or pale purple.

ReFERENCES:

Vigna sinensis (Stickman) Endl.; Hassk. PJ. Jav. Rar. 386. 1848.

Dolichos sinensis Stickman, Herb. Amb. 1754; Amoen. Acad. 4: 132. 1759; L. Cent. Pl. 2: 28. 1756. 
Vigna lutea.

SEASIDE BEAN.

A trailing, yellow-flowered, perennial plant growing on sandy beaches. Leaves trifoliolate; stipules minute, lanceolate, attached by the hase; leaflets obovate, obtuse, rather fleshy, entire, glabrous; racemes many-flowered, long-peduncled; pods short, few-seeded, resembling those of Phaseolus.

It is possible that the allied Vigna luteola occurs in Guam, although I have not found it on the island. It differs from the preceding in having acute, membranous leaflets, the lower tooth of the calyx lanceolate, as long as the tube, and the pod recurved, containing 6 to 12 seeds.

REFERENCES:

Vigna lutea (Swartz) Gray, Bot. U. S. Expl. Exped. 1: 452.1854.

Dolichos luteus Swartz, FI. Ind. Oce. 3: 1246. 1806.

Vinagrillo (Porto Rico). See Oxalis corniculata.

Vinca rosea L. Same as Lochnera rosea.

Vitex incisa Lam. Same as Vitex negundo.

Vitex negundo.

LAGUNDI.

Family Verbenaceae.

Local NAmes._Lagundi (Guam, Philippines); Nika (Ceylon).

A shrub or small tree, with palmately compound aromatic leaves and cymes of small lilac-blue flowers. Branchlets 4-cornered, finely pubescent; petioles slender, pubescent, 4 to $6.5 \mathrm{~cm}$. long; leaflets 3 or 5 , the two lowest smaller and nearly sessile, the others long-stalked, 7.5 to $10 \mathrm{~cm}$. long, linear-lanceolate, acute and often unequal at base, tapering to a very acute apex, nearly glabrous above (when mature), covered with a dense, white, fine pubescence beneath; flowers numerous on very short pubescent pedicels; cymes small, stalked, opposite, on erect branches of an erect, pyramidal, terminal panicle; bracts caducous; calyx small, pubescent, segments 5 , very short, triangular; corolla pubescent outside, tube hairy within, the 4 upper lobes short, triangular, lowest one large, rounded, forming lower lip; drupe under $6 \mathrm{~mm}$. long, nearly globose, black.

The leaves are aromatic when bruised. In India pillows are stuffed with them and are said to relieve headache. The leaves and root are used medicinally, and are said to be tonic. This species was collected by Lesson and Gaudichaud in Guam, and given in Endlicher's Flora der Südseeinseln as Vitex incisa Lam. Growing in low places and on the borders of streams.

REFERENCES:

Vitex negundo L. Sp. Pl. 2: 638. 1753.

Vitex paniculata Lam. Same as Vitex negundo.

Vitex trifolia.

WILD PEPPER.

LOCAL NAMES.-Lagundi (Guam); Rara (Rarotonga); Namulenga (Samoa); Hamagō, Hamashikimi (Japan); Wild pepper (India).

A shrub resembling Vitex negundo, but with lighter-colored flowers and leaves sometimes simple and sometimes 3 -foliolate. Bark smooth, pale gray; lateral leaflets smaller than the terminal; leaflets sessile, tapering to base, obtuse, all entire, glabrous above, very finely and closely white-pubescent beneath; petiole about $1 \frac{1}{4} \mathrm{~cm}$. long, pubescent, flowers on short pedicels; cymes paniculate, $1 \frac{1}{4} \mathrm{~cm}$. long, pubescent; bracts minute; calyx white-pubescent, enlarged in fruit, segments obscure; corolla pubescent outside, tube cylindrical funnel-shaped, $6 \mathrm{~mm}$. long, mouth oblique, upper lip with 2 obtuse lobes, lower 3 -lobed, the middle one much the longest; stamens 4, didymous, much exserted; ovary 2 or 4-celled; ovules 4; stigma bifid; drupe globose, about $6 \mathrm{~mm}$. in diarneter, the lower half or more closely invested by the enlarged calyx, slightly scurfy, purplish black, stone usually 1-celled by abortion.

A shrub usually growing in swampy places near the coast, differing from the preceding species in having obtuse leaflets. The leaves are pleasantly aromatic when 
crushed. The species is of wide distribution, occurring in tropical Asia, the East Indies, the islands of eastern Africa, and Polynesia. Of the variety unifolictu, which grows on the seacoast of Japan, the small, round, fragrant seeds are gathered and used medicinally.

REFERENCES:

Vitex trifolia L. Sp. PI. 2: 638. 1753.

Vitis.

Grape.

Family Vitaceae.

LOCAL NAMES.-Parra (Spanish).

Grapes are cultivated by a few of the natives, but they are of inferior quality and thus far have not proved successful.

\section{Vittaria elongata.}

RIBBON FERN.

Family Polypodiaceae.

An epiphytal fern with grass-like fronds, having its sori in a continuous line in a furrow along the margin.

\section{References:}

Vittaria elongata Sw. Syn. Fil. 106. 1806.

Vittaria ensiformis Llanos. Same as Vittaria elongata.

Volkameria inermis L. Same as Clerodendron inerme.

Waltheria americana.

Matico.

Family Sterculiaceae.

Local Names.-Hialoa (Hawaii); Malva blanca (Cuba); Malvabisco, Basora prieta (Porto Rico); Matico, Hierba del Soldado (Trop. America).

A perennial weed with a woody base, 30 to $60 \mathrm{~cm}$. high, densely tomentose or softly hairy in every part. Leaves ovate-oblong, $1.5 \mathrm{~cm}$. by 2 to $3 \mathrm{~cm}$., on petioles $12 \mathrm{~mm}$. long, obtuse, dentate, feather-veined; down stellate mixed with simple hairs; stipules narrow, deciduous; flowers small, sessile in close clusters along axillary peduncles $t \mathrm{~cm}$. long; bracts linear; calyx 5-lobed, downy, lobes acute; petals little longer, unguiculate or clawed, orange-colored; stamens 5 , opposite the petals, united at the base, with 2 parallel anther cells; ovary downy, sessile, of a single carpel with 2 erect ovules, style excentrical, with fringed stigma; capsule opening at the back into 2 valves; seeds usually solitary.

A common weed of wide distribution in the Tropics and occuring on many Pacific islands.

REFERENCES:

Waltheria americana L. Sp. Pl. 2: 673. 1753.

Waltheria indica L. Sp. Pl. 2: 673. 1753.

Waltherice elliptica Cav. Diss. 6: 316. t. 171. f. 2. 1788.

Waltheria elliptica Cav. Same as Waltheria americana.

Waltheria indica L. Same as Waltheria americana.

Walwalisán (Philippines). See Sida carpinifolia.

Water fern. See Ceratopteris thalictroides.

Water hyssop. See Bacopa monniera.

Watermelon. See Gardens.

Water-root. See Nervilia arragoana.

Wax-gourd. See Benincasa cerifera.

Weather plant. See Abrus abrus.

Wedelia biflora. Same as Stemmodontia biflora.

Wedelia canescens. Same as Stemmodontia canescens.

Wedelia chamissonis Less. Same as Stemmodontia canescens. 



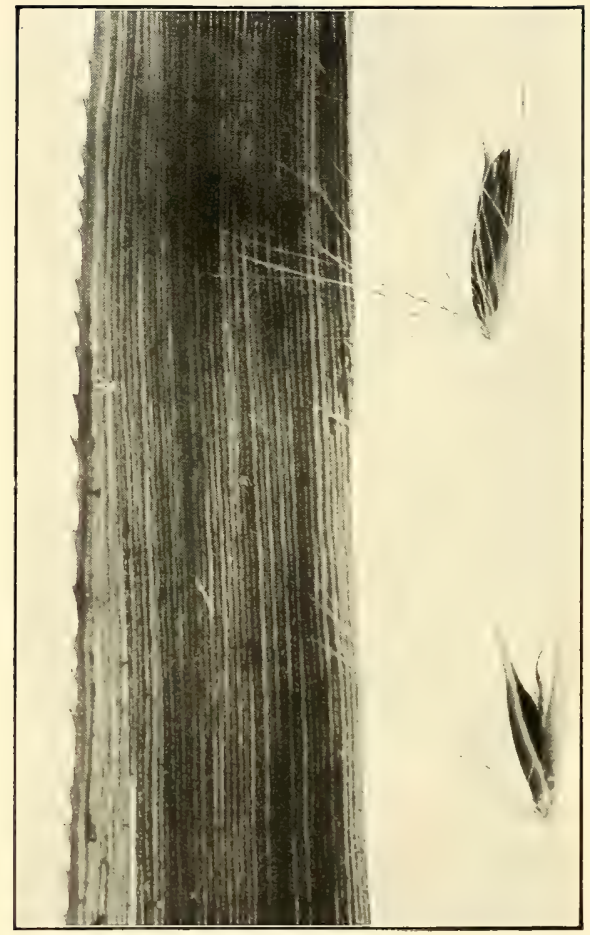

Xiphagrostis floridula (SWord Grass). Spikelets and Portion of leaf Blade Magnified, Showing Cutting Teeth. 
Weeds. See page 151 .

Weissia. See Mosses.

Wild elder. See Premna gaudichaudii.

Wild ginger. See Zinziber zerumbet.

Wild ipecac (Hawaii). See Asclepias curassavica.

Wild mangosteen. See Sandoricum indicum.

Wild olive (Jamaica). See Ximenia americana.

Wild orange. See Citrus aurantium.

Wild yam (Guam). See Dioscorea spinosa.

Wire fern. See Lygodium scandens, under Ferns.

Wire vine. See Cassytha filiformis.

Witchleaf. See Bryophyllum pinnatum.

Wollastonia biflora DC. Same as Stemmodontia biflora.

Wollastonia canescens DC. Same as Stemmodontic canescens.

Wollastonia scabriuscula DC. Same as Stemmodontia biflora.

Woodsorrel. See Oxalis corniculata.

Wormwood. See Artemisia vulgaris.

Ximenia americana.

False SANDALWOOD.

Family Olacineae.

Local names.-Pi'od, Piut (Guam); Moli-tai (Samoa); Somisomi, Tomi-tomi (Fiji); Jía manzanilla, Ciruelo cimarron (Cuba); Wild olive (Jamaica); Hog plum, Seaside plum (West Indies).

A shrub or small tree bearing an edible, spherical, orange-colored drupe, flarored like a bitter almond and tasting somewhat like a crab apple. Branches thorny, spreading, glabrous, covered with a red astringent bark, often ending in a spine; young shoots angular; leaves shortly petioled, alternate, simple, $2.5 \mathrm{~cm}$. wide by $3 \mathrm{~cm}$. long and upward, coriaceous, glabrous, ovate-oblong or roundish, emarginate, base rounded; flowers 2.5 to $7.6 \mathrm{~cm}$. long, usually hermaphrodite, sometimes polygamous, white, fragrant, in short racemes, which are axillary or on the ends of thickened contracted shoots; rachis terete, 4 to 6-flowered; bracts-minute; buds oblong, acute; calyx minute, 4 or 5 -toothed; petals 4 or 5 , oblong, hairy within, equal to the stamens in length; stamens twice the number of the petals, borne at the base of the ovary; anthers linear, 2-celled; ovary sessile, superior, ovoid-oblong, glabrous, surrounded at the base hy the persistent, ultimately reflexed calyx; style as long as the stamens.

Of wide distribution throughout the Tropics. In Guam the fruit is much relished by the fruit pigeons. The wood is hard and is sometimes used as a substitute for sandalwood.

\section{REFERENCES:}

Ximenia americana L. Sp. Pl. 2: 1193. 1753.

Ximenia elliptica Forst. Same as Ximenia americana.

Xiphagrostis floridula.

Sword GRass. Plate lixix.

Family Poaceae.

Local Names.-Nete, Neti, Tupun-neti (Guam); Ngasau, Vitavita (Fiji); Kakao

(Rarotonga); Fiso (Samoa); Non kai (Kaiser Wilhelmsland).

A tall perennial grass with terminal feathery panicles, growing in damp places and also covering large tracts on the hills, called "sabanas." Leaves long and flat, the edges armed with minute sharp teeth; spikelets in pairs on the joints of the rachis, one pedicelled, the other nearly sessile, awned, with a cluster of silky hairs rising from the base of both, giving to the panicle its feathery appearance; glumes 4 . This grass resembles the "cogon" (Imperata arundinacea) of the Pbilippines, which cov- 
ers abandoned clearings on many islands; but it is much taller and its 1-flowered spikelets are awned and are borne in a spreading panicle, while those of Imperata are not awned and are in a silvery cylindrical thyrsus with dark anthers and stigmas.

The species is widely spread throughout the islands $0_{i}$ the Pacific. It has been confused by Hackel with the closely allied northern species Xipheagrostis japonica.

Its identity was first established by Warburg. " Distribution: from Java through Malaysia to Polynesia and Formosa.

In Guam this grass is sometimes used for thatching, and is more durable than either coconut or nipa thatch. A roof of coconut thatch will last four years; one of nipa-palm leaflets will last from ten to twelve years; and one of neti will last longer than this. $b$ In other islands of the Pacific it is also used for thatch, especially in Fiji, Samoa, and Rarotonga; and some of the Malanesians harden the straight light stems and use them as shafts for their arrows. On the island of Guam large areas of "neti" are frequently burned by hunters to drive out the deer which take refuge in them. The young shoots which spring up are eaten by deer, cattle, and buffaloes, but when it is fully grown it is too rough for fodder. The minute teeth which arm the margins of the leaves make them very sharp; and one is almost certain to be cut on the face or hands in passing through a thicket of this grass. It is on this account that the English-speaking inhabitants of the island call it "sword-grass."

REFERENCES:

Xiphagrostis floridula (Labill.) Coville.

Saccharum floridulum Labill. Sert. Austr. Caled. 13. t. 18.1824.

Miscanthus floridulus Warb.; K. Sch. \& Laut. Fl. Deutsch. Schutzgebiet. in der Sudsee 166. 1901.

The first species and type of the genus Miscanthus, established by Andersson in 1856, is $M$. capensis, a species which is not congeneric with those referred to the genus by later authors. The plants commonly included under Miscanthus are therefore left without a valid generic designation, and the name Xiphagrostis ( $\xi i \phi o 5$, sword, and $\not ̈ y \rho \omega \sigma \tau \imath 5$, grass) is here proposed, the type species being floridulus, the citation to the original description of which is given above. Another well-known grass of the same genus, in frequent cultivation under the name Eulalia japonica, becomes Tiphagrostis juponira (Thunb.) Coville (Saccharum japonicum Thunb., Eulalia japonica Trin., Miscanthus sinensis Anders.).-Frederick V. Coville.

Xylocarpus granatum.

Cannon-Ball TREe. $c$

Family Meliaceae.

Local xayes.—Lalányog, Lalányog (Guam); Kaliunpag-sa-lati, Libato-pula (Philippines); Dabi (Fiji).

A glahrous, evergreen, littoral tree, with a large, hard, brown, irregularly globose fruit with a thin rind, containing 6 to 12 large, angular, hard, corky seeds. Leaves alternate, pinnate, 2 to 6 -foliate; leaflets stiff, opposite, entire, ovate or obovate, usually obtuse, very shortly petiolulate; panicles lax, axillary; flowers small, sweetscented, yellowish or white, hermaphrodite, sometimes in simple racemes; calyx 4 -fid, short; petals 4 , reflexed, contorted sinistrosely; stamens united into an urceolateglohose tube which is 8-toothed at apex, the teeth bipartite; anthers 8, 2-celled, just included, sessile at top of tube, alternating with the teeth; style short; stigma discoid; ovary 4-celled, 4 -sulcate; cells 2 to 8 -ovuled; pericarp fleshy, dehiscing by 4 valves opposite the obliterated dissepiments.

A tree widely spread on tropical shores, common in India and Ceylon, the Malay Archipelago, North Australia, and on many islands of the Pacific. The astringent

a See Schumann und Lauterbach, Die Flora der deutschen Schutzgebiete in der Südsee, pp. 166, 167, 1901 .

$b$ MS . notes furnished me by Don Justo Dungca, late justice of the peace of the island of Guam, and one of the principal coconut planters of the island.

c Trimen, Handbook Flora of Ceylon, vol. 1, p. 251, 1893. 
bark is red and flakes off. It is used as a remedy in dysentery. In Guam the wood is used for making spokes of wheels and for floors of small houses. It is fine-grained, heavy, hard, durable in water, and of a red or brown color. Logs 4.5 meters long and $30 \mathrm{~cm}$. in diameter may be obtained. The tree yields a resin and from the seeds a whitish semi-solid oil is expressed which becomes fluid at a high temperature. This is used in India for burning, and in some places as a hair oil.

REFERENCES:

Xylocarpus granatum Koen. Naturf. 20: 2. 1784.

Carapa moluccensis Lam. Encyc. 1: 621. 1783.

Xylocarpus moluccensis (Lam.) Roem. Syn. Hesper. 124. 1846.

Yabag (Philippines). See Sophora tomentosa.

Yahon-yahon (Philippines). See Centella asiatica.

Yam, Chinese. See Dioscorea glabra.

Yam, common. See Dioscorea sativa.

Yam, Guinea. See Dioscorea aculeata.

Yam, kawai. See Dioscorea aculeata.

Yam, kidney-potato. See Dioscorea fasciculata.

Yam, negro. See Dioscorea sativa.

Yam, Papuan. See Dioscorea papuana.

Yam, prickly. See Dioscorea aculeata.

Yam, round-stemmed. See Dioscorea sativa.

Yam, spiny. See Dioscorea spinosa.

Yam, square-stemmed. See Dioscorea alata.

Yam, ubi or uvi. See Dioscorea alata.

Yam, wild. See Dioscorea spinosa.

Yam, wing-stemmed. See Dioscorea alata.

Yam, white. See Dioscorea alata.

Yam-bean. See Cacara erosa.

Yampong (Philippines). See Abutilon indicum.

Yard grass. See Eleusine indica.

Yard-long bean, Asiatic. See Vigna sinersis.

Yellow-wood, Marianne. See Ochrosia mariannensis.

Yerba-buena (Guam). See Mentha arvensis.

Yerba de Clavo (Porto Rico). See Centella asiatica.

Yerba de Santa Maria (Guam, Philippines). See Artemisia vulgaris.

Ylang-ylang. See Canangium odoratum.

Yogâ (Guam).

A large forest tree with buttressed trunk, bearing a bluish fruit like a large grape in appearance, dry and insipid, but eaten by birds. Wood not very durable; sometimes used for oars. Also written "joga," the Guam Y being pronounced like the English J. According to Governor Perez it yields logs 12 to 14 meters long.

Yovas (Philippines). See Graptophyllum pictum.

Yuka (Guam). See Manihot manihot.

Yuquillo (Porto Rico). See Curcuma longa.

Zacate.

A name applied in Guam, Mexico, and the Philippines to grass, hay, or forage for animals.

$9773-05-26$ 
Zacate limon (Guam). See Andropogon nardus.

Zapote chico, Zapotillo chico (Philippines). See Sapota zapotilla.

\section{Zea mays.}

MaIze. Indian CORN.

Family Poaceae.

Local Names. - Maeis, (Guam); Maiz (Spanish); Borona (Philippines).

Indian corn is now the principal food staple of the natives of Guam. It was brought by the Jesuit missionaries from Mexico nearly two centuries ago. It immediately became the principal source of food for the mission and the soldiers, ${ }^{a}$ and in a few years was adopted by the natives. It is now planted by every family on the island.

Two crops a year are produced upon the island. The first, called "las primeras," planted after the first showers of April, or in May or June, is harvested in August, September, or October. The second, called the "aventurero," planted in September, October, or November, is harvested four months after planting. Low and moist situations must be selected for the aventurero, as well as for all other plantings except the primeras; for as a rule crops planted on high land in the dry season suffer from drought and are fit for nothing but forage. In certain low valleys which are flooded during the rainy season and become dry in December maize is planted in January, February, or March and harvested four months later.

Immediately after having been gathered it must be shelled and dried in the sun, to prevent molding. At times the streets of Agaña are so thickly covered with mats of drying corn that it is difficult to make ones way through them without stepping on the corn. After having been thoroughly dried the grain is stored in earthen jars (tinajas) having a capacity of about 16 gantas (48 liters). This is necessary on account of weevils which infest the island. Under good condition 60 tinajas of shelled corn are obtained from one hectare of land, $b$ which is approximately equivalent to 38 bushels to the acre.

Only one variety of maize is successfully grown on the island. It is soft-grained and white, resembling that which is most common in Mexico. Attempts have been made to introduce sweet corn, pop corn, and several varieties of field corn from the United States, but they have been failures. Maize is usually prepared for food in the form of tortillas, after the Mexican manner. The grain is put to soak overnight with a certain quantity of lime, which softens it and loosens the husk. It is then washed in cold water and rolled on an inclined stone slab called "metate" to a paste, by means of a stone rolling-pin called a "mano." Both the metate and mano are Ilexican intrusions, having found their way to Guam with the maize itself, and are also used for grinding cacao leans and nuts of Cyces circincelis, in making chocolate and tortillas or fadan. The tortillas are like very thin flat cakes. They are baked on a griddle or iron plate and are browned on both sides. When fresh they are very palatable, having a flavor of parched corn and a crisp consistency. When cold, however, they hecome tough and leathery, and are only fit to feed to animals.

REFERENCES:

Zea mays L. Sp. Pl. 2: 971. 1753.

Zebrawood (Madagascar). See Guettarda specinsa.

Zephyr lily. See Atamosco rosea.

Zephyranthes rosea. Same as Atamosco rosea.

$a$ In the annals of the mission it is related that on the night of October 15,1676 , the natives "destroyed a field of maize, which was the principal sustenance of the missionaries and solilicrs;" and in $167 \mathrm{~s}$ that the natives had "learned to eat pork, and were becoming fond of maize, although they did not make bread of it, not having instrmuents for its preparation. They were also planting many watermelons and tohac'(o), hut they did not know how to prepare it or cure it." (Padre Francisco Gareia, Vida e Martyrio, etc., pp. 554 and 572.)

$b$ MS. notes of Don Justo Dungea, one of the principal planters of the island. 
This family is represented in Guam by Curcuma longa, Zinziber zerumbet, and the cultivated Z. zingiber.

\section{Zinziber zingiber.}

Ginger.

Family Zinziberaceae.

Local nayes.-Asñgod (Guam); Luya, Baseng, Pañgas, Layâl (Philippines).

An aromatic plant with a horizontal, tuberous rootstock. Leafy, stem elongated, 90 to $120 \mathrm{~cm}$. long; leaves lanceolate, glabrous beneath, 15 to $32.5 \mathrm{~cm}$. long by 2.5 $\mathrm{cm}$. broad, tapering gradually to the point, clasping the stem by their long sheath; spikes usually radical, rarely lateral or terminal on the leafy stem; oblong-cylindric; bracts greenish, suborbicular, cuspidate; corolla segments greenish, lanceolate, sul)equal, lip small, purplish black, shorter than the corolla segments; stamens dark purple. Rarely flowers.

\section{REFERENCES:}

Zinziber zingiber (L.) Karst. F1. Deutsch. 1: 488. 1895.

Amomum zingiber L. Sp. Pl. 1: 1. 1753.

Zingiber officinale Rosc. Trans. Lin. Soc. 8: 348. 1807.

Zinziber officinale Same as Zinziber zingiber.

Zinziber zerumbet.

WILD GINGER.

Local names.-Asñgod halom-tano (Guam); Luyâluyâ, Támo, Dao (Philippines); Ava-pui (Samoa); Awa-puhi (Hawaii); Réa (Tahiti).

An aromatic plant, with a horizontal, tuberous rootstock, of a pale yellow inside; leafy stem 90 to $120 \mathrm{~cm}$. long; leaves $30 \mathrm{~cm}$. long by 5 to $7.5 \mathrm{~cm}$. broad, oblonglanceolate, glabrous beneath; spike oblong, very dense; bracts very obtuse, green, with a paler edge; corolla tube as long as the bract; segments $2.5 \mathrm{~cm}$. long, upper broader, whitish, lip sulphur-yellow, unspotted, with a midlobe 7.5 to $10 \mathrm{~cm}$. broad; stamen pale, as long as the lip; capsule oblong, above $2.5 \mathrm{~cm}$. long.

A plant widely distributed in the Tropies of the Old World, common on nearly all the islands of the Pacific.

\section{REFERENCES;}

Zinziber zerumbet (L.) Rose.; Smith, Exotic Bot. 2: 105. t. 112. 1805.

Amomum zerumbet L. Sp. Pl. 1: 1. 1753.

\section{Zizyphus jujuba.}

JUJUBE.

Family Rhamnaceae.

Local Names.-Manzanas (Guam); Manzanitas (Philippines).

A small tree bearing an edible spherical drupe, which is yellow when ripe. Leaves alternate, 3-nerved, elliptic-ovate, ovate, or suborbicular, dark green and glabrous above, covered beneath with a dense woolly tomentum; branches usually armed with stipulary prickles, which are either solitary and straight, or geminate and then one shorter and recurved; flowers hermaphrodite or polygamous, small, greenish, fascicled, or in cymes; cymes 7.5 to $10 \mathrm{~cm}$. long; calyx 5-fid, glabrous within; petals 5, subspathulate, very convex, reflexed; calyx tube filled by disk; styles 2 , united to the middle; drupe smooth, sweet, and mealy; nut rough, 2-celled. Cultivated in many tropical countries. Introduced into Guam about fifty years ago, but not generally cultivated.

\section{REFERENCES:}

Zizyphus jujuba (L.) Lam. Encyel. 3: 318. 1789.

Rhamnus jujuba L. Sp. Pl. 1: 194. 1753.

\section{Zornia diphylla.}

ZorNIA.

Family Fabaceae.

A leguninous plant with many wiry branches, compound leaves with a single pair of small leaflets, large stipules, and small, sessile, papilionaceous flowers, which are borne in long lax spikes, inclosed each in a pair of large flat bracts. Stipules lance- 
olate, acuminate, produced below into an acuminate appendage, rachis of the leaflets 8 to $12 \mathrm{~mm}$. long, leaflets very shortly stalked, linear-lanceolate or lanceolate, acute, often unequal-sided, glabrous, rigid, dotted with black glands beneath; bracts inclosing the flowers ovate, acute, reticulate-veined, leaf-like, persistent, often ciliate, dotted like the leaves, arranged in stiff, erect, very lax axillary spikes; flowers with minute calyx having the upper segments connate, the petals exserted, and the stamens monadelphous; pod jointed, easily separable into flattened, indehiscent 1-seeded joints, either quite inclosed between the bracts or slightly exceeding them; surface of the joints set with numerous short, straight spines.

A common weed growing in waste places and on the sites of abandoned clearings. References:

Zornia diphylla (L.) Pers. Syn. 2: 318. 1807.

Hedysarum diphyllum L. Sp. P1. 2: 747. 1753.

Zostera tridentata Solms. Same as Halodule uninervis.

Zygomenes cristata.

Crested spiderwort.

Family Commelinaceae.

A common weed growing in open places, with 3-petaled flowers in terminal scorpioid, bracteate cymes, inclosed in large falcate, imbricating, 2-seriate bracteoles. Stem creeping below, branches ascending; leaves ovate-oblong, subacute; the petals and stamens alone are exserted beyond the bracteoles; sepals 3 ; corolla with a funnel-shaped tuke and a spreading, equally 3-lobed limb; stamens 6, bearded; ovary 3 -celled; cells usually 2 -seeded; style thickened at tip; seeds striate and pitted.

A plant widely spread in the Tropics.

ReFerences:

Zygomenes cristata (L.)

Commelina cristata L. Sp. Pl. 1: 42.1753.

Cyanotis cristata (L.) D. Don, Prod. Fl. Nep. 46. 1825.

Tradescantia cristata L. Syst. ed. 12. 233. 1767.

Salisbury's name, Zygomenes is thirteen years earlier than Don's publication of Cyanotis. 


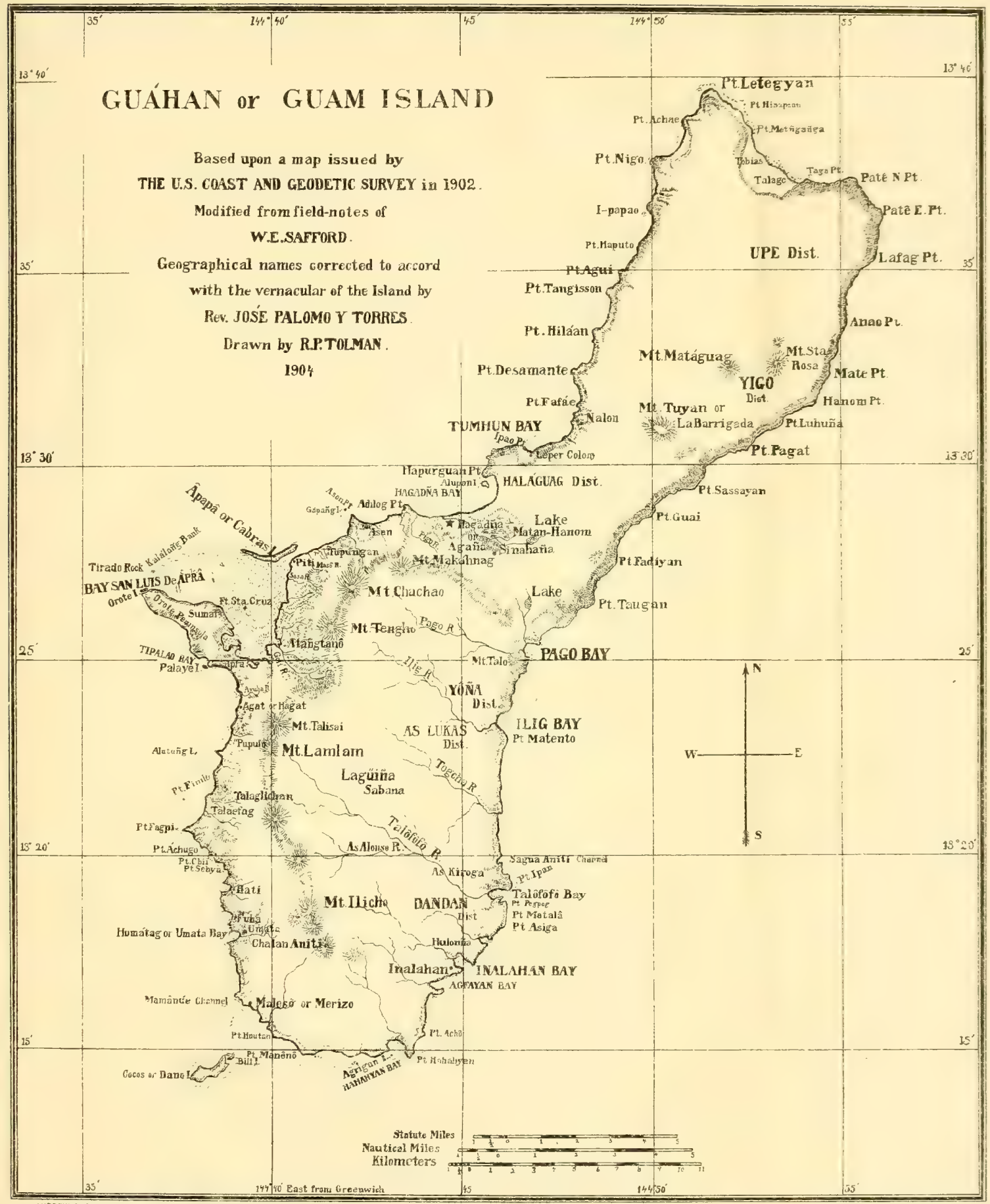





\section{IN DEX.}

[As the descriptive catalogue of plants, which forms the principal part of this work, is alphabetically arranged the names which it contains are not repeated in the index.]

Abacá, or abaká (Manila hemp) ......... 57,148

Abacá fiber, preparation of............ 329

Abandoned clearings .................... 141

Abbe, Cleveland, jr., on earthquakes..... 51

on meteorology of Guam .............. 4, 41

suggests meteorological station ......... 44

Aboriginal inhabitants of Guam ........ 95-117

Abrin, a toxalbumen.................... 172

Abudefduf, fishes called "fomho" ....... 84

Acapulco, a Mexican seaport.............. 13

Acarina infesting cattle................ 77,94

Acrid plants used for food .............. 179, 180

Acrocephalus luscinia, only song bird...... 30,79

Adultery, punishment................... 104

Adzes of the aborigines ................ 100

Aegialites mongola, a shore bird........... $\quad 80$

Aerial roots ............................ 53

Aga, a crow ............................ 79

Agaña, capital of Guam .................. 11

chief town of aborigines................ 98, 104

oldest settlement in the Preific .......... 24

population ........................... 137

Agaña harbor, small size ................. 46

Agaña river ............................. 52

Agassiz, Alexander..................... 46

Agat district, population ............... 137

Aged, respect shown .................... 129

Agricultural implements............... 125, 143

Agriculture of aborigines............... 98

of modern inhabitants ................ 34, 139

Agrigan Island, present population ....... 138

Aguardiente from cocoanut sap.......... 99, 237

Air cavities in sea beans................... 73

Alamágan Island, present population..... 138

Albatross expedition ................... $\quad 47$

Aleurites, extrafloral nectaries............ . 67

Algæ, edible...........................

Alimasag, a crab

Alligator pears absent from Guam ......... .

Alocasia, needle crystals ................. eaten by hogs .........................

vernacular names . . . . . . . . ..............

Amanses sandwichensis, a fish armed with spurs

American plant names...................

Amphiprion (demoiselle fishes) ............

Amusements of aborigines ................

of modern inhabitants .............. 130,131

Anampses coeruleopunctatus, a fish called "tátalun"

Anas oustaleti, a wild duck ............ . . 80, 126

Ancestors, veneration of
Anchorage ......................... 46

Anchorage charges recommended by Villa-

lobos ........................... 34

Anderson, John, a settler in Guam....... 31

Anguilla, a fresh-water eel ............... $\quad 85$

Aniculus, a hermit crab ................... 90

Animal pests ........................... 152

Animals of Guam .................... 76

Animism of aborigines ..................... 109

Aniti (demons) .......................... 15, 109

Anito of Philippine tribes ............... 110

Annelids, marine....................... 89

Anosia plexippus, a butterfly ............... 91

Anous lencocapillus, a sea-bird.............. 80

Anous stolidus, the common noddy ........ 80

Anson, English navigator ............... 20

Ants................................ 91

attracted by nectar.................. 67

white (termites) ....................... 94

Apapâ Island, geological structure....... 48

Aplonis kittlitzi, a starling ................ $\quad 79$

Apogon fasciatus, a cardinal fish.......... 82, 86

Apparitions, supernatural ................. 14

Aprâ, harbor......................... 46

Aquatic sports of aborigines.............. 107

Arago, Jacques ........................... . 29, 32

Arak, or aguardiente, from coconut sap... 237

Archives of Guam . . . . . . . . . . . . . . . . . . . . $\quad 32$

Ardetta sinensis, a bittern................. 79

Areca cathecu, the betel-nut palm ....... 154, 187

Arecaine, an anthelmintic ............... 187

Arenaria interpres, a shore-bird ........... 80

Aroids ............................... 13

Arroba, a measure of weight............. 139

Arrow root....................... 127, 145, 318

Polynesian . . . ....................... 380

Arts of aborigines ....................... 100

Arts of modern inhabitants ............... 124

Ashmead, W. H., entomologist ........... 90

Asio accipitrinus, an owl ............... 79

Astrolabe and Zelé, visit ................. $\quad 32$

Astrolabe, visit ......................... 30

Atangtano River ....................... 49

Atrevida and Descubierta, visit .......... 25

A ugustinian friars...................... $\quad 23$

Authorities consulted ................. 1it

'Ava-drinking not practiced ............ 99, 354

Aveyro, Duchess of, patroness of Padre

Garcia .............................. 157

Avocado (fruit) absent from Guam........ 11

Ayuyu, the robber-crab ................. 91

Bachelors (urritaos)................ 15,98, 165 
Baguios (hurricanes)

Page.

Balsas (rafts) of bamboo

Bamboo water vessels

Bamboos

98,194

Banana flour - 329

Bánanas.......................................... 63

Banner-fish (Zanelus) ................... 83

Banyans ........................ 55, 63, 65, 275

germination........................ 65

haunted by spirits.................... 109

Baptism of aborigines.................. 14

Barbudo fish (Polydactylus) ............. 83

Bark cloth ........................... 189

Barrigada hill (Tiyan) .................. 51

Barringtonia fruit, a fish intoxicant ...... . 75,81

Barringtonia formation ................. 54

Barringtonia speciosa, dispersal ........... $\quad 75$

Barter of early inhabitants........... 13, 17, 102

Barter of modern inhabitants............. . 33

Baskets................................ 98

holding skulls ..................... 109, 111

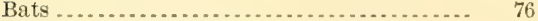

Beach, inner, vegetation ................. . 54

Beads, seeds used ................... 172, 174, 212

Beans ......................... 197, 272, 281

Bêches de mer........................... 89

Beliefs of aborigines.................. 109, 113

Beliefs of modern inhabitants............. 131

Belostoma, an aquatic insect.............. 94

Belt, nectar glands of bulls-horn acacia.... 68

Ben oil .............................. 148

Bengough, William .................... 4

Bermuda grass ......................... 151;212

Betel chewing................... 21, 99, 127, 187

nuts offered to visitors................. 103

nut palm spontaneous in Guam ......... 146

pepper........................ 99, 146, 154, 353

Beverages of aborigines .................... 99

Beverages of modern inhabitants ......... 127

Bibliography ............................ 154

Birds eaten by lizards .................... 81

Birds of Guam ........................ 78

Birgus latro, the robber crab ........... 90, 90, 235

Bithynis, fresh-water crustaceans......... 90

Bittern, called kákkag.................... $\quad 79$

Black-fiber palm ......................... 368

Blinding tree.......................... 271

Blindworm (Typhlops).................. 81

Boathouses.............................. 97

Boats of aborigines ................... $\quad 100$

Boatswain, or tropic bird................ 80

Bocoa erdulis (Polynesian chestnut) absent. $\quad 98$

Bones, human, used for spear-points ....... 106

Boobies (sea-birds) .................... 80

Botanical names, authority .............. 171

Botany of Guam, work needed........... 63

Bows and arrows not used ................ 106

Brandy distillation forbidden............ 147

Bread made with fermenting toddy....... 127

Breadfruit.......................... 63, 145, 189

Dampier's description.................. 18

described by Crozet ..................... 23

leaves used as forage................ 150,190

preparation .......................... 99

preservation........................ 189

use of bark ........................... 96
Page.

Breadfruit wood used in construction...... 190

Breakwater on reef proposed............. $\quad 49$

Bruguiera, dispersal................... $\quad 72$

Buffalo used as a beast of burden ......... $\quad 77$

Buoyancy of certain seeds and fruits...... $\quad 73$

Burial customs of aborigines ............ 108

Burney's Chronologieal History ............ 157

Butterflies.............................. 91

Butterfly-fishes ....................... 83

Buttons made of ivory nuts ............... $\quad 244$

Caban, or Kaban, a measure ............. 139

Cabbage, coconut palm ................. 239

Cabinet woods............................ 204

Cable route, survey .................... 44, 45

Cables of bark rope for ferries............ $\quad 149$

Cabo-negro palm ....................... 148, 368

Cabras, or Apapâ Island.................. 48, 49

Cabrilla, a spotted fish................... $\quad 84$

Cacao................................ 146, 385

Caladium colocasia, the taro plant........ 69,206

Caltrops used in early wars ............. 107

Camba, Don Andres Garcia ............... $\quad 30$

Cambodian tribes allied to Malayo-Polynesians.............................. 117

Camphire .............................. 306

Candle nut (Aleurites moluccana) ......... 67, 117

Candles imported from Japan............ 137

Cannibalism, absence ..................... 98

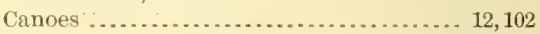

Capers indigenous to Guam .............. 212

Capital, lack and need ................. 40,1อิ2

Carangus ascensionis, a pómpano, ealled tarakito ........................... 88

Carcharius melanopterus, a shark, called halúo......................... 85

Cardisoma rotundum, a crab............. 90

Cardol, a resinous oil..................... 148

Carlos III, King of Spain................ 21

Carlos IV, King of Spain ................ 25

Caroline Islanders living in Guam....... 11,119

Carts ................................... 125

Cart-wheels, wood used .................... 209

Carving, natives ignorant of the art....... 116

Cascajo (gravel) for road-making .......... 142

Cashew-nut, oil from ...................... 148

Cassava, preparation of................... 316

Castanets............................ 108

Caste distinctions of aborigines ........... 104

Catalangan tribes of Philippines, beliefs ... 110

Cattle used for steeds..................... $\quad 77$

Cavan, a measure ....................... 139

Cavendish, English navigator............ 155

Cavern in the Talofôfô Valley ............. $\quad 52$

Caverns in cliffs ...................... 44

Centipedes (saligao), habits............... 94

Cereals cultivated in Guam .............. 143

Ceremonial customs of aborigines....... 107, 108

Ceremonies and feasts of modern inhabitants................................ 130

Cervus mariannus, an introduced deer..... $\quad 76$

Chachao Mountain, height of ............. 51

Chaetodons, called abábang (sea-butterflies) 83

Chamisso, Adelbert von.................. 28, 29

Chamorri, or nobles, regarded with dread. 104

Chamorro, language, ancient ............ 113 


\section{Page.}

Chamorro language, modern, modified by Spanish

Chamorros, name applied to Marianne Islanders .............................

Chanting for the dead ...................

Charadrius fulvus, a shore-bird.

Cheilinus tritobatus, a fish, called gadu ....

Chesnut, V. K.

Chestnut, Polynesian, absent from Guam.

Chiefs or nobles called chamorri .......... 104

Children and parents ............... 106, 129, 130

Choco, a Chinaman, shipwrecked on the island ..............................

Chocolate ............................... 127

Choris, Ludwig.......................... 28

Christian rites, establishment........... 112

Chrysarobin (Goa powder) .............. 121

Ciénaga (marsh) prepared for rice culture. $\quad 34$

Cigars wrapped with fiber............... 176, 183

Citizenship desired by natives............ 136

Citrons ................................ 146, 229

Citrus fruits plentiful................... 146

Clearings, abandoned .................. 58

Clesmeur, Chevalier du, visit............. 23

Cliffs, caverns........................ 47

vegetation............................ 54

Climate.............................. 41

Climbing plants ...................... 231

Clothing of aborigines.................. 96

of modern inhabitants................ 123

Coal (lignite) ........................... 51

Coal depot at Guam ................... $\quad 50$

Cockfights.............................. 131

Coconut, described by Dampier ......... 18, 234

butter ................................ 240

fiber (coir) . . . . . . . . . . . . . . . . . . . . . . 75,241

groves owned by nobles ................ 106

oil ...................... _ 95, 127, 147, 236

products............................. 239

sap made into toddy (tuba) ............ 99

sugar ................................ 127

thatch ............................. 125, 150

vernacular names .................... . 115, 153

Coconut-eating crabs................... 236

Coffee ........................... 127, 143,244

culture suggested as a commercial enterprise...

substitutes.

211,218

(3)

Coir .................................. 241

Coleoptera............................. 94

College endowed by Maria Anna of Austria, 21, 127

Collins, Guy N........................ 4, 40

Collocalin fuciphaga, the edible-nest swift .. $\quad 79$

Communal methods in labor.............. 131

Communication, means .................. 57

Concubinage among aborigines ........... 105

Conquest by Spaniards ................... $\quad 15$

Convict labor, experiments.............. $\quad 36$

Convirts, uprising ..................... $\quad 38$

Cook, O. F........................ 4, 10

Cook, O. F., on collecting botanical specimens of tropical trees.....................

Cooking of aborigines ....................

modern methods.

Copra.

137,239

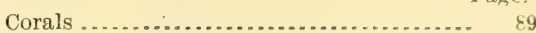

Coral-eating animals .................. 90

Coral-fishes........................... 84

Coral reefs. . . . . . . . . . . . . . . . . . . . . 11,47

structure ......................... 49

vegetation............................. 52

Coralliferous limestone .............. $47,48,51$

Cordage made of bark .................. . 148, 346

Coris aygula, a fish called tátanung........ $\quad 89$

Corn (maize) . . . . . . . . . . . . . . . . . . . . . 141,402

introduction ....................... 24

Corte, Felipe de la. See La Corte.

Corvus kubaryi, a crow .................. $\quad 79$

Cosmogony of the aboriginal inhabitants.. $\quad 110$

Cotton ............................... 285

Cotton fabries, importation ............. 137

Cotton leaves, nectar glands ............ 67

Counting, method ...................... 102

Courtesy shown to visitors................ . 103

Coville, Frederick V ......... 10,359, 370, 385, 400

Cowley, an English pirate.............. 16, 155

Cows and oxen used for steeds.......... 77

Crabs................................ 90

Craven, Lieutenant Commander J. E..... 4

Crayfish (Panulirus) .................... 90

Creation myth.......................... 110

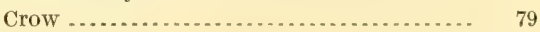

Crozet's visit .......................... 23

Cruel treatment of natives ........... 12, 15, 105

Crystals, needle, in taro leaves............ 70

Cultivated plants.................... 143

Curlews, called Kalálang ................ 80

Currents, ocean........................ 13,45

Customs of aborigines . . . ............... 104, 109

Customs of modern inhabitants . ........... 128

Cycas circinalis ....................... 71,252

Cycas nuts used for food .................. 98, 145

Dampier, English navigator...... 17, 101, 190, 234

Dances of aborigines ..................... 107

Dances of modern inhabitants ............ 130

Dardanus punctulatus, a hermit crab ....... 90

Darwin on nectar glands ................ $\quad 67$

sea beans collected by ................... $\quad 74$

Date palm introduced................... 61

Dead, spirits invoked . .................. 109

Deer, destruction caused by.............. 152

introduction......................... 76

Delpino on nectar glands ................. 68

Demigretta sacra, a heron................ $\quad 79$

Demons, or aniti ....................... 109

Denudation of mountain slopes.......... 48

De Pagès, a French traveler . . . . . . . . . . . . . 21, 156

Descriptions of Guam ................... 156

Detergents, or plants used for cleansing ... 256

Devil called Chayfi ....................... 109

Devils, or aniti ............................ 109

Dewey, Lyster H ...................... 10,151

Dhobie itch ............................ 121

Diodon hystrix, a poreupine-fish .......... 83

Dioscorea, confusion of species............ 64

alata, vernacular names.............. 116, 153

spinosa, a yam with spines protecting roots............................... 68

Diptera................................ 92

Discovery of Guam ................... 12

Diseases, freedom of aboriginal inhabitants. $\quad 95$ 
Diseases of modern inhabitants ........ 119

Dispersal of plants by ocean currents ..... $\quad 72$

Distillation of aguardiente forbidden ...... 147

Divorce among aborigines ............... 105

Dogs.

Domestic animals .....................

Doves...

Doyle, C. B .................................

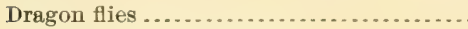

Dress of modern inhabitants .............

Drift, seeds and fruits ......................

Drinking water of Agaña polluted

Ducks, wild

Dugdug, or fertile breadfruit.

Dumont d'Urville, two visits of ........ . 30,32, 156

Dungea, Don Justo ....................... 10

Durian (fruit) absent from Guam ......... 61

Dutch navigators........................ 13

Dwellings of aborigines ................. 97

modern ................................ 123

Dyes........................ 198, 199, 203, 264

Earthquakes in Guam ................. . 36, 50,51

Easter Island, language ................. 113

Eaton, English pirate ..................... 16

- Economic conditions in Guam ...... 32,33,34,136

Economic plants, indigenous and spontaneous.

Economy, personal and domestic, of aborigines.

Modern inhabitants

Edible-nest swift

Edible roots

Education of natives discouraged.

Educational statistics

Eels, fresh-water

not eaten by aborigines

salt-water

Elegies of aborigines

Elemi, Manila.

Emballonura semicaudata, a bat

Emoia cyanura, a lizard

English pirates.

Epidemics

...................... $36,39,12$

Epinephelus hexagmutus, at spotted fish.... 84

Epiphytes ......................... 55, 56, 65,269

Equatorial current in Pacific ............. 13

Eschscholtz, Johann Friedrich ......... 28, 29

Esplana, Spanish governor............... 16, 18

Etiquette observed by aborigines ... . . . . . 103, 104

Evans, Lieut. Franck T

Evermann, Dr. Barton W

Excalfactoria sinensis, an introduced quail.

Exports at present time

Extrafloral nectaries

Family organization of aborigines

Famine foods

Famine of 1849

Fandangos

Fanihi, a fruit-eating bat .............. 76, 18

Fan-tailed fly-eateher.................... 79

Farms, cultivation of ................. 131

Fasting as a manifestation of grief....... 108

Feasts of aborigines ..................... 107

Feasts of modern inhabitants ............. 130

Fecundation of cycads .
Page.

273

Ferns............................... 273

Ferries across the mouths of rivers ....... $\quad 149$

Fiber, coconut ......................... 236,241

Fiber plants ............................ 148, 274

Ficus, Guam species not identified.........

Fighting . . ............................ 108

Fijian islands resembling Guam .......... $\quad 47$

Fijian plant names...................... 170

File-fish, long-beaked .................... $\quad 85$

Filial piety ............................ 130

Filipino rice planters in Guam........... 143

Fire known to the aborigines .............. 99

vernacular words pertaining to ......... $\quad 100$

Fischer, Louis A . . . . . . . . . . . . .......... 139

Fish called mañahag preserved by aborigines............................. 99

Fish intoxicants ................... 81, 196, 301

Fishes, alphabetical list................... 83

Fishing, decline......................... 126

Fishing, methods .................... 81, 100

Fishing nets of pineapple fiber ........... 183

Fistularia depressa, a trumpet fish.......... 83

Flammeo sammara, a squirrel fish ......... 83

Fleas ................................. 93

Flies.................................. 92

Floras of Pacific island groups ........... 158

Floras, tropical . . . .................... 158, 159

Flores, José, Alcalde of Umata........... 30

Florida Island, houses .................... 97

Flounders ............................. 82, 88

Flour, importation ...................... 137

Flycatchers ............................. 79

Flying fish called gahga ................ 84

Flying fox, a fruit-eating bat ............. $\quad 76$

Flying prao ....................... 100, 101, 102

Food staples.......................... 126

Food staples of aborigines................ 98

Forage plants . . . . . . . . . . . . . . . . . 150, 190, 317

Foreign commerce ...................... 137

Foreigners a source of trouble in Guam ... $\quad 36$ settling in Guam ..................... $\quad 119$

Forest vegetation ....................... 55

Fossils................................ 148

Free trade and protection .................. 32,33

with ships granted by Villalobos........ $\quad 36$

Fregata aquila, the frigate bird............ 80

Fresh-water duck ...................... 80, 126

Fresh-water fish called pulan ............. 87

Fresh water, source .................... 46, 49

Freycinet expedition..................... $\quad 29$

Frigate, or man-of-war, bird ............ $\quad 80$

Fruit doves............................ 78

Fruit-eating bat ........................ $\quad 76$

Fruits of Guam....................... $\quad 145$

Funeral ceremonies, aboriginal.......... 108

modern........................... 130

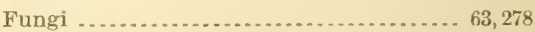

Furniture and utensils of aborigines ....... 98

Furniture, modern .................... 124.125

Fuuña, sacred rock ..................... 111

Gaimard, zoologist ....................... 29, 30

Gallinago megala, a snipe................. 80

Gallinula chloropus, a water-hen.......... $\quad 79$

Ganga-Herrero, Spanish governor.......... 31

71 Gannets, or boobies .................... 80 
Page.

Ganta, a measure.

Garcia, Francisco, life of the missionary

Sanvitores..

95,157

Garden plants

Garden seed, preservation ..............

Gardens

abandoned

destruction.

Garfish

Garrett, Albin, on coconut products . .....

Gaudichaud-Beaupré, botanist ........... . .

Gaudichaud, trees mentioned.............

Geckos (house-lizards)

Generosity of natives.................. 108

Geographical description .............. 11, 46

Geology of Guam . ....................... 47

German islands of Marianne group . . . 11, 119, 138

Ghosts haunting banyans and ruins ..... 109, 110

Glands, nectar, of plants ............ 66, 67,68

Goatfishes (Mullidae) called salmonete.... 88

Goats ................................... 77

Gobien's history of the Mariannes ........ 99, 157

Gods of the aborigines like lares of the

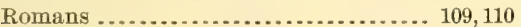

Godwit, Pacific, a shore bird ............. 80

Golden plover ......................... 80

Gomphosus (parrot fishes)............... 85

Gomuto palm.......................... 148, 368

Gossy pium, nectaries .................... 67

Government employees, pay ............ 136

Government of early inhabitants . ........ 106

Grams, green .......................... 350

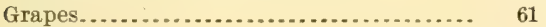

Grapsus, a erab....................... 90

Grasses . . .......................6.60, 151, 286

Grasshoppers ........................... 94

Graves of aborigines..................... 108

Great houses of aborigines . . . . . . . . . . 15,98, 105

Greeting ceremonial ................... 103

Grief for the dead ..................... 108

Griffin, A. P.C. Bibliography of Guam and Samoa ................................

Groom, Percy, on extrafioral nectaries .....

Groupers, leopard spotted fishes............

Grunwell, Dr. Alfred G .................

Gryllotalpæ (mole-crickets) ...............

Guam language, works on................

Guam plant names, pronunciation........ origin

Guam, population -0.--

Guam the first European settlement in the

Pacific Ocean.

Guava.

Guilandina crista, dissemination.

Guillemard's erroneous statement regard-

ing inhabitants.

Gulf stream indicated by sea beans .......

Gulls absent from Guam

Gums

Guppy, Doctor

Gygis alba kittlitzi, a snowy tern...........

Hades, belief in

Haenke, Thaddeus, botanist ...............

Haenke's collections .

Hahahyan port.

Hair, bleaching
Hair of animals lost by feeding on Leu-

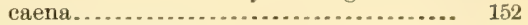

Halcyon (kingfishers) ................. 79

Half-beaks, fishes called hankut ......... 85

Halimeda (seaweeds) ................... 52

Halom-tano, etymology of ............. 172

Hanom point.......................... 47

Harbor of Aprâ, proposed improvement of. 48

Harlequin fish (Zanclus) ................ 83

Harpe axillaris, a fish.................. 85

Hartert, Ernst, zoologist. . . . . . . . . . . . 79, 158

Hats, or sunshades, of aborigines ......... 109

Hat-making materials............... 150, 183

Hawaiian language .................... 113

Hawaiian plant-names................. 170

seaweeds used for food ................. 178

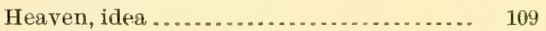

Hedges ................ . . . . . . . . . . . 273, 280

Helmet pith .......................... 175

Hemiptera ........................... 94

Hemp, Manila. ... . . . . . . . . . . . . . . . 57, 148, 329

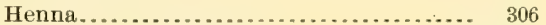

Hepaties of the island ............... 63, 292

Herbarium of Chamisso ................. 29 of Gaudichaud ................................ 29

of Haenke............................ 27

of Hombron ............................ 32

of Née ................................ 27

Hereditary suceession among aborigines... 106

Hermit crabs ........................ 90

Herons, called chúchukô................. 79

Heteractitis brevipes, a shore-bird ......... 80

Hibiscus bark for ropes. . . . . . . . . . . . . . . . . 124

Hill, T. G., on the spines of a yam........ 69

Historical works ......................... 157

History of Guam ...................... 12

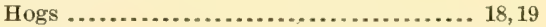

wild ................................. 77

Holacanthus cyanotis, a flsh............. 89

Holocentrus, squirrel-fishes ............. 83

Holocentrus unipunctatus, a fish ......... 88

Holothurians . . . . . . . . . . . . . . . . . . . . . 89

Hombron and Jacquinot, naturalists...... 32

Homón rock......................... 51

Honesty of aborigines ................... 103

Honey-eating birds. . . . . . . . . . . . . . . . . . . 79

Hooker, Sir Joseph, on confusion of Dios-

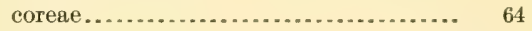

Horse-eye sea-beans . .................... 73

Horses................................ 34

Horticulture, tropical .................. 279

Hospital established for the natives..... . 122, 136

for sailors.............................. 121

Hospitality of aborigines .............. . . 14, 103

Hound-fishes (Tylosurus) . ............... 82

House-gods (lares) . . . . . . . . . . . . . . . . . . 109

House-lizards (geckos) ................. 81

Houses of aborigines....................... 97

Houses, modern ....................... 123

Howard, B. J., micro-photographs by . 4, 10, 67, 69

Humboldt, on treatment of Malaspina..... 27

Humuyong-mañglo mountain............. 51

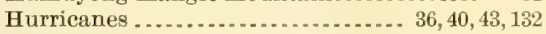

Husbands punished by wives ............. 104

Hydrographic Office, United States, meteorological reports...................... 41

Hydrography ........................... 44 
Hymenophyllaceae, absence of ...........
Hymenoptera ..........................
Ibañez y Garcia, misstatements regarding,
natives .............................

Ichthyology

Ichthyosis .

Ifil wood (Intsia)

Iguanas (see Varanus)

Ilangilang oil, preparation

Ilicho mountain

Illegitimate children eared for.

Illiteracy.

Illuminating oils..

Images, destritetion - -

Immortality, belief in..... . . . . . . . . . . . . 109, 131

Implements of agriculture . . . . . . . . . . . . . . 144

Importation of rice...................... 143

Imports............................... 137

Inalahan village, population of.......... 137

Independence of Spanish American colonies

India Refining Company of Philadelphia . . 240 Incest not tolerated .................... 104,105 Industrial system. . . . . . . . . . . . . . . . . . . . . 131

Industries suggested by Villalobos ......... 34

Industry of the natives.................. 40,138

Infanticide ............................... 16

Inhabitants, ancient ................... 95-117

modern............................ 117-133

Inheritance, laws ..................... 106

Insects, names........................... 93

Insects of Guam ... . . . . . . . . . . . . . . . . . . . . . 90 90-94

Intercourse of the sexes................... 105

Invertebrates, marine .................. 89, 90

Invocation of spirits. . . . . . . . . . . . . . . . . . . 15, 111

Ipil wood (Intsia) ....................... 297

Iraya tribes of Philippines, religion....... 110

Irisari, governor, cruelty .................. 105

Iron prized by the natives ............... 13,17

Ironwood.............................. 220

Isabel Island, houses ..... . . . . . . . . . . . . . . 97

Islanders, names .......................... 119

Ivory nut............................. 244

Jacquin, botanist........................ 25

Jaequinot, botanist . . . . . . . . . . . . . . . . .

Jaggery............................ 238

Japanese laborers in Guam ............... $\quad 40$

Jatropha curcas, oil from seeds of. .......... 147

Jellies, fruits used ......................... 184, 193

Jesuits, the first colonists of Guam . . ....... 14

annual reports ....................... 157

expulsion ............................. 21

useful arts taught ....................... $\quad 22$

zeal................................. 111

Jujube introduced ....................... 61

Kaban, a measure ....................... 139

Kalaling loank ........................ 45,49

Kalalang, name applied to curlews....... $\quad 80$

Kapok.................................. 221

Kava ............................. $\quad 230$

Kaya unknown in Guam.................. . 99

Kearney, Thomas H..................... 10

Kebler, Lyman F....................... 69

Kidnapping of natives .................. 13,103
Page.

Kingfishers, terrestrial .................. $\quad 79$

Kipuha, a native ehief, burial of......... 112

Kiteflying ............................. 131

Kotzebue expedition ..................... 28

Kuhlia rupestris, a fresh-water fish ........ $\quad 87$

Kuntze, Otto, on raphides................ 71

Labor, conditions ...................... 131, 133

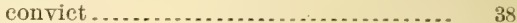

Laborers, dearth .................. $36,133,134$

Japanese ............................ 40

La Corte, Felipe de................. 39, 128, 133

Ladrones (thieves), name applied to natives........................... 13, 103

Lake Matan-hanom ....................... 52

Lances .................................. 20

Lancet-fishes ......................... $82,85,88$

Land birds ............................ $\quad 78$

Land crabs ............................ 90

Land measurement . . . . . . . . . . . . . . . . . . 138

Language of Guam............... 113, 116, 158

modification of ..................... 117

Lantana camara absent from Guam........ 152

Lanzon (fruit) absent from Guam........ . . 61

La Perouse's account of Governor Tobias .. $\quad 24$

Lares (house-gods) . ..................... 109, 110

Lauka rock............................. $\quad 51$

Law, respect for....................... 130

Lawn making...................... 213, 306

Leather .............................. 126

Legazpi ....................... 13, 95, 96,97, 102

Legends, recitation ...................... 110

Le Gobien, Charles, history ............. 157

Le Gobien's erroneous statement as to ignorance of fire ....................... 99

Lemons ................................ 146, 229

Lens phaseoloides, seeds adapted for floating. $\quad 74$ Leprosy ............................... 119,120 Lesson, botanical collector ................ 30 Leucaena glauca injurious to animals ..... 151 Lewton, F. L . ........................ 4,10 Lichens of Guam ...................... 63, 309 Lignite ............................... 51 Lime from coralliferous limestone ........ $\quad 126$ Limekilns, cocoanut wood used........... 239 Limosa lapponica bauer $i$, a shore bird ...... $\quad 80$ Literature . . . . . . . . . . . . . . . . . . . . . . . 154 Litmus paper.......................... 294 Littoral species, seeds .................... 75 Liverworts (sec Hepaticæ) ................. 292 Lizard fishes (synodus) ................ \$2 Lizards ................................ 80 Loaisa expedition..................... 12, 155 Lobsters, spiny (Panulirus) ............... 90 Longevity of aborigines.................. 95 Looms unknown in Guam ................. $\quad 100$ Lumber imported from the United States.. 137 Lumbricoid worms...................... 122 Luminan reef .......................... 48, 49 Lung-fish............................... . 82,86 Lupog (sink holes) ...................... 52 Lutianus (snappers) ..................... 83,86 Mracissiar oil ...................... 210 Madagascar, natives ..................... 117

nanie for taro........................ 154 Magellan's royage of discovery ........ 11, 12,154 Magic ................................. 111, 112 
Page.

Maile, a fragrant plant .................. 289

Maize ............................... 24, 144

Maize, preparation ..................... 127

Maize, preservation recommended........ 40

Makáhnag Mountain...................... 48,51

Makáhnas (sorcerers) ............ 15, 109, 111, 112

Malaria, absence....................... 122

Malaspina, Alessandro, life ............... 27

Malaspina expedition ................... 25, 156

Malaspina's narrative unpublished ........ 28

Malayan affinities of the aborigines of

Guam ......................... 113,117

languages .............................. . . 113

Malaysian languages.................... 115, 116

Malvaceae, nectar glands ................ 67

Mammals on the island .................. 76,77

Mañáhag, small fishes preserved for food. . 87,88

Mandioc.............................. 145, 316

Mangoes, fine quality ................... 145, 315

Mangosteen absent from Guam ........... 61

Mangrove-hopper (Periophthalmus) ...... 86

Mangrove swamps ..................... 52

fruits, dispersal.......................... 75

Mangroves ............................ 202, 363 germination.....

Manila elemi, a balsam ................. 210

Manila hemp (abaká) ................. 57,329

Man-of-war, or frigate, bird.............. $\quad 80$

Mansfield, Charles M. .................. 4

Manuel Encarnacion, Fray .............. 37, 38

Manures............................... 280

Maori language ......................... 113

Maria Anna of Austria............... 21,127,137

Marianne Islands, description and names.. 11

origin of name ....................... 22

Marine animals used for food ........... 90

invertebrates........................... 89

Marion, murder by cannibals ............. 23

Marriage customs .............. 104, 105, 128, 129

Marshes, cultivation .................. 34,140

soils ................................. 140

vegetation........................... 57, 379

Martinez, Don Antonio .................. 10

Massacre of natives ..................... 15, 105

Mastophora lamourouxii, a sea weed....... 52

Matáguag district, fine soil............... 141

Maternal descent....................... 106

Mats.............................. 98, 100,183

Maxon, William L ..................... 10

Mayer, Alfred G........................ 4

Measures used in Guam ................... 138

Medicinal plants ...................... 320

Medicines of aborigines ................... 96

Medina, Padre Luis de, work ........... 111, 112

Medinilla, Spanish governor .............. 31

Megapode, a mound-building bird........ 78

Melanesians, arts...................... 116

Merizo village, population ................ 137

Mesa of Guam, soil ....................... 141

Metamorphosis of limestone ............. 48

Metates introduced from Mexico ......... 144

Meteorological station recommended by

Doctor Abbe

Meteorology.

Mexican implementsintr

Mexican plant-names
Page,

Mexico ard Guam, traffic between........ 13

Mexico formerseat of government of filam. 13

Migrations of Pacific islanders.......... 117

Minerals............................... 51

Miracles............................... 14

Missionaries, cordial reception of ......... 14

killed by natives .................... 15, 106

zeal of ........................... 15, 105

Missionaries, descriptions of natives ...... 103

Modern inhabitants..................... 117

statistics.......................... 137, 138

prominent names..................... 119

Mole-crickets ........................... 94

Mollusks ............................... 90

Money, dearth......................... 33

sent away from island................ $\quad 136$

tortoise-shell .......................... 106

Monoceros, fishes armed with spurs . . . . 85, 86, 88

Monroy, Padre, death of ............... 105

Monsoon, southwestern . ................ 18, 41

Moore, Prof. Willis L . .................... . . 4, 42

Moral character of modern inhabitants. . 129, 130

Morals of aborigines...................... 102, 104

Morinda citrifolia, seeds adapted for floating $\quad 74$

Moringa moringa used for forage .......... 151

Moscoso, Franeisco, Spanish governor ..... 40

Mosquitos ................................ 92,93

Mosses of Guam ......................... 327

Moths ............................... 91

Mountains.............................. 48,51

Mourning for dead ..................... 108

Mucuna (see Stizolobium)................ 73

Mugil vaigiensis, a mullet................. 86

Mullet, gray................................ 84

Muraena (sea-eels) ........................ 82,83

Mus decumanus, the brown rat ............ $\quad 76$

Music of aborigines ........................ 108

Mutiny on the Aquiles and Constante...... 31

Myiagra freycineti, a fly-catcher .......... $\quad 79$

Myripristis murdjan, a squirrel-fish........ 87

Myths .......................... 107,110,111

Myzomela rubratra, a honey-eater .......... 79

Narcotics............................. 99, 146

Nassau fleet ....................... 13, 155

Natives, aboriginal. (See Aboriginal inhabitants.)

described by Woodes Rogers in $1710 \ldots .20$

diseases of ............................ 119

injustice toward .................... 12

language of ....................... 113,116

modern, arts of........................ 124

origin of........................... 117, 119

religion of .......................... 109, 113

Natural history of Guam, works relating to. 158

Naval station, advantages of Guam ....... 11

Navidad, an ancient port of Mexico ....... 13

Navigation of aborigines .................. 100

Nectar glands of plants .................., 67

Nectaries, extrafloral.................... 66

Née, Luis, botanist of the Malaspina expe-

dition ................................. 25, 26

Nee, plants collected.................... 27

Needle-crystals (raphides) in taro leaves... 69

Nero deep ..... . . . . . . . . . . . . . . . . . . . . . 45

Nero, U. S. ship, trans-Pacific survey ...... 44

Neuroptera............................... 94 
Page.

New Zealand language .................... 113

Nicker nuts ....................... 73, 74, 288

Nipa leaves used for thatch . . . . . . . . . . . 150, 334

Nipa palm, habitat.................... 72

Nobles, position ........................ 104

Noddies (sea-birds) . . . . . . . . . . . . . . . . . . 80

Nuestra Señora de Guadelupe (vessel) ..... 22

Nuestra Señora de la Incarnacion (vessel). $\quad 22$

Nulton, Lieut. L. N . . . . . . . . . . . . . . . . . . . . . 4

Numenius, migratory shore birds........ $\quad 80$

Numeral system, adopted from the Spanish. 118

Numeral system of the aborigines....... . 102,113

Ocean bottom near Guam................ 44

currents as a means of dispersing plants. $\quad 72$

Ochrosia mariannensis, buoyant fruits..... $\quad 75$

Oil, coconut............................ 240

Oil plants . . . . . . . . . . . . . . . . . . . . . . 147, 337

Ophicthus, snake-fish, or sea-eel ........... 82

Oratory of aborigines................... 110

Origin of natives of Guam ............... 116

of modern inhabitants ................ 117, 138

Orkney Islands, West Indian seeds cast upon ................................

Ornaments of aborigines ..................

Orote Peninsula.

geological structure of . . . . . . . . . . . ....

Orthoptera .

Ostracion, trunk fish .

Oustalet, ornithologist

Ovens, ancient . modern.

Owls.

Oxymonacanthus longirostris, a file-fish.....

Paa, an ancient village of Guam ......... 14

Pacific, early navigation .................. 12, 13

Agaña, the first European settlement in.. 24 contour of bottom.................... 45 currents

Pacific islands, botany .................. 158

Padina (seaweeds) . . . . . . . . . . . . . . . . . . . 52

Pagan Island, population .............. 138

Pago Bay .............................. 47

Paint made of turmeric .................. 252

mixed with breadfruit latex ............ 190

Palmer, Edward, Mexican plant names collected ............................. 170

Palo Mæria wood .......................... 97

Palomo, Rev. José ....................... 4, 10, 122

Panama Canal, importance to Guam...... 50

Panama plant names................... $\quad 170$

Pandanus fruit not a food staple........... 98

Pandanus leaves, use................. 124, 150

Pandanus seeds sometimes eaten........... 98

Pandanus, species confused............. 64, 343

Panulirus, a spiny lobster................. 90

Pnpaw ferments......................... 215

Paper mulberry absent from Guam ... . . . 117, 189

origin ........................... 154

Papuans compared with Chamorros....... 116

Paradise, aborigines' idea ................. 109

Parasites, animal......................... 122

Parasitic plants ......................... 194, 219

Parental authority recognized by adults... 129

Parents and children, relations ...... 106, 129, 130

Parexocoetus (flying. fishes) ................. 84

Pariti tiliaceum, extrafloral nectaries...... 67
Page.

(Gomphosus and Scarus) ..... 86

lana River......................... 49

Peanuts .......................... 143, 151,186

Pempheris otaitensis, a fish ................. 88

Peonage abolished by Americans......... 133

Perez, Atanasio T ........................ 10

Perez, Don Pablo, Spanish governor ...... $\quad 36$

Percis cephalopunctatus, a fish ............. 87

Perfume, ilangilang...................... 210

jasmine........................... 200

Periophthalmus koelreuteri, an air-breathing

fish ................................... 82

Pests, animal....................... 152

Pests in gardens.......................... 280

Phaëthon lepturus, the boatswain bird..... 80

Phaseolus mongo, the green gram........ 151, 350

Philippine languages compared with the

Chamorro ............................. 115, 116

Philippine plant names .................. $\quad 170$

Phlegoenas xanthonura, a fruit dove ........ $\quad 78$

Physic nut oil .......................... 147

Physical characteristies of aborigines..... 95

Physical conditions of the island ......... 41

Physical geography ................... 46, 52

Picul, a measure of weight............... 139

Pigafetta .............................. 12

Pigafetta's description of canoes .......... 100

Pigeons............................... 78

Pigments ............................... 190

Pigs................................... $\quad 77$

Pillars, ancient stone .................. 97

Pimentel, Spanish governor, trial of ...... 19, 20

Pineapple fiber..................... 124, 183

Piper betel leaves used as a narcotic ....... $\quad 99$

Piper methysticum absent from Guam...... 99

Pirates, English ........................ 16

Pith plants ......................... 175, 310

Pithecolobium dulce for forage ............ 151

for $\tan$ bark ......................... 126

Piti, landing place of harbor............. $\quad 50$

Pittier, Professor H. . . . . . . . . . . . . . . 159, 160

Placuna shells for window panes ......... 123

Plantains and bananas................. 63, 145

Plant nomes......................... 152, 154

Plant World, articles on Guam .......... 167

Plants absent from Guam ............... 56

introduced by the Jesuits ............... $\quad 22$

not well known ....................... 62

of special interest ...................... 61

origin indicated by vernacular names... 152

unidentified........................... $\quad 61$

Platophrys pavo, a flounder ............. $\quad 88$

Ploteres (aquatic insects) . . .............. 94

Plovers called dulili.................... $\quad 80$

Plow points made of musket barrels ...... 143

Poetry, natives' regard for ................ 103

Poisoned weapons....................... 107

Poisons, fish ........................... 103

Poisonous nuts used for food....... . .... 98, 253 plants . ............................. 358

Poliolimnas cinereus, a rail ............... $\quad 79$

Polistes, a wasp......................... 91

Polydactylus sexfilas, a thread-fin fish...... 83

Polygamy unusual.................. 104

Polynesia ............................. 113

botanical works..................... 158 
Page.

Polynesian languages and Chamorro .... 115, 116

Pómpano (Carangus) ...................... 88

Population, diminution................ 16

of Guam......................... 137, 138

of the German Mariannes............... 138

Porcupine-fish....................... 83

Poreupine wood......................... 239

Porto Rico plant names ................... 170

Potatoes, sweet.................... 98 98, 145, 297

Pot-herbs............................ $\quad 359$

Pottery unknown to early inhabitants.... 100

Poverty, absence ........................ 132

Praos, flying........................ 12, 20, 100

Prawns, fresh-water................... 90

Prayers and invocations ................. 111

Prehistoric remains ...................... 97

Premiums for agrieulture suggested by Vil-

lalobos

Present conditions on the island..........

Prices of food staples in 1904

Products of the island, early

described by Crozet.

- n - n

Progress of Guem, how hindered ......... . 31, 39

Pronunciation of vernacular names....... 170

Propagation of plants by suckers......... $\quad 145$

Property, laws governing ............... 106

destruction as punishment.............. 104

destruction as sign of grief ............. 108

Prostitution rare ........................ $\quad 129$

Protective devices of Guam plants ....... 68,71

Protoparce celeus, a sphynx moth........... 91

Provisions supplied to early navigators .... 13,17

Pteropus keraudreni, a fruit-eating bat .... 76

Ptilopus roseicapillus, a fruit dove ......... $\quad 78$

Publie houses of the aborigines ........... 15

Punishment of offenses.................. 106

Quail, pigmy, an introduced bird .......... 78

Quintal, a measure of weight ............ 139

Quoy and Gaimard................... 29, 30, 81

Races, amalgamation .................... 119

Rails (birds) . . . . . . . . . . . . . . . . . . . . . . . $\quad 79$

Rain invoked by sorcerers ............... 111

Rainbow, myth regarding............... $\quad 110$

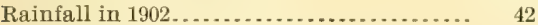

Raphides, or needle-crystals ............ 70

Rarotongan, a Polynesian language ....... 113

Rathbun, Miss Mary J. .................... 89

Rats ................................ 76, 152

Rattles used in dancing................ 108

Raynal, Abbé ........................... 23

Reed-warbler (Acrocephalus luscinia) ...... 79

Reeds used for mat-making .............. 150, 391

Reef animals ......................... 89

Reef-flats............................ 47

Reef-heron .......................... $\quad 79$

Reef plants.............................. 52

Relics, veneration.................. 15, 107, 111

destruction by missionaries ........... 111, 112

Religion of aborigines............... 109, 111, 113

misstatements of Ibañez y Garcia ....... 157

Religion of Philippine tribes ............. 110

Reptiles of Guam...................... 80

Resins............................... 289

Respect for the dead ................... 108

Respect for women...................... 103

Respect shown to parents ............... 129

Rhipidura uraniae, a fan-tailed flycatcher.. 79
Rhizophora, dispersal by currents ........ 72

Rice ............................... 389

cultivated by aborigines . . . . . . . . 13, 19, 100, 198

importation ......................... 137

origin ................................ 153

price in time of famine ............... 37

vernacular names.................... 115, 153

Richmond, Charles W., ornithologist ..... 78

Ricinus communis, extrafloral nectaries... $\quad 66$

Ringworm bush....................... 293

River vegetation ..................... 53

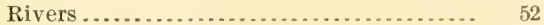

Roads ................................. 134

Road-taxes . ........................... 135

Robber-crab (Birgus latro) .............. 90, 235

Rogers, Woodes, English privateer....... 19, 101

Romanzoff expedition.................... 28

Roots, edible ............................ 144

Rope made of bast fiber ................ 149, 346

Rota Island, population................. 138

Rotation of crops, peanuts suggested....... 186

Rubber................................. 365

Sacred rock called Fuuña............... 111

Sacrifices, erroneous statement of Ibañez y

Garcia regarding ................... 157

Sailing routes, early ................... 13

Saipan Island ........................ 11, 51, 138

Salt evaporated from sea-water ......... 127

Salutations of aborigines................ 103

Samoa compared with Guam............. 11

Samoan language ...................... $\quad 113$

Samoan plant names .................. 170,171

San Luis de Aprâ, harbor................. 46

Sand dotterel, Mongolian ................. 80

Santa Rosa Mountain.................. 47,51

Santol (fruit) introduced................. 61

Sanvitores, Jesuit missionary . . . . . . . . . . . 1, 13, 15

Sarigan Island, population. ............. 138

Sasalaguan Mountain ..................... 51

Savannas ......................... . 57, 142, 370

Scarus (parrot-fishes) $\ldots \ldots \ldots \ldots \ldots \ldots \ldots . . . . .44,86,87$

Schools .................................. 128, 136

Schroeder, American governor........... 120,

$122,130,133,135$

Scientific expeditions .................. 25, 156

Scofield, Carl \$......................... 4,10

Scolopsis lineatus, a fish, called Sihig ...... $\quad 88$

Scorpions.............................. 94

Serewpine, textile, origin .............. 154

Screwpines (Pandanus) ................. 64,343

Scuffle hoe (fosiño) ..................... 144

Seabeach cultivation .................... 139

Sea-beans................... 73, 288, 307,378

Sea birds ............................. $\quad 80$

Sea-eels.............................. 82, 83

Sea-urchins.......................... 89

Seaweeds $($ see algæ) ................... 52,177

Seaweeds, edible ....................... 178

Sedges............................... 60, 254

Seedless varieties of Artocarpus and Musa.. $\quad 145$

Seeds, dispersal by ocean currents ........ $\quad 73$

of fertile breadfruit eaten .............. 190

used for weights. . .................... 172, 174

Selkirk, Alexander, visit to Guam ........ 19

Semper on the religion of certain Philip-

pine tribes...................... 110

Serpents absent ....................... 81 
Page.

Sewers needed at Agaña

Shark .................... 85

Shells used for rattles and trumpets ....... 108

Shipwrecked sailors, kind treatment....... 14

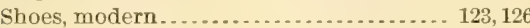

Shore birds.......................... 179

line of island ....................... 46

plants ................................ 58

Shrines in modern houses................ 124

Sick, care by medical officers of the Navy .. 136

Siganas, fishes..................... 85, 87, 88

Sihig, a bird ......................... 79

Sihig, a fish...................... 88

Silversmiths........................... 125

Sink-holes on the island.................. 52

Skinks (small lizards) ..................... 81

Skulis of ancestors kept in houses......... 109

carried in war ........................ 107

Skulls, veneration....................... 107, 111

Slings used as weapons................ 20, 106

Sloane, Hans, on the Gulf Stream. ......... 73

Smallpox.................................. 39, 122

Snakes, absence ....................... 81

Snipe................................... 80

Soap oranges used for washing . .......... 227

Soap made from coconut oil............ 147, 241

Social institutions of modern natives ..... 128

Soil exhausted by cultivation........... . 139-141

Soils of the island ....................... 141

Solano, Padre, Jesuit missionary ........... 16

Solenopsis, an ant ....................... 92

Solomon Islands. . . . . . . . . . . . . . . . . . . . . . . 97

Song bird (Acrocephalus luscinia) .......... 79

songs .............................. 102, 110

Sorcerers (makahna)............. 109, 111, 112

Soul (ante) belief in..................... 109

Spaniards criticised by Chamisso........... 29

Spears and slings of aborigines........... 106

Spermatozoids of Cycads ................... 72

Sphinx moth larvæ on tobacco........... 91, 152

Spiders ................................. 94

Spilbergen, Dutch admiral, visit.......... 13

Spirits of the dead ....................... 109

Spitting, superstition regarding.......... 112

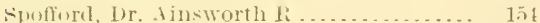

Sports and pastimes .................... 107,131

Squatarola squatarola, a plover ............ 80

Stahl, Ernst, on raphides................. 71

Standards of measure ..................... 138

Starch, preparation ................... 317, 318

Starch-yielding plants.................... 145, 376

Starehy fruits........................... 145

Starfish .................................. 89

Starling ............................. 79

Statistics of commerce, population, etc.... 137

Stavers, English captain ................. 36

Stejneger, Leonard...................... $\quad 80$

Stengel, Xavier, Jesuit missionary ..........

Sterile plants, propagation .................

Stizolobium giganteum, a sea-bean .......... .

Stoasodon, a ray..........................

Stone implements, ancient .................

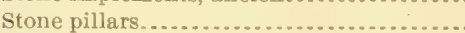

Storms.

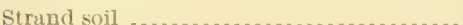

Strand vegetation ......................
Page.

Streams............................. 53

Strongholds of aborigines ................ $\quad 107$

Succession, laws ....................... 106

Suicide of natives ....................... 16

Sugar imported into Guam ................ 137

made of coconut sap.................... 238

Sugar cane ............................. 366

origin.............................. 153

vernacular names of.................. 115

Sula (sea birds) ....................... $\quad 80$

Sumai village ....................... $\quad 49$

population ........................... 137

Sun, myth regarding .................. 110

Sunday, observance .................... 131

Superstitions of aborigines .............. 109,113

Surface of the island .................... 46

Surgeon-fishes. See Lancet-fishes.

Surgeon-General of the Nary, report....... 121

Surmullets called Salmonete............... 87

Survey board appointed by Secretary of the

Navy ............................ 48

Survey of island by Duperrey ............ $\quad 30$

Swamp called la Cienaga ............... 34,52

Swamp plants ....................... $\quad 379$

Swan, Captain, a privateer .............. $\quad 17$

Sweet potatoes ....................... 145, 297

un known to the aboriginal inhabitants... 98

Swift, edible nest.......................... $\quad 79$

Sword grass for thatching .............. 57, 150

symener ia thersits, a poisonous fish ....... $\quad 87$

Synaptr, a holothurian.................. 89

Synodus (lizard-fishes) ................. $\quad 82$

Syphilis, inherited, among natives........ 121

Tacamahac resin ................... 208, 289

Tachogña farm....................... 22

Tahitian language ...................... 113

plant names......................... 170

Talage Bay ........................... 47

Talisai village, night attack............. 105

Talofôfô River............................ . 52

Valley, fertility .................... 140,144

cavern .............................. 52

Tamarind ............................. 146

Tanning materials ............. 126, 203, 357, 383

Tapa (bark cloth) . . . . . . . . . . . . . . . . . . 96, 189

Tapioca .............................. 317

Taro ............................... 69, 207

acridity destroyed by heat ............69,70

cultivation .......................... 144,207

Guam name similar to that of the Mala-

gassy ............................. 154

giant, eaten only in case of necessity .... $\quad 144$

needle crystals (raphides) ............... $\quad 69$

Tattler, Asiatic wandering ................ $\quad 80$

Telegraphic cable ...................... 44,45

Temperance of aboriginies............... 99, 103

Temperature statistics for 1902 ............ 42

Temples, absence ..................... 109

Tengho Mountain ...................... 48,51

Terminalia nuts eaten by aborigines....... 98

Termites (white ants) .................. 94

Tern, snowy, a sea-bird ................. $\quad 80$

Terraces caused by successive upheavals.. 47,51

Titrurliachmum aruanum, a fish .......... 83

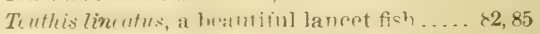

Textile pandauus, uses................. 150 
Page.

Turtile plants . ....................... 64, 148

Telephone poles, trees planted for ........ 221

Thanksgiving celebration in 1849 ........ 37

Thatch ............................ 150,238

Thieves (ladrones), islanders called ..... 13,103

Thrust hoe (fosiño) . . . . . . . . . . . . . . . . 144, 280

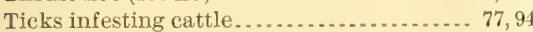

Tides ................................. 45

Timber. See cabinet woods.............. 207

Tinaha, a measure ..................... 139

Tinea circinata, a skin disease.......... 121

Tinea pellionella, an insect............... 91

Tinian Island . . . . . . . . . . . . . . . . . . . . 20, 21, 131

Tiyan Hill. ............................ . . 51

Toad-fish, poisonous..................... 87

Tobaceo .......................... 147, 331

Tobaceo worms. . . . . . . . . . . . . . . . . 91, 152

Tobias, a victim of the inquisition ........ 24

Tobias, Spanish governor .............. 23, 76

Toddy (tuba) ..................... . 99, 147, 237

Tonga, language ...................... 113

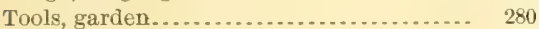

Torches of dry coconut leaves........... 238

Torres, Don Luis de, Sargento Mayor ...... 28

Tortillas of Cycas nuts ................ 253

Tortillas of maize....................... 127

Tortoise shell valued by aborigines ... 96, 106, 107

Trade conditions ................... 31, 136

Trade winds........................... 13, 41

Trades............................. 131, 132

Traditions of natives ................. 110,111

Traffic with ships..................... 13

Transportation facilities in Guam........ 134

Trees and shrubs, littoral................ 75

Trees, forest.......................... 54,55

introduced ............................. 58,61

Polynesian, absent from Guam ......... 56

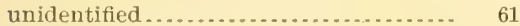

Trepang (edible holothurians) ........... 90

Treub, Doctor .................................. 76

Tribal organization, lack............. 106, 107

Trickery of early natives................ 102

Triton shells used as trumpets ........... 108

Tropic bird, or boatswain ................ 80

Tropical agriculture, works relating to .... 159

Tropical floras. ......................... 159

True, Rodney H......................... 10

Trumpet-fishes ..................... 83

Trumpets made of shells ................. 108

made of papaw leaf petioles............ 216

Trunk-fishes (ostracion) ................ 8. 84,89

Tuba, fermenting, a beverage............ 127

Tuba, or toddy, made from coconut sap.... 99,

147,237

Tuberculosis ......................... 122

Tumhun Bay.......................... 47, 120

Turmeric ............................. ${ }_{252}$

Turnstone, a migratory shore-bird ........ 80

Turpin, P.J. F., on raphides ............ . 71

Turtles .......................................... 81

Turtur dussumieri, an introduced dove.... 78

Tylosurus giganteus, a gar-fish ............ 82,87

Type plants from Guam................. 63

Typhlops braminus, a blind worm ........ 81

Typhoid fever.........................., 122

Ty phorons
Umata fern (Humata) ................... 295

Umata, or Umatag village, population.... 137

Umata roadstead .......................... 46

Unidentified trees and shrubs........... 61

Upcness saffordi, a surmullet............ 87

Uranie, French corvette................. 29

Urena sinuata, nectaries on leaves ....... 67

Urritaos (bachelors) . . . . . . . . . . . . . 15, 98, 105

Useful arts of aborigines ................ 100

of modern inhabitants ............... 124

taught by Jesuit missionaries ........... 22

Utensils, garden....................... 280

household....................... gs

Vaccination of natives in $1830 \ldots \ldots \ldots \ldots . . . . . .34$

Vanity of aboriginal inhabitarets......... 104

Van Noort, Duteh navigator ............ 13

Vara, a measure of length............. 139

Varanus, a large lizard..................... 80

Varnish for protecting books........... 182

Vegetables, garden. . . . . . . . . . . . 280

Vegetation of Guam .................... $\quad 52$

described by Gaudichaud .............. $\quad 29$

Veneration of relies . . . . . . . . . . . . . . . . 15, 111

Venison a food staple ................... 127

Vernacular names of plants. . . . . . . . . . 115, 153

Village sites .............................. 97

Village environs, vegetation ............ 60

Villages of aborigines . ................. 98

Villalobos, Spanish governor............ 34

discourages education of natives......... 128

Vinegar made from coconut sap ......... 127

Violin strings made of agave fiber ........ 176

Visitors, treatment ..................... 103

Volcanic origin of Marianne Islands...... . 11

outerops.............................. 48

range, submarine. ...................... 45

Volcanoes ............................ 11,51

Voyages, early, narratives............... 154

Wages paid to laborers ....................... 136

Wailing for the dead ................... 108

Wallace, James, on sea-beans ............ 73

War for independence of Spanish-Ameri-

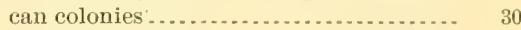

War of extermination in Guam .......... 15

Warburg on Pandanaceae............... 64

Warfare of aborigines ............... 106, 107

Wasps attracted by nectar.............. 67

Wasps, habits......................... 41,91

Water hen, or gallinule ............... $\quad 79$

Water supply needed........................ 136

Water vessels of bamboo .............. 98, 194

Wattling of reeds coated with clay....... 150

Wealth, absence in Guam .............. 132

Weapons of aborigines ................. 106

Weather plants..................... 172, 173

Weaving, looms not used............... 100

Weaving of mats and hats............... 124

Webber, H. J., on fecundation of cycads ... 72

Wedding feasts ........................... 130

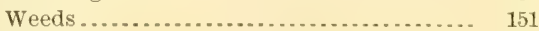

Weevils ................................. 94

Weights used in Guam .................. . . 139

Wells of Agaña polluted ............... 136

Whaling vessels at Guam ............. ỏs

Whimbrel, oriental, a migratory shore-bird. $\quad 80$

Whitewash sized with bread-iruit latex ... 190 
Whitney, Milton ..................... 139

Whittaker, Dr. Harvey ................ . 4

Witcheraft, or magic ................... 111

Wight, W. F., author of new botanical names and critical notes ............. 3,171

Wiley, Dr. H. W. . . . . . . . . . . . . . . . . .

Wiley on raphides of the taro plant...... 69,71

Wind, prevailing directions of ........... 41, 43

Window panes of placuna shells .......... 123

Wizards (makahna)..................... 15

Women of aborigines, feasts ............. 108

of Guam, description................. 95

position ............................. 103

Woodes Rogers . . . . . . . . . . . . . . . . . . . . . $\quad 155$

Woods. See Cabinet woods ............... 204

Works consulted in preparing this work ... 160

Worship of spirits of the dead............ 111

Ximenia americana, fruit eaten by doves...
Page.

Xiphagrostis floridula, sword grass........ 57, 150

Xylocarpus granatum, a littoral tree ....... 53,75

Yam, spiny, thorns about base ............ 68

Yam, wing-stemmed, origin............. 153

Yam-beans .............................. 204

Yams .............................. 63, 145, 257

Yigo, agricultural district................ 141

Ylang-ylang .......................... 209

Yosemite, U. S. ship, loss................. 44

Yura, a native chief, revolt of............ 16

Zamia, fecundation ...................... $\quad 72$

Zanclus canescens, a fish................... 83

Zebrasoma guttatus, a fish ................. $\quad 85$

Zelée, French corvette, visit.............. 32

Zoology, Ereycinet expedition ............ $\quad 30$

Zoology of Guam ........................ 76

Zosimus aeneus, a crab.................... 90

Zosterops conspicillata, a honey-eater ....... $\quad 79$ 





